\title{
UC-NRLF
}

|||||||||||||||||||||||||||||||||||

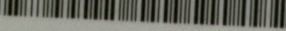

+ $B \quad 34 \quad 059$ 

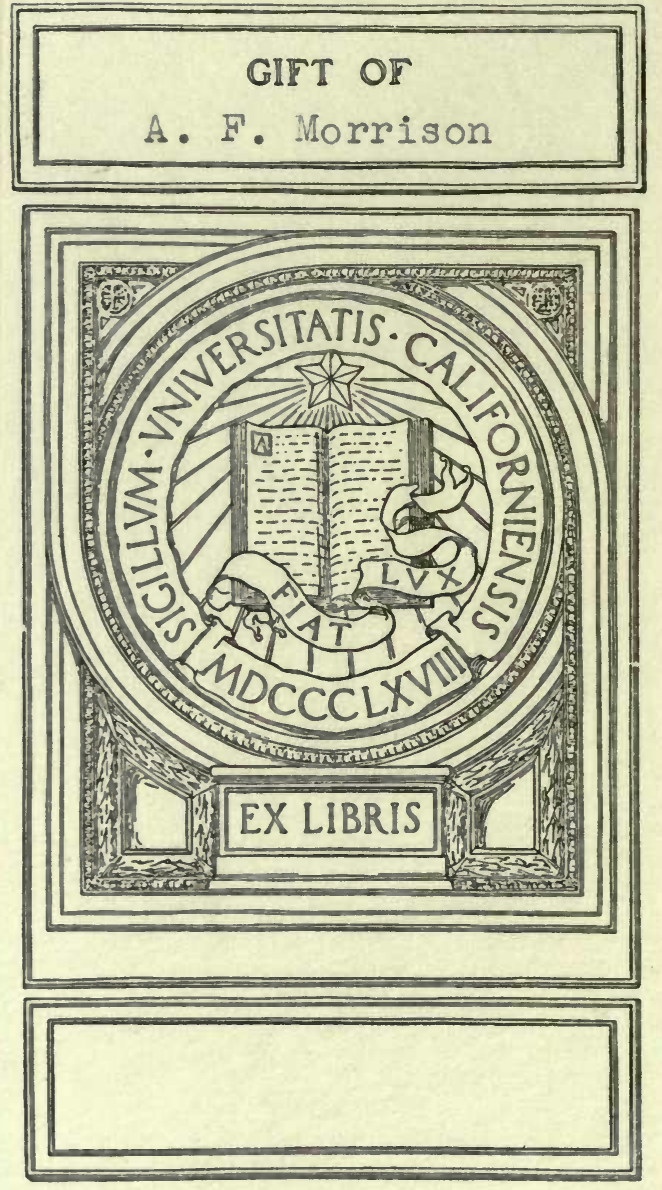



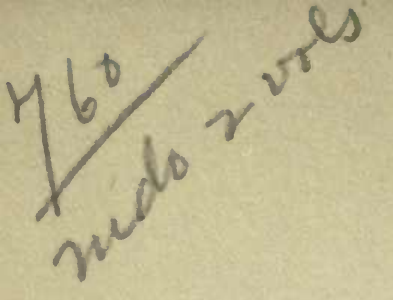

$$
10
$$






\section{THE HORSE}

\section{By J. H. WALSH, F.R.C.S. \\ AND}

HAROLD LEENEY, M.R.C.V.S., ETc. 


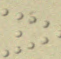

, , , 23,

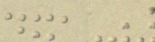

ע3

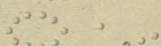

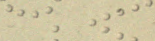

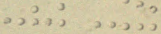

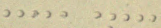

3 3.

50

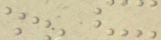

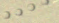

$\sin ^{2,2,3}$ 


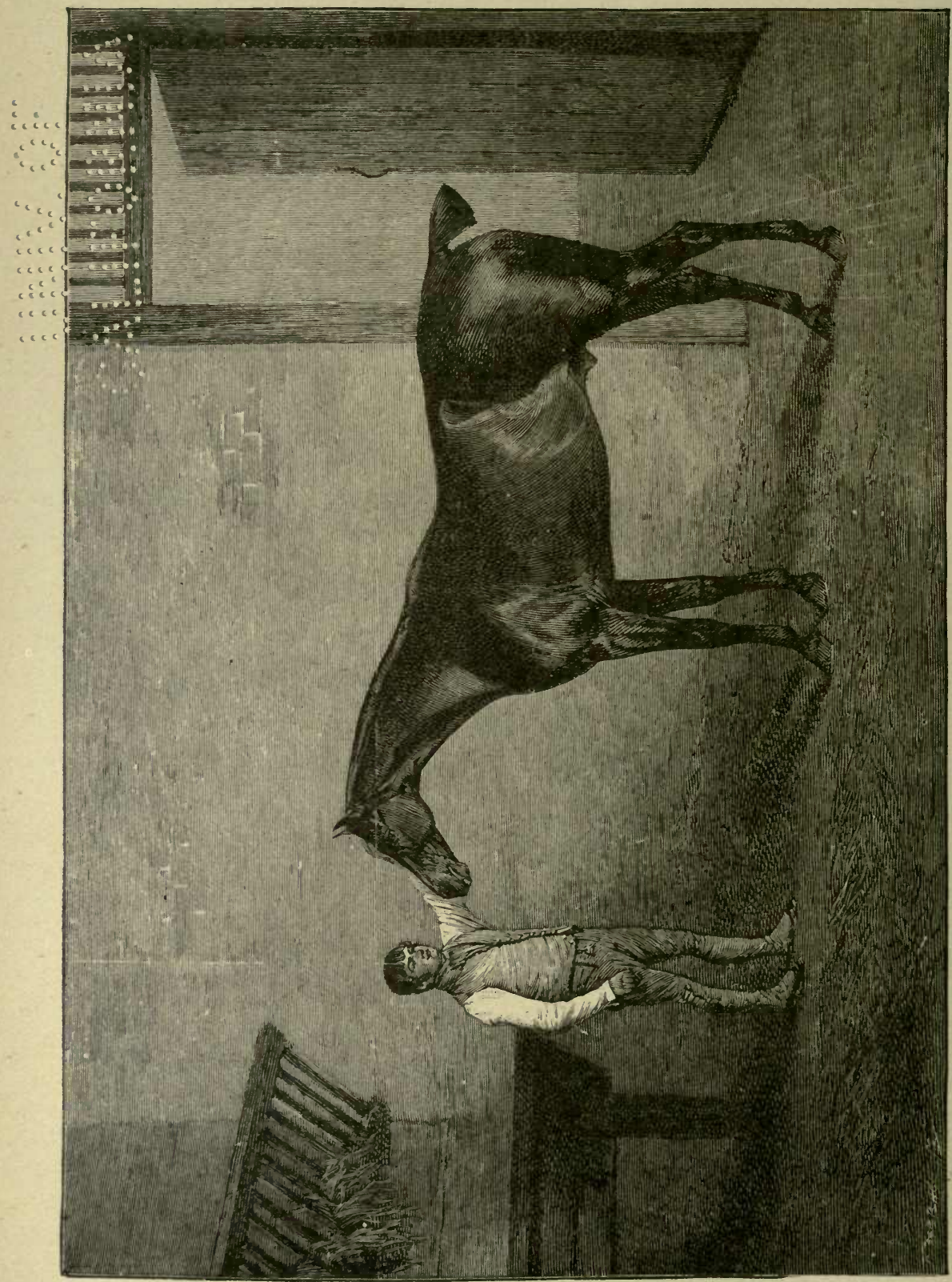




$$
\text { , }
$$




\title{
THE HORSE
}

\section{IN THE STABLE AND THE FIELD}

\author{
HIS VARIETIES
}

MANAGEMENT IN HEALTH AND DISEASE

ANATOMY, PHYSIOLOGY, ETc.

By J. H. WALSH, F.R.C.S. (STONEHENGE)

EDITOR OF 'THE FIELD'

AUTHOR OF 'BRITISH RURAL SPORTS,' ETC.

REVISED BY HAROLD LEENEY, M.R.C.V.S., ETc.

WITH TWO HUNDRED AND THIRTEEN ILLUSTRATIONS bX HAKRISON WEIR, ZWECKER, AND OTHERS

SIXTEENTH EDITION, IN TWO VOLUMES

WITH FOUR COLOURED PLATES

VOL. I

LONDON

GEORGE ROUTLEDGE AND SONS, Limited

NEW YORK : E. P. DUTTON AND CO.

I 907 


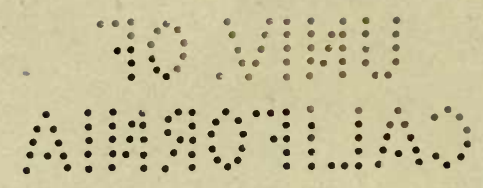

PRINTED BY

COWAN \& CO., LTD.

PERTH

a.3. Morison 


\section{PREFACE}

THE demand for another edition of this work has afforded the opportunity for a careful revision. This, however, has taken the shape of addition rather than alteration, save in a few instances where the discoveries of the last decade have added materially to our scientific knowledge.

The art of equitation and the general management of horses "in the stable and the field" have not undergone any great change since the talented author gave to the world the present treatise, one of the best and most complete, suitable for the private owner. His admirable style has suffered as little as possible at my hands, the original text being retained, save where alteration was clearly desirable.

The most generous assistance has been accorded by many wellknown authorities, a list of whom will be found elsewhere.

The chapter dealing with Arab horses is contributed by Wilfrid Scawen Blunt, Esq., and the Hon. Miss Dillon, and extends to several pages. The importance of Eastern blood having been so much insisted on by the author, it seemed consistent with the original character of the work to incorporate the experience of two such acknowledged authorities on Arab horses, bred in this country for several generations.

The description of the Clydesdale is from the pen of Lord Arthur Cecil ; and, with Sir. Walter Gilbey's kind permission, I have drawn largely on his War Horse or Shire Horse for an account of that useful animal. Captain Smyth, V.C., of the Queen's Bays, contributed the portrait of a Dervish charger, and Slatin Pasha, of the Intelligence Department, the matter referring to horses of the Sudan generally. 
Captain Hayes has afforded valuable assistance in connection with the (to me) difficult subject of equine locomotion, and from his valuable Veterinary Notes frequent excerpts are made in the department dealing with the diseases of the horse.

While reference has been made to many new methods of medical and surgical treatment, the greater part of the materia medica has been retained, as well as the bulk of the prescriptions, the latter being of proved value, and within the capacity of the amateur to prepare or obtain where the services of a skilled veterinarian are not available.

HAROLd LeENEy. 


\section{CONTENTS}

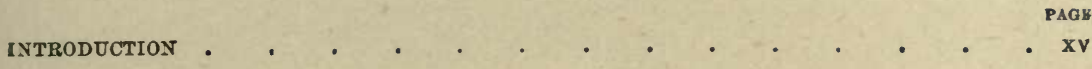

\section{CHAPTER T \\ EARLY HISTORY OF THE HORSE}

The horse of Scripture-The Greek horse-That of the Romans-The Arab of antiquity-Egyptian, Libyan, Numidian, and Moorish horses-The original British horse-Ancient methods of using the horse . . . . . . 1

\section{CHAPTER II}

\section{NATURAL HISTORY AND GENERAL CIIARACTERISTICS}

Synonyms and classification in the scale of creation-Habits-External form as indicated by points - Proportions-Period of maturity-Average age-Periodical moulting-Mental development-Small stomach .

\section{CHAPTER III}

\section{TIIE HORSES OF THE EAST}

The Barb-The Egyptian horse-The Dongola horse-The Burma and Manipur ponies-Sumatra and Java ponies-Chinese and Corean ponies-Japanese horses - The modern Arab-The Persian horse-The Turkish horse-Other Asiatic horses-East Indian horses-The Australian horse-South African horses .

\section{CHAPTER IV}

THE HORSES OF THE WESTERN HEMISPHERE

The South American horse-The Mustang-The Morgan horse-The Indian ponyThe Canadian horse-The American trotter-The American thoroughbred-The Vermont cart-horse-The Conestoga draught-horse . . . . . . 3

\section{CHAPTER V}

\section{EUROPEAN CONTINENTAL HORSES}

Spanish and Portuguese horses-The Italian horse-The German horse-The French horse-The Flemish horse-The Hanoverian horse-The Russian horse-Norwegian and Swedish horses .

\section{CHAPTER VI}

THE ENGLISH THOROUGHBRED HORSE

General history - The English thoroughbred horse of 1750-His origin-The modern thoroughbred-Increase of size and symmetry-Comparative stoutness-Early maturity-Object of encouraging the breed-Essentials in the thoroughbredPurity of blood-External formation-Height-Colour-Coat, mane, and tailThe thoroughbred hunter and steeplechaser. 


\section{CHAPTER VII \\ HALF-BREDS, COBS, AND PONIES}

The half-bred hunter-The Irish hunter-The charger-The covert-, road-, and park-hack-The ladies' horse-Cobs, galloways, and ponies-The carriage, brougham, or cab-horse-The heavy machiner-The phaeton-horse, gigster, or fast trotter. . . . . . . . . . . . . 112

\section{CHAPTER VIII}

\section{THE DRAUGHT HORSE}

The shire-horse-The Suffolk cart-horse-The improved Lincolnshire dray-horseThe Clydesdale-horse-Other mixed breeds .

\section{CHAPTER IX}

ON THE LOCOMOTIVE ACTION IN THE VARIOUS PACES

Natural and acquired paces-Distribution of weight-Attitude assumed in standing - Mode of progression-The walk-The trot-The canter-The hand gallop-The gallop-The amble-The paces of the manege-Leaping or jumping .

\section{CHAPTER $\mathrm{X}$}

\section{THE PRINCIPLES OF BREEDING APPLICABLE TO THE HORSE}

Theory of generation-In-and-in breeding-Out-crossing-Advantages and disadvantages of each plan-Causes of a "hit"-Importance of health and soundness in both sire and dam-Best age to breed from-The inflnence of the sire and dam respectively-Choice of sire and dam-Selection of blood in each class of horse-The kind of horse most profitable for the breeder to choose-Concluding remarks on breeding

\section{CHAPTER XI}

THE BROOD MARE AND HER FOAL

Hovel and paddock-General management of the brood mare-Treatment when in foal-Treatment after foaling-Early treatment of the foal-The weaning and after treatment of the foal-Castration

\section{CHAPTER XII}

THE BREAKING OF THE COLT

Mr. Rarey's mode of breaking - The ordinary English method of breaking for the saddle-Superiority of the ordinary method-Breaking to harness

\section{CHAPTER XIII}

\section{STABLES}

Situation and aspect-Foundations-Superficial area and height required-Stalls versus loose boxes-Hay chamber and granary-Best materials for walls, floors, doors, and windows-Drainage and water supply-Ventilation and lightingStable fittings-Harness-room-Coach-house-Servants' rooms-Plans of stables -Necessity for airing new stables

\section{CHAPTER XIV}

\section{STABLE MANAGEMENT}

'The coachman, groom, and helper-Clothing, stable implements, etc.-Food and water-Roots-Green food suitable for soiling horses-Artificial condimental foods-Watering horses - The theory and practice of feeding-Bedding-Dressing or grooming - Clipping, singeing, and trimming - Use and application of bandages-Management of the feet-Daily exercise 


\section{CHAPTER XV}

\section{STABLE MANAGEMENT CONTINUED}

Recapitulation of daily duties-Proper temperature of the stable-Remedies for stable vices and bad habits-Preparation for work-Ordinary sweating-The Turkish bath-Physic-Final preparation-Treatment after work-SummeringA winter's run-The straw-yard-Care of saddlery and harness .

\section{CHAPTER XVI}

\section{RIDING AND DRIVING}

Saddles-Bridles-Mounting and dismounting-The seat-Management of the reins -Use of spurs-Modes of starting the horse into his various paces-Riding to hounds-Out-door vices and bad habits-Harness-Driving a single horse-A pair-Four-in-hand 



\section{INTRODUCTION}

Theologians AND Naturalis's who were content to accept the book of Genesis verbatim et literatim were formerly agreed that all aninals sufficiently distinct to constitute a species had a separate origin. No scientific proof of this can of course be adduced. The structure of the horse and the fossil remains by which his past can be traced afford evidence of transmutation.

The horse of to-day has rudimentary structures which in other animals perform definite functions, but to him are useless or apparently so. The study of paleontology leads to the supposition that the horse, as we know him now, is the product of a very late period in the world's history, but through fossil remains he may be traced back through the pleistocene, the pliocene, the miocene into the eocene, beyond which no fragmentary evidences exist upon which to build up an ancestor.

The horse, as Sir W. H. Flower says in Modern Science, cannot be treated of "as an isolated form, but as one link in a great chain, one term in a vast series, one twig of a mighty tree : and to endeavour to trace as far as our present knowledge permits what its relations are to the rest, and by what steps of modification in its varius parts it has come to be the very singular and highly specialized animal we have now before us, so distinct from all existing forms of life that in most of the older zoological systems it was (at least associated only with some very immediate allies, structurally almost identical) placed in an order apart from all other mammals under the name of Solidungula, Solipedia, or Monodactyla, the animal with the solid foot, or rather with a single toe on each extremity."

The genus Equus, family Equida, include the ass and zebra, whose organization differs only in minor retails. 
The following ladies and gentlemen have afforded the editor assistance, either by special contributions, the loan of photographs and blocks, or permission to quote from their works.

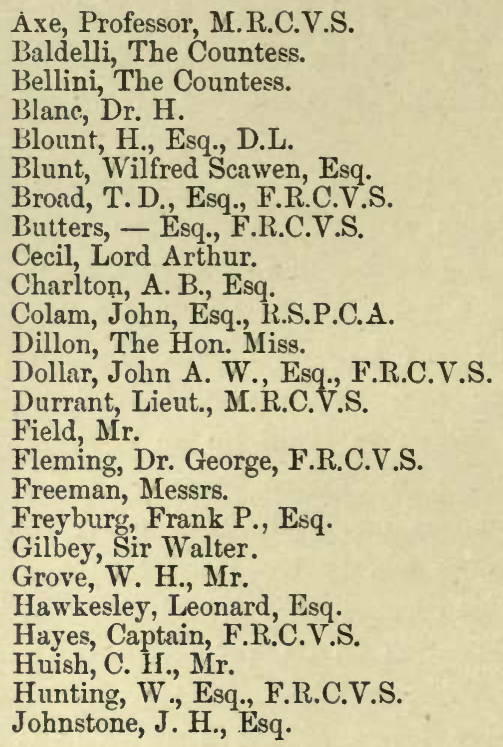

Kingham, R. T., Esq.

Krohne and Seseman, Messrs.

Miller, E. D., Esq.

Musgrave, Messrs.

Nettleton and Nash, Messrs.

Patton-Bethune, Captain.

Penberthy, Professor, F.R.C.V.S.

Ringrove, R., Esq.

Robertson, Professor.

Rogers, H. G., Esq., M.R.C.V.S.

Rogerson, - Esq., F.R.C.V.S.

Sermoneta, Her Grace the Duchess.

Sheather, C., Esq., F.R.C.V.S.

Slatin Pasha.

Smith, A. Pye, Esq.

Smyth, J. C. Warrington, Esq.

Smyth, Captain N. M., V.C.

South, W. A., Esq., F.R.C.V.S.

Stock, R. A., Esq., F.R.C.V.S.

Toms, F., Esq.

Urquhart, George, Mr.

Vinton \& Co., Messrs.

Wheatley, - Esq., F.R.C.V.S.

Willis, William, Esq., F.R.C.V.S.

Wilson, Miss M. 


\title{
THE HORSE CHAPTER I
}

\author{
EARLY HISTORY OF THE HORSE
}

IHE HORSE OF SCRIPTCRE-THE GREEK HORSE-THAT OF THE ROMANS-THE ARAB OF ANTIQUITY-EGYPTIAN, LIBYAN, NUMIDIAN, AND MOORISH HOISES-THE ORIGINAL BRITISH HORSE-ANCIENT METHODS OF USING THE HORSE.

\section{THE HORSE OF SCRIPTURE}

THe Earliest RECORD of the Horse which we possess is in the Old Testament, where we first find him inferentially mentioned in the thirtysixth chapter of Genesis, as existing in the wilderness of Idumea about the beginning of the sixteenth century before Christ. Many commentators, however, render the word which is translated "mules" in our version, as "waters," and thus a doubt is thrown upon the correctness of the inference which is thence drawn. Moreover, in the thirty-second chapter of Genesis, camels, goats, sheep, cattle and asses are all severally alluded to, but no horses; so that it is highly probable that in the time of Jacob, whose departure from Laban is there narrated, horses were unknown to the Israelites. It was not until after their arrival in Egypt that the horse is clearly alluded to. Jacob, on his deathbed, leaves us no room to doubt his knowledge of the horse, and of its being domesticated, for he speaks of the "horse and his rider" in the same sentence. We need, therefore, go no further for a proof of the early existence of this animal in Egypt, and may assume that there were large numbers of them there, for Pharaoh is recorded to have taken "six hundred chosen chariots, and all the horses," to pursue the Israelites to the Red Sea. It is generally supposed from the omission of all mention of horses while the Israelites were in Arabia, that this country, which has since become so celebrated for them, was at that time entirely without them. The proof, however, is entirely of a negative character, though I confess that it is as strong as any of that nature can well be. Indeed, six hundred years later, Arabia could not have been remarkable in any way for her horses, for Solomon, whilo he resorted to her for silver and gold, mounted his cavalry from 
Egypt. Yet the latter country could scarcely be the native land of the horse, not possessing the extensive plains which are peculiarly suited to his existence in a wild state, and it is considered probable that he was introduced from the central regions of Africa, which are undoubtedly the native plains of the Quagga, the Zebra, and some other congeners of the Horse; but where, curiously enough, he is not now found in a wild state. Thence he would naturally find his way into Egypt, and through Arabia to Persia, Tartary, and Greece, ultimately reaching Great Britain; but in what century he was introduced there we are quite at a loss to conjecture.

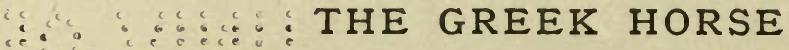

OF THE PRECISE FORM of the Horse of Scripture we have no account, taryond the glowirg larguage of Job, which will apply to almost any "variety possessing the average spirit of the species. The horse of the Greeks is far better known, being handed down to us in the writings of Xenophon, and preserved in the marble friezes of the Parthenon, which are now removed to our own National Museum. The above Greek writer, in giving his advice on the purchase of a horse, says, "On examining the feet, it is befitting first to look to the horny portion of the hoofs, for those horses which have the horn thick are far superior in their feet to those which have it thin. Nor will it be well, if one fatl next to observe whether the hoofs be upright both before and behind, or low and flat to the ground; for high hoofs keep the frog at a distance from the earth, while the flat tread with equal pressure on the soft and hard parts of the foot, as is the case with bandy-legged men. And Simon justly observes that well-footed horses can be known by the sound of their tramp, for the hollow hoof rings like a cymbal when it strikes the solid earth. But having begun from below, let us ascend to the other parts of the body. It is needful then, that the parts above the hoof and below the fetlocks be not too erect like those of the goat, for legs of this kind being stiff and inflexible, are apt to jar the rider, and are more liable to inflammation. The bones must not, however, be too low and springy, for in that case, the fetlocks are liable to be abraded and wounded, if the horse be galloped over clods or stones. The bones of the shanks should be thick, for these are the columns which support the body, but they should not have the veins and flesh thick likewise; for if they have, when the horse shall be galloped in difficult ground, they will necessarily be filled with blood, and will become varicose, so that the shanks will be thickened, and the skin be distended and relaxed from the bone; and when this is the case, it often follows that the back sinew gives way and renders the horse lame. But if the horse, when in action, bend his knees flexibly at a walk, you may judge that he will have his legs flexible when in full canter; for all horses as they increase in years increase in the flexibility of the knee. And flexible goers etre esteemed highly, and with justice, for such horses are much less liable to blunder or to stumble than those which have rigid, unbending joints. But if the arms below the shoulder-blades be thick and 
muscular, they appear stronger and handsomer, as is the case also with a man. The breast also should be broad, as well for beauty as for strength, and because it causes a handsomer action of the fore-legs, which do not then interfere, but are carried wide apart. And again, the neck ought not to be set on like that of a boar, horizontally from the chest, but, like that of a game-cock, should be upright towards the crest, and slack towards the flexure; and the head, being long, should have a small and narrow jawbone, so that the neck shall be in front of the rider, and that the eye shall look down on what is before the feet. A horse thus made will be the least likely to run violently away, even if he be very high spirited, for horses do not attempt to run away by bringing in, but by thrusting out, their heads and necks. It is also very necessary to observe whether the mouth be fine or hard on both sides, or on one or the other. For horses which have not both jaws equally sensitive, are likely to be hard-mouthed on one side or the other. And it is better that a horse should have prominent than hollow eyes, for such a one will see to a greater distance. And widely-opened nostrils are far better for respiration than narrow, and they give the horse a fiercer aspect; for when one stallion is enraged against another, or if he become angry while being ridden, he expands his nostrils to their full width. And the loftier the crest, and smaller the ears, the more horse-like and handsome is the head rendered; while lofty withers give the rider a surer seat and produce a firmer adhesion between the body and shoulder. A double loin is also softer to sit upon, and pleasanter to look at, than if it be single; and a deep side, rounded toward the belly, renders the horse easier to sit, and stronger, and more easy to keep in condition. The shorter and broader the loin, the more easily will the horse raise his fore-quarters and collect his hind-quarters under him in going. These points, moreover, cause the belly to appear the smaller; which, if it be large, at once injures the appearance of the animal, and renders him weaker and less manageable. The quarters should be broad and fleshy, in order to correspond with the sides and chest; and, should they be entirely firm and solid, they would be the lighter in the gallop, and the horse would be the speedier. But if he should have his buttocks separated under the tail by a broad line, he will bring his hind-legs under him with a wider space between them, and, so doing, he will have a prouder and stronger gait and action, and will in all respects be the better on them."

Here we have described, in most exact terms, a cobby but spirited and corky horse, with a light and somewhat peculiar carriage of the head and neck, just as we see represented in the Elgin marbles.

\section{THE ROMAN HORSE}

Of the Rovan Horse we know far less than of that of the Greeks, but the fact of its inferiority to those of the surrounding nations is established, for no sooner were they brought into collision with the cavalry of Macedonia and Epirus than they succumbed. This could only be owing to the quadruped, for the Roman foot-soldier was still 
unmatched. Casar depended for his cavalry upon Gallic horses, which were able to ride down the Roman horses of his rival Pompey without the slightest difficulty. So also Crassus was unable to make head in Asia against the Parthian horse; and from his day until British horses were transported to Oriental soil, the superiority of Asiatic horses remained undisputed.

\section{THE ARAB OF ANTIQUITY}

The Arab of the present day is said by his countrymen to be the same in form, in courage, and in endurance, with the horse which existed in Arabia before the time of Christ. There is a poetry surrounding the Arab horse which we must needs unlearn, as all scientific knowledge goes to disprove the popularly accepted idea that the horse was originally to be found wild in Arabia. The absence of water and of pasture have made him remarkably dependent upon man, and as man's associate more intelligent than other breeds. Professor Huxley, in a letter to Mr. Wilfrid Blunt, says, "It appears to me certain that horses and chariots were unknown to the old and middle empires of Egypt, while in the early age of the new empire they abounded. Egypt, however, had a hold on Northern Arabia from at least the fourth dynasty, or very early in the days of the old empire. If horses ivere known and domesticated in Arabia at that time, how is it for a good thousand years the Egyptians knew nothing about them?" I have shown that there is every reason to believe that the Israelites who dwelt in Arabia had no horses in the time of Jacob, and therefore it is scarcely likely that this variety could have arrived at its present state of excellence much before the commencement of the Christian era. But beyond the traditional accounts which are preserved in the various tribes, there is no means of arriving at the truth, and they are to be regarded with considerable suspicion. Buffon comes to the conclusion, nevertheless, that Arabia is the birthplace of this animal, and his opinions are followed by a host of subsequent writers; but I have already given the reasons for the contrary conclusion. The dry nature of the country, and the scantiness of herbage, show that in a wild state the horse could hardly exist there, and that it is only by the care and superintendence of man that the Arabian horse has become so famous.

\section{EGYPTIAN, LIBYAN, NUMIDIAN, AND MOORISH HORSES}

The Egrptian Horse is handed down to us on some of the sculptures found in the ruins of Nineveh; the carvings of which are in a high state of preservation, and are very elaborate and spirited. Even the superficial veins are carefully rendered; and hence we may place some reliance upon the fidelity of the portraiture. In all these bas-reliefs the animal is represented with a large and coarse head, a high crest, and a heavy, lumbering body, not very dissimilar to the Flemish horse of the nineteenth century. 
Of the Libyan, Numidian, and Moorish horses which are alluded to by classic writers, we know little beyond the cursory description of Alian, who says that they were slenderly made, and carried no flesh.

\section{THE ORIGINAL BRITISH HORSE}

The vature of the original stock which formed the foundation of the modern European horse is extremely doubtful. Sir Walter Gilbey claims it for the Shire Horse, and Lord A. Cecil for the Clydesdale; both may be right, as certain points could well have developed from the original stock to make them now so different. In Great Britain horses' bones are found in caves which are of extreme antiquity, but they do not define with any certainty the form of the original British horse, nor can we, with certainty, arrive at the exact era at which the animals to which they belonged lived and died. It is, however, an ascertained fact that when the Romans invaded Great Britain they found the people in possession of horses, and using them for their chariots as well as for the purposes of riding. After the irruption of the Goths, and the commencement of the dark ages, we have no reliable history to guide us, and we are left to grope in the dark from the fourth century, when Vegetius wrote on the veterinary art, until the Elizabethan era, when more attention was paid to the improvement of the breed of horses in this country.

\section{ANCIENT METHODS OF USING THE HORSE}

THe MODE OF Using the horse adopted by the ancients was at first by harnessing him to a rude chariot, without springs. In course of time the grooms who took care of him found that they could manage him while on his back without the aid of the saddle and bridle, which are comparatively modern inventions. Hence, we see the horse represented in the Elgin marbles as ridden without either the one or the other; and there is also abundant written testimony in support of this mode of equitation being practised by the early Greeks. This ingenious people, however, invented the snaffle-bridle, and both rode and drove with its aid, after the establishment of the Olympian games, in which chariot races formed an essential feature. The curb-bit was invented by the Romans, or, at all events, was first used by them; but both that people and the Greeks were ignorant of the use of the stirrup, and either vaulted on their horses, or used the back of a slave as a stepping-stone, or sometimes had recourse to a short ladder for the purpose. The earliest period when it can be proved that the stirrup was in use was in the time of the Norman invasion of this country. The incidents of this event in history were recorded on the Bayeux tapestry by the wife of William the Conqueror, and on this the stirrup was depicted, according to the authority of Berenger, as a part of the trappings of the horse. Shoeing was not practised by either the Greeks or Romans, and only in cases of lameness was the foot defended by a sandal, which, however, was sometimes tipped with iron.

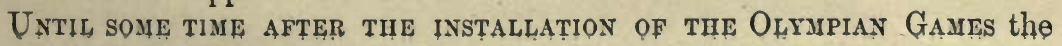


use of the horse was confined to war and the chase. These games were held every four years, and are supposed to have commenced about 774 years before Christ, and as it was not until the twenty-third Olympiad that the horse was introduced in the arena, the birth of horse-racing may bo fixed at about the year 680 B.c. At first the horses were ridden, and the distance was about four miles, but in the twenty-fifth Olympiad the chariot was introduced, and after this time became the prevailing instrument of testing the speed and powers of the Grecian horse. Here, also, the distance was about four miles, but as a pillar was to be rounded several times, the race depended quite as much on the skill of the charioteer as on the qualities of his horses. 


\section{CHAPTER II}

\section{NATURAY HISTORY AND GENERAL CHARACTERISTICS}

SYNONYMS AND CLASSIFICATION IN THE SCALE OF CREATION-HABITS-EXTERNAL FORM AS INDICATED BY POINTS - PROPORTIONS - PERIOD OF MATURITY - AVERAGE AGEPERIODICAL MOULTING-MENTAL DEVELOPMENT-SMALL STOMACH.

\section{SYNONYMS AND CLASSIFICATION}

THE Horse, in English, is synonymous with i $\pi \pi 0 s$, Greek; equus, Latin; pferd, German; cheval, French; paard, Dutch; häst, Swedish; hest, Danish ; cavallo, Italian ; caballo, Spanish ; loschad, Russian; kon, Polish ; sukh, Turkish ; hysán, Syriac ; hozan, Arabic ; al, Torrkman ; ma, Siameso ; fur or pur, Bornou; barree, Timbuctoo; as, Pustoo.

IN 'SHE CLASSIFICATION adopted by modern naturnl historians he belongs to the division Vertebrata, class Mammalia, tribs Ungulata, order Pachydermata, family Solipeda, and genus Equus.

His DeNTal formula is as follows:-Incisors $\frac{8}{6}$, zanine (in the male only) $\frac{1}{1} \frac{1}{1}$, molars $\frac{6}{6} \frac{6}{6}$, total 40 .

\section{HABITS}

The Habits of the horse in a wild or free state are similar to those of most of the gregarious and graminivorous animals. That is to say, he places his safety in flight; but when compelled to make a stand against any of the larger carnivora, he fights strongly with his heels and teeth. In all countries he feeds upon grass (green, or dried as hay), straw or grain; and those succulent plants generally called "roots," as swedes, mangels, parsnips, carrots, kohl-rabi, etc. None of the brassicas come amiss to him when confined to the stable. The leaves of trees and young shoots are particularly relished in some seasons. The habits of the horse may be so modified by circumstances, that it has been seriously proposed to make cakes containing a proportion of animal food for convenience of transport over desert places and for use in beleaguered cities. Although the editor has seen samples of such food, he is not aware of any practical trial having been given to what certainly seems a wholly unnatural food for a graminivorous animal. Camels' milk is given to horses in Arabia in times of scarcity of other food.

Forsage. - In a frce state, where the horse has to travel far for his food, 
he becomes inured to fatigue, and is able to make long journeys, without the training which the domesticated animal requires. Thus the South American and Californian horses, as soon as caught, are able to carry their riders for sixty or seventy miles on end at a fast pace, suffering, of course, from the unaccustomed pressure of the saddle, but not otherwise the worse for their exertions. The walk and gallop are the only natural paces of the wild horse; the trot and canter being acquired, though to some extent exhibited by the domesticated horse before breaking, and evidently the result of the tendency which is always displayed to hand down from one generation to another habits which are not natural to the species.

Most half-bred as well as cart-colts inherit the trot to such an extent, that when approaching an unaccustomed object in which they are suddenly interested, they will fall into that pace as an intermediate one between walking and galloping.

\section{EXTERNAL FORM, AS INDICATED BY POINTS}

The axatomy of this animal will form the subject of a special division of this book, but the external form may now be discussed with propriety. By horsemen in general this is considered under certain subdivisions, which are called "points," and which are severally represented by figures in the following outline.

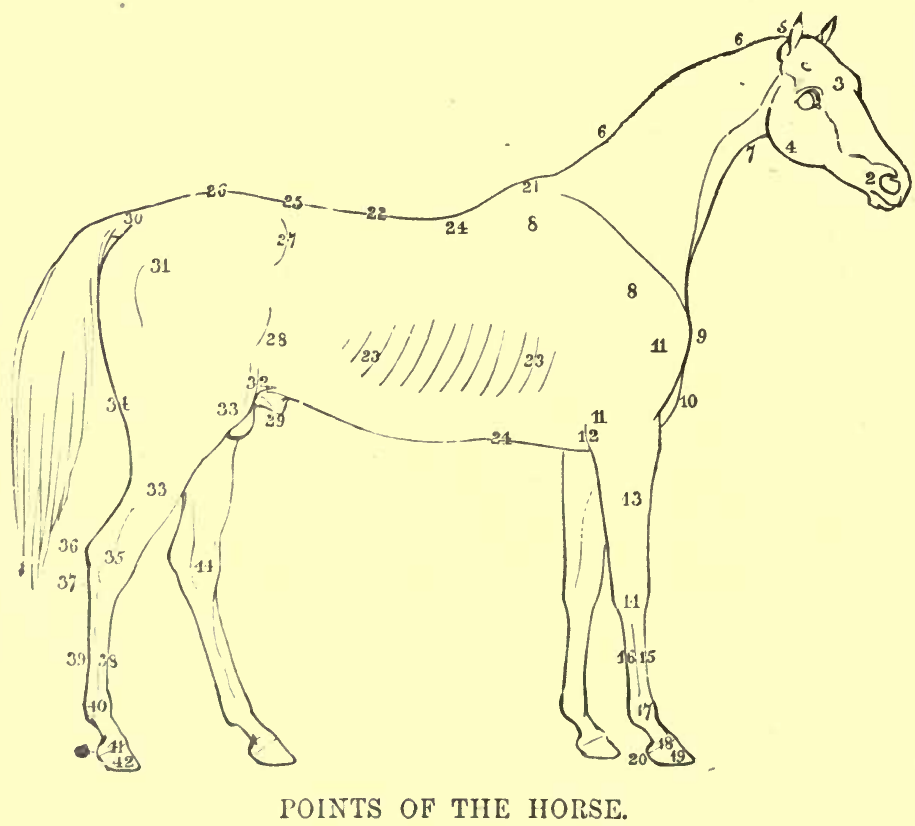

HEAD.

1. Muzz!e.

2. Nostril.

3. Foreheal,

4. Jaw.

5. Poll. 
NECK.

6. 6. Crest.

7. Throttle or windpipe.

\section{FORE-QUARTER.}

8. 8. Shoulder-blade.

9. Point of shoulder

10. Bosom or breast.

11. 11. True-arm.

12. Elbow.

13. Fore-arm (arm).

14. Kinee.

15. Cannou-bone

16. Back sinew.

17. Fetlock or pastern-joint.

18. Coronet.

19. Hoof or foot.

20. Heel.

BODY OR MIDDLEPIECE.

21. Withers.

22. Back.

23. 23. Ribs (forming together the barrel or chest).
24. 24. Circumference of the chest at

25. Loins.

this point, called the girth.

26. Croup.

27. Hip.

28. Flank.

29. Sheath.

30. Root of the dock or tail.

IIIND-QUARTER.

31. Hip-joint, round, or whirl-bone.

32. Stifle-joint.

33. 33. Lower thigh or gaskin.

34. Quarters.

35. Hock.

36. Point of the hock.

37. Curb place.

38. Cammon-bone.

39. Back sinew.

40. Fetlock or pastern-joint.

41. Coronet.

42. Hoof or foot.

43. Heel.

44. Spavin-place.

The relative proportions of, and exact shape desirable in, each of these points, vary considerably in the several breeds. Thus, when speed and activity are essential, an oblique shoulder-blade is a sine qua non; while for heavy harness it can scarcely be too upright, enabling the pressure of the collar to be more easily borne, and allowing the animal to exert his strength at right angles to its long axis. Many men are good judges of hunters and hacks, but are almost wholly ignorant of the qualities desirable in a coachor cart-horse. There are some elements, however, which are wanted in any horse, such as big hocks and knees, flat legs with large sinews, open jaws and full nostrils. It will, therefore, be necessary to describe the points of each breed; but I shall here give those which are always to be attended to as being of importance in any kind, whether used for racing or hunting, for the road or for agricultural purposes.

TAKING FIRST tHe HEAD:-It should be known, that the volume of brain contained within it determines the courage and other mental qualities of the individual. Now as, ceteris paribus, size is power, so without a wide forehead (which part marks the seat of the brain), you cannot expect a full development of those faculties known as courage, tractability, good temper, etc. The size of the muzzle is partly regarded as an element of beauty, and partly as a sign of high breeding. Hence, in the cart-horse, a coarse jaw and thick muzzle are not regarded. A large and patent nostril can not be dispensed with in horses intended for fast work, and should be desired even in the cart-horse, for in drawing heavy loads on a hot day, his breathing may be rendered almost as laborious as that of the highly-tasked race-horse or hunter. So also with the jaw, if there is not ample width between the two sides for the development and play of the larynx and windpipe, the wind is sure to be affected, and, in addition, the head cannot be nicely bent on the neck. A defect in this last point is the usual cartse of that straight and inelegant setting on of the head which is so common, and which the practised horseman avoids, as alike unsightly and prejudicial to the wind and the 
mouth ; for a horse which cannot give way to the pressure of the bit is sure to become dull in his mouth, and therefore unpleasant to ride or drive. The eye is to be examined with a twofold purpose, firstly, as an index of the temper, the nature of which is marked by the expression of this organ; and secondly, in reference to its present state of soundness, and the probability of its continuing healthy. A full and clear eye, with soft, gazelle-like expression, is scarcely ever associated with a bad temper, and will most frequently continue sound, if the management of the horse to which it belongs is proper in itself. The ear should be of medium size, not too small, nor too large, nor should it be lopped, though many good lopeared horses have been known, and some very superior breeds, like that of the celebrated Melbourne, are notorious for this defect.

THE NeCK should be of moderate length, all beyond a certain dimension being waste, and even a moderate-sized head at the end of an extremely long lever being too much for the muscles to support. It should come out full and muscular, with a sweep between the withers and the bosom, and should gradually diminish till it runs into the head, with an elegant bend just behind the ear. A very narrow throat suddenly bent at the upper part, marked as the throttle, is apt to be connected with roaring, and on that account is objected to by horsemen.

IN the Fore-quarter there are several points to be attentively examined, and among these, the shoulder is regarded as of most consequence, when the horse under consideration is intended for the saddle. It is evident that, unless there is length of the blade, and also of the true-arm, there cannot be a full surface for the attachment and play of the muscles, nor can there be the same amount of spring to take off the jar which follows each footfall. The straighter the angle formed by the long axis of each of these bones, the less spring there will be. So, also, if the angle is not sufficient, the muscles of the shoulder-blade will not thrust forward the true-arm, nor will the latter be sufficiently clothed with muscles (without being loaded) to act on the fore-arm, commonly known by the horseman as the arm. Hence it is found, that with an upright shoulder, not only is the stride in all the paces short and the action stumpy, but there is not that elastic movement which enables the horse to carry his body along rapidly and evenly, without rising alternately behind and before, and thereby jarring himself or his rider. On the other hand, the upright shoulder, loaded with a thick mass of muscles, is useful in the cart-horse, and to a certain extent also, in the carriage-horse, in both of which the pressure of the collar requires a steady and comparatively motionless surface to bear it. The difference between the two extremes of oblique and upright shoulders is well illustrated in the accompanying woodcut, in which it will be seen that in the former the angle between the blade $(a)$ and the true arm $(b)$ is very considerable, while in the latter it is much less. Hence it results, that when the muscles of the blade bring the axis of the arm into nearly the same line with its own axis, the fore-arm $(e)$ in the oblique shoulder will be thrust forward and raised to a greater degree than in the upright formation, as is shown in the engraving in the parts represented by dotted lines $(d e)$. It follows, therefore, that horses intended to have high, and at the same time forward, action should have oblique shoulders, for without them they will almost to a certainty either have 
very mean and low action, or, if they do bend their knees, they will put their feet down again nearly on the same place as they took them from, which peculiarity we so often see displayed in the cart breed, or those nearly allied to it. This is one of the most important uses of the obliquity of the shoulder-blade as it seems to me, and one which has not been generally admitted by writers on this branch of the subject, though all are ready to admit that in some way or other this formation is essential to good action. Another reason for the obliquity of the shoulder in the riding-horse, is that without it the saddle is not kept back in its proper place, and the horseman's weight being thus thrown too forward, the action of the fore-quarter is impeded. Mere obliquity, however, is not sufficient for this purpose; for, without a proper development of muscle, the blade

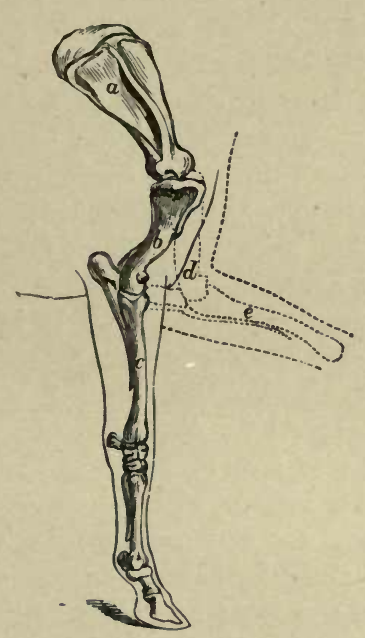

UPRIGIIT SHOULDER.

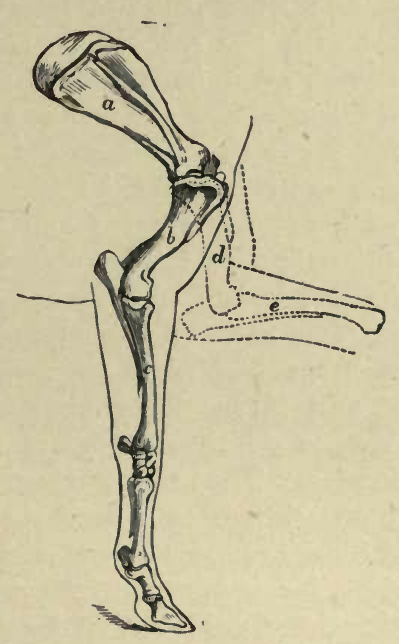

OBLIQUE SHOULDER

itself will not keep the saddle in its place. If, therefore, there is a hollow just behind the top of the blade, even if this is slanting enough, you must expect the saddle to slip forward, and should, in all doubtful cases, be careful to put one on before concluding a purchase. The point of the shoulder should be well developed, but not showing any rough protuberances, which are equally objectionable with a flat or ill-developed point. The length of the true-arm is mainly dependent upon that of the blade; but sometimes, when this is oblique enough, the true-arm is short and upright, and the elbow stands under, or only a little behind, the shoulder-point. This is a very faulty conformation, and is seldom attended with good action. The chief defect in the elbow is seen when it turns inwards, and rubs so closely against the ribs that the finger can hardly be insinuated between them and it. Here the elbow is said to be tied or confined, and the horse is very apt to turn his toes out; while the opposite formation is indicated by turned-in, or "pigeon" toes, and turned-out elbows. It does sometimes happen, however, that the toes are turned in or out without affecting the 
elbow, but this is an exception to the rule. A long and muscular fore-arm is a sure accompaniment of strong and sweeping action, and should be carefully prized; in other respects there is little to be noted here. Next comes the knee, which should be broad, and when looked at from the front should be much wider than the limb above and below. It should taper off backwards to a comparatively thin edge, and should have a good development of the pisiform-bone, which projects backwards at its upper part. The leg, immediately below the knee, should be as large as any other part, and not "tied in" there, which indicates a weakness of this part. A bending of the knee backwards is called a "calf-knee," and is not objected to in eart-horses, in which it is by no means uncommon; but it is very apt to lead to strains of this joint in the race-horse or hunter. A knee naturally bending somewhat forward is much preferred by good judges, though, when it is the result of over-work, it is almost equally to be avoided with the calf-knee. Flat, and at the same time large, cannonbones, without gumminess, are of great importance, and if attended with a full-sized suspensory ligament, and with strong, clean, and free back sinews, the leg is to be considered faultless. The fetlock-joint should be of good size and clean, whilst the pasterns should form an angle with the ground, of between forty-five and sixty degrees. Lastly, the foot should be well formed; but the construction of this part being hereafter more fully described, I shall omit its consideration here.

In trie Middiepiece the withers come first under notice. It is usual to desire them high and thin, but they are very commonly too much developed, and if the bony processes stand up like the edge of a razor, without muscle on them, they are to be regarded us objectionable rather than otherwise. The inexperienced horseman is apt to consider the existence of high withers as a sure sign that the saddle will be carried well back, but there are some horses whose withers are the greatest annoyance to the rider, for having upright and short shoulder-blades, together with high withers, the saddle rides forward upon the latter, and chafes them in spite of all the padding which can be introduced. In looking at this point, I believe the purchaser should almost entirely disregard it, excepting to take care that it is not too high for the formation and position of the shoulder-blades. If these are long, and therefore slanting, and especially if in addition to a proper position of the bones they are furnished with plenty of muscle, the withers may be disregarded, and the action may be expected to be good even if they are so low as to show no rise between the neck and the back:

The volume of the chest is the measure not only of the capacity of the lungs, but of that of the large organs of digestion. Hence, unless there is a middlepiece of proper size, the wind is seldom good, and the stamina of the individual will scarcely ever be sufficient to bear hard work. But there is a limit to the development of this part in those breeds which are required to move with much velocity, where weight is a great object; and if the body of the race-horse or hunter was as heavy as that of the drayhorse, the speed would be greatly reduced, and the legs would give way during the first severe gallop. So also, a wide chest interferes with the free and rapid action of the shoulders and arms as they glide on the ribs; and an open bosom is almost always fatal to high speed. In the race-horse 
and hunter, therefore, capacity of chest must be obtained by depth rather than width; while in the cart-horse, a wide chest and a frame roomy in all directions is desired, so as to give good wind, and, at the same time, enable the animal to keep up his flesh while working eight or nine hours per day. For light, quick draught, a formation intermediate between the two is the proper one; the large frame of the cart-horse being too heavy for the legs to bear at a fast rate, and leading to their rapid destruction in trotting over our modern hard roads. The capacity of the lungs is marked by the size of the chest at the girth ; but the stamina will depend upon the depth of the back ribs, which should be especially attended to.

A sHorT BACK, with plenty of ground covered nevertheless, is the desideratum of every practised horseman. Unless the measurement from the shoulder-point to the back of the quarters is somewhat greater than the height at the withers, the action is confined, especially in the gallop, for the hind-legs cannot be brought sufficiently forward on account of the interference of the fore-quarter; and, indeed, from the want of play in the back, they are generally too much crippled in that respect. A horse "short above and long below" is the perfection of shape in this particular, but he is not very commonly met with. Where length below is seen, there is generally too much space between the last rib and the hip, while, on the other hand, coupled with a short back we too often see the legs all " jumped up together," and the action short and stumpy. Next to these points in the middlepiece, it is important to pay attention to the upper line of the back, which should bend down a little behind the withers, and then swell out very gently to the junction with the loins, which can hardly be too wide and muscular. The inexperienced eye will often be deceived by the hips, for if these are narrow the muscles rise above them, and make the loin and back look stronger than they really are, the contrary being the case where the hips are wide and ragged. This latter formation, though not so elegant as the level hip, is prized by the man who wishes to be carried well to hounds, and he will jump at a horse which would be passed over with contempt by the tyro as "a great rawboned brute." A slightly arched loin is essential to the power of carrying weight ; a much arched, or "hog " back, is almost sure to give uneasy action from its want of elasticity.

In examining the Hind-quarter, so much depends upon the breed, and the purposes to which the animal is to be put, that only a few general remarks can be given. Thus, for high speed, there should be plenty of length in the two bones which unite at the stifle-joint, without which the stride must be more or less limited in extent. The exact position of the hip joint not being easily detected, the tyro has some difficulty in estimating the length from it to the stifle-joint, but he can readily measure the - length from the root of the tail, either with his eye or with a tape, if he cannot depend upon his organ of sight. In a flat outline this will come to twenty-four inches in a horse of 15 hands 3 inches, but measured round the surface it will be two inches more. Again, the lower thigh or gaskin should bo of about the same length; but if measured from the stifle to the point of the hock it will be fully twenty-eight inches in a well-made horse of high breeding. These measurements, however, will be much greater in proportion than those of the cart-horse, who requires strength before all things, 
and whose stride is of no consequence whatever. In him, the length of the upper or true thigh is generally as great as that of the thoroughbred, but the lower thigh is much shorter, and the horse stands with a much straighter hind-leg, and consequently with his hocks making a very slight angle. Muscular quarters and gaskins are desirable in all breeds; for without strong propellers no kind of work to which the horse is put can be duly performed. The judge of a horse generally likes to look at the quarters behind, so as to get a good view of their volume, and unless they come close together and leave no hollow below the anus, he suspects that there is a want of constitution, and rejects the animal on that account. But not only are muscles of full size required, but there must be strong joints to bear the strain which these exert, and one of the most important of all the points of the horse is the hock. This should be of good size, but clean and flat, without any gumminess or thoroughpins, and with a good clean point standing clear of the rest of the joint; the "curby place" and the situation of spavin should be free from enlargement; but to detect these diseases a considerable amount of practice is required. Lastly, the hocks should be well let down, which depends upon the length of the thigh, and ensures a short cannon-bone. The pasterns and feet should be formed in correspondence with those of the fore extremity, to which I have already alluded.

Such are the recognized points to be desired in the horse; but in spite of the general opinion of good judges being in favour of them, as I have described, no one can predicate with certainty that a horse possessing them all in perfection will have a corresponding degree of action out of doors. No one who has bought many horses will be content. with an inspection in the stable, even if the light is as good as that of the open air, for he well knows that there is often a vast difference between the estimate of the value of a horse which he forms indoors and out. Much of this depends upon the temper of the individual, for if he is dull and heavy he will not "make a good show," though still he may be capable of being sufficiently excited by hounds, and many such horses are invaluable hunters. Independently, however, of this element, it will be sometimes found that the frame which looks nearly perfectly symmetrical while at rest, becomes awkward and comparatively unsightly while in motion; and the horse which is expected to move well will often be sent back to his stall with "That will do, thank you," after a single run.

It is but right to say that there are many exceptions to the above general points, and every now and again a horse as ugly as a camel turns out to be a fine performer. One of this class which excited ridicule in the Leicester country was taken to France by the owner, who declared that no one under the rank of an emperor was worthy to own him, and whether on his merits or not we cannot say, but Napoleon III. bought him on seeing him ridden over a country by the English veterinary surgeon to whom he belonged. 


\section{PROPORTIONS OF THE VARIOUS POINTS}

THE proportions of the component parts of the horse, as I have already remarked, vary a good deal in the different breeds. The following, however, may be taken as the most perfect; but they refer especially to the racer, hunter, and hack, as well as to the lighter and more blood-like harness horses, and must not be strictly applied to the draught-horse in any of his varieties:-

Height at withers and eroup . . . $\quad 63$ From the withers to the hip . $6 . \quad 0^{\text {inches. }}$ inches.

Length from shoulder-point to quarter. 66 From the stifle to the point of the

From the lowest part of chest to the hock, in the attitude shown in ground ....... 36 the plan . . . . . . . 28

From the elbow-point to the ground 39 From the root of tail to stifle-joint : 26

From the withers to the pole, just be- From the point of the hock to the

hind the ears, in a straight line . 30 ground ........... 221

The same measured along the crest .32 Length of arm from the elbow to the

Length of head ....... 22 pisiform-bone........ 191

Width across the forehead $: 9_{2}$ From the pisiform-bone to the ground $19 \frac{1}{2}$ Girth varies from 76 to 79.

Circumference of fore cannon-bone, $7 \frac{1}{2}, 8,8,8,8 \frac{1}{2}$, and 9 inches.

Circumference of arm just below the elbow, $16 \frac{1}{2}$ to 18 inches.

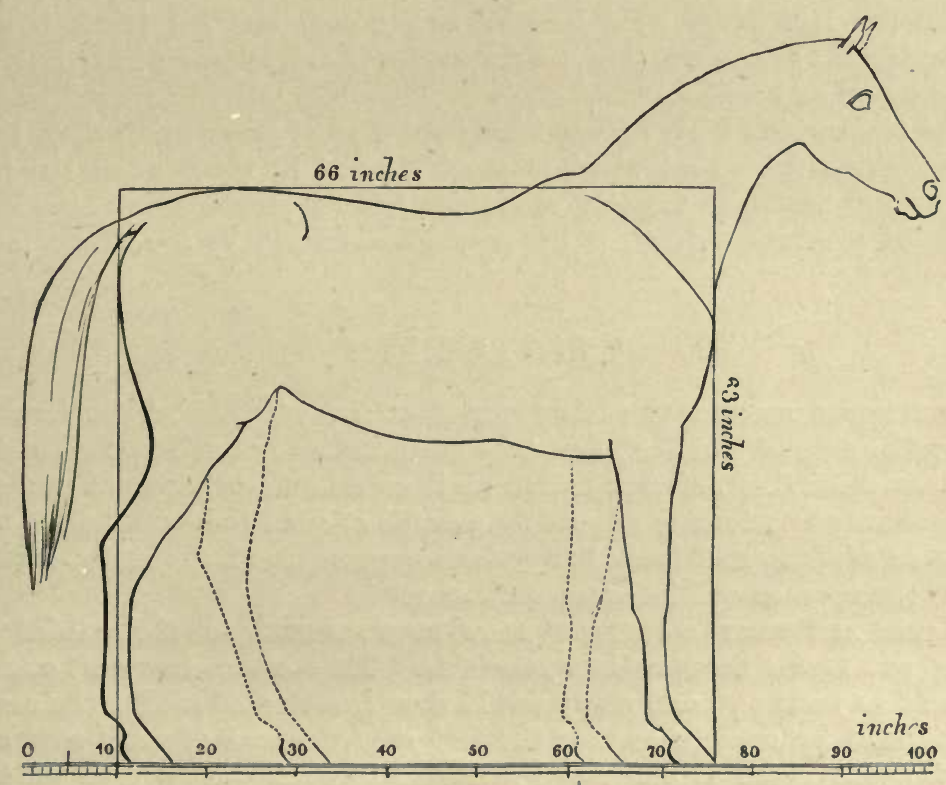

This scale is drawn in inches, and, in the outline, the horse is supposed to bo 15 hands 3 inches, or sixty-three inches high. The measurements are the average of those carefully taken from six horses considered to be of perfect symmetery. Two of these were celebrated stallions, two thoroughbred hunters, and two chargers of great value.

On comparing these measurements with those of Eclipse, as recorded 
by St. Bel, it will appear that there is some considerable variation from those of that celebrated horse, which he is said to have measured during life, and to have also checked his dimensions after death. Thus, though Eclipse was very low before, and yet was sixty-six inches high, his head was twenty-two inches long, being the same as the average length of the six horses given by myself, though they are three inches lower at the withers, and at least five inches lower at the croup. Again, though thus shown to be particularly short, it must have been of extraordinary width ; for, according to the same authority, it measured one foot across below the eyes; but, as Mr. Percivall remarks, this must be a mistake for above the eyes. Indeed, I cannot help thinking, in accordance with the opinions of the above distinguished English veterinarian, that in other respects " there appears some discordance in his admeasurements " of Eclipse. Nevertheless, it may safely be assumed, according to Mr. Percivall's summing up, that "he was a big horse in every sense of the word; he was tall in stature, lengthy and capacious in body, and large in his limbs. For a big horse his head was small, and partook of the Arabian character. His neck was unusually long. His shoulder was strong, sufficiently oblique, and though not remarkable for, not deficient in, depth. His chest was circular. He roso very little in his withers, being higher behind than before. His back was lengthy, and over the loins roached. His quarters were straight, square, and extended. His limbs were lengthy and broad, and his joints large, in particular his arms and thighs were long and muscular, and his knees and hocks broad and well formed."

The scale which I have given likewise differs in many particulars, though only slightly, from that which is usually found in treatises on the horse; but I have preferred trusting to Nature herself rather than to the observations of previous writers, which may be consulted by the reader at any time.

\section{MATURITY}

THe hoRse COMPLETES his DENTtTion at five years old, when he may be said to be mature. At eight or nine years the lower teeth lose their marks, or black concavities, after which there is no reliable evidence of age, which can however be tolerably accurately guessed at from the length of the front teeth or nippers, and from the general appearance of the horse, especially about the eyes, as will be hereafter shown.

- Mares are very comonly allowed to breed in their third year, being put to the horse as two-year olds. They often, however, come "in season" as yearlings, and many would then breed if allowed to be covered. It is found by experience that the foal robs the dam of some part of the nourishment which is destined by nature to develop the maternal frame, and hence the young mare is injured in size and substance if she breeds before she has come very near to maturity.

\section{AVERAGE AGE}

The average AGE of the horse, when allowed to live without the risk of accidents and disease which he incurs in his usual work, is about 
twenty-five years. Instances of greater longevity are recorded on good authority, and there is reason to believe that occasionally he has reached to thirty-five or even forty years, but these are rare exceptions, and there are few which live beyond the twenty-eighth year, while a large proportion die before the twenty-fifth. Stallions are over-fed and under-exercised in proportion, so that it is no wonder they become diseased, and seldom die from old age; but brood-mares are not so mismanaged, and it is found that they become quite worn out soon after their twentieth year; and even if allowed to live they waste away and die by degrees, generally somewhere between their twenty-third and twenty-eighth year. The charger ridden by the Duke of Wellington at the battle of Waterloo is said to have attained to the age of forty-eight years.

In 1872 there was a horse at Arundel, in Sussex, which made two daily journeys to and from the town to the railway-station in a single-horse omnibus, and he was well known at that time to be thirty-nine, the greatest age the editor has been able to find that any horse actually did serviceable work. There can be no doubt that many horses attain to a good age, but the difficulty of getting accurate information on the subject is owing to the fact that old horses are destroyed by the merciful, and those not so disposed of, fall into the hands of poor men and low-class dealers who do not sell them as older but younger than when they bought them. An examination of dead horses at the great slaughterers' reveals the fact that the majority die young, the middle-aged are comparatively fow, while the very old constitute a considerable proportion.

\section{PERIODICAL MOULTING}

THE HORSE SHEDS HIS COAT once a year in all countries, and in our climate a second half-moult is performed in the autumn, when the summer short coat is partially shed. This second change consists, however, chiefly in a growth of the already existing hairs, which become coarser and longer, especially about the legs and under-parts of the body. At the same time the coat loses its gloss, and the colour is less rich, blacks becoming rusty brown, and bays more yellow or sandy-coloured than before. The hair of the mane and tail is constantly in a state of growth, and is not shed periodically.

\section{MENTAL DEVELOPMENT}

IN MeNTAL DEvelopuent the horse ranks below the dog, but he is capable of a considerable degree of education, though in countries where he is kept constantly confined he does not appear to great advantage in this respect. That he may be made to understand what is said to him is clear enough from the mode of managing farm-horses, which are all taught to obey the voice. I have on one occasion seen a circus-horse walk, trot, and gallop at the word of command, and change his paces on the instant; but this feat I have never known performed by any other exhibitor, nor do I think it would easily be imitated. It requires a high order of intellect to distinguish between the three paces and change them on the instant, and if 
I had not myself witnessed the performance on two several occasions 1 should scarcely have credited it. The brain of this animal does not require much rest by sleep, and four or five hours in quiet are sufficient to keep him in health if he is not very hard worked. He readily sleeps standing, and some individuals never lie down; but this habit of sleeping standing should not be encouraged, as it greatly distresses the legs, and tends to produce fever of the feet, or some other mischief in the lower extremities.

\section{SMALL STOMACH}

ONE OF THE GREATEST PECULIARITIES in the structure of the horse is the small size of his stomach, which is also of a very simple nature. $\mathrm{He}$ is likewise without a gall-bladder, showing that the digestion must be continuous and not interrupted by distinct intervals, as in the ruminants and carnivora. Nature has thus framed this animal, in order that he may be at all times able to exert his utmost speed, which he could not do with the mass of provender in his stomach which is carried by the cow or sheep. The same provision is shown in the udder of the mare, which is not larger than that of the goat or sheep.

All these several characteristics of the horse will be more minutely considered under the different heads to which they each belong; but they are here grouped together to give a better general idea of the animal which is under examination. 


\title{
CHAPTER III
}

\author{
THE HORSES OF THE EAST
}

THE BARB-THE EGYPTIAN HORSE-THE DONGOLA HORSE-THE BURMA AND MANIPUR PONIES-SUMATRA AND JAVA PONIES-CIINESE AND COREAN TONIES-JAPANESE HORSES-THE MODERN ARAB-THE PERSIAN HORSE-THE TURKISH HORSE-OTHER ASIATIC HORSES-EAST INDIAN HORSES-THE AUSTRALIAN HORSE-SOUTH AFRICAN HORSES.

\section{THE BARB}

Tris KIND is named after the country in which it is found, which is rather an extensive one, comprehending the states of Tunis, Tripoli, Algiers, $\mathrm{Fez}$, and Morocco, all lying on the northern coast of Africa to the west of Egypt. Vegetation is very luxurious in the valleys watered by the streams which descend from the Atlas Mountains in their course to the Mediterranean, and grass is abundant in the early spring and autumn, but in the summer season the great heat burns it all up; and therefore the horse is dependent upon the care of man for fodder during a great part of the year. Berenger describes the true Barb as follows:-

"The fore-hand is long, slender, and badly furnished with mane; but the neck rises distinctly and boldty out of the withers; the head is small and lean ; ears, of good size, and well placed; shoulders, light, obliquely sloping, and broad; withers, thin and high; loins, straight and short; flanks and ribs, round, and well developed; haunches, strong ; croup, somewhat too long; quarters, muscular and full; legs, clean, and the tendons clearly marked and separate from the bone; pasterns, somewhat too long and slanting; feet, sound and of good shape. In size they are lower than the Arabs, seldom measuring more than fourteen and a half hands, and they have not as much spirit, speed, or endurance, although in external things they are perhaps superior to him."

The Godolphin Arabian, of which the annexed cut is a representation, is said to have been imported into France from Barbary, and is supposed to have been presented by the Emperor of Morocco to Louis XIV. as a fine Barb; but he was thought so little of in Paris that he was set to draw a cart about the streets, from which ignoble occupation he was rescued by Mr. Coke, and brought over to England. This gentleman gave him to a Mr. Williams, who kept the St. James' Coffee-house, and by him he was presented to the Earl of Godolphin for stud purposes. It was, however, only by chance that his value was discovered; for being used as teazer to 
Hobgoblin, he was merely put to Roxana on the refusal of that horse to cover her, the produce being Lath, one of the best horses of the day. The Godolphin Arabian was of a brown bay colour, and is said to have been about 15 hands in height. $\mathrm{He}$ is supposed to have been foaled about the year 1724, and died in 1753. A remarkable feature in this horse is the height of his crest, and he is also invariably represented with round and drooping

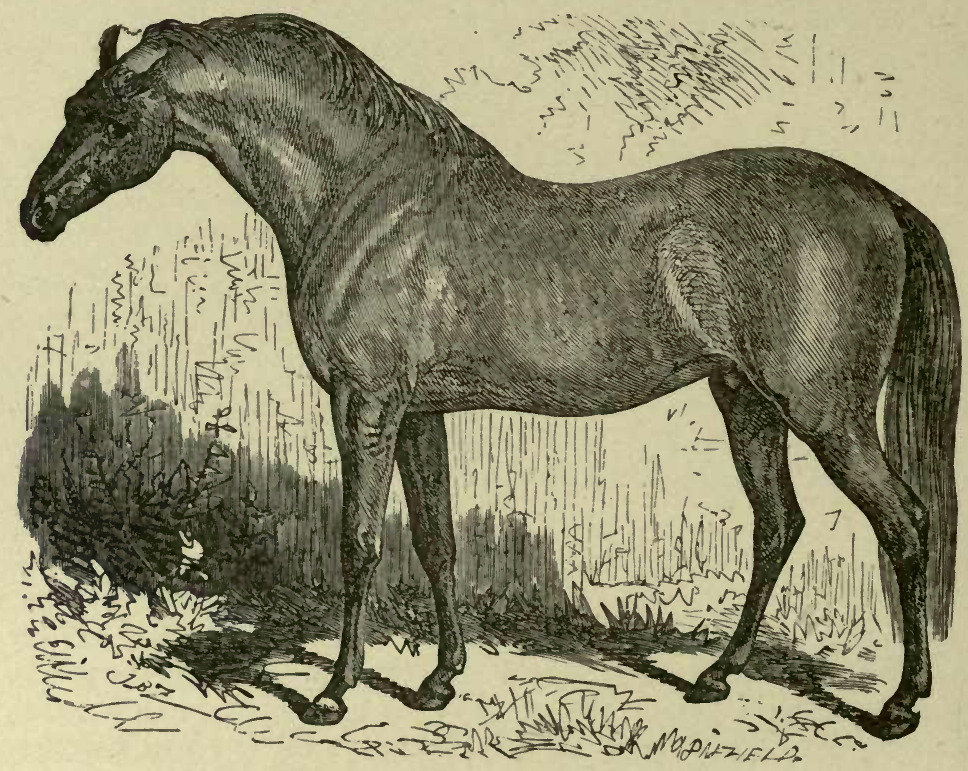

quarters. Several portraits of him are in existence, but all render these points in the same manner. I am not aware that there are any reliable grounds for considering this celebrated horse as a Barb rather than an Arab, and according to the usual description of the former, his size is against the hypothesis. - Still, as he is generally so considered, I have added his description to that of the Barb, leaving my readers to draw their own conclusions.

\section{THE EGYPTIAN HORSE}

IN THE FIRST Chapter I have shown that there is a strong reason for believing that the horse was introduced to Arabia through Egypt, and that the latter country again derived its supply from the central regions of Africa, which probably also furnished the Barbary States. The modern Egyptian horse is a very second-rate animal, and, according to Burckhardt, ${ }^{1}$ "is ugly, of coarse shape, and looking more like a cart-horse than a racer." He says, "Their legs and knees, and short and thick necks, are frequent

1 Since Burckhardt wrote the above description, the British occupation has had the effect of greatly improving the native horses, and no doubt can be entertained that lasting benefit will accrue from the importation of English blood-horses and Australian "Walers." 
defects among them. The head is sometimes fine; but I never saw good legs in an Egyptian horse. They are not able to bear any great fatigue, but when well fed their action occasionally is more brilliant than that of the Arabian; their impetuosity, however, renders them peculiarly desirable for heavy cavalry, and it is upon this quality alone that their celebrity has ever been founded."

Many Egyptian ponies have been trained for polo and sent to this country, where, if they have not distinguished themselves in competition with the miniature blood-horses of Irish nationality, they have taken a good place, the chestnut "Khalifa," owned by Mr. Drybrough, being deemed worthy of a portrait in Mr. Miller's Modern Polo. In describing Egyptian ponies that gentleman says, that "of half-a-dozen, each will differ from the other five, and that the importation of Syrian Arabs and continual crossing makes it difficult to define what is or is not an Egyptian," as they "are of all sorts and shapes," without any special characteristics of a well-defined breed. Those passing under the name of Bellady ponies are believed to be Egyptian, but according to the above quoted authority the term is used to distinguish them from Syrians.

\section{THE DONGOLA HORSE}

The Dongora Honse was formerly esteemed by Europeans in Egypt and the Soudan on account of his height, "his one merit," according to Mr. Wilfrid Blunt, who further states that "he is very nearly extinct as a breed, though a specimen or two is occasionally to be seen in Egypt. I don't think it is much loss, except as a curiosity, for he is an ungainly beast, with all the points an Arab breeder would most avoid, a coarse head, long cannon-bones and a drooping quarter." $\mathrm{He}$ is generally bay or dark bay with four white legs, and his height as much as 15 hands 2 inches or 15 hands 3 inches, but at present he is neglected and almost unknown.

The following account is from the pen of Slatin Pasha, who, it will be remembered, passed so many years of captivity under the Khalifa :-

"Regarding the Dervish horse, whether he be of the Dongola, the Darfur, or the Abyssinian breed, the first fact which is impressed on the observer is that the owner is a bad horse-master, and on further experience he will be found to be a careless breeder and a negligent trainer.

"The Khalifa's oppression has depopulated nearly 75 per cent. of the Sudan; it has also rooted out the best of the once famous breed of Dongola horses, and is answerable for the destruction of many thousands, and the degeneracy of nearly all the horses of the Nile basin during the period of war, famine, and brigandage, from 1885 to 1896 .

"Every suitable foal, horse, and mare has been seized by the Baggara raiders, and frequently had its miserable existence terminated by being ridden to death or allowed to die of thirst in the desert.

"In the recent forced march by Osman Digna, in the spring of 1896 , from Kassala to Suakin and back to the Atbara, more than half his animals and probably most of his cavalry horses died of exhaustion.

"Of the horses captured at the battle of Firket, the foals were all in a 
miserably neglected state, and most of the horses had galled backs and tender feet ('heffi') from marching on rocky ground. Only the horses of a few Emirs were in good condition. What different treatment did the noblest of animals receive in the Sudan twenty years ago.

"Fast-trotting, upstanding pairs of Dongola horses were much prized in Cairo, and a well-matched pair would fetch $£ 100$. The best saddle-horses

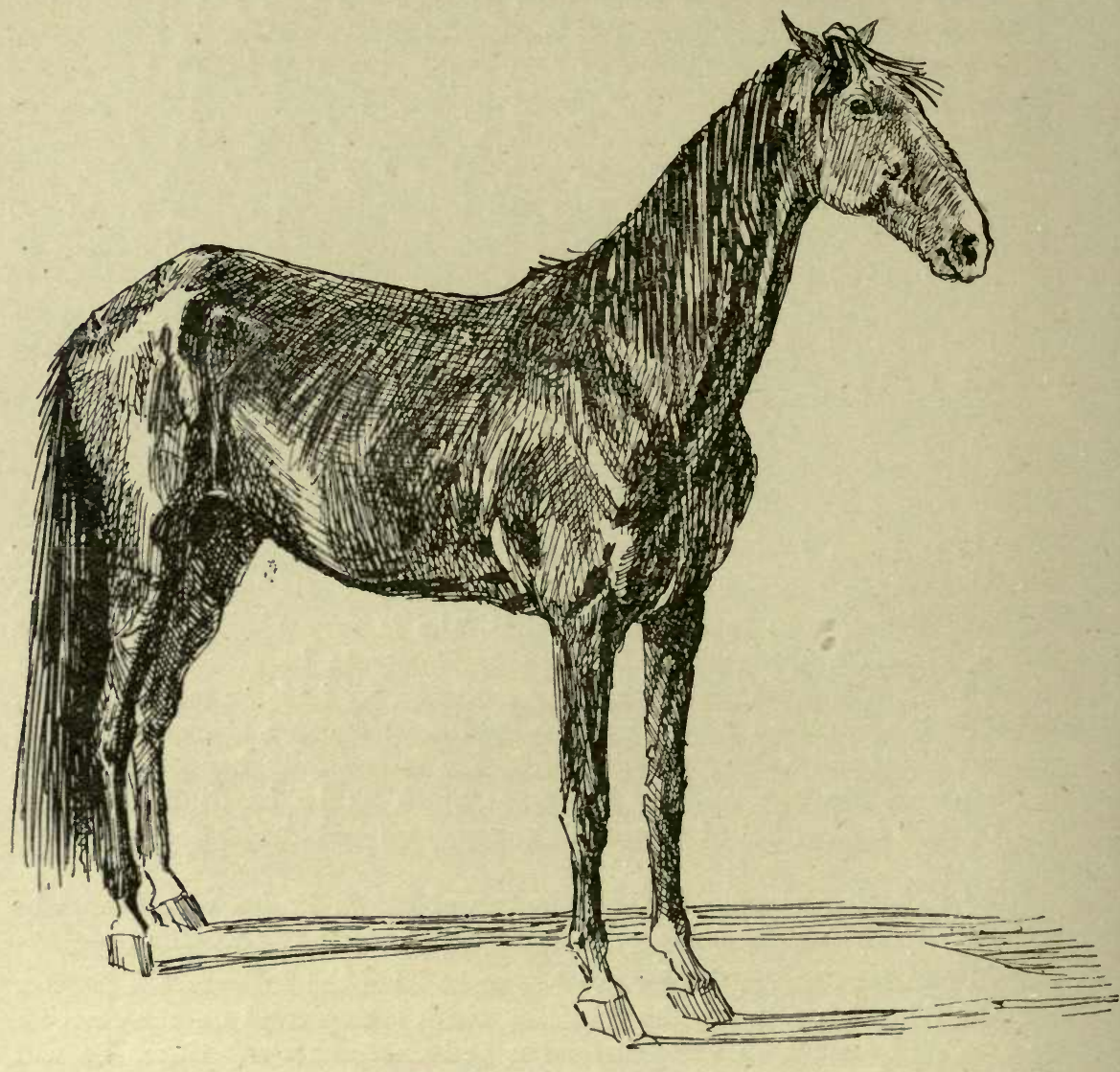

DERVISH CAVALRY IYORSE.

Spccimen captured at the battle of Firket, drawn by Lieut. $N$. M. Smyth, and sent to the cditor by Slatin Pasha, 1896.

were descended from a well-known horse called Abu Dru. The Dona breed of the island of Argo, north of Dongola, is also celebrated, and a fable exists that it owes its excellence to a strain of supernatural blood introduced by a river-horse in the remote past. The peaceful inhabitants of the Dongola province, always with an eye to the main chance, were naturally careful of so valuable an inheritance in horseflesh. The Dongola horse was stabled in a well-built thatched shelter, brick houses being considered ill-ventilated; in summer-time he was picketed out at night. The winter 
coat was often clipped once in the season. Dhura, or barley for preference, was fed to the horse before and after daylight, and milk was often given in the evening. During four months of the spring the horse was put out to grass, and dates were given as a change in season. Water was kept in a jar always standing in the stable, and the horse would often be given a fresh drink before and after the heat of the day.

"In size the Dongola horse ranges from 16 hands to about $14 \frac{1}{2}$ handsthe usual height. The head is coarse and long from eye to muzzle, the ears large, the withers high, sides somewhat flat, the hips ragged, the quarters weak, the tail put on too low; long fetlocks are preferred for speed, short fetlocks for long marches. The hocks are coarse and curved, the legs deficient in bone. The feet are not shod. Another fact fully appreciated by the Sudani is that white hoofs are less suitable for work in rocky districts than black feet. The feathered heels, want of bottom, and underbred character of the horse, which is only a three-furlong courser, and has not a point in common with the Arabian, tend to cause me some astonishment at the claim to Arab descent which has been put forward by a French author. The colour varies: browns, bays, and chestnuts are commonest, and greys comparatively rare, though thought well of.

"The Darfur pony bears little resemblance to the true Dongola horse, bus an admixture of the breeds has taken place since most of the Dongola horses were taken south by the Dervishes. The head is more shapely, the jowl more pronounced and the face less heavy; the back is shorter than that of the Dongola horse, the quarters more powerful and not sloping, the hocks are straighter, the bone is more compact, the animal hardier, smaller, but of stronger frame, well let down behind, and faster in proportion to its height, which is from 13 hands 1 inch to 14 hands 1 inch as a rule. The fastest runners are reputed to be chestnuts; the royal colour of the Sudan is bay; blacks are the strongest and most commonly seen, and, as in most Arab-speaking countries, various superstitions are connected with the combinations of colour. Thus a horse with four white feet and a blaze is much admired. Three white feet, two being on the near side, is considered lucky, but if the dark foot be on the near side the horse is ill-fated. If the white extends to above the hock or knee of one leg only the rider will be wounded in battle. If the blaze be not straight the horse will be unlucky for a single owner, and he should arrange a part ownership.

"A proof of the quality of the Darfur horse is to be found in the method of hunting ostriches in vogue among the Hamr, Saiädía, and Maharía Arabs. An ostrich on being sighted is immediately pursued at full speed; the bird taking fright runs away for three or four miles. Meanwhile the horseman reins in and proceeds to track the bird slowly. The ostrich finding itself no longer followed and prompted by curiosity now runs back at speed along its tracks; on sighting it the horseman again pursues at a gallop for a short distance, the bird dashing away as before at full speed and eventually returning again at the same pace. The tactics may be repeated three and four times until the ostrich shows signs of exhaustion by dropping its wings instead of holding them extended above its back, at which the Arab literally rides a finish up to the bird and clubs it.

"The Darfur horse is usually picketed under trees and fed on corn and camels' milk, being watered once a day, late in the afternoon, or by 
some tribes only every second day; but careful training precedes a hunting excursion which may continue for one or two months during which no corn is obtainable, and the rider's life may depend upon the fettle of his mount. For two months in the winter the hunter is given no work but as much corn and grass as he can eat. A drench of six to eight gallons of boiled butter is administered to the horse, cast for the purpose, as a preliminary and at intervals of two or three times a fortnight. After nearly two months have elapsed grain only is fed and water once or twice a day for about ten days, during which the horse is schooled and the size of the stomach reduced. The horse is now considered fit for the chase of the giraffe, elephant, antelope, or buffalo.

"It may be added that the Saiädia and Hamr tribes of camel Arabs keep the best animals, the former owning a cross between the Darfur and Arabian called the Gyouliat breed.

"During the rainy season no horses are taken south of the eleventh degree north latitude as an approximate line, owing to the prevalence of the tsetse fly.

"In Abyssinia, contrary to the general rule in the Sudan, most horses are cut, and mule breeding is extensively carried on. The horse is shaped like that of Darfur, but is smaller and up to very little weight. The Galla country is the principal breeding-ground, to the north of which the royal breed named Gena Fingan is to be found, though said to have degenerated very much from in-breeding, since for a long time it was kept entirely apart.

"As I have no experience and little exact information of the Abyssinian horse, I will merely add that it does not hold a very high place in the estimation of the wild horsemen who roam the pastures of the Sudan and Central Africa."

\section{THE BURMA AND MANIPUR PONIES}

The Burma Pony is a stout useful little fellow, up to great weight, not by any means fast, but a good jumper and very hardy. The Shan Hills are the home and birthplace of this variety, but he is called a Fegu as often as not.

The Manipur is a distinct breed, smaller, quicker, and better looking. This pony is famous for polo, which may almost be said to "run in the blood," as polo has been played in his country for centuries.

\section{SUMATRA AND JAVA PONIES}

A COMPACT BREED of PONIES about " 11 to 13 " hands are found in these countries. They have handsome heads, high crests, plenty of spirit, and great muscular power. It is a common sight to see one of these cobby ponies trotting away with a four-wheeled carriage containing four persons, and apparently doing it with all the ease in the world.

The Javanese are of the same type, but decidedly inferior to those of Sumatra, whether Deli or Acheen. 


\section{CHINESE PONIES}

These ane Mostly bred in Manchuria, and are strong useful animals about 13 hands in height. They have good feet and legs, are sure-footed, and with fair shoulders; are not bad mounts for steady work. Racing is much appreciated by the populace, but Europeans consider them too slow.

\section{COREAN PONIES}

IN TIIS COUNTRY of the comfortless, a very pretty pony is to be found, built as it were on Arab lines, but as diminutive as those of Iceland, 9 or 10 hands being a common size. $\mathrm{He}$ is said to be a good little worker, and for pluck and endurance much admired by those who have had the opportunity of putting him to the test.

\section{JAPANESE HORSES}

IN tHE MATter of horseflesh, Japan has not gone ahead as she has in nearly everything else, and her native horse is still a wretched slab-sided, weak, long-legged pony. The stout cobby ponies of Manchuria are imported and used to a considerable extent in the treaty ports. With the establish. ment of a race club there is a prospect of early improvement.

\section{THE MODERN ARAB}

The controversy relating to the value of this breed in the stud has raged with such vehemence that it is difficult to obtain an unprejudiced opinion upon it. One thing, however, is quite clear, namely, that to it in great measure we owe the pre-eminence of our English thoroughbred. But how long it would take to bring a modern Arab, even of the highest caste, to the state of perfection in which we find our own Ormes and Persimmons it would be difficult to say. This subject, however, will be better discussed in treating of the English breed itself.

The answer given to the above question by the late eminent veterinary surgeon, Mr. Mannington of Brighton, was "two hundred years." The editor, meeting him at a sale of Mr. Wilfrid Blunt's at Crabbet Park, asked Mr. M. if he were a buyer, and he replied that he would breed out roaring from English thoroughbreds if he had two hundred years to live. His opinion, like that of many other breeders and trainers of thoroughbreds, was that the Arab was no good in competition with the greater size of his English rival, but that for wind and endurance he could not be surpassed. It was formerly claimed for the Arab that his failure to meet English horses on equal terms was due to adverse climatic conditions, but the position has been frequently reversed and with the 
same result, the English thoroughbred horse maintaining his supremacy in every fair trial of speed.

When the earlier editions of this work were brought out, no large studs of Arab horses existed in this country, but we have now the advantage of seeing the effect of climate and conditions other than those with which this breed is associated. Mir. Wilfrid Blunt of Crabbet Park, and the Hon. Miss Dillon of Pudlicote, have bred Arabs for many years, and probably possess greater knowledge on the subject than any other two persons living. Both have favoured the editor with their opinions, which we insert in extenso:-

Mr. Blunt says, "In answer to your question about the effect of climate on Arab horses bred in England, I may say that my experience is that where the breeding is carried on, on the same rigid principles of bloodrelation as in Arabia, the type remains unchanged and with it the native advantages of the breed. I do not find any falling off in the points of constitutional hardiness and freedom from disease. On the contrary, the English-bred stock seems less liable in some ways to suffer than the stock I originally imported. This is especially the case with the eyes, where several of my imported mares have suffered from cataract without their produce being at all so affected.

"Of defects in the respiratory organs, roaring, whistling, and the like, we have not had a single case, nor do I think there is the least tendency in that direction.

"My mares and young stock after the first year stand out in open yards or in the fields all through the winter, and are none the worse for it.

"As to speed and endurance, I do not put my colts into training for racing, but as far as my experience goes there is little difference between the home-bred and the imported Arab. On the road and in the hunting-field they seem to have the same qualities. I have found home-bred ones do as long journeys in harness as those I brought from Arabia. Their action is certainly better than those bred in the desert.

"I am, however, of opinion-and on this point I acknowledge to a change of mind some fifteen years ago - that increased size and probably increased speed can only be obtained by a sacrifice of qualities of greater importance. The tallest Arabs are seldom those of the best blood, and to choose a stallion for his height to breed from, or even as a rule for his speed, is contrary to Bedouin practice, and in my experience is attended with poor results. Every inch over 14 hands $2 \frac{1}{2}$ inches takes away something from the purity of the type and the perfect organization of the animal, nor would I breed from a stallion over 14 hands 3 inches. In his own country it would be safer to put the standard two inches lower. The blood and the type are the essential things in a sire, next to them thickness (not height) and.action. I find these two last qualities improve in England, and weed out my tallest ones. It is a departure from this principle in the search for superior inches for military purposes that has caused the decay of some of the once excellent Arab studs abroad, notably those in Russian Poland. In the matter of courage and sagacity they are mainly inherited with the skull formation, but are also due in some measure to education. A horse brought up on the English system in paddocks and 
locse boxes cannot be expected to have the same fearless knowledge of the world as the same animal bred and handled in a Bedouin camp. The home-bred stock I believe to be precisely as teachable as the desertbred. They certainly inherit the original kindness of temper, and are less likely than horses of other blood to lose their heads in moments of difficulty.

"I may add that I consider the practical value of the Arab in England and the world in general, especially in Southern Europe and the hotter colonies, is for cross-breeding. Here in England I prefer the cross with the Suffolk Punch, which gives handsome carriage stock 15 hands 2 inches to 16 hands in height."

The Hon. Miss Dillon says, "I consider no horse is the equal of the Arab or Barb in power of endurance and long-continued work." Miss Dillon is our authority for stating that many horses of this type, under 14 hands 3 inches, are imported into France from Algeria at a cost of about $£ 12$, English, and they have the reputation of being very enduring and plucky. "Among my own high-bred horses I find the same indomitable spirit; they never seem to have enough, and, what is more, impart their most valuable virtue to their half-bred descendants. The size is decidedly very greatly increased in England by breeding from the largest specimens, due consideration being given to the alliances being in every other way suitable; still, sometimes the stock of an unusually big mare will fall short of her height. I have now a young horse that measured at three years 15 hands $2 \frac{1}{2}$ inches, and I believe he will reach 15 hands 3 inches. I have never had but one case of whistling or anything like it; that was after a very severe attack of influenza. Strange to say he entirely recovered and is now absolutely sound. I am sure that the Arab, large or small, is the weight-carrier of creation."

This lady speaks with a very great experience, her own stud-groom being well carried in the first flight on a 14 hands 1 inch horse with not less than thirteen stone above him.

AlI BEY, who has investigated the subject with great acuteness, and who has had opportunities beyond the reach of ordinary writers, describes six distinct breeds of Arabs. " The first," he says, " named the 'Dgelfe,' is found in Arabia Felix. They are rare at Damascus, but pretty common in the neighbourhood of Anaze. They are remarkable for speed and fire, yet mild as lambs; they support hunger and thirst for a long time, are of lofty stature, narrow in the chest, but deep in the girth, and with long ears. A colt of this breed at two years old will cost in its own country two thousand Turkish piastres.

"The second breed, called 'Seclaoni,' comes from the eastern part of the Desert, resembles the 'Dgelfe' of Anaze in appearance, but is not quite so highly valued.

"Next comes the 'Mefki,' handsome, though not so swift as the two former breeds, and more resembling the Andalusian in figure. They are very common about Damascus.

"Then the 'Sabi' resembles the 'Mefki'; and the fifth breed, called 'Fridi,' is very common, but it is necessary to try them well, for they 
are often vicious, and do not possess the excellent qualities of the other breeds.

"Sixth comes the 'Nejdi,' from the neighbourhood of Bussorah, and if they do not surpass, they at least equal, the 'Dgelfe of Anaze, and Seclaoni.' Horses of this breed are little known at Damascus, and connoisseurs assert that they are incomparable; thus their value is arbitrary, and always exceeds two thousand piastres."

The first and last of these breeds are those which are most sought after by East Indian sportsmen; and Colonel Bower, who is one of their strongest admirers, tells that he once possessed a three-year-old colt which stood 15 hands 1 inch at that age. He describes him as having "the stereotyped assortment of Eastern beauties: could stick his nose in a tumbler, and looked the gentleman all over; remarkably muscular, and as stately in his bearing as an autocrat, but his clean flat wiry legs, measuring eight inches round the shank below the knee, had nothing English in their composition. This was a pure Anaze Arab, but his career in the field was cut short by his casting himself in his stall, and dislocating his hip." It will be seen that no mention is here made of the breed which has been so long familiar to those who read our modern histories of the horse as that called "Kochlani" or "Kailhan," descended from the stud of Mahomet, who is supposed by many historians to have laid the foundation of the Arabian pedigrees. There is a tradition that the Prophet, being desirous of selecting mares for his stud, had a number of them which had been used as chargers kept for two days without water. At the end of that time, when mad with thirst, they were set at liberty, and at the moment when they were close to the coveted water, his trumpets sounded a war charge, which had such an effect upon five of them that they abandoned the water, and galloped to the spot where they expected to meet with the still greater excitement of war. These five were therefore selected to form the foundation of his stud, and from them it is supposed that the race called "Kochlani" are descended. There is a slight similarity between this name and that of the second in the list enumerated by Ali Bey, and perhaps his "Seclaoni" may be identical with the "Kochlani" of previous writers. It is asserted by Oriental travellers that pedigrees exist which can be traced five hundred years back, and in the highest breeds there is no doubt that at present great care is taken, and many ceremonies performed at the covering of the mare. After the birth of the foal, a certificate is always duly made out by the local authority, and this must be done within seven days of its being dropped.

ARABIA is, in great measure, made up of rocky mountains and sandy deserts; but in Arabia Felix there are numerous valleys of remarkable fertility; though it is chiefly on the limited oasis surrounding each well or spring of water that the Arab horses are dependent for their food. It is found even in this country that a very luxuriant herbage does not suit the horse, whose frame becomes coarse and heavy if he is reared upon the succulent grasses of rich meadows, and therefore it is probable that much of the wiriness of leg and lightness of frame in the Arab is due to the sandy soil in which the grasses of these oases take their roots. Besides this, the dry air may have something to do with the development of muscle and tendon, while the soft sands of the desert render it unnecessary to protect 
the feet with iron shoes, and thus they are enabled to grow into the form which nature has designed for them as the most suitable to bear the superincumbent weight.

Pure Arabs are considerably smaller than our modern thoroughbreds, seldom exceeding 14 hands 2 inches in height. The head is remarkable for the width across the forehead, which is also full and square, while the muzzle is finer, the face more hollowed out, and the jaws more fully developed in their proportions than in any other breed with which we are acquainted. The eye is full and soft, yet sparkling with animation on the slightest excitement; the ear is small; the neck arched; the shoulders oblique, but muscular : the withers moderately high and thin;

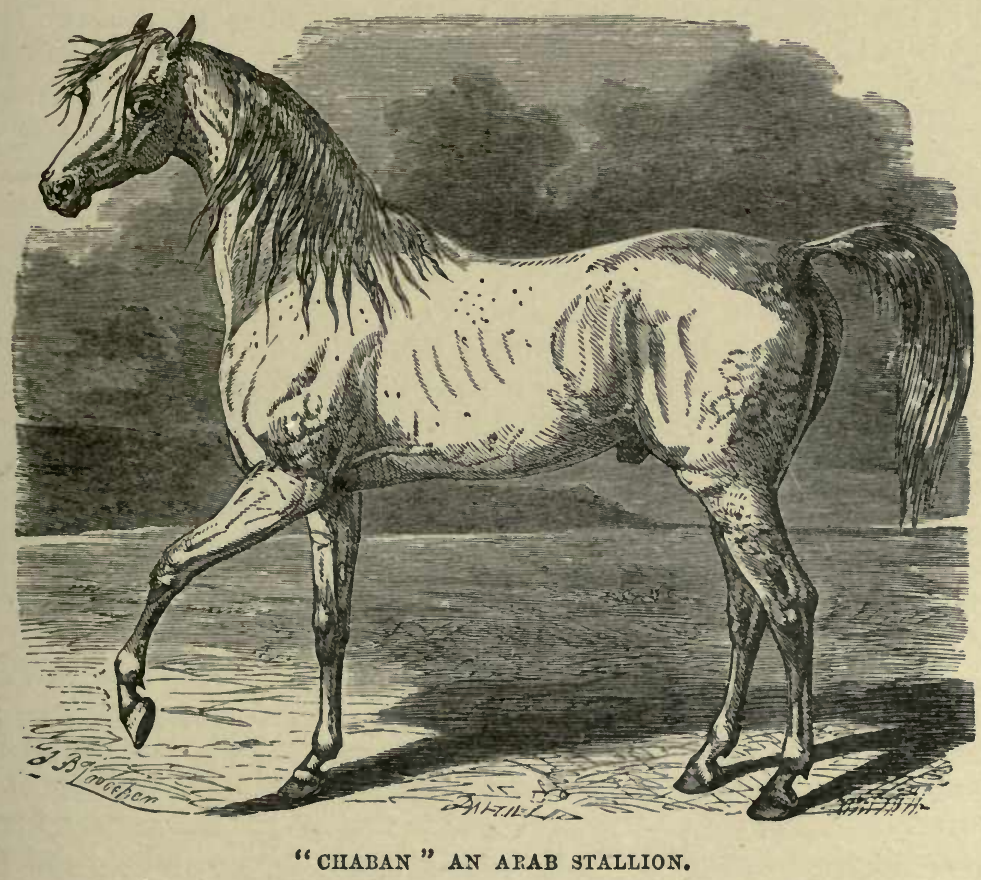

the chest rather light in girth, but the back ribs deep in proportion, and the hips, though narrow, well united to the back by a rounded mass of powerful muscles. The croup is high, and the tail set on with a considerable arch. The bones of the leg are large in proportion to the size, and the tendons full and free, the suspensory ligaments being particularly strong and clean. The hocks are large and free both from curbs and spavins; and, lastly, the feet, though small, are sound, and capable of bearing an amount of battering which few well-bred English horses can sustain. The prefixed engraving of "Chaban," an Arabian stallion shows most of these points extremely well, and the general characteristics of the breed are particularly well indicated by the artist, who took the sketch from a celebrated Arabian of high caste in the stud of the King of Wurtemburg. 
From the FULi, Development of the brain in this breed it might bo expected, à priori, that the amount of intelligence and courage possessed by them would be far above the average ; and such is the result of experience. Most of them are extremely docile, and in their native plains, where they pass their lives in constant communion with their masters, they are possessed of fine tempers; but if they are highly fed, and at the same time deprived of exercise and cruelly treated, their nervous system is so sensitive that they rebel, and when they fight they persevere to the death. A vicious Arabian is, therefore, a very unmanageable brute, and difficult to cure of his bad propensities. Good treatment, however, has its effect upon him, and when he once shows his forgiveness he may be depended on by the individual that he takes into his good graces. This trait was well exemplified in the savage Arabian tamed by Mr. Rarey, and in a still more marked manner in former years in the case of Chillaby, who was, if possible, more savage than Cruiser, and yet was so completely tamed by Hughes, the celebrated circus-horse trainer, that he was able to exhibit him as a trained horse, and was never once disappointed by him.

THE FOoD of this kind of horse is of a very dry though nourishing nature, and neither when at liberty nor when tied up can he get much water, the prevalent opinion being that an unlimited supply of this fluid injures his shape, and interferes with his wind. It is said that the Arab horse is only fed twice a day; but I conclude that this only refers to his allowance of corn, and that in the intervals he is permitted to pick up what little dry herbage the soil affords. Wonderful stories are told of the distances which young colts are compelled to go when first mounted, but I confess that I look with great suspicion upon these travellers' tales. About five or six pounds of barley or beans, or a mixture of the two, constitute the daily allowance of corn, which is about the weight of half-a-peck of good oats, and would be considered poor feed by our English horses, unless the proportion of beans is very large.

THE colours of the Arabian horses are mostly bay, chestnut, and grey, but occasionally black. The skin itself of the grey horses is of a deep slate colour, and the manes and tails are darker than the rest of the body.

THE SPEED of the Arabs, which have recently been brought over to this country, is undoubtedly not nearly equal to that of our thoroughbred horses for courses of moderate length, that is, not exceeding two miles; and there is no reason to believe that at longer distances there would be any essential difference in the result. In the Goodwood Cup an allowance is made them of a stone, yet no Arab has ever had a chance of winning, and as far as this test goes they are proved to be inferior to the French and American horses. In India a difference of weight, varying from 1 stone to 1 stone 7 pounds, is made in favour of Arabs as against imported English horses, "in order to bring the two together" in racing parlance, yet even then few Arabs can compete with the second-rate horses which are imported from this country. Colonel Bower tells us that "in India the weights range from $7 \frac{1}{2}$ stone to 10 stone, and no uncommon timing for Arabs is 2 minutes and 54 seconds the mile and $a$ half ; 3 minutes and 52 seconds the 2 miles -it has been done in 3 minutes and 48 seconds, and the Arab that did it was once my property, and his name was the Child of the Islands. $\mathrm{He}$ was a daisy-cutter, and yet I have ridden him over the roughest ground and 
never detected him in a trip. A pleasanter, safer hack could not be, and a fleeter Arab the world never saw. He stood 14 hands 2 inches, bay with black points, wiry limbs, very muscular all over, and measured $7 \frac{3}{4}$ inches round a fore-leg of the finest bone and flattest sinew." This time is as good as that of the average of our Derbys, but the test is a very fallacious one, and unless the time is taken over the same course, and that in the same running condition, no comparison can possibly be drawn.

Captain Shakspear, in his work on the Wild Sports of India, gives the following most minute description of the Arab, as he is now met with in India. As it differs in some particulars from the accounts of other observers, I extract it entire. The price of a good Arab, he says, varies from $£ 150$ to $£ 200$, and there is plenty of choice in the Bombay and Bengal markets.

"The points of the highest caste Arab horse, as compared with the English thoroughbred, are as follow:-the head is more beautifully formed, and more intelligent; the forehead broader; the muzzle finer; the eye more prominent, more sleepy-looking in repose, more brilliant when the animal is excited. The ear is more beautifully pricked, and of exquisite shape and sensitiveness. On the back of the trained hunter, the rider scarcely requires to keep his eye on anything but the ears of his horse, which give indications of everything that his ever-watchful eye catches sight of. The nostril is not always so open in a state of rest, and indeed often looks thick and closed; but in excitement, and when the lungs are in full play from the animal being at speed, it expands greatly, and the membrane shows scarlet and as if on fire. The game-cock throttle-that most exquisite formation of the throat and jaws of the blood-horse-is not so commonly seen in the Arab as in the thoroughbred English race-horse; nor is the head quite so lean. The jaws, for the size of the head, are perhaps more apart, giving more room for the expansion of the windpipe. The point where the head is put on to the neck is quite as delicate as in the English horse. This junction has much more to do with the mouth of the horse than most people are aware of, and on it depends the pleasure or otherwise of the rider. The bones, from the eye down towards the lower part of the head, should not be too concave, or of a deer's form; for this in the Arab as in the English horse denotes a violent temper, though it is very beautiful to look at. Proceeding to the neck, we notice that the Arab stallion has rarely the crest that an English stallion has. He has a strong, light, and muscular neck, a little short perhaps compared to the other, and thick. In the pure breeds, the neck runs into the shoulders very gradually; and generally, if the horse has a pretty good crest, comes down rather perpendicularly into the shoulders; but often, if he is a little ewe-necked, which is not uncommon with the Arab, it runs in too straight, and low down in the shoulders. The Arab, however, rarely carries his head, when he is being ridden, so high in proportion as the English. $\mathrm{He}$ is not so well topped, which I attribute to the different way he is reared, and to his not being broken in regularly, like the English horse, before he is put to work. His shoulders are not so flat and thin, and he is thicker through in these parts generally for his size than the English tl or unghbred horse. His girth does not show so deep, that is, he does not look so deep over the heart; but between the knees and behind the saddle, where the English horse very often falls off, the Arab is barrel-ribbed; and this gives him his wonderful 
endurance and his great constitutional points. This also prevents him from getting knocked up in severe training or under short allowance of food, and in long marches. His chest is quito broad enough and deep enough for either strength or bottom. The scapula, or shoulder-blade, is both in length and backward inclination, compared to the humerus, or upper bone of the arm, quite as fine in the high-caste Arab as in the English horse; while both bones are generally better furnished with muscles, better developed, and feel firmer to the hand. But some of the very fastest Arabs have their forelegs very much under them; indeed, so much that no judge would buy an English horse so made. Yet, whether it be that this form admits of the joints between these bones becoming more opened, when the horse extends himself, or whatever be the cause, it is a fact that blood-horses thus made are almost always fast horses. The upper part of their shoulder-blade seems to run back under the front part of the saddle, when they are going their best. This formation is most common in the lower-sized Arab, and apparently makes up to him for his deficiency in height. The very finest-actioned Arabs have had this peculiarity of form. They are rather apt to become chafed at the elbow-points by the girths, and almost require to have saddles made on purpose for them. The elbow-point, that essential bone, which for the sake of leverage should be prominent, is fine in the Arab, and generally plays clear of the body. The fore-arm is strong and muscular, and is pretty long; the knee square, with a good speedy cut for the size of the animal, equal to the English horse; while below the knee the Arab shines very conspicuously, having a degree of power there, both in the suspensory ligaments and flexor tendons, far superior, in proportion to his size, to the English horse. These are distinct and away from the shank-bone; they give a very deep leg, and act mechanically to great advantage. The bone looks small, but then it is very dense, the hollow which contains the marrow being very small, and the material solid, more like ivory than bone, heavy, and close-grained. The flexor tendons are nearly as large and as thick as the cannon-bone. The pasterns and their joints are quite in keeping with the bones above them, and are not so long, straight, and weak as those of the English horse. The feet are generally in the same proportion : but the Arabs themselves appear to be very careless in their treatment of them. The body or centre-piece of the Arab horse has rarely too great length. This is a very uncommon fault in the pure breed; and there is no breed of horses that are more even in this respect than the Arab. Behind this, we come to a great peculiarity in the breed-his croup. I might say an Arab horse is known by it: he is so much more beautifully made in his hind-quarters, and in the way his tail is put on, than most other breeds. His loins are good; he is well coupled; his quarters are powerful, and his tail carried high; and this even in castes that have very little more than a high-bred stallion to recommend them. The straight-dropped hind-leg is always a recommendation, and almost all racing Arabs have it; and this, when extended, brings the hind-foot under the stirrup, and the propellers being of this shape give a vast stride, without fear of over-reach. The thighs and hocks are good; the latter very rarely know either kind of spavin or curbs. The points and processes are pre-eminently well adapted for the attachment of the muscles; while the flexor tendons of the hind-legs generally correspond with thuse of the fore. The hocks are not so much 
let down, nor the hind-legs so greyhound-like, as in the thoroughbred English horse. In stride, too, he is somewhat different, inasmuch as it is a rounder way of going, and is not so extended or so near the ground, but is more like a bound. However, there are exceptions; and I have bred pure Arabs whose stride, for their size, was very extended, and quite like that of English race-horses."

The Mare is commonly supposed to be more highly prized by the Arabs than the stallion; but this idea is said to be unfounded by the celebrated Abd el Kader, in a lighly interesting letter to General Daumas, which is published in the fifth number of Baily's Magazine of Sports. He remarks :-

"It is true that the foal proceeds from the sire and from the dam, but the experience of ages has proved that the essential parts of the bodysuch as the bones, the tendons, the nerves, and the veins-proceed always from the sire. This is beyond all doubt. The meanest Arab knows now that any malady specially belonging to the bones, under which the sire may be suffering at the time of covering, will be perpetuated in his produce, such as splints, bone and blood spavins, the shape of the bones, and all diseases of the vertebral column. The dam may give to her produce colour, and a certain amount of resemblance in form, the foal naturally partaking of some of the qualities of the animal which had so long borne it; but it is an incontestable fact, that it is the sire who gives strength to the bones, substance to the tendons, vigour to the nerves, rapidity of pace, in short, all the principal qualities. He also communicates what may be called moral qualities, and if he be unquestionably of high blood the foal is preserved from vice. Our fathers have said, El aônd pôr ma audouche hiela'A horse of noble race has no vices.' An Arab will lend his stud horse gratuitously; he never accepts payment for his services. To hire out a stud horse for money is, in the eyes of an Arab, an unworthy action, and is contrary to the generosity for which he is renowned, and although the law allows it, I have never known an instance of it. But though the Arab lends his stud horse gratuitously, he does not do so to the first comer, nor for any mare. No ; the suppliant is often obliged to make use of the intercession of persons of great interest, or even of his wives, if he would not see his request refused. On the other hand, the Arabs are very difficult in their choice of a stud horse, and if they cannot find one of pure blood, they prefer leaving their mares unproductive rather than put them to a common horse. To procure a good sire they do not hesitate to travel any distance. The proceeding has already intimated to you my conclusion, that the sire has more to do with the foal than the dam. And my conclusion is identical with the universal opinion of the Arabs. They say, El hôr ilebal el fahal"The foal follows the sire."

In corroboration of this opinion, he describes the Arab horses as distinguished under the following heads :- "El Horr, El Hadjim, El Mekueref, and $\mathrm{El} \mathrm{Berdoune.} \mathrm{El} \mathrm{Horr}$ is that in which sire and dam are both of noble race; that takes the lead. El Hadjim is that in which the sire is noble and the dam of common race; it is considered less than El Horr, its name IIadjim, 'defective,' being derived from the word 'Hurdjiss,' which signifies faulty. El Mekueref is that in which the dam is high-bred and the sire is half-bred; although this approaches the Hadjim, it is of much less value. The name of this class is derived from 'haraf,' mixed. El Hadjim is 
superior in quality on the same principle that a man whose father is white and whose mother is a negress is superior to him whose mother is white and whose father is a negro. El Berdoune is that class in which both sire and dam are badly bred. This animal is a stranger to our country. The value of a horse is in its breeding."

\section{THE PERSIAN HORSE}

Sir John Malcoly and Sir Robert Ker Porter, both of whom resided many years in Persia, are the chief authorities on this subject. The former says :- "A variety of horses are produced in Persia. The inhabitants of the districts which border on the Gulf still preserve here those races of animals which their ancestors brought from the opposite shore of Arabia. In Fars and Irak they have a mixed breed from the Arabian, which though stronger is still a small horse compared with either the Toorkoman or Khorassan breed, which are most prized by the soldiers of Persia. Both these latter races have also a great proportion of Arabian blood." Sir Robert thus alludes to them:- "The Persian horses never exceed fourteen or fourteen and a half hands high; yet certainly on the whole they are taller than Arabs. Those of the Desert and country about Hillah seem very small, but are full of bone, and of good speed. General custom feeds and waters them only at sunrise and sunset, when they are cleaned. Their usual provender is barley and chopped straw, which, if the animals are picketed, is put into a nosebag and hung from their heads; but if stabled, it is thrown into a lozenge-shaped hole, left in the thickness of the mud wall for that purpose, but much higher up than the line of our mangers, and then the animal eats at his leisure. Hay is a kind of food not known here. The bedding of the horse consists of his dung. After being exposed to the drying influence of the sun during the day, it becomes pulverized, and in that state is nightly spread under him. Little of it touches his body, that being covered by his clothing, a large nummud from the head to the tail, and bound firmly round his body by a very long surcingle. But this apparel is only for cold weather; in the warmer season the night-clothes are of a lighter substance, and during the heat of the day the animal is kept entirely under shade. At night he is tied in the courtyard. The horses' heads are attached to the place of security by double ropes from their halters, and the heels of their hinder-legs are confined by cords of twisted hair, fastened to iron rings and pegs driven into the earth. The same custom prevailed in the time of Xenophon, and for the same reason, to secure them from being able to attack and maim each other, the whole stud generally consisting of stallions. Their keepers, however, always sleep in their rugs amongst them to prevent accidents, and sometimes notwithstanding all their care they manage to break loose, and then the combat ensues. A general neighing, screaming, kicking, and snorting, soon rouse the groom, and the scene for a while is terrible. Indeed no one can conceive the sudden uproar of such a moment who has not been in Eastern countries to hear it, and then all who have must bear me witness that the noise is tremendous. They seize, bite, and kick each other with the most determined fury, and frequently cannot be separated before their heads and haunches stream with blood." 


\section{THE TURKISH HORSE}

Triss variEty seems to be merely the Arab developed by higher food into a larger size and more massive proportions. The horses of Constantinople are often 16 hands in height, with very elegant proportions and a crupper more highly developed than that of the Arab. They are said to be extremely docile, and the two specimens which $\mathrm{I}$ have seen imported into this country certainly bore out this character, both of them, though stallions, being as quiet as any English geldings. They had very high crests and arched necks; and this is said to be one of the characteristics of the breed. In the records of the turf in this country, many of the most celebrated sires are mentioned as Turks; but though imported from Turkey, it is very probable that some of these were genuine Arabs.

\section{OTHER ASIATIC HORSES}

The Horses of Tooriistan are described by Sir R. K. Porter as scanty in barrel, long in the leg, with ewe necks and large heads. When crossed with those of Persia, they, however, are said by him to produce a most magnificent animal, all elegance and elasticity, and of a stronger form and somewhat larger size than the best Arabians. Sir Alexander Burns attributes to them, on the other hand, a very high crest, and large and bony though somewhat long bodies. He says, also, that in Bokhara there is a breed of Kuzzak horses, sturdy and small, with shasgy coats and very long manes and tails, much and deservedly admired.

The Tartar Horses are small and narrow, with long necks, weak legs, large heads, and light middles. Nevertheless they are described as fast and untiring, and of the most hardy nature, so that they can support themselves on a quantity and quality of food upon which even our donkeys would starre.

IN VARIOUS PARTS OF TARTARY horses are found in a wild state, and present a rough inelegant form not unlike that of our New Forest ponies. In them the characteristics of the domesticated Tartar horse already described are exhibited in a marked manner, and there is every reason to believe that the two breeds are identical, and that the ranks of the latter are recruited from the enormous herds of wild horses which are found in countless thousands on the edges of the vast deserts of the country. They are generally of a red colour, with a black stripe along the back, and manes and tails of the latter colour, but almost always reddish at the roots of the dock and edges of the mane. The Tartars eat the flesh both of the wild and domesticated horse, and are said to cook the meat under their saddles. They also manufacture a drink called koumiss from the milk obtained from the mare, which is fermented and distilled into an intoxicating beverage.

Visitors to the Health Exhibition in London will perhaps remember a not very attractive corner of the grounds where these mares were kept and attended to by natives not at all remarkable for cleanliness, but in a condition fairly representative of their country. 
IN so vast a COUNTRy as INDia, it might be expected that numerous breeds of horses would be found, varying almost as much as the climates and soils of Bengal and Cabool. In the immediate neighbourhood of the three presidencies imported and country-bred Arab, as well as Persian and Toorkoman horses are common enough, as also are importations from the Cape of Good Hope, Australia, and Van Diemen's Land.

\section{EAST INDIAN HORSES}

The NATIVE HoRSES are small and hardy, and should not exceed fourteen and a half hands if quality and staying power are expected. They have good fore-hands, are clever jumpers, quick in turning, and consequently in request for sporting purposes as pig-sticking and polo. Though able to sustain a lot of work their legs are often ugly from such defects as cow-hocks, calf-knees, and turned-out toes. They can endure thirst and hunger, long marches, and carry heavy weights in proportion to their size.

\section{THE AUSTRALIAN HORSE}

The IrISHMAN'S FIFTH QUARTER OF THE WORLD is now abundantly supplied with horses of the first class, in size, speed, and stoutness, though less than a century ago the animal was altogether unknown there. At first, from the proximity of India and the Cape of Good Hope, the horses of these colonies, and those of inferior value only, were imported into the new settlement; but about the year 1835 great efforts were made by several enterprising settlers, both in the island of Van Diemen and also on the continent of Australia, and several horses of good breeding were imported from this country, especially by Mr. Wilmore in the former island. It was soon found that the climate is admirably suited to this animal, and there are now colonial-bred horses, adapted for the turf and the road, as well as for agricultural purposes, superior in soundness and probably in stoutness, even if they are deficient in pace, as compared with the British thoroughbred. Still I am inclined to believe that as the soil and climate are admitted to improve the appearance of the imported horses, as indeed they do all our domestic animals, and as disease of all kinds is extremely rare, so it will be found that in all good qualities the Australian horse is at least on a par with our own. Their breeders are so spirited and determined that neither money nor trouble is spared in procuring the best blood, an evidence of which is afforded by the fact that at the sale of Lord Londesborough's stud, the large sum of 3120 guineas was invested for Australia. This, probably, is the heaviest price yet paid at one sale by any colonial breeder, but numerous smaller speculations have been going on for years. Hence, the position attained by our friends over the water they entirely owe to the parent country; and I strongly suspect that before long we shall have to go to them ${ }^{1}$ to procure sound horses of high breeding for our own studs.

1 "In many parts of the interior of New South Wales and Queensland large mobs of wild horses ( $x$ r warrigals, as they are called) infest the outlying stations, to the great annoyance 
In loin, barrel, and croup Australian horses are not perhaps equal to our own, but they are superior in endurance and better jumpers, being lighter in the forehead and enjoying longer freedom on big runs, not being taken up for work as a rule until four years old. There are more thoroughbred horses capable of carrying weight in Australasia than in England, but it is found that imported sires are more successful in getting winners than those bred in the colonies. The racing ponies can be beaten by those brea in Ireland, but as a rule they are remarkably good.

\section{SOUTH AFRICAN HORSES}

ARE WEEDY AND SLOW, and have the appearance of a cross between the blood-horse and the Arab. For light weights and long journeys they are useful animals, as they have good legs and feet, and there are large tracts of country admirably adapted for horse-breeding, but here sickness is so prevalent that there is not much inducement to embark capital in it. "Salted" horses which have gained immunity from the disease fetch good prices, and it is probable that in course of time the virulence of the plague will die out, or a preventive be discovered.

The Basuto PoNY is a short-legged hardy little animal, but there is no pace in him as compared with English animals of his size.

and loss to the owners of the property, not only on account of the feed they consume, but also because the horses on the stations clear out and join their ranks. On many of the runs where large mobs are known to exist, the station hands are put on to run them into specially prepared yards, where the entires and old ones are destroyed and the balance broken in for station use or sent away to some market for sale. For some nights before the muster all the water-holes where they are known to drink are watched and the warrigals kept away from them, so that when they are tackled by the musterers they are more easily run down than they would otherwise be." (The Graphic, April 1896.) 


\title{
CHAPTER IV :
}

\author{
THE HORSES OF THE WESTERN HEMISPHERE
}

THE SOUTH AMERICAN HORSE-THE MUSTANG-THE MORGAN HORSE-THE INDIAN PONY -THE CANADIAN HOISE-THE AMERICAN TROTTER-THE AMEICAN THOROUGHBRED -THE VERMONT CART-HORSE-THE CONESTOGA DLAUGHT-HOLSE.

\section{THE SOUTH AMERICAN HORSE}

For SOME TIME AFTER THE DISCOVERY OF AMERICA, at the conclusion of the fifteenth century, the horse was entirely unknown in that hernisphere, but according to Azara a few specimens were introduced there by the Spaniards in the year 1535 , and in the year 1537 several were shipped to Paraguay. From these have been bred the countless herds which have since spread over the whole southern part of the western world, and passing the Isthmus of Panama have wandered into North America. In both these divisions the horse runs wild, wherever there are plains suitable to him, and not yet brought under cultivation; but it is in the south that the wild horse is to be found in the greatest numbers, on the extensivo plains which stretch almost unbroken from the shores of $\mathrm{La}$ Plata to Patagonia. Here herds numbering some thousands in each are to be met with, each under the guidance of a master stallion, who enforces entire submission to his will as long as he has the power to do so. Here the native Gaucho has only to throw his lasso, and he can at any time supply himself with a horse which will carry him for miles at a hand gallop, when he changes him for another, and is thus always mounted at a cheap and easy rate. In this way Captain Head rode all across the continent from one shore to the other, nearly using up one horse in the course of fifty or sixty miles, and then looking out for another before the first was so spent as to be unable to assist him in making the exchange. These wild horses greatly resemble their Spanish ancestors in make and shape. They are said to be possessed of a fair amount of speed, but not above the average of foreign breeds. They are, however, from their roving habits, in excellent wind, and it is said that a Gaucho has been known to ride one fresh caught nearly a hundred miles without drawing bit.

A few consignments of South American horses have been sold in England and at low prices. The venture seems to have been a failure, as many proved vicious and intractable. A more careful selection and preliminary 
education might have conduced to greater success, but the general verdict in this country was that they are a slab-sided, "three-cornered " lot, and unable to compete on any sort of terms with our own.

\section{THE MUSTANG, OR WILD HORSE OF NORTH AMERICA}

Like the wild horses of South America, those of Mexico and Cali. fornia are in all probability descended from Spanish blood, and indeed it is impossible now to discover, with anything like certainty, the source of the Indian ponies, large herds of which run wild in the northern and north-western parts of this extensive continent. So little do the Americans now know or care about these wild horses, that the late Mr. Herbert, who has treated of the American Horse in two vols. quarto, omits all mention of them, excepting the most cursory allusion to the Mustang as the origin of the Indian pony, in common with the Canadian horse. I shall, therefore, not weary my readers with extracts from Mr. Catlin's somewhat fanciful writings, but at once proceed to allude to the modern domesticated breeds of horses met with in the United States and Canada.

\section{THE MORGAN HORSE}

The Morgan Horse has been paraded in America as a distinct strain, kept pure in its own district for more than half a century, and descended from a single horse in the possession of Mr. Justin Morgan, a school-master in Vermont. In the year 1856 the Agricultural Society of Vermont offered a prize for the best essay on the subject, which was awarded to Mr. Lindsey, an inhabitant of the same state. According to this authority, the founder of the family, or strain, was got by a horse called "True Briton," which was said to have been stolen, and whose pedigree is therefore doubtful. Mr. Lindsey endeavours to prove, however, that he was a son of the English thoroughbred horse Traveller, which he assumes to be identical with the son of Partner, known as Moreton's Old Traveller, giving as his authority a pedigree inserted in the Albany Cultivator of 1846. The same authority is also adduced to prove that the dam of True Briton and also of Justin Morgan's horse were of nearly pure English blood, and that the latter was descended from the famous "Cub" mare; but the facts adduced seem of the most doubtful nature, and I believe that the Morgan horse would in this country be considered as undoubtedly half-bred.

Mr. Lindsey describes the founder of the Morgan strain in the following terms:- $-\mathrm{He}$ "was about 14 hands high, and weighed about nine hundred and fifty pounds. His colour was dark bay, with black legs, mane, and tail. He had no white hair upon him. His mane and tail were coarse and heavy, but not so massive as has been sometimes described; the hair of both was straight, and not inclined to curl. His head was good, not extremely small, but lean and bony, the face straight, forehead broad, ears small and very fine, but set rather wide apart. His eyes were medium size, very dark, and prominent, and showed no white round the edge of the 
lid" (Qy. iris ?). "His nostrils were very large. the muzzle small, and the lips close and firm. His back and legs were, perhaps, his most noticeable points. The former was very short, the shoulder-blades and thigh-bones being very long and oblique, and the loins exceedingly broad and muscular. His body was rather long, round, and deep, close ribbed up; chest deep and wide, with the breast-bone projecting a good deal in front. His legs were short, close-jointed, thin, but very wide, hard and free from meat, with muscles that were remarkably large for a horse of his size, and this superabundance of muscle manifested itself at every step. His hair was short, and at almost all seasons soft and glossy. He had a little long hair about the fetlocks, and for two or three inches above the fetlock on the back side of the legs; the rest of his limbs were entirely free from it. His feet were small, but well shaped, and he was in every respect perfectly sound and free from blemish. He was a very fast walker. In trotting his gait was slow and smooth, and his step short and nervous; he was not what in these days would be called fast, and we think it doubtful whether he could trot a mile much, if any, within four minutes, though it is claimed by many that he could trot it in three. Although he raised his feet but little, he never stumbled. His proud, bold, and fearless style of movement, and his vigorous untiring action, have perhaps never been surpassed."

He describes him as being fast for short distances, by which he explains that he means a quarter of a mile, which he says was the usual distance run in those days. From this celebrated horse are descended, more or less remotely, "Black Hawk," "Ethan Allen," "American Eagle," and a host of horses celebrated for gameness, and many of them for fast-trotting powers. But those who dispute the claims of Mr. Justin Morgan's horse to be considered the founder of the family, assert that before his time a similar horse prevailed in this district, which was made up of crosses between the Canadian horse and the English thoroughbred. I shall, however, leave this much-vexed question for the Americans to settle among themselves, contenting myself with a description of the modern Morgan horse as he is recognized throughout the states of America. He is generally, though not universally, admitted to be very stout and enduring, with good action, especially in the trot, and great hardness of constitution. He shows very little evidence of pure blood, indeed, it may be said that the reverse is the case, as he invariably possesses a thick and long mane and tail, with a considerable curl in both, signs which may be truly said are fatal to his claims. In height he seldom exceeds 15 hands. His frame is corky, but not remarkably well put together, there being generally a deficiency in the coupling of the back and loins. The forehead is very light, and carried high, somewhat in the fashion of the Canadians, but not so heavy in the crest and junction of the neck to the shoulder, though the setting of the head is equally thick. On the whole, the Morgan horse may be described as extremely useful, but deficient in what we call "quality," in proportion to the absence of thorough blood.

According to Mr. Herbert, who seems to have taken great pains to arrive at the truth, "with the one solitary exception of the Norman horse in Canada, no special breeds have ever taken root as such, or been bred, or even attempted to be bred, in their purity, in any part of America. In Canada East the Norman horse, imported by the early settlers, was bred 
for many generations entirely unmixed; and, as the general agricultural horse of the province, exists, yet so stunted in size by the cold climate and the rough usage to which he has been subjected for centuries, but in nowise degenerated, for he possesses all the honesty, courage, endurance, hardihood, soundness of constitution, and characteristic excellence of feet and legs of his progenitor." Besides this native Canadian there are also, among the more active kinds, the Morgan horse, the American trotter, and the thoroughbred descended from English imported horses, with scarcely any admixture of native blood; and of the agricultural varieties, the Vermont and Conestoga draught-horses, in addition to several others not so easily made out.

\section{THE INDIAN PONY}

The Indian Ponx, which seldom or never exceeds 13 hands in height, is remarkable for activity and strength, as compared with its size, appearing, like its Scotch congener, to be almost overwhelmed with its rider, whose feet nearly touch the ground, yet moving under its load with freedom. It has a high crest, and a flowing mane and tail, with a proud carriage of the head of a very pleasing character. The body is strongly built, and the legs and feet are made of the most lasting materials. Large herds of these ponies run wild in the prairies of the north-west, and many are brought into Canada for the use of the inhabitants.

\section{THE CANADIAN HORSE}

The Canadian Horse is a remarkably hardy animal, capable of travelling very long distances, but in his pure condition not above the average in speed. When crossed, however, with a thoroughbred horse, he combines the speed of the latter with his own endurance and iron constitution and legs, and in this way a great many of the best American trotters are bred. Mr. Herbert says, "His crest is lofty, and his demeanour proud and courageous; his breast is full and broad; his shoulder strong, though somewhat straight, and a little inclined to be heavy; his back broad, and his croup round, fleshy, and muscular; his ribs are not, however, so much arched, nor are they so well closed up as his general shape and build would lead one to expect; his legs and feet are admirable - the bone large and flat, and the sinews big and nervous as steel springs; his feet seem almost unconscious of disease; his fetlocks are shaggy; his mane voluminous and massive, not seldom, if untrained, falling on both sides of his neck, and his tail abundant, both having a peculiar crimpled wave, if I may so express myself, the like of which I never saw in any horse which had not some strain of his blood." I append a sketch of one of these horses, showing the shape and action peculiar to them. It is said by good judges to be an excellent likeness.

Since the above paragraph was written quite a large trade has sprung up in Canadian horses. The first few consignments of 500 each were carefully selected by Mr. Ffoulkes, M.R.C.V.S., and on landing in England were as carefully nursed through strangles and other troubles so often incurred in transit, and when offered by Messrs. Freeman at St. Martin's Lane 
realized something like 70 guineas apiece. They were well bred as a rule, with many of the points we usually associate with the English blood-horse, who doubtless had a share in their production. Many of them were 15 hands 3 inches and 16 hands high, with admirable tempers, fair action, and, as a rule, fast in harness. These may have been said to give general satisfaction, the "trade" having bought freely and taken kindly to them. The difficulty of procuring high-class horses and the expense of importation deterred the original company from prosecuting the business, but a very large trade has since sprung up in the useful kinds, and in London a

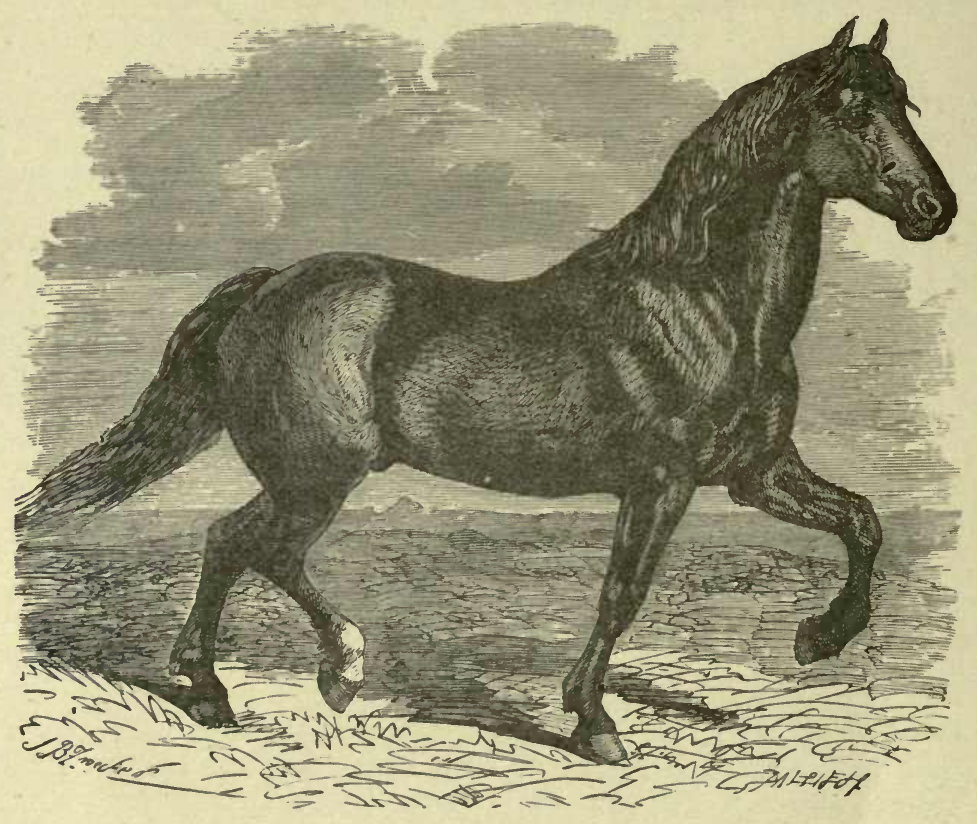

CANADIAN HORSE.

special sale yard for bi-weekly consignments. Some 40,000 so-called Canadian horses were imported into this country in the year 1897, but rather more than three-fourths of them came from the United States. They appear to be the result of several crosses with the original horses mentioned in the earlier editions of this work; many Clydesdales, Percherons, and other European sires contributing to the useful breed now all but established. It is thought that America will have always to renew her blood from Europe, as there is a tendency in horses as well as cattle to revert to the type of the country. The severe winters and hot summers are very trying to the constitution, and by the rule of the survival of the fittest there should be developed a breed more hardy than the stock from which they are derived. Nature, however, seeks compensation in some other direction, and stature is sacrificed, as in the hardy Shetland and Iceland pony, unless, as suggested above, the blood is recruited from the original stock. 


\section{THE AMERICAN TROTTER}

THE TRUE MODERN TROTting HoRse is a most remarkable instance of what may be done by keeping an animal to one kind of work for generations, and selecting the specimens best fitted for it to breed from. In this country a thoroughbred horse, or even one of nearly pure blood, could not be found at any price to trot a mile in three minutes, yet in America there are plenty, of blood almost entirely derived from the English turf horse, which will perform the distance in 2 minutes and 40 seconds, and some in considerably less time. In America private and public trotting matches in harness have been for many years the chief amusement of the town population, and, until very recently, when flat racing or running, as it is called there, has been more developed, a fast trotter fetched a higher price than any other description of horse. Trotting matches are, in fact, the national sport, just as racing is that of our own country.

The trotting time given in the original edition of this work, when Flora Temple did a mile in 2 minutes $19 \frac{3}{4}$ seconds, was thought too marvellous an achievement to be ever surpassed, yet we have seen the record broken by Maud S. and plenty of others since. "Jay Eye Sie" did the mile in 2 minutes $8 \frac{3}{4}$ seconds in 1885 , and more seconds have been chipped off the record in this last decade of the nineteenth century.

The most extraordinary performances of these trotters, as recorded in the American Racing Calendar, are as follows:-

\section{MILE HEATS.}

Flora Temple, b. m. in harness . . Kalamazoo, Mich. . Oct. 15, 1859 min. sec.

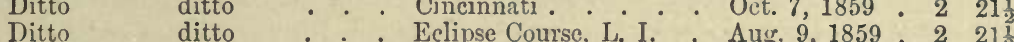
Tacony and Mack in 1853, Lancet in 1856, and Patchen in 1859, each in harness . $2251_{2}$ Ethan Allen, stallion, $105 \mathrm{lb}$. wagon . Union Course, L. I. . Oct. 28, 1858 . $228^{2}$

TWO MILE HEATS.

Flora Temple in harness . . . . L. I. . . . . . Aug. 16, 1859. $450 \frac{1}{2}$

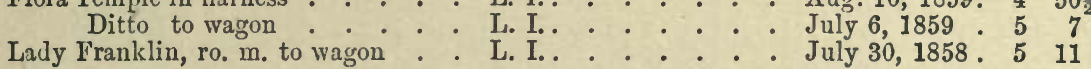

THIRE MILE HEATS.

Dutchman, b. g. under saddle . . . Beacon Course, N. J. . August 1839 - $732 \frac{1}{3}$ Ditto in harness. . . Beacon Course, N. J. . July 1839 . 742

FOUR MILES.

Trustee, ch. g. in harness. . . . . L. I. . . . . . . June 13, 1849. 116 Sally Green, br. m. $250 \mathrm{lb}$ wagon . L. I.. . . . . May 6, 1850 1356

FIVE MILES.

Mary Warren, b. m. to road wagon . L. I.. . . . . . July 5, 1854 - 1442 Lady Agnes, gr. m. in harness . . . L. I.. . . . . . Nov. 25, 1850. 1518

TEN MILES.

Prince, ch. g. in harness, driver to weigh 165 lbs. ....... $\}$

L. I.. . . . . Oct. $20,1849.28$

TWENTY MILES.

Trustee, ch. g. to ord. trotting sulky,

weighing 150 lbs., driver 145 lbs. .

L. I. . . . . . Nov. 11, 1853. $5935 \frac{1}{2}$

Lady Fulton, b. m. in harness . . . L. I.. . . . . . July 12, 1855 59 
FIFTY MILES.

hs. $\min$. sec.

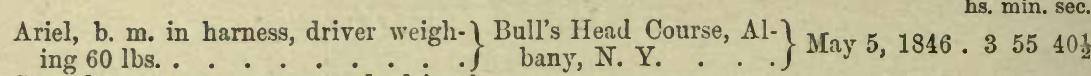
Spangle, sp. g. wagon and driver weighing 400 lbs.

L. I.

\section{ONE HUNDRED MIILES.}

Conqueror, b. g. in harness . . . L. I.. . . . Nov.12,1853. 8561 Fanny Jenks, in harness (feather-
weight). Bull's Head Course, Al- May 5, 1845 94257

Pacivg is considerably faster than trotting, as will be shown in the following recorded feats :-

MILE HEATS.

min. sec.

Pocahontas, ch. m. in wagon weighing
265 lbs. with driver. L. I. . . . . . . June 21, 1855 . $217 \frac{1}{2}$

Pet, r. g. in harness . . . . . . . L. I.. . . . . . Sept. 9, 1852. 2181

Hero, g. g. in harness . : . . . L. I. . : . . : May 17, 1853. $456 \frac{1}{2}$

Young America, b. g. wagon . . . S. Francisco . . . . Jan. 10, 1859. $458 \frac{1}{2}$

The extent to which match trotting is carried on in America may be guessed from the fact that Lady Suffolk won, at various times, 35,311 dollars, or more that $£ 7000$. The exact value of the stakes which have fallen to the lot of the owner of Flora Temple I do not know, but three years ago it amounted to 46,850 dollars. Mr. Herbert in his quarto work on The Horse of America clearly shows the reason why our transatlantic cousins excel us in their trotters, and why they take to this species of amusement in preference to others. After enumerating several which do not appear to us quite so cogent as to him, he more pertinently says, "Another reason, inferior in practical truth to the others adduced, but physically superior, is this - that before American trotters could be generally used in Great Britain, the whole system of British road-making must be altered, which is not likely to occur. On an ordinary English macadamized turnpike, which is exactly the same as the hardest central part of the New York Third Avenue, without any soft track alongside of it, an American trotter would pound his shoes off in an hour's trot, and his feet off in a week's driving; and this is doubtless, whatever may be said of the objections heretofore offered, one which must operate for ever against the general use of trotters after the American fashion, unless they be trained and kept exclusively for sporting purposes. This, however, is no more, but even less likely to occur than the total alteration of the whole system of English road-making, and the entire change of the tastes and habits of the English people: since the point which renders the trotting horse so popular here would then be wanting, namely, his equal adaptability to ordinary road driving and purposes of general utility, and to occasional matching and turf amusements of a peculiar though inferior description." This is the true cause of the "decline and fall " of trotting horses in England, for in the early part of the nineteenth century there were ten good performers on the trot for one now. The pace is not a natural one, and in its highest perfection, especially, it must be developed by constant practice. But this is forbidden on our modern roads, which, as Mr. Herbert truly remarks, would ruin the legs and feet of any horse 
ridden or driven at such a pace as to do a mile in two minutes and thirty seconds. I fully believe that the horses of America have sounder legs and feet than those of our own country, partly from being kept cooler in their stables, partly from their being less stimulated by inordinate quantities of oats and beans, but chiefly from their ancestors having been less injured by hard roads than those of our own. If this is the case we must have in every succeeding generation more and more difficulty in getting sound roadsters, and such, I believe, is really the fact.

By MANY people it is supposed that the American trotter is a distinct breed or strain of horses, and that we can in this country easily obtain plenty of horses able to do their mile "within the thirties," by importing individuals and breeding from them. This hypothesis, however, appears to be unfounded according to the evidence of Mr. Herbert, as recorded in his " magnum opus," and that of other writers in the New York sporting press. The former gentleman, who is "well up " on this subject, says:- "And first we shall find that the time-trotter in America is neither an original animal of a peculiar and distinct breed, nor even an animal of very long existence since his first creation. Secondly, we shall find that in an almost incredibly short space of time, owing to the great demand for and universal popularity of the animal, united to a perfectly devised, and now ubiquitously understood, system of breaking, training, and driving him so as to develop all his qualities to the utmost, the trotting horse of high speed, good endurance, showy style of going, and fine figure, has become from a rarity a creature of every-day occurrence, to be met with by dozens in the eastern and middle states, and scarcely any longer regarded as a trotter, unless he can do his mile in somewhere about two minutes and a half. Thirdly, it will appear that the trotting horse is, in no possible sense, a distinct race, breed, or family of the horse; and that his qualities as a trotter cannot be ascribed or traced to his origin from, or connection with, any one blood more than another. It is true, and it is to be regretted, that of trotting horses the pedigrees have been so little alluded to, and probably from the nature of circumstances are so seldom attainable, that few, indeed, can be directly traced to any distance in blood. Enough is known, however, to show that some horses of first-rate powers have come from the Canadian or Norman-French stock ; some from the ordinary undistinguished country horse of the southernmost of the midland states ; some from the Vermont family; some from the Indian pony; and lastly, some mainly, if not entirely, from the thoroughbred. To no one of these families can any superiority be attributed as producing trotters of great speed. All have shown their specimens by means of which to claim their share in the production. Only it may be affirmed, generally, that while some very famous trotting horses have been nearly, if not entirely, thoroughbred, the low, lazy, lounging, daisycutting gait and action of the full-blooded horse of Oriental blood is not generally compatible with great trotting action or speed. Still it is true that the best time-trotters have not the round, high-stepped action which is prized in carriage-horses, or parade-horses for show, and which probably originated and existed to the greatest extent in the Flemish or the Hancverian horse of the coldest of all imaginable strains of blood; and that they have in a great measure the long-reaching stride, the quick gather, and the comparatively low step of the thoroughbred." 
IN ORDER TO ESTIMATE the truth of this statement it is only necessary to investigate the pedigrees of the chief public performers in trotting and pacing. Among those most celebrated in the "fifties" may be mentioned Flora Temple, whose portrait is here reproduced.

\section{FLORA TEMPLE。}

This celebrated mare was got by a horse of doubtful pedigree, called "One-eyed Kentucky Hunter," out of a clever and fast-trotting mare, Madame Temple, who was said to be by a spotted Arabian sire. She was foaled in 1845, at Langerford, Oneida County, New York, and was sold by her breeder to Messrs. Richardson and Kellog, of Eaton, Madison County,

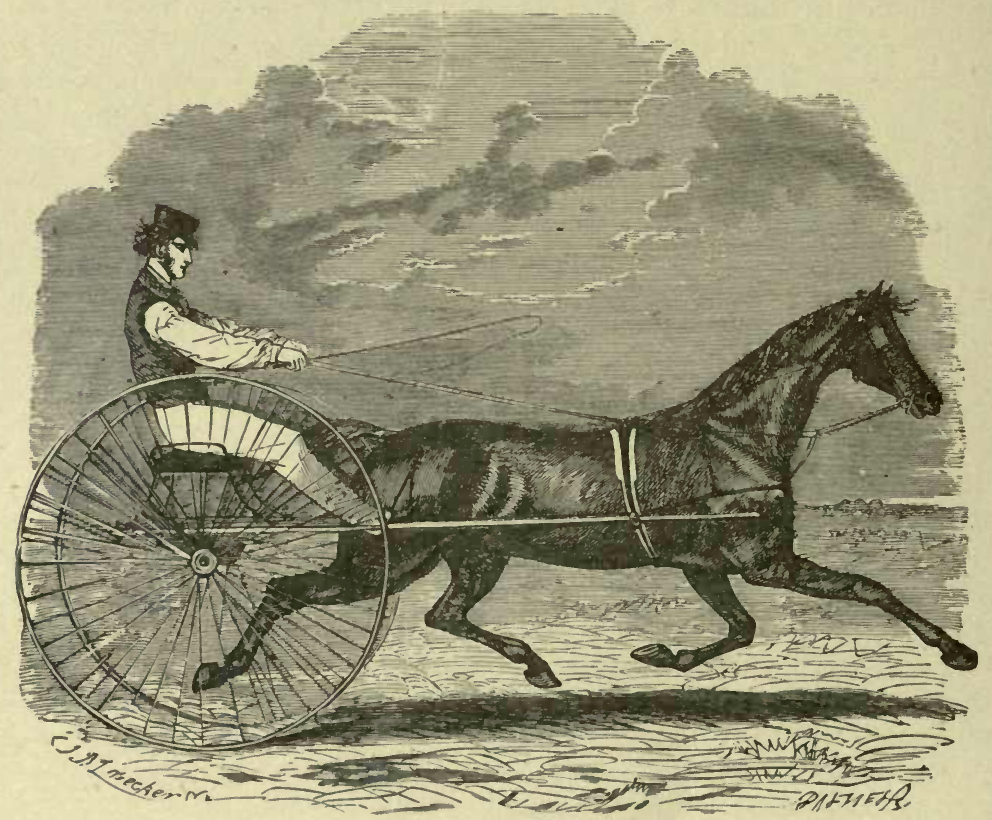

FLORA TEMPLE.

New York, who used her for livery purposes for nearly two years, when she was resold to a Mr. Velie, and finally to Mr. G. E. Perrin, of New York City, who speedily developed her extraordinary powers by constant trials against the trotters of the various gentlemen of that city. In September 1850 she won her first public match over the Union course, since which, with the exception of the year 1851 when she was lamed by an accident, she has had an almost uninterrupted series of victories, winding up with her defeat of Geo. M. Patchen, in June 1860. She was a rich blood bay, with black points, and no white. In height, 14 hands 2 inches, with great power and wiriness of frame. Her head, as will be seen by reference to her portrait, is as light as that of an Arab, and has, indeed, all the characteristics of that blood. Her shoulders are very long and sloping, and, though standing over a deal of ground, she is very short 
in the back. Indeed, her shape is faultless in all essentials, and her action is remarkably long, yet as her pace tells you it must be particularly quick.

\section{THE AMERICAN THOROUGHBRED}

Until the English Thoroughbred Horse is described, it is scarcely possible to enter fully into the pedigree of the American, descended as the latter is from stock imported from the mother country. But, taking the fact for granted, I may proceed to allude to the progress which has been made in the United States, from the date of the first importation. It appears that shortly prior to the year 1750 , a Mr. Ogle, the Governor of Maryland, was in possession of Spark, presented to him by Lord Baltimore. About the same time he also imported Queen Mab, by Musgrove's grey Arab; and, soon afterwards, Colonel Tasker obtained Selima, daughter of the Godolphin Arabian; while Colonel Colville's Miss Colville, known in the English Stud-book as Wilkes' Old Hautboy mare, Colonel Taylor's Jenny Cameron, and Routh's Crab, were severally introduced into the colony. In 1747, Monkey, by the Lonsdale bay Arab, though in his twenty-second year, crossed the Atlantic, and got some good stock, followed during the next year by Jolly Roger, by Roundhead, out of a Partner mare. About 1764, Fearnought, a son of Regulus and Silvertail, and therefore of the very highest English blood, went to America, and within a few years of that date Morton's Traveller, by Partner, out of a mare by the Bloody Buttocks Arabian, which completes the list of the importations prior to the War of Independence. It must be observed, that, before the year 1829, no Turf Register existed in America, and hence there is not the same guarantee for the fidelity of a pedigree as in England, where there are authentic records which reach to a much earlier period. Moreover, the war upset the homes of so many families, that multitudes of documents were lost; but, nevertheless, I believe sufficient has been preserved to prove the authenticity of the pedigrees belonging to the horses which $I$ have enumerated, and whose progeny can be traced down to the present day, their blood being mingled with that of numerous importations of a more recent date. The love of racing was very soon implanted in the colonists of Maryland and Virginia, from whom it spread to North and South Carolina, and in these southern states the sport has been kept up to the present day with great spirit. Tennessee was inoculated with the virus of the racing mania soon after its first settlement, as also may be said of Kentucky, both states having possessed some very celebrated horses at various times. New York joined in at a much later period than the southern states, no organized racing club existing there until after the commencement of the present century; although there were small racecourses at Newmarket and Jamaica before the Revolution. But the energy of the true Yankee sent the New Yorkites ahead, and they soon became worthy rivals of the southern statesmen. From 1815 to 1845 the great stables of the North and South were carried on under a most honourable rivalry; but at the second of these dates it so happened that a vast number of the most energetic supporters of the turf in the northern states withdrew from the arena, and, as they disappeared, none filled the gaps, except a few 
professed trainers and jockeys, who carried racing on entirely as a business, and regardless of that honourable spirit which had previously distinguished it. Trotting also came into fashion, and the fanatics preached a crusade against both, which took double effect upon the sport, already tottering to its fall. It may indeed be said, that from 1845 to 1855 , racing in America was confined entirely to the south; but about 1855 or 1856 a new jockey club was established in New York, and its members laid out a new racecourse on Long Island.

In oRDER To sHow how largely the Americans are indebted to English blood, I insert here the following list of horses imported by them from this country, for which I am indebted to Mr. Herbert :-

Abjer, 1817, by Old Truffle-Briseis by Beninborongh.

Actæon, 1837, by Comus or Blacklock-Panthea.

Admiral, 1799, by Florizel-Spectator niare.

Admiral Nelson, 1795, by John Bull-Olivia.

Ainderby, 1832, by Velocipede-Kate.

Alderman, 1778, by Pot8os-Lady Bolingbroke.

Alexander, by Alexander, son of Eclipse; dam's pedigree unknown.

Alexander, 1791, by Champion-Countess.

All Fours, 1772, by All Fours-Blank mare.

Amıbassador, by Emilius - Trapes by Tramp.

Americus, 1755, by Babraham-Creeping Molly.

Amurath, 1832, by Langar-Armida.

Apparition, 1827, by Spectre-Young Cranberry.

Archduke, 1796, by Sir Peter Teazle-Horatia.

Archer, 1760, by Faggergill-Eclipse mare.

Archibald, 1801, by Walnut-Bay Javelin.

Arrakooker, 1789, by Drone-Camilla.

Autocrat, 1822, by Grand Duke-Olivetta.

Bachelor, 1753, by Blaze-Smiling Tom mare.

Barefoot, 1820, by Tra:zp-Rosamond.

Baronet, 1782, by Vertumnus - Penultima.

Bay Richmond, 1769, by Feather-Matron.

Bedford, 1752, by Dungaunon-Fairy.

Belshazzar, 1830, by Blacklock-Manuella.

Bergamot, 1788, by Highflyer-Orange Girl.

Berner's Comus, 1827, by Comus-Rotteriam.

Black Prince, 1760, by Babrahain-Riot.

Blossom, 1795, by Bordeaux - High flyer mare.

Boaster, 1795, by Dungannon-Justice mare.

Bolton, 1752, by Shark-Partner mare.

Brilliant, 1791, by Phenomenon-Faith.

Bryan O'Lynn, 1756, by Aston-Le Sang mare.

Brutus, 1748, by Regulus-Miss Layton.

Buffcoat, 1742 , by Godolphin Arab-Silverlocks.

Buzzard, 1787, by Woodpecker-Misfortune.

Camel, 1822, by Whalebone-Selim mare.

Cannon, 1789, by Dungannon-Miss Spindleshanks.

Cardinal Puff, 1803, by Cardinal-Luna.

Celer, 1774, by Old Janus-Brandon.

Centinel, 1758, by Blank-Naylor, by Cade.

Cetus, 1827 , by Whalebone-Lamia.

Chance, 1787, by Lurcker-Recovery.

Chariot, 1789, by Highflyer-Potosi, by Eclipse.

Chateaux Margeaux, 1822, by Whalebone-Wasp.

Citizen, 1785, by Pacolet-Princess.

Claret, 1850 , by Chateaux Margeaux-Partizan mare.

Clifden, 1797 , by Alfred-Florizel mare.

Clifton, 1797, by Abbé Thullé-Eustatia, by Highflycr.

Clockfast, 1774, by Gimcrack-Miss Ingram.

Clown, 1785, by Bordeaux-Eclipse mare.

Cœur de Lion 1789, by Highflyer-Dido. 


\section{LIST OF IMPORTED HORSES}

Commodore, 1820, by Caleb Quot'em-Mary Brown.

Consol, 1828, by Lottery-Cerberus mare.

Consternation, 1841, by Confederate-Curiosity.

Cuntent, 1823 , by Catton-Helen.

Cormorant, 1787 , by Woodpeeker-Nettle.

Coronet, 1828, by Catton-Paynator mare.

Crab, 1736, by Crab-Councillor mare.

Crawler, 1792, by Highflyer-Harriet.

Creeper, 1786, by Tandem-Crawler's dam.

Cub, 1739, by old Fox-Warlock Galloway.

Cynthius, 1799, by Acacia-Yarico.

Dancingmaster, 1787, by Woodpecker-Madcap.

Dare Devil, 1787, by Magnet-Hebe.

David, 1756, by Gower Stallion-Fox Cub mare.

De Bash, 1792, by King Fergus-Highflyer mare.

Denizen, 1836, by Actæon-Design.

Derby, 1831, by Peter Lely-Urgunda.

Diomed, 1777, by Florizel-Spectator mare.

Dion, 1795, by Spadille-Faith.

Doncaster, 1834, by Longwaist-Muley mare.

Don John, 1835, by Tramp or Waverley - Sharpset's dam.

Don Quixote, 1784, by Eclipse-Grecian Princess.

Dormouse, 1753, by Dormouse-Diana, by Whitefoot.

Dragon, 1787 , by Woodpecker-Juno.

Driver, 1784, by Driver-Dorimont mare.

Drone, 1778, by Herod-Lily.

Druid, 1790, by Pot8os-Maid of the Oaks.

Dungannon, 1793, by Dungannon-Miss Spindleshauks.

Eagle, 1756, by Volunteer-Highflyer mare.

Eastharn, 1818, by Sir Oliver-Cowslip.

Eclipse, 1778, by Eclipse-Phœbe.

Emancipation, 1827, by Whisker-Ardrossan maro.

Emilius colt, 1836, by Bourbon-Fleur de Lis.

Emu, 1832, by Pieton-Cuirass.

Englishman, 1812, by Eagle-Pot8os mare.

Envoy, 1827, by Comus-Aline.

Escape, 1758, hy Precipitate-Woodpecker mare.

Espersykes, 1837, by Belshazzar-Capsicum mare.

Eugenius, 1770, by Chrysolite-Mixbury.

Expedition, 1755, by Pegasus-Active.

Express, 1785, by Postmaster-Syphon mare.

Exton, 1785, by Highflyer-Io.

Fairfax Roan, 1764, by Adolphus-Tartar mare.

Fallower, 1761, by Blank-Partner mare.

Fearnought, 1755, by Regulus-Silvertail.

Fellow, 1755, by Cade-Goliah mare.

Felt, 1826, Langar-Steam.

Figaro, 1830, by Figaro-Catton mare.

Figure, 1747, by Standard-Beaufort Arabian mare.

Firebrand, 1802, by Braggart-Fanny.

Firetail, 1755, by Phenomenon-Columbine.

Flatterer, 1830, by Muley-Clare.

Flexible, 1822, by Whalebone-Themis.

Flimnap, 1765, by South-Cygnet mare.

Florizel, by Florizel-Alfred mare.

Fop, 1832, by Stumps - Fitzjames mare.

Frederick, 1810, by Selim-Englishmau's dam.

Friar, 1759, by South - Sister to Lowther Babraham, by Babraham.

Fylde, 1824, by Antonio-Facladinada.

Gabriel, 1790 , by Dorinant-Highflyer mare.

Genius, 1753, by Babraham-Aura.

Gift, 1768, by Cadormus-Old Cub mare.

Glencoe, 1831, by Sultan-Trampoline, by Tramp.

Gouty, 1796, by Sir Peter Teazle-Tandem mare.

Granby, 1759, by Blank-Old Crab mare.

Grecian, 1821 (Brother to Alasco), by Clavalino-Pioneer mare.

Grey Highlander, 1787, by Bordeaux-Teetotum mare. 
Greyhound, 1796, by Sweetbriar-Miss Green, by Highflyer.

Hambleton, 1791, by Dungannon-Snap mare.

Hamilton, 1793, by son of Highflyer-Eelipse mare.

Hector, 1745, by Lath-Childers mare.

Hedgeford, 1826, by Filho-da-Puta-Miss Craigie.

Hark Forward, 1840 (Brother to Harkaway), by Economist-Naboclish mare.

Hibiscus, 1834, by Sultan-Duchess of York.

Highflyer, 1782, by Highflyer-Angelica.

Honest John, 1794, by Sir Peter Teazle-Magnet.

Hugh Lupus, 1836, by Priam-Her Highness.

Humphrey Clinker, 1822, by Comus-Cilinkerina.

Invalid, 1822, by Whisker-Hamilton mare.

Jack Andrews, 1794, by Joe Andrews-Highflyer mare.

Jack the Bachelor, 1753, by Blaze-Gallant mare.

James, 1746 , by Old James-Little Hartley mare.

John Bull, 1799, by Fortitude-Xantippe.

John Bull, 1833, by Chateaux Margeaux-Woful mare.

Jolly Roger, 1741, by Roundhead-Partuer mare.

Jonah, 1795, by Escape-Lavender mare.

Jordan, 1833, by Langar-Matilda.

Julius Cæsar, 1757, by Young Cade-Snip mare.

Juniper, 1782, by Babrahanl-Anna.

Junius, 1752, by Starling Crab-Monkey mare.

Justice, 1782 , by Justice-Curiosity.

Justice, 1759, by Blank-Anna, by Stamford Turk.

King William, 1777, by Herod-Madcap.

King William, 1781, by Florizel-Milliner.

Knowsley, 1795, by Sir Peter Teazle-Cupella, by Herod.

Kooli Khan, 1772, by The Vernon Arab-Rosemary.

Langar colt, by Langar-Malvina.

Langford, 1853, by Starch-Peri.

Lapdog, 1823, by Whalebone-Canopus mare.

Lath, 1763, by Shepherd's Crab-Lath mare.

Leopard, by Liverpool-Sneaker, by Camel.

Leviathan, 1823, by Muley - Windle mare.

Lofty, 1753, by Godolphin Arab-Croft's Partner mare.

Ludford, 1832, by Wamba-Idalia.

Lurcher, 1832, by Greyleg-Harpalice, by Gohanna.

Luzborough, 1820, by Williamson's Luzborough-Dick Andrews' mare.

Lycurgus, 1767, by Blank-Snip mare.

Magic, 1794, by Volunteer-Marcella.

Magnum Bonum, 1774, by Matchem-Snip mare.

Manfred, 1796, by Woodpecker-Mercury mare.

Mark Antony, 1767, by Spectator-Rachel.

Margrave, 1829, by Muley-Election.

Marmion, by Whiskey-Young Noisette.

Marplot, by Highflyer-Omar mare.

Master Robert, 1793, by Star-Young Marske mare.

Matchem, 1773, by Matchem-Lady.

Matchless, 1754, by Godolphin Arab-Soreheels.

Medley, 1766, by Gimcrack-Arminda, by Snap.

Mendoza, 1778, by Javelin-Pomona.

Merman, 1835, by Whalebone-Orville mare.

Merryfield, 1808, by Cockfighter-Star mare.

Messenger, 1778, by Mambrino-Turf mare.

Meux, 1816, by Chorus-Diana.

Mexican, 1775 , by Snap-Matchem mare.

Molock, by Muley Molock-Sister to Puss.

Monarch, 1834, by Priam-Delpini mare.

Monkey, 1725, by Lonsdale bay Arab-Curwen's Bay larb mare.

Mordecai, 1833, by Lottery-Miss Thomasina.

Moro, by Starling - Brown Slipby.

Morven, 1836, by Rowton-Naneen, by Selim.

Moscow, 1746, by Cullen Arab-Croft's Starling mare.

Mousetrap, 1772, by Careless-Regulus mare.

Mufti, 1783, by Fitzherod-Infant mare.

Nicholas, 1833, by St. Nicholas-Moss Rose. 
Nonplus, 1824, by Catton-Miss Garforth, by Walton.

North Star, 1768, by Matchem-Lass of the Mill.

Northumberland, by Old Bustard-Old Crab mare.

Onus, 1835, by Camel-The Etching, hy Rubens.

Oroonoko, 1745, by Old Crab-Miss Slamerkiu.

Oscar, 1795, by Saltram-Highflyer inare.

Othello, 1743, by Crab-Miss Slamerkin.

Pam, 1757, by Regulus-Cade mare.

Pantaloon, 1778, by Herod-Nutcracker.

Partner, 1760, by Partner-Camilla.

Partner, by Duke of Hamilton's Figure-Old Figure mare.

Passenger, 1836, by Langar-My Lady.

Passaic, 1836, by Reveller-Rachel.

Paul, 1807 , by Saltram-Virago.

Phenomenon, 1780, by Herod-Frenzy.

Pharaoh, 1753, by Moses-Godolphin mare.

Phil Brown, by Glaucus-Bustle.

Phœnix, 1798, by Old Dragon-Portia.

Pilgrim, 1762, by Samson-Regulus mare.

Play or Pay, 1791, by Ulysses-Herod mare.

Plenipo, 1837, by Plenipotentiary-Polly Hopkins.

Portland, 1834, by Recovery-Caifacaratudaddera.

Post Captain, 1835, by The Colonel-Postluma.

Precipitate, 1787, by Mercury-Herod maro.

Priam, 1827, by Emilius-Cressida.

Priam, 1834, by Priam-Soothsayer mare.

Prince, 1773, by Herod-Helen.

Prince Ferdinand, by Herod-Matchem mare.

Punch, by Herod-Marske mare.

Regulus, 1747, by Regulus-Partner mare.

Restless, 1788, by Phenomenon-Duchess.

Revelier colt, 1836, by Reveller-Rachel.

Rutland, 1810, by Stamford-Worthy mare.

Riddlesworth, 1828, by Emilius-Filagree.

Roan colt, 1802, by Sir Peter Teazle-Mereury mare.

Robin Redbreast, 1796, by Sir Peter Teazle-Wren.

Roman, 1815, by Camillus-Leon Forte.

Rosalio, 1836, by Vanish-Rose Leaf.

Rotherham, 1838, by Grey Conqueror-Camilla mare.

Rowton, 1826, by Oiseau-Catherina.

Rowton colt, 1836 , by Rowton-Nannie.

Royalist, 1790, by Saltram-Herod mare.

Ruby, 1836, by Ëmilius-Eliza.

St. George, 1789, by Highflyer-Sister to Soldier.

St. Giles, 1829, by Tramp-Arcot Lass.

St. Paul, 1789, by Saltram-Purity.

Saltram, 1780, by Eclipse-Virago.

Scout, 1836 , by St. Nicholas-Blacklock nare.

Scrub, 1821, by Phantom-Jessie.

Scythian, 1851, by Orlando-Scythia.

Selim, 1780 , by Bajazet-Miss Thigh.

Shadow, 1759 , by Babraham-Bolton Starling mare.

Shakspeare, 1823, by Smolensko-Charning Línlly.

Shamrock, 1827, by St. Patrick-Fairy.

Shark, 1771, by Marske-Snap mare.

Silver, by Mercury-Herod mare.

Silver Eye, by Cullen Arab-Curwen's Bay Barb.

Sir Harry, 1794, by Sir Peter Teazle-Natron.

Sir Peter Teazle, 1802, by Sir Peter Teazle-Nercury marc.

Sir Robert, 1833, by Bobadil-Fidalma, by Waxy l'ope.

Skylark, 1826, by Waxy Pope-Skylark.

Slender, 1779, by King Herod-Rachel.

Slim, 1768 , by Wildman's Babraham-Babraham mare.

Slouch, 1745, by Cade-Little Hartley mare.

Sloven, 1756, by Cub-Bolton Starling mare.

Sorrow, 1836, by Defence-Tears.

Sour Crout, 1786, by Highflyer-Jewel. 


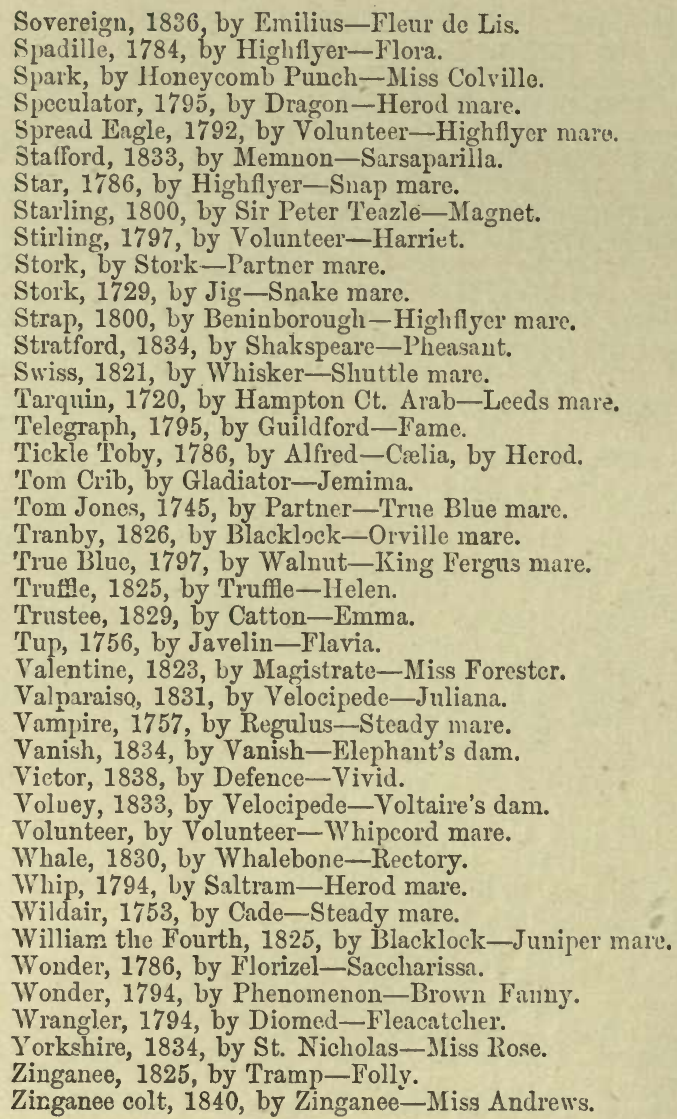

THE LIST OF IMPORTED MARES is most probably still more numerous, but they are not so easily ascertained, as, prior to the establishment of the American Turf Register, there was no record of them, whereas most of the stallions are mentioned in our English Stud-book as having been sent out. Mr. Herbert, it is true, gives a long list of them, but many of these he himself rejects as apocryphal; and there are some of those accepted by him as correct which I have reason to believe have never left this country. So also in his list of stallions, even such a well-known English covering stallion as Launcelot (brother to Touchstone) is included as having been imported into America; but still, on the whole, I believe that his list of mares is not far from the truth.

The American thoroughibred horse is said to be much stouter than the modern English strains; and without doubt Mr. Ten Broeck's Prioress could stay better than most English horses, though she was not considered by the Americans themselves to be quite up to the best staying form which they possess. This subject, however, will be better considered after the performances of the English horse are carefully examined. It must be remembered that, with the exception of the horses brought over to this 
country, we have no means of comparison beyond the time-test, which is not a reliable one; firstly, because we have no time-races here; and, secondly, because none of our long distances are run from end to end. As far as I have had an opportunity of seeing, and with the single exception of Charleston, all Mr. Ten Broeck's horses were extremely narrow, the crack Umpire in particular being "like two deal boards nailed together," as the "men of stable mind" say here. His hips were the narrowest I ever saw in a horse supposed to be of first-class, and those of Prioress are not much more developed. The celebrated horse, Lexington, who was out of the same mare as Umpire, was also reported to have been very narrow in the hips, so that probably this peculiarity runs throughout that strain of blood, but whether derived from Alice Carneal or from Boston (who got both Lexington and Lecompte, the latter the sire of Umpire) I cannot say. Nevertheless, unless the time-test is utterly fallacious, both Lexington and Lecompte must have been stout, for they have each done four miles, under 7 stone 2 lbs., in 7 minutes 26 seconds, with a start similar to that adopted in England. Lexington, with the same kind of start, performed the same task in 7 minutes $23 \frac{1}{2}$ seconds, and with a running start against time, in the extraordinarily short time of 7 minutes $19 \frac{3}{4}$ seconds. The American Journal, Spirit of the Times, says (1893), "The success of imported English sires within the past twenty years, beginning with Lennington, has certainly impressed many breeders with a belief in their superiority. Glenelg, Australian, Bullet, King Bon, The Ill-Used, Great Tom, King Emest, Bonnie Scotland, Rayon d'Or, Prince Charlie, Phæton, Eclipse, St. Blaise, etc., have well-nigh driven the native stallions into exile. Virgil may be said to be the only stallion who was native bred on both sides of his pedigree, and who has held his own against the imported horses. Longfellow, Spendthrift, Enquirer, Eolus, King Alphonso, and other successful native sires were the sons of imported horses. The English mares have also succeeded in a great degree." This native testimony to the superiority of the English horse for racing purposes must not be understood to imply all-round points, for both American and Australian horses are in some respects better (see Australian horses, p. 36).

\section{THE VERMONT CART-HORSE}

A Distinct BREED of draught-horses under this name is described by Mr. Herbert as existing in Vermont and the adjacent country, though now, he says, less marked than it was prior to the introduction of railroads. I cannot, however, find any other authority for it, nor do I quite agree with the above writer in thinking the breed, if he rightly describes it, as identical with the Cleveland Bay. He says, "These are the very models of what draught-horses should be; combining immenso power with great quickness, a very respectable turn of speed, fin $\curvearrowright$ show, and good action. These animals have almost invariably lofty crests, thin withers, and well-set-on heads; and although they are emphatically draught-horses, they have none of that shagginess of mane, tail, and fetlocks which indicates a descent from the black horse of Lincolnshire, and none of that peculiar curliness or waviness which marks the existence of Canadian or Norman blood for many genera- 
tions, and which is discoverable in the manes and tails of very many of the horses which claim to be pure Morgans. The peculiar characteristic, however, of these horses is the shortness of their backs, the roundness of their barrels, and the closeness of their ribbing up. One would say that they are ponies until he comes to stand beside them, when he is astonished to find that they are oftener over than under 16 hands in height." Now these are just the peculiar points of the Clydesdale cart-horse, as we shall find in examining into that breed, when I come to treat of the English horse, and as may at once be seen by an inspection of the engraving accompanying the description of him.

\section{THE CONESTOGA DRAUGHT-HORSE}

THE LAST on the list of American horses is that known under the above name, which was given to it from being produced in the valley of Conestoga, within the state of Pennsylvania. It is a very large muscular horse, often

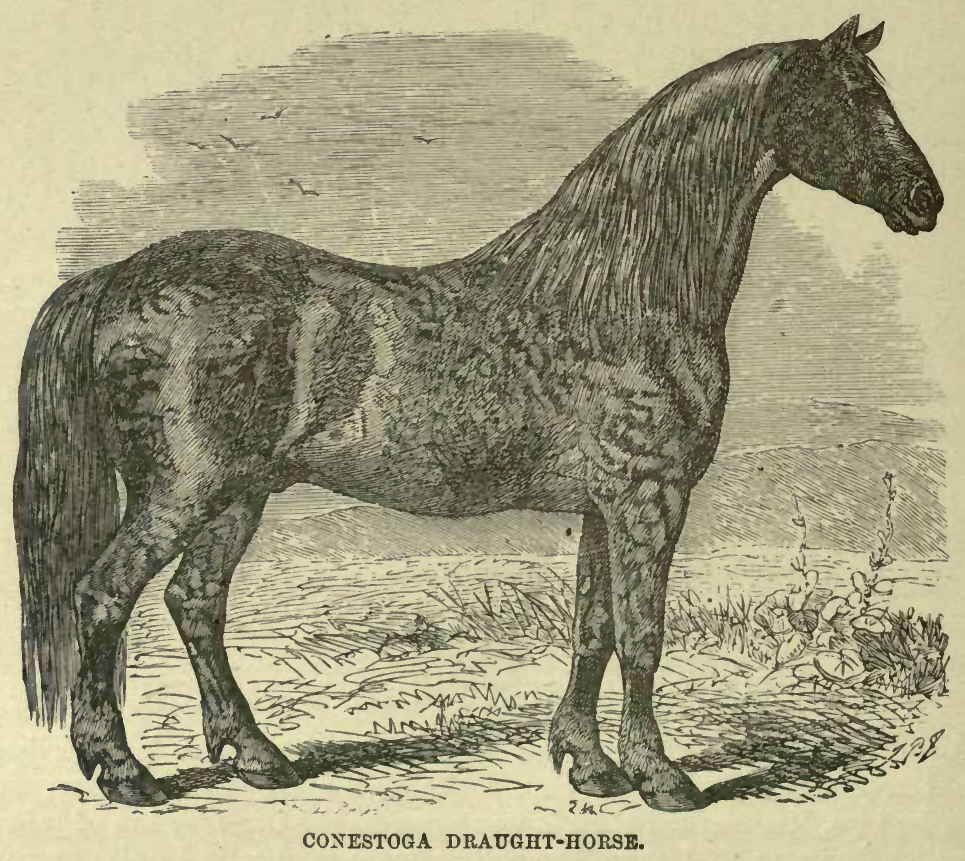

reaching to 17 hands and upwards, and closely resembling the heaviest breeds of German and Flemish cart-horses. The early settlers of this part of the United States were mostly Germans, and they either brought over with them some of the horses of their country, or else they have since selected from those within their reach the animals most resembling in appearance their old favourites when in their fatherland. There is, however, no record of the origin of the breed, and all that can be done is to describe it as it now exists. 
The ACCOMPanying sketch embodies the general appearance of these horses, and by comparing it with the London dray-horse, it will be seen that it differs only slightly, having the same heavy outline of form, united with similar comparatively light limbs, but not burdened with the mountains of flesh and heavy crests which have been produced in England for purposes of show. In Pennsylvania, these horses are chiefly used for wagons, and some few of them, when of inferior shape, for the canal traffic. They are good honest workers, and are quicker and lighter in their action than might be expected from their weight. Indeed, some of them are still used for heavy carriages; but even in Pennsylvania, for quick work, they are generally replaced by the Vermont horse, or some nondescript of mixed blood, with which America is completely overrun.

In colour they follow the Flemish horses, except that black is rare among them, but like the Flemish they are free from chestnut, and the larger proportion of them are bay, brown, or iron greys. 


\title{
CHAPTEP V
}

\author{
EOROPEAN CONTINENTAL HORSES
}

SPANISI AND PORTUGUESE HORSES-THE ITALIAN HORSE-TIIE GERMAN HORSE-TIIE FRENCH HORSE-THE FLEMISH HORSE-THE HANOVERIAN HORSE-THE IRUSSIAN HORSE - NORWEGIAN AND SWEDISH HORSES.

\section{SPANISH AND PORTUGUESE HORSES}

Throughout Spain and Portugal there formerly existed a hardy and useful breed of horses, of different degrees of lightness and activity, according to the use for which they were designed. But in both countries they have greatly degenerated from their former excellence, and in Portugal they have dwindled down in size and appearance until they can scarcely now be recognized as belonging to the same class of animal. The old breeds were greatly improved by the Moors during their occupation of Spain, by importing the Barbs of their own country, and hence those provinces which were most overrun by that people possessed the best breeds of horses. The Spanish Jennet has always been celebrated for easy paces and gentle temper, and these have been the characteristics of all the breeds of the Peninsula, united in most of them with a high courage which would induce them to face either the dangers of war or of a bull-fight without flinching. One chief peculiarity of the Spanish horse is the fulness and width of the bosom, which has always made them slow in the gallop, but extremely easy, while their powerful shoulders have rendered their action good and safe. In the present day the Spanish horse is seldom seen out of his own country.

\section{THE ITALIAN HORSE}

LIKE THose of Spain the Italian horse is supposed to be descended from the Barb, but in the last two or three centuries the breed has greatly degenerated from the original type. The horses used for the saddle are light and active, and at Rome as well as at Florence ${ }^{1}$ public

1 The custom was suppressed at Rome about the year 1891, and at Florence also by the Queen of Italy's personal disapproval and by the energetic action of the Duchess Sermoneta (the English wife of the Minister of Foreign Affairs). Mr. Leonard Hawkesley states on the authority of the Countess Baldelli that "the custom has long ceased." Only in a few provincial towns does it now linger. 
races take place between them without riders. These are managed by goading them in the only direction which they can take by suspending balls covered with sharp points from a surcingle passed round the body, in such a way that at every stride they rebound against the sides of the animal and prick him severely. A street is chosen for the purpose, and in one end of this they are confined by a rope drawn across it till the moment of starting, when it is dropped, and the whole lot getting away gallop to the other end, where again they are stopped by an impassable barrier. The horses employed for this purpose are called Berberi, though none of them in the present day are pure Barbs, but they retain the appellation as indicative of their Oriental origin. The Italian horse seldom attains the height of 15 hands, the average probably being little more than $14 . \mathrm{He}$ is thick in the shoulder and wide in the bosom, but has a tolerably light forehead, good legs and feet, and short drooping hind-quarters.

\section{THE GERMAN HORSE}

In Austria Proper, Hungary and Prussia, horses are bred in extensive studs for military purposes, and of late years the rulers of those countries have been largely indebted to English blood for the improvement which has been made in the horses of the respective countries. The Emperors of Austria have also caused races to be established at Vienna, Pesth, Buda, Breslau, etc. Some idea may be formed of the extent to which the sport is carried on at these meetings, when it is stated that at the meeting at Vienna, in May 1860, nine races were run, the value of the stakes being more than 2000 sovereigns, while at Pesth they amounted to $£ 3320$. Even the latter of these is a poor sum when contrasted with our own Epsom, Newmarket, and Doncaster meetings, where five times the amount are won by the horses engaged in them; but as compared with foreign races of an older date, it is a magnificent one, and the spirit which has been displayed shows that the present state of things is doubtless a forerunner of still greater successes in turf proceedings. The plan of breeding stallions for the supply of the provinces, adopted by the Austrian Government, is excellent, and I should much like to see a similar one introduced into this country. From 100 to 200 stallions are annually bred for this purpose, and sold for about 100 guineas apiece, which price is quite sufficient to cover all expenses, and leave a slight surplus to the imperial treasury towards lowering the cost of the cavalry horses, bred at the same studs.

There is a considerable variety in the native breeds of the three countries mentioned, but they are all useful in their several ways. ${ }^{1}$ In speed and stoutness they cannot compete with our thoroughbreds, nor with our "half-bred" hunters, many of which have at least seven-eighths of pure blood. They are generally light in the middlepiece, with

1 Since the above words were written, we have become largeiy dependent on carriage. horses of German and Hungarian origin. The majority of matched pairs scen in London liave erossed the silver streak. 
drooping quarters, and somewhat long in the leg-qualities which are all opposed to stoutness at a high pace. But they are very hardy, and can live on food which would starve an English horse, so that in a campaign they are not by any means to be despised. The German cart-horses are thick, strong, and useful, of great size, but somewhat slow in their movements, and flat in their feet.

\section{THE FRENCH HORSE}

The Norman Charger or Destrier has been celebrated for ages as the type of horse for the purposes of show and utility combined. With a fine upstanding fore-hand he unites a frame of the most massive proportions, and this is moulded in a form as elegant as is consistent with his enormous power. Even the diligence horses of many parts of France are of very handsome frames, and their legs and feet are so sound that they are able to trot over the paved roads at a pace which, slow as it is, would speedily lame our English horses of similar size and strength. Their tempers, also, are so good that the stallions may be used together with mares in all kinds of work, and though vice in its various forms is not altogether unknown, yet it is comparatively rare. Their countrywoman, Rosa Bonheur, has made this variety of horse familiar to most of my readers, and I need not, therefore, trouble myself to describe them minutely. The Limousin is chiefly used for the saddle, and is supposed to be descended from some one of the Eastern horses introduced by the Crusuders. He was not, however, in high request until the invention of gunpowder caused heavy cannon to go out of use, when a lighter horse was required, and the old heavy animal bred between the Flemish and Norman cart-horse went entirely out of fashion. The true Norman horse is large, powerful, sufficiently active, and very hardy. He has, however, the disadvantages of a heavy head and long cannon-bones. The valley of the Meuse is supplied with a small, active horse, generally of a roan colour, with strong limbs, clothed with an abundance of hair, and a large heavy head. The Lingone horse, in the valley of the Marne, is still smaller, with lop-ears, drooping quarters, and cat-hams, which latter qualities enable him to display the activity and sure-footedness of the goat in scrambling over the rough mountain passes bounding the district. Lastly, the Barrois variety, in the valley of the Arne, is a mere pony, but makes up for his want of size by his agility, hardiness, and good temper.

As in Austria and Prussia, so in France, the Government has done its utmost to encourage the breeding of horses for cavalry purposes, and numerous "haras" have been established throughout France. For a long time purchases have annually been made of first-rate English blood stock, chosen, like those selected by the Americans, chiefly for their stoutness and soundness of constitution. Still there are so many drawbacks in the shape of bad hay, hard training-ground, etc., in the way of the breeder and trainer, that though their horses run us hard, we are still enabled to give them a lump of weight. Throughout nearly the whole of France there is no upland grass in the summer months, 
and neither meadow grass nor meadow hay is suited to the horse intended for fast work. We may, therefore, hope still to be able to maintain our supremacy in horses intended for the racecourse or the huntingfield; but, as far as I can learn, the French cavalry are gradually obtaining a class of animal bred out of their lightest and stoutest Norman mares crossed with thoroughbred horses of pure English blood, some imported direct, and others bred with great care in France. The produce are of good size, very hardy, and possessed of excellent legs and feet, indeed in every way calculated for troop-horses, and should our cavalry ever come in contact with them, and any advantage is to be gained, it must be through superior horsemanship alone.

The Following LIST of Stallions at the various "haras" in France during the year 1858 will show the extent to which English blood has been used in that country. Many of them are bred in France, but a very large proportion, as will be evident, are of English descent, and as thoroughbred as any in our Stud-book. The importance of carefully examining this list will be apparent to all those who know the value of this breed as a cross for low-bred mares.

\section{LIST OF GOVERNMENT STALLIONS IN FRANCE, 1858}

\section{AT ABBEVILLE.}

Auckland, by Touchstone-Maid of Honour. Bedford, by California, dam by The Colonel. Maryland, by Royal Oak-Pecra.

Mulatto, by Royal Oak-Eglé.

Rémunerateur, by The Baron-Marguerita.

\section{AT ANGERS.}

Aquila, by Gladiator-Cassandra.

Badpay, by Caravan-Miss Rainbow.

Caravan, by Camel-Wings.

Fontaine, by Mr. Waggs-Lanterne.

Geometrician, by Theon-Jerv Girl.

Grog, by Nautilus-Discrète.

Hernandez, by Pantaloon-Black Bess.

Iago, by Don John - Scandal.

Jules, by Pickpocket-Amazone.

Lucullus, by Harlequin-Crochet.

Madrigal, by Napier-Celeste.

Shylock, by Simoom-The Queen.

Spartacus, by Gladiator-Discrète.

Strongbow, by Touchstone-Miss Bowe.

The Prime Warden, by Cadland-Zarina.

Tivioli, by Hæmus-Follette.

\section{AT ARLES.}

Fortunatus, by Piccaroon-Lucia.

Gringalet, by Mr. Waggs-Marcella.

Sophiste, by Tarrare-Miss Sophia.

\section{AT AURILlad.}

Arion, by Royal Oak-Agar.

Exilé, by Brandyface-Phenice.

Marengo, by Alteruter-Young Urganda.

Minotaure, by Général Mina-Pulchra.

Nuncio, by Plenipotentiary-Folly.

Orphelin, by Napier-Mademoiselle Dupare. 
AT BESANÇON.

Petrarque, by Caravan-Lauretta.

Vanton, by Napoleon or Jeroboam-Danaë.

AT BLOIS.

Attorney, by Brocardo-Mazzia.

Bind, by Prince Caradoc-Molina.

Buckthorn, by Venison-Lelia.

Constellation, by Lanercost-Moonbeam.

Minotaur, by Taurus-Lyrnessa.

Ronald, by Polecat-Regatta.

Saint Germain, by Attila-Currency.

Velox, by Velocipede, dam by Whisker.

AT BRAISNE.

Bataclan, by Lanercost-Basinoire.

Delegate, by Nuncio-Loisa.

Elthiron, by Pantaloon-Phryne.

Fagus, by Elthiron-Discrétion.

Faust, by Lontherbourg, dam by Rambler.

Firstborn, by Nuncio-Bienséance.

AT CHARLEVILLE.

Napier, by Polecat-Bella.

Rabelais, by Royal Oak-Emelina.

AT CLUNY.

Fitz Touchstone, by Touchstone-Rose of Sharon.

Jutino, by Nuncio-Discrétion.

Marlborough, by 'Tragedian-Urania.

Profil, by Nelson-Silhouette.

Tragedian, by Sir Isaac-Fanny Kemble.

Valbruant, by Nuncio-Wirthschaft.

Young Lanercost, by Lanercost-Io.

Zéphyr, by Young Emilins-Miss Tandem.

AT LAMBALLE.

Avron, by Nuncio-Coquette.

Craven, by Giraffe-Mab.

Duguesclin, by Caravan-Midsummer.

Electrique, by Young Emilius-Kermesse.

Géranium, by The Emperor-Anémone.

Horace, by Mameluke-Bellone.

Nantilus, by Cadland-Vittoria.

Punch, by Paradox-Marionetto

Ulyssé, by Elis-Deception.

\section{AT LANGONNET.}

Antithèse, by Napoleon-Delphine.

Artenay, by Polecat-Camelia.

Cassique, by Young Emilius-Cassicn.

Croque-en-Bouche, by Lottery-Marga: :ivil.

Diamant, by Prince Caradoc-Opale.

Lieutenant, by Royal Oak-Lydia.

Mars, by General Mina or Dangerous-Foilis.

Prince, by Napoleon-Moselle.

Yricix, by Prospero-Iris.

\section{AT LIBOURNE.}

Artisan, by Lanercost-Skilful.

Black Brown, by Nunnykirk,-Tanais.

Brocard, by Brocardo-Lac Dye.

Cataract, by Hurnsea-Oxygen.

Félix, by Accident, dam by Mameluke.

Gogo, by Terror-Kate Nickleby. 
Lugarto, by Crispin-Venus.

Mors-aux-dents, by Napier-Curl.

Sancebox, by St. Lawrence-Priscilla Tomboy.

Télémaque, by Ali Baba-Calypso.

Yorick, by Commodore Napier-Kiatinka.

Yves, by Prospero-Dulcinée.

Zadig, by Commodore Napier-Jocaste.

AT MONTIER-EN-DER.

Buzzard, by Napier-Teresina.

Croissant, by Caravan-Discrète.

Eremos, by Young Emilius-Agar.

Saint Leger, by $\Lambda$ ttila-Cassandra.

Sword, by Gladiator-Defy.

Wagram, by Napoleon-Bellona.

AT NAPOLÉON VENDÉE.

Arc-en-Ciel, by Brocardo-Iris.

Bretignolles, by Caravan-Margaret.

Dash, by Polecat-Aline.

Florist, by Fancy Boy-Malay.

Frohsdorff, by Copper Captain-Almée.

Johann, by Young Emilius or Garry Owen-Miss Jenny

Monsieur de Saint Jean, by Commodore Napier-Jocaste.

Schamyl, by Redshank-Currency.

Sir Benjamin, by Lanercost-Queen of Beauty.

The Roné, by Claret-Roulette.

Tippler, by Tipple Cider-Emelina.

AT PARIS.

Cossack, by Hetman Platoff-Joannina.

Iol1, by Cain-Margaret.

Priasse, by Terror-Miss Scheneitz-Hoeffer.

The Baron, by Birdeatcher-Echidna.

Womersley, by Birdcatcher-Cinizelli.

AT PAU.

Ali Baba, by Holbein-Cloton.

Astre, by Ali Baba-Stella.

Baladin, by Commodore Napier-Nymphæa.

Caen, by Mr. Waggs-Destiny.

Capharnaum, by T'Touchstone-Sweetlips.

Fitz-Carolus, by Charles XII.-Revival.

Gélos, by Ali Babr-Celina.

Gibbon, by Skirmisher-Mademoiselle de Bric.

Irou, by Sting-Margaret.

Jumeau, by Terror or Eylau-Lily.

Make Haste, by Ionian-Mademoiseile Reja!t.

Marc Antoine, by Mameluke-Cléopatre.

Memory, by Nuncio-Paméla.

Météore, by Jocke-Jessica.

Napier, by Gladiator-Marion.

Nelson, by Garry Owen-Zamira.

Opéra, by Terror, dam by Waverley.

Papillon, by Gladiator-Effie Deans.

Pasha, by Ibrahim II.-Melissa.

Prince Eugène, by Young Enilius-Adamantine.

Sampson, by Young Emilius-Belladomna.

Tibi, by Eylau-Silvie.

Tic Tac, by Caravan-Miss Rainbow.

AT LE PIN.

Bolero, by Young Emilins-Doria.

Brocardo, by Touchstone-Brocade.

Dirk Hatteraick, by Van Tromp-Blue Bonnet.

Eperon, by Sting-Maid of Fez. 
Faugh-a-Ballagh, by Sir Hercules-Guiccioli.

Fitz Pantaloon, by Pantaloon-Rebuff.

Lanercost, by Liverpool-Otis.

Lully, by Tipple Cider-Pecora.

Mastrillo, by Sylvio-Miss Anna.

Prince Colibri, by Sylvio-Fraga.

Ramsay, by Sylvio-Emelina.

Schamyl, by Rough Robin-Kate Kearney.

Stoker, by Steamer-Motley.

Tipple Cider, by Defence-Deposit.

AT POMPADOUR.

Alpha, by Caravan-Emerande.

Baba, by Commodore Napier-Mercédés.

Brocard, by Brocardo-Maltzia.

Commodore Napier, by Royal Oak-Flighty.

Garry Owen, by Saint Patrick-Excitement.

Ionian, by Ion-Malibran.

Mokanna, by Gladiator-Zenobia.

Malton, by Sheet Anchor-Fair Helen.

Nunnykirk, by Touchstone-Beeswing.

Point-et-Virgule, by Brandyface-Syl vandiro.

Quaker, by Napoleon-Follette.

Uriel, by Nunnykirk-Opale.

Victor, by Mr. Waggs-Destiny.

Yedo, by Commodore Napier-Venezia.

AT RODEZ.

Brandyface, by Inheritor-Tiffany.

Lodin, by Terror-Engenia.

Noka, by Frivole-Médine.

Philosopher, by Voltaire-Mina.

Sledmere, by Sleight of Hand-Hamptonia.

William the Conqueror, by Charles XII. - Emerald.

AT ROSIÈRES.

Backgammon, by Prince Caradoc-Poulette.

Chesterfield Junior, by Chesterfield, dam by Glaucus.

Hasard, by Chance-Filagree.

Mythéme, by Caravan-Miss Rainbow.

Peu-d'Espoir, by Sting, The Baron, or The Emperor-Belvilcre.

'Tender, by Strongbow-Miss Tarrare.

Yatagan, by Ionian - Jocaste.

Young Caravan, by Caravan-Olinga.

AT SAINTES.

Accroche Cœur, by Malton-Jocaste.

Alerte, by Brocardo-Belle Poule.

Babiega, by Attila-Essler.

Emilien, by Royal Oak-Corysandre.

Meriadée, by Prince Caradoc-Fretillon.

Nathaniel, by Mr. Waggs - Nativa.

Piédestal, by Commodore Napier-Sylvina.

Ronconi, by Sting-Lydia.

Scarborough, by Ratan, dam by Muley Moloch.

Sir Charles, by Sleight of Hand, dam by Macketh.

Soulouque, by Beggarman-Molokine.

Topinamboor, by Ionian-Eugénie.

Ulric, by Terror-Luna.

AT SAINT LO.

Adolphus, by Royal Oak-Anna.

Assault, by Touchstone-Ghuznee.

Ballinkeele, by Birdcatcher-Perdita.

Bravo, by Sylvio-Belle de.Nuit.

Debardeur, by Young Emilius-Donar Pilar.

Don Quichotte, by Sylvio-Moïnar. 
Eylau, by Napoleon-Delpline.

Guignolet, by Gladiator or Sting-Discrète.

Isolier, by Nunnykirk or The Baron-Deception.

Jocko, by Harlequin-Priestess.

Marengo, by Napoleon-Cloris.

Omar Pasha, by Brocardo-Cochlea.

Penkam, by Caravan-Mariquita.

Royal Quand-même, by Gigès-Eusebia.

Sharavogue, by Freney, dam by Skylark.

Tais-toi, by The Emperor-Sérénade.

The Caster, by Emilius-Castaside.

\section{AT SAINT MAIXENT.}

Alcide, by Nunnykirk-Tanais.

Arnac, by Brocardo-Didon.

Clubstick, by Royal Oak-Vesper.

Incertain, by Tipple Cider-Emerald.

Saint Simon, by Gladiator-Sweetli[ $\mathbf{s}$.

Sans Façon, by Morok-Symmetry.

\section{AT STRASBOURG.}

Bon Voyage, by Malton-Fringanto.

Clovis, by Tipple Cider-Danaide.

Coustranville, by Gladiator-Beeswing.

Cupidon, by Nelson-Vesper.

Landry, by Young Emilius-Miss King.

Lézard, by Caravan-Polyxêne.

Quadrilatère, by Mameluke-Noémi.

Young Talisman, by Garry Owen-Skirmish.

AT TARBES.

Assassin, by Taurus-Sneaker.

Beaucens, by Sting-Eccola.

Canton, by Cain, dam by Bustard.

Collinwood, by Sheet Anchor-Kalmia

Corazon, by Swinton-Duet.

Coucron, by Caravan-Penance.

Ethelwolf, by Faugh-a-Ballagl-Espoir

Farfadet, by Saint Francis-Samphire.

Flight Away, by Gladiator-Flighty.

Fragile, by Young Emilius-Eloa.

Fulger, by Young Emilius-Candida.

Grey Tommy, by Sleight of Hand, dam sy Ćomus.

Kremlin, by Napoleon-Danaë.

Lindor, by The Emperor-Suavita.

Mardain, by Slane-Misère.

Marly, by Attila-Maria.

Morok, by Beggarman-Vanda.

Moustique, by Sting-Essler.

Premier Aoat, by Physician-Princess Edwis.

Prospectus, by Camel-Jenny Vertpré.

Saint Bernard, by Napoleon-Midsummer.

Slane, by Royal Oak-Naiad.

Sting, by Slane-Echo.

The Ban, by Don John-Young Defiance.

Toison d'Or, by Prince Caradoc-Honeymoon.

Vendredi, by Cain-Naiad.

Zoïle, by M. d'Ecoville.

\section{AT VILLENEUVE.}

Aramis, by Royal Oak-Chimere.

Clown, by Commodore Napier-Hoema.

Epervier, by Caravan-Emilia.

Lilliput, by Sting-Miss Lot.

Lamartine, by Epirus-Grace Darling.

Philip Shah, by The Shah-Philip's dam.

Sir Roland de Bois, by Touchstone-Falernia. 
The French Government, ever alive to the importance, from a military point of view, of keeping up the quality and quantity of horses in the country, continue from time to time to import English blood, but not to the extent that was necessary when the above list was first published.

The number of English thoroughbreds now imported into France is comparatively few, as will be seen by the following official information kindly supplied by Mr. Henry Blount :-

"The French Jockey Cuub sends each year a commission to England with the intention of purchasing thoroughbred stallions. Names of some of those purchased in recent years are appended, but it will be seen that none have been purchased since 1893 .

1888. No purchase.

1889. Magician for Saint Lo (dead).

" The Minstrel Boy for Le Pin.

, Bob Sawyer for Blois.

1890. No purchase.

1891. Sacramento to Pompadour.

" Ham to Saint Lo.

," Gambler to Saint Lo.

1892. Homewood to Le Pin.

From 1893 to 1896. No purchases."

\section{THE FLEMISH HORSE}

The Netherlands have a great advantage over most of the countries nto which the continent of Europe is divided, in the possession of extensive meadows which are not flooded, and in which the fine clovers, so requisite to the development of the horse, are produced in tolerable abundance. For this reason chiefly, I believe, the Flemish horses have long enjoyed a high reputation, second only to our own, and to them we owe many useful crosses among our dray and heavy agricultural draughthorses. Both their light and heavy breeds are remarkable for high crests, small heads, somewhat narrow across the eyes, heavy shoulders, and round, powerful, but very drooping quarters. Their hocks are comparatively small, but clean, and their legs light and free from hair. Their worst point lies in the feet, which almost always have flat and thin soles, unfitting them for fast work on hard roads. Just prior to the introduction of railroads the English system of coaching was introduced into Belgium, and I have sat behind several teams of mares drawing a heavy diligence more than ten miles within the hour. We now possess a class of animals in our heavy omnibuses, a pair of which will draw the enormous weight of four tons at the rate of six or eight miles per hour; but they do not run more than six miles in one stage, nor, as far as I am aware, does any omnibus travel nearly as fast as the crack Belgian diligences which were running between 1830 and $1840 .^{1}$ Indeed, I hardly think any horses could have been found in this country at a price suited to coaching work,

1 Large numbers of these horses were imported into London and other great cities in the "sixties" and "seventies," but proved incapable of sustaining the concussion of roads which at that time were chiefly stone and macadam. Their feet were flat and weak, which gave rise to much lameness. With heavy heads, light middlepieces, and goose rumps, they must have been but sorry representatives of the class described by the author. $\Lambda$ few years after the importations ceased they disappeared as it were from the streets of London. 
which would have done the work of these Flemish mares. Almost all were bay with black points, and their legs were nearly as clean and free from hair as those of our thoroughbreds. They were extraordinarily goodtempered, and suffered their attendants to "put them to" all together, being all attached to a splinter-bar, which was turned over the quarters of the wheelers. In this way the change was effected even in less time than by our crack coaches, when one and a half minutes was considered the outside time to be allowed. All that was necessary was to pull up nearly close behind the four horses standing ready for the change, then unhooking the bar of those just come in it was turned over their quarters, and they were taken forwards till they cleared the pole, when they were in a body turned on one side. The four fresh horses were then quickly backed to their places, a wheeler passing on each side the pole, the bar was dropped to its place and hooked, the reins in the meantime being taken out of the terrets by the coachman, and the change was effected in less than a minute.

\section{THE HANOVERIAN HORSE}

EvERY ONE wHO HAS SEEN her Majesty's black carriage-horses must be familiar with this breed. Some are also brought over to this country for the use of the undertaker, but they are more costly than the Flemish and Holstein horses, and are only used by the most fashionable houses in that trade. They are remarkable for the length and beauty of their manes and tails, and for their brilliant black colour. This is specially developed in the entire horses, which are therefore used for purposes of show. They have neat heads and well-arched necks, but have very light middlepieces, badly ribbed up. Their shoulders are somewhat upright, and their arms and thighs are lighter than in any other European breed of the same size and beauty. The action of these horses both on the walk and trot is high and proud, yet tolerably fast, and I believe in their native country they make useful troopers and light harness horses. Here the hard macadamized roads forbid their being employed for any purposes but those to which I have alluded.

\section{THE RUSSIAN HORSE}

The native Russian horse is a small, active, and hardy animal, capable of undergoing great fatigues and privations, but not possessed of much speed in any of its paces. Of late years great progress has been made in improving them by crossing the blood with that of English and Arab thoroughbreds, and also by mixing with these the best Flemish and French light harness horses. Throughout the vast grassy plains of the interior of Russia there are the finest opportunities afforded for the breeding of horses.

A regular trade in the export of these ponies to England is now established, although the first few consignments, about the "eighties," were not good enough to attract buyers except for the coster's barrow, the laundress's cart, and the coal-pit. Each year has seen a marked improvement, since then, and now (1898) one may often see well-marked Arab 
features combined with that good action in front and sure-footedness which has always been a recommendation to Russian horses. The small size is owing to governmental interference in not permitting the export of horses over 14 hands or 14 hands 2 inches. The standard of height varies, but we have seen a number refused at the ports of embarkation that appeared to be only slightly over 14 hands. Their chief defect is that of shying, and the worst bred ones are incurable. Where the intelligence of the Arab sire has taken effect they can be induced to walk over a sewer grating, for instance, when once thoroughly satisfied of its safety. Exmoor stallions have also contributed to the improvement so far as quality goes, but not size, as our readers will doubtless know they are small on their native heath.

\section{NORWEGIAN AND SWEDISH HORSES}

In NoRway the horses are almost all of a colour midway between cream and dun, with black manes and tails, and a black stripe along the back. Several stallions of this breed were introduced into Wales early in the century, and these peculiar markings are still prevalent there. They are of good shape, very safe, and possessed of clean but not very high action.

THE SwEDISH HORSES are smaller than those of Norway, and of all colours. They are chiefly used in harness, being driven in a carriole with very long shafts, so that the body is suspended midway between the horse and the wheels. This gives it a very uneasy motion, which requires some time to accustom the rider to it. When larger carriages are required, four of these little creatures are put to them, and they will gallop a ten mile stage within the hour. 


\section{CHAPTER VI \\ THE ENGLISH THOROUGHBRED HORSE}

GENERAL HISTORY-THE ENGLISH THOROUGHBRED HORSE OF 1750-HIS ORIGIN-THE MODERN THOROUGIBRED-INCREASE OF SIZE AND SYMMETRY-COMPARATIVE STOUTNESS-EARLY MATURITY-OBJECT OF ENCOURAGING THE BREED-ESSENTIALS IN THE THOROUGHBRED-PURITY OF BLOOD-EXTERNAL FORMATION-HEIGHT-COLOUR-COAT, MANE, AND TAIL-THE THOROUGHBRED HUNTER AND STEEPLECHASER.

\section{GENERAL HISTORY}

We HAVE NO RECORD of the existence of the horse in England until tle time of the Roman invasion of the island, when we know that large numbers were found here ready to oppose the landing, and used both in chariots and as cavalry. But this country never became remarkable for her breed of horses until after the time of the Stuarts, who paid great attention to this animal, and caused numbers of Arab stallions and mares to be imported. In the time of Henry the Eighth, the want of good horses was so much felt, that an Act was passed, forbidding any entire horse of a greater age than two years, and less than 15 hands high, to be turned out in any common or waste land in the counties of Norfolk, Suffolk, Cambridge, Buckingham, Huntingdon, Essex, Kent, Hampshire, Wiltshire, Oxford, Berkshire, Worcester, Gloucester, Somerset, Bedfordshire, Warwickshire, Northampton, Yorkshire, Cheshire, Staffordshire, Lancashire, Salop, Leicester, Hereford, Lincoln, and North or South Wales. In other counties the limit was put at 14 hands, but for what reason I am not aware. Small weedy mares and foals were also ordered to be destroyed; and the owners of horses infected with a contagious disease, who turned them out, were fined ten shillings. Still, the deficiency was so great, that in the time of the threatened invasion by the Spanish Armada, in the reign of Queen Elizabeth, only three thousand horses could be collected for the cavalry; and, to procure these, a serious interruption was produced in the internal traffic of the kingdom, which was then carried on by means of pack-horses. It appears, however, that on board the Spanish ships there were a great number of the Andalusian horses, which were then considered the best in Europe; and these being taken possession of by the victorious admiral for his mistress, were of great service in improving the breed. In her reign coaches were invented, and this was another reason for encouraging the size and strength of the 
horse; the depth of the ruts and the steep hills on all the roads of the country demanding much greater power than at present, and six horses being the smallest team in use. For the purpose of carrying the mail-clad men-at-arms, a powerful horse of great size had long been wanted, but not of quite the same colossal proportions as was required for the use of the heavy lumbering coaches which were now introduced. In course of time, however, after gunpowder was invented, armour became useless, and then a lighter horse was in request. Racing had long been established in a few small meetings every year; but no sooner was a light cavalry demanded than a double impetus was given to the amusement, and Arabs, Barbs, and Turks were imported in large numbers, for the purpose of breeding animals suited either to turf or the saddle. This was in the middle of the seventeenth century, during which time a number of books on the management of the horse were published in France and England, showing the interest which was generally taken in the subject. Of these, the most celebrated is the magnificently illustrated work of the Duke of Newcastle, who occupied himself in writing it at Antwerp, during his banishment in the time of the Commonwealth, between 1650 and 1660 . He describes the horses of his time as follows:- "The Turkish horse stands high, though of an unequal shape, being remarkably beautiful and active, with plenty of power, and excellent wind, but rarely possesses a good mouth. Much praise is given to the grandeur of carriage of the Neapolitan horse; and, in truth, they are fine horses, those I have seen being both large, strong, and full of spirit. I have not only seen several Spanish horses, but several have been in my possession. They are extremely beautiful, and the most eligible of any, either to form subjects for the artist, or to carry a monarch, when, surrounded by the pomp and dignity of majesty, he would show himself to his people; for they are neither so intemperate as the Barbs, nor so large as the Neapolitans, but the perfection of both. The Barb possesses a superb and high action, is an excellent trotter and galloper, and very active when in motion. Although generally not so strong as other breeds, when well chosen I do not know a more noble horse; and I have read strange accounts of their courage-for example, when so badly wounded that their entrails have protruded, they have carried their riders safe and sound out of danger, with the same spirit with which they entered it, and then dropped dead." From the engravings in this book, the war-horse of that period closely resembled the Flemish or Hanoverian blacks which we now have, but of greater substance, the man in armour weighing between twenty and twenty-five stone. But even supposing this to be the horse of the country in the time of the second Charles, a very few crosses of Arab blood would fine it down, till in appearance it would not be distinguishable from its Eastern progenitor. Oneeighth of cold blood is not very perceptible, and this proportion would exist in the third cross, and would therefore occupy only ten or a dozen years to produce it. Gradually a breed of horses was established which has been celebrated throughout the world for the last century, for speed, stoutness, and beauty; in all which qualities the present stock excels their parents on both sides. Much of this excellence is doubtless due to the climate and soil of the country, which encourage the growth of those fine grasses that exactly suit the delicate stomach of this animal. But without care and 
judging in the selection and breeding of the horse, our ancestors never could have arrived at such extraordinary success; and whether this depended upon chance or preconceived theory, nearly equal merit is due, for there is as much credit in seizing hold of facts which upset a prejudice, as in acting upon those that support it. For a century and a half we have carefully preserved the pedigrees of our pure bred horses, and for more than a third of that time they have been recorded in the Stud-book by the Messrs. Weatherby. Besides these, we have breeds suited to the various purposes for which horses can be required-namely, hunting, hacking, light and heavy harness-work on the road, and agricultural operations. Each of these varieties must, therefore, be considered separately; and, as the grand pièce de résistance, I shall begin with

\section{THE ENGLISH THOROUGHBRED HORSE OF I750}

IN OUR HISTORICAL RECORDS there are sundry notices of the importation of Spanish and Flemish horses to serve as chargers, but there is no clear account of any Eastern horse being brought into the country until the reign of James the First, when Mr. Markham, a merchant of London, sent for an Arabian from Constantinople, and sold him to the King for $£ 500$, an enormous sum in those days. A great deal was expected from this horse, but both the individual and his stock were found to be too slow to race, and no other effort was made by either James I. or Charles I. in the same direction. A Mr. Place, who was stud groom to Oliver Cromwell, obtained possession of an Eastern horse, which appears in the Stud-book as "Place's White Turk," but of his history nothing is known. Fairfax's Morocco Barb, and the Helmsly Turk, the property of the Duke of Buckingham, were used to cross the blood of the four Barb mares imported by Charles the Second from Tangiers, and known in the Stud-book as the "Royal Mares;" and for many years, that is, nearly to the end of the seventeenth century, no other Eastern blood was employed in the English breeding studs, with the exception of the three Hamburg mares which were taken at the siege of Vienna, and brought over in 1684. These are generally considered to be the foundation of the breed of our English thoroughbred. It is quite clear, however, that prior to this time we were in possession of a strain of race-horses which were possessed of fair speed, for it is absurd to suppose that the Arabs of these days are faster than they were two hundred years ago, and yet, those imported then specially to run at Newmarket were beaten with ease. It is also highly probable that the imported horses and mares were not bred from, exclusive of the native or Spanish horses already in the country, for we find in almost all the old pedigrees a break-down somewhere or other. Thus, in the pedigree of Eclipse there are two blanks, which, it is true, may have been filled by mares of Eastern blood, but the omission of the name looks extremely like a desire to hide what has since been considered a blot in the escutcheon. My own belief is that the race-horse of that day was imported from Spain, and bred from a cross of the Andalusian mare with the Barb introduced by the Moors. A fresh infusion of Eastern blood therefore was likely to "hit," as we know it did ; and by care, and taking advantage of our climate and 
other natural advantages, the fine breed was produced which we now possess. The Duke of Newcastle in his advice to breeders, after describing the sort of mare suitable to breed race-horses, says :- " Your stallion by any means must be a Barb, and somewhat of the shape that $I$ have described the mare to be of. For a Barb that is a jade will get a better running horse than the best running horse in England: as Sir John Fenwick told me, who had more experience in running horses than any man in England. For he had more rare running horses than any man in all England beside, and the most part of all the famous running horses in England that ran one against another were of his race and breed. Some commend the Turk very much for a stallion to breed running horses, but they are so scarce and rare that I can give no judgment of them, and therefore I advise you to the Barb, which I believe is much the better horse to breed running horses."

Is THIS PASSAGE it is clearly established that the mare used for breeding race-horses in the times $I$ am alluding to was not necessarily of Eastern blood, for he says your stallion must be a Barb; but though minutely describing the make and shape of the mare, and that as well as the most skilful breeder of the present day, he does not place any limitation on her breeding. Indeed, I believe that the use of the Spanish, mixed, perhaps, with native English blood in the mare, was the real cause of the success which attended the cross with the Barb; the mare being of greater size and stride than the horse, and giving those qualities to the produce, while the horse brought out the original strain of Eastern blood, which possessed the wind and endurance so peculiar to it. We may, therefore, conclude that the origin of the thoroughbred horse of the present day is to be laid in the following strains.

\section{ORIGIN OF THE THOROUGHBRED HORSE}

1. Native mares used for racing, and bred from Spanish and English strains, the former most probably descended from the Barbs of Morocco.

2. Markham's Arabian, imported in the time of James the First, but proved to be good for nothing, and most probably there is now not the slightest strain of his blood extant.

3. Place's White Turk, extensively used, and to him most of our best horses can be traced through Matchem.

4. The Three Turks brought over from the siege of Vienna in 1684.

5. The Royal Mares, imported by Charles the Second, who sent his Master of the Horse to the Levant specially to procure them. These also are mentioned in all the best pedigrees.

VARIOUS OTHER HORSES AND MARES are mentioned in the early pedigrees between the times of Charles II. and James II., when the Byerley Turk makes his appearance. Of these we have no exact record, either as to the date of their importation or the country from which they came, so that all that can be done is to enumerate them. They are Alcock's Arab, the Morocco Barb, D'Arcy's Yellow Turk, the White D'Arcy Turk, Leedes Arab, the Brownlow Arab, Harper's Arab, Pullen's Chestnut Arab, Honeywood's White Arab, the old Bald Peg Arab, and the Arab sire of Makeless. Most of these occur in our best pedigrees, but the two D'Arcy Turks, as we shall hereafter find, are particularly conspicuous there. 
THE NEXT ERA in breeding is the introduction of the Byerley Turk and Lister's, or the Stradling Turk. The former was used in the Irish wars between James II. and William and Mary, as Captain Byerley's charger, about the year 1689 ; and being afterwards put to the stud, was the sire of the Duke of Kingston's Sprite, Lord Bristol's Grasshopper, Sir Roger Moyston's Jigg (sire of Partner, and Basto), from whom, through his daughter (the sister to Soreheels), were descended Crab, the Bald Galloway, and the celebrated Matchem. The Lister Turk was brought over from the siege of Buda during the reign of James the Second, by the Duke of Berwick. He was sire of Snake, and therefore great-grandsire of Squirt, from whom was descended the celebrated Eclipse.

The Darley Arabian marks another step, and must have been imported somewhere between the years 1700 and 1715 , his son Childers being foaled in the latter. He belonged to Mr. Darley, of Buttercramb, near York, who obtained him through his brother, a merchant of Aleppo. He is said to have been a native of Palmyra, but this is only traditional, and there is really nothing certain known of his blood. He was the sire of the Devonshire Childers, and his brother, Bartlett's Childers; the former not being now represented by any horse through the male line, but being the maternal great-grandfather to Herod, while the latter is well known to all horsebreeders as the great-grandsire of Eclipse. He also was the sire of Almanzor, a good race-horse, Cupid, Brisk, and Dædalus, all fast, and of a host of inferior runners, though he had few mares put to him. The Devonshire Childers is supposed to have been the fastest horse of his day, and it is recorded that he ran the round course at Newmarket (three miles six furlongs and ninety-three yards) in six minutes forty seconds. Bartlett's Childers was not trained. In addition to the Darley Arabian, there were also imported, between the years 1700 and 1724, when the Godolphin Barb appeared, Curwen's Bay Barb, the Thoulouse Barb, the Belgrade Turk, the Lonsdale Bay Arab, Compton's Barb, afterwards named the Sedley Grey Arab, the Cullen Arabian, the Leedes Arabian, and St. Victor's Barb. The Curwen Bay Barb was grandsire on the maternal side of Partner, and with the Thoulouse Barb was presented to Louis XIV. by the King of Morocco. They were purchased from the natural son of Louis by Mr. Curwen, of Workington, Cumberland, and brought over to England. The Belgrade Turk was taken at the siege of Belgrade. Nothing is known of the antecedents of the Lonsdale Bay Arab, but he was sire of a great many good horses; yet he is not now represented by any descended through the male line. Of the others we have no record beyond their names in the various pedigrees.

The Godolpuin Arabian is very commonly supposed to have been the last Eastern horse of any note used in the stud, with the exception of the Wellesley Grey Arab, in the early part of the present century. This, however, is not true ; for whereas he was foaled about the year 1724, there are the following names to be seen in the best pedigrees, all of later date; viz. the Damascus Arab, 1754; the Newcombe Bay Arab, 1756; the Coombe Arab, 1760; and Bell's Grey Arab, 1765. The Godolphin Arabian, or Barb as he is very commonly supposed to have been, was about 15 hands high, and of a rich brown bay colour. The tradition is that he was sent to France from Barbary, as a present to Louis XIV. by the Emperor 
of Morocco; but, like the Curwen Bay and Thoulouse Barbs, he was not. valued as he deserved, but being turned out of the stud, was employed to draw a water-cart in Paris. From this ignoble occupation he was rescued by Mr. Coke, but when brought to England he was at first no better off, for he was used as teazer to Hobgoblin, and was only allowed to cover Roxana on the refusal of that celebrated horse to do his duty. The produce was Lath, the most celebrated race-horse of his day, and reputed to be only second to Childers. This success immediately procured him plenty of mares, chiefly, however, belonging to the Earl of Godolphin ; and it is not a little remarkable that before Lath could have been tried, in fact, when he was only a yearling, his dam, Roxana, was put to the Godolphin Arabian again, producing Cade, the sire of Matchem, who though less famous in his own day, is now much better known from his greater success as a stallion. He also got Regulus, the maternal grandsire of Eclipse, Blank, and Babraham, both represented in our best pedigrees. The shape of the Godolphin Arabian was very remarkable, as may be seen on examining the engraving of him given at page 20 .

The Damascus Arab, imported in 1760 , was said to be of pure Arab blood, having been presented by the Sheik of Acria to the Pasha of Damascus, who gave him to a merchant at Aleppo, and he again sold him to an Englishman who was then on his travels. He is not now represented in the stud, though of some celebrity in his day as a stallion. The Newcombe Bay Arabian was of considerable size and substance, resembling in these respects the Godolphin Arabian more than the ordinary run of Eastern horses. He, however, had very few mares. Bell's Grey Arabian was the last of the importations made during the eighteenth century, being extensively used in the stud between the years 1765 and 1772 , when he died. He was sire of a great many good runners in his day, but his blood is now entirely extinct.

DURING THE FIRST HALF of the eighteenth century, besides the two Childers which have been already mentioned under the head of the Darley Arabian, the following celebrated horses and mares were foaled:-

Basto, 1703; who was considered to be one of the best horses of his year.

Makeless, a son of the Oglethorp Arabian.

liay Bolton, 1705 ; a great winner.

Brocklesby Betty, 1711 ; who was thought to be superior to any horse of her time, and was not trained till after she had produced a foal.

Brockleshy, 1728 .

Bonny Black, 1715.

Buckhunter, 1715; better known as the Carlisle Gelding, being obliged to be castrated on account of vice.

Fox, 1714.

Squirrel, 1719.

Miss Neasham, 1720; dam of Miss Patty, and through her granddam of Captain Macheath, who travelled and raced more than 500 miles by road in seven weeks

Old Cartouche, and Bald Charlotte.

Crab, 1722.

Hobgoblin, 1724; by Aleppo, son of the Darley Arabian.

Fearnought, 1725.

Starling, 1727.

Partner, 1731.

Little Partner, 1731.

Miss Layton, 1736.

I.ath, 1732 ; the cause of the Godolphin Barb coming into use.

Second, 1732. 
Volunteer, 1735 .

Mooreork, 1740 .

Babraham, 1740 ; son of the Godolphin Arabian, out of the large Hartley mare. Little Driver, 1743.

Silver Leg, 1743.

Othello, afterwards called Black and all Black, 1743.

Sampson, 1745.

Brilliant, 1750 .

Forrester, 1750.

Marske, 1750 ; sire of Eclipse.

Snap, 1750.

Syphon, 1750.

IN THE YEAR 1750 there came off at Newmarket the celebrated match made by the Duke of Queensberry (then Earl of March), to get four horses to draw a carriage with four wheels, and a person in it, nineteen miles within the hour. The feat was performed in fifty-three minutes twenty-seven seconds; and the four horses engaged, which were each ridden, were Mr. Greville's Tawney, Mr. Hammond's Roderick Random, the Duke of Hamilton's Chance, and Mr. Thompson's Little Dan. The horses ran away for the first four miles, which were accomplished in nine minutes.

Between the years 1748 aNd 1764 the repeated use of Arab, Turkish, and Barb blood had produced the happiest effect upon our race-horses, and during this period three celebrated horses were foaled, which respectively carry on the blood of the Byerley Turk, the Darley Arabian, and the Godolphin Barb through the male lines. These three are Herod, or as he was then called King Herod, foaled in 1758 ; Eclipse, foaled in 1764; and Matchem, in 1748. Mr. Goodwin, Veterinary Surgeon, of Hampton Court, has published a table in which he traces all our good thoroughbred horses of the present day to one or other of the three Eastern roots above mentioned; but he seems to have forgotten that in each case, even prior to the time of Herod, Matchem, and Eclipse, there had been a mixture with one of the other two, and since then in almost every case with the third. It is, therefore, scarcely fair to attribute the excellence of Melbourne, for instance, to the Godolphin Arabian, from whom he is descended in the male line through Matchem, for the latter horse was also closely allied to the Byerley Turk through his dam, and had moreover a second more remote strain of the same blood. The same may be said of Melbourne's great rival, Touchstone, who is set down by Mr. Goodwin as a proof of the value of the Darley Arabian, to whom he can readily be traced through a series of sires numbering Eclipse among them. Now a glance at the pedigree of this latter horse will show that though he was a great-great-grandson of the Darley Arabian through Bartlett's Childers, he was a great-grandson of the Godolphin Barb on the side of his dam, and therefore one remove nearer to the latter. Again, Bay Middleton, the contemporary of Touchstone and Melbourne, and a representative of the Byerley Turk, according to Mr. Goodwin's table, is descended through Herod from the Darley Arabian on the dam's side, as well as from the Byerley Turk on that of his sire. To make this clear, however, I will give the pedigree tables of the three horses above mentioned, which will also serve to illustrate another point which must be subsequently discussed. 


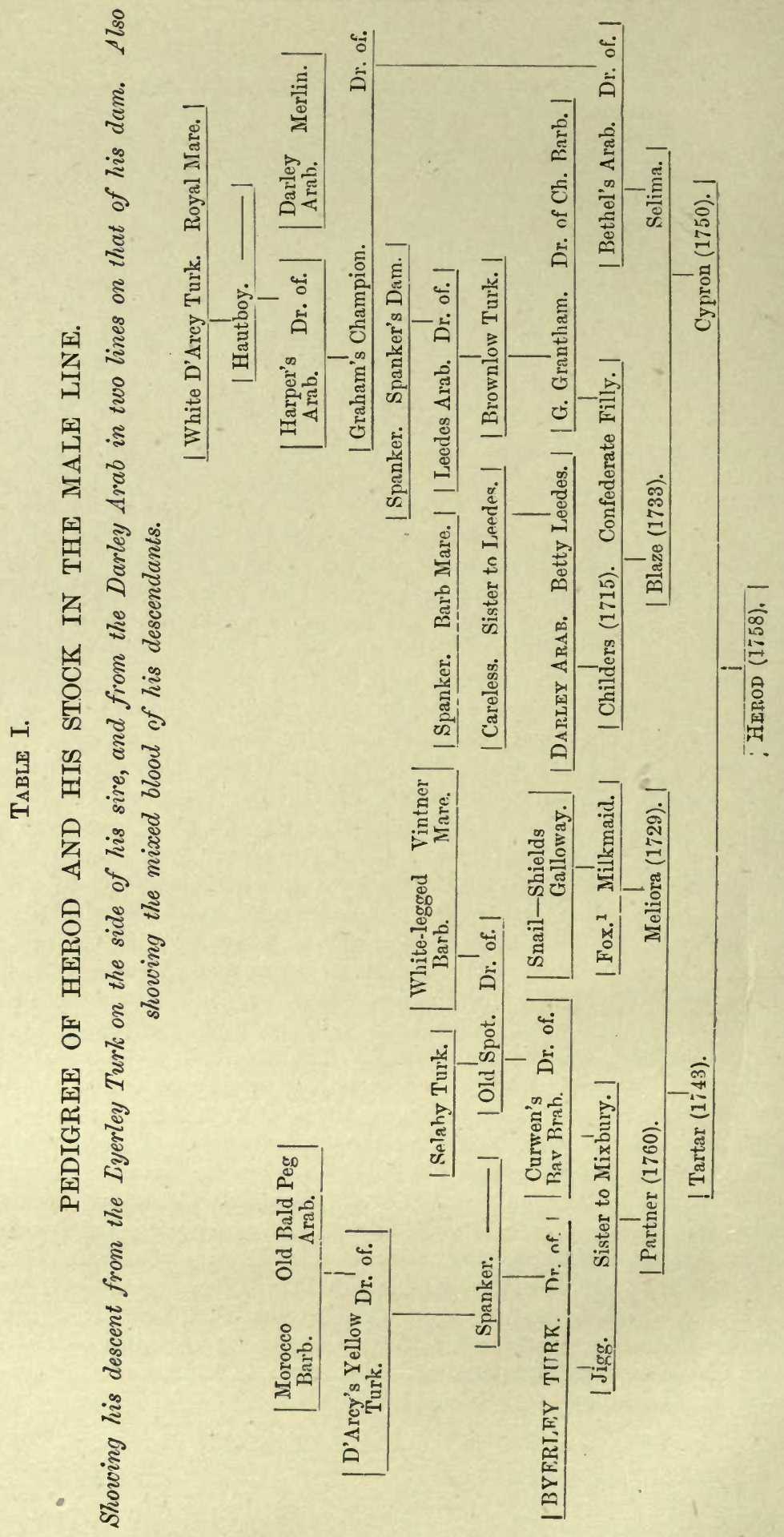




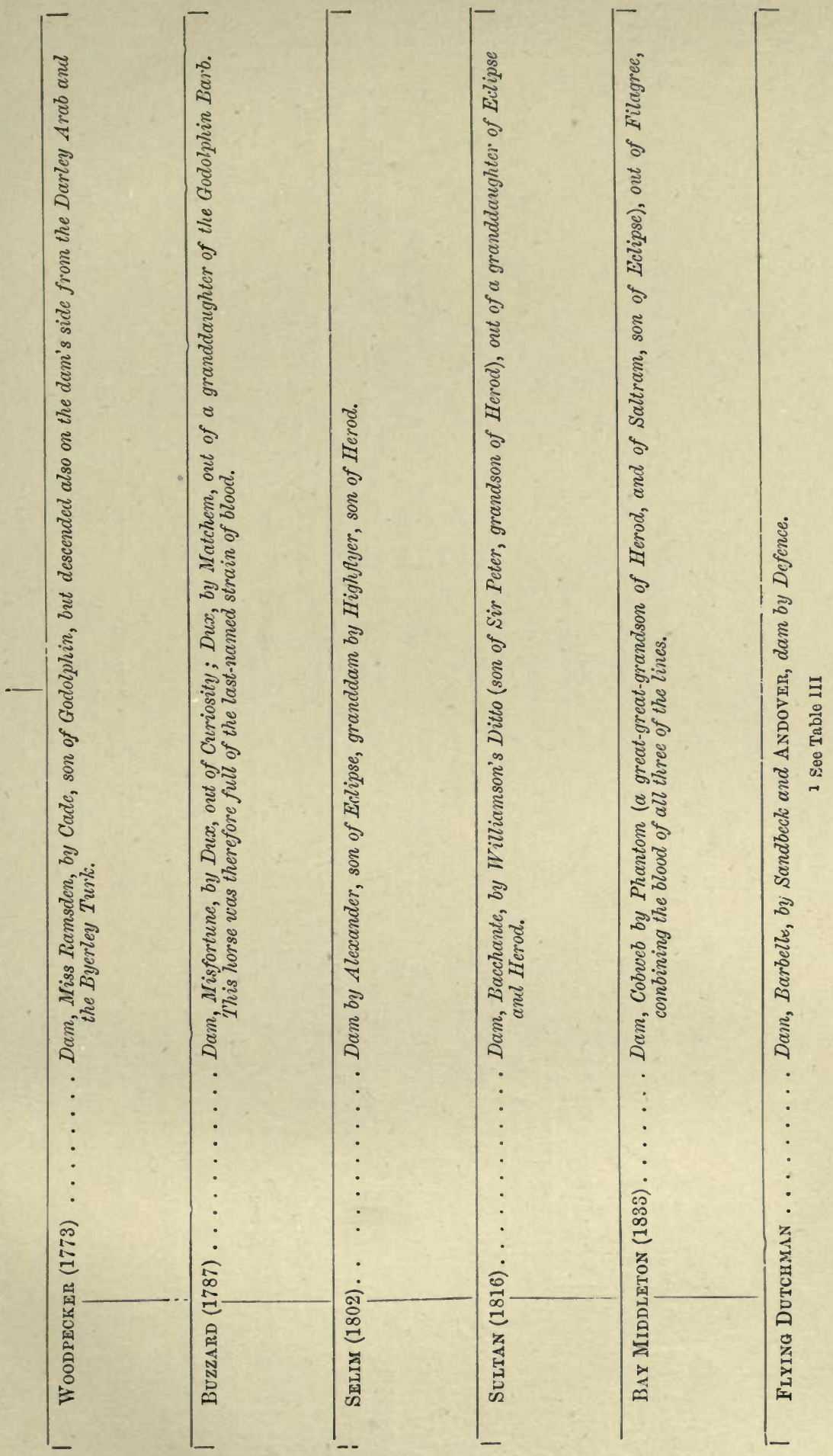


THE HORSE

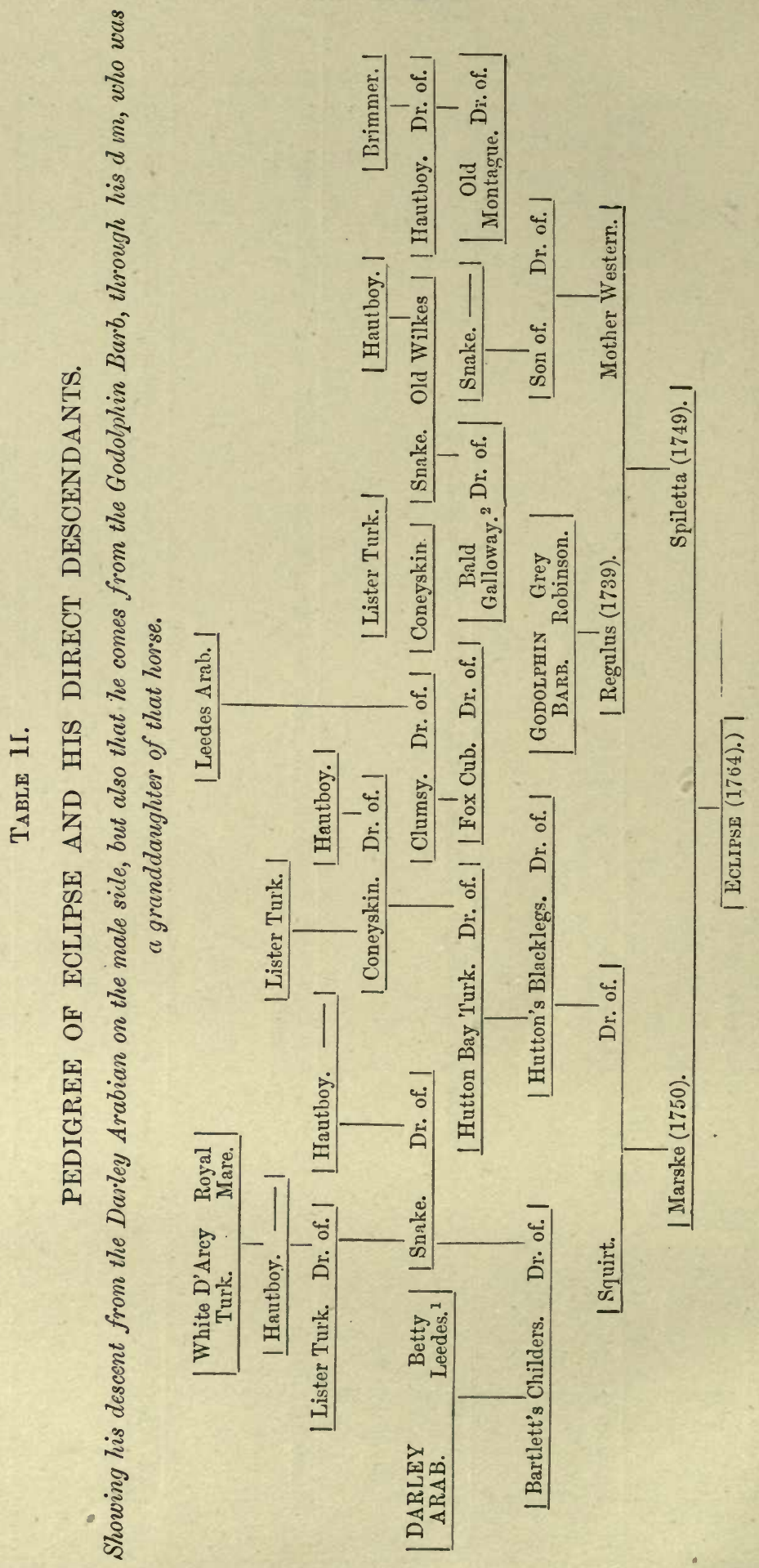


PEDIGREE OF ECLIPSE

77

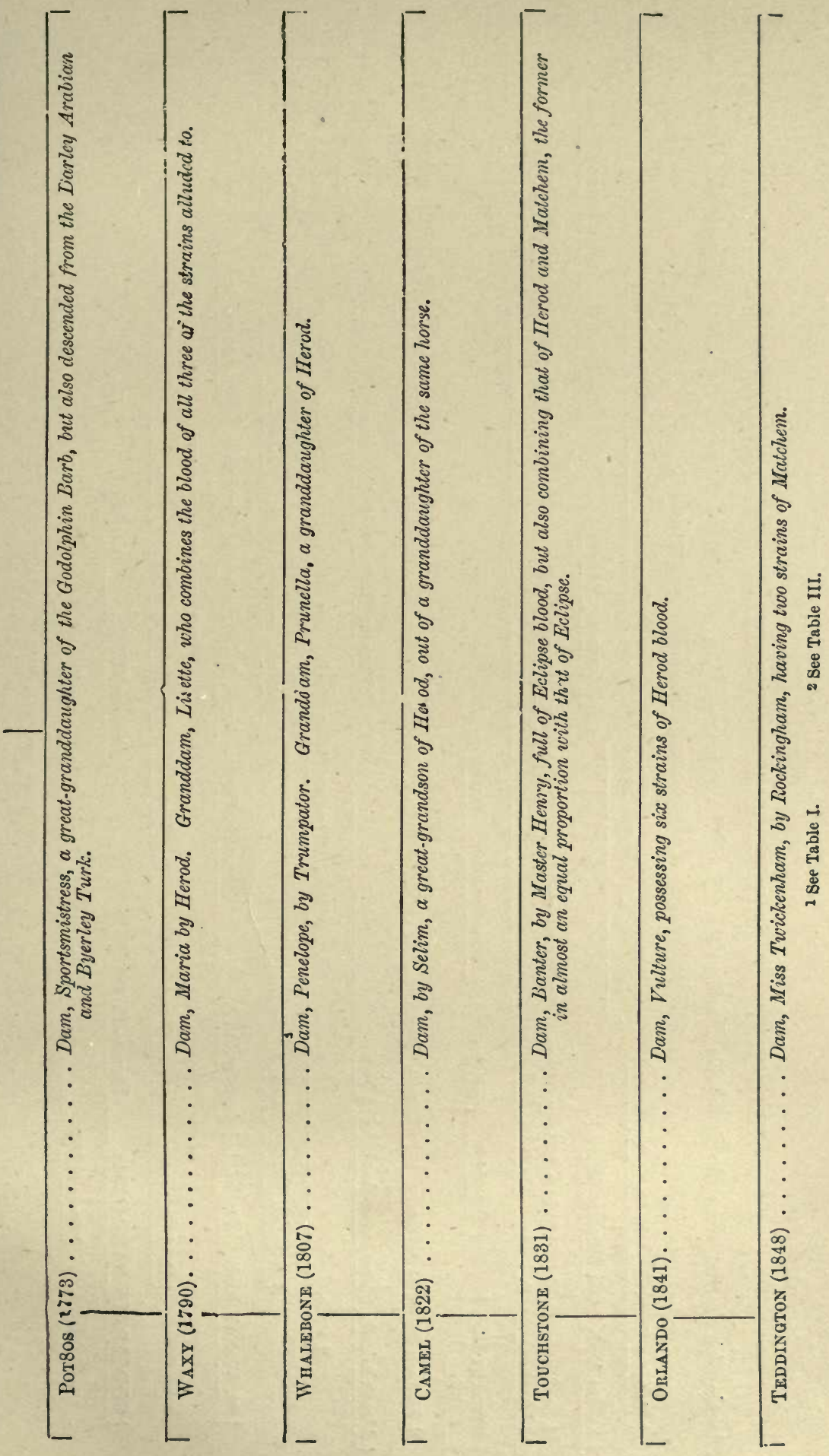




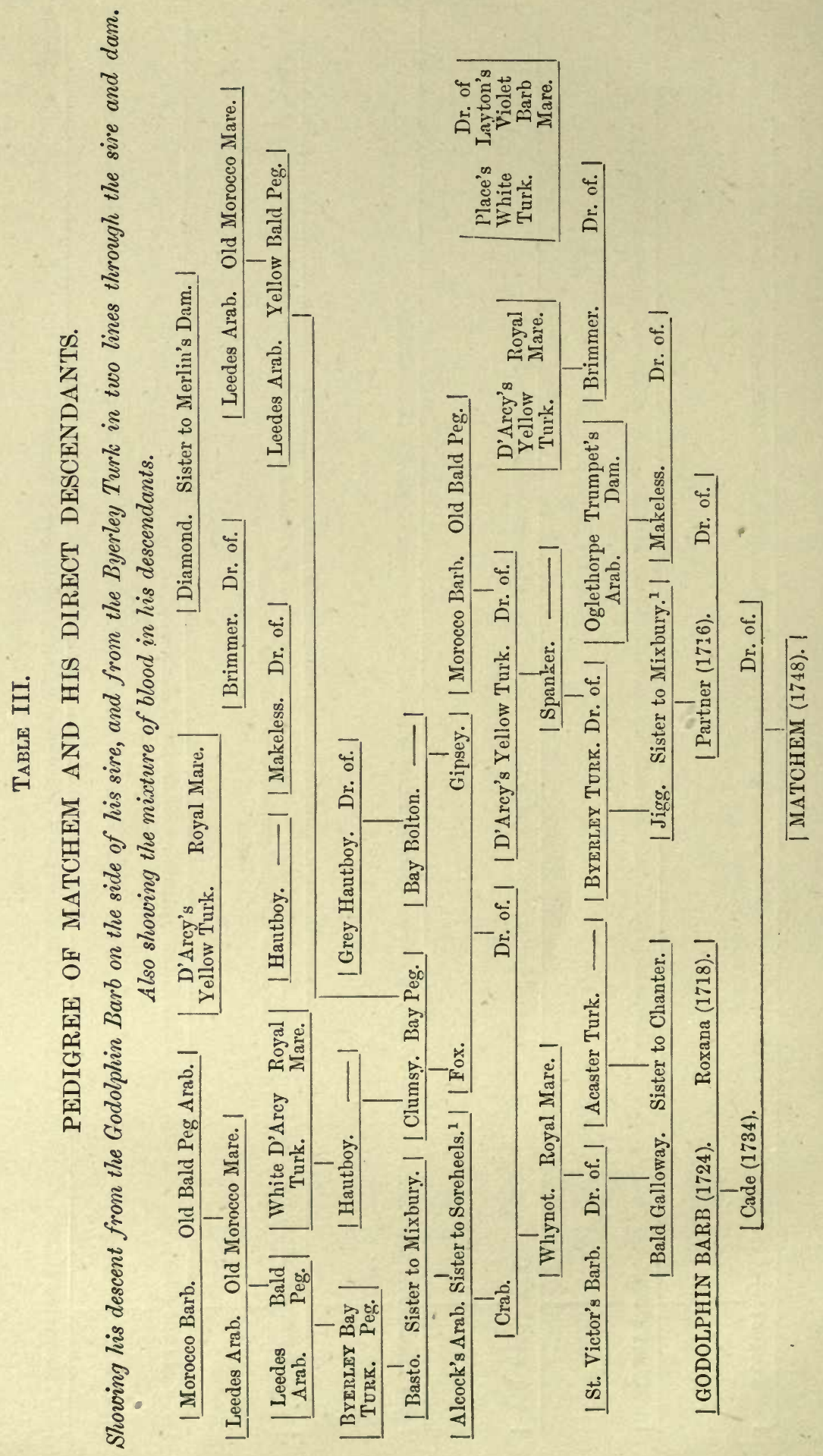


PEDIGREE OF MATCHEM

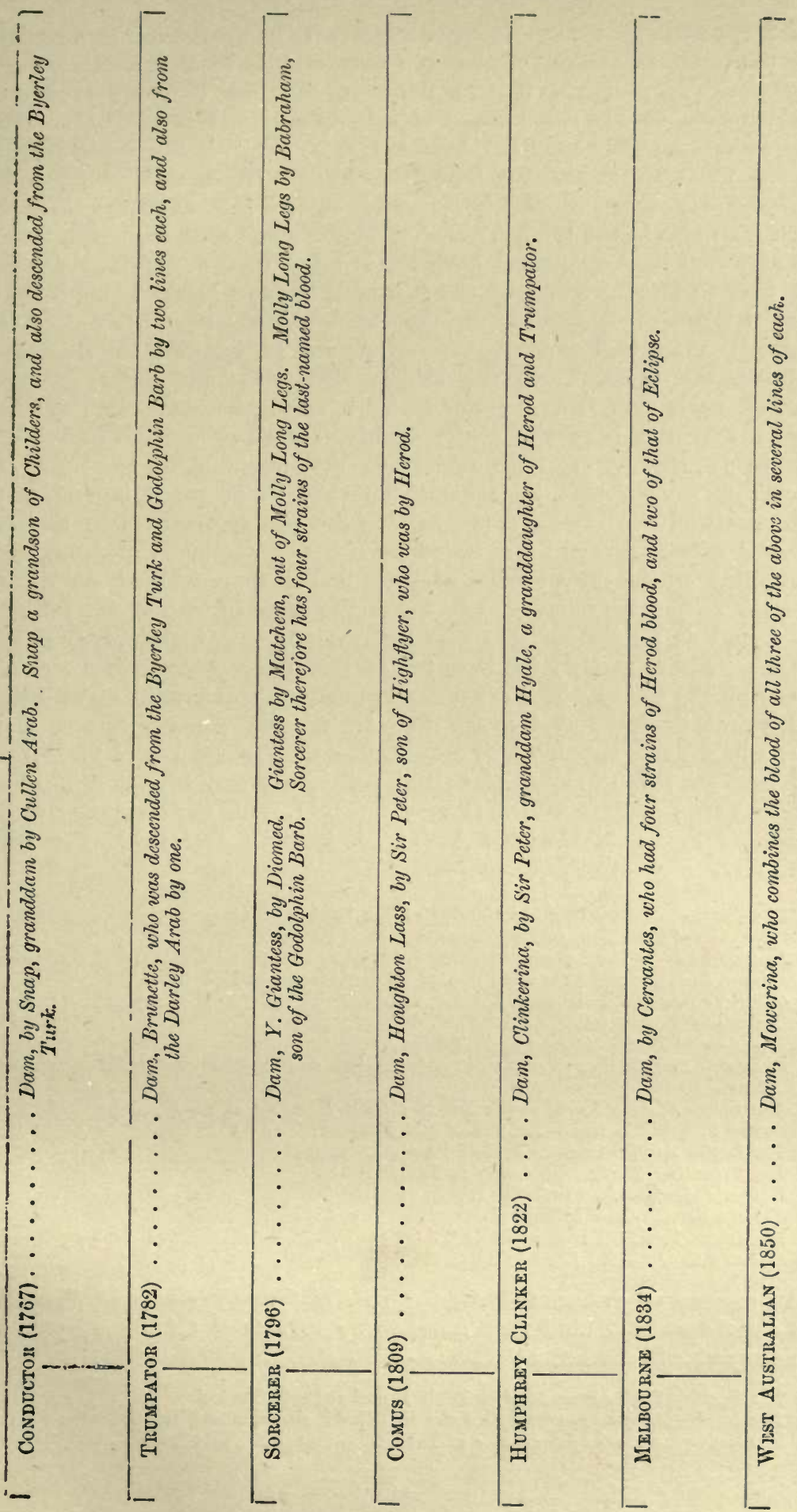


I HAVE SAID that there is another point to be considered in examining into the claims of these three Eastern sires, and to be estimated above all others. Each pedigree, it will be seen, contains the names of other Eastern sires, besides a fer mares of that blood; and it has been argued that we are therefore as much indebted to the St. Victor's Barb, D'Arcy's Yellow Turk, Curwen's Bay Barb, the Acaster Turk, and Place's White Turk, for the success of Matchem and his descendants, as to the Godolphin Barb. So also in the table which has Herod's name at the head, we find not only that he is descended from the Byerley Turk and Darley Arabian, but that he has the names of the following Eastern horses in his pedigree, viz.- the White D'Arcy Turk, the Leedes Arab, the Brownlow Turk, Harper's Arab, and Bethel's Arab. Again, in relation to Eclipse, he numbers the Lister Turk, the Leedes Arab, Hutton's Grey Barb, St. Victor's Barb, and D'Arcy's Yellow Turk among his ancestors; and why should they not have the credit of his success as well as the Darley Arabian? Now, some have replied to this question by asserting that though it is true that their names do thus occur, yet it is only as the progenitors of the various dams, as they are not represented in the male ine. Another argument is founded upon the accumulative evidence which is afforded by the three celebrated roots of our thoroughbred stock. For whereas we find the names of two out of the three in each of the pedigrees viven, and as we descend, the whole of them almost invariably, yet, as is alleged, we have rarely more than one of the other Eastern sires occurring in any of the tables. This argument requires a little careful investigation, and I will therefore analyze the three tables with reference to each of the sires I have enumerated, which are-1. The St. Victor's Barb ; 2. D'Arcy's Yellow Turk; 3. Curwen's Bay Barb; 4. The Acaster Turk; 5. Place's White Turk; 6. The White D'Arcy Turk. 7. The Leedes Arab; 8. The Brownlow Turk; 9. Harper's Arab; 10. Bethel's Arab; 11. The Lister Turk; 12. Hutton's Grey Barb.

1. The St. Victor's Bay Barb, as the sire of the Bald Galloway, is met with once in the pedigree of Matchem, and also once in that of Eclipse.

2. D'Arcy's Yellow Turk occurs in Table 1, thrice as sire of Spanker ; in Table 3, twice as sire of Spanker and Brimmer; and in Table 2, as sire of Brimmer.

3. Curwen's Bay Barb. Once in Table 1, as sire of the Sister to Mixbury, which mare also occurs in Table 3 twice.

4. The Acaster Turk. Once only in Table 3.

5. Place's White Turk appears only once as the sire of the great-great-granddam of Matchem.

6. The White D'Arcy Turk, as the sire of Hautboy, occurs seven times in Table 2, and twice in Table 1, also as the sire of that horse.

7. The Leedes Arab. Once in Table 1; twice in Table 2.

8. The Brownlow Turk. Once only in Table 1.

9. Harper's Arab. Once in Table 1.

10. Bethel's Arab. Once in Table 1.

11. The Lister Turk. Thrice in Table 2.

12. Hutton's Grey Barb. Once in Table 2.

IN COMPARING THESE, therefore, with the three "great roots," as they are called, we shall find that numerically several of them are equal, and some superior to the latter; thus :-

1. The Byerley Turk occurs once in Table 1, and twice in Table 3.

2. The Darley Arabian is met with twice in Table I, and once in Table 2.

3. The Godolphin Barb appears once in Table 2, and once in Table 3. 
IF, THEREFore, the value of a particular strain descending through the female line is the same as that passing through the male branches, the foregoing calculation would place the two D'Arcy Turks considerably ahead of all competitors. The Yellow D'Arcy Turk, for instance, appears in all three of these great pedigrees (altogether six times), while the White D'Arcy Turk, through Hautboy, is met with nine times in two out of the three pedigrees. Mr. Hanckey Smith and other writers on the horse have drawn attention to this subject, and although I have on former occasions disputed the correctness of his arguments, yet on a careful reconsideration I am bound to admit that there is perhaps some tenable ground for the hypothesis, even if we do not accept it. But though it is quite true that, as I before remarked, these horses occur more frequently than any other in the three pedigrees, yet still the strains are much more remote ; and in the pedigree of Eclipse, for instance, the whole seven, when put together, only amount to $\frac{9}{128}$ of that horse. Now this is only a trifle over $\frac{1}{16}$, while the Darley Arabian makes up exactly that proportion, and the Godolphin Barb twice as much, or $\frac{1}{8}$. But when, in addition to these facts, it is considered that both the one and the other of the last-named horses are continually being renewed as we come nearer to our own times, while the re-appearance of the White D'Arcy Turk is much more rare, the argument is no longer felt to be tenable. Eclipse himself, I think, may very probably have owed his good qualities to the numerous lines of the White D'Arcy Turk; but taking his son Pot8os and his grandson Waxy, the probability is all the other way. For Eclipse, being composed of a little more than $\frac{1}{16}$ of the White D'Arcy, of $\frac{1}{16}$ exactly of the Darley Arabian, and $\frac{1}{8}$ of the Godolphin Barb, is put to Sportsmistress, possessing a trace of the White D'Arcy Turk, but made up of $\frac{1}{8}$ of the Godolphin Barb, and $\frac{1}{64}$ each of the Darley Arab and Byerley Turk. The composition, therefore, of the produce, Pot8os, will be $\frac{1}{4}$ Godolphin Barb, $\frac{5}{64}$ Darley Arabian, $\frac{1}{64}$ Byerley Turk, and $\frac{9}{128}$ of the White D'Arcy Turk. To make this calculation intelligible, it is necessary to study the subject of breeding, to the chapter on which my reader is referred for its explanation. Proceeding, however, io the next step, we see Pot8os put to Maria, who is composed of $\frac{11}{128}$ D'Arcy White Turk, but then $\frac{1}{4}$ of her blood is that of the Godolphin Barb, $\frac{3}{32}$ of the Darley Arab, and $\frac{9}{128}$ Byerley Turk. Her composition therefore becomes $\frac{3}{8}$ of Godolphin Barb, $\frac{5}{32}$ of the White D'Arcy Turk (or a little more than $\frac{1}{8}$ ), $\frac{11}{84}$ of Darley Arab blood (or about $\frac{1}{6}$ ), and $\frac{11}{128}$ Byerley Turk ( or about $\frac{1}{12}$ ), proving, on this method of calculation, the superior claims of the Godolphin Barb and Darley Arabian to those of the White D'Arcy Turk, in estimating the value of the several elements of which Waxy is composed.

THis arithmetical METHOD of calculation is not to be entirely depended on, for we shall find, in discussing the theory and practice of breeding, that where $n$ domestic animal (A) composed of eight several strains is put to another (B) composed also of eight strains of blood, but one of them being similar to one in $(\mathrm{A})$, the produce shall be more than $\frac{1}{4}(\mathrm{~A})$ in appearance and qualities, and this goes on increasing in proportion to the number of times that the experiment is repeated. Eclipse, then, having nine distinct lines of the White D'Arcy Turk, might be expected, on this hypothesis, to be really composed of much more than the exact propor- 
tionals of that horse which I have assigned to him; and it is on these grounds only that Mr. Hanckey Smith's theory can be supported, unless the preponderance of the male is admitted to be less than it is very generally supposed to be. The subject is one not merely historically curious, but of the deepest interest to the breeder of any of our domestic animals, and I shall again return to it hereafter. I merely mention it in this place to show there are two sides to the question, and that on the value of the paternal in comparison with the maternal blood depends, not only the relative importance of the Byerley Turk, the Darley Arabian, and the Godolphin Barb, in reference to each other, but to the earlier Eastern strains, and more especially the Two D'Arcy Turks.

Having given the Pedigrees of these three celebrated horses, I shall now allude to their characteristics and performances, as well as those of one or two of their contemporaries, as detailed in the chronicles of the day, which, however, I am afraid are not strictly to be depended on.

The Flying or Devonshire Childers was a chestnut horse, with a white nose, and four white legs. He was bred by Mr. Childers, near Doncaster, and sold by him to the Duke of Devonshire. He is pictorially handed down to us as possessing the shape and action of a light showy carriage-horse, but I am afraid that the animal painters of those days are not much to be trusted. Fortunately two-year-old races were not then thought of, and Childers did not appear on the turf till April 1721, when he won a four-mile match for 500 guineas at Newmarket, beating the Duke of Bolton's Speedwell, who also forfeited the stake to him in a return match made for the following October. His races were, as was the custom of those days, either for four or six miles, and the weights from 8 stone 7 pounds to 10 stone, under which he is said to have performed the following wonderful feats; but the timing was made with ordinary watches, and mistakes must undoubtedly have occurred:-About the year 1721, he is said to have run a trial with Almanzor and the Duke of Rutland's Brown Betty, carrying 9 stone 2 pounds, over the Round Course ( 3 miles, 4 furlongs, 93 yards) at Newmarket in 6 minutes and 41 seconds; and soon afterwards he ran the Beacon Course ( 4 miles, 1 furlong, 138 yards), under 9 stone 2 pounds, in 7 minutes and 30 seconds, which is about the rate of speed of our modern horses, over our shorter courses, and under 8 stone 7 pounds. It is therefore very doubtful whether the speed has not been exaggerated, and especially as we shall presently find a still higher rate is accorded to Matchem. He was never beaten. His brother Bartlett's Childers was never trained, owing to a bleeding from the nostrils to which he was subject, but was at once put to the stud, and was the sire of numerous winners.

Matchem was bred by Mr. John Holon of Carlisle in the year 1748, but was sold as a foal to Mr. Fenwick, of Bywell, Northumberland. He, like Childers, did not appear till he was five years old, when he won a subscription purse at York, and had a long series of successes at Newmarket, winning on one occasion, as it is said, a $£ 50$ plate, over the B. C., 8 stone 7 pounds, in 7 minutes and 20 seconds; but this being a greater performance than that of Childers, may be considered still more doubtful. He was subsequently beaten over the same course for the Jockey Club Plate, in three heats, the first being timed at 7 minutes $52 \frac{1}{2}$ seconds; the second, in 7 minutes 40 seconds; and the third in 8 minutes 5 seconds; which 
still further upsets the probability of his having performed the wonderful feat above mentioned. In 1859 , he won a $£ 50$ plate at Scarborough, after which he was put to the stud, his price being at first 5 guineas, but the success of the stock caused this to be doubled in 1765 ; and again, in 1770 , when it was raised to 20 guineas; the lapse of another five years inducing his owner to limit him to 25 mares at 50 guineas each. He is supposed in this way to have earned $£ 17,000$, and in twenty-three years his stock won upwards of $£ 150,000$.

Herod, foaled in 1758 , was a rich bay, and of very fine symmetry anc? size. He was bred by the Duke of Cumberland, and sold to Sir John Moore at his death. After a long series of successes at Newmarket, he burst a blood-vessel in running for a subscription-purse at York, in 1766, after which he was never quite in his previous form, and was put to the stud, commencing with 10 guineas, in 1768 , and ending with 25 guineas, from 1774 to his death, which occurred in 1780 . His stock won upwards of $£ 201,000$, besides many hogsheads of claret, whips, cups, etc.

ECLIPSE (so named from being foaled in the year 1764, when there was an eclipse of the sun) was a chestnut horse, like Herod bred by the Duke of Cumberland, and at his decease sold to Mr. Henry Wildman, a Smithfield salesman, who kept race-horses at Mickleham, near Epsom. Prior to the, sale he must have had some private intelligence of the merits of the horse, for we are told that when he arrived there in ample time, according to the terms of the advertisement, the sale had been effected, but, claiming that the lots already knocked down should be resold, the result was that he purchased Eclipse for 75 guineas. In a short time he sold a moiety to Colonel O'Kelly for 650 guineas, and in the following year the othor moiety for 1100 guineas. In May 1769, when five years old, Eclipse won $£ 50$ at Epsom, and it was on the second heat of this unimportant race that Colonel O'Kelly is said to have won a very large sum of money, by laying against all the five horses engaged in it. Such a feat is so improbable, according to the laws of chance, that his offer was immediately taken at much less than the legitimate odds, and on being called on to declare, he complied with the demand by placing "Eclipse first and the rest nowhere," winning his bet by the great speed of his horse. During the two seasons which he was on the turf he won an immense number of stakes for Colonel O'Kelly, but at last his extraordinary powers were so generally admitted that no owner would enter a horse against him, and he was obliged to retire, never having been beaten or paid forfeit. Among his victories are eleven King's plates, the weights for all but one of which were 12 stone, which now-a-days would be considered a crusher, even for a mile or a mile and a half. He covered at Clay Hill near Epsom, his price being at first fixed at 50 guineas, but in 1772 it was reduced to the more reasonable sum of 25 guineas, fluctuating between which and 30 guineas he continued at the service of the public till 1789 , when he died. He was so lame in his feet, that on being removed from Epsom to Cannons in Middlesex, he was obliged to be placed in a caravan on four wheels, and this was the first instance in which a van was used for this purpose, though now so commonly employed. The proportions of Eclipse have been minutely described by St. Bel, the founder of the school which afterwards became The Rojal Veterinary College, London. 
The skeleton of Eclipse is well set up in the new museum, and visitors can usually see it by presenting their cards at the portal of this famous institution, over whose centenary H.R.H. the Prince of Wales presided in 1894. St. Bel took the admeasurements during life, but verified them after death, and they are, therefore, as reliable as any such can possibly be, but it must be remembered that they were taken when he was twenty-four years old.

\section{ST. BEL'S MEASUREMENT OF ECLIPSE.}

The length of the head of the horse is supposed to be divided into twenty-two equal parts, which are the common measure for every part of the body.

Three heads and thirteen parts will give the height of the horse from the foretop to the ground.

Three heads from the withers to the ground.

Three heads from the rump to the ground.

Three heads and three parts, the whole length of the body, from the most prominent part of the chest to the extremity of the buttocks.

Two heads and twenty parts, the height of the body, through the middle of the centre of gravity.

Two heads and seven parts, the height of the highest part of the chest from the ground.

Two heads and five parts, the height of the perpendicular line which falls from the articulation of the arm with the shoulder, directly to the hoof.

One head and twenty parts, the height of the perpendicular line which falls from the top of the fore leg, dividing equally all its parts to the fetlock.

One head and nineteen parts, the height of the perpendicular line from the elbow to the ground.

One head and nincteen parts, the distance from the top of the withers to the stifle. The same measure also gives the distance from the top of the rump to the elbow.

One and a half head, the length of the neck from the withers to the top of the head. The same measure also gives the length of the neck from the top of the head to its insertion into the chest.

One head, the width of the neck at its union with the chest.

Twelve parts of a head, the width of the neck in its narrowest part.

The same measure gives the breadth of the head taken below the eyes.

One head and four parts, the thickness of the body from the middle of the back to the middle of the belly.

The same measure gives the breadth of the body.

Also the rump from its summit to the extremity of the buttocks.

Also the distance from the root of the tail to the stifle.

Also the length from the stifle to the hock.

Also the height from the extremity of the hoof to the hock.

Twenty parts of a head, the distance from the extremity of the buttocks to the stifle.

Also the breadth of the rump or croup.

Ten parts of a head, the breadth of the fore-legs from their anterior part to the elbow.

Ten parts of a head, the breadth of cne of the hind-legs taken beneath the fold of the buttocks.

Eight parts of a head, the breadth of the ham taken from the bend.

Also the breadth of the head above the nostrils.

Seven parts of a head, the distance of the eyes from one great angle to the other.

Also the distance between the fore-legs.

Five parts of a head, the thickness of the knees.

Also the breadth of the fore-legs above the knees.

Also the thickness of the hams.

Four parts of a head, the breadth of the pastern, or fetlock joint.

Also the thickness of the coronet.

Four and a half parts of the head, the breadth of the coronet.

Three parts of a head, the thickness of the legs at their narrowest part.

Also the breadth of the hinder legs or shanks.

'Two and three-quarter parts of a head, the thickness of the hind pasterns.

Also the breadth of the shanks of the fore-legs.

Two and a quarter parts of a head, the thickness of the fore pisterns.

Also the breadth of the hind pasterns.

One and three-quarter parts of a liead, the thickness of the fore and hind shanks. 
From these proportions it appears that the horse was generally long and low, and that he had a remarkably low forehand as compared with his hips, which were considerably higher than his withers. I have already gone into this subject, however, and must refer my readers to page 16 for the particulars of it. The stock of Eclipse won $£ 158,047$, being little more than three-fourths of that which fell to the share of that of Herod, and I believe the same proportion would be found to exist in the next remove from each horse.

As AN INSTANCE of the stoutness of the horse of this period, I shall insert a record of the match against time won by Mr. Shafto, on June 27, 1751. The conditions were that he should ride fifty miles, on an unlimited number of horses, in 2 successive hours, and he accomplished the task in 1 hour, 49 minutes, 17 seconds, with the ten following horses, using four of them twice.

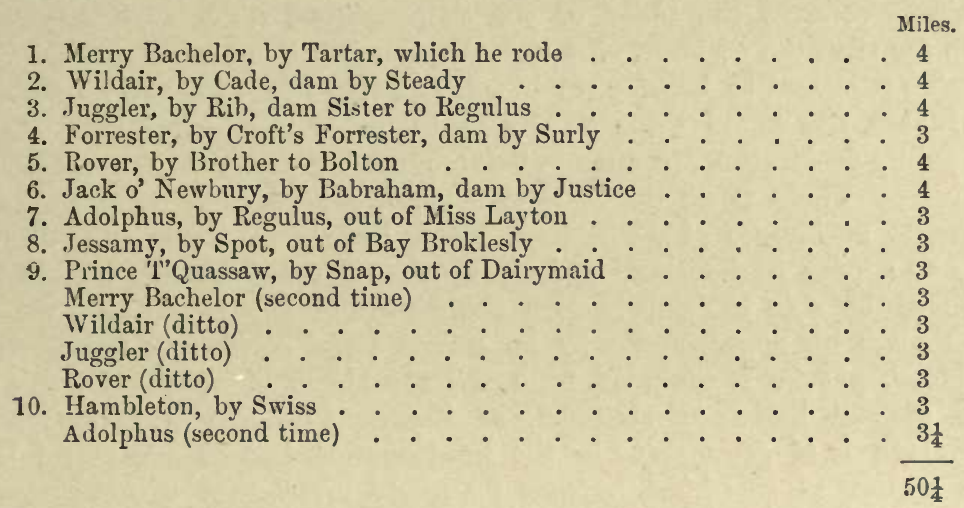

Allowing the odd minutes and seconds for the fifteen changes, this makes the rate exactly two minutes per mile, which was the fastest rate made by Mr. Osbaldeston in any of his four-mile stages when doing his 200 mile match, and then only by one horse, Tranby. And thus we get some definite idea of the performance of the horses of those days, which we can by and by compare with those of our own.

\section{THE MODERN THOROUGHBRED}

To DEFINE the thoroughbred horse of the nineteenth century is easy enough, because it is only necessary to adduce the law that he must appear in the Stud-book. Without this testamentary evidence no other will be received, nor even theoretically can any other be adduced. By some it is supposed that he is a horse descended from sires and dams of Eastern blood, that is, either Turks, Barbs, or Arabs; but this has iong been known to be a fallacy, for we find numerous gaps in almost all the old pedigrees, which there is every reason to believe ought to be occupied with the names of native or Spanish mares. But though the Studbook is thus received as the existing authority on this matter, it is open to a question whether it may not be desirable to amend it by introducing into its pages horses and mares which can be proved to be stainless for a 
certain number of generations. The subject is a difficult one, for while it is comparatively easy to keep a record year by year of the foals as they are dropped, it is extremely difficult to obtain satisfactory proof of similar facts which occurred six generations back, and this would be the earliest period at which it could be supposed that the stain of impure blood could be washed out. For instance, supposing a thoroughbred horse is put to a common mare in 1859, and the produce is a filly in 1860 ; this filly might again breed a filly in 1864, and have a granddaughter in 1868, and a great-granddaughter in 1872, and so on to the year 1870, when the produce would still be composed of one sixty-fourth part common blood and the rest thoroughbred. But twenty years would elapse without any public record of the facts, and we all know how difficult it is to disprove any statement made under such circumstances. The safest plan, I believe, is to adopt the course now pursued, unless it can be shown that it is expedient to cross the blood of our thoroughbred stock with some other strain for the sake of improving it. An Eastern horse is at once admitted as being supposed to be of pure blood, and there is therefore no difficulty in his case, nor would there be any in the other to which $I$ have alluded if a public declaration were made beforehand, but for this there is now no provision. There is no doubt that when half-bred races were in fashion numerous exchanges of foals took place, by which thoroughbreds were made to appear as half-bred and vice-versa. But though the pseudo halfbred may be able to compete with the winner of the Derby or St. Leger, and though his appearance may be almost proof positive of the purity of his blood, yet he is excluded from the Stud-book for ever. In this way some of our half-bred stallions are known to be of pure blood, and their stock is of great value in the hunting-field, but no one would breed from a mare of this kind, because he would know that Mr. Weatherby's pages are shut against him, and he could not claim that her produce should receive the seal of purity afforded by that gentleman's pen.

\section{INCREASE OF SIZE AND SYMMETRY}

THE SIZE AND SHAPE of the race-horse of our own days are superior to those of the early part of the last century, as far as we can judge of the latter by a comparison with the portraits painted by Stubbs and his cotemporaries. In point of height there can be no question, for we have numerous records of the number of hands which may be ascribed to the celebrities of the age of Charles II. and his immediate successors.

Out of one hundred and thirty winners in the middle of the last century, only eighteen were 15 hands and upwards, whereas now, a winner below that height is a very great rarity indeed, even among the mares. This increase of size is doubtless mainly due to the influence of the Godolphin Barb, who was himself larger than most of the Eastern sires, and got stock of a still greater height. His son, Babraham, was 15 hands high, then considered an extraordinary development; and of the eighteen winners mentioned above as being 15 hands and upwards, eleven were by the Godolphin Barb or his sons. The average at present may be fixed at 15 hands 3 inches, as I have already shown at page 15. As far as shape is 
concerned, the modern horse has profited by the long-continued and careful selection which has been made of sires and dams. Every breeder has considered good blood a sine qua non, but to this he has added a frame as well adapted as possible to the requirements of the turf. The improvement has chiefly been in the length and slope of the shoulders, and in the length of the arms and thighs, the head also being a good deal attended to, but perhaps as often improperly chosen. No doubt the muzzle can hardly be too fine, but with a small one are often coupled a narrow forehead, and a contracted jaw, two defects of the greatest possible importance; the one interfering with the amount of nervous energy, and the other with good wind. There is no disputing the perfection of shape of the modern English race-horse, and I believe that, perhaps with the single exception of the greyhound, he is the most beautiful animal in creation. Indeed, under certain conditions, he is superior to his canine rival; because he can be so excited as to induce him to display his shapes better than the greyhound, and his superficial veins, being more readily seen when distended, add greatly to his fiery and spirited appearance. I am very doubtful whether the choice of shape has always been correct, and especially in selecting shoulders and quarters. Many breeders have had a fancy for the high croup which is so constantly seen among the Arabs, but which I cannot help fancying to be a defect. A very sloping quarter is almost equally bad, but of the two extremes I much prefer it. Our modern trainers are quite aware of this, and a "peacocky" horse, that is, with his tail set on high, is their aversion. The true shape is that which is given in the portrait of Saunterer, in which horse there is a fine amount of fall, without going into either extreme.

\section{COMPARATIVE STOUTNESS}

BUT ARE OUR MODERN HORSES AS STOUT as those of the last century? Such is the question which has been very differently answered by Lord Redesdale and Admiral Rous, in their correspondence on the alteration of the weights proposed by the former, who contends that while their speed for short distances has been developed to a great extent, their stoutness, or the power of staying over a distance of ground, has greatly diminished. The arguments pro and con which each has adduced would occupy too much space for me to go into them at length, especially as they have been mixed up with others which bear upon the degeneracy of man rather than of his slave the horse. I may however quote one extract from an article in Baily's Magazine of Sports, by the Admiral, which supports his position in an exceedingly clear manner. He says-

"A very ridiculous notion exists that because our ancestors were fond of matching their horses four, six, and eight miles, and their great prizes were never less than four miles for aged horses, the English race-horses of 1700 had more powers of endurance, and were better adapted to run long distances under heavy weights, than the horses of the present day; and there is another popular notion that our horses cannot now stay four miles.

"From 1600 to 1740 most of the matches at Newmarket were above 
four miles. The six-mile post in my time stood about two hundred yards from the present railroad station, Six Mile Bottom, and the eight-mile post was due south from the station on the rising ground; but the cruelty of the distance, and interest of the horse-owners, shortened the course in corresponding ratio with the civilization of the country. Two jades may run as fine a race for eight miles as for half-a-mile-it is no proof of endurance. You may match any animals for what distance you please, but it is no proof of great capacity. We have no reason to suppose that the pure Arabian of the desert has degenerated; his pedigree is as well kept, his admirers in the East are as numerous, and his value in that market has not been depreciated. In 1700 the first cross from these horses were the heroes of the turf. Look at the portraits of Flying Childers, Lath, Regulus, and other celebrated horses, including the Godolphin Arabian. If the artists were correct in their delineations, they had no appearance of race-horses; they of course were good enough to gallop away from the miserable English garrans of that era, as a good Arab or a Barbary horse, like Vengeance, would run away from a common hackney in the present day. Amongst the blind, a one-eyed man is a king.

"My belief is, that the present English race-horse is as much superior to the race-horse of 1750 , as he excelled the first cross from Arabs and Barbs with English mares, and, again, as they surpassed the old English racing hack of 1650 .

"The form of Flying Childers might win now a $£ 30$ plate, winner to be sold for $£ 40$; Highflyer and Eclipse might pull through in a $£ 50$ plate, winner to be sold for $£ 200$. This may be a strong opinion; it is founded on the fact that whereas, one hundred and fifty years ago, the Eastern horses and their first cross were the best and fastest in England, at this day a second-class race-horse can give 5 stone to the best Arabian or Barb and beat him, from one to twenty miles. I presume, therefore, that the superiority of the English horse has improved in that ratio above the original stock."

Granting, as demanded by the Admiral, the premises he assumes, namely, that the Arab of the present day and that of 1750 ars identical in speed and stoutness, the argument is closed, because it is proved that with the exception of Markham's Arabian, who was a failure, the imported Arabs, Turks, etc. of the former period, and more especially their immediate stock, were able to beat the native horses of that day, whereas now an imported Arab is wholly unable to cope with ours. But what right have we to assume that the Arab of 1700 or 1750 is identical with his descendant of 1850 ? Certainly there is no proof to the contrary, but we must remember that during the intervening period Great Britain, France, Germany, Russia, Hungary, America, India, the Cape of Good Hope, and Australia, have all been draining the East, and vieing with one another in their endeavours to procure specimens of her best breeds.

It is asserted that the Arab cannot be induced to part with his best mares, and can seldom be tempted to sell his most highly prized horses; but when money and the pressure of political influence are both brought to bear, we much question his powers of resistance. Besides, 
even supposing that he retained his best mares, if he sold his most valuable stallions the breed would still be more likely to degenerate than if he kept both, as he had always previously done. No one can contend that we are quite as well off in this country without Glencoe, Ion, The Baron, Priam, The Emperor, and other valuable stallions which have been exported to other countries; and if this is admitted, then, by a parity of reasoning, the Arab has suffered in the same way. I cannot, therefore, quite see the force of the argument adduced by Admiral Rous, which depends upon the admission of the identity of the Arab of 1700-1750 with his descendant in the present day. Nor do I think much of that which is grounded upon the unracing-like appearance of "the portraits of Flying Childers, Lath, Regulus, and other celebrated horses" (of that date), "including the Godolphin Arabian." Most of those now extant are mere daubs, and of the better executed productions of Stubbs I confess that I have no great opinion as correct portraits. They are all deficient in that kind of minute fidelity which alone gives unmistakable evidence of a truthful imitation of nature; and if we were left to this evidence alone, I should certainly be unable to make up my mind on the subject. But there is one point in corroboration of Admiral Rous's opinion, though not, I think, warranting him in setting down Highflyer and Eclipse as common platers. I have already alluded to the time in which Childers is said to have run the B. C. at Newmarket, and Matchem four miles at York; but it may be as well to recapitulate here the best recorded times of four miles run near the middle of the last century, and contrast them with those of the English and American horses of our own day. I must, however, first show that the latter should be included in the same boat with our own, and I confess that I should be reluctant to do so but that it is impossible to find on our turf any recent examples of four-mile races run from end to end. Moreuver, we have no reason to suppose that they are stouter than their English relations, though, as is admitted by Admiral Rous, Prioress was, in 1859, "the best four-mile mare in England." To avoid any chance of misrepresentation, I will extract the passage entire.

"Our American friends have improved their race-horses in an equal degree to our own, by sticking to the same blood. They have had the good sense and discrimination to buy the cream of our best stallions,-Precipitate, Diomed, Priam, Trustee, Glencoe. They adhere to the principles which our fathers adopted, of breeding only by stallions which could stay a distance; and very naturally, when all their great prizes and matches vary from two to four miles. We played the same game until the commencement of this century; but when great stakes were made for shorter distances, it was soon ascertained that the sons of the stout old stallions could not win a 2000 guineas stake against the blood of Rubens, Castrel, and Selim. For the last fitty years we have been breeding from our stoutest horses, but principally from large powerful horses with extraordinary speed. The Americans havo bred for stoutness; both parties have succeeded. I cannot shut my eyes to the fact that the American Prioress was the best four-mile mare in England, and that one-half of the American horses brought over to do 
a good thing cannot last over three-quarters of a mile. Such is the lottery of breeding race-horses. Venison, the best four-mile horse of his year (excepting Slane), was got by a speedy jade, Partisan, out of Fawn, which could not race five hundred yards; and Plenipotentiary's dam had great difficulty to run beyond five furlongs. The comparative stoutness of the American and English race-horse is not yet decided. The odds in our favour ought to be three to one, estimating our numerical superiority: if we beat them we shall have no pretensions to crow."

Since the time at which the above remarks were published, Mr. Ten Broeck's Umpire, who was then first favourite for the Derby, in running that race showed a deficiency in the quality which we are now discussing, and his case, therefore, tends to support the Admiral's opinion. The Americans themselves admit that, as far as the performances of their horses in 1857 and 1858 can be considered a criterion, they "had not proved the race-horse of America to be the equal of the race-horse of the English turf ;" my authority being the article on "The American Horses in England," published in the American Racing Calendar for 1859. These conclusions were arrived at after the experience of four seasons, during which Mr. Ten Broeck spared neither money, industry, nor talent, the last being proved by the amount of money which he won in stakes and bets during the time. About twenty horses were trained, and among these he had the luck to have one extraordinarily stout mare, and a first-class two-year-old in Umpire; but all the rest were below mediocrity, and have only "paid their way" in matches and handicaps, when they certainly were so weighted as to lead one to suppose that they are of a superior class to our own horses. I shall, however, separate the performances of the three, so that the reader may not only contrast the old with the modern horse, but also the English with the American.

\section{TIMES MADE BY THE HORSES OF THE MIDDLE OF THE LAST CENTURY.}

About 1721, Childers ran in a trial, carrying 9st. 2 lbs., the R. C., Newmarket

( 3 miles 4 fur. 53 yds.) in. . . . . . . . .

The same horse is also recorded to have run the Beacon Course, Newmarket (4 miles 1 fur. 138 yds.) in . . . . . .

In $1745, \mathrm{Mr}$. Thornhill rode from Stilton to London, back, and again to London

(213 miles) in. 1752 , Skewball, by the Godophin Barb, carrying 8st. 7 llbs., ran 4 miles over

In 1753, at Newmarket, Matchem ran the Beacon Course $(\dot{3}$ miles 4 fur. $\dot{93}$ yds.)

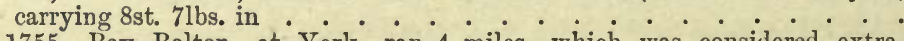

In 1755 , Bay Bolton, at York, ran 4 miles, which was considered extraordinary time, in . . . . . . . . . . . . . . . . .

In 1759 , at York, Careless, carrying 9 st., ran 4 miles in . . . . . . .

Hs. Min. Sec.

\section{BEST MODERN ENGLISH TIMES.}

In 1831, Mr. Osbaldeston, 11st., rode 200 miles over the R. C., Newmarket, using 28 horses, including 1 hour 22 min. 56 sec. for stoppages, in . . .

In 1846, Sir Tatton Sykes ran the St. Leger Course at Doncaster (1 mile 6 fur. 132 yds.) in . . . . . . . . . . .

In 1847, Cossack and War Eagle ran for the Newmarket Stakes D. I. 7 fur. 210 yds. in .

In 1848, Surplice and Cymba, in the Oaks and Derby, cach ran $1 \frac{1}{2}$ miles over this severe course, 8 st $7 \mathrm{lhs}$, and 8 st. 3 lbs., in 
In 1853, the Emperor's Plate at Ascot was won by Teddington, 5 years, 9st., Stockwell, 4 years, 8st. 5lbs. (2 miles 4 fur.), in . . . . . . .

In 1854, at Ascot, West Australian and Kingston ran in the Cup (2 miles 4 fur.) in .

11s. Min. Sec.

In 1857, for the Ascot Gold Cup, Skirmisher, 3 years, German Di Vergy, 3 years, and the Saunterer, 3 years, 6st. 10lbs. each, with Polestar 5 years, 9st., were all placed, the time being ( 2 miles 4 fur.).

In 1859 , Artless, 3 years, 5st. 2 lbs., and Gaspard, 3 years, 6 st. 91 bs., ran a deai heat for the Casarewitch ( 2 miles 2 fur. 28 yds.), beating Prioress, 6 years, 8st. 5lbs

\section{BEST AMERICAN TIME MADE IN AMERICA AND ENGLAND.}

In 1842, Fashion, 5 years, 7st. 13lbs., ran 4 miles over the U. C., Long Island, in

In 1850, Hegira, 4 years, catch weight, ran 2 miles at New Orleans in.

In 1855 , Lexington, 4 years, 7 st. 5lbs., ran 4 miles (with a running start) at New Orleans in .

In 1855 , the same horse and weight beat Lecompte in the final heat of a regular match in

In 1855, Brown Dick, 3 years, 6st. 2lbs., ran 3 miles at New Orleans in $\cdot \dot{-}$

In 1856, Prioress, 2 years, 5st. 13lbs., ran a mile over the Metairie Course, New Orleans, in

In 1857, Prioress, 4 years, 6st. 91bs., ran a dead heat for the Cresarewitch (2 miles 2 fur. 28 yds.) with El Hakim, 3 years, 6 st. 9lbs., and Queen Bess, 3 years, 4st. 10lbs., in

In 1858, Nicholas, 5 years, 7st. 31bs., ran 4 miles-Fashion C-Long Island

Here, then, we have data to found a calculation upon, but whether reliable or not is still a matter of dispute. Of course it is quite unfair to compare the speed in a short race with that displayed in a long one, but we shall find that between a mile and a half and two miles and a half there is not much difference in the rate of going. The nature of the course alters the time very considerably, that run over in the Derby being very hilly, and therefore unusually severe, while the Cresarewitch course is comparatively level, though the Newmarket trainers complain of the hill as if it was as steep as the roof of a house. Much also depends upon the way in which the running is made, for if the pace is very good at first, the distance is not run in the same time as in a race run more slowly at the start. Thus Blink Bonny was scarcely extended in her race for the Derby, and, being able to run the first mile at a steady pace, she made the best time on record; while at Doncaster, where she was beaten, the time was much worse, being three minutes twenty-five seconds, or nine seconds behind the time of Sir Tatton Sykes. On examining the three lists, we find the performance of this last-named horse to be the fastest on record for his age and weight, he having run at the rate of thirteen seconds and a half per furlong, nearly, while Blink Bonny's Derby time is, as near as may be, thirteen seconds and three-quarters per furlong. We have no reliable record of any horse having run any distance over a mile at so fast a rate as this. Childers and Eclipse are said to have each run a mile in a minute, but this is manifestly absurd, and if the former could only run the Beacon Course, in a trial, at the rate of thirteen seconds and three-quarters per furlong, and the Round Course, in an actual race, at a still slower pace, it is absurd to suppose that he could run a mile in sixty seconds, or at very nearly double this rate. It has been ascertained by experience that a horse loses his pace for moderately short distances if he is strained to the utmost for three or four miles, and our trainers are therefore careful in 
trying the extreme length which their horses can get. Long courses have been given up almost entirely for this reason, among others, and because also, in particuiar, it has been found that the competing horses do not really race for more than half or a quarter of the distance; consequently, we have no true test in England beyond two miles four furlongs, which have been run over the somewhat severe course of Ascot by West Australian and Kingston, at the rate of thirteen seconds and a quarter per furlong, the latter horse carrying 9 stone. This feat will most triumphantly contrast with any performance of ancient or modern times, either in England or America, for it will be found on examination to be from threequarters to half a second per furlong faster than the recorded rate of Childers, and half a second faster than Lexington, even with the advantage of a running start, and carrying 7 stone 5 pounds as a four-year-old, against Kingston, five-year-old, with 9 stone. We may, therefore, assume that some, at all events, of our modern horses are capable of successfully contending with the American horses at any reasonable distance, for the latter have never yet come up to the time made in this country, either here or in America, and without an allowance of at least a stone they have never yet had a chance, with the exception of Umpire in lis two-year-old career. My belief is that early training for short distances interferes with the chance of any individual horse doing a long distance in the shortest possible time, but the power remains in the breed, and can at any time be developed in a sound horse of the stoutest blood we possess. Unfortunately, of late years, speed has been all in all, and we have too much neglected the stout old strains of Waxy and Tramp for that of the three sons of Bussard-Selim, Castrel, and Rubens. The Jockey Club, however, at the instigation of Lord Redesdale, have it in contemplation to prevent two-year-old races early in the year, and I trust that by this and other regulations a stop may be put to the course of events which certainly seem to have a tendency to produce the mischief which, however, is not yet finally accomplished. I am afraid that there would be some difficulty in now getting twenty-eight horses to repeat Mr. Osbaldeston's feat, which I have inserted as one proof of the stoutness of our modern breed; but this would be entirely a matter of price, for there are plenty of thoroughbred hunters which are capable of effecting it, the value of such animals being about 300l. apiece, and few owners would therefore lend them. Lord Redesdale seems entirely to have overlooked the enormous increase of this class of horses within the last forty years. Prior to that time a thoroughbred hunter was only to be met with, as a rule, in the great grass countries, and "the provincials" were contented with half-breds, which were supposed to be, and really were, better able to get over the great sprawling fences and other difficult jumps which were to be found at every two or three hundred yards. Fashion, however, supported by the change in the agricultural management of the country, has brought the thoroughbred into general use ; and with a long list of more than a hundred packs of foxhounds, each perhaps followed by, on the average, thirty reputed thoroughbreds, more or less up to weight, we find 3000 horses of this class to be supplied. Now the whole of the foals dropped in each year and recorded in the Stud-book do not altogether come up to one-half of this number, and, deducting those horses which are unable to carry more than 7 
stone, the stallions and mares which are put to the stud here and abroad. and the unsound animals of both sexes, it is equally astonishing that the demand should be so well supplied as it is, and that there should bo any horses able to stay a distance left. The owner of a horse will always do with him what he considers most to his own advantage, and, whereas formerly he had no choice but either to sell an aged horse as a hack, or to keep him in training, he now teaches him to get over a hurdle and a few fences, and he has a dozen customers ready for him at eight or ten times the old hack price. I do not for a moment contend that even the most valuable of these hunters are as sound on their legs as the average of racehorses fifty or a hundred years ago, but that they are as stout, I think, is quite clear, and the reason of their being more unsound is only that they are sooner used up. A railway locomotive will only travel a definite number of miles, varying in relation to the speed at which it is used, and if it is brought on to the rails before it is in perfect working order, it will very much sooner fail. So in the present day, from the facilities of travelling from place to place, and from the length of the racing season, our horses, when in training, have little or no rest, and thus, though their career is a short one, "the candle is burnt at both ends" while it is alight, and it is consumed in half the time. Look at the performances of Rataplan, Fisherman, and Thornmanby, and compare them with the much-vaunted feats of the Carlisle Gelding in 1720 to 1731, and of Black Chance from 1736 to 1746 . Even the still more celebrated Catherina, who ran one hundred and seventy-seven races in ten years, did not work half so hard on the racecourso as Fisherman with his one hundred and twenty races in five years.

\begin{tabular}{|c|c|c|c|c|c|c|c|}
\hline & & $\begin{array}{l}\text { Age when } \\
\text { irst ran. }\end{array}$ & Races woon & Races lost. & $\begin{array}{c}\text { Total } \\
\text { of Races. }\end{array}$ & $\begin{array}{l}\text { Years on } \\
\text { the Turf. }\end{array}$ & $\begin{array}{l}\text { Left the } \\
\text { Turf. }\end{array}$ \\
\hline Carlisle Gelding . & . & 5 & 25 & 9 & 34 & 13 & 1731 \\
\hline Arthur O'Bradly . & . . . & 5 & 15 & 10 & 25 & 4 & 1749 \\
\hline Black Chance. . & . . & 5 & 25 & 5 & 30 & 10 & 1746 \\
\hline Euphrates & . . & 3 & 42 & 57 & 99 & 10 & 1828 \\
\hline Independence. . & . . & 2 & 40 & 44 & 84 & 10 & 1835 \\
\hline Catherina . . & . . . & 2 & 79 & 98 & 177 & 10 & 1841 \\
\hline Rataplan & . & 2 & 42 & 29 & 71 & 4 & 1855 \\
\hline Fisherman . . & . . & 2 & 70 & 50 & 120 & 5 & 1859 \\
\hline
\end{tabular}

IN SPITE, HOWEVER, of all the elaborate calculations which others as well as myself have made, I cannot quite divest myself of the belief that Lord Redesdale is correct in his assumption that the thoroughbred horse of the present day is on the average less stout than he was of yore. That there are some few which can race and also stay I firmly believe, and that many which cannot race but can stay, are early drafted into the hunting-stable, is also my opinion; but that the majority are deficient in stoutness seems 
to me to be a patent fact. Wherever speed is considered to be $\mathbf{A} 1$, such horses as Sultan, Partisan, and Velocipede will be used in the stud, the breeder flattering himself that a cross of stout blood will put all right. And so it frequently does for one or two generations, and then the strain comes out, and the stock shows sometimes the speed without the stoutness, and at others neither one quality nor the other. Thus, Verison was got by that speedy but flashy horse, Partisan; but the stout Pot8os, Sorcerer, and Gohanna strains enabled him, as well as his son Kingston, to perform the tasks of endurance for which they were each so celebrated. It is also well known that Lord Winchelsea had great difficulty in finding three horses on the turf able to stay four miles, but this is explained by the facts to which I have already alluded, and therefore does not so much bear upon the argument before us. It is a very difficult matter to prove, because the circumstances of the two periods are so different; but I am quite of opinion that, taking any number of race-horses at random in the year 1860 , they will not on the average bear comparison, in point of stoutness, with a similar number, either of the year 1800 or of the year $1760 .^{1}$

\section{EARLY MATURITY}

IT Is AN UNDENIABLE fact, as I believe, that preternaturally early maturity is incompatible with lasting qualities of any kind; but, though the same rule generally holds good throughout nature, there are some exceptions. Thus, the oak is more lasting than the larch, and the elephant outlives the horse, but the goose and the duck, which arrive at maturity in the same number of months, do not live through a corresponding series of years. The forcing process in gardening is always productive of tenderness, whether the produce be the cucumber or the sea-kale, and this tenderness is only another name for imperfect formation to resist decay. In the days of Eclipse and Childers they were permitted to attain their full growth without forcing, and, not being wanted till five years old, their ligaments, tendons, and bones had plenty of time to be consolidated before they were submitted to the strains and jerks of the extended gallop. There is also reason to believe that they were not nearly so much or so soon stimulated by large feeds of oats, as is now invariably the custom, and that they were allowed to remain at grass, with the shelter of a hovel, during the first three or four years of their lives. All this is now changed;

1 At the present date, when the century is nearing its close, we have only too many proofs of that prophetic vision for which the author was remarkable. Weedy roarers, capable of carrying feather-weights over five or six furlongs, having brouglit so much disgrace upon the thoroughbred horse, as to be a principal cause of the diversion of the money formerly given as Queen's Plates to purposes more in accordance with the original intention-namely, improvement of the breed of horses.

Whether the deterioration has been recent is a debatable question, but that we are on the road to improvement cannot be doubted, now that hereditary defects are so generally recognized by many princely owners having the real interests of the turf at heart, and not lending themselves to the propagation of mere "gambling machines."

The Hunter's Improvement Society has sliown the way to help the farmers to the use of good sound stallious at moderate fees, and the Royal Agricultural Society and the Royal Commissioners on Horse-breeding have wisely pursued the same sound and hopeful policy.

The races known as the Queen's Guineas have been abolished, and the money devoted to the more useful purposes of Queen's Premiums. 
the foal is filled with corn as soon as he will eat it, and at the end of the first year he is furnished as much as the old-fashioned three-year-old. One chief difficulty of the trainer now is to keep his horse sound, and, unfortunately, as disease is in most cases hereditary, and too many unsound stallions are bred from, the difficulty is yearly on the increase. Without doubt roaring is far more common than it used to be, and the possession of enlarged joints, and back sinews, is the rule instead of the exception. During ten years the Derby was five times won by an unsound animal, which the trainer was almost immediately afterwards obliged to put out of work, either from diseased feet or a break-down, and yet few breeders think of refusing to use such horses as these. Nevertheless, good legs and feet, and a hearty constitution, are no small recommendations, and Mr. Merry may thank them for winning him the great prize of the year 1860, with Thormanby, a son of that wonderful mare Alice Hawthorne. Thormanby, however, is not an instance of a colt having been reserved till he was arrived at his growth, for there are few horses which have been more used, having run fourteen times as a two-year-old; but his naturally excellent legs and feet, and the fine down on which he was trained, enabled him to pull through unscathed. Now the reliance which was placed by his backers on these good qualities, proves that he was an exception to the rule; for if they were at all common, they would be of comparatively little advantage. The truth really is, that the average race-horse of modern times is of such forced growth, that he is unable to bear the wear and tear of training as he used to do, and hence a much larger percentage of unsound animals is to be met with. $\mathrm{H}_{\Theta}$ is bred mainly for speed, superadded to which is as much stoutness and soundness of constitution as can be procured among the most speedy horses at the service of the breeder. By a perseverance in this method of selection, he has undoubtedly become more speedy, and less lasting in proportion to his speed, that is to say, he cannot be extended for as long a time as he used to bear with impunity. But that he cannot cover as much ground in a given time as formerly is, I think, an error-for there is every reason to believe that any distance may now be run in as short a time at least, as either in the middle of the last century or the beginning of this.

\section{OBJECT OF ENCOURAGING THE BREED OF HORSES}

THE GREAT OBJECT of encouraging the breed of race-horses is, however, lost sight of, if suitable crosses for hunting, cavalry, and hack mares cannot be obtained from their ranks. In these three kinds, soundness of the feet and legs is all important, together with a capacity to bear a continuation of severe work. These qualities are highly developed in the Arab, and until lately were met with in his descendants on the English turf. Even now a horse with a stain in his pedigree will not bear the amount of training which a thoroughbred will sustain, his health and spirits soon giving way if forced to go through the work which the race-horse requires to make him "fit." But the legs and feet of the latter are the drawbacks to his use, and the trainer of the present day will generally be sadly taxed to make them last through a dry summer. Our modern roads are also much 
harder since the introduction of macadamization, and thus, in proportion to our greater demands, is the absence of the material to meet them. A hack that is not pretty well bred is now neglected, except for high weights, because his paces are not soft and pleasant, and he does not satisfy the eye. But how many of the fashionable sort will bear constant use on the road without becoming lame? And how many sound horses are there to be met with out of a hundred, taken at random from the ranks of any kind tolerably well bred? Every horse proprietor will tell you, scarcely five per cent.; and some will even go so far as to say, that a sound horse is utterly unknown. In considering the principles and practice of breeding, I shall again refer to this subject; but I wish now to impress upon my readers that while the race-horse is as fast as ever, as stout as ever, and as good-looking as ever, he is made of more perishable materials in proportion as he comes to maturity at an earlier period. Any of our modern twoyear-olds would probably give 2 stone and a beating to Eclipse at the same age, but if afterwards they were put to half-bred mares for the purpose of getting hacks, chargers, or hunters, the stock of Eclipse or Childers would be much more valuable than any which we have at present. We are sadly in want of sound and well-bred stallions for general purposes, and if the Government ${ }^{1}$ of the country does not soon interfere, and adopt some means of furnishing these islands with them, we shall be beaten on our own ground, and shall have to import sound useful horses from Belgium, France, Hungary, or Prussia, whichever country can best spare them. The old-fashioned and sound thoroughbred horse has been the means of improving the above three breeds; and eren now we possess horses which are perfect in every other respect but soundness, being excellent hacks, hunters, and light carriage-horses, and often all in one. This last kind is the perfection of the horse; and if many such could be produced it would be a great advantage, because most people would like a horse which could "make himself generally useful," if such an animal could be obtained. Without high-breeding, however, this is impossible; and yet with most of our purest strains, though it is attainable for a time, the condition in which it exists does not last long, in consequence of the effect of the hard road upon their soft legs or contracted feet. Consequently, as I have already remarked, there is a necessity for Government interference to produce such a breed of thoroughbred horses, by careful selection, as shall give us the above three kinds of horses useful in civil life, from which may be culled a plentiful supply of cavalry horses, whenever wanted; for the very same qualities are demanded in all, and what will suit the one will be equally advantageous to the other.

But even though the thoroughbred horse is well fitted to compete with others in all cases where speed is the chief point of trial-as in flat-racing, steeplechasing, hunting, etc.-yet he is not so well qualified for some kinds of harness-work, or for road-work of any kind, as the horse expressly bred for these purposes. There is no doubt that thoroughbred horses might be selected and bred expressly for this kind of work, and would excel all

1 Thoroughbred horses which have undergone a rigid veterinary examination now enjoy a Government premium on certain conditions, being required to serve mares in prescribed districts and at certain fees. This and other causes have contributed to a largely increased number of good horses bred in the British Isles, and our cavalry is in no serious danger. 
others, because originally their limbs and constitutions were at least as sound as, or perhaps even sounder than, any other class of horses; but while they are selected and bred solely for speed, without much reference to these other qualities, it is useless to expect much improvement; but, on the contrary, they may be expected to become yearly more and more soft and yielding. For many purposes the Eastern horse is wholly unfit-as, for instance, for heavy and dead pulls ; here his high courage, light weight, and hasty temper are adverse to the performance of the task, and he is far excelled by the old English, or modern improved cart-horse. No thoroughbred horse would try again and again at a dead pull like many of our best breeds of cart-horses; and therefore he is little calculated for work which requires this slow struggling kind of exertion. The pull of the Eastern horse, or his descendant, is a snatch ; and though it may to a certain extent be modified by use, yet it can never be brought up to the standard of the English cart-horse, even if the weight of carcass and size and strength of limb of the former could be sufficiently increased.

\section{ESSENTIALS IN THE THOROUGHBRED}

SUCH THeN ARE THE GeNeral QUALities of the thoroughbred horse and the purposes to which he can be beneficially applied. It remains now to consider the formation and specific characteristics best adapted to the turf, which is his chief arena; and also to the hunting-field, which now absorbs a very large number of his breed. Finally, it will be necessary to consider him as a means of improving other breeds, such as the cavalry-charger, hack and harness horse, but these subjects will fall under the respective heads here mentioned.

\section{PURITY OF BLOOD}

IN THE FIRST PLACE PURITY OF BLOOD must be considered as a sine qua non, for without it a horse cannot be considered thoroughbred, and therefore we have only to ascertain the exact meaning of the term "blood." It is not to be supposed that there is any real difference between the blood of the thoroughbred horse, and that of the half-bred animal ; no one could discriminate between the two by any known means; the term "blood" is here synonymous with breed, and by purity of blood is meant purity in the breeding of the individual animal under consideration; that is to say, that the horse which is entirely bred from one source is pure from any mixture with any other, and may be a pure Suffolk Punch, or a pure Clydesdale, or a pure thoroughbred horse. But all these terms are comparative, since there is no such animal as a perfectly purely bred horse of any breed, whether cart-horse, hack, or race-horse ; all have been produced from an admixture with other kinds, and though now kept as pure as possible, yet they were originally compounded from varying elements; and thus the race-horse of 1700 was obtained from a mixture of Turks, Arabs, and Barbs. Even the best and purest thoroughbreds are stained with some slight cross with the old English or Spanish horse, as I have shown at page 70, and therefore it 
is only by comparison that the word pure is applicable to them or any others. But since the thoroughbred horse, as he is called, has long been bred for the race-course, and selections have been made with that view alone, it is reasonable to suppose that this breed is the best for that purpose, and that a stain of any other is a deviation from the clearest stream into one more muddy, and therefore impure; the consequence is, that the animal bred from the impure source fails in some of the essential characteristics of the pure breed, and is in so far useless for this particular object. Now, in practice this is found to be the case, for in every instance it has resulted that the horse bred with the slightest deviation from the sources indicated by the Stud-book, is unable to compete in lasting power with those which are entirely of pure blood. Hence it is established as a rule, that for racing purposes every horse must be thoroughbred; that is, as I have already explained, descended from a sire and dam whose names are met with in the Stud-book.

\section{EXTERNAL FORMATION}

NAXT COMES THE EXTERNAL SHAPE or conformation of the race-horse, which is a subject very much studied by those who have the selection and management of them. Experienced trainers, and those who have watched the performances of the celebrities of the turf for successive years, will tell you that "the horse can run in all forms," and so no doubt he can as an exception, but the rule nevertheless is, that there is a standard which should be regarded as the best suited for the racecourse, and this will vary somewhat according to the performance which is required of each individual. There is no doubt that the most skilful selection is not al ways attended with success, and the statistics of the turf do not lead us to believe that $£ 1000$ invested under the advice of John Scott or John Day, in the purchase of a yearling, will always bring a remuneration. Indeed, the contrary has so often been the case, that high-priced yearlings are generally regarded with suspicion when they make their first appearance on the course. The winner of the Derby of 1860 went a-begging, and was at last bought for a very moderate price. So also with Butterfly, the winner of the Oaks; no store was set upon her until she came to be tried; and even on the morning of the race she was not generally thought good enough to win. The celebrated Blink Bonny was a mean-looking mare, and would not have fetched $£ 50$ at Tattersall's, from her appearance alone, and that wonderful animal Fisherman was never liked till he proved his powers. Still, it cannot be denied that a good judge will select the ten best horses out of twenty, or perhaps out of a hundred; but he will possibly leave the very best out of his list. The theoretical rule is simple enough, but it requires great experience and a good eye to carry it out in practice. It is simply this, that, coeteris paribus, the horse which is formed in the mould most like that of the greatest number of good race-horses, will run the best. Thus, supposing it is found that out of fifty good horses forty-nine have neat heads, light necks, deep chests, oblique shoulders, long racing hind-quarters, strong hocks, etc., the presumption will be that a horse resembling those forty-nine in shape, will also resemble them in speed and endurance. On the other hand, 
it is admitted on the turf, that high-breeding is of more consequence than external shape, and that of two horses, one perfect in shape but of an inferior strain of blood, and the other of the most winning blood, but not so well formed in shape, the latter will be the most likely to perform to the satisfaction of his owner on the racecourse. On this principle the proverb has been framed and handed down to us, that "an ounce of blood is worth a pound of bone," and with the above explanation such is really the case. But in spite of all this recognized superiority of blood, it is indisputable that for the highest degree of success there must be not only high purity of blood, and that of the most winning strains, but there must also be a frame of the most useful character, if not always of

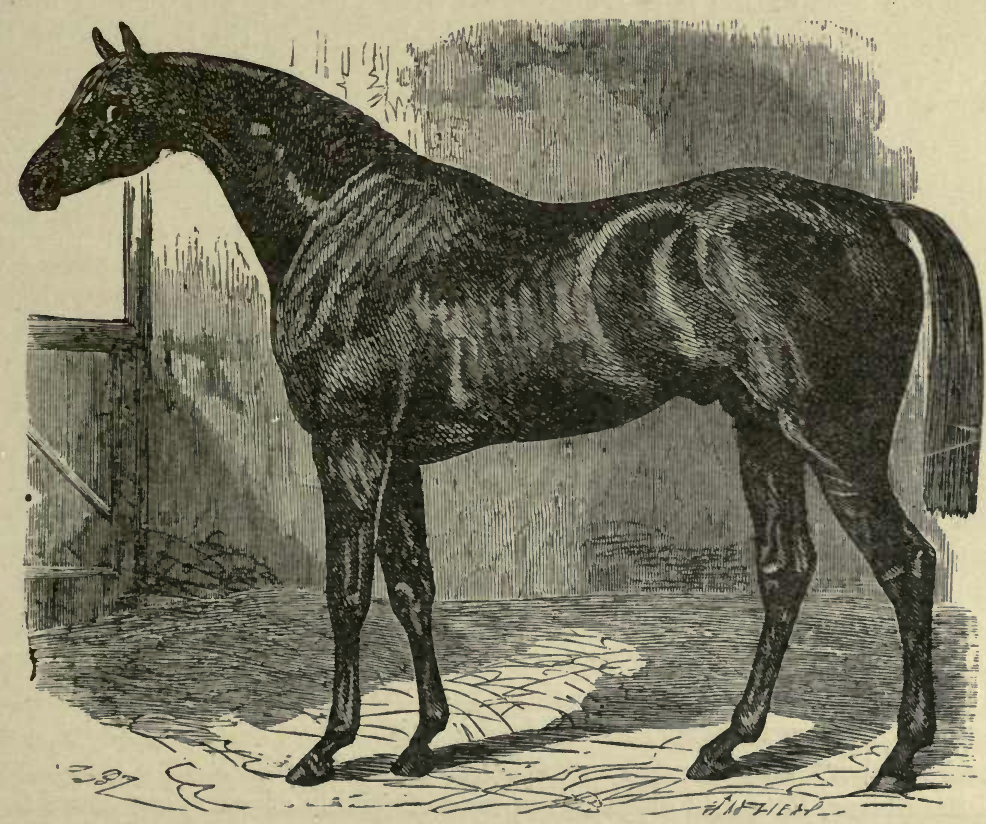

FISHERMAN.

the most elegant form. Many of our very best horses have been plain, and even coarse-looking - as, for instance, most of the Melbournes, and especially that very fast horse, Sir Tatton Sykes ; but in spite of their plainness, all their points are good and useful, and the deficiency is in elegance, not in real utility. On the other hand, there are some strains which unite elegance with utility, such as the fast and stout Venisons, which are remarkable for their beautiful frames and neat Arabian heads. But there must always be a distinction made between what is really useful and what is only agreeable to the eye. There are some characteristics which, over and above their mechanical advantagss, indicate high-breeding, and as such are regarded with especial favour by purchasers. For these a term has of late years been invented, the meaning of which is well understood, but somewhat difficult 
to define. Thus we hear it often remarked, that a particular horse is deficient in "quality," or that he has it in perfection; and in proportion to the one or the other of these conditions is he meant to be praised or condemned. It is not simply a word synonymous with " breeding," for a horse may show high-breeding, and yet be deficient in "quality," but if with a look which convinces you that he has a pure pedigree, he conjoins a perfect symmetry in all his parts, and in the shapes displayed by the thoroughbred, he then comes up to the description which stamps a horse in these days with the highest seal of approbation, for "he has plenty of quality."

But what is the recognized form of the race-horse? I must here explain to the tyro that the word "form "is used with two different significations by racing men, and like the word "box" is very puzzling to foreigners. In the common acceptation it is synonymous with "shape," and merely means the mechanical development of the individual. But in the language of the turf, when we say that a horse is "in form," we intend to convey to our hearers that he is in high condition and fit to run. So again, the word is used in still another sense, for we speak of a horse's "form " when we wish to allude to his powers on the turf, as compared with other well-known animals. Thus, if it is supposed that two three-year-olds, carrying the same weight, would run a mile and a half, and come in abreast, it is said, that "the form" of the one is equal to that of the other. It is necessary, therefore, in order to make a description intelligible, when using the term in its mechanical signification, to add the adjective, external, although, at first sight, it may appear to be an instance of tautology, for it might be alleged that internal forms can only be ascertained by dissection. With this explanation, I must now proceed to discuss what are generally considered to be the best shapes, for the purpose of combining speed with stoutness, remembering that we are examining the thoroughbred horse, and are not alluding to any other. As an instance of a very opposite conformation to that of Fisherman at page 99, I insert here a portrait of Saunterer, both after careful paintings by Mr. Barraud. These are generally admitted to have been the two best horses of their time, yet it is scarcely possible to imagine a greater difference to exist in first-class animals, than is displayed by them. Fisherman, short and strong, looks more like a hunter than a race-horse; while Saunterer, long and elegant, appears incapable of carrying more than 10 stone. The student will do well to study these animals carefully, but it must not be omitted that the portrait of Fisherman was taken when he was thrown out of training.

The Bodr or trunk is the grand centre of all the muscular pulleys and bony levers, which are used to move the horse, and it must, therefore, first come under consideration, although, as a matter of convenience, the horseman generally commences with the head. It is quite true that it in turn receives its orders from the brain, as will be hereafter explained, in treating of the nervous system, but as a mere machine it may be regarded independently of that organ altogether. It must, however, be viewed in three different aspects, inasmuch as it has three different offices to perform. These are, first, to carry its load, and propel it by means of the levers connected with it. Secondly, to afford room for the heart and lungs to perform their funct ons in its "chest," without interfering with the play of the shoulders; and, thirdly, to lodge an efficient apparatus of nutrition. 
The first of these divisions comprehends THE BACK, LOINS, AND CROUP; the second is THE CIIEST; and the third may be considered under the head of THE BACK-RIBS, FLANK, AND BELLY.

The BacK, Loins, AND Croup of the race-horse, as indeed of all horses but those used exclusively for draught, are generally described as necessarily moulded more or less in the form of an arch. Every architect is aware that this formation is best adapted to carry weight. A straight-backed greyhound is, by some experienced coursers, preferred to one which has a slight arch in that part; but in this animal there is no weight to be carried beyond that of his own carcass, and, therefore, even granting the superiority in him of a straight loin (which I do not), there is no analogy between the

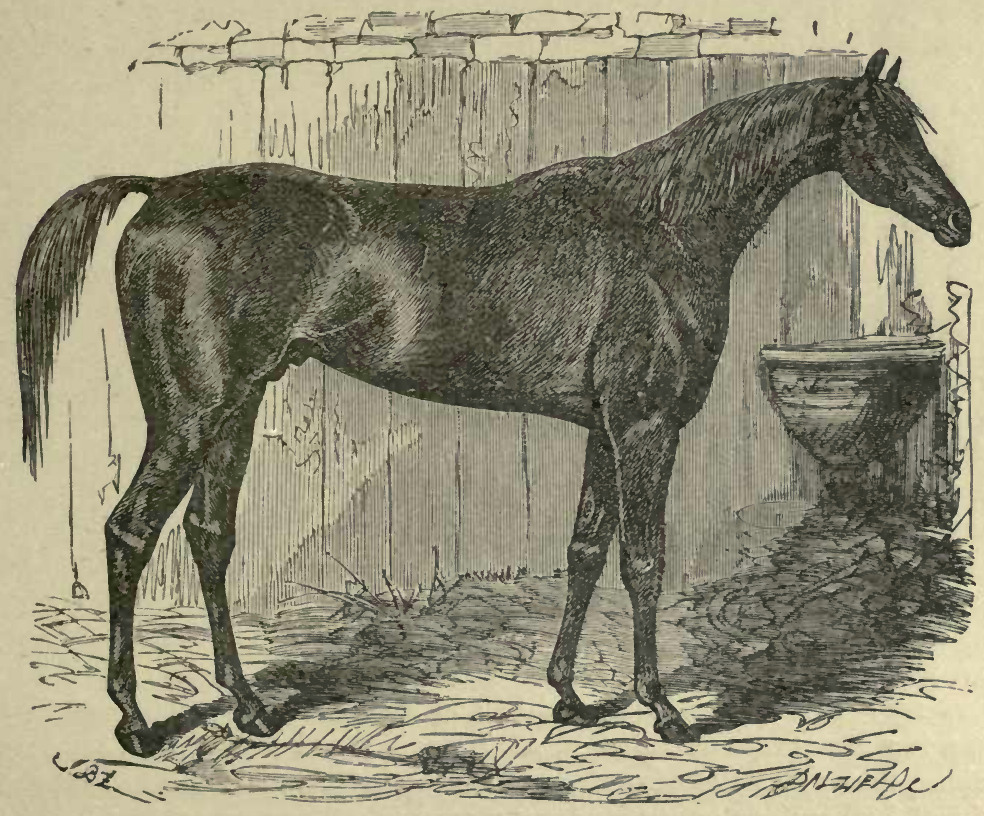

SAUNTERER.

two animals. Nor do I believe altogether in the received theory which attaches importance to the arched loin, because of its greater capacity for bearing weight from its mechanical form. Practically I concede, as an admitted fact, that a horse with this construction of frame will carry weight better than one which has a hollow loin; but, on examining the skeleton of each, it will be seen that in neither are the bodies of the vertebræ in this part of the spine arranged so as to form an arch, or if there is one, it has its concavity, not its convexity upwards, which certainly will not conduce to its weight-bearing powers. The fact really is, that in the arched loin the spinous processes are unusually long, and are raised into a crest like the high withers. By this development of bone an extra space is afforded, for both the lodgment and attachment of muscles, and herein is the secret of the extra power. Between the pelvis and the bodies of the 
vertebræ a true arch is formed, and according to the slope or fall of the quarters will it be useful in carrying weight; but this is quite irrespective of the loin, which may be arched or flat in conjunction with either formation. It is, however, most common to find an arched loin united with an inclined pelvis, and when the two are found together, the horse possessing this formation may be considered so far as "up to weight." Sometimes we see the pelvis inclined, but the tail set on high, and the loin hollow, and then we may surely predicate that there will be a want of power in these parts, and that the 7 stone of Lord Redesdale will be quite sufficient for the animal to carry. With this objectionable shape, there is a hollow on each side of the croup, which is very characteristic of the defect, and which is carefully eschewed by the experienced horseman. If the spine between the two supports afforded by the fore and hind extremities were really an arch, length would but little affect it, for we know that an arch of ninety feet span, is no stronger than one of a hundred feet, if both are properly constructed; but being nearly a straight line, with its component parts kept in their proper places, by a series of levers and pulleys, length tells most unfavourably; and "a short back, with plenty of length below" is the height of a horseman's ambition to possess. Mr. Percivall has fallen into a strange error in estimating the advantages of a long back, as may be readily seen on an examination of the following passage:- "Regarding the dorsal portion of the spine, with its superimposed burthen, as a pole or lever, supported in front by the fore limbs, and behind by the back limbs, after the manner of a barrel of beer, or a sedan between its bearers; it is manifest, that the greater its length, the greater must be the leverage, and consequent reduction of the weight of the burthen. On this principle, the legs of the long-backed horse are actually sustaining less load than those of the short-backed horse, even though their riders or burthens may be of equivalent weights, from the circumstance of their operating at a greater distance from the load." The fallacy of this argument is apparent to every person who has the slightest knowledge of mechanical powers; but as my readers may not all be in a position to estimate its value, I shall just make a few observations upon it, as I have heard it adduced on several occasions, to support the advantage of a long back. Now we will suppose a weight of 500 pounds on a plank, supported upon four props, two being five feet from the other two, and the pairs one foot apart, resembling, in fact, the relative position of the feet of a horse. Let the whole be arranged on a weighing-machine, so that only the four legs touch its table and take the weight. Then remove the two pairs of legs to a distance of six feet, and again take the weight. According to Mr. Percivall it ought to be less than before, but, tested by actual experiment, there will not be the hundredth part of a grain variation, even if the instrument is sufficiently delicate to register that weight. $\mathrm{A}$. and $\mathrm{B}$. carry a weight between them, suspended to a pole, and they find it more convenient to have that pole tolerably long, because they'can shift the weight from one to the other more easily than with a shorter one, but they carry the same weight in either case. A. can raise it by means of his long lever more casily than with a short one, but he can only effect this by making use of B.'s hand as a fulcrum, and for the moment throwing the weight off himself upon it, while B. returns the compliment in his turn, and both are relieved. For the mere purpose of 
carrying weight, therefore, a short back is to be preferred; but there is a limitation put to this by the necessity for length of limb to give pace, and if the legs are too long for the back, the action of the fore-quarter is impeded by the hind, and vice versa. Hence, in all horses, a reasonable length is preferred, and this will vary according to the occasion for weightcarrying power. In the thoroughbred horse, pace is essential, and his back must consequently be of sufficient length to allow the free use of such limbs as will give stride enough to develop it. We shall hereafter find, that the cart-horse may have a much shorter back, even though he has no weight to carry, but he requires strong couplings of the hind and fore-quarter for the former to act upon, in dragging heavy weights, and as in him pace, beyond the walk, is never required, a short back may be allowed to be a great advantage without any attendant evil. The most important elements of strength in the back and loins are the depth and breadth of its muscles, for they, and not the bones, as I have shown, are the real mechanical means by which not only weight is carried, but propelled. Now to lodge these muscles, there must be high spinous processes, wide hips, and such a formation of the ribs as to give width at their upper parts. Generally speaking the two last coincide, but sometimes the hips stand out in a very "ragged" or prominent position, while the ribs are flat. This formation, however, comes next to the most approved combination, and is far better than the narrow hips and flat sides which we now see in too many of our thoroughbred horses. In connection with this division of the body may be taken the croup, the upper outline of which is formed by the prolongation of the spine towards the root of the tail; but the essential parts are made up by the pelvis. It is very generally assumed that in order to develop high speed, the pelvis must be long, and this I believe to be perfectly true; but the length need not be in a perfectly horizontal direction, and is I think much better if developed at an inclination of about twenty-five degrees, that is to say, with a considerable fall. With this formation there may be the same length for the attachment of muscles and the same leverage in their action on the thigh, for the situation of the hip-joint (or round bone) is not altered in relation to them, though it is lower and more forward in reference to the spine. Hence the muscles which draw the thigh forward have more power, and also act much more quickly, giving that rapid thrust of the hind-legs forward which is essential to good and strong action. With the perfectly horizontal croup you may have a long sweeping stroke which tells over such a course as Newmarket, but you very rarely meet with a quick coupling and uncoupling, unless the pelvis is set on to the sacrum or continuation of the spine, at a considerable angle, so as to give the quarters more or less droop. Most of our best horses have exhibited this formation, while a great number of very handsome, but utterly useless brutes, might be enumerated which possess the high croup of the Arab in an exaggerated condition. If the portraits of the Godolphin Barb are at all to be depended on, we are indebted to him for the introduction of this useful, though not particularly elegant shape, and I believe that it is in this direction, and in point of size, that he has been so useful in the stud. The eye is captivated by the animal, which, as the dealers say, "has both ends up;" and experience teaches every horseman, who will profit by it, that both the stargazer and the high-crouped horse are to be avoided. In selecting the thoroughbred horse, then, choose 
such as have a deep and wide back and loin, avoiding either the "roach back," which causes that part to be inflexible, and the hollow one, which tends to give way too much under weight, but regarding as most desirable such a width of ribs and hips, and depth of spinous processes as shall give sufficient lodgment for muscles, and looking also for a proper length of spine, not too short for stride, nor too long for strength. Lastly, let the pelvis be attached at such an angle as to give a slight droop to the quarters, whether the tail be set on in correspondence with it or not, for the dock does not always come out of the pelvis in the same position viewed in relation to that part alone. Some of the above opinions are in opposition to those of Mr. Percivall, who objects to a great width of hip in the race-horse, and also asserts that he cannot be too lengthy and straight in his quarters. $\mathrm{He}$ says, "although the race-horse may prove disadvantageously broad across his hips, I believe that he will never be found either too lengthy or too straight in his quarters; by which I mean the length and elevation of an imaginary line carried from either hip to the point of his quarter, or of another carried from the summit of his rump to the root of his hock. Such straight formation of quarter implies small degree of inclination in the position of the pelvis, the effect of which is extension of the angles between the pelvis and the femoral bones, and corresponding increase of the distances between the pelvis and the stifles in front, and between the pelvis and hocks behind; thereby augmenting the dimensions of the muscles running between these salient points, and at the same time furnishing them with, under the circumstances, the greatest advantages in their action. Length and straightness in the quarters must therefore be regarded as characteristic attributes of the race-horse." Of the probability of meeting with too great a width of hip in the race-horse I am extremely doubtful. The Melbournes, which have this part wider than in any other strain, are certainly not to be despised, and, in spite of Mr. Percivall, I must, on the contrary, continue to admiro them, whenever they are to be found; my chief regret is that wide hips are so scarce among the descendants of that horse.

ThE SECOND DIVISION OF THE BODY, OR THE CHEST, in the thoroughbred horse, must afford sufficient room for the heart and lungs, but it must not be too wide, or it will interfere with the free play of the shoulder blade as it glides on the side. An open bosom is regarded as a sure sign of want of pace by every racing man of experience and I know of no single exception. One of the finest two-year-olds I ever saw in every other respect was Lord Standbroke's IRose de Florence; but I could have laid any reasonable odds that she would be deficient in pace, because she was made as wide as a cart-horse between the fore-legs, and she proved to be so on trial. A horse of 15 hands 3 or 16 hands when in stud condition should measure at least seventy-four inches, and should be wide through the part where the rider's knees come on the saddle; but below this the ribs should rapidly shelve inwards, and in this way allow the shoulder points to come closer together, and the elbows to act without being "tied." The anatomy of this part is treated of elsewhere, and I am now regarding it simply in its proportion to the rest of the body. Anatomically, and considered per se, a round or barrel-like chest is the best, because it admits of more free expansion and contraction, but when either high speed or smooth action is required, this formation is objectionable for the reasons I 
have given above, and in all cases it is to be avoided in the thoroughbred horse, while in some other breeds it must be looked for with great anxiety. It has been proved that good wind may be obtained from a chest possessing great depth without much width, and in some cases with a very narrow bosom, us in the celebrated Crucifix (dam of Priam); and as the opposite proportions are incompatible with speed, they must on that account be altogether rejected. THE withers are generally thin, and sometimes raised quite into a razor-like form, which, however, is a defect, as it is attended with no advantage to counterbalance the difficulty which it presents in the way of the saddler, who is constantly being called on to prevent his tree hurting the horse's back. A moderate development of the spinous processes is required to give attachment to the muscles which support the neck and move the shoulder, but the excessive height which we sometimes see is not of the slightest avail for this purpose.

THE NEXT AND LAST COMPONENT PARTS of the body are THE BACK-RIBS, FLANK, AND BELLY. Here we have chiefly to consider the proper lodgment of the organs of nutrition; but there is also the junction of the fore and hind quarters to come under review. For both these purposes the back-ribs should be long, or, as such a formation is generally called, "deep," so as not only to give protection to the contents of the belly, but to afford a strong attachment to the muscles which connect the chest to the hips. The space, also, between the latter and the last rib should not be large, or there will be an element of weakness; but if too limited, the action in the gallop will be confined, and the hind-legs will not be brought sufficiently forward. About the breadth of the hand is the proper allowance to make for this space in a horse of average size and make, and either more or less than this may be considered a defect. To obtain this formation, the ribs themselves must be set wide apart, and not huddled up together, as you sometimes see, leaving a great space between the last and the hip. When the back-ribs are long, the lower outline of the belly swells considerably below the level of the girth-place, and a very elegant shape is developed, as well as one generally united with a hardy constitution. Sometimes, it is true, the two are not combined, and now and then we meet with a very good feeder and robust animal with shallow back-ribs; but the rule may be considered to be as I have stated it, and the pur shaser will do well to attend to it in making his selection, when he kuows nothing of the character of the individual. For fast road-work, where the failure of the legs is generally the limit to the amount of work, a very heavy carcass is an objection, as it increases the weight upon them ; and an overtopped harnesshorse - that is, one with a body too big for his legs -is a most worthless brute; but in the thoroughbred there is seldom this formation, and the tendency is, on the other hand, to be too light in the flank, rather than too deep. A light-carcassed or herring-gutted horse when "set" for the racecourse or the fast hunting country looks cut in two, and his performances generally correspond with his appearance.

Projecting Forward with a beautiful sweep, the neck comes out of the chest in this kind of horse with a most elegant outline. Of a greater length than in any other, it is also proportionally thin; but both these dimensions may easily be exaggerated, a very long and thin neck being objectionable, and rarely corresponding with good wind. The lines re- 
semble greatly those of the neck of the gamecock; and when there is a decided angle about three or four inches from the jaw, the horse is said to be "cock-throttled," and it is then generally supposed that he is more than usually liable to become a roarer or a whistler. The curve of this part a good deal depends upon the breaking and subsequent riding, different hands producing a great variation in the carriage; but if the bones are so formed and connected together that the natural curve has its concavity upwards, it is almost impossible to produce a proper bend in the other direction, though still much may be accomplished by perseverance. A "ewe-neck," as this is called, is very objectionable on this account; but it is very often combined with speed, fine action, and great gameness. More depends upon the junction between the head and neck, than upon the latter in itself, for by long-continued perseverance, it may be made so supple as to bend at the rider's will; but if the jaws are too narrow to allow the head to bend upon the neck, no means that can be applied will make any impression, and the result is that the mouth is spoiled, and frequently the temper also. A large and free windpipe, that is, one of sufficient diameter for the passage of air, and not tied down by any bands of fascia, will be necessary for good wind; and this point should specially be examined.

IN THE HEAD is contained the organ of intelligence, which is also the chief seat of that nervous energy which animates the whole body. Here also are the eyes, and the external apertures of the breathing apparatus; so that the form of this part of the body is of great importance. Size is power, and, cateris paribus, a large brain is to be regarded as a most valuable adjunct. Hence the head should be wide above the eyes, as well as between the ears, and somewhat full or projecting in the forehead also, in order to give lodgment to a brain of good volume. It is the great development of this organ in the thoroughbred and his Eastern relations, that gives the extraordinary stoutness and fire for which they are so remarkable; and therefore a horse of this breed deficient in volume of brain will be found in these respects no better than his low-bred rivals. In every other part, the weight should be reduced to the minimum necessary for carrying on the functions peculiar to it, save only the eye, a very small one being generally found to be prone to disease. The thoroughbred horse has a beautifully full and gazelle-like eye; but in this organ many half-bred animals are quite equal to him-the eye of the cart-horse, however, showing the opposite extreme. A very prominent or unnaturally convex eye, called a "buck-eye," is not to be regarded as desirable, being an evidence of shortness of sight, and therefore not to be confounded with the full and soft expression indicative of good manners, high courage when roused, and soundness. Next to the eyes in importance are the nostrils, which should be open, and when the horse has galloped should stand out stiffly, showing the red lining membrane, and admitting the air freely. Of course, even the smallest nostrils are of larger area than the wind-pipe; but there is generally a coincidence between their size and that of the internal passages higher up, and on that account a patent nostril is to be looked for with some anxiety. I have known some horses with small nostrils possess excellent wind, because in them the internal conformation was of full size, and if, as I before remarked, the area of the two nostrils 
together is always much greater than that of the windpipe, they cannot in themselves offer any impediment to breathing. Without a trial, however, as the internal passages cannot be measured, the size of the nostrils must be accepted as the best guide to that of the more essential parts, and practically this is sufficient for general purposes, only inferior to an actual trial. The ears should be moderately long, thin, and not inclined to "lop." The muzzle should be fine; but in those very pointed jaws, which their owners regard with so much pride, as "small enough to drink out of a quart pot," the nostrils are seldom large enough, and hence they are to be regarded with great suspicion, beautiful as they undoubtedly are. A slight concavity in the front line, descending from the forehead to the front of the muzzle, is regarded as a mark of breeding, and, if not too marked, deservedly so; but a very deep concavity is often attended with a vicious temper. Lastly, a lean and wide lower jaw should not be omitted as a grand desideratum; the former point is merely a sign of breeding, but the latter is (as I before remarked in describing the neck) essential to the proper bending of the one part on the other. The experienced horseman always passes his fingers between the angles, and if there is not plenty of room, he knows that the head cannot be well carried, and he is inclined to suspect that the larynx will be impeded in its functions, and that, consequently, respiration will be affected either by roaring, whistling or some or other of the many forms of "making a noise." With all these dimensions, which may, comparatively, readily be described, there should be combined a cheerful and airy expression of countenance, without any appearance of vice. The thoroughbred horse is not often too sluggish, and it is not in that direction that we should look for infirmities of temper; nor is it easy to describe the marks or signs by which vice of any kind can be at once recognized from the mere expression. Still the horseman will do well to study the countenance of this as well as other breeds of horses, and he will find, in course of time, that no little assistance will be derived from it.

The Shoulder-Blade is, like the head, peculiarly formed in the Eastern horse, having greater obliquity in its position, and a superior length and breadth, as compared with all others. For the reasons which may be alleged for the desirability of these characteristics, I must refer to pages 10,11 , where I have already given them. Suffice it to observe, that an obliquely-placed and broad blade, well clothed with muscles, is the desirable formation of this part, added to a welldeveloped "point," as the prominence at the joint between the blade and true arm-bone is called by the horseman. If this is too level and smooth, the muscles which are attached to it have not sufficient leverage; while if it is very ragged and prominent, it is a mark of diseased or excessive growth of bone, and is generally attended with a stiffness of the part. Indeed, in examining a shoulder-blade, freedom of action is to be regarded much more than its exact position when at rest; for if you have the desired effect, it matters not (except for breeding purposes) whether it is exceptional or not; and, as a matter of course, it is better to have a freely-playing shoulder which when at rest is too upright than a perfectly formed one confined to its place, as we sometimes see it. The oblique shoulder-blade is specially required in 
all horses which come down upon their fore-legs after a spring, whether this is in the gallop, or the leap, or the trot, for the use of it is by its elasticity to break the jar which is thereby occasioned. The upright form is stronger, as the weight is placed more directly over the column which bears it, but it allows of less elasticity under the sudden shock given by the impetus of the body as it approaches the earth, and for this reason is only suited to the slow work of the cart-horse, or heavy machiner. In conjunction with the oblique, and therefore long blade, is always found a long true arm, which is sometimes so extended backward as to place the elbow absolutely in the way of the girths, and then perhaps may be considered as too long, especially as it throws the weight of the fore-quarter much in front of the fore-legs, and tends to make the horse possessing it somewhat unsafe unless his action is particularly free. This part also should be well clothed with muscles.

THE Fore-ARM or ARM, as it is generally called, is not remarkable for any great peculiarities, but it is somewhat larger in proportion to the cannon-bone than in other breeds.

ThE KNEE is broad and deep, from before backwards, and the leg below the knee is peculiarly free from that contraction or "tying in" which in the cart-horse and allied breeds is so objectionable, being an element of weakness when the joint is exposed to the strains incidental to fast work of any kind. So also a bending backwards of the joint called the "calf-knee," common in the cart-horse, is condemned in the race-horse for the same reason.

THE BONE of THE LEG both in the fore- and hind-quarter is small, but of compact substance, while the suspensory ligament and back sinew are so large, and stand out so freely, as to appear to form quite one-half of the leg. The fetlock joints are clean and of good size, the pasterns long and elastic, and the feet though small as compared with other breeds, yet large enough for the weight they have to carry, their horny covering being also tough and compact.

IN THe HIND-QUARTER the Eastern horse and his descendants excel all others in symmetry and in the length of the various parts composing it. Comparing the cart-horse with the subject of the present investigation, one is struck with the greatly increased length of the thighs of the latter, approaching almost to the proportions of the greyhound. In the cart-horse, when walking, the stifle-joint can hardly be seen, while in the race-horse it is brought out prominently at every step. This gives the stride necessary for pace, and the first strain of blood known as that of Selim, and his brothers Castrel and Rubens, possesses this peculiarity in a marked manner, though from the high position of the stifle in them, and their straight hocks, many people lose sight of this peculiarity. With regard to the hocks of a race-horse, they should be of full size, clean, and as a matter of course, free from curbs or spavins. They are also generally considered to require very long points, that is to say, the projecting lever to which the ham-string is attached should be long. From an examination of many race-horses I am satisfied that for speed this may be over-done, for though power is gained by it, quickness is sacrificed; and a very long point to the hock is apt to give long, dull, and dwelling action, entirely opposite to quick pace, 
though perhaps telling over a long flat. All are agreed that the gaskin or lower thigh must be muscular, and both for beauty and effect this is a most important point. In other respects, the hind-quarter of the thoroughbred should resemble that of any other variety of the species.

Tre wrole of these points should be in proportion to one anotherthat is to say, the formation of the horse should be "true." He should not have long, well-developed hind-quarters, with an upright, weak, or confined fore-quarter. Nor will the converse serve, for however well formed the shoulder may be, the horse will not go well unless he has a similar formation in the propellers. It is of great importance, therefore, that the race-horse should have all his various points in true relative development; and that there shall not be the hind-quarter of a long racing-like horse with the thick confined shoulder which would suit a stride less reaching in its nature. A remarkable instance of the advantages of such a formation is exhibited in Saunterer, whose frame is not characterized by power or any other special perfection, but being perfectly true in his formation he was one of the best, if not the very best, horse of his year, as he proved by his various achievements. At page 101 will be found an engraving of him, copied from one of the best portraits I ever saw, by Mr. H. Barraud, which should be carefully examined.

\section{HEIGHT}

IN HEIGHT the race-horse varies from 15 hands to $16 \frac{1}{2}$, or even 17 hands; but the general height of our best horses is about 15 hands 3 inches. Few first-class performers have exceeded the height of Surplice, who was 16 hands 1 inch, as was also another Derby winner, Wild Dayrell. Sir Tatton Sykes was $15 \frac{1}{2}$ hands; and between his height and that of Surplice may be ranged the majority of great winners. The average, therefore, may fairly be laid down as the best height for the race-horse, though it cannot be denied that for some small and confined courses-as, for intance, that of Chester - a smaller horse of little more than 15 hands height has a better chance, as being more capable of turning round the constantly recurring angles or bends.

\section{COLOUR}

THE CoLour of the thoroughbred horse is now generally bay, brown, or chestnut, one or other of which will occur in ninety-nine cases out of a hundred. Grey is not common, but sometimes appears, as in the case of Chanticleer and many of his stock. Black also occasionally makes its appearance, but not more frequently than grey. Roans, duns, sorrels, etc., are now quite exploded, and the above five colours may be said to complete the list of those seen on the racecourse. Sometimes these colours are mixed with a good deal of white, in the shape of blazes on the face, or white legs and feet: or even all these marks may occur, and the horse may have little more than his body of a brown, bay, or chestnut. Most people, however, prefer a self colour, with as little white as possible; and nothing 
but the great success of a horse's stock would induce breeders to resort to him if they were largely endowed with white. Grey hairs mixed in the coat, as in the Venison's, are rather approved of than otherwise; but they do not amount to a roan, in which the grey hairs are equal, or even more than that, to those of the other colour mixed with them.

\section{COAT, MANE, AND TAIL}

The texture of the coat and skin is a great proof of high-breeding, and in the absence of the pedigree would be highly regarded; but when that is satisfactory it is of no use descending to the examination of an inferior proof ; and, therefore, except as a sign of health, the skin is seldom considered. In all thoroughbred horses, however, it is thinner, and the hair more silky than in common breeds; and the veins are more apparent under the skin, partly from its thinness, but also from their extra size and number of branches. This network of veins is of importance in allowing the circulation to be carried on during high exertions, when, if the blood could not accumulate in them, it would often choke the deep vessels of the heart and lungs; but by collecting on the surface great relief is afforded, and the horse is able to maintain such a high and long-continued speed as would be impracticable without their help. Hence, these points are not useful as a mere mark of breed, but as essential to the very purpose for which that breed was established.

The MANE AND TaIL should be silky and not curly, though a slight wave is often seen. A decided curl is almost universally a mark of degradation, and shows a stain in the pedigree as clearly as any sign can do. Here, however, as in other cases, the clear tracing of that all-powerful proof of breeding will upset all reasoning founded upon inferior data. The setting on of the tail is often regarded as of great importance, but it is chiefly with reference to appearances; for the horse is not dependent for action or power upon this appendage. Nor is strength of dock of any certain value as a sign, for I have known some very stout horses with flaccid and loosely pendent tails; but still it may be accepted as a general rule, that when the muscles of the tail are weak, those of the rest of the body are likely to be so also.

\section{THE THOROUGHBRED HUNTER AND STEEPLECHASER}

Hitherto we have considered the thoroughbred horse as intended to be tested "over the flat," that is to say, on our ordinary racecourses, but, as I have before mentioned, the hunting-field is also largely supplied from the same source, and in addition the steeplechase is now almost entirely carried on by means of thoroughbred animals. It is found that many horses which are too slow when tried as two or three-year-olds over our ordinary courses, and therefore discarded from the racing stable, are able to beat all others over a country, either with hounds or in the steeplechase. Whether this improvement in form is owing to the greater distance, or to increased age, or to the, addition of fences, such is undoubtedly the fact, as might be 
proved by innumerable well-known instances. Sometimes perhaps one, sometimes another, of these may effect the change, and perhaps, occasionally, all three may combine to produce it, but undoubtedly the first hope of the owner of a slow race-horse is that he may yet become a good, and therefore fast, hunter or steeplechaser. In the palmy days of steeplechasing, when $£ 1000$ was a common price for a first-class horse suited to the purpose, such an animal was as difficult to procure as a horse to win the Derby, and a man who had one congratulated himself on his good fortune. But now, in spite of the fresh impetus given to the sport by the establishment of aristocratic and national hunt races, it languishes sadly, and no one would dream of entering it as a speculation, either by breeding or purchase. All that is wanted is a race-horse of sufficient power to carry 11 or 12 stone, and with temper and courage to make him take to jumping. Without these qualities it is useless to attempt to do much with a young horse in the way of education, for though in the hands of a determined school-master he may be made to jump, yet he will never be to be depended on, and when most wanted, he will be sure to fail. So also with his action, it must be rounder and have less of the daisy-cutting style than is required on the flat, for otherwise he will be sure to fall in passing over the grips and other inequalities which he has to encounter. If therefore, a slow race-horse of stout blood, has good manners and courage, and is possessed of a sufficiently strong frame to stand the shocks of the steeplechase course, he may be thrown by till the ground is fit to begin to school him, and he will often reward his owner by becoming a first-rate performer over a country. I have specially noted the character of the blood, for there are some strains which may be relied on with far more certainty than others for this purpose. The descendants of Waxy, for instance, wherever they have good shoulders, and of sufficient size and substance, are most valuable; while on the other hand the Selims are too flashy as a rule, though one or two sons of Ishmael and Ratcatcher may be instanced as exceptions. Drayton, who got more first-rate steeplechasers than any stallion of his day, being sire of Bourton, Standard-Guard, Victim, and several others of less note, was by Muley, son of Orville, out of Prima Donna, by Soothsayer, grand-dam by Waxy. He was not himself successful on the flat, nor has he got a good race-horse, but his stout blood, good temper, and strong frame and constitution, were exactly suited to the task required of steeplechasers and hunters.

THE THorovahbred hunter is similar in external form to the steeplechaser, but in him "good manners" are still more requisite. So also when a high weight is to be carried a stronger frame is required than for the 11 or 12 stone of the steeplechase courso. 


\title{
CHAPTER VII
}

\author{
HALF-BREDS, COBS, AND PONIES
}

TIIE HALF-BRED HUNTER-THE IRISH HUNTER-THE CHARGER-THE COVERT-, ROAD-, AND PARK-HACK-THE LADIES' HORSE-COBS, GALLOWAYS, AND PONIES-THE CARRIAGE, BROUGIIAM, OR CAB-HORSE-THE HEAVY MACHINER-THE PHAETON-HORSE, GIGSTER, OR FAST TROTTER.

All the varieties included in this chapter require a considerable infusion of Eastern blood, inasmuch as though some of the harness-horses are not called on to travel very fast, yet considering the weights they have to draw, their efforts are violent enough to tax both the wind and stamina to an extent which can only be endured by the Eastern horse or his descendants. Even the omnibus-horse, travelling only six or seven miles within the hour, including stoppages, must not be of cart blood, or he will knock up before he reaches the end of his first journey, when called upon to draw his share of four tons at that pace. The Exmoor ponies have a strong infusion of Eastern blood in them, and the light and elegant head of the Shetlander in itself would almost warrant us in including him in the list. It is well known that the New Forest ponies in the last century were repeatedly supplied with an Eastern cross, and the celebrated Marske, sire of Eclipse, is said to have covered several of the mares of this brecd, while standing at Bistern, near Ringwood, in Hampshire, in 1767-1768, for want of mares of a superior character. This chapter, therefore, will include a description of every English horse but the thoroughbred and the heavy draught-horses used for agricultural purposes, and the moving of heavy goods. The term "half-bred" is a misnomer, for it is generally applied to those horses which have a much larger proportion of Eastern blood than half, and, in many cases, they possess fully thirty-one parts out of thirty-two, or even more. Mr. Apperley (Nimrod) advocated the first cross between the cart-mare and the thoroughlibred horse for hunting purposes, but the plan lias not been found to answer, and it is now entirely abandoned from a long experience of the want of symmetry in the produce, and from their deficiency in staying powers over a distance of ground. Even for fast road.work their legs do not stand, but throw out splints, side bones, or spavins, so soon and so frequently, that they are never chosen for the purpose by good judges on that account alone. 


\section{THE HALF-BRED HUNTER}

The Hunter in our fast countries, such as Leicestershire, Northamptonshire, parts of Oxfordshire, and Gloucestershire, is generally selected (if the purse will permit it) with a pedigree entirely contained in the Stud-book. There are, however, few true thoroughbreds that can carry 12 stone across country, that is to say, as compared with the number of lhunting men of that weight, and consequently their price is raised to a height that can only be reached by a long purse. A "made hunter" of this class is worth from $£ 250$ to $£ 500$ according to his "manners"-for as many of them have been broken for the racing stable and have passed through that mill, they are liable to be somewhat inclined to pull, and to exhibit other failings incidental to that school. In cramped countries, the thoroughbred horse is not so well calculated as the half-bred to get over standing jumps, for his hindlegs are not so well under him; and from the absence for generations of practice in any paces but those required for racing, he has lost in some measure the power to put his fore- and hind-feet wherever they are wanted to be, which is so constantly in demand in "provincial countries." Where, however, pace is the chief desideratum, and where hounds go so fast that without that quality in the horse, also, his rider is soon thrown out, the thoroughbred horse alone can be sure of keeping a front place, and for that reason is in such great demand. $\mathrm{He}$ can undoubtedly carry any weight up to 12 stone, or even sometimes 16 stone, over a wider brook or double post and rails, than the half-bred, but I know of no instance in which a pure thoroughbred has ever got over any very high jump, such as a six-foot stone wall or piece of timber. Chandler and Proceed, who cleared thirty-seven feet and thirty-nine feet respectively, were both thoroughbred, though not in the Stud-book, and no half-bred horse has ever come near to these performances; but if a match was made to get over a high wall no one would select a thoroughbred horse for that purpose. Hence, the half-bred hunter has still many admirers, and, on the average, ninetenths at least of the horses which appear at the covert side throughout the kingdom must be included in this class. Many have fully seveneighths of pure blood, and perhaps few have less than that proportion, but there is a distinct stain in the third or fourth generation which entitles them to affix h.b. to their names if they are entered for any race where there is an allowance for half-breds. There is always great difficulty in obtaining the bones and joints in a thoroughbred of sufficient size to stand the shocks of the hunting field, and for weeds of this class there is a very limited sale. Hence, the breeder naturally avoids the risk, especially as he must go to a very high price for his mares if he is to obtain them of such a size and substance as he will desire. A half-bred mare may be purchased for $£ 20$ or $£ 30$ with big legs and joints, and she therefore is chosen, often without knowing her pedigree or even where she was foaled. The consequence is that the country is deluged with colts of all shapes and characters, some of which 
may be thoroughbred without the knowledge of their breeders, but most are really what they are said to be, namely, half-bred, which I have explained as meaning the possession of more or less stain of nondescript blood. I have described the shape and characteristics of the thoroughbred horse so fully that it is needless for me to return to the subject; but as far as his powers for hunting purposes are concerned, it was necessary to allude to them here as I have done.

IN choosing the half-bred hunter, regard must be had to the weight he has to carry and the country he has to cross-for the lighter the weight and the more open the country, the more highly bred should he be. A man of 18 stone must generally be contented with an active cart-horse, but sometimes a remarkably strong colt is reared possessing a good deal of blood, for his shape, and he is worth a large sum, when taught the trade which he has to carry on. In any case, however, the hunter should have the free use of his legs, and should be able to gallop over rough ground without a mistake. It is here that the training for the racecourse so often tells unfavourably, for every training-ground is kept as level as possible, and the racing colt has had no necessity for picking his way. From his earliest days he has been either turned out in a level paddock or he has been in a loose box, and hence he has had little occasion to look where he is going. On the other hand, the half-bred is turned out till he is four years old, and the fields which he runs over are composed of every variety of ground, often crossed by roads with deep ruts, or containing such other inequalities of surface, that if he does not take care he will fall over them. The breaker, likewise, if he knows his business, takes him over undulating ground, and thus he learns to avoid mistakes which might break his own or his rider's neck in the hunting field. No fall is so dangerous as one occurring from the horse putting his foot into a blind drain, which a clever animal will seldom do, while a race-horse will rarely avoid it for any length of time if ridden over ground containing these dangerous traps without great care on the part of the rider.

THE PoINTS ESSENTIAL to the hunter are chiefly the following:-First and foremost, he must have a good shoulder-blade, placed obliquely to sustain easily the shock of falling from a height, and enable the horse to get away again quickly from it. It should also be particularly well clothed with muscles, or the part will soon tire, and after getting over the first few fences in good style a fall will occur. The muscularity of the fore-arm is likewise of great importance for the same reason, for this part also soon tires if not sufficiently powerful. Next to the shoulder and arm come the hind-quarters, which should be powerful in proportion to the weight which is to be carried. In this class of horses still more than in the race-horse a straight quarter is my aversion, and I never yet saw a perfect hunter with this kind of shape in the fullest degree.. Wide hips are especially necessary in the hunter intended to carry weight, and even ragged ones are to be preferred to the narrow weak hips which give a good side view, but look like a deal board from behind. Large and nuscular haunches and gaskins (or thighs) can alone 
give propelling power, but if these exist with small or diseased hocks the power will be thrown away. In the hunter far more than in the racehorse, the hocks should be well bent, and the stifles high and wide, or the action will be disunited, and the power of shifting the fore-feet so as to avoid holes, etc. will be wanting. Below the hocks and knees the cannonbones should be large, and the suspensory ligaments and tendons strong, clean, and free, while the pasterns should be strong and shorter than in the race-horse, terminating in feet large enough to avoid sinking in deep ground. In the middlepiece a greater width is desirable than in the race-horse, where excessive speed compels, to some extent, a sacrifice of "bellows room," and a chest slightly wider than in that variety may be admitted as perfection, though still not too wide and open. The back and loins must be strong, and well united to the hips by the back-ribs, being deep and close up, so as to bear the strain given by the superincumbent weight in coming to the ground after a leap. This kind of horse also has great demands upon his stamina, for he is sometimes kept out for a whole day without food, and has generally an empty stomach from nine o'clock in the morning till five or six in the afternoon, which is double the interval best suited to his constitution. Hence a full middlepiece is a desideratum, and in no class of half-bred horse is it so much required, for no other is exposed to such calls upon the digestive organs. The race-horse even when deprived of his hay by "setting" is allowed plenty of corn a very short time before running, but the hunter may leave his stable at eight or nine o'clock in the morning, and after being out for hours either drawing coverts blank or perhaps getting a moderate run, a fresh fox is found at three o'clock, and he must nevertheless go to the front or his master will despise him. Such a tax can only be borne by digestive organs which have plenty of room, and therefore it is that deep back ribs are so specially looked for by the hunting man of any experience.

IN HEIGHT the hunter may vary from 15 hands 1 inch to 16 hands 2 inches, the former being the lowest limit which as a rule will give size and power sufficient to get over a big place. Exceptions have occurred, such as in Mr. Vevers's Little Tommy, who was not more than $14 \frac{1}{2}$ hands, and yet both in the steeplechase and hunting field was very nearly A 1 , and could carry 11 stone 7 pounds with great ease. Few men, however, like to be mounted on ponies; and unless your nerve is very great, a big fence looks still bigger when you look up to its top than when you can look down upon it in riding towards it. On the other hand, an overgrown animal is seldom able to do more than carry himself, and frequently he cannot do that for any distance. Here, also, exceptions are met with, and Sir Piers Mostyn's Seventy-Four, who was 17 hands 1 inch, is a case in point, being a splendid hunter, and though not a winner of any great steeplechase, yet running a good second once or twice.

Manners MaKe THE MaN, but still more the hunter; and without "good manners" no horse can be considered fit for a gentleman to ride to hounds. A strong puller may make an excellent steeplechase horse, as I have already said, but even then he will not be equal to the more composed yet equally high-couraged animal who takes nothing more out of himself than is absolutely requisite for the task he has to perform. And no one who could 
afford to pay for what he regards as perfection would willingly ride a pulling horse to hounds, and one that is also irritable at a check is still more objectionable. Some horses will not wait for their turn at a gap or gate, but, in spite of bit and heel, will rush at some part of the fence, and thus jeopardize their riders. Such propensities are extremely disagreeable, and condemn their possessors in the opinion of all men of experience. Good manners generally are displayed when the head is well formed and the expression of countenance is good, but an experienced eye alone can judge of these particulars.

LASTLY, A GOOD моUтн should never be overlooked, and as the setting on of the head is essential to perfection in this respect, a purchaser should not omit to notice that fact, in selecting a hunter without a trial. Many a horse's mouth is spoiled from attempting to alter the shape of the neck by its means; while, again, a too supple neck gives way so much that it is difficult to get a mouth sufficiently dull to bear the slightest handling. It should always be remembered that an over-tender mouth may easily be altered for the better, while a dull one will remain so in spite of all the expedients which may be adopted. The only sure way to arrive at a knowledge of this point in any individual horse is to ride him under the same circumstances as he will be required for. Some will display an excellent mouth when ridden singly on the road, while with hounds they will pull one's arms off; others, again, will be pleasant enough if allowed to sail along at best pace, but cannot be kept away from the hounds without showing temper and disregarding the bit. It is, therefore, not only necessary to ascertain the nature of the mouth when the animal is not excited, but also to try it when he is wound up to the highest pitch; and a disregard of this precaution is constantly leading to disappointment.

\section{THE IRISH HUNTER}

Between the English and Irish Hunter there are several slight points of difference. Thus the latter is remarkable for a particularly neat head, almost too narrow across the forehead, but full between the ears. The muzzle is small, but with good nostrils; jaws open, and head well set on. The shoulders are particularly sloping and powerful, middlepiece well ribbed but slightly flat, hips wide and powerful, the loins also being muscular and well united to the back. The croup is almost always sloping and the tail set on low. Legs and feet clean and sound. With these external characteristics a sour temper is often combined; but the constitution is almost always hardy, and the powers of jumping are of a high order, displayed in height rather than in width. When an Irish hunter can be obtained possessed of good manners, he is very valuable indeed, but there is so much doubt on this point that a careful trial should always be obtained.

The Hunters' Improvement Society has done much to "promote the breeding of riding, driving, and military horses." 


\section{THE CHARGER AND TROOPER}

IT CANNOT BE SAID that any particular breed of horses merits this name, but there are some characteristics which must always be looked for in a horse intended for this purpose. Between the officer's charger and the troop-horse of the private soldier the only difference is in the degree of perfection to which the above points are carried, for there is no doubt that the same qualities which are desirable in the one are also required in the other. In the one case, however, there is a limit put to the price by Government, while in the other, the purse of the officer is alone the measure

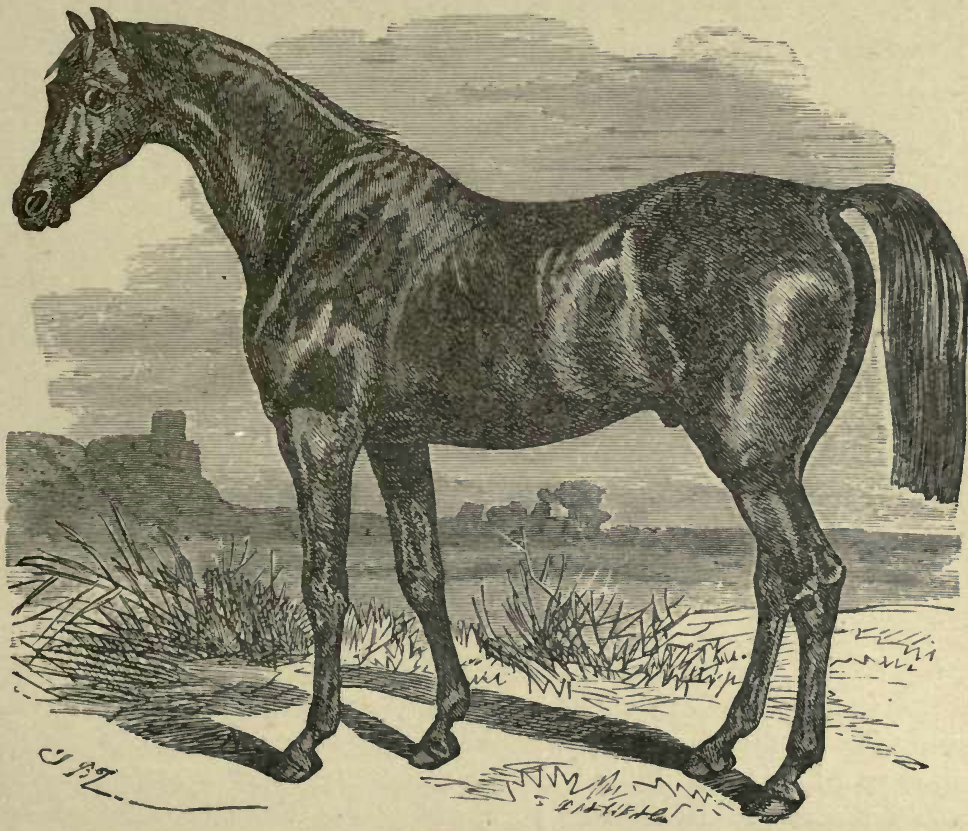

THE CHARGER.

of the extent to which the market may be searched. Two points are specially desirable, namely, sufficient size and power to carry the heavy weight of a dragoon or lifeguardsman triumphantly against opposing cavalry; and secondly, so much handiness at all paces that complete control of the horse may be maintained with the bridle-hand, while the sword, lance, or carbine is used by the other. An officer's charger is usually 16 hands high, and of power proportioned to the weight he has to carry. His hind-legs ought to be well under him, and his shoulders must be sloping and powerful, with a head and neck well put together, and rising out of the chest so as to give effect to the bridle. Such a horse is well displayed in the engraving, which is from a painting of a well-known charger belonging to an officer in the 1st Life Guards, by Mr. Barraud. Unless the hocks 
are well bent and the stifles forward it is almost impossible to teach a horse the military manège to its full extent, and hence this point is carefully insisted on by cavalry officers. Occasionally, a thoroughbred horse is met with possessing this formation, but generally that breed is deficient in it, in consequence of the different style of going which is adapted for racing. Nearly all the chargers used in the cavalıy are therefore half-bred, and a large proportion of them come from Lincolnshire, where, indeed, almost all of the Life Guards' troop-horses are bred specially for that purpose, being the produce of the black Lincolnshire cart mare crossed with the thoroughbred. These are sent up as three-year-olds to the three regiments, at $35 \mathrm{l}$. apiece, but of late years there has been a difficulty in procuring sufficient numbers to fill up the gaps made by disease and death. The troop-horses of the dragoons and lancers are bought as four-year-olds, and are obtained from various sources throughout England, Ireland, and Scotland.

\section{THE COVERT-, ROAD-, AND PARK-HACK}

BY THE WORD HACK is understood a horse specially intended for the saddle, and to be used on some kind of road, which may be the cross roads in the way to covert, or the ordinary turnpike, or lastly, the loose gravelly roads of our parks. The same class of animal is used in all, but there are some slight differences between the three kinds, as we shall presently see, corresponding with the purposes for which they are severally used.

THE COVERT-HACK is required to carry his master to the meet of the pack of fox-hounds to which the hunter or hunters have been sent on. The object of this arrangement is to save time to the rider, and also to allow the hunter to be taken quietly to the fixture by the groom, who exchanges the one for the other just before the hounds are thrown into covert. Hence this kind of hack must be fast as well as stout, and it is expected that he shall be able to carry any ordinary weight from twelve to sixteen miles within the hour, to do which he must maintain a fast handgallop over all sorts of ground, and occasionally "do" a little fence or two to cut off a corner. In days of yore, our grandfathers breakfasted at daybreak, or sometimes rode ten miles on an empty stomach to the house of a friend near the appointed meet; and they were contented to do this at a pace which would not turn a hair of their hunter's coat, even though that was perhaps not quite so silky and short as it is expected now to be. Such a practice would now be voted slow, even though the breakfast-hour might easily be appointed for eight A.M., leaving an hour and a half or two hours to ride quietly to covert. But, no, the fast man must ride fast, and makes his appearance on his blood-hack, galloping sixteen miles an hour, and with his overalls bespattered with mud. He leaves his house at halfpast nine or ten A.M., and reaches the meet just in time to put off his outside skin of dirt, and appear without a blemish on his boots and leathers. ${ }^{1}$

1 The need of covert-hacks in many hunting districts is no longer so great, as railway companies seeking dividends have cast about them for new customers and discovered the fact that many men can afford the money but not the time to go a-hunting unless it can be 
For this purpose the hack must be a galloper, capable of keeping up a fast hand-gallop all the way from point to point : he should be an easy goer at this pace, safe, and clever enough to take any moderate fence which may interfere with a short cut from one point to another. Green lanes are often very deep, and it would be impossible to get along them at the desired pace; the only alternative therefore is to turn out on the adjoining sound ground, and get over or through the fences as well as the hack is capable of doing them. If he is a perfect covert-hack he will creep or jump in hand, or get across the country in some way, according to the weight he has to carry; and he should therefore be a miniature hunter, with the additional requisite of being a good hack on the road. Many a horse is a pleasant and safe goer on soft ground, but if he is set going on a turnpike-road, he will roll over his rider in the first half-mile. This is what the covert-hack should not be; what he should be is, a clever and safe galloper. A trotter is tiring, in the first place; and in the second, is not suited for the green sides of a road or the green lanes which can generally be met with in reaching the meet. About 14 hands is the best average size for these hacks, whatever the rider may be; if for 16 stone or upwards, the hack must be a cob; but if for much less, he may be blood-like, or even quite thoroughbred, if he can be obtained of that breed with sufficient action. Most covert-hacks, however, are undersized hunters, the produce of mares intended to breed something more valuable in the market; but not growing into the contemplated proportions, the breeder is obliged to sell them as hacks; and when fast and clever enough, they are devoted to the purpose now under consideration. Action is the main point; not too high, so as to throw time and space away, but a fast stealing-away kind of style, which gets over the ground without distressing either horse or rider. If the hack can get along in this way, safely over all sorts of ground, and can last at his three-quarter pace for ten or a dozen miles, he is a good covert-hack, let his appearance be what it may; but most men prefer good looks in addition, especially as these hacks are available during the summer for other purposes. A neat head and neck, with, a general outline calculated to please the eye, are therefore eagerly looked for ; and the consequence is that one of 14 hands, or a little more, tolerably well-bred and good-looking, which is capable of carrying from 12 to 16 stone comfortably, and at a fast pace for the distance above specified, is worth from 50l. to 100l., according to his looks and action. A good judge will of course suit himself for one-half the lower sum; but in London, or any of the best hunting countries, such an animal is worth as much as I have stated. It must be recollected that he requires all the good qualities of the horse, except flying speed and great size; and that he must possess beauty of form and good temper, safe and fast action, cleverness, and above all good sound feet and legs to stand the battering of the roads over which he must often be ridden at his three-quarter pace. Now, many scores of hacks, so called, may be looked over before a good judge could

accomplished in one day. At any of the great Metropolitan termini may now be seen horseboxes being put together to convey "the horse and his rider," aye and his groom too, at a swift pace and a low rate to some stations near the covert-side. Dressing and breakfasting may be done in the train, and a change to comfort and dry things again effected on the return journey, and in time to attend some social function. 
select one corresponding in all points with the above description, and consequently when one is found it is fair to expect that his value will be estimated accordingly. Such animals fetch long prices even at the hammer; and when Mr. Tattersall has one before him, with a known good character, it more frequently reaches above the first-named sum than drops below it.

THE ROAD-HACK varies from the foregoing in being necessarily more of a trotter than a galloper, inasmuch as he is intended for use on macadamized roads, many of which are made of granite or flint, and are, therefore, as hard as iron. To gallop much on such a surface is to lame your hack; and even a fast trot is not to be indulged in for any distance, or on successive days, for fear of the same results. The Americans drive their trotters in their own country, and do not ride them, by which a faster pace may be obtained without injury; but in England the roads, being so much harder, soon compel a moderation of the fast trot, even in the imported horses, whose legs and feet are undoubtedly very sound and good, but still not capable of sustaining the wear and tear of granite roads at the rate of sixteen miles an hour. Hence, on our roads, we give up the gallop in favour of the walk and trot, which must be done cleverly. The former pace, especially, should be carefully inspected in selecting a hack, for nothing is so unpleasant and trying to the rider as an unsafe or rough walker. The fore-foot should be well lifted and put down again on its heel with a corresponding action of the hind-leg, by which, on the one hand, "knuckling over" is avoided, from reaching the ground too soon; and, on the other, "over-reaching," from the opposite extreme. A good hack should walk nearly or quite five miles an hour, and though some will do considerably more, it is seldom by anything but a kind of shuffle, which is not pleasant to the rider, nor elegant to the spectator. The trot should be of that character that it may be brought down to eight miles an hour, or extended to fourteen; and this is the perfection of the pace, for few horses can do both well, being either too close to the ground in the former for safety, or too set and lofty in the action for the latter. No defect is worse than the unsafe action, which results from a weakness of the extensor muscles of the arm, and in which the trot is pretty good as long as the horse is not tired, but after a few miles the leg is not lifted with power enough, and the toe is constantly striking against some inequality of the ground, from which it is not recovered. This marks the defect; for it must not be confounded with habitual stumbling, which is as likely to occur at starting as at any other time, and which is always easily detected by watching the mode of putting down the foot in the naturally unsafe trotter, where the toe touches the ground first, and the heel then follows, as is evidenced by the state of the tip of the shoe. Here a trip may occur often, and yet no fall follow, because the extensors are strong, and effect a recovery after the mischief has been nearly done. But when the extensors are weak, the toe, which has been well raised at first, after a few miles touches the ground, and, not being rapidly recovered, a fall ensues of the most severe character. For this reason it is necessary to ride a horse some distance before this action can be pronounced upon, and only then can it be said that he is fit for a timid or bad rider. As we shall hereafter 
find in discussing the mode in which the several paces are performed, the trot of our horses is somewhat different from that of the Americans, the knee in ours being more rounded, and the foot therefore reaching the ground with a greater tendency to "toe" it. With regard to shape, though, as in the race-horse, there is a particular formation which is more likely to give good hacking powers than any other, yet experience teaches every horseman that it cannot be relied on either negatively or positively. From a stable full of hacks no one would dream of making a selection without seeing them out, for it would be a hundred to one that the same animal would not be fixed upon before and after a trial. Every butcher's boy who has been a year or two in the trade will tell you that hacks, still more than race-horses, go in all shapes, and though oblique shoulders may be desirable, yet many a good hack is without. Action is the sine qua non, united to stoutness, temper, and soundness both of wind and limb, as well as of the eyes. A horse with a thick-loaded shoulder often makes a good hack, while a very thin one is not suited for long-continued journeys, its muscles soon tiring, and a trip, or series of trips, being the result. There are, however, one or two essentials in the shape of a good hack which should never be overlooked, let the action be what it may. Firstly, the shoulder-blade must be wide enough at its upper part and sufficiently clothed with muscle behind it to keep the saddle in its place, which may readily be ascertained by the most inexperienced person by putting one on and riding a mile or two, partly down-hill. The horseman knows at once whether the shape of this part is suitable, but practice is required for this, and unless it has been obtained, it is better to leave nothing to chance, but to take the trouble to ascertain the fact. Secondly, the jaws should be wide, and the head and neck so put together that they can be bent into proper form, without which the mouth cannot remain good, and no hack can be considered perfect. This, however, I have previously enlarged upon at great length, and therefore $I$ need not repeat what I have written. I have alluded to the walk, trot, and gallop in mentioning the paces of the hack, but have said nothing of the canter, because it is not much used by gentlemen, on account of its wearing the off-leg out more than the trot, from the great stress laid upon that limb. Even if the lead is continually changed, more mischief is done by 10,000 hard blows than by 20,000 comparatively gentle, and therefore, excepting on the turf by the side of the road, the canter should not be indulged in by the male sex.

THE PARK-HACK should be the road-hack I have described with the most showy form within reach; but as this last is the point which is the most attended to, an animal is often selected of the most worthless kind in other particulars, either from some deficiency of constitution or infirmity of legs. There are every year some scores of useless brutes turned out of the racingstables with legs which will not stand a preparation, in consequence of their tendency to inflame and become unsound. Now, these horses are often barely up to 11 stone, and also unfit for the hunting field, from defective hocks, or from some peculiarity of temper which prevents their taking to jump. They are "well topped"-that is, well formed about the head, neck, and body; and to the inexperienced eye are very taking. They may also have high action, and sometimes particularly so; for the 
higher it is, the more likely to occasion inflammation of the legs. These animals are put by, cooled down, and blistered, and are then brought out as showy hacks, for the use of gentlemen who merely require a short constitutional airing every fine day of an hour or an hour and a half; and, as fine days do not average above four per week, many horses even with the most infirm legs can accomplish that amount of work, if ridden quietly over hard ground. Many such animals are exhibited daily in Hyde Park, where the soft ground of Rotten Row exactly suits them; but there are others to be seen there of the most perfect description, capable of standing as much work as any butcher's pony. Nevertheless, it must be admitted that the great majority of our park-hacks, even if they are specially bred for the purpose, are incapable of doing as much work over hard ground as the coarser-bred and more common-looking brutes in use among the butchers and general dealers who attend country fairs from long distances. Eastern blood is a great advantage in most respects, and no doubt when the animal possessing it is sound, he will bear the shocks of the road with impunity; but there is no question in my mind that he fails in the matter of enduring daily concussion on the road, and that a Welsh pony or Norman horse will stand nearly twice the amount of this work without showing its effects. This is the weak point in the breed, partly arising from original want of size in the bone and joints, but chiefly, I imagine, from the constant use of stallions for inferior stock which have themselves suffered from inflammation of the legs and its consequences; hence, in process of time, a breed of horses is formed, which has legs more than usually prone to lameness, in consequence of being the produce of sires and dams that have been turned out of the racing stable for this very infirmity, which is transmitted to the offspring. That Eastern blood is not necessarily prone to inflammation of the legs and feet is tolerably manifest from our experience of modern Arabs and their descendants in this country, as well as abroad. Since the Crimean war, the number imported into Great Britain has greatly increased, and though most of them have been selected almost at random, they are certainly not defective in their legs, though perhaps not coming up to the degree of wiriness which is possessed by the Welsh pony. I have myself owned an Arab as well as a grandson of an Arab, which would bear any fair amount of hammering uninjured, and from these facts, and others not within my own knowledge, I am led to conclude that the cause is not inherent in the breed, but is accidentally introduced by the use of rejected stallions for farmers' purposes. These get good-looking colts, which fetch high prices, and therefore suit the breeder's purpose just as well as the sounder horse, who would perhaps cost twice as much for his services. The farmer seldom tries the legs much, and it is only when put to work that the weakness is discovered, which to the eye is not by any means perceptible. From a long experience in my own case, and in that of others, I am convinced that legs cannot be selected by the appearance or feel. I do not mean to say that out of forty horses the twenty with the best-looking legs will not beat the others, but that it is impossible for any juage, however good, to pronounce with anything like certainty whether a certain leg will stand or not, without knowing anything of the possessor of it. In so many instances have I seen 


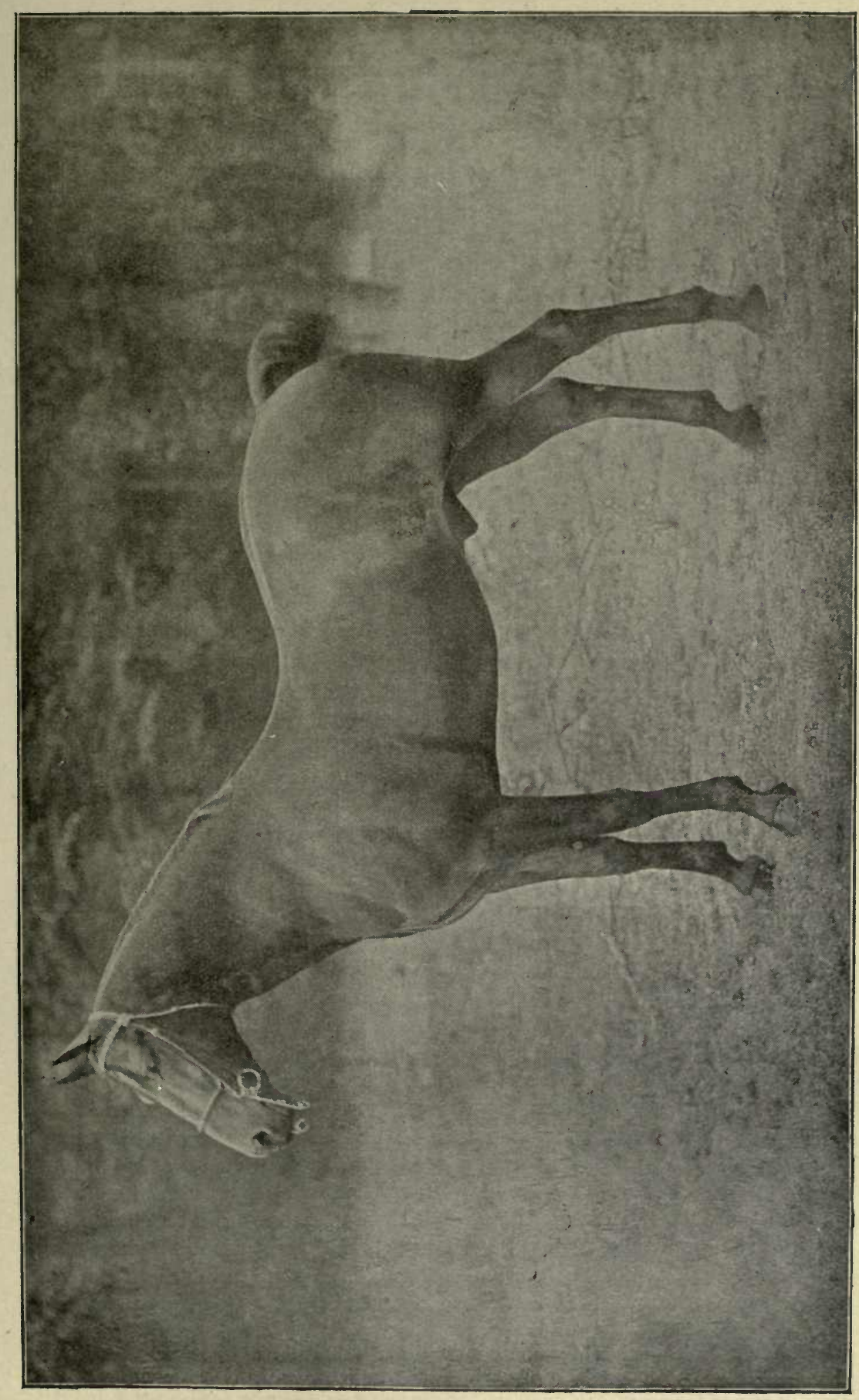

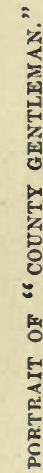

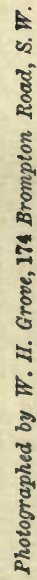


a leg, pronounced by several good judges to be undeniably good, go to pieces directly, and a bad one stand, that I can only come to the conclusion that no certain opinion can be formed from a mere inspection. This is a great source of loss to the dealer who buys his horses after a long rest, and with their legs looking fine and sound; for even the necessary "showing out" will make many give way, and lameness ensue of a character which will not warrant a "return," yet sufficient to prevent a profitable sale. A horse sore from work is cooled down, physicked, and put into a loose box; he is then blistered, and kept without more than quiet exercise till he is to be sold, and by that time his legs are as fine as the day he was foaled. Now, I defy any one, however skilful, to detect the inherent weakness; but there it is, and on the first week's severe work the inflammation returns as bad as ever. The park-hack not requiring legs to stand severe work, his place is well filled by any horse of good temper, safe, and showy action, and of elegant shape. Good temper is necessary, because, as these horses are not worked hard, they speedily become unmanageable if they are naturally of a vicious disposition. Work will quiet almost any horse; but in order to have a horse pleasant to ride at all times, whether fresh or stale, he must be of a very tractable temper indeed. Many horses which will come out of the stable, when fresh, in a state of fiery and hot impatience, rearing and kicking like mad animals, will, when in good work, be as quiet as donkeys; and hence it is not always wise to reject one showing these qualities, nor yet is it prudent for a bad horseman to mount one without previous riding, although he may know him to be quiet enough when regularly worked.

\section{THE LADIES' HORSE}

THIS VARIETY OF THE HORSE should be a perfect park-hack such as I have already described, but moulded in somewhat longer proportions, so as to give room for the habit to spread without quite eclipsing the animal. ${ }^{1}$ Many a hack looks extremely well under a man, but when a side-saddle and habit are on him, he shows nothing on the near side from the point of the shoulder to the hip, and hence is not adapted in appearance to a lady's use. A back too long to carry the weight of a man above 9 stone is yet strong enough for a lady of average proportions, who seldom weighs, even with an eighteen pound or twenty pound saddle, more than 10 stone, and many not near so much. This formation also gives a softer canter, and therefore possesses every good quality desired for a lady's use without any drawback. To be in proportion to this increased length of body, the neck should also be long, and thus an animal is well chosen for a lady which would be rejected by most male judges for their own use. In point of soundness, mouth, and temper, he must be unimpeachable, for the legs are far more tried by the canter than by any other pace, and

1 The fashion in habits has been continuously in the direction of closer skirts since the abore indictment was penned against the ladies, and the present editor feels unable to endorse the charge of bad "hands" when recollecting the many occasions he has been "pounded" with a screw, but with a fast-fading "vision of fair women" in front. 
ladies generally choose the cleanest, and therefore the hardest part of the road, and ride the faster there, because they ean do so without splashing their habits. In wind also there should be no defect, as a gallop is not avoided whenever turf is at hand, and sometimes when this is not to be obtained, it is taken on harder ground. The mouth of a lady's horse should be light and level, and the neck so easily bent that there is not the slightest tendency to throw the head up, even when the hands are so high as they necessarily must be from the nature of the lady's seat. There is a popular idea that a horse does not pull as much with a lady as with a gentleman, which is very erroneous. The hands of most men are bad enough, but for one good pair of female hands there are a dozen possessed by men, and this is irrespective of the greater number of riders among the male sex, but calculated in proportion, that is to say, the percentage of good hands is, far greater among men than among women. Of course we do not see the same severe hanging on the bit displayed by ladies, because they have neither the same weight nor the same strength as their brothers, fathers, or husbands ; but as far as they can, they spoil their horses' mouths, with some few occasional exceptions. From the nature of the lady's seat, the hands cannot be held low over the withers, and if the horse's mouth absolutely requires the hands to be kept down below the level of the knee, they must be divided, and a rein taken in each. This generally gives an inelegant seat, but a year or two ago it was the fashion, and wherever it could be adopted it was: in order to maintain an upright position of the body, the hands must be brought almost back to the hips, and no shifting of the rein from one to the other can be effected without raising them above the knee. It follows, therefore, that the lady's position causes great difficulty in the management of an awkward mouth, and that, therefore, a very perfect one should be chosen for her use. In addition to good legs, length of body and neck, and a perfect mouth, the ladies' horse should be of a fine temper, and not too lazy, or he will need the spur; nor too hot, or he will get beyond her control. In height he should be between 15 and 16 hands, less than the former being objectionable on account of the splashes on the habit which is caused by too low a horse, and a greater height being generally attended with a rough and therefore unpleasant action. The walk and canter are the absolutely essential paces, but a good and even trot should, if possible, be superadded, for the sake of giving useful exercise to the rider, and at the same time saving the legs of her horse, which are tried far less in this pace on hard roads than in the canter.

\section{COBS, GALLOWAYS, AND PONIES}

Tни Сов is merely a thick and strongly-made hack about 14. hands in height, and suited to carry from 15 to 20 stone. All the points are therefore such as are required in the ordinary hack, but they must be strong in proportion to the weight to be earried. The 20 -stone cob is in fact a compact and active little cart-horse, with cannon-bones as large as in that variety, and generally with the same tendency to throw out bony growths. In those up to less weight more breeding may be displayed, but 
even in them the cart-horse generally predominates, with all his attendant disadvantages. Few breeders take any pains to obtain the cob, and his occurrence is chiefly accidental, being a dwarf among those colts intended for hunters, or an unusually well-shaped and active little cart-horse. The former is the more valuable by far, as his action will be cleaner and less heavy, while his limbs will stand fast work much better, and if wanted for the gallop his wind will be far more lasting.

The term "cob" has become very generally used as denoting a stout littlo horse or large pony, and one frequently sees animals advertised under that name but having no clain whatever to be so classed.

As to the Galloway, the term itself as well as the animal it represents are quite out of date. Originally, the word was confined to the full-sized ponies which were bred in the south of Scotland, and which showed more Eastern blood than the Highlanders. They seldom exceeded 14 hands, and are described as possessing all the attributes of a clever hack. The distinct breed, however, is now lost, though the revival of so-called Galloway races at Barn Elms and other places keeps alive the name. Undersized thoroughbreds, polo-ponies, et hoc genus omne take part in these competitions.

AMONG MODERN PONIES there is great variety, but the breeds are seldom kept distinct. It may, however, be said that the following are sufficiently so to be considered as sub-varieties of this division-namely, those of Wales, the New Forest, and Exmoor, in the South ; and the Highland and Shetland pony in the North.

THE Welsi PoNy is a strong, useful animal, averaging about 13 hands in height, and possessed of a neat head, good shoulders, a capital back, and most enduring legs and feet. Many of them are of a cream or dun colour, and if the latter, marked with a dark stripe down the back, which colour extends to the mane and tail. These peculiarities are supposed to be derived from Norwegian sires, which some years ago were introduced into the district in the hope of improving the breed, which was then very small and weedy, with a remarkable preponderance among them of "cat hams." The cross has proved useful; but either from it or from the original breed, the Welsh pony is extremely disposed to be obstinate; but as man is very apt to convey his own qualities to the dumb creatures about him, and as obstinacy is notoriously prevalent among the biped inhabitants of the province, it seems probable that Norway is altogether innocent. These ponies are bred in considerable numbers by the farmers, and suffered to run on the hills till they are three years old, when they are collected and either sold by auction on the spot, or sent in droves into England, where they are readily disposed of at prices varying from $5 l$. to 15l. The Rev. T. Williams of Try-y-cwm, near Swansea, was one of the most celebrated of these breeders, and I have seen some of his ponies, especially a stallion ridden by himself, of very fine symmetry and action.

The New Fonest Pony.-In the earlier editions of this work the New Forest Pony was spoken of disparagingly, and with good reason, as he had suffered neglect and deterioration, and the author contemplated his early extinction by laying down the forest and cutting it up into farms. Such has not proved to be the case. The rights of the foresters, as well as the 
ponies, have received consideration, and the breed has been "enlarged and improved," prizes being annually offered and well bestowed, and there is further prospect of retaining it in all its native hardihood and with increased size and symmetry.

The Exmoor Pony.- To our mind this pony has but one fault, and that is want of size; what there is of him is remarkably good, and for all purposes. He will carry a man as big as himself, pull a load like a cart-horse, and trot in good style and at a high rate of speed if not overloaded. He is docile, intelligent, handsome, and not given to shy or be tricky, and seen upon his native heath there is a romance about him that might well have inspired the author of "Caterfelts," whether or no there is any truth in the story of that remarkable stallion. The small size may be, and is, probably due to the short keep which the yearling has to expect, since two-year-olds caught up and liberally treated grow to a very fair size. The beautiful little heads and clean limbs of these ponies are suggestive of the thoroughbred in miniature, while they rarely have his defective action in front, neither daisycutting nor turning out their toes, but coming down on all fours like a cat and with something like her power of jumping. At West-country horse shows we have seen these little ponies carrying weights out of all proportion to their size, yet clearing the same jumps as other horses in the competitions. At the annual great sales at Bampton the competition of buyers is keen, and dealers often travel long distances in the hope of securing a choice of them beforehand.

The Highland Pony is remarkable for his docility and general good manners, by which circumstance he makes the best shooting pony in the world, and can be taught almost anything, except perhaps to gallop with the race-horse. These ponies have, like the old Welsh breed, the formation of hind-quarter called "cat hams," but this only gives a greater power of using them, and especially of creeping over broken ground, in which they are unapproachable. Their intelligence also is so great that it is almost impossible to get them into a bog; and if by chance they find themselves sinking, they avoid the struggles which are instinctive in other breeds, and manage either to creep quietly out, or else wait patiently till assistance comes. In size they vary from $12 \frac{1}{2}$ to $13 \frac{1}{2} \mathrm{hands}$, and in shape they present little to be remarked except their neat heads and cat hams. They are able to carry considerably more weight than their frames would lead one to expect, and sometimes a six-foot brawny Scotchman may be seen on one of them without causing any apparent distress, and with difficulty keeping his legs off the ground.

The Polo-PonY. - Though he can be hardly termed a distinctive breed it needs no prophet to say that he shortly will be, as a Stud-book already exists; the game for which he is destined is ever increasing in popularity, and the supply being unequal to the demand, there will doubtless be an increasing number of gentlemen who for amusement and a possible profit will succeed in establishing a race that will breed to type. Hitherto poloponies have come from anywhere and been bred anyhow so that they have been capable of being made into good performers, but the polo-pony most esteemed is a dwarf hunter or steeplechaser. Lieutenant E. D. Miller in his Modern Polo says, "any of the old breeds of ponies belonging to these islands.... are useless for polo by reason of their small size, coarseness, 
and want of pace. The great love of blood entertained by breeders in Ireland makes that country the best in the world for finding ponies suitable for polo; although I have known but few suitable for the game. As a rule, an Irish breeder tries to get a hunter, or failing that, a smart trapper; for his countrymen love to drive a bit of blood. From the Irish animals which are too small for either kind of work we get the large majority of our polo-ponies."

Up to the present, the majority of attempts at breeding ponies within narrow limits of height have failed, on account of the tendency sires and dams have of "throwing back"; the fillies being frequently too small for polo: the colts too big. By the rules of the game polo-ponies may not exceed 14 hands 2 inches. Captain Daly's "Wig," who rode to victory in

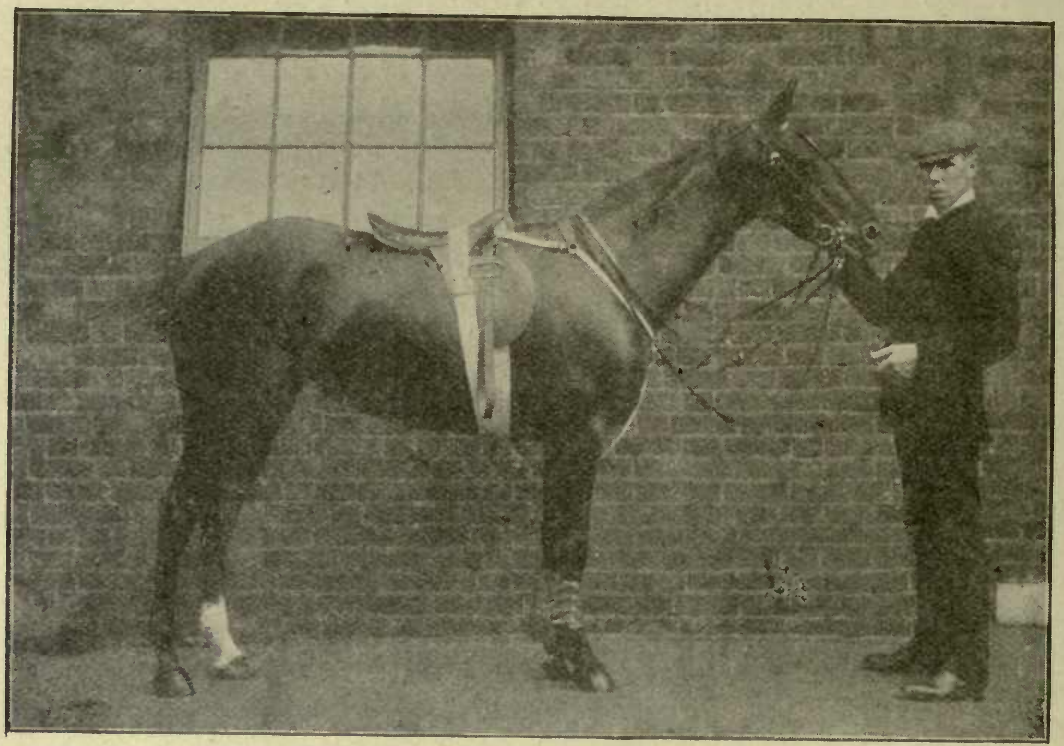

From a photograph by Field, Puiney.

THE POLO-PONY.

the champion cup of 1894 , is thus described by Lieutenant Miller- "He can, if required, carry the fourteen stone of his owner for a full half-hour in a tight match. He stands on the best of legs and feet, has excellent shoulders, well-set-on head and neck, plenty of rein, great bone, strong back, arched ribs, deep through the middle of the body, powerful quarters, the best of hocks, and no superfluous weight." In fact all the points of a high-class pony without any faults. The amusing author finishes his description by inviting his readers to "kindly add to this the temper of an angel and the wisdom of the Evil One, and they will have his idea of a perfect pony."

Lastly, the Shetlander comes under review. He is the smallest variety of the British horse, and his appearance is well delineated in the annexed engraving. His head, almost concealed by his rough shaggy mane and forelock, looks smaller than it really is, while his neck is extremely well 
formed, and his shoulders are slanting, muscular, and full of liberty. In fact, these little animals have powers proportionally as great as that of a dray-horse, and appear to carry with ease a man of 11 or 12 stone, if only he can arrange his legs so as to avoid walking and riding at the same time. They vary in height from 9 to 11 hands, or sometimes a little

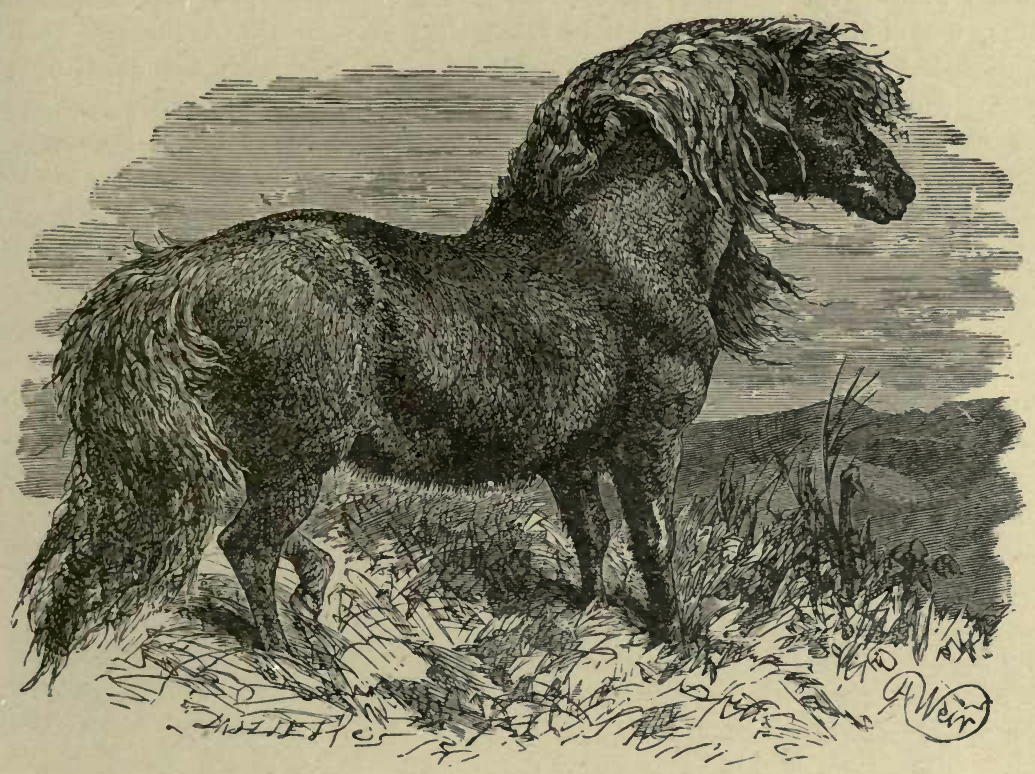

THE SHETLAND PONY.

more, and hence they are admirably calculated in this respect for the use of children, while their tempers are generally so good that they may be pulled about with as much impunity as a Newfoundland dog. Their colours are chiefly bay, brown, or rusty black, chestnuts and greys being extremely rare. Large numbers are imported into England every year by the steamers from the North, and sold at prices varying from $£ 5$ to $£ 30$ according to appearance and action. Their commonest fault is an unwillingness to "back" in harness.

\section{THE CARRIAGE, BROUGHAM, OR CAB-HORSE}

MOST OF OUR BEST-SHAPED CARRIAGE-HORSES are now bred in Yorkshire and Lincolnshire; but some few, and those not the worst, come from Shropshire and the borders of the adjacent counties. These horses are chiefly the result of a cross between the old Cleveland horse (now nearly extinct) and the thoroughbred Eastern horse, the proportion of the latter blood being difficult to ascertain, as in most instances the pedigrees of the stallions and mares cannot be traced with any certainty for more than two or three generations, in spite of the assertions to the contrary of their breeders. Grand figure and high action, rather than pace, are the objects 
aimed at, extravagant knee-action is considered essential to a perfect turnout. The original from which my illustration of this variety is taken was for some months in the possession of Mr. Anderson, of Piccadilly, and sold by him at a long price to go abroad. He was painted by Mr. Barraud as a fine specimen of his class, and certainly the artist has conveyed to his canvas with great success the characteristic action of the cab or carriagehorse, which it will be seen differs from that of the fast American trotter represented at page 46 in its roundness and in the high elevation of the knee. Hence, it is more showy, or "gaudy" as the dealers say, and much less fast, ten miles an hour being the outside pace of these horses, and even this being too much for their legs and feet on our roads. At the

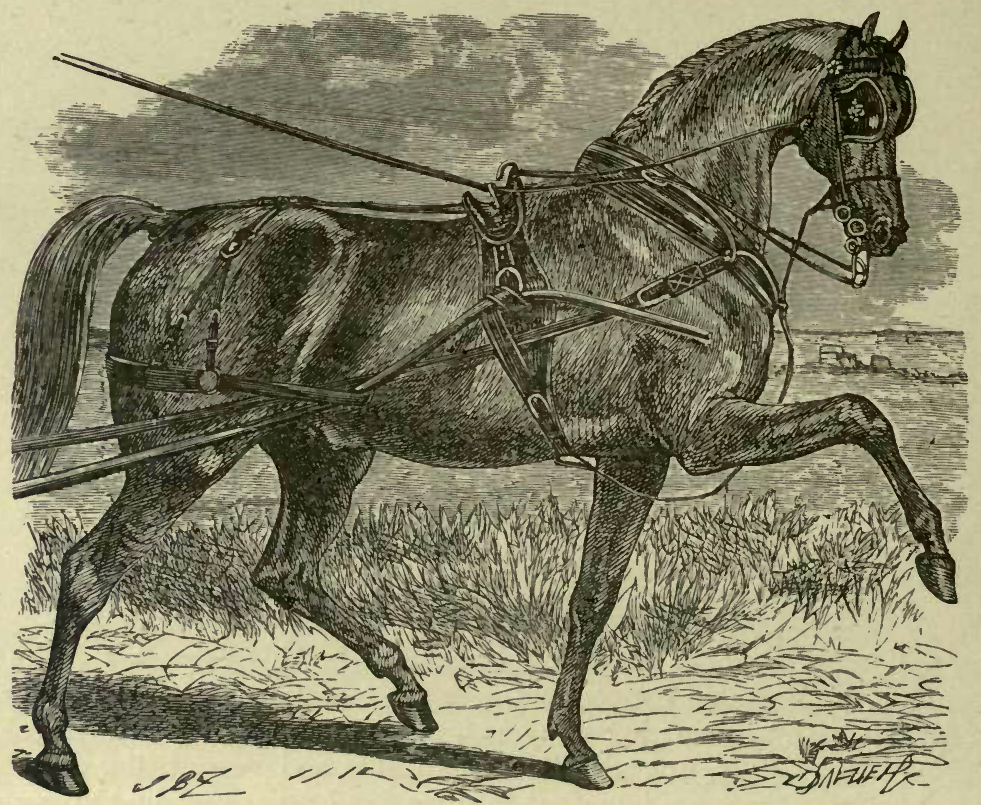

THE CARRIAGE, BROUGHAM, OR CAB-HORSE.

time when Count Bathyany was so celebrated for his carriage-horses, whose action was splendid, he always "threw by" each pair at stated intervals, so as to reduce the inflammation of the feet and legs caused by tho hammering on the road, before it had had time to leave any organic mischief. Being at least sixteen hands in height, with round barrels on which flesh is always loaded for the sake of show, their legs and feet have a good deal of weight to carry, and even with moderate action these soon wear out, if they are of bad form or materials. Hence, they are never used till they either are, or are supposed to be, five years old; but to make them handy and safe in London they must be driven about the streets in the break for some months before they will stand a crush at the opera, or any other similar trial of steadiness and nerve. Some hundreds of pairs of these horses are jobbed in London, while nearly as many more are kept by their owners for their own use. The engraving I have given 
will convey the characteristics desired in this horse better than any written description; but though it will serve to show the external form and action, it is on too small a scale to indicate in a reliable way the wiry and clean legs which are indispensable, and without which work soon causes lameness of some kind or other. The head is particularly good for so mixed a breed, and indicates the care which has been paid for many years to the selection of sires and dams. But the neck is the main feature in point of show, being of a most elegant formation; and the head being well set on gives that beautiful rainbow sweep, which is shown in the portrait of $\mathrm{Mr}$. Anderson's horse. Much of this is produced by careful breaking; but without a naturally good formation of the bones, all the breakers in the world cannot make a horse bend himself into the beautiful outline so frequently displayed in Hyde Park. Oblique but muscular shoulders, short backs, and long though strong quarters, with a great deal of ground covered below, constitute the remaining points characteristic of this horse, and leave nothing to be desired except that more of the same sort should be annually bred. The broughams of London take those of inferior shape and action, but some of them are furnished with horses of nearly as much fashion and action as the cabriolets and carriages of the most aristocratic houses. Still, on the whole, there is no doubt that the latter take off the cream of this variety of horse.

It is an open secret, that by far the greater number of showy harness horses and especially matched pairs are the produce of the Continent, more particularly of Hungary, where breeding to type has been carried to great perfection. They are passed off as English and Irish, and do well enough for a short display in the park, but have neither the endurance nor constitution of the home-bred animal. Being made in Germany, they are cheaper and afford the seller a better profit than home-bred animals, which zannot be found in sufficient numbers to supply the demand.

\section{THE HEAVY MACHINER}

OUR OMNIBUSES AND vaNS are supplied with a most wonderfully active yet strong kind of horse, which is in some measure obtained from the breeders of the last variety, being too plain in appearance, and sometimes too heavy in action, for private use. Their price is so low, averaging about $£ 30$ when sound and five or six years old, that no one would be remunerated by attempting to breed them exclusively for the purpose to which they are finally put, and hence they are to be considered as the blanks in the breeder's lottery planned for other and more valuable kinds, such as the carriage horse or hunter, or as agricultural stock which have paid for their keep since their second year. The pair-horse omnibus also is a comparatively modern invention, and many are now drawn eight miles within the hour, conveying twenty-six passengers, besides the driver and conductor, whereas sixteen used to be the full complement for four horses, and with the use of a lighter vehicle. In those districts where the soil is light and G.O. ploughs are in vogue, the agricultural horses are so active that a selection from them will give a number of useful heavy machiners; and some horses which refuse to work steadily at plough, will take to faster 
work with comparative kindliness. This last sort, however, do not bear a fast pace, but up to six miles an hour they can perform extremely well. The action of our omnibus horses is remarkably good for all useful purposes, being so safe that one rarely sees a mistake, and when a fall occurs it is almost invariably from a slip and not from a stumble. Much of this improvement in action is due to the absence of the bearing-rein and the general use of the snaffle, leaving the animal at liberty to move without the dreadful restraint which was formerly so indiscriminately imposed. Canadians of stout build are also put to this kind of work.

\section{THE PHAETON-HORSE, GIGSTER, OR FAST TROTTER}

Between the Norfolk and American trotters, which may be taken as the types of the two kinds of trotting developed in the horse, there is a very considerable difference. I have already described the latter, but it remains for me to say a few words about his English rival. In both there must be a considerable infusion of Eastern blood, not for the purpose of giving pace, but endurance. Many a low-bred animal can trot a mile in pretty fair time, but he cannot keep his pace up; and indeed when very fast time is to be made, as, for instance, what the Americans call "low in the two-thirties," that is, a mile in little over the two and a half minutes, blood is almost equally in demand for that distance as for a longer, and the distress is nearly as great as in running a mile over the flat at Newmarket. Norfolk has long been celebrated for her breed of trotters, and these are still in considerable demand for our gigs and phaetons, but their trot is not soft enough to make them desirable hacks, and they are little used for that purpose. The same applies to the American trotters, which are kept to their wagons all over the States. The action of the Norfolk trotter is more showy than that of the American, chiefly because the eye is the sole test applied in this country, no purchaser caring for a faster pace than fourteen or fifteen miles an hour, and most contenting themselves with twelve, whereas, on the other side of the Atlantic, the time-test is applied in all cases, and the value of a horse is in proportion to what he can do with the stop-watch in the hand of his examiner. The action of our best trotters resembles that of the carriage-horse displayed at page 130 , but in the smaller animals it is somewhat shorter and sharper. The foot is not thrust forward so much as in the American, either before or behind, and hence there is more time lost in each step. In point of appearance and breeding, our gigsters and phaeton-horses are of all kinds, from the pure thoroughbred to the strong but undersized carriage-horse. 


\title{
CHAPTER VIII
}

\author{
THE DRAUGHT HORSE
}

\begin{abstract}
THE SHIRE-HORSE-THE SUFFOLK CART-HORSE-THE IMPROVED LINCOLNSHIRE DHAY-HORSE -THE CLYDESDALE-HORSE-OTHER MIXED BREEDS.
\end{abstract}

\section{THE SHIRE HORSE}

According to Sir Walter Gilbey, who has done so much for this breed, we have in the class before us the descendants of the old English Great Horse or War-Horse, the oldest form of horse in this island. "A thousand years ago this form was written of as 'the Great Horse,' and nearly a thousand years before that we have evidence which goes to prove that the same stamp of horse then existed in Britain." Those who saw it and recorded their opinions, considered it to be the best of its kind to be found in any country. The most powerful type of horse now in use for agriculture and general draught purposes is, according to the above-named high authority, the direct descendant of the horse which Julius Cæsar found here, and attracted his attention for its efficiency as a war-horse in the service of the Ancient Britons.

Much credit is due to our countrymen for their careful and judicious selection of the two types of horse which have been brought to such perfection for their respective purposes. If we have so improved upon the Oriental type that no Arab or Barb can compete upon equal terms with their English descendants, so also have we continued to improve upon the native heavy horse, now known as the Shire. The Great Horse was essentially a war-horse until the middle ages in this country, farm work and general haulage being performed by oxen. Although improved from time to time by the judicious introduction of foreign blood, this type of horse can be traced back for many centuries. Camden's Britannia gives an engraving of two British coins of Cassobelin struck in the first century, and depicting the English Great Horse. White animals of large size were highly prized according to the above authority, and only the great ones of the earth were permitted to appear in state so mounted. When John of France was conducted as a prisoner to London, he was given "a white steed to ride, while the Black Prince in meaner attire was carried by his side on a black palfrey." This affectation of humility was intended to make it appear that John was a royal guest.

According to the Venerable Bede the English did not use saddle-horses 
until about A.D. 631 , and Church dignitaries requiring horses to ride were counselled to use mares, in order to spare the horses for the mail-clad warriors, whose persons and "kit" made up some thirty stones according to our present reckoning.

These powerful animals are not mentioned as being used for cartage until about 1154, when a monk of Canterbury, William Stephanides, wrote"Without one of the London City Gates is a certain Smoothfield (Smithfield). Every Friday there is a brave sight of gallant horses to be sold. Many come out of the city to buy or look on-to wit, earls, barons, knights and citizens. There are also to be found here cart-horses, fit for the dray, the plough, or the chariot."

During the Wars of the Roses horse-breeding was seriously checked as either side would requisition them, and probably, like Warwick, "first they wore the roses white and then the roses red" (but "many nobles for such things were shorter by a head").

As many as a hundred stallions were imported in the reign of King John from the Netherlands, and "it is," says Sir Walter Gilbey, "from the blending, nearly seven hundred years ago, of these animals with the English breed, that some strains at least of our heavy draught-horses, must be said to date their origin.

Successive kings of England appear to have striven both to increase the size and numbers of such horses within the realm, and King Henry VIII. enacted that "all prelates and nobles (whose wives wore French hoods or velvet bonnets) should keep stallions for the saddle of a certain size." Although the introduction of carriages by Fitz-Alan, Earl of Arundel, led to the use of lighter horses, and Queen Elizabeth's successors had no need to ride on the back of what we now call cart-horses, the breed continued to receive care and judgment in selection. The Great Horse is again described in 1658 by the Duke of Newcastle, as having "large limbs, heavy crest, silky-haired fetlocks, and flowing mane and tail," a not inapt description of his present day descendant. The engraving of Staunton Hero is selected by Sir Walter Gilbey, and is a good portrait.

\section{THE SUFFOLK CART-HORSE}

IN THE LATTER PART of the eighteenth century the agriculturists of Norfolk and Suffolk were far more enterprising than their brethren throughout the remainder of England. Among other subjects to which they paid special attention was the cart-horse, which, though said by Mr. Culley to be a plain horse, was far more level and symmetrical than the aboriginal horse of the country. The Suffolk horses of the early part of the present century were thus described by the above observer:- "Their merit probably consists more in constitutional hardiness than fine shape, being in general a very plain horse. Their colour is mostly yellowish, or sorrel, with a white ratch or blaze on their faces. The head large, ears wide, muzzle coarse, fore-end low, back long, but very straight, sides flat, shoulders too far forward, hind-quarters middling, but rather high about the hips, legs round, and short in the pastern, deep barrelled, and full in the flank. Here, perhaps, lies much of the merit in these horses, for we 


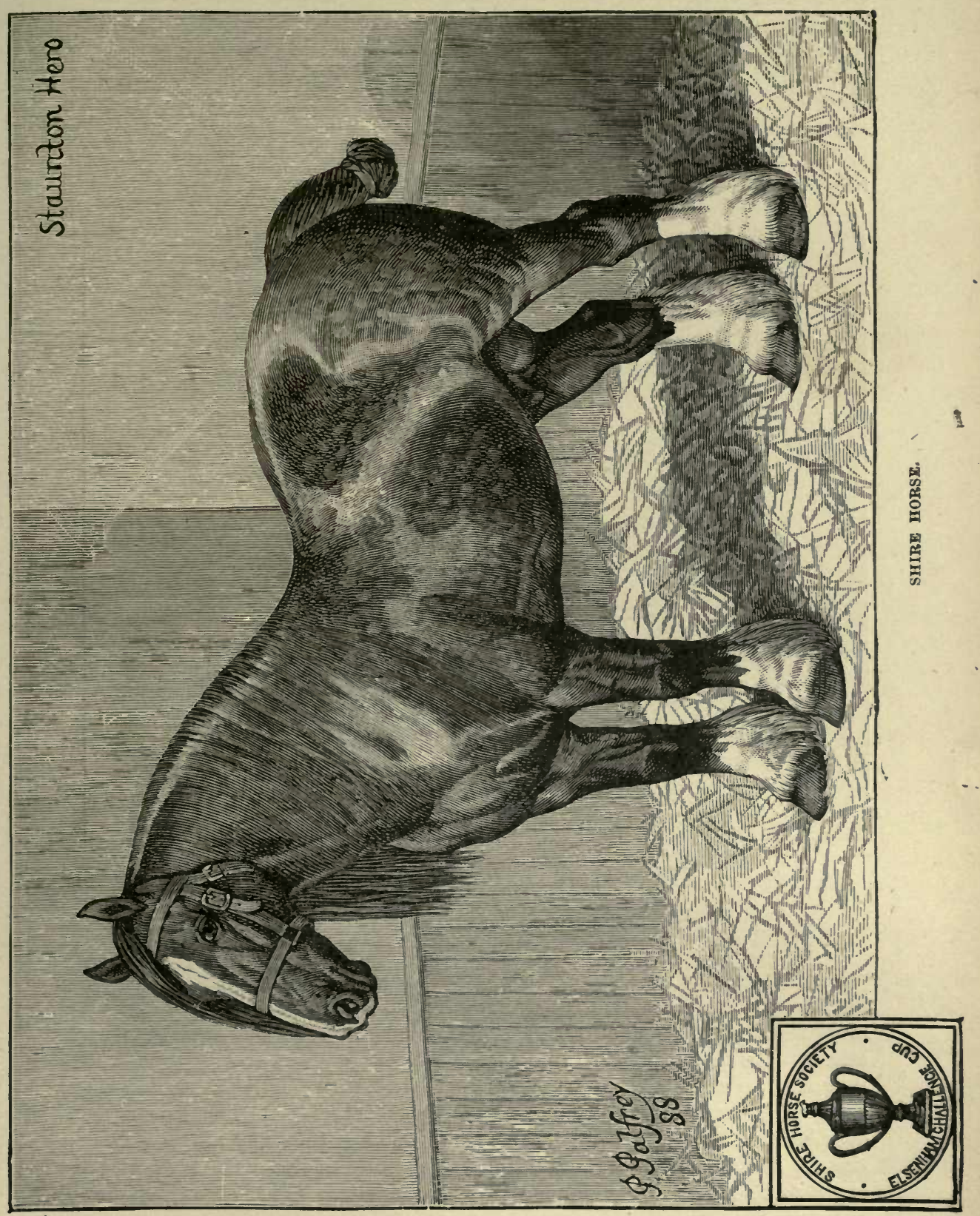


know from observation and experience that all deep-bellied horses carry their food long, and consequently are able to stand a longer and harder day's work." This variety is now quite extinct; the improved Suffolk is lighter and quicker than the old breed, with a low, powerful shoulder, and very drooping croup. The legs also are very clean and wiry. A good example will be found in the engraving.

The Suffolk now shares with the Clydesdale pretty equally the approbation of the farmers throughout Great Britain, the former being generally

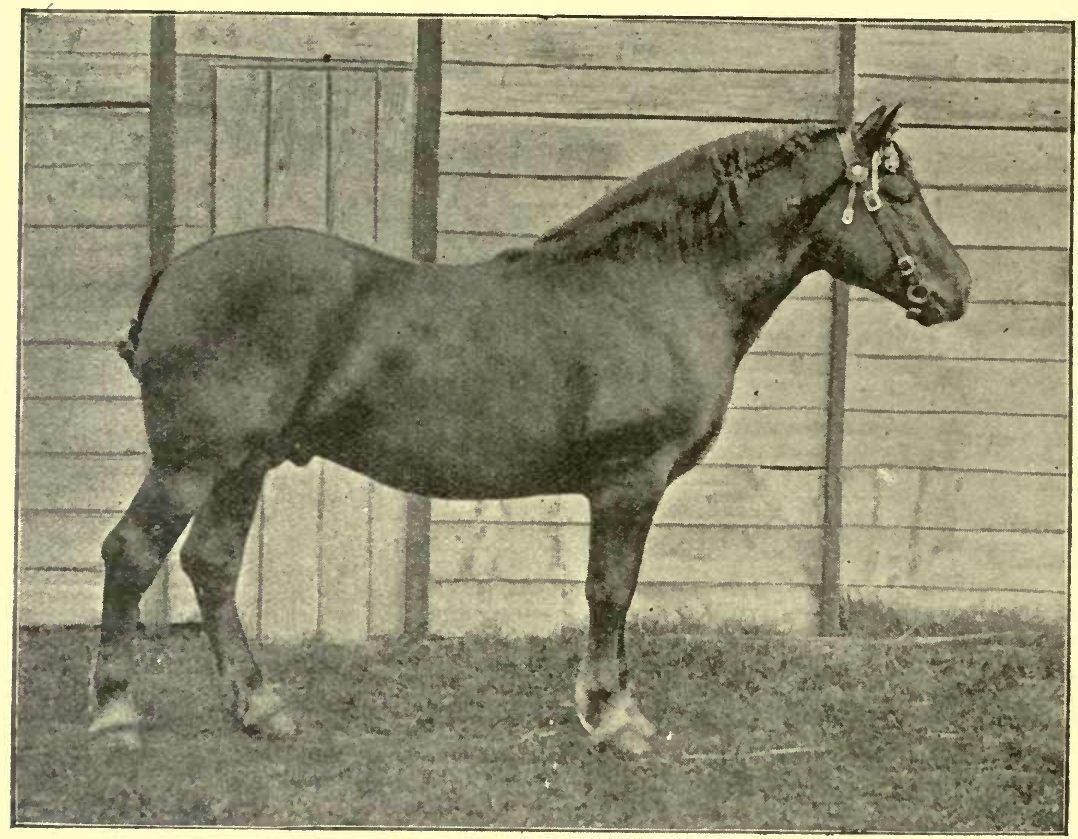

From a photograph by Pratt and Son.

CEAMPION SUFFOLK STALLION, 'IIIS GRACE.'

preferred in the south, and the latter in the north. Admirers of the Suffolk maintain that no other horse is so hardy, and that he will do more work in the same time, and on the same amount of food, than any other. The testing of such a matter is not so simple as it may appear, for it would be necessary to try the experiment with a number of horses of each kind, and carry it on for months together. A less severe and complete trial would be of little use, and could not by any means be considered as definitive, nor would it be so even conducted as I have said it ought to be unless it was under the actual superintendence of unprejudiced observers. 


\section{THE IMPROVED LINCOLNSHIRE DRAY-HORSE}

AвоUT THE SAME TIME the farmers of Lincolnshire were employed in producing, partly for their own heavy clay lands, but chiefly for the use of the London drays, a large and magnificently-shaped animal, generally known as the Dray-Horse. Many of these stand from 17 to 18 hands high, with bodies of enormous girth, and legs, if not in proportion, yet of greater size than in other breeds.

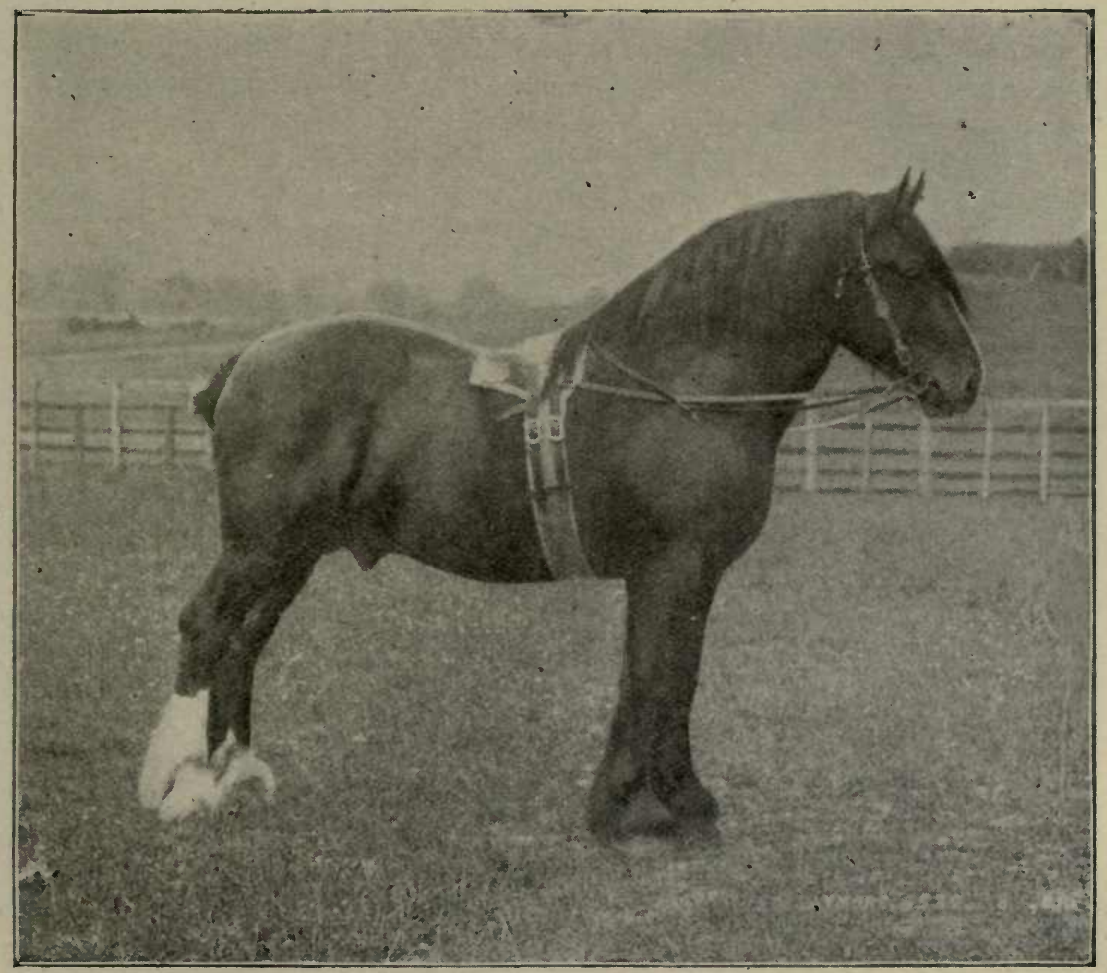

THE DRAY-HORSE.

They are the produce of a cross between the old English black and the Flemish horse; but the former had previously increased in size and substance, from the nature of the grasses of the district, which seem peculiarly adapted to develop the growth of this animal. Unfortunately, both sire and dam are slow, and the produce, from its increased bulk, is rendered still slower, being wholly unfit for agricultural operations in competition with the Suffolk or the Clydesdale horses, and only well adapted to move heavy brewer's drays, which cannot from their weight be expected to travel very rapidly. Breeder's work them moderately, and feed them highly for 
the two seasons between their second and fourth years, when they are put into a loose box, and made up with oil-cake or linseed, barley, and clover hay, till they are as fat as bacon hogs : after which consummation they are fit for the London market, and fetch high prices. It is no wonder, therefore, that their naturally thin and large soles become convex, or that sidebones are thrown out, attended by lameness, which makes so many of them utterly useless. These horses are of all colours, but chiefly bays and browns.

\section{THE CLYDESDALE HORSE}

The BREED OF DRAUGHT-HORSES known as Clydesdales are renowned for their activity, hardness and good temper. They are, at the same time, high spirited and courageous, and require handling with more intelligence and kindness than is usually allotted to other breeds of cart-horses.

In the districts of Scotland, however, where they are most highly prized, it is no uncommon sight to see a pair of these horses weighing from sixteen to eighteen hundredweights, going in their stall collars very often with no bit in their mouths, and guided almost entirely by the voice. The long ugly whips and tight bearing-reins are unknown to them, and they would take it very badly if such were applied to them.

The great points among Clydesdales have always been large, open feet, and heels well set on clean defined pasterns, sloping back to the fetlock joint, from which should hang delicate sillky hair reaching down to the heels behind, and fringing gracefully over the coronet, whose outlines, however, it should not hide. The cannon-bones should be hard and flat, and the legs should show the tendons standing out clear and strong as in a thoroughbred or Arab. The knee should be broad, strong and firm, while from the inside and down the sharp inner edge of the leg should hang silky hair, gradually increasing in quantity till it reaches the fetlock joint. The tendons and muscles above the knee should be again clearly defined, rising and swelling gradually into a muscular fore-arm, like the biceps of an athlete. The shoulder of a Clydesdale is usually more oblique than in the other breeds; this is bound to be the case, as a sloping pastern must give a sloping shoulder above it to obtain a true natural balance. The sloping pastern of the Clydesdale is not that associated with a thin, weak heel, but goes with a strong and open heel, and ii is from this formation that he gets his springy, active step. The hind-legs are as much the care of the breeder as the fore-legs, and their action is even more characteristic of the breed than that displayed in front. The hind as well as the front feet should be large and open, the pastern moderately sloping and well defined, the fetlock joints clean and hard, and absolutely free from any cracks, while the hair on the legs fringes delicately up the thin edge of the bone nearly, but not quite, to the hock, which is broad and long, and free from fleshiness. The whole hind leg should be well behind the body of the animal, with the strength of the thigh rather throwing the hock inwards than outwards, thus keeping the whole of the propelling power of the animal within its centre of gravity. This point in a Clydesdale is more studied than any other. An animal that turns its hocks outwards necessarily loses some of its power.

The head is usually broad and intelligent, the eyes large and full, with 
something of kindly inquiry in them. The ears are large and widely set. but mobile and full of attention, a drooping ear or dull, heavy eye being very rare.

The large exportation of Clydesdale stallions from Scotland to England, from the earlier part of the century onwards, and the continued demand for them for this purpose, induced many unscrupulous persons to re-import the more likely looking cart-horses, and by recrossing with the native breed to produce and sell these to the English buyers as Clydesdales. To avoid this deception a Stud-book was started, and the number of registered animals in 1896 had reached 10,147 stallions and 12,697 mares.

The exact origin of the Clydesdale, or indeed of any of the breeds of cart-horses, is difficult to determine, but it is fair to conclude that the heavy chargers of the knights of old (more especially as most of them were stallions) were the foundation of them all, but clean, hard-wearing bones, have always been the watchwords of the Clydesdale breeders.

The average mare weighs from 15 to $18 \mathrm{cwt}$., though many exceed this, and the average weight of stallions may be put at $17 \frac{1}{2}$ to 19 cwt. Average measurement of bone below the knee and hock in both sexes $10 \frac{3}{4}$ to $11 \frac{1}{4}$ inches, though many stallions are larger than this. When the above measurements are exceeded, the bone as a rule has lost some of its Clydesdale character, and is consequently more difficult to measure as bone.

In their own country Clydesdales are worked in pairs, abreast in the plough even in the stiffest land, where they can easily draw a furrow eight or nine inches wide by seven inches deep. In harness each horse draws a cart $8 \frac{1}{2}$ cwt., and capable of being loaded with $20 \mathrm{cwt}$. The farm man drives the leading horse with reins in his right hand, from the back of the first cart, leading the second horse with his left. As a rule, however, this is not necessary, as the horses being without blinkers or bearing-reins work entirely at the word of command.

The above description is from the pen of Lord Arthur Cecil, who was largely instrumental in establishing the Stud-book.

\section{OTHER MIXED BREEDS}

The Cleveland, if it ever existed as a variety of the cart-horse, cannot now be found, and it is probable that the original breed was employed as a pack-horse solely, being too light for the heavy plough work of our ancestors. At present he is a coach-horse, and cannot therefore be classed among those which I am now describing, though he is still claimed by the breeders in the district of Yorkshire from which he takes his name as a distinct variety. It is true that he is sometimes used for agricultural purposes, resembling the Suffolk horse in quickness, yet not being equal to him in constitution. But he is chiefly sought after for the carriages of the aristocracy, to which his rich bay colour, and clean legs, often of a jet black, are well suited. I do not myself believe in the purity of the breed, nor can I find from the Yorkshiremen themselves any signs by which it can be distinguished.

Throughout England and Ireland cart-horses of every shape and size 
are met with, possessing no peculiarity which can entitle them to be considered as separate breeds, and indeed being produced from working mares put to stallions selected at random from those offered in the immediate neighbourhood. Some of these sires are individually very perfect animals in shape, and can compete with the best Suffolks or Clydesdales; but they cannot generally be depended on to the same extent for getting stock as good as themselves. This is caused by their being the produce of various strains; but when the breed to which they belong has been kept pure for some generations, as is the case in certain families and districts, this remark does not apply to any extent. Most farmers now, however, who are particular about their horses, either use the pure Suffolk or Clydesdale, or put their cross-bred mares to stallions of one or other of these breeds. 


\title{
CHAPTER IX
}

\author{
ON THE LOCONOTIVE ACTION IN THE VARIOUS PACES
}

NATURAL AND ACQUIRED PACFS-DISTRIBUTION OF WEIGHT-ATTITUDE ASSUMED IN STANDING-MODE OF PROGRESSION-THE WALK-THE TROT-THE CANTER-THE HAND GALLOP-THE GALLOP-TIIE AMBLE-THE PACES OF THE MANEGE - LEAPING OR JUMPING.

\section{NATURAL AND ACQUIRED PACES}

IN A STATE of NATURE it is probable that the horse only possesses two paces, namely, the walk and the gallop; but when he is the produce of a domesticated sire and dam, even before he is handled, he will generally show a slight tendency to trot, and sometimes to amble, rack, or pace, if any of his progenitors have been remarkable for these artificial modes of progression. In this country, however, it may be assumed that the horse, without being taught, walks, trots, and gallops, more or less perfectly, according to his formation and temperament.

\section{DISTRIBUTION OF WEIGHT}

EXCEPT IN THE GALLOP AND CANTER, in the fast trot, and in leaping, the weight of the horse is borne by two or more of the legs, and we shall find that in consequence of the projection forwards of the head and neck, the larger moiety is sustained by the fore-leg (or legs) than by the hind. This can easily be demonstrated in the act of standing; but the same rule which applies to that position will also serve for any other.

It is important to the horsemaster to ascertain the circumstances which will change these proportions, because he finds practically that, in road work, the fore-legs wear out faster than the hind, and consequently any means by which the weight on them can be reduced will be a gain to him in a pecuniary point of view. M. Baucher placed a horse with his fore and hind-legs on separate weighing machines, and found that a hack mare when left to assume her own attitude, weighed on the fore scales 210 kilogrammes, while her hind-quarters drew only 174, the total weight of the animal being 384 kilogrammes, each of which is equal to $2 \mathrm{lbs} .2 \mathrm{ozs}$. 4 drs. 16 grs. avoirdupois. By depressing the head so as to bring the nose to a level with the chest, eight additional kilogrammes were added to the front scales, while the raising of that part to the height of the withers 
transferred ten kilogrammes to the hindermost scales. Aggain, by raising and drawing back the head, in a similar way to the action of the bearing rein, eight kilogrammes were transferred from the fore to the hind scales, and this should not be forgotten in discussing the merits and dernerits of that much-abused instrument of torture. M. Baucher then mounted the mare, when it was found that his weight, which was sixty-four kilogrammes, was placed in the proportion of forty-one kilogrammes on the fore-quarters to twenty-three on the hind. A considerable change was of course produced by leaning backward, and by using the reins in the manner of the bearing rein, the former transferring ten kilogrammes from the fore to the hind-quarters, and the latter act adding eight more.

EvERY PRACTISED horseman knows that his horse's fore-legs will suffer in proportion to the weight which is thrown on them, while their relief is an additional source of strain to the hind-legs. The spavined, and more especially the curby-hocked horse, relieves these parts by using his fore-legs to carry more than their proper proportion of weight, while the animal affected with any painful disease of the fore-limbs carries almost all the weight of his body on his hind-legs, which are advanced under him in the most peculiar manner. The value of artificially changing the natural carriage of the horse, so as to make his hind-legs come forward and carry more than their own share of weight, is chiefly felt in chargers, hacks, and harness horses, while, on the contrary, it is injurious to the hunter and race-horse, whose hind-quarters bear the greatest strain.

\section{THE ATTITUDE ASSUMED IN STANDING}

Standing may be considered under two heads, the first comprising the attitude naturally assumed by the horse when inclined to rest himself, and the second that forced upon him by education, for the sake either of appearances, or to keep him ready to start at a moment's notice, as in the cavalry horse. When standing free or naturally the horse always rests one leg, and that generally a hind one, changing from one to the other as each becomes tired in its turn. In the forced attitude all four are on the ground, and each supports its share of the superincumbent weight. In either case the different joints are kept from bending, by the almost involuntary combined action of the flexor and extensor muscles, which will keep him standing even in sleep, in which respect he differs from the human subject. The oblique position of the pasterns affords a considerable aid, but without the semi-involuntary support afforded by the muscles, the stifle and hock joints behind, and the shoulder and elbow before, would inevitably give way.

\section{MODE OF PROGRESSION}

Is MOVING FORWARD, whatever the case may be, the hind-quarters are the main propellers, and thrust the body forward on the fore-legs, which serve as imperfect segments of wheels, each in its turn making a revolution forwards and backwards through a segment of a circle, like a pendulum. This forward motion is either effected by one hind-leg at a time, as in the 
walk, trot, amble and rack, or by the two, nearly if not quite synchronously, as in the canter, gallop, and leap. In any case, the hind-legs (or leg) must be drawn forwards under the body, or the body thrust backwards upon thern, when a contraction of various muscles tends to straighten them, and as they are fixed upon the ground, which acts as a fulcrum, the body must give way, and thus passes forward with a speed and force proportionate to the muscular power exerted. In the various paces this mechanical action is differently effected in detail, but the principle is the same in all those contained in each class to which I have alluded. In the first the weight is borne by the hind and fore-quarters between them, while propulsion is effected by one side of the former; but in the second, it is taken at intervals by the fore and hind limbs, the latter propelling it with great force, and the former serving as props to it when it comes to the ground from the air, and also causing it to re-bound for another interval of time.

\section{THE CANTER}

The CANTER is a thoroughly artificial pace, at first extremely tiring to the horse, and generally only to be produced in him by the restraint of a powerful bit, which compels him to throw a great part of his weight on his haunches. It is very difficult to describe or define this pace, either in

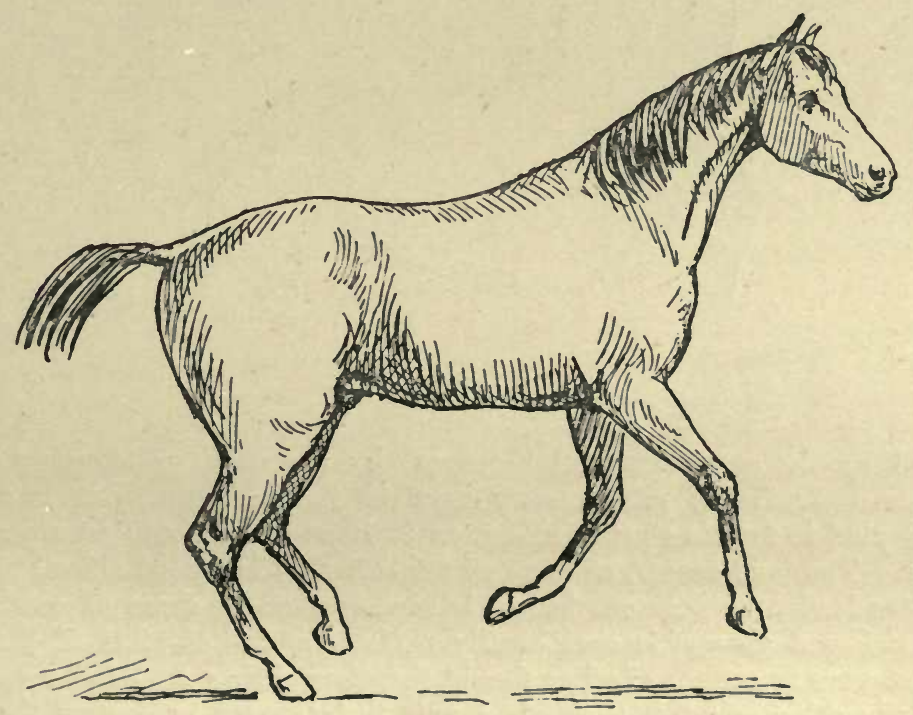

a pen-and-ink sketch or by the aid of the painter. Indeed it is often quite a matter of opinion to decide whether a horse is cantering or galloping. Many writers, and among them Mr. Blaine, have attempted to draw a distinction, by confining the canter to the pace which is executed without the feet ever leaving the ground altogether; but this definition is not ginerally admitted and followed, and many a horse whose canter would be readily allowed by all horsemen to be true, may be seen to leave 
the ground entirely for a certain interval of time, however small it may be. There is so great a variety in the modes adopted by different horses for performing the canter, that no single description will suffice, nor indeed is it easy, as I before observed, to define any one of them. Sometimes the carriage is extremely elegant, the hind-legs well under the body, and all moving like clockwork, with the head bent on the neck, and the mouth playing lightly on the bit. When such a pace is performed with the right leg leading, the canter is exactly adapted for the female seat, in which the right shoulder is of necessity slightly advanced, and it is therefore the object of the breaker to obtain it. But it is only in those horses which combine a free use of their limbs with fine temper and good mouths, that such a pace can be developed, and if any one of these qualities is deficient it is useless to attempt to teach them. On the other hand, the pony or galloway will often canter without throwing any extra weight on his hindlegs, with a loose rein and extended neck. This kind of pace may be

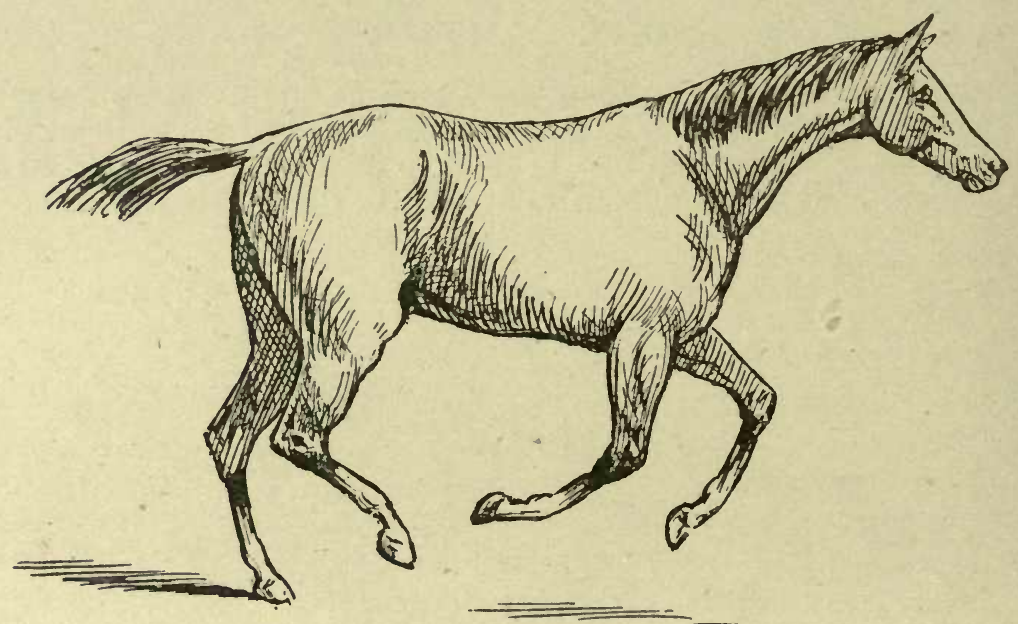

detected by the ear on a turnpike road, by the quick pat-ter-ring sound which is evolved. It is extremely easy to the horseman, but is not so well adapted to female equestrianism, as it jerks the body in an ungraceful manner. The true canter, as adapted for ladies, is indicated above. When the off-leg leads, the near one has to bear more than its share of work, and hence, unless a change is occasionally made, the fetlock-joint of that leg is almost sure to suffer. Ladies should therefore either trot for a part of their daily rides, or teach themselves and their horses to change the lead from that with the off-leg to that with the near.

The canter is a three-time movement generally, as proved by photographs taken of heavy horses while in motion, but in the light riding-school hack, accustomed to make short collected movements, it may be one of four-time.

As an example, commencing with the support of the off hind-limb, the sequence will be-(1) off hind, (2) off fore and near hind, (3) near fore, commonly but not always followed by a period of suspension before the off 
lind comes down. The leading fore-leg is that which does not form the diagonal support.

\section{THE WALK}

Before instantaneous photography had proved otherwise it used to be supposed that two feet must necessarily be upon the ground at once while

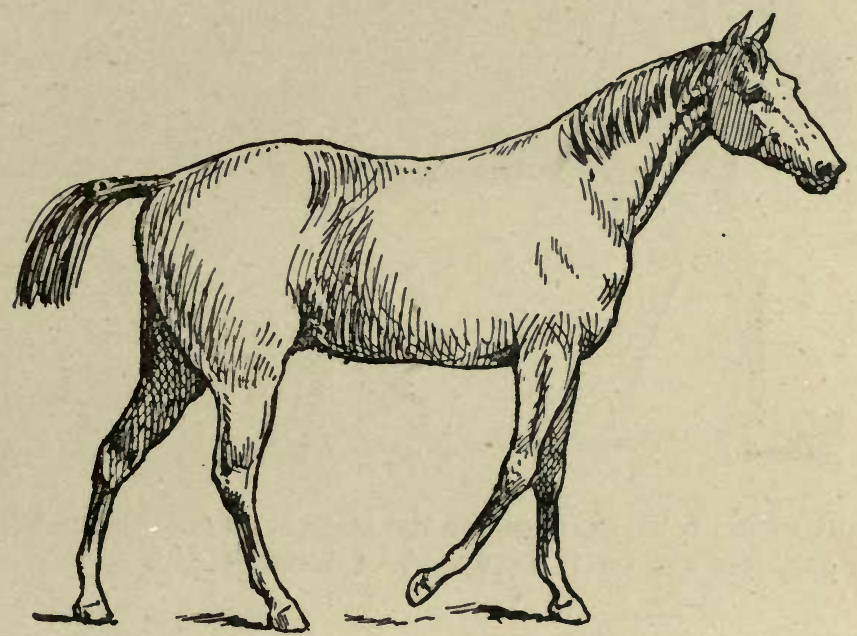

the diagonals were advanced, and that the legs moving in pairs synchronously, four would be on the ground for a fraction of time. The camera

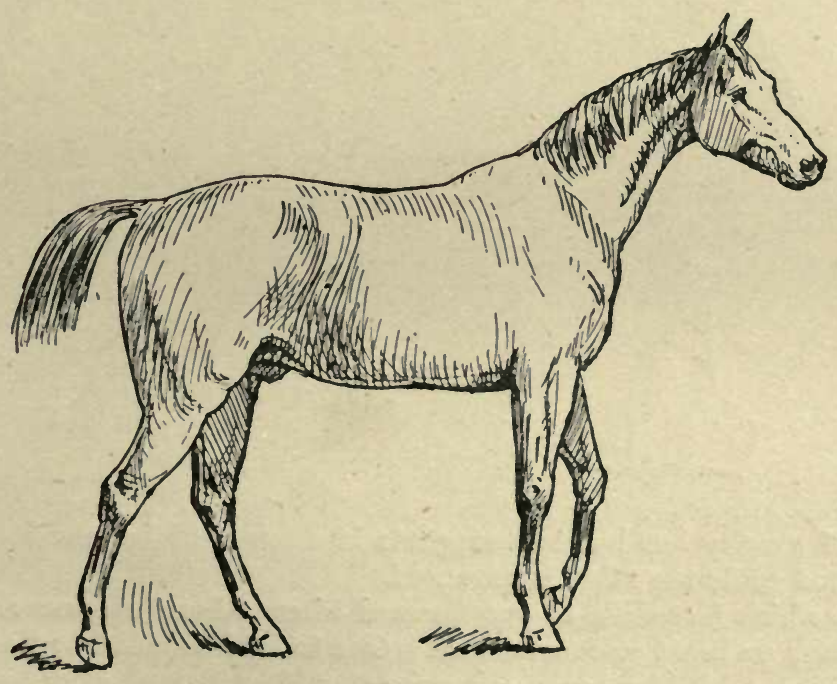


proves that as many as three feet may be on the ground but never four. The diagonal limbs in quadrupeds do not act synchronously as at a slow pace it is more difficult to maintain the equilibrium. The centre of gravity

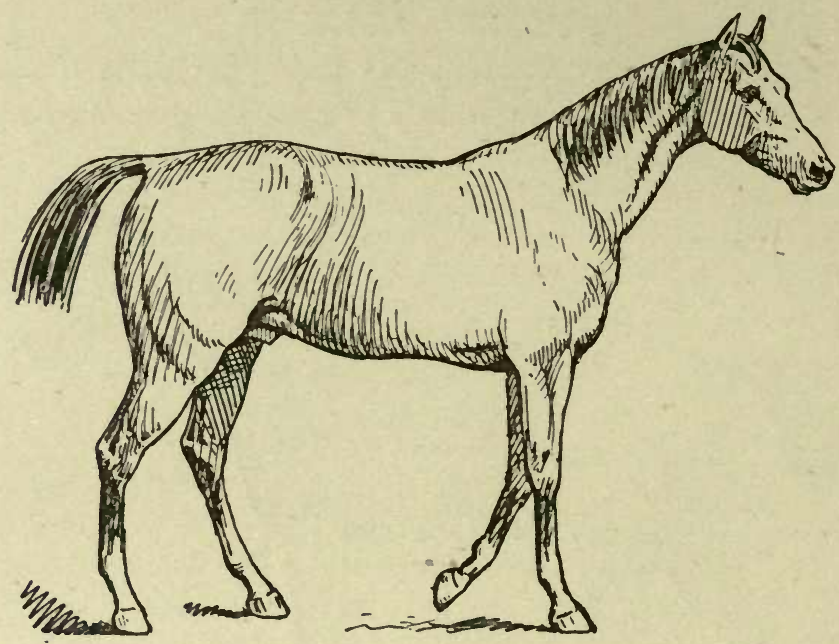

always falls within a triangle because the horse rests on two front legs, and one hind one, but not on two only. The duration of time in which the

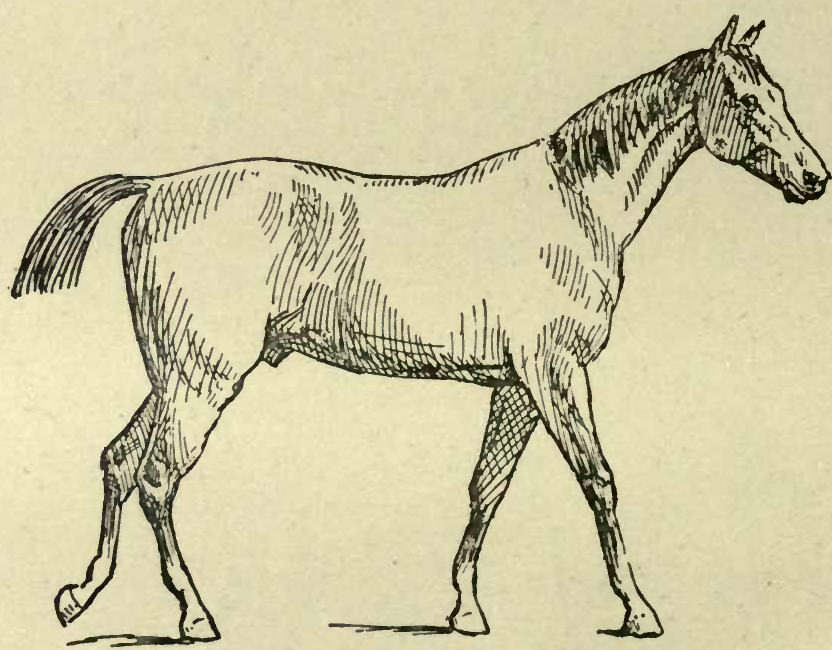

centre of gravity has but two supports is diminished by one foot holding the ground while the other is advanced.

As to which foot shall be put forward when a horse commences to walk will depend on habit or convenience. One trained to stand to "attention" (not resting a hind-leg as he otherwise would) will lead off with his near 
fore, if a well-trained saddle-horse, but if standing at ease without bit or bridle, he will be as likely to use one limb as another.

When desiring to increase the pace he extends the length of the strides, making them uniform and only breaking into a trot when a difficulty is experienced in any further extension.

The walk is a four-time movement, the limbs moving one after the other in about half the time which is occupied in one step.

In the case of the well-trained saddle-horse referred to above, and in which the lead is taken with the near fore, the sequence will be-(1) near fore, (2) off hind, (3) off fore, (4) near hind ; while if the animal's movements commence with the near hind, the sequence will be-(1) near hind, (2) near fore, (3) off hind, (4) off fore; and the resulting supports-(1) right pair, (2) right diagonals, (3) left pair, and (4) left diagonals.

\section{THE TROT}

This PACE may be described under three heads, namely, the jog trot, the true trot, and the flying trot. In all three the diagonal limbs move exactly together, but in the first the time during which each foot is on the ground is much greater than that in which it is in the air. In the second, the contrary is the case; while, in the third, the horse is carried completely off his legs for a considerable space of time, between the several bounds which are made by the two feet of opposite sides as they touch the ground in succession. The jog trot seems to come naturally to the horse when he is first mounted; and as long as he is fresh and fiery, the colt will maintain this pace, unless he is permitted to exceed it. He will prefer it to the walk for a long time; and it is only by good hands, combined with patience, that a spirited colt can be made to walk; for he can generally jog quite as slowly, and often much more so. Farmers are very apt to accustom their young horses to the jog trot, because they find by experience that it does not injure their legs or feet; but to a rider unaccustomed to this pace it is by no means an easy one. In the true trot, as exemplified below, the feet are on the ground a comparatively short space of time, the body being carried so rapidly forward that they are moved off almost as soon as they are deposited on it. By examining this outline, it will be seen that the position of the fore and hind limbs of the two opposite sides exactly corresponds, and this will be the case, whatever may be the period of the action in which the observation is made.

The trot is a two-time movement effected by the alternate action of the two diagonals, the fore and hind-legs moving in the same way.

Fig. 1 shows the left diagonals or near fore and off hind supporting the horse while the off fore and near hind limbs are flexed.

Fig. 2. The position is reversed, the opposite diagonals being shown as supporting the animal, while the near fore and off hind are reflexed.

Figs. 3 and 4 represent the position occupied immediately prior to the feet leaving the ground.

In the flying trot, which is well shown in the portrait of Flora Temple, at page 46 , all the legs are for a very short period of time off the ground, as is there delineated, but still there is always an exact correspondence 
between the position of the fore and hind-legs of opposite sides. The chief difference between these three varieties of the trot consists in the rapidity of the propulsion which is going on. This in the first is very slight; and the more elastic the fetlock-joints, the better and softer is this pace. The

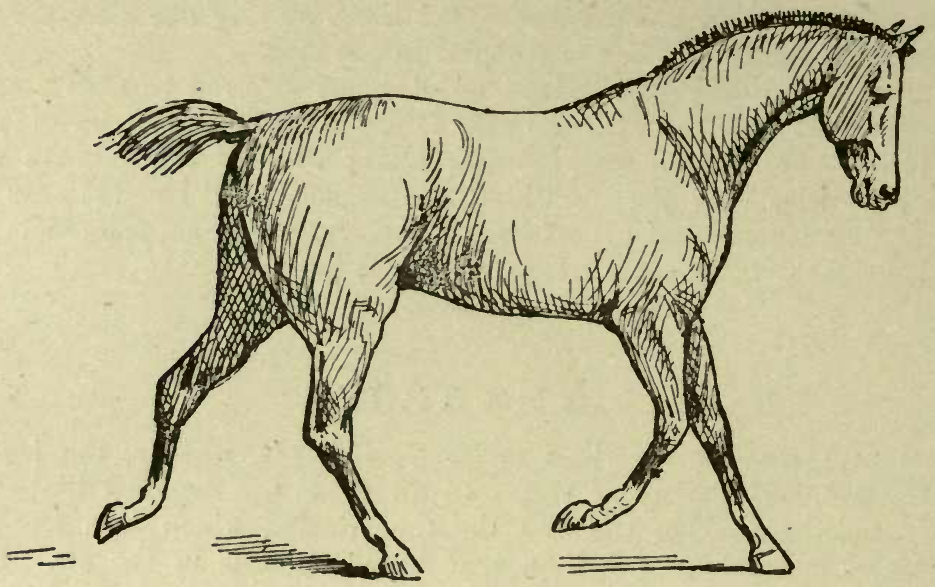

feet are raised, and the legs are rounded or bent; but the body is not thrust forward, nor are the shoulders moved in the same direction to any appreciable extent. The consequence is, that the feet are deposited again

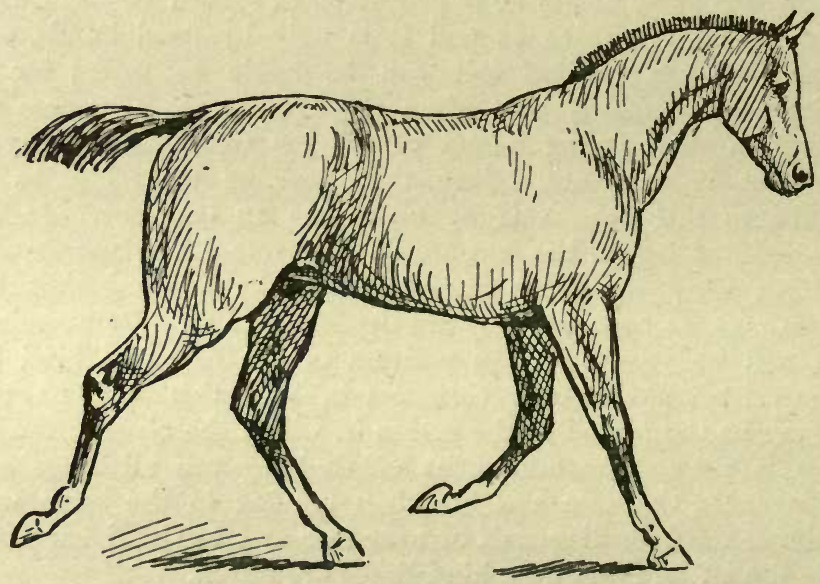

very close to the spot from which they are taken, and the pace is as slow as the walk. In the true trot, if it is well performed, the hind-legs must be moved as rapidly as, and with more force than, the fore-legs, because they have more work to do in propelling the body, the latter having only to sustain it during the operation. Good judges, therefore, regard the hind action as of even more importance than that of the knees and 
shoulders; for if the former do not drive the body well forward, good pace cannot be obtained, nor will it be easy and rhythmical. In this kind of trot elastic fetlocks are fatal to speed, as they prevent the instantaneous effect upon the body of the muscular contractions of the hind limbs, and

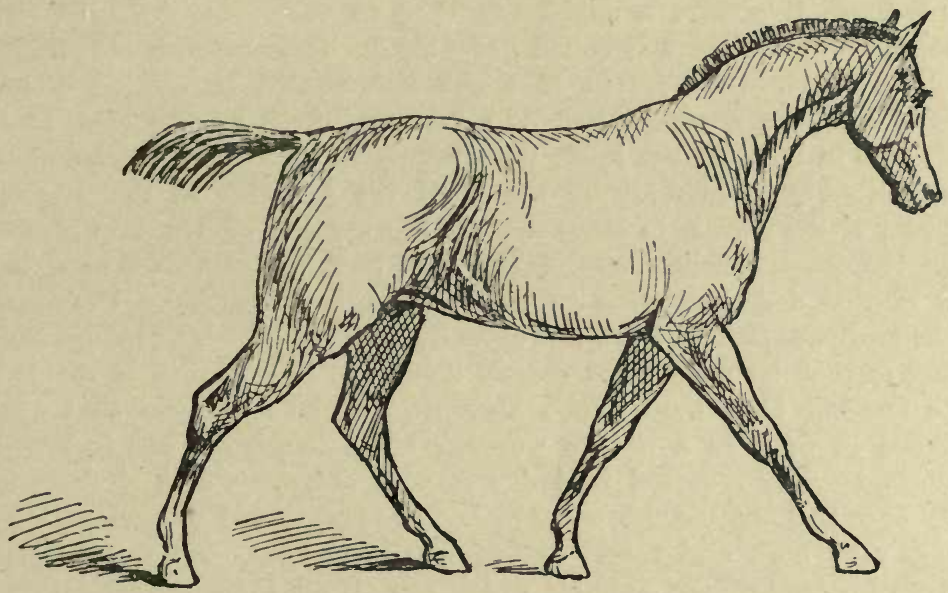

cause the action to be dwelling and slow. Very fast trotters are, therefore, rough in their "feel" to the rider, and are not suited for the purposes of pleasure. Indeed, no one would mount one of them from choice: but

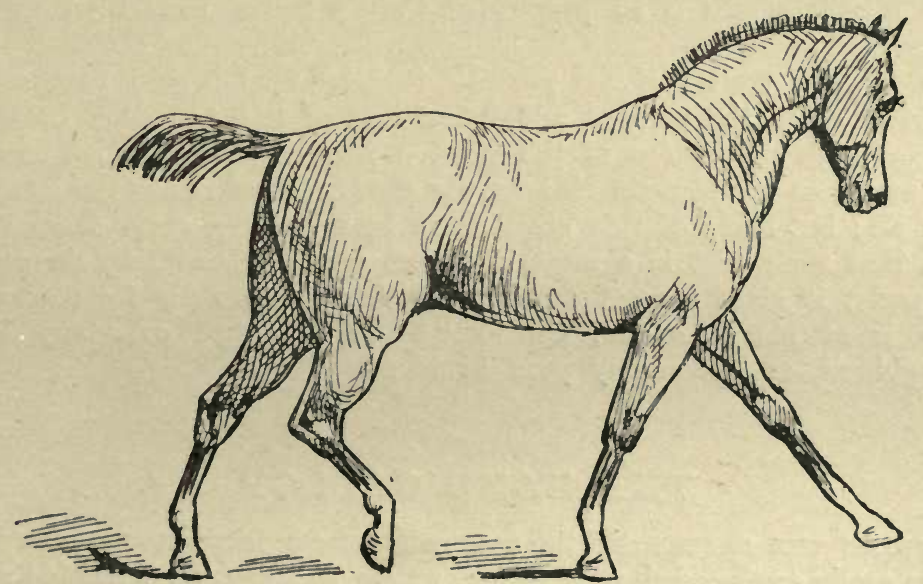

when they possess good mouths, they are pleasant enough to drive. In examining trotting action, regard should be paid to the plane through which each limb passes, for if this is not parallel with that of the median line of the body the action is not true and smooth, and there is great risk of one limb cutting the other. This is best seen by watching the trot 
from behind as well as before, which gives an opportunity of investigating the movements of both pairs of limbs. Every horse should be so made that, when he stands, his fore cannon-bones should be quite parallel ; but in order to be so, as they stand closer together than his elbows, they must form a slight angle with the arm at the knee; and hence, as this part is bent, there is always a slight tendency to turn out the foot, the exaggerated form of which is called "dishing." The observer will, therefore, do well to ascertain the extent to which this should be carried, or he will be apt to condemn a perfect goer as a "disher," from finding that he turns out his toes in bending the knee, though only in the trifling degree ordained by nature. If, in bending by the hand the fore-foot to the elbow, the inner heel of the shoe is in contact with the outside of the arm, there will not be too much turning out of the foot, and the purchaser need not be afraid of this defect existing in the horse he is examining. Provided the fetlocks and cannon-bones are not actually touched or "hit" in trotting, the fore-legs cannot be moved too closely together; but if they pass very near to one another in a fat dealer's horse, it may be suspected that when he is reduced in flesh to a proper working condition, boots will be necessary. A practised eye is required to judge of this correctly, and, if there is any doubt, one had better be consulted. In London, for park-riding and driving, very high and round action is the fashion, and fabulous prices are given for well-shaped animals which can "pull their knees" almost up to their noses. Pace is sacrificed; and many of the most highly-prized London trotters are unable to do ten miles an hour. A favourable specimen of this kind of trotting action is shown in the cab-horse at page 130, in which the shoulders are so well-formed that although the knee is remarkably well-bent and raised, the whole limb is well thrust forward, and the action of the hind-legs also is so propulsive that a faster pace than usual is obtained.

The Norfolk trotter of the present day has very perfect action, intermediate between the pointed and flying trot of the American horse, and the round high knee-action of the London park-horse. Even he, however, is not nearly so pleasant to ride as the thoroughbred, when the latter can trot at all; but many of this breed have been so long accustomed to the gallop, that their trot is a most imperfect pace. When they do perform it properly, it gives a most delightful feel, and no rider for pleasure, if money is at his command, should "throw his leg" over any but a thoroughbred, or one nearly pure in blood.

\section{THE HAND GALLOP}

BetWeEN the CANTER and the true gallop there intervenes a pace which may be easily confounded with either, unless Mr. Blaine's definition of the canter is accepted, when the hand gallop can easily be distinguished from it. This pace is merely a slow and measured gallop, in which for a very short period all the legs leave the ground, but in which the propulsion is steadily given, and not with those snatches or jerks which are necessary to develop the high speed of the extended gallop. The body also is not nearer the ground than in the act of standing, and this may be considered as one of 
the best distinctions between the hand gallop and the extended stride of the faster pace. The French writers distinguish between the two by asserting that in the hand gallop there are three beats, while in the flying gallop two only are performed; but in practice there is no such variation.

In Stillman's Horse in Motion the hand gallop is ignored altogether, although Muybridge employed a range of twenty-four cameras and spent years in the production of thousands of photographs. Captain Hayes (Points of the Horse) distinguishes between a "typical canter" and a "smooth style of canter, which might be termed (to use a popular expression) a hand gallop."

\section{THE GALLOP}

THERE are still many artists who regret the introduction of instantaneous photography, and regard the discovery as revealing ugliness instead of beauty. Mr. Stanford, who is responsible for the revolution, said, "a revelation so startling as that made by the camera carried results too far-reaching and revolutionary to be at once accepted, though it came direct from heaven. There is too much capital invested in works of art all over the world to

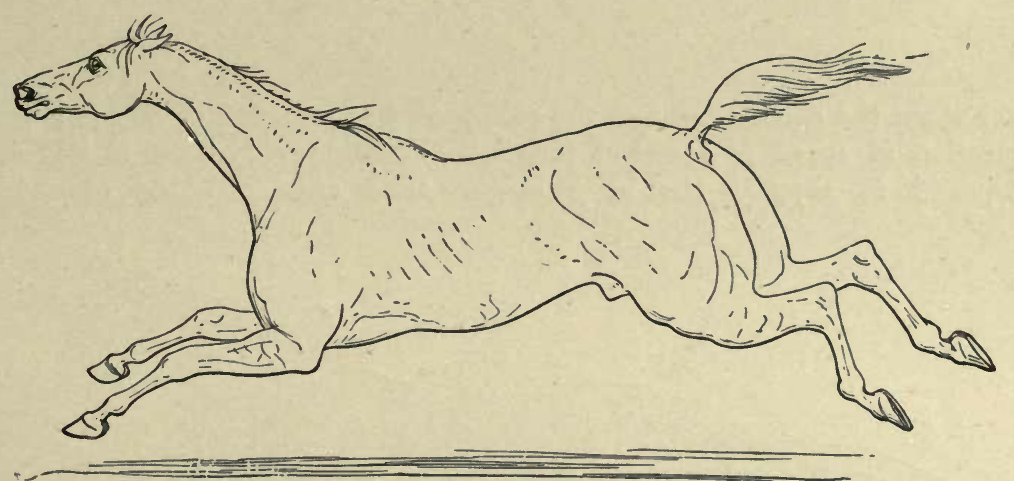

RECEIVED INTERPRETATION OF THE GALLOP.

permit the innovation without protest, and ridicule is the cheapest argument that can be employed in controversy, for it does not require truth for its foundation, and but a low order of talent for its display." Since these words were written by Mr. Stanford, who must have spent many hundreds of pounds in experiment, truth has prevailed.

The great work from which the above paragraph is quoted, is not so well known in England as it deserves to be. Marie and others on the Continent have amply confirmed the American's discovery, and Captain Hayes has made the subject well understood in his own clear and concise manner in Points of the Horse, which he has illustrated very fully.

The GALlop, or, as Stillman prefers to call it, the run, is a pace of fourtime, in which the feet follow one another successively, allowing an interval in which the leading fore-foot touches ground and then that of the opposite hind one. In the canter it is not so, the front diagonal support touches the 
ground at the same time or even sooner than its hind fellow, but follows it in the gallop. The difference in the canter and the gallop consists in this interval and the greater extension of the fore-leg that is not leading. The rider can

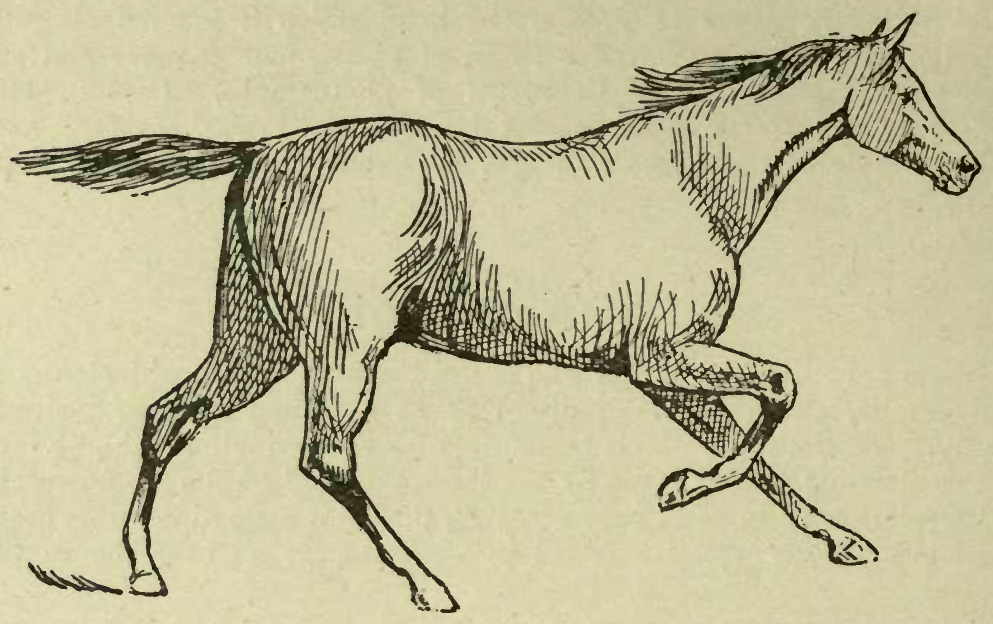

feel when the canter becomes the gallop, and as a matter of fact it is only a question of speed or reach of fore-leg. Whichever fore-leg is leading is required to support the body longer than either of the others, the

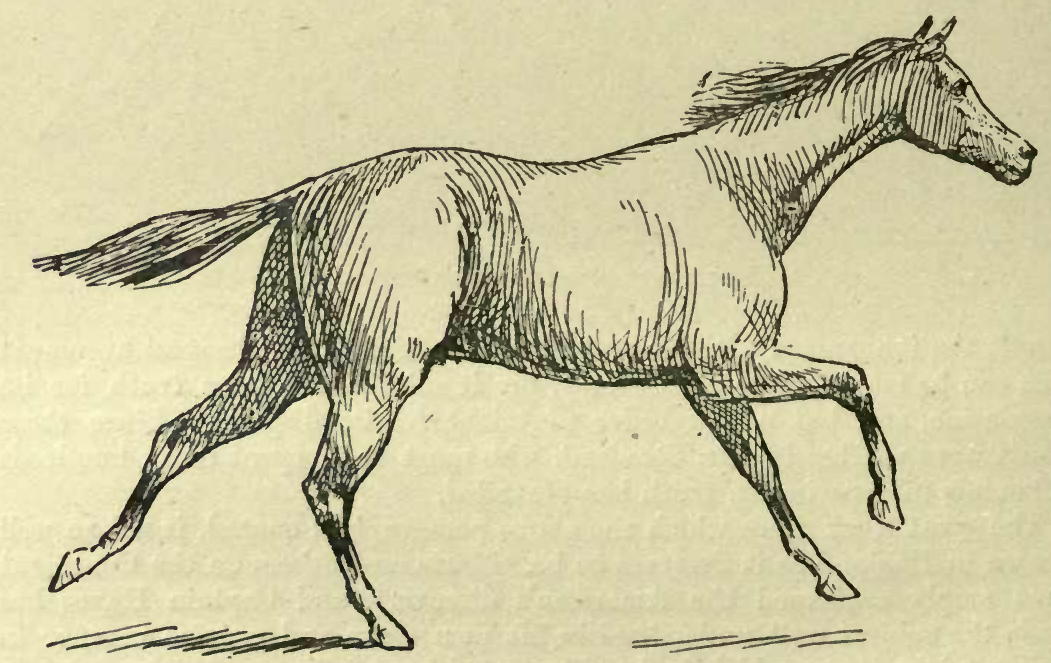

time in which they sustain it being about equally divided. It will readily be understood then, how much more liable to sprains must be the tendons and ligaments of the fore-legs than the hind ones. The fore-legs have 
to hear a greater weight and for a longer time, even supposing no rider is on the animal's back.

Over extension rather than concussion or sudden jerks is the most

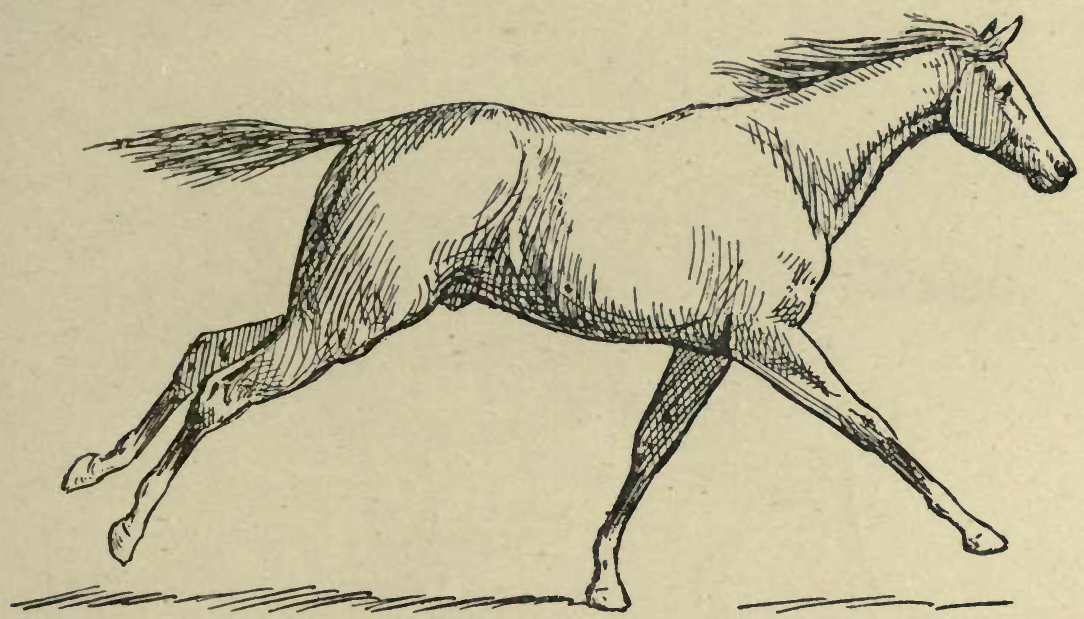

frequent cause of strained back tendons. When galloping, or indeed going at any other pace in deep ground, sprain of the leg that is not leading is liable from the fact that it has just prior to the period of suspension to help

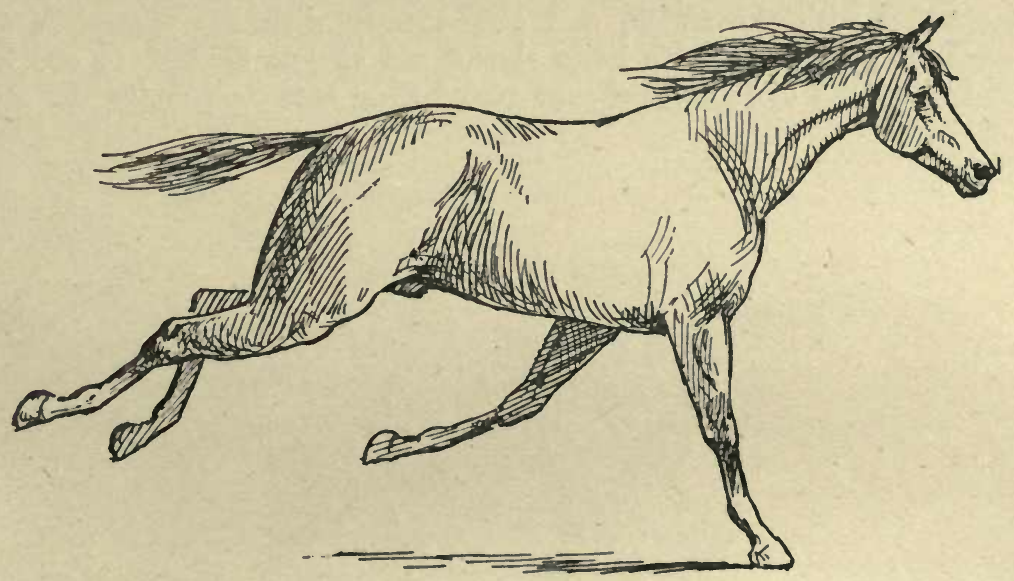

raise the fore-hand by making the fetlock straight, and in addition to overcome the suction of wet land.

The fast galloper has never more than two feet on the ground, or rarely and but for a fraction of a second, suspension being brought about by flexing (doubling up) the legs rather than by elevating the body from the ground.

As in the canter so in the gallop, a lead is always made of one leg 
before the other, and as one tires the other changes places with it. A good, true, and strong galloper will seldom require this relief, but a weak one, especially if not completely broken, will effect the change continually. Sometimes this causes the loss of a race, for it cannot be done without

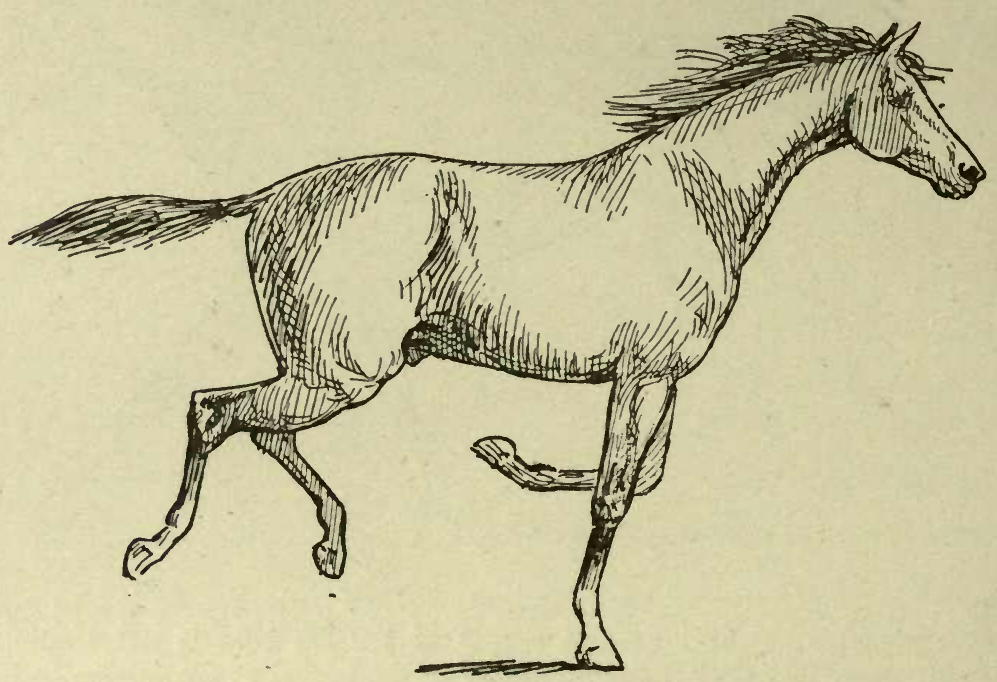

interfering with the action, and consequently with the pace. A good horseman prefers that his horse should not confine himself to one lead, but he does not like him to change after he has once started, for the above

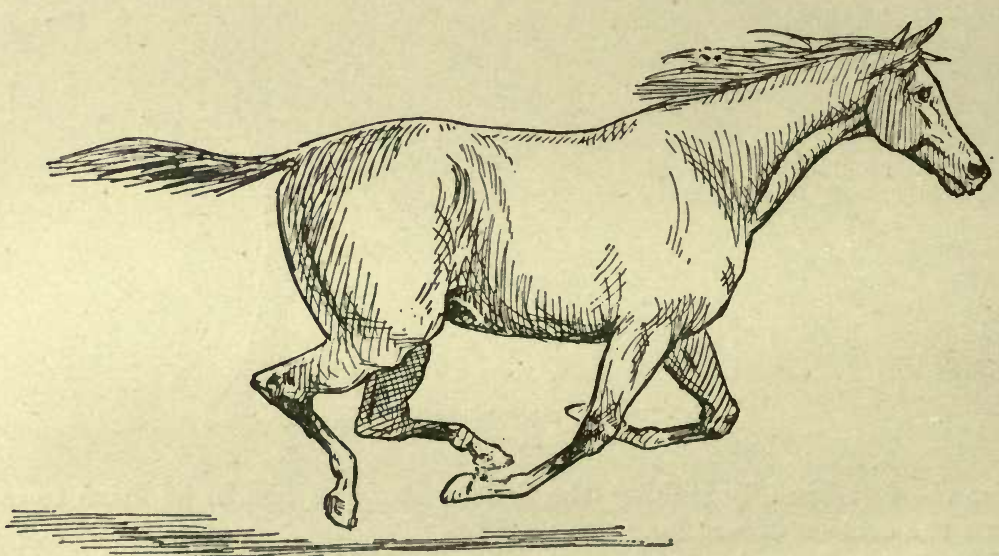

reason. The right leg in front is more easy even to the male rider than the left, but not materially so, and except for female equestrianism no horse should be taught to lead invariably with the right leg either in the gallop or canter. In the change the truth or harmony of action is often 
disturbed, and the horse jerks himself and his rider in a disagreeable manner, which is another reason why the change of legs should not be encouraged.

There is a great variation in the length of the stride, and in the rounding or bending upwards of the foot under the knee. Sometimes even in a fast gallop the distance between the prints of the same feet will be no more than sixteen feet, while in others it will measure twenty-four,

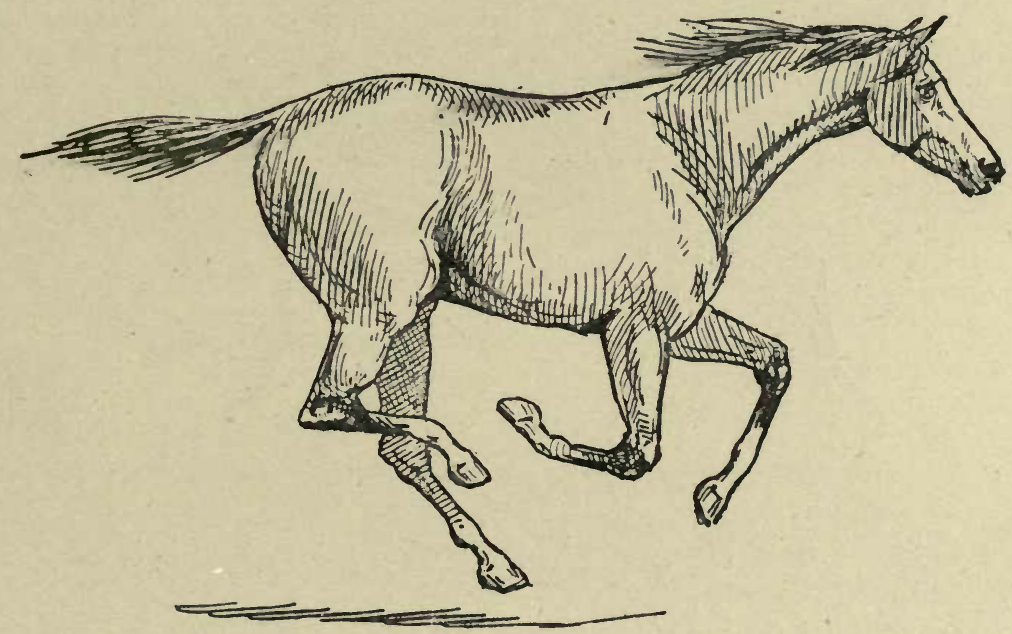

twenty-five, or even twenty-six feet. The first is too short for any racehorse; but a moderately short stride enables the horse to get off with a quicker start, and to ascend and descend hills better than a very long one. Where, however, a distance of level ground is to be covered a long stride tells, and a horse possessing it has a great advantage over one whose gallop is short, however quick and smart it may be. For this long stride theru must be length of limb, especially of the two bones meeting at the stifle joint; and this is the perfection of the form of the race-horse, as I have already described at page 104 .

\section{THE AMBLE}

Trie AMbLE is an artificial pace which few horses adopt except under com pulsion, although we are told by such high authorities as Barrier and Gobaux, that colts are sometimes met with which amble at first and learn to trot subsequently, when they have become older and stronger. On the same authority we are assured that ambling is again resorted to by old animals or those whose legs have suffered severe wear.

It is a two-time pace, consisting in alternate progressive movement of the right and left pair of legs.

In the fast amble, which in America is called "pacing," there is between 
each stroke a short period of suspension, not discernible in the ordinary amble.

There is no more comfortable pace than the amble, and in countries where

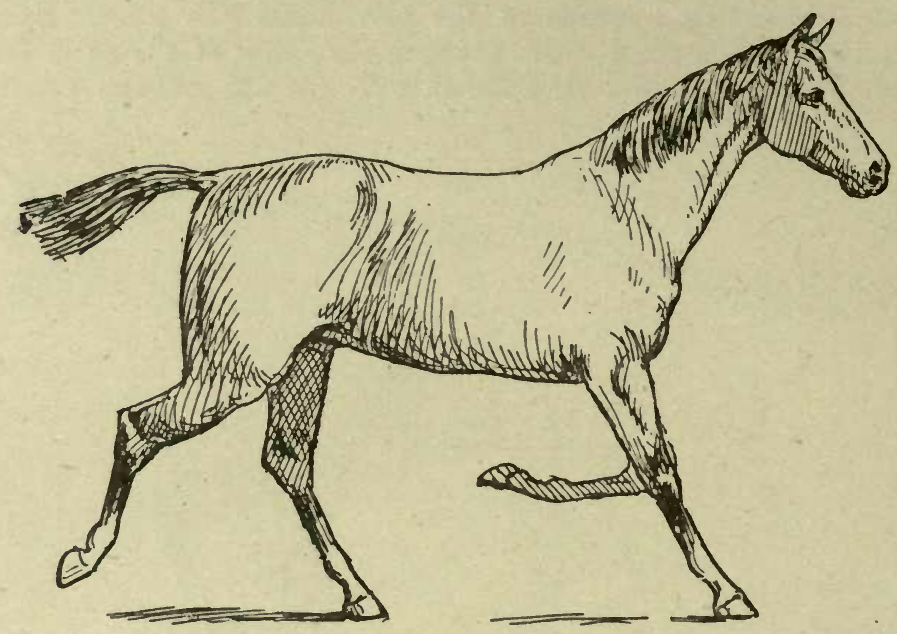

long distances have perforce to be performed on horseback it is much more propular than in England.

The instability of the equilibrium in this pace necessitates it being some

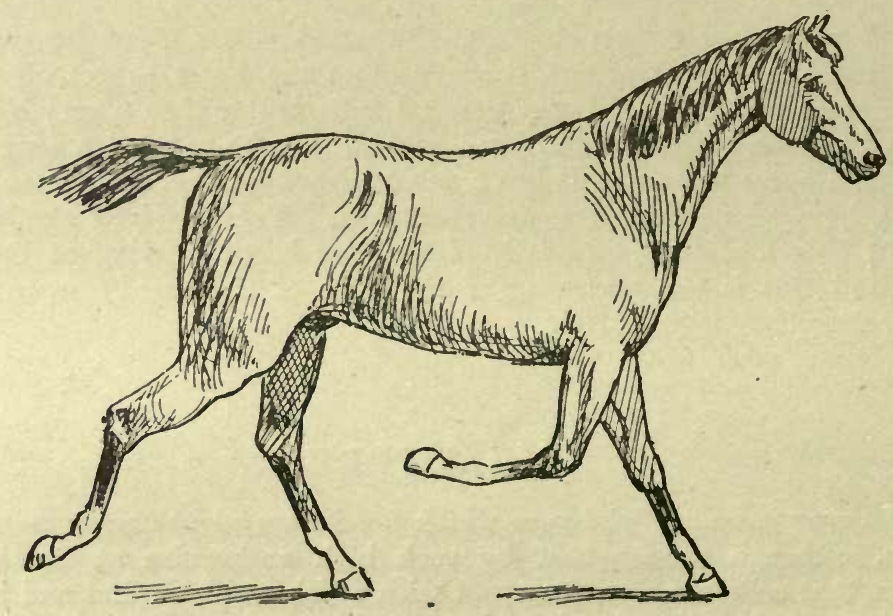

what fast, probably faster than the trot of the same horse, on the principle of the spinning-top.

In the cameleopard the amble is the only kind of progression, whether the animal goes slowly or fast; and in dogs, especially in pointers, greyhounds, and Newfoundlands, this pace is occasionally displayed. 


\section{THE PACES OF THE MANEGE}

IN THE MILITARY SCHOOLS OF RIDING a variety of paces are taught even in the present day, but the old riding-masters adopted many more, which are now discontinued. Some of them are intended to enable the soldier to use his sword or spear with double advantage, as the volte and semivolte, but the majority of those still retained are for the purpose of carrying out the combined evolutions necessary to cavalry. The "passage," for instance, is a side movement, that enables a number of horses to be changed from close to open order, which would be a difficult task to perform with horses not taught to perform it. Backing is likewise necessary for similar purposes; but this should always be taught to every horse, whether used by the military or by civilians. A minute description, however, of the several paces of the manege would occupy too much space here, and is only useful to the cavalry soldier, who will learn their nature much better from practical instruction by the riding-master of his regiment.

\section{LEAPING OR JUMPING}

IN THE CANTER OR GALLOP the first period of suspension occurs when the leading fore-leg is raised, but in the leap it takes place at the moment when the hind-legs leave the ground.

THE TAKE-OFF.-The horse which walks up to a fence and takes it standing, does so ky rearing on his hind-supports and projecting himself in an upward and forward direction.

If trotting or ambling he takes off from either fore-leg (the most convenient), bringing the hind ones under the body.

In the canter or gallop the take-off commences with placing the leading fore-foot down, changing the pace on the instant, and planting the hind-feet well under the body. This may be easily seen by the footprints in soft ground, the hind ones (making a different impression) being found close to that made by the leading fore.

Cleverness in jumping, which is partly hereditary and partly the result of training, is largely due to an ability to calculate distance in such a manner that during the last 15 to 25 feet before the obstacle is reached the psychological moment shall be chosen for the take-off. Failing this nice estimate the animal will take off short or be compelled to jump "too big," and with the result of landing into instead of over the object, or of unseating the indifferent horseman who is not prepared for the rise. A long-striding horse is more liable to make this mistake than others, while one who "creeps" up to his fences is generally esteemed in a cramped or "blind" country. The flying jumper is all very well for hurdle races or a made course, but the animal which can regulate his stride is the more valuable as a safe conveyance over a country.

Since there is only one period of the canter or stride at which a horse can take off for the jump, it is well that he should be ablo to do so from other paces, or he will be "pounded" in a narrow lane, out of which some 
very indifferent performer could extricate himself with ease. For high jumps a certain amount of impetus is necessary, for, as Captain Hayes points out, the horse "has a long distance to carry over a fence (that from his hocks or buttocks to his muzzle) independently of raising it to a sufficient height: hence his high jump partakes more of the long jump than the high jump of a man, whose body is carried more vertically than horizontally."

The speed and impetus obtained will therefore determine the width he can clear, provided, of course, that the pace is not such as to preclude him from collecting himself at the moment prior to taking off. It is not a fact that speed helps a horse in a high jump, as greater weight is thrown on the fore-hand at a fast pace, and the difficulty of raising the fore-hand by the

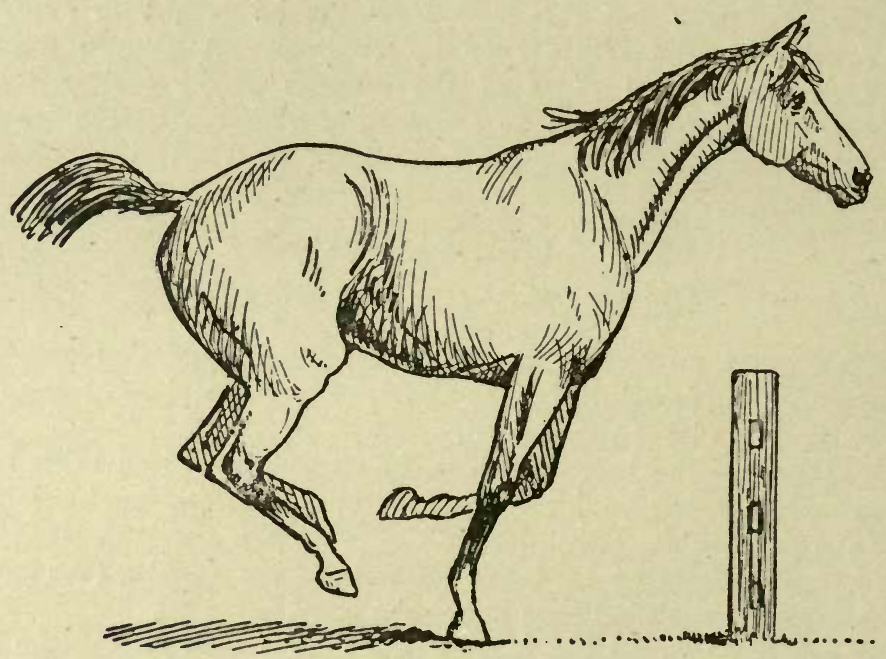

leading leg is increased. Experience has of course taught hunting-men to ride slowly at stiff fences. The horse ridden fast at timber takes off sooner than he would otherwise do, but compensation is not wholly assured to him in this manner.

By raising the head and bringing back the centre of gravity the angle of elevation is increased, and the nearer the hind-feet are brought forward to the leading foot(print) the greater the angle at which his body can be projected forward. When commencing the leap hind-legs are straightened to a great extent and the fore-hand raised, a position in which the weight of the rider must necessarily affect the animal's capacity to rise. Captain Hayes, speaking for the horse, says "The rider should refrain from leaning forward when a horse is rising at an obstacle. He should, on the contrary if anything, lean back at the moment so as not to put any avoidable weight on the fore-hand."

Mr. E. L. Anderson, speaking for the rider, gives the following directions: "As the horse rises for the leap the rider will lean forward, yielding the hand at the same time, so that there shall be no tension upon the reins." This seeming contradiction is quite reconcilable when viewed from 
the different stand-points of the two authors, both experts on the subject of riding. Undoubtedly the horse is impeded in his efforts to rise when the rider leans forward, but the latter must indeed be a good horseman, unless, to some extent, he accepts Mr. Anderson's teaching.

While, as has been already stated, the hind-legs are straightened the clever hunter will double his front ones as closely as possible to avoid striking, for should the knee come in contact with a stiff rail he will generally fall, while a blow on the fetlock or other part below may result in

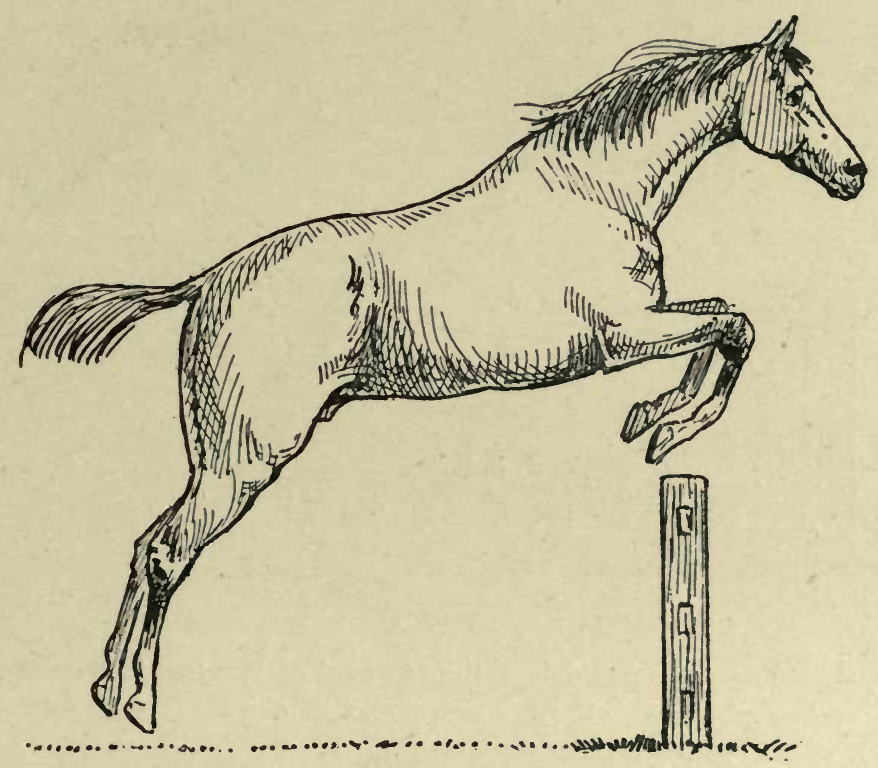

nothing worse than a "peck." In the same way a well-schooled hunter tucks up his hind-legs the moment they leave the ground, and he is prepared to use his limbs while in the air in whatever manner seems most likely to serve him on the other side, which he cannot always see until he has risen above the obstacle.

LANDING. - If one watches a good jumper, taken steadily over moderate fences, he appears to first extend his front-legs to the fullest, and then come down on both feet at the same time. The camera proves the extension, buti it is found that one foot is slightly in advance of the other and comes down before it. On consideration, it will be seen that it is a safer method than if the animal came down on both feet at once, as one knee is slightly bent and ready to save him from a fall if the first leg fails from not being perfectly straight as it should be, at the moment of impact with the ground.

As a fall generally results from the knee being bent, one would naturaliy suppose that a horse "over" at the knee, would be a very unsafe animal to ride. but the editor's experience does not confirm this. It may be that 
the horse has become so during a long experience of jumping, and learned to accommodate himself to a defect of which he is conscious.

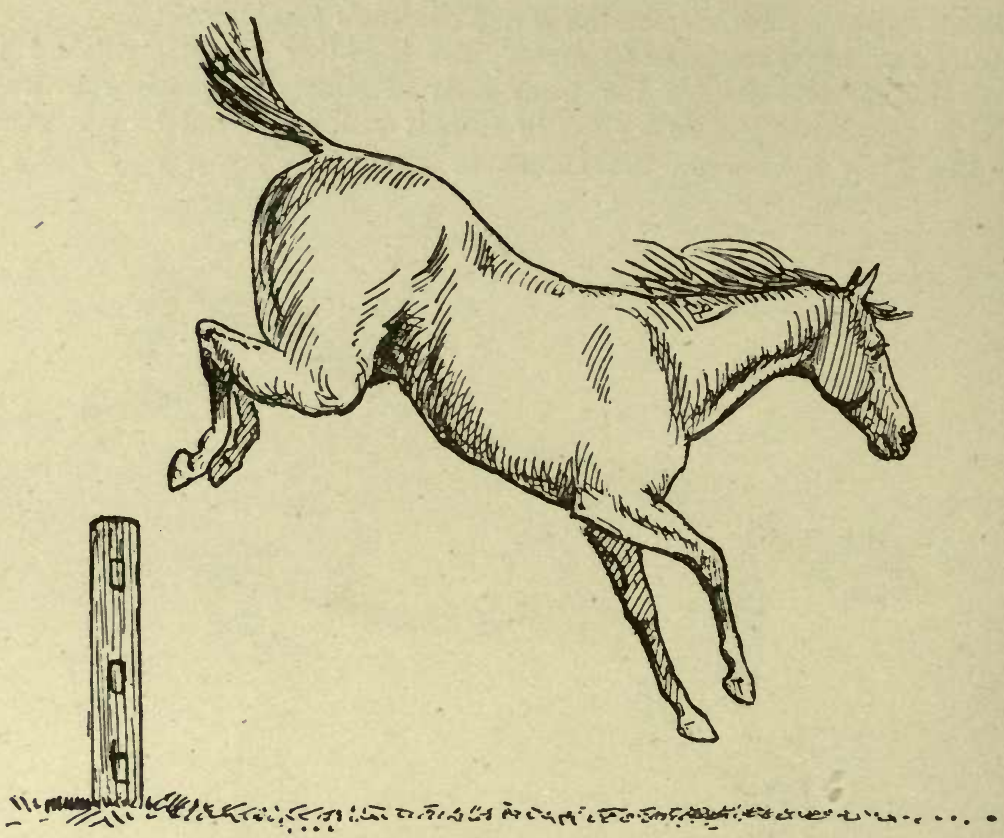

Deep, "holding" ground delays the removal of the fore-feet so that overreaching takes place, and the toe or quarter of a hind-foot strikes the heel or fetlock of a front one. 


\section{CHAPTER X}

THE PRINCIPLES OF BREEDING APPLICABLE TO THE HORSE

THEORY OF GENERATION-IN-AND-IN BREEDING-OUT-CROSSING-ADVANTAGES AND DISADVANTAGES OF EACH PLAN-CAUSES OF A "HIT"-IMPORTANCE OF HEALTH AND SOUNDNESS IN BOTH SIRE AND DAM-BEST AGE TO BREED FROM-THE INFLUENCE OF THE SIRE AND DAM RESPECTIVELY-CHOICE OF SIRE AND DAM-SELECTION OF BLOOD IN EACH CLASS OF HORSE-THE KIND OF HORSE MOST PROFITABLE FOR THE BREEDER TO CHOOSE-CONCLUDING REMARKS ON BREEDING.

\section{THEORY OF GENERATION}

THE IMPORTANCE of understanding the principles upon which the breeding of the horse should be conducted is so great that every one who superintends a stud, however small, should study them carefully. To do this with advantage, he must investigate the changes which take place after the union between the sexes, and must endeavour to ascertain the influence which the sire and dam respectively exert upon their offspring.

In the year 1855, while engaged in preparing the article on the breeding of the horse in British Rural Sports, I carefully drew up the following epitome of the laws which govern the generation of the mammalia. Since then, the subject has constantly been before me; but, in spite of the numerous investigations carried on by other observers, I have seen no reason to modify, in any material degree, what I then wrote; and I shall, therefore, to prevent confusion, insert it entire, what slight additions may be necessary being included within parentheses.

1. The union of the sexes is, in all the higher animals, necessary for reproduction; the male and female each taking their respective share.

2. The office of the Male is to secrete the semen in the testes, and emit it into the uterus of the female, (in or near which organ) it comes in contact with the ovum of the female-which remains sterile without it.

3. The Female forms the ovum in the ovary, and at regular times, varying in different animals, this descends into the uterus, for the purpose of fructification, on receiving the stimulus and addition of the sperm-cell of the semen.

4. The Semen consists of two portions-the spermatozoa, which have an automatic power of moving from place to place, by which quality it is believed that the semen is carried to the ovum; and the sperm-cells, which 
are intended to co-operate with the germ-ced of the ovum in forming the embryo.

5. The Ovum consists of the germ-cell, intended to form part of the embryo-and of the yolk, which nourishes both, until the vessels of the mother take upon themselves the task; or, in oviparous animals, till hatching takes place, and external food is to be obtained. The ovum is carried down by the contractile power of the fallopian tubes from the ovary to the uterus, and hence it does not require automatic particles like the semen.

6. The Eubryo, or young animal, is the result of the contact of the semen with the ovum, immediately after which the sperm-cell of the former is absorbed into the germ-cell of the latter. Upon this a tendency to increase or "grow" is established and supported, at first, by the nutriment contained in the yolk of the ovum, until the embryo has attached itself to the walls of the uterus, from which it afterwards absorbs its nourishment by the intervention of the placenta.

7. As the Male and Female eaeh furnish their quota to the formation of the embryo, it is reasonable to expect that each shall be represented in it, which is found to be the case in nature; but as the food of the embryo entirely depends upon the mother, it may be expected that the health of the offspring and its constitutional powers will be more in accordance with her state than with that of the father; yet since the sire furnishes one-half of the original germ, it is not surprising that in externals and general character there is retained a fac-simile, to a certain extent, of him.

8. The Ovum of Mammalia differs from that of birds chiefly in the greater size of the yolk of the latter, because in them this body is intended to support the growth of the embryo from the time of the full formation of the egg until the period of hatching. On the other hand, in mammalia the placenta conveys nourishment from the internal surface of the uterus to the embryo during the whole time which elapses between the entrance of the ovum into the uterus and its birth. This period embraces nearly the whole of the interval between conception and birth, and is called ultra-gestation.

9. In all the Mammalia there is a Periodical "Heat," marked by certain discharges in the female, and sometimes by other remarkable symptoms in the male (as in the rutting of the deer). In the former it is accompanied in all healthy subjects by the descent of an ovum or ova into the uterus; and in both there is a strong desire for sexual intercourse, which never takes place at other times in them (with the single exception of the genus Dimana).

10. The Semen retains its fructifying power for some days, if it is contrined within the walls of the uterus or vagina, but soon ceases to be fruitfur if kept in any other vessel. ${ }^{1}$ Hence, although the latter part of the time of heat is the best for the union of the sexes, because then the ovum is ready for the contact with the semen, yet if the semen reaches

I It has been conveyed in a suitable vessel and at the natural temperature of the body to great distances, and extending over many hours without losing its fecundating properties. An instrument known as the certes impregnator has been employed successfully, first in America and subsequently in England. 


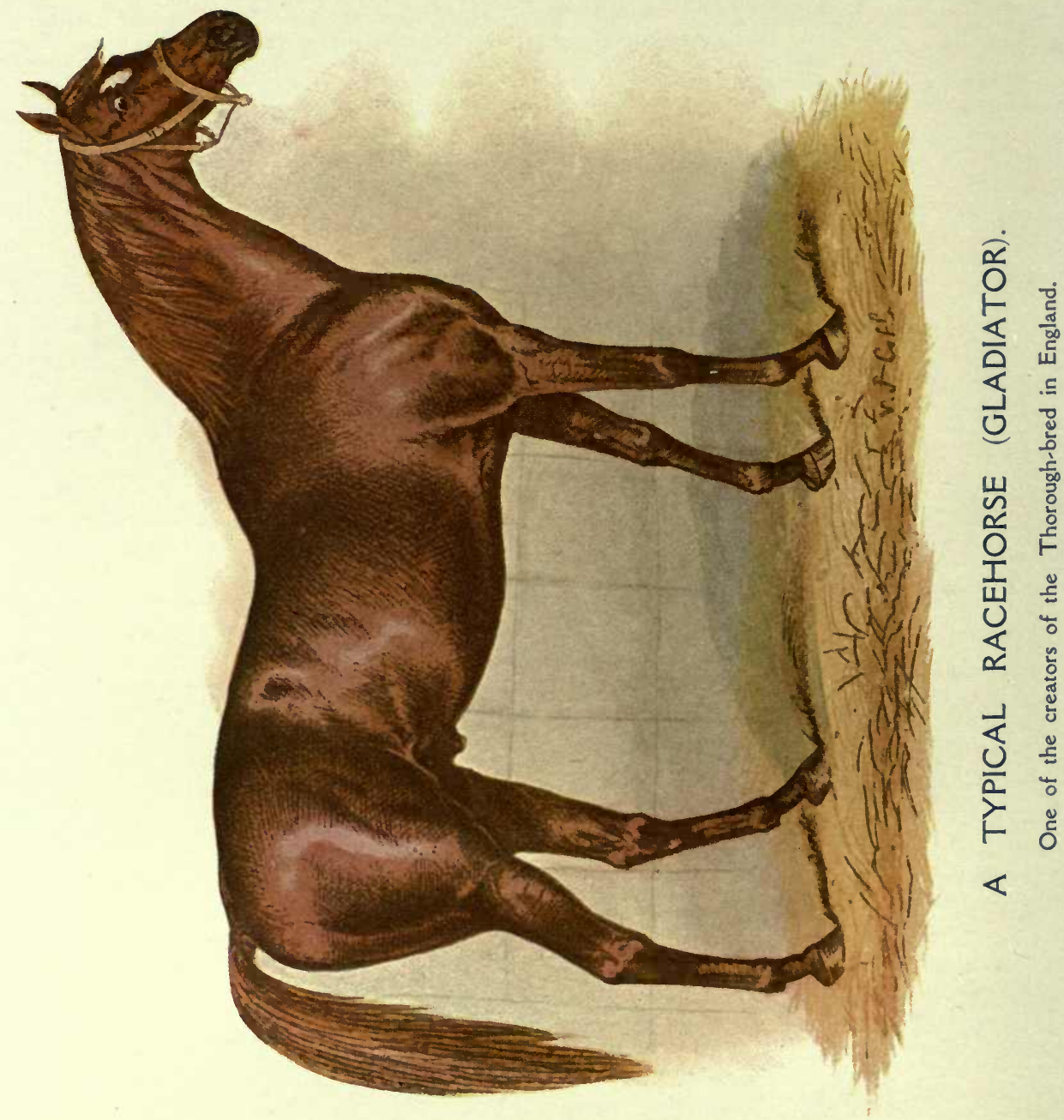


the uterus first, it will still cause a fruitful impregnation, because it remains there (or in the fallopian tubes) uninjured until the descent of the ovum.

11. The Ixfluence of the Male upon the embryo is partly dependent upon the fact, that he furnishes a portion of its substance in the shape of the sperm-cell, but also in great measure upon the effect exerted upon the nervous system of the mother by him. Hence, the preponderance of one or other of the parents will, in great measure, depend upon the greater or less strength of nervous system in each. No general law is known by which this can be measured, nor is anything known of the laws which regulate the temperament, bodily or mental power, colour or conformation of the resulting offspring.

12. ACQUIRED QUALITIEs are transmitted, whether they belong to the sire or dam, and also both bodily and mental. As bad qualities are quite as easily transmitted as good ones, if not more so, it is necessary to take care that in selecting a male to improve the stock he is free from bad points, as well as furnished with good ones. It is known by experience that the good or bad points of the progenitors of the sire or dam are almost as likely to appear again in the offspring as those of the immediate parents in whom they are dormant. Hence, in breeding, the rule is, that like produces like, or the likeness of some ancestor.

13. The PURER or LESS MIXED the breed the more likely it is to be transmitted unaltered to the offspring. Hence, whichever parent is of the purest blood will be generally more represented in the offspring; but as the male is usually more carefully selected and of purer blood than the female, it generally follows that he exerts more influence than she does; the reverse being the case when she is of more unmixed blood than the sire.

14. BREEDING "IN-AND-IN" is injurious to mankind, and has always been forbidden by the Divine law, as well as by most human lawgivers. On the other hand, it prevails extensively in a state of nature with all gregarious animals (such as the horse), among whom the strongest male retains his daughters and grand-daughters until deprived of his harem by younger and stronger rivals. Hence, in those of our domestic animals which are naturally gregarious, it is reasonable to conclude that breeding "in-and-in" is not prejudicial, because it is in conformity with their natural instincts, if not carried farther by art than nature teaches by her example. Now, in nature, we find about two consecutive crosses of the same blood is the usual extent to which it is carried, as the life of the animal is the limit; and it is a remarkable fact that, in practice, a conclusion has been arrived at which exactly coincides with these natural laws. "Once in and once out" is the rule for breeding given by Mr. Smith in his work on the breeding for the turf; but twice in will be found to be more in accordance with the practice of our most successful (early) breeders.

15. Tue influence of the first inpregnation seems to extend to the subsequent ones; this has been proved by several experiments, and is especially marked in the equine genus. In the series of examples preserved in the museum of the College of Surgeons, the markings of the male quagga, when united with the ordinary mare, are continued clearly for three generations beyond the one in which the quagga was the actual 
sire: and they are so clear as to leave the question settled without a doubt. ${ }^{1}$

16. When SOME OF tHE ELEMENTS of which an individual sire is composed are in accordance with others making up those of the dam, they coalesce in such a kindred way as to make what is called a "hit." On the other hand, when they are too incongruous, an animal is the result wholly unfitted for the task he is intended to perform.

THESE PRINCIPLES, together with the observations following upon them, have been quoted verbatim, at great length, by the late Mr. Herbert, in his elaborate quarto work on "The Horse of America," with the very flattering testimony that he had done so "not for the purpose of avoiding trouble, or sparing time, but because he conceives the principles laid down to be correct throughout, the reasoning logical and cogent, the examples well taken, and the deductions such as can scarcely be denied." In support of this opinion, he adduces several instances in which a "hit" has occurred in America by carrying out the last axiom in the preceding list. Thus he says, at page 260 of his second volume, "I think myself that it is made clear by recent events, and that such is shown to be the case by the tables of racing stock given at the close of the first volume, ${ }^{2}$ that, previous to the last quarter of a century, the American turfman was probably breeding in too much of the old Virginian and South Carolina ante-revolutionary stock, and that the American race-horse has been improved by the recent cross of modern English blood. It is also worthy of remark, that every one of the four most successful of modern English stallions in this country which have most decidedly hit with our old stock-Leviathan, Sarpedon, Priam, and Glencoe-all trace back to several crosses of Herod blood; Glencoe and Priam not less than three or four several times each to crosses of Partner blood, and directly several times over to the Godolphin Barb, or Arabian, which are the very strains from which our Virginian stock derives its peculiar excellence. It is farther worthy of remark, that two stallions have decidedly hit with the imported English mare Reel, as proved by her progeny, Lecompte and Prioress, respectively to Boston and Sovereign. Now Reel, through Glencoe, Catton, Gohanna, and Smolensko, has herself no less than seven distinct strains of Herod blood. Boston, as every one knows, traces directly through Timoleon, Sir Archy, Diomed, Florizel, to Herod, Sovereign, also, through Emilius, his sire, has Herod on both lines as his paternal and maternal g.g.g. sire; and Tartar, the sire of Herod, a third time, in one remove yet farther back. Now this would go to justify Stonehenge's opinion that the recurrence to the same original old strains of blood, when such strains have been sufficiently intermixed and rendered new by other more recent crosses, is not injurious, but of great advantage; and that, on the whole, it is better, cceteris paribus, to do such than to try experiments with extreme out-crosses."

1 In 1897 a pony mare, the property of Lord Morton, gave birth to a foal with well-marked zebra stripes through the influence of a previous sire. The case excited very wide interest in natural history circles as proof of telegony, which is now considered to be finally settled. -Editor.

2 These tables I have extensively drawn upon at pages 48-52 et seq., correcting then where they required it. 


\section{IN-AND-IN BREEDING}

WHEN ANY NEW BREED of animals is first introduced into this country, in-and-in breeding (by which is to be understood the pairing of relations within the degree of second cousins twice or more in succession) can scarcely be avoided; and hence, when first the value of the Arab was generally recognized, the breeder of the race-horse of those days could not well avoid having recourse to the plan. Thus we find, in the early pages of the Stud-book, constant instances of very close in-breeding, often carried to such an extent as to become incestuous. The result was our modern thorough-bred; but it does not follow that because the plan answered in producing that celebrated kind of animal, it will be equally successful in keeping up the breed in its original perfection. In British Rural Sports, I have given a series of examples of success resulting from each plan, which I shall not now repeat, merely remarking that the opinion which I formed from an attentive examination of them remains unchanged. This opinion was expressed in the following words :-

"If the whole of the pedigrees to which $I$ have drawn attention are attentively examined, the breeder can have no hesitation in coming to the conclusion, that in-breeding, carried out once or twice, is not only not a bad practice, but is likely to be attended with good results. Let him ask what horses have been the most remarkable of late years as stallions, and, with very few exceptions, he will find they were considerably in-bred. It has been remarked, that the Touchstone and Defence blood almost always hits with the Selim; but it is forgotten that the one was already crossed with that horse, and the other with his brother Rubens. On the other hand, the Whisker blood in the Colonel has not succeeded so well, it being made up of much crossed and more distantly related particles, and therefore not hitting with the Selim and Castrel blood, like his cousins, Touchstone and Defence. It has, however, partially succeeded when in-bred to the Waxy and Buzzard blood, as in Chatham and Fugleman, who both reunite these three strains. The same applies to Coronation. who unites the Whalebone blood in Sir Hercules with that of Rubens in Ruby; but as Waxy and Buzzard, the respective ancestors of all theso horses, were both grandsons of Herod, and great-grandsons of Snap, it only strengthens the argument in favour of in-breeding. This conclusion is in accordance with the 14th and 15th axioms, which embody the state of our present knowledge of the theory of generation; and if they are examined, they will be seen to bear upon the present subject, so as to lead one to advise the carrying out of the practice of in-and-in breeding to the same extent as has been found so successful in the instances which $I$ have given. Purity of blood is intimately connected with the practice, because the nearer it is to one standard, the more unmixed it is, and by consequence the more fully it is represented in the produce. Hence, it is doubly needful to take care that this pure blood is of a good kind; because if bad, it will perpetuate its bad qualities just as closely as it would the good, or perhaps still more so."

I have nothing to add to these remarks; and if I were to adduce the 
few instances in their support which can have occurred since 1855-6, when they were written, I should add little to the mass of evidence which I have already collected. An appeal to the past can only be answered in the way which I have recorded; for the evidence of repeated success in resorting to the practice of in-breeding is too strong to be gainsaid. We will now consider whether the effects of an out-cross are of superior or equal value.

\section{OUT-CROSSING}

BeTwEen IN-AND-IN BREEDING, which I have defined as the pairing of animals within the relationship of second cousins, and the opposite extreme of uniting those which are not at all allied in blood, there are many degrees; but as, in the thoroughbred horse, there are scarcely two in the Stud-book which cannot be traced back to the same stock in one or more lines, we do not generally understand " a cross" to demand absolute distinctness of blood. For instance, Teddington is generally considered as the result of as marked a cross as we ever meet with in the modern Stud-book. For five generations, the same name never appears in the pedigree tables of his sire and dam; but in the sixth, we find the name of Sir Peter oecur three times on the side of his sire, and twice on that of his dam, besides six other lines of Herod blood on the part of the sire, and eight on that of the dam. Here, therefore, there was a return to the original lines of blood, which had been in-bred twice each, after five successive departures from them as far as could be effected in this particular kind of horse. These last are called "crosses," though not being exactly the reverse of in-breeding, for the reason, as I before remarked, that an absolute freedom from relationship is not to be found, or, if so, extremely rarely. Breeders very often fancy that they put two animals together which are without any corresponding lines or strains of blood in their composition; whereas, in point of fact, the relationship exists only four or five degrees off. The horse and mare are, perhaps, fourth or fifth cousins, often second or third; but, in examining the Stud-book, the blood of the sire, grandsire, and great-grandsire is apt to be forgotten, because it is not given, the name only being mentioned. In the book to which I have already alluded, I have inserted a long series of pedigree tables, drawn out to the sixth generation, with a reference also to the earlier pedigrees; by which, at one glance, the breeder may see how constantly, in going back, the same names occur in every table. Eclipse, Herod, and Conductor, the three contemporary descendants of the Darley Arab, the Byerley Turk, and the Godolphin Barb, or one of their immediate descendants, will be seen in the fifth, sixth, or seventh remove of all our thoroughbred horses, and often the names of all three will be found repeated four, five, or six times apiece; yet the horse itself whose pedigree is being examined, as in the instance of Teddington, is considered to be the produce of a cross, and is not, therefore, said to be in-bred. 


\section{ADVANTAGES AND DISADVANTAGES OF EACH PLAN}

Havivg tuUs Explained the meaning of the two terms, and having, in British Rural Sports, collected a series of examples of success in crossing nearly equal in number to those adduced in which in-breeding had been resorted to advantageously, I shall now proceed to say a few words upon the probable advantages to be derived from each plan. In the first place, it may be laid down that nearly an equal number of good horses have lately been bred by adopting either mode of proceeding; but no first-rate horse has appeared whose parents were incestuously allied. In the second place it may be gathered from experiments with horses and other domestic animals, that very close in-breeding, continued for any length of time, is apt to develop the weak points in the constitutions of the breed in which it is adopted. The cautious breeder, therefore, will do well to avoid running this risk, and will strive to obtain what he wants without having recourse to the practice, though, at the same time, he will make up his mind that it is unwise to sacrifice a single point with this view. Experience tells us that it is useless to expect to develop a new property or quality in the next generation, by putting a female entirely deprived of it to a male which possesses it eyen in a marked degree. Some instances of success will attend the adoption of this course, but as a rule it cannot be relied on in the majority of instances. Thus, a slow, stout mare, containing no lines of fast blood in her pedigree, will not be likely to breed a fast colt, though put to a flying stallion, whose blood is not stout in a considerable proportion of his ancestry. Two or three consecutive crosses with the same or similar blood will almost of a surety effect the object; but the first will rarely do so. Again, we know, if we put two animals together, equally in-bred or equally crossed, the produce is, on the whole, as likely to resemble the one parent as the other, though there may be a difference of opinion as to particular points. But, if not thus equally composed of similar elements, the more in-bred parent will be represented in a greater proportion than the crossed one; and hence it follows, that if it is desired to keep up the qualities of the horse or mare in his or her descendant, the mate must be selected, if possible, less in-bred than he or she is. West Australian himself and his stock are excellent examples of this theory. His sire, Melbourne, was the result of a series of crosses; while his dam, Mowerina, was in-bred to Whalebone and Whisker, own brothers; and her sire and dam were second cousins. The result has been, that both in "The West" and in his stock the Whalebone element has been universally manifested, and not the slightest trace of Melbourne has ever appeared, as far as my knowledge of his stock allows me to judge. This is in perfect accordance with the 13th axiom in the epitome of the laws which govern the breeding of our domestic animals. (See page 163.) 


\section{CAUSES OF A "HIT"}

A "HIT," in breeding, is understood to mean an instance of success, but though it often occurs, the reason for it is not always very clear. My own belief is that it generally results, as I have laid down in the 16th axiom, from the reunion of lines which have been often kept separate for several generations. Thus, it is a fact (so patent that every writer on the breeding of the horse, of late years, has admitted its truth), that the Touchstone and Sultan blood have almost invariably hit. The reason, granting the premises which I lay down, is plain enough-each goes back to Selim, the former through the dam of his sire, Camel, and the latter being son of that horse. Many other examples of a similar nature might be adduced, though not observed so extensively as in the case of Touchstone, because few horses have been put to so many mares as he has. I do not mean to assert that no hit can occur without such a reunion of previously separated lines, but I believe that, under other circumstances, it will rarely be found to show itself; and if, as I before observed, there is a relationship between all thoroughbred horses, either remote or near, there must be this reunion to some extent. This, however, is not what I mean; the return must be to a line only removed two, three, or four generations, in order to be at all marked; and if more than these intervals exist, the hit cannot be said to depend upon the reunion, since this must occur in all cases ; and what is common to all cannot be instanced as a particular cause of any subsequent result.

THE FACT REALLY Is, as proved by thousands of examples, that by putting $A$ and $B$ together, the produce is not necessarily made up of half of each. Both parents have qualities belonging to the several members of a long line of ancestors, and their son (or daughter) may possibly be made up of as many as seven proportions of one parent, and one propor: ion of the other. It generally happens, that if there is any considerable degree of consanguinity, or even a great resemblance in form, to some of the ancestry on each side, the produce will draw together those elements, and will be made up of the characteristics peculiar to them in a very large proportion. This accounts for the preponderance of the Touchstone form in the West Australian stock; while the same horse is overpowered in Orlando and his stock, by the greater infusion of Selim blood in the dam Vulture, who is removed exactly in the same degree as Touchstone from Selim and his brother Castrel; and the two latter, therefore, have more influence on the stock than the former. Here, then, we have two remarkable instances, which each show a hit from the reunion of strains after two out-crosses; while, at the same time, they severally display an example of two lines overpowering one in the stock of the same horse. It may be argued, that in each case it is the blood of the dam which has overpowered that of the sire,-West Australian being by Melbourne, out of a daughter of Touchstone; while Orlando is by Touchstone, out of a mare descended from two lines of Selim and his brother Castrel. Now, I am myself a great believer in the influence of the dam over her progeny, and therefore I should be ready to accept this argument, were it not that, under ordinary 
circumstances, both Melbourne and Touchstone have been sure to reproduce their likenesses in their several sons and daughters. Every racing man who has been on the turf while the Melbournes and Touchstones were in their glory, was able, in almost all instances, to say at the first glance, "That is a Melbourne or a Touchstone colt or filly." But, in the cases of Orlando and West Australian, the resemblance to their respective sires was not apparent; and, as I before observed, it is still less visible in their stock. In the language of the stud, this is called "going back" to a particular strain; and it is so constantly observable, that there is 110 necessity for dwelling further upon it.

\section{IMPORTANCE OF HEALTH AND SOUNDNESS IN SIRE AND DAM}

OUR PRESENT BREED OF HORSES is undoubtedly less healthy than that of our ancestors; and this tendency to unsoundness is not marked in any particular department of the animal economy, but the defect shows itself wherever the strain is the greatest from the nature of the work which the animal has to perform. Thus, the race-horse becomes a roarer, or his legs and feet give way. The hunter fails chiefly in his wind or his hocks, because he is not used much on hard ground, and therefore his fore-legs are not severely tried, as in the case with the racer, who often has to extend himself over a course rendered almost as hard as a turnpike-road by the heat of a July or August sun. The harness-horse often becomes a roarer, from the heavy weights that he has to draw, especially if his windpipe is impeded by his head being confined by the bearing-rein. The hack, again, suffers chiefly in his legs, from our hard macadamized roads; while the cart-horse becomes unsound in his hocks or his feet, the former parts being strained by his severe pulls, and the latter being battered and bruised against the ground, from having to bear the enormous weight of his carcass. But it is among our well-bred horses that unsoundness is the most frequent; and in them, I believe, it may be traced to the constant breeding from sires and dams which have been thrown out of training, in consequence of a break-down, or "making a noise," or from some other form of disease. It is quite true, that roaring is not necessarily transmitted from father to son $;^{1}$ and it is also manifest that there are several causes which produce it, some of which are purely accidental, and are not likely to be handed down to the next generation. The same remarks apply to the eyes; but in the main, it may be concluded that disease is hereditary, and that a sound horse is far more likely to get healthy stock than an unsound one. In the mare, probably, health is still more essential ; but if the breeder regards his future success, whether he is establishing a stud of race-horses, or of those devoted to any kind of slower work, he will carefully eschew every kind of

1 With more careful tabulation of hereditary defects on the part of reterinary surgeons and breeders, the principle is now so well established that the Duke of Westminster was well advised in selling "the horse of the century," as Ormondo has been called, and as the editor of the Field remarked, "at four or five times the price of a sound one." It was thought that the dry climate of a South American state would cure him of roaring, and so much did many people regret his leaving the country, that a proposal was set on foot to form a syndicate for his re-purchase. 
unsoundness, and especially those which are of a constitutional character. If a horse goes blind in an attack of influenza, or if, without any previous indications of inflammation, he breaks down from an accidental cause, the defect may be passed over, perhaps ; but, on the contrary, when the blindness comes on in the form of ordinary cataract, or the break-down is only the final giving-way in a leg which has been long amiss, I should strongly advise an avoidance of the horse which has displayed either the one or the other. I believe that a Government inspection of all horses and mares used for breeding purposes would be a great national good; and I look forward to its establishment, at no distant time, as the only probable means of ensuring greater soundness in our breeds of horses. I would not have the liberty of the subject interfered with. Let every man breed what he likes, but I would not let him foist the produce on the public as sound, when they are almost sure to go amiss as soon as they are worked. Ships must now all be registered at Lloyd's, in the classes to which they are entitled by their condition; and horses, as well as mares, should be registered in the same way, according to the opinion which the Government inspector may form as to their health and the probability of getting or producing sound and useful foals. The purchaser would call for the registrationmark, when he asked for the pedigree of the horse he was about to buy; and if it was not a favourable one, he would, of course, be placed upon his guard. If this plan could be carried out in practice, as well as it looks on paper, much good might be done, I am assured; but we all know that inspectors are but mortals, and that they are liable to be biased in more ways than one.

\section{BEST AGE TO BREED FROM}

The General opinion throughout England is, that one or other of the parents should be of mature age; and that if a very young mare is chosen, the horse should not be less than eight, ten, or twelve years old. If both are very young, or very old, the produce is generally small and weakly; but by adopting the plan above-mentioned, the services of young and old may be fully utilized. A great many of our very best performers on the turf have been got by old stallions; as, for instance, Whisker, son of Waxy, in his twenty-second year; Emilius, son of Orville, in his twentieth; Voltigeur and Newminster, whose sires were respectively twenty-one and seventeen; Blink Bonny, who was got by Melbourne, in his twentieth year; and Wiid Dayrell, by Ion, when seventeen years old. To these may be added, Gemma di Vergy, Lifeboat, and Gunboat, three celebrated sons of Sir Hercules, and all got by him after he was twenty years old-the last named when he was twenty-five years of age. So, also, many were out of old mares; including Priam, whose dam was twenty when she dropped him; Crucifix, the daughter of Octaviana, when twerity-two years old; Lottery, out of Mandane, in her twentieth year; and Brutandorf, produced by the same mare when she was twenty-two. From these instances, the breeder may conclude that age is no bar to success, if matched with youth on the other side; but the instances of success in breeding from two aged parents are rare indeed. It is next to be ascertained what is the earliest 
age at which this animal can be relied on for breeding; and here, again, example is better than theory. The most remarkable instance of moderate success in adopting this plan is in that of The Ugly Buck, whose dam, Monstrosity, was put to Venison when only a two-year-old. The horse, also, was not more than seven, and the dam of Monstrosity bred her in her fourth year. But though Ugly Buck promised well as a two-year-old, he failed in his subsequent career, and his example is not, therefore, to be considered as at all conclusive. Still, his is a most extraordinary instance, and as such it should not be lost sight of. There are many cases in which the first produce of a mare has been her best; such as, in former times, Mark Anthony, Conductor, Shuttle Pope, Filho da Puta, Sultan, Pericles, Oiseau, Doctor Syntax, Manfred, and Pantaloon. Nevertheless, these may be considered to be exceptions, and a large majority of the brood mares in the Stud-book are credited with their most successful produce subsequently to their first. The rule generally adopted is to wait till the mare is three years old before breeding from her, and then to put her to a horse of at least full maturity - that is to say, seven or eight years old.

\section{THE INFLUENCE OF THE SIRE AND DAM RESPECTIVELY}

I HAVE ALREADY at page 33 alluded to this question as relating to the breeding of the Arab horse in his native country, and have there shown that the opinions held by Abd-el-Kader in modern days do not coincide with those which have long been supposed to be general in Arabia. In the passage which I have there quoted, this celebrated chief attempts to define the exact part which each parent takes in producing the foal, but he goes still farther in subsequent answers to the questions asked by General Daumas, in relation to the value put by the Arabs on their stallions and mares respectively. To these Abd-el-Kader replies as follows: "It is true that Arabs prefer mares to horses, but only for the following reasons: the first is that they look at the profit which may arise from a mare as very considerable. Some Arabs have realized as much as 20,000 dollars from the produce of one mare. They have a proverb that 'the fountain-head of riches is a mare that produces a mare.' This is corroborated by the Prophet Mahomet, who says, "Let mares be preferred, their bellies are a treasure, their backs the seat of honour.' 'The greatest blessing is an intelligent wife or a mare that produces plenty of foals.' These words are thus explained by commentators. Their bellies are a treasure because the mare by her produce increases the riches of her master; and their backs are the seat of honour because the pace of a mare is easier than that of a horse; and there be those that say it is sufficiently so as in time to render a horseman effeminate. The second reason is that a mare does not neigh in war, that she bears hunger, thirst, and heat better than a horse, and that therefore she is more useful to people whose riches consist in camels and sheep. Now all the world knows that our camels and sheep thrive only in the desert, where the soil is so arid that Arabs drinking chiefly milk find water seldom oftener than every eight or ten days, in consequence of the distances between the pasturages, which are only to be found in the neigh. 
bourhood of wells. The mare is like the serpent, their powers increase in hot weather and in arid countries. Serpents which live in cold or watery countries have little venom or courage, so that their bite is seldom mortal, whereas those that live in hot countries are more irritable, and the virulence of their poison is increased. Whilst the horse can less easily bear the heat of the sun, the mare, doubtless from constitutional causes, finds her energies increase with the greatest heat. The third reason is that the mare requires less care and less nourishment. The owner can lead and turn her out to graze with the sheep and camels, and he is not obliged to have a person constantly watching her; whereas a horse cannot do without being highly fed, and he cannot be turned out without an attendant for obvious reasons. These are the true reasons of an Arab's preference for mares. It does not arise from the foal inheriting the qualities of the dam rather than those of the sire; it does not proceed from its being better at all times and under all circumstances to ride a mare rather than a horse; but it is based upon material interests, and on the necessities enforced by the description of life which Arabs lead. It must, however, be admitted that a horse is more noble than a mare. $\mathrm{He}$ is stronger, more courageous, and faster. That a horse is stronger than a mare is thus proved. If both were struck by the same mortal wound a mare would fall at once, but a horse would seldom drop until he had carried his rider into safety. I saw a mare struck by a ball on the leg; the bone was broken; unable to bear the pain she fell immediately. A horse was hit in the same manner; the broken limb hung only by the skin; he continued his course, supporting himself on his sound leg, until he bore his rider from the battle-field and then fell. The Arabs prefer mares to horses for the reasons I have given, and those reasons are sufficient to show why amongst us the value attached to the possession of a mare is greater than that they attach to the possession of a horse, even though the breeding of each were the same; for whilst on the one hand the foal takes more after the sire than the dam, on the other the proprietor of a horse cannot gain in many years as much as the proprietor of a mare can gain in one year if she throw a foal. However, when a horse has displayed any extraordinary qualities, it often happens that he will not be parted with, probably producing to his master in the way of booty or otherwise as much as the most valuable mare. I saw amongst the Annazas, a tribe extending from Bagdad to Syria, horses so beyond all price that it was almost impossible to purchase them, and certainly impossible to pay ready money for them. These animals, of a fabulous value, are sold only to the highest personages, or to rich merchants who pay for them by thirty or forty instalments, or by a perpetual rent settled on the vendor or his descendants. The birth of a horse can never be considered a misfortune by an Arab, however much he may prefer a mare for the material advantages which they procure. Mares almost always produce, and it is on that account principally that they are preferred. I repeat it - the birth of an animal that guarantees its master against humiliation can never be considered a misfortune. A poet says : 'My brothers reproach me with my debts, yet I never contracted one but for an honourable purpose. In giving the bread of heaven to all, in purchasing a horse of noble race, and buying a slave to attend upon me.' "Baily's Magazine of Sports, June 1860. 
MY oWv BELIEF in this matter, founded upon observations made during a long series of years on the horse as well as the dog, is that no rule can be laid down with any certainty. Much depends upon the comparative physical power and strength of constitution in each parent, even more perhaps than the composition of the blood. There have been many instances of two brothers being used in the stud, both among horses and greyhounds, in which one has almost invariably got his stock resembling himself in all particulars, not even excluding colour, while the descendants of the other have rarely been recognizable as his. Thus among horses the Touchstones have been mostly brown or dark bay, and as a lot have shown a high form as race-horses, while the Launcelots have been of all colours, and have been below mediocrity on the turf. Several examples of the same nature may be quoted from among greyhounds, such as Ranter, Gipsy Prince, and Gipsy Royal, three brothers whose stock were as different as possible, but the fact is so generally recognized that it is not necessary to dwell upon it. Now surely this difference in the power of transmitting the likeness of the sire, when the blood is exactly the same as it is observed to extend over large numbers, can only depend upon a variation in individual power. Not only does this apply to the males, but the females also show the same difference. Some mares have gone on producing foals which afterwards turned out first-class whatever horse they were put to, as, for instance, Phryne (dam of winners by Pantaloon, Melbourne, and The Flying Dutchman), Barbelle, who produced Van Tromp by Lanercost, De Witt by The Provost, and The Flying Dutchman. by Bay Middleton; Alice Hawthorn, successively as well as successfully put to Birdcatcher, Melbourne, Touchstone, Windhound, Melbourne or Windhound, and Sweetmeat; and lastly, Ellerdale, dam of Ellington and Ellermere, and Gildermire by Flying Dutchman, Summerside by West Australian, and Wardersmarke by Birdcatcher. On appealing to the greyhound, also, we see some remarkable instances within the last few years, of which Mr. Jardine's Ladylike and Mr. Randell's Riot may be considered as very strong cases in point. The latter bitch also may be instanced as having been extremely successful in the stud, while her own brother, Ranter, in the same kennel, was a total failure. There must consequently be something more than mere breeding to produce a successful result, and this I am inclined to think resides in the strength of the constitution possessed by the individual.

BUT EVEN SUPPOSING the horse or mare displays this constitutional power, there is a something which controls it, as we have seen in the two cases already instanced of Orlando and West Australian. In the former horse the influence of the sire, great as it usually has been shown to be, was compelled to succumb to the combination of the three lines traceable to Selim and his brother Castrel, while in the other this same horse Touchstone prevailed (still, however, on the side of the dam) apparently only because there was a combination of two very recently separated lines of Waxy blood through his sons Whalebone and Whisker. The second of these examples is the more worthy of note, because, in tracing back the lines of the sire and dam, the name of Trumpator, from whom Melbourne is lineally descended, is met with three times in the pedigree of the former, and four times in that of the latter. Here then, but for the nearness of the two 
lines of Waxy, I should have expected the produce to follow the Trumpator strain through Melbourne, but, as I have already observed, beyond the third remove this influence is very much weakened. We may therefore come to the conclusion that it is not always superior strength of constitution, nor the greater purity or antiquity of the blood, which determines the influence to be expected by either parent, but that sometimes the one and sometimes the other is the cause. And as the former cannot well be determined, the latter is the foundation for the plans of the breeder, who will on the whole do well to follow the maxims first laid down by that celebrated breeder of horses and cattle, the second Earl Spencer, whose opinions were in conformity with the 13 th axiom for breeders which $I$ have inserted at page 163.

\section{CHOICE OF SIRE AND DAM}

THE NECESSITY FOR HEALTH in each parent has already been insisted on, but beyond this point, which is generally admitted, there are several others to be attended to. Thus, since the preponderance of either over the form and temper of the progeny will, in all probability, fall to that one which has the superior purity of blood, it follows that if the breeder wishes to alter in any important particular the qualities possessed by his mare, he must select a horse which is either better bred or some of whose lines will coalesce with those of the dam's which it is desired to perpetuate. Thus, supposing a mare to be made up of four lines, two of which are decidedly bad, and one which is so good as to attract the notice of her owner, then let him look around and select some horse in whose pedigree is to be found a similar strain, taking care that the relationship is not so close as to lead to disappointment on the score of the bad effects attributable to in-breeding. But there are many brood mares not in the Stud-book, whose pedigrees are not ascertainable, and in their case this rule will not apply. Here a different plan must be pursued, and a horse must be chosen whose shape, action, or temper coincide with the particular quality which it is desired to perpetuate. I am strongly inclined to believe that it is comparatively of little use to look about for sires who possess those qualities in which the dam is deficient. Such a course of proceeding has so constantly ended in disappointment, within my own knowledge, that I believe I am justified in condemning it. A stallion (whether horse or greyhound, the same is observable) is known to have been very fast, or very stout, as the case may be, and having obtained the one character or the other, breeders have supposed that they have only to send mares deficient in either quality, and they would ensure its development in the produce. If the mare or bitch happens to possess among her ancestry stout or fast lines of blood, the produce will display the one or the other, if she is put to a horse possessing them; but, on the contrary, if the lines of the dam are all fast, or all stout, no first cross with a sire possessing the opposite qualities will be likely to have any effect, though no doubt there are some few exceptions to this, as to all other rules. The instances in support of this position are so numerous within my own knowledge, that I should scarcely be able to make a beginning, and every one who draws upon his own experience, or who will examine 
the Stud-book and the Coursing Calendar, will find examples without end throughout every volume of each. It would be invidious to select any stallion now in this country, but among those which have been well tried here in the stud, and are here no longer, may be mentioned the Flying Dutchman. This horse was well known to have been himself not only fast, but stout, and, as a consequence, even those breeders who are aware of the necessity for regarding both of these qualities were induced to breed from him, expecting that the result would be to give them similar stock in the next generation. The contrary, however, was the case. In many cases speed was developed, but in almost every instance, without an exception, that speed was not allied with staying power. The unlooked-for result has been attributed to his sire, Bay Middleton, whose stock have been notoriously flashy; but if the pedigree of Barbelle, his dam, is carefully examined, a still stronger reason may be assigned. If her lines are traced back fivo generations, it will be seen that out of her thirty-two progenitors in that remove fourteen are descended from Herod or his sire, Tartar, and these in addition to the already overflowing quantum of the same blood in Bay Middleton himself. Now I am a great admirer of the blood of Herod, and I believe him to be one of the chief foundations of the high form of our modern horses ; but its peculiar characteristic is speed, not stoutness, and it requires a combination with the stouter blood of Eclipse, or some other horse of that strain, to make the possessor capable of staying a distance. With these fast lines the produce of Barbelle has always been fast, but it can scarcely occasion surprise that her stoutest son, Van Tromp, should be by Lanercost, nor that Orlando, with his double lines of Selim and Castrel blood, should get a mere half-miler like Zuyder Zee. The Flying Dutchman was, no doubt, a grand performer himself, but this may be regarded as a somewhat exceptional case, and this opinion is supported by the failure of his own brother (Vanderdecken) on the turf, although cast in a mould which would lead one to expec's a still greater success.

In PAYING atT ENTION TO THE PERFormances of the ancestry of both sire and dam, regard must also be had to their size, as this element is considered of much importance. Neither a large nor a small sire or dam will perpetuate the likeness of himself or herself unless descended from a breed which is either the one or the other. It only leads to disappointment to breed from a tall stallion or mare if either is only accidentally so, and not belonging to a breed generally possessing the same characteristics. Many a small mare or bitch has surprised her owner by producing him animals much larger than herself, but on tracing her pedigree it will almost always be found to contain the names of animals of above the average size. Moderately small mares are generally of a stronger constitution than very large ones, and on that account they will often answer the purposes of the stud better than larger animals, provided they are of the sort usually cast in the mould which is desired. This should never be lost sight of by the breeder, and where, as in breeding thoroughbreds, the pedigree can be traced far enough for this purpose, there is no excuse for neglecting the circumstance.

The ABOVE PRECAUtions are sufficient in all those cases where the pedigree is attainable, but there are many brood mares, as I before remarked, in which nothing is known of their antecedents. Here, the breeder can oniy 
act upon the general rule that "like produces like," and cannot take advantage of the addition which I have made to the 12 th axiom, at page 163 , of the words, "or the likeness of some ancestor." In such cases, for the reason which I have given, disappointment will constantly attend upon the first experiments, and until the mare has produced her first foal, and he has gone on to his third or fourth year, the value of the dam can hardly be ascertained. Breeding is always, more or less, a lottery, but when it is carried on with dams of unknown parentage, it is ten times more so than it need be. Were I to commence the establishment of a breeding stud, whether of cart or carriage horses, hacks or hunters, I would never introduce a single mare whose dam and grand-dam as well as the sire and grand-sire would not be produceable as good specimens of their respective kinds. Beyond the second remove there would always be some difficulty in going with the lower-bred mares, but I would certainly go as far as this in all cases. If the sire and dam, grand-sire and grand-dam, were, on the whole, of desirable form and performances, I would choose the produce as a brood mare, but not otherwise; and though, of course, I should be obliged to pass over some important defects in individuals, I would not do so if they were common to all, or nearly all, of the four. In this way I should expect to do more than by simply choosing "a great roomy mare" without knowing her pedigree, in the belief that she would be sure to reproduce her likeness

\section{SELECTION OF BLOOD IN EACH CLASS OF HORSE}

IN THE RACE-HORSE the choice of blood will always greatly depend upon the fashion of the day, if the produce is to be profitably disposed of, and even by following this plan great risk is incurred, for what is fashionable one year is often despised the next. The winner of the Derby, more especially if he can also pull off the St. Leger, raises the fame of his sire from twenty to a hundred per cent.; and if the next year his stock go on well the value put upon them is still further advanced. These remarks especially apply to the choice of a stallion, but at the onset they more or less influence every person who is purchasing mares for the stud. When, however, these are already procured, the investment must be considered in the main to be permanent, as it would be ruinous to be constantly changing the blood. But beyond the reach of fashion there are several broad lines of demarcation between the strains of blood which are prevalent in the present day, and which it is well to notice. It is now idle to go back to the days of Eclipse, Herod, and Matchem, for their descendants are so intermixed that no mare could be found possessing the blood of one without that of another also, and generally of all three. We must, therefore, confine our observations to strains coming much nearer to our own times.

In British Rural Sports, I enumerated ten distinct strains of blood as those at all likely to be useful in the racing stud. Since that time there has been a means of testing the truth of my observations, and I shall there- 
fore insert my remarks here entire, adding to each strain, in a parenthesis, what may occur to me as bearing upon the question. ${ }^{1}$

" 1 . The almost pure, in-bred Waxys, exhibiting, of course, a mixture with other strains, but in all cases being chiefly of Waxy blood. These are-Cotherstone, The Baron, Chanticleer, Chathan, Chabron, and Idle Boy. This strain of blood is admirably adapted as the foundation of a general breeding-stud, being likely to turn out stock which will serve him as hunters or hacks, if they fail as race-horses."

(Among these The Baron and Chanticleer had previously distinguished themselves, the former as the sire of Stockwell and Rataplan; the latter, to a less extent, as having got several good second-class horses. The Baron has, since that time, been in France; and Chanticleer has gone down in public estimation, having only been credited with 12 foals in the Calendar for 1860. Cotherstone, Chabron, Chatham, and Idle Boy have done little for the turf, but they have fulfilled my expectations as sires of hunters, all having obtained considerable celebrity in that department. In addition to those above-mentioned, Sir Hercules and his son, Gemma di Vergy, should not be forgotten, nor the further descendants of the former-Birdcatcher (now dead) and Daniel O'Rourke.

"2. The union of Waxy and Orville, as seen in Retriever, Drayton, Ambrose, Robert de Gorham, The Hero, Mathematician, and Theon. These will be almost equally useful as a general breeding-stock with those included under No. 1; but I suspect will produce fewer first-class race-horses."

(These remarks have been verified to the letter. Ambrose has certainly got a Cynricus, but he is far from first-rate, and the single exception goes to prove the rule. On the other hand, Drayton and Theon have been celebrated as sires of hunters.)

"3. The Buzzard blood, not of course pure, but comparatively so, as in Epirus, Bay Middleton, and the Flying Dutchman. Calculated to get first-class race-horses rather than general stock."

(I believe there is no exception to this rule.)

"4. The Waxy, Orville, and Buzzard united in the following celebrated horses:- Touchstone, Orlando, Surplice, Windfall, Longbow, The Libel, Hobbie Noble, Windhcund, Assault, and Storm. Here we have the very best racing-blood in existence, varying in degrees of excellence, but all more or less good."

(The horses in this list, with their descendants, continue in as high favour as ever. Touchstone is, of course, almost superannuated, being now in his thirtieth year, but he is still credited with 11 foals in the list of the past year; Orlando maintains his reputation with 21 ; Surplice has 4 ; Longbow, 6 ; Hobbie Noble, 8 ; Windhound, 13 ; and Storm, 3. But, in addition, we find Newminster (son of Touchstone) as the sire of 39 ; Teddington (son of Orlando) with 33 to his name; Annandale, Flatcatcher, Lord of the Isles, De Clare, and Mountain Deer (all sons of Touchstone), with $7,7,14,21$, and 29 respectively; and, lastly, West Australian (out of a Touchstone mare) has 22 foals in the list.)

1 Although a period of thirty or forty years has elapsed since Stonehenge made these selections and the horses are all dead, the present editor has thought well to let the original text stand as proof of the author's keen insight and prophetic vision. He who will take the trouble to trace the descendants of the "ten distinct strains of blood "will share some of the editor's admiration of the author. 
"5. The Orville and Buzzard strains together, as in Pompey, Cowl, and Glentilt. This is good racing blood, but not equal to Nos. 3 and 4."

(The three horses named above have only two foals among them in the Calendar, and there can be no doubt that I was right in ranking this strain as inferior to the two already alluded to.)

"6. The Waxy and Buzzard, as in Coronation, Pyrrhus I., Stockwell, Safeguard, Newcourt, Pitsford, and Bessus. Very good, stout, and fast blood, but requiring the dash of Orville to make it equal to No. 4, and, for this reason, suitable for crossing with mares descended from that horse."

(At the time when these remarks were written Pyrrhus I. was at the zenith of his reputation, his daughter Virago having just proved herself the best of her year. Since then, however, he has verified my prognostications, having been generally pronounced to be inferior to many horses of the strains numbered under 3, 4, and 5, and latterly he has been estimated so lightly that he has been among those sold to go abroad, at the usual price for that purpose. Coronation has done nothing at the stud. Stockwell and his brother, Rataplan, are, however, in high force, the former having 19 and the latter 16 foals in the list. With the single exception of Newcourt, who has one foal, these two horses are the only ones of this strain which are at all fashionable among breeders.)

“ 7. The Blacklocks, represented by Hetman Platoff, Tearaway, Neasham, and Ratan. This strain has been lately quite out of favour; but the extraordinary success of Wild Dayrell, a descendant of Blacklock on both sides of his pedigree, may possibly restore it to its former position."

(A mistake was here committed in the pedigree of Wild Dayrell, who is descended from Blacklock only through his dam, a great-grand-daughter of that horse. Voltigeur had also been favourably mentioned at page 435, and his stock, together with that of his son, Vedette, as also of his brother, Barnton, and Fandango, son of the last-named horse, now rank as high as any others in the opinion of breeders. Thus in the Calendar Voltigeur has 30 foals; Vedette, 26 ; Barnton, 32 ; and Fandango, 33.)

"8. The Tramp blood, now only to be met with at all unmixed in Weatherbit, Lanercost, and Collingwood, and of doubtful utility."

(Of late years Weatherbit [owing to the handicap successes of Weathergage and the Epsom victory of Beadsman, who was, however, out of Mendicant by Touchstone] has come into fashion, and last year had 26 foals to his name. With his exception, however, the blood is not fancied, Van Tromp and Collingwood being the only horses descended from Tramp in the male line who have had much chance allowed them, and they have been almost total failures.)

"9. The Partisans and Filho da Putas, seen in Venison and his sons, Alarm, Kingston, and Vatican; also in Sweetmeat, Colwich, and Giovanni. Nothing can exceed the beauty of form resulting from these combinations of the Waxy and Sir Peter blood; and it seems to be perpetuated in all the descendants, which are remarkable for blood-like frames, with Arabian-looking heads, fine muzzles, full eyes, light necks, and good shoulders, and also for wiry and lasting legs and feet. This latter pechliarity is perhaps owing to their light girth, and consequent want of weight for their legs to carry; but nevertheless they are almost all scolt enough, and especially the Venisons." 
(Curiously enough, the stock of Kingston and Sweetmeat have been remarkable rather for pace than stoutness, but this is probably owing to the number of mares put to them which were deficient in the latter quality. Nevertheless they are both still fashionable, Kingston having 33 and Sweetmeat 19 foals ; Alarm also has 12, but Vatican has only 1.)

"10. The Sorcerer blood, now chiefly to be depended on in Melbourne (almost worn out in the service), and his sons, West Australian, Sir Tatton Sykes, and Oulston. The first of the three is more Waxy than Sorcerer, the second is mixed with Orville and Cervantes, and the third is very much the same combination as that of Sir Tatton. I have fully commented on these horses at paragraph 272. Large, fast, and loose, they require room to display their peculiar powers, which are calculated to shine over a flat, or any straight course, rather than a small and confined one. Few of this blood are neat, and some are peculiarly coarse and gaunt, like the Melbournes, but yet so well proportioned and truly made as to catch the eye of the connoisseur. With large heads, roomy frames, big legs and joints, united to great useful hocks and powerful propellers, they are fit for any work but turning corners, where they are undoubtedly out of their element. Such were the Soothsayers, Comuses, Revellers, Humphrey Clinkers, and Melbournes; together, also, with the last horse's celebrated sons, Sir Tatton Sykes, West Australian, and Oulston. All are fast enough for anything, but require time to fill up their fine frames, and should have been reserved till five years of age, if justice could have been done them. On the whole, this blood may be considered as inferior to none but the three first described strains, in which it is surpassed in persistence of good qualities for a series of years, though, taking any single horse against him, Melbourne will perhaps make a good fight for superiority."

(I have nothing to unsay here, and I may specially call attention to the fact that prior to the appearance of West Australian's stock I had remarked that he is more Waxy than Sorcerer. Many other descendants of Melbourne in the male line are known in the stud, but there are none of any great promise at present.)

TURNING NOW TO TIE BLOOD most suitable for getting hunters, I may be pardoned for again inserting what $I$ have already written in British Rural Sports, comprised in the following words, to which I have now nothing to add, and in which there is little or nothing which I should wish unsaid :-

"For this kind of breeding, nothing answers better than a cross of the Waxy, Orville, and Sorcerer blood, or of the two former with any of the descendants of Sir Peter or Woodpecker; but in all cases provided they have good shoulders, and are sound. Thus, Drayton has been remarkable in this way, as also is Windfall, and Retriever promises to be equally useful. Of all others, the Waxy blood seems to be most telling in hunting stock; and if only it is joined to sufficient size, both of bone and frame, it almost always produces a hunter. The temper, constitution, action, and heart are all good in this strain, and nothing is wanted but the above-named element. Defence is the progenitor of a great number of good hunters, both directly, and through Safeguard and Bath, his sons. Chatham, Cotherstone, Annandale, Weathergage, Newminster, John o' Gaunt, Theon, The Hero, Chanticleer, Harkaway, Connaught Ranger, Footstool, Fugleman, Idle Boy, Newcourt, Ravensbone, and Russborough, are of the very best blood for getting hunters, 
with the chance of an occasional race-horse among them, if put to stout, thoroughbred mares of a sort which is usually large-boned, and of good size. Small-boned horses are not to be thought of for this purpose; and hence the Epirus strain is objectionable on that score, they being smaller in the bone even than the Waxys, and, in addition, less lasting. All the sons of Venison are suitable, but especially those crossed with the Orville or Whisker blood-as, for instance, the Fallow Buck and Red Hart; also Vatican, but that I believe his temper is somewhat ungovernable; and they generally make good hunters, but not with very high action. The Lottery and Tramp strains I have also already mentioned as being valuable for the purpose of getting hunters and steeplechasers; and the following stallions descended from them should be prized when within reach, especially such as are also crossed with Waxy or his descendants-as Birkenhead, Sir Peter Laurie, Footstool, Meteor, Sweetmeat, Tearaway, and his son Kingstown. These also are almost all likely to get good hacks; but the Buzzard and Whalebone blood seems to suit in this way better than most others, except in the case of the Touchstones, which are by no means good in this respect. Defence, on the other hand, who is similarly bred, but without the Orville cross, is famous for getting good hacks, and many of his stock have been very fast and fine trotters - as, for instance, Safeguand and Rector. The former of these horses, though blind, could, when in his prime, bend himself and trot with any thoroughbred horse in the world; and the latter could do his sixteen miles an hour, carrying twelve stone."

I would strongly advise the breeder to select, for the purpose of getting hunters, those horses, whether thoroughbred or otherwise, whose action before is unexceptionable. So many of our race-horses now are full of Touchstone blood, that they are defective in this respect, and are totally unfit for any other purpose.

When Carriage Horses are bred for the special purpose to which they are afterwards devoted, a particular class of stallions is used which is generally only to be met with in Yorkshire and Lincolnshire. These are put to large mares of the same breed, or the latter are sometimes crossed with the thoroughbred. Hacks and light harness horses are bred in small numbers only by farmers, and are generally the result of a cross between small chance mares and second or third rate thoroughbred stallions, or they are the weeds culled from racing or hunting studs, being too small and light for either one or the other purpose.

\section{THE KIND OF HORSE MOST PROFITABLE FOR THE BREEDER TO CHOOSE}

WHEN A PERSON makes up his mind to bestow his attention on the breeding of horses as a speculation, it behoves him to consider what kind is best suited to the nature of his land and the length of his purse, as well as to his own knowledge of horses. Unless he has plenty of fine upland grass and a command of money, it is quite useless for him to think of the racehorse ; nor will he do well, without these concomitants, to dabble in hunters. Cart-horses, now-a-days, pay well when there is work for them to do up to their third or fourth year; and carriage-horses are likewise a good specula- 
tion when the land is suitable to their development. No one, however, should turn his attention to the breeding of hacks on a large scale, since they will almost inevitably cost more than they will fetch at five years old. The farmer who keeps one or two "nag " mares is the only person who can be said to rear hacks without loss; and he only does so because he begins to use them for his own slow work as soon as they are three years old. Even in his case, however, I much doubt whether the same food which has been given the colts would not have been turned to greater profit if given to horned cattle; and the only thing which can be said in favour of the former is, that they eat coarse grass which the latter will refuse. To make the breeding of the horse turn out profitably, the hack and inferior kind of harness-horse ought to be the culls from a lot of colts intended for the hunting-field, and then, the one with the other, they may be made to pay.

\section{CONCLUDING REMARKS ON BREEDING}

The ANGRY Discussions which took place in the year 1860, between Lord Redesdale and Admiral Rous, indicate plainly what is the general spinion on the subject of the diminution in the stoutness of our horses. Breeders, therefore, should turn their attention to this point, and should be doubly careful to avoid weedy or diseased sires and dams. It cannot be denied that our modern thoroughbreds possess size and speed; but they certainly do not shine in staying powers, as I have already more than once remarked. But there are some strains particularly free from this defect, and these I have endeavoured to point out. It should not, moreover, be forgotten that though the thoroughbred horse will bear more work, especially at high speed, than any other kind, yet he can only do this if well fed and warmly housed. Being a native of a warm and dry climate, he requires to be protected from the weather; and the young stock must be well reared in all respects, or they will never pay. If, therefore, the breeder is not determined to put up warm hovels in every paddock, and if he is stingy of his corn, he had far better let his stud of mares be composed of lower-bred animals. If a thoroughbred horse and a donkey are both fed upon the lowest quantity and quality of food which will keep the latter in condition, the donkey would beat its high-bred antagonist over a distance of groundthat is to say, supposing the experiment to be continued long enough to produce a permanent effect upon the two animals. A cart-horse colt, or one of any kind of low blood, will do well enough if reared, till he is put to work, upon grass and hay ; but a race-horse or hunter, of high breeding, would show a badly-developed frame, and be comparatively worthless for his particular kind of work, if he were not allowed his corn from the time that he is weaned. 


\title{
CHAPTER XI
}

\author{
THE BROOD MARE AND HER FOAL
}

\begin{abstract}
HOVEL AND PADDOCK-GENERAL MANAGEMENT OF THE BROOD MARE-TREATMENT WIIEN IN FOAL-TREATMENT AFTER FOALING-EARLY TREATMENT OF THE FOAL-THE WEANING AND AFTER TREATMENT OF THE FOAL-CASTRATION.
\end{abstract}

HAVING ALREADY ALLUDED to the principles which should guide the breeder in the choice of his mares, I need not further allude to them beyond the remark that, independently of those which I have indicated, he must take care that they are each possessed of a frame suitable to carry a foal, and of a constitution hardy enough to sustain the drain upon the system caused by the young animal, both before and after birth. If the pelvis and back ribs are not large and deep, the foetus will not have room to be developed and brought into the world; and unless the mare is a good feeder, and is also furnished with an udder which will give sufficient milk, she will not afford enough nourishment to her foal, which will, therefore, be weakly and badly developed in its proportions. The shape may be easily detected beforehand, but the constitution and milking properties cannot so well be predicated, though the experienced eye and hand of the stud-groom will enable him to give a tolerably correct guess.

\section{HOVEL AND PADDOCK}

IF THE BREEDER is about to undertake the production of a number of horses of any kind, he must establish a regular stud-farm, which for all horses should be on sound upland, with a subsoil of chalk or gravel. The presence of fine white clovers is in itself almost sufficient to show that the soil will be suitable to the horse; but, if possible, there should be an absolute practical knowledge that the situation has agreed with the animal, before any heavy investment is made. If the surface fall is good, draining may not be necessary, but in most cases the herbage will be greatly improved by the introduction of tiles. Low, marshy situations may serve during the autumn months to freshen up a stall horse, but they are utterly unfit for the rearing of young stock, and should be carefully avoided. If the stud is highly bred, and the feeding is to be good, the colts will be very mischievous, and unless care is taken to make the fences safe, they will break bounds, or injure themselves in the attempt. Deep ditches are 
very unsafe, ${ }^{1}$ for the mare as well as her foal are very apt to get cast in them, with a serious or fatal injury as the result. Posts and rails answer well enough, where timber is plentiful, but, in the long run, they are expensive from the necessity for constant repairs. Banks with thorn hedges on the top are the very best of all means for enclosing the paddacks, and are even better than stone walls, which, however, are excellent for the purpose if they have the soil raised against their bases, without which the foal is liable to slip up against their surface, and thus sometimes blemish his knees. There is a great difference of opinion as to the size necessary for the paddocks, and the number of mares which should be allowed in each. In some well-conducted stud-farms, the enclosures are very large, and a dozen, or even as many as eighteen, mares and their foals are turned out together as soon as the weather permits, and the spring grass grows high enough. In others, as at the Hampton Court and Middle Park establishments, the paddocks are each only calculated to take three or four mares and their foals; and the yearlings, also, are never allowed to exceed four in any one paddock. Mr. Martin, the clever and experienced manager of the first-named stud, was of opinion that colts should have room enough to gallop, and thus early accustom their joints and sinews to bear the strains which they must, some time or other, be subjected to. On the other hand, the argument is held that in a small paddock the foal gallops quite as much as in the larger one, and puts his joints to the strain in stopping himself at the corners, whilst there is less injury from other accidental causes, such as kicks and the jamming of a lot together in a narrow gateway. On the whole, I am inclined to believe that the latter plan is the best, for experience shows that a well-fed foal will gallop daily, for hours together, even in a two-acre paddock.

Aт FOALING TIME each mare must have a separate hovel or loose-box, but as, practically, it is found that she always gives some few hours' notice of her approaching parturition, it is the custom to bring her into the close neighbourhood of the house of the stud-groom at night, so that he may be at hand to render her assistance, if necessary. Any loose-box answers for that purpose, if it does not open to a warm stable, which would render it too hot for an animal which has been for months exposed to the open air. But after foaling the mare will also require a hovel to herself for six weeks or two months, when the foal will be strong enough to take care of itself in running among other mares. Indeed, at all times, the mares should at night be in separate hovels, even when during the day they run in the same paddock with two or three others. This hovel should be about twelve to fifteen feet long, and not less than ten feet wide. The height may easily be too great, because in the early spring the weather is often so severe that the mare cannot impart sufficient heat to a very large volume of air. From eight to nine feet will therefore be ample, the former being well suited to the larger area which $I$ have given above, and the latter to the smaller. It is a very common plan, when economy is much studied, to build four hovels back to back, at the angles formed by four small runs, by which a

1 A special instinct is developed in animals bred upon marshes surrounded by ditches, and the foals seldom come to grief if born on the spot, while hill-bred animals brought on to the lowlands are extremely likely to get in the water, especially during thunderstorns. Wo have known farmers in the Cheddar Valley to throw purchased stock into the ditches in order to show them the danger. 
saving in the internal walls is effected. This, however, necessitates a northerly or easterly aspect for two out of the four, either of which is objectionable. Two hovels may readily be placed side by side in the most desirable situation, and these may be made to open into separate runs. The walls should be built of brick or stone, whichever is locally the cheaper material, or where gorse is abundant they may be formed from it, being the cheapest of all. In some counties what is called "wattle and dab" is very generally employed for outbuildings of this kind, and when they are roofed with thatch, which carries the water well off the sides, it answers very well. It is composed of common wood quarterings, with the uprights connected together by transverse bars like the rounds of a ladder, about eight inches apart. When the whole framework is put together thus, some soil, which should be clay or loam, is well worked together with straw and water into a tenacious mixture, which is forked over each transverso bar in succession, and the whole smoothed down till it assumes a regular and even surface. Cottages and outbuildings are put up in this way in Devonshire and Dorsetshire at very little expense, either for walls or roof, wood being also the produce of his own land. The labour, therefore, is the only considerable outlay, and that is not paid for at a very high rate, wages being still very slow. When gorse is used, it is adopted in the following way :-The door-posts and uprights are first fixed, and should be either of oak-which is best-or of good sound Memel fir; they should be about six inches by four, and should be fixed six feet apart, with three feet sunk in the ground. After thus fixing the framework, and putting on the wall-plate and rafters, the whole internal surface is made good by nailing split poles of larch, or other timber, closely together across the uprights, taking especial care to round off the ends when they appear at the doorposts. Thus the whole of the interior is tolerably smooth, and no accident can happen from the foal getting his leg into any crevice between the poles, if care is taken to nail them securely, and to leave no space between them. When this internal framework is finished, the gorse is applied outside, as follows :- It is first cut into small branches, leaving a foot-stalk to each, about twelve or fifteen inches in length: these branches are arranged in layers between the uprights, the stalks pointing upwards and inwards, and the prickly ends downwards and outwards. When, by a succession of layers of these brushy stalks, a height of eighteen inches has been raised, a stout and tough pole, about the size of an ordinary broomstick, and six feet long, is laid upon the middle of the gorse, and so as to confine it against the split poles and between the uprights. The workmen kneel upon this pole, and by its means compress the gorse into the smallest possible compass, and while thus pressed down, and against the internal framework, it is confifed to the latter by five or six loops of strong copper wire. When this is properly done, the gorse is so firmly confined, and withal so closely packed, that neither wind nor rain can penetrate, nor can all the mischief-loving powers of the foal withdraw a single stalk. After fixing the first layer, a second is built up in the same way, and when neatly done the exterior is as level as a brick wall; but if there are any very prominent branches they may be sheared off with the common shears, or taken off with the ordinary hedging bill-hook. When it is desired to make the exterior look very smooth, a hay-trusser's knife is used; but tho 
natural ends, though not so level, are a much better defence, and last longer than the cut gorse. In the interior the stalks sometimes project, and if so they must be smoothly trimmed off. The roof should be covered in with some material, which is cool in summer and warm in winter, and for this purpose, therefore, nothing is so bad as iron, or so good as thatch. Objections are sometimes made to the latter material that it harbours vermin, but if the mares are well fed, I must doubt their ever becoming lousy, unless these parasites are introduced by some animal from without. Tiles are preferable to slates, and on the average they are also cheaper. Pantiles are not easily made proof against the wind, but plane-tiles, when properly pointed, are quite air-tight, and are far warmer in cold weather than slates, while they are also cooler in summer. The door should be at least four feet or four feet six inches wide, and seven feet to seven feet six inches high, with all the angles to the sides and top of the frame rounded off to prevent accident from striking the hip or head. The door, of oak or elm, should be cut in half across the middle, so as to allow the lower half to be shut, while the upper, being open, admits a free supply of air. A small window should be inserted in the wall, for light and ventilation when the door is closed. When straw is abundant it is usual to leave the floor in its natural state, the litter absorbing all that falls from the mare and foal, and being changed often enough to keep the place dry. In case, however, this cannot be done, the flooring should be similar to that for ordinary stables, that is to say, laid with bricks or pebbles, clinkers being much too expensive for such a purpose. Where chalk is abundant, it forms an excellent floor, if a drain is cut all round the building, and the soil being taken out to the depth of nearly a foot, the chalk is filled in to a little above the level of the natural surface, and is then well rammed down, a drain and trap being inserted in the middle. The last point which requires consideration is the kind of manger which is best adapted to the use of the mare and her foal, if the latter is to be fed in the way proper to thoroughbred stock. In any case, a wooden manger of the ordinary kind should be fixed, with a staple for the rack-chain to fasten her up. A hay rack should be so arranged that it can be filled from the outside without diffculty; which is easily managed by building a little wooden excrescence on to one of the outer walls, leaving a hole in the latter for the mare to feed herself through. A wooden lid, covered with zinc, lifts up and permits the introduction of the fodder without the necessity for carrying a fork into the hovel, which will sometimes injure the mare or her foal. Wellbred young animals of this species are so mischievous that when shut up they will jump into any place which can possibly hold them, and many a broken leg or back has ensued from an open hay-rack, placed near the ground, attracting the gambols of a foal. A few wooden bars nailed across the opening effectually prevents this, while the addition of a low manger in another corner provides for the feeding of the foal with kibbled oats, if such should be the plan adopted, and the fourth is occupied by a watertank. External to the hovel the only provision necessary is a yard, which may be omitted if the paddock is always dry from the land being well drained. Unless this is the case, however, the yard should always be provided, as there are many days throughout the year when the weather is fine enough overhead to allow of the foal being turned out of doors with 
advantage, if it can be protected from the wet grass or wetter soil. A yard is, therefore, truly valuable in the absence of a dry soil, and it should be paved with bricks, stones, or pebbles, well covered with a layer of litter, to prevent slips and strains.

\section{GENERAL MANAGEMENT OF THE BROOD MARE}

WhEN IT HAS BEEN DECIDED to breed from a mare, if she is not already thrown out of work, it will often be necessary to cool her down, by turning her out to grass and taking away her corn, before she will become stinted. Thorough-bred mares are not, as a rule, allowed to take the horse while in work ; but sometimes they are so constantly "in use," that no other means will enable the trainer to go on with his work of preparation. There is a wonderful difference in this respect: some animals are rarely "in use," once or twice a year being the outside; while others are so every nine days throughout the spring - the average, perhaps, being in that state at about intervals of two or three months from the time of shedding their coats till the beginning of autumn. Again, some are not upset in their work by this natural process; while others refuse to feed, lose condition, and cannot be depended on for half their usual exertions. Either extreme requires a change of feeding; for, on the one hand, the cool temperament is excited by the freedom of a run at grass, and on the other, the warmer one is benefited by losing the heating qualities of her corn. At all events, it is found, in practice, that though the majority of maiden mares will become stinted while at work, yet that a large number require a run at grass before they will become in foal. As I before remarked, thoroughbred mares are generally entirely devoted to the stud from the time that they are put to the horse; but there are many others of lower breeding which their owners desire to work on for some months afterwards. It is often apparent that the legs of a hack or harness-mare are wearing out, and her owner decides upon having a foal from her, but wishes to avoid the expense of keep from the spring, when he puts her to the horse, till the next January or February, varying, of course, with the time of foaling. All mares are the better for slow work up to within two months of foaling; but they should not be ridden or driven so fast as to occasion exhaustion. Cart-mares are generally used to within a few days of their time, taking care to keep them at light work and to avoid straining them. With these precautions, if the legs keep tolerably sound, a mare may be made to earn her keep for nine months out of the eleven which are the duration of her pregnancy.

THE TIME of sending the mare to the horse will vary with the purposes for which her produce is intended. If for racing, it is desired that she shall foal as soon as possible after the first of January; and as she carries her foal about eleven months, the first time of her being "in use" after the first of February is the period chosen for her. All other horses take their age from the first of May; and as this is the time when the young grass begins to be forward enough for the use of the mare, the breeder is not anxious to get his half-bred foals dropped much before that time. As, however, mares are very uncertain animals, he will do well to take advantage of the first 
opportunity after March, as by putting off the visit to the horse he may be disappointed altogether, or the foal may be dropped so late that winter sets in before he has acquired strength to bear it. These remarks apply to maiden mares only; those which have dropped a foal are generally put to the horse nine or ten days afterwards, when almost every mare is in season. For this reason, valuable thoroughbred mares are often sent to foal at the place where the sire stands who is intended to be used next time. The travelling to him so soon after foaling would be injurious to both the dam and her foal, and hence the precaution I have named is adopted. The mare then remains to be tried at intervals of nine days, and when she is stinted the foal is strong enough to bear any length of journey with impunity. Mares and their foals commonly travel by road twenty miles, or even more, for this purpose; but they do not often exceed that distance, and about fifteen miles a day is quite as much as a nine-days-old foal can compass without injury, and that done very quietly, the mare being led at a slow pace all the way.

Many owners prefer sending them by rail, whether the distance be long or comparatively short. Race-horses are so accustomed to travel by rail that there is less risk in boxing under the superintendence of trained men, than is to be encountered on ordinary roads frequented by cyclists, tractionengines, and other horse-frightening contrivances.

The general custom among breeders of cart and nag-horses is not to send the mare and foal away, but to receive a visit from the horse on the ninth day. I have had mares successfully stinted on the seventh, eighth, ninth, and tenth days respectively after foaling. Some of the stud companies do not let their stallions travel a district, but receive mares as above, while the competition of the present day makes it unnecessary for the owner of a lame mare to send her to the horse.

\section{TREATMENT WHEN IN FOAL}

WheN tHe MARE IS IN FOAL, if not intended to be kept at work, she should be turned out in good pasture; but it should not be so rich and succulent as to disagree with her stomach, or make her unwieldy from fat. The former mistake is a constant cause of miscarriage, the bowels becoming relaxed from the improper nature of the food. On the other hand, if it is not sufficiently good, the mare will become thin, and will starve her foal in its growth. Mares that have been corned highly all their lives should have a feed or two daily, after they are are six months gone, and especially if the autumnal grasses are not rich and plentiful. Most half-bred animals, however, do very well till about Christmas; after which, hay and corn, with a few carrots, should be liberally given them, still allowing them to pick up what grass they can find in their paddocks. Excessive fat is a state of disease, and interferes with the due nutrition of the foetus, while it is very dangerous at foaling-time, when it not only interferes with the process, but also tends to produce fever. Supposing the mare to be at work, she should have some kind of green food-lucerne being the best, and vetches, perhaps, the worst for the purpose, the latter being too heating, especially to the organs contained within the pelvis. Any of the grasses or 
clovers answer well; and, after they are done, carrots form an excellent succedaneum, given sliced in a bran mash every night. By adopting these articles of food, the mare is kept free from inflammation, and yet the foal is well nourished, which are the two essential points to be considered.

EXCITEMENT OF EVERY KIND is a fertile source of "slipping" the foal; and everything which is at all likely to have that effect should be carefully avoided. The smell of blood is said to have a very prejudicial influence in this way; and there is no doubt that one mare miscarrying will in some mode affect others in proximity to her. Possibly the same cause may act on all ; but it seems to be generally concluded that the act is really contagious, ${ }^{1}$ either from what is called sympathy, or in some other as inexplicable way. If a mare has "slipped " a foal in a previous pregnancy, double care should be taken, as she will be far more likely to do so again than another which has hitherto escaped the accident. It occurs most frequently about the fourth or fifth month, therefore extra care should be taken at that time. The suspected individual should be kept quiet by herself; but it is better to allow her the run of a small retired paddock than to confine her to her hovel, where, for want of exercise, she will become restless and anxious. Purging physic should not be given, unless it is absolutely necessary ; and if the bowels are so confined as to require some stimulus of this kind, and bran mashes and other changes in the food fail to produce any effect, choice should be made of the mildest aperient which is likely to answer the purpose. With regard to the management of the mare in parturition, if assistance is demanded, it is safer to have recourse at once to a properly educated veterinary surgeon. Stud-grooms who have had much experience will sometimes be able to aid Nature with advantage ; but, in the long run, they will probably do more harm than good, if they attempt any serious interference.

\section{TREATMENT AFTER FOALING}

IN A HEALTHY STATE, the mare very soon recovers the efforts which she has made in bringing forth the foal; and, in fine weather, she may be allowed to enter her paddock on the second day afterwards, which is generally soon enough to suit the strength of the foal, though occasionally the young animal is very active within six hours after it comes into the world. For a couple of months, or perhaps less in some cases, the mare and foal are better kept in a paddock by themselves; but in a large stud this is difficult when the foals come very quickly; and then several mares of quiet temperament are put together, still keeping separate those which are shy or vicious. Until the mare can get plenty of grass, she should have carrots, bran mashes, and a feed or two of oats, which at first are better given in the shape of gruel-the water with which this is made having the chill taken off. Rye-grass is cultivated and cut for the mares daily by those who have early foals ; but, though it is better than hay, it is not equal to good upland clover-grass. Lucerne is excellent, but it cannot be grown so early as rye. I have already described, at page 187, the proper

1 Recent investigations leave no doubt of the fact that abortion is contagious among bovines, and it may well be supposed that the same is the case among mares. 
time for again putting the mare to the horse, so that I need not enter into that subject here. During the remainder of the time of suckling, no special treatment is required, except to see that the mare is well fed and protected from the weather. At weaning-time she sometimes requires a dose or two of cooling medicine; but generally she is so nearly dry that no interference is required.

\section{EARLY TREATMENT OF THE FOAL}

IF THE YouNG ANIMAL is well formed and healthy, it will require no attention beyond that which I have specified as necessary for the dam. There are, however, several accidents to which it is liable; such as rupture either at the navel or flank, inversion of the feet, etc. ; all of which will be treated of in their proper place. About the time of the mare being "in use," the foal is generally purged a good deal, and a warm drench will often be required. At the end of a month, or sometimes earlier, the foal will eat bruised oats; and highly-bred young stock are generally allowed, from this time, first a single quartern, and then by degrees two quarterns of oats. Half-breds, and even cart-horses, would be the better for this stimulus to development; but if it is begun, it should be continued; and, unless the foal shows such promise that it is expected to turn out extraordinarily well, the extra expense will not be reimbursed, though in the depth of winter a quartern or half a peck is generally given with a little bran, yet, when there is good grass, this is neither necessary nor is it economical. Shelter from the weather should, however, be afforded to colts of all classes during the winter season; and unless they have this, they soon grow out of form and lose flesh, however well they may be fed. It is now fully recognized that warmth and protection from the rain encourage the growth of all our domestic animals; but in none are they more influential than in the one which I am now discussing. A colt neglected in its first winter never recovers its proper shape, nor does it grow into the size and strength of body and limbs which naturally appertain to its breed. Independently, therefore, of the cruelty in exposing the young animal to a climate for which it is not fitted, the plan does not pay; and on the latter account, if not on the former, even the most heartless, who consider their own interests, will make suitable provision for protecting their young horse-stock from the inclemency of our winter climate.

THE FOAL SHOULD BE HANDLED from the very first week of its existence; but there is no occasion to use it roughly in accustoming it to the pressure of the hand on all parts of its body and limbs. If this process is very gradually commenced, no resistance will at any time be offered, and the foal will allow its feet to be picked up, and its head and ears to be rubbed, without taking offence. Grooms are sometimes in the habit of showing off their powers in this way, by taking up the foal in their arms; but this can do no good, and may possibly lead to injury of the walls of the abdomen. About the fourth or fifth month, and before weaning is commenced, a light head-collar should be put on; and after the foal is accustomed to its pressure, by repeatedly handling the part on successive days, a leading-rein should be buckled on, and the young thing enticed to follow the groom 
without any absolute coercion. At the same time, it must be made to feel that resistance is useless; and if it begins to pull, it must on no account be allowed to get away, the groom yielding as long as the foal pulls straight back, but coercing it gently with a side strain. A carefully handled foal will rarely give any trouble in this way; but there is an astonishing variation in the power which different men have over the animal creation. Some will gain control without using the slightest violence, while others will be always fighting with their charge, and after all will not be able to do nearly as much with them as their more quiet and clever rivals. The latter class should never be allowed to have anything to do with young horses; and though there may be occasional exceptions which require severe measures, yet if once a man is found resorting to violence with a foal which he has had the management of from the first, he should, in my opinion, be removed from his post; or, at all events, he should be carefully watched, and a repetition of the offence ought to be considered as a notice to quit. Isong before the coming among us of Mr. Rarey, this was recognized amongst the most extensive breeders of horses in this country; and though cruelty was not unknown among them, any more than it is now, it was fully recognized as not only an unnecessary but an unsatisfactory means of mastering the horse.

\section{THE WEANING AND AFTER TREATMENT OF THE FOAL}

The USUal AGE FOR WEANing the foal is about the end of the sixth month, that time being selected because the dam is generally about "half gone" with her next foal, and cannot bear the double drain upon her system. Nor does the foal benefit much by the milk after this age, the teeth and stomach being quite strong enough to crop and digest the succulent grasses that are to be had from August to October, those being the months during which the several breeds attain the middle of their first year. If the autumn is a dry one, and grass is scanty, a few steamed turnips or carrots may be mixed with bran and given to the foal night and morning; but, as a rule, unless it is to be highly forced into its growth for the purpose of early racing, it will require only the grass which it can pick up when it is turned out. Three or four foals are generally placed together in the same paddock for company, and in this way they miss their dams far less than if confined by themselves. Care should be taken that nothing is left within their reach which can do injury, every fence and gate being carefully examined to see that no projecting bolt, nail, or rail is likely to lay hold of their bodies or limbs as they gallop about in their play. Foals of all ages are mischievous animals, and the better fed they are the more inclined they seem to lay hold of anything which attracts their notice.

Besides tHe Shelter of A HOvel, which I have already insisted on, the foal requires throughout its first winter good feeding proportioned to its breeding and the purposes for which it is intended. Racing colts are allowed three or four feeds of bruised oats with steamed carrots or turnips, and sometimes steamed hay; but the general plan is to give as much as 
they will eat of the best upland hay, in its natural state, after they have finished their allowance of corn. Young stock intended to be sold as hunters and first-class carriage-horses are always allowed half a peck of bruised oats, and a few carrots and turnips will not be thrown away upon them. Hacks, and inferior young stock of all kinds, get through the winter upon hay and barley-straw, part being sometimes cut into chaff, and mixed with a quartern of bran, daily ; and if they are very low in flesh, a few oats being added. During severe frosts the straw-yard is the best place for the foal, on account of the hardness of the ground in the fields, and here he will easily keep himself warm and dry, and he can be attended to according to his wants. Let the breeder, however, constantly bear in mind that a check given to the growth in the first winter is never afterwardss entirely recovered, and that if the colt which has experienced it turns out well he would have been still better without it.

\section{CASTRATION}

THE OPERATION for converting the horse into the gelding is usually performed when the colt is a yearling. In the southern and western counties April and May may be chosen, and further north June and July. The weather should be warm and dry, avoiding east winds, and not deferring the operation till the flies become numerous. Many castrators hold the opinion that "it cannot be too hot for a colt or too cold for a lamb." Although this is somewhat of an exaggeration we would prefer a hot day to a cold one. Much, however, will depend upon the development of the individual, it being ascertained that the longer a colt remains uncut the more is the fore-quarter developed, and especially the head and neck. If, therefore, these parts, as well as the shoulders, are already forward in their growth, the operation should be performed early; while, if the contrary state exists, it should be deferred till a later period.

There is, of course, an element of danger in castration at any age, and with each year it would appear to increase. The insurance companies charge at about the rate of four per cent. for colts under two years. When asked the rate for an eight-year-old son of Bendor, one company replied ten per cent., and another twelve. The greatest age at which we have known a horse successfully operated on, was seventeen (a son of Wild Dayrell). As to the operation itself, the preparation necessary and the subsequent treatment, full directions are given at page 630 . 


\title{
CHAPTER XII
}

\author{
THE BREAKING OF THE COLT
}

MP. RAREY'S MODE OF BREAKING - THE ORDINARY ENGLISH METHOD OF BREAKING FOR THE SADDLE - SUPERIORITY OF THE ORDINARY METHOD - BREAKING TO HARNESS.

The year 1858 will ever be memorable in the annals of the English stable for the success of Mr. Rarey and his partner, Mr. Goodenough, in extracting $£ 25,000$ from the pockets of English horsemen by the promise of a new method of breaking and training the animal which they all loved so well, but so often found not quite obedient to their wills. The plans by which obedience was to be ensured were kept a profound secret, but to prove Mr. Rarey's power, the French coaching stallion, Stafford, the English thoroughbred, Cruiser, and a grey colt in the possession of Mr. Anderson, of Piccadilly, all notoriously vicious, were privately subdued, and afterwards exhibited in public. Subscribers were invited to pay ten guineas each, with the engagement that as soon as five hundred names were put down, the American would teach them in classes, each subscriber binding himself, under a heavy penalty, to keep the secret. The result was that eleven hundred ladies and gentlemen paid their money, and kept their promise so well that until the appearance of a small shilling volume, published by Messrs. Routledge and Co., which detailed the whole process, in the very words given to the American public some years before by Mr. Rarey, no one but the subscribers had any certain knowledge of the secret, although it subsequently appeared that it had oozed out, and had been propounded in several directions as a rival scheme of much older date. However, it is not now my intention to attempt the discovery of the inventor of the system generally known as Rarey's, my sole object being to ascertain its real worth in breaking young stock, and in remedying or curing the vices to which older horses are occasionally subject. It will be seen hereafter that though I think the plan of great service in some cases, I doubt its utility as an aid to the breaker; but, having cost the country far more than $£ 25,000$, and having received the approval of hundreds of experienced horsemen, it would ill become me to pass the subject over without giving reasons for the conclusions to which I have arrived. I was not one of the original subscribers, but I have seen Mr. Rarey exhibit his extraordinary powers over the horse more than a dozen times, so that 
I an in a position to form an opinion upon the whole process as compared with our ordinary English methods, with which I have also long been practically acquainted.

In HIS PUBLIC DEMonstrations Mr. Rarey always commenced by some introductory remarks on the natural history of the horse, in which there was nothing to impress the auditor with any great respect for his powers. At the end of this act, which was evidently intended to kill time, we were put in possession of the three fundamental principles of the new theory of the proper management of the horse, namely:-

First, "That he is so constituted by nature that he will not offer resistance to any demand made of him which he fully comprehends, if made in a way consistent with the laws of his nature."

Secondly, "That he has no consciousness of his strength beyond his experience, and can be handled according to our will without force."

Thirdly, "That we can, in compliance with the laws of his nature, by which he examines all things new to him, take any object, however frightful, around, over, or on him, that does not inflict pain, without causing him to fear."

No one will, I believe, dispute the first two of these principles, which have certainly nothing very novel in them. The third, when promulgated, was more opposed to our experience, and a demonstration of its truth was naturally enough required before it was accepted. To comply with this demana iurse after horse was submitted to an exhausting and painful proof, which I shall presently describe, and then certainly anything which did not inflict pain was borne without apparently producing fear. This, therefore, was proving the letter of the third principle; but was the spirit of it established? The words just quoted, if they mean anything, signify that it is only necessary to allow a horse to examine the drum and he will show no fear of it. But is this the real fact? I trow not. Before a highcouraged horse will allow a drum to be beaten on his back he must either submit to a long course of training under the old system, or he must go through the royal road of Mr. Rarey, of which nothing whatever is said in the three principles alluded to. Take an ordinary hunter after he is exhausted by a long run, and he will bear the noise of a drum, or any other alarming agent, to which he would, when fresh and active, show the greatest objection. Why, then, should we be astonished that a shorter method of exhausting the nervous energy should have the same effect ever if it is shown in a still more remarkable manner, as we shall presently seo it is? As far, therefore, as Mr. Rarey's principles are concerned I have little to say against them, except that if the third is meant to apply to the exhibition of the drum beaten on the backs of his several subjects, it is not very ingenuous in the language which is used.

Before Mr. Rarey came to England he had, as I have already remarked, published in America a little pamphlet which described his several plans for driving a colt from pasture;- driving into a stable and haltering, and the kind of halter used, etc. It also contained an account of an experiment with a robe, showing that the horse, as soon as he discovers by his senses that an object has no power or will to hurt him, goes up to it, and soon becomes regardless of its presence. All these remarks, however, have no interest for my readers, as they are of no utility whatever, 
and the sole remaining contents of the pages which were published by Messrs. Routledge, and received with so much interest in this country, were the directions for throwing the horse, and afterwards handling, or "gentling" him, as the American operator calls the stroking the limbs, which he always puts into practice after the horse is down. If this little book had been published a few months earlier it would have entirely destroyed the pecuniary prospects of the partners, but coming late as it did, it prevented the payment of any more ten-guinea subscriptions, and reduced the charge for the sight of the process to guinea and half-guinea tickets for seats at the Alhambra. I shall, therefore, proceed to describe the casting process, as witnessed by myself, and then examine into its nature and effect upon the horse, whether in breaking or taming him.

The apparatus which is required is, first of all, an ordinary snaffle or straight bit in the mouth, without which nothing could be done with any vicious horse; and if any animal is to be "Rareyfied," the preliminary operation is to get this into the mouth. Stafford was brought to Mr. Rarey with the aid of guide-ropes, which were fastened to his head and held by grooms on each side. In him, therefore, this first essential point was accomplished. Cruiser also had a halter, strengthened with iron, and in him also there was a means of laying hold of the head, which was eagerly seized by the operator. The plan adopted in his case was to fix an iron staple to the door-post, and then running through this a strong leather strap, to which a spring hook was attached, the opportunity was seized when the horse came open-mouthed to the door, and he was securely laid hold of and drawn up to the staple, so as to compel him to allow the introduction of a bit. The grey colt at Mr. Anderson's was bitted; but the zebra was loose in his cage, and I do not at all know how the gag in which he was exhibited was forced into his mouth, but I believe it was effected by a rope thrown round his neck and drawn up to the bars of his cage.

ThE SECOND PART of the apparatus is the leg-strap for the near fore-leg, being very similar to a stirrup-leather, which, with the addition of a strong loop, can be made to answer the same purpose very well. Before applying

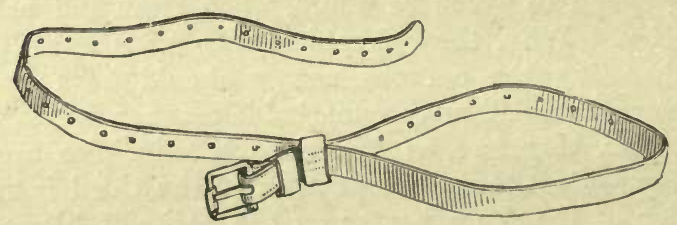

RAREY'S LEG-STRAP. No. 1.

this strap, which at once makes the horse harmless for offence, he must be rendered approachable, which, in ordinary animals, is effected merely with the aid of the bridle. In Stafford, however, as I before remarked, guideropes were used; and in the case of Cruiser, he was enticed up to a wagon loaded with hay, under which was Mr. Rarey, and through the wheel of which this leg-strap was quietly and cautiously buckled on his leg. As soon as this is done the horse is innocent of all mischief except with his 
teeth, for he cannot kick on three legs, and even his mouth may be kept away from the operator by drawing on the off rein. To bring him speedily to submit to the power of the operator, the other leg must also be confined, which is effected by first buckling on a surcingle, as represented in the

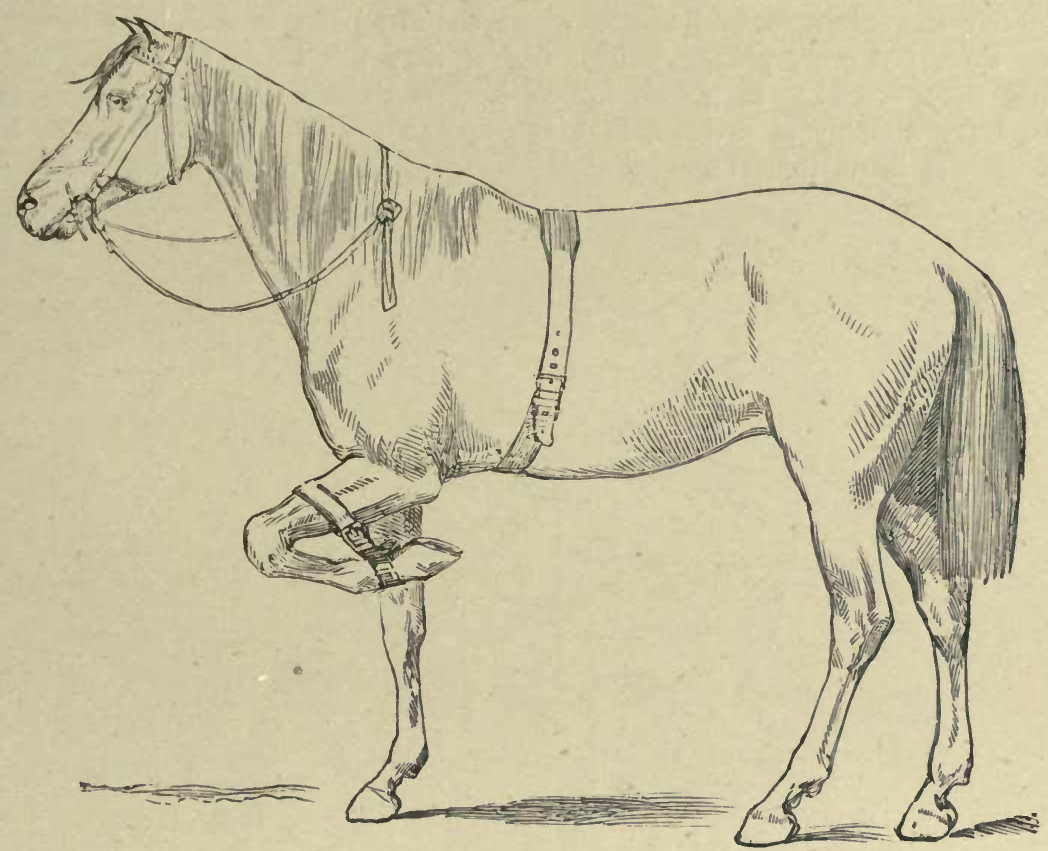

ORUISER WITH THE LEG-STRAP AND SURCINGLE ON.

sngraving, and then catching the off fetlock in the running noose of legstrap No. 2, which is made in the annexed form. Provided with this

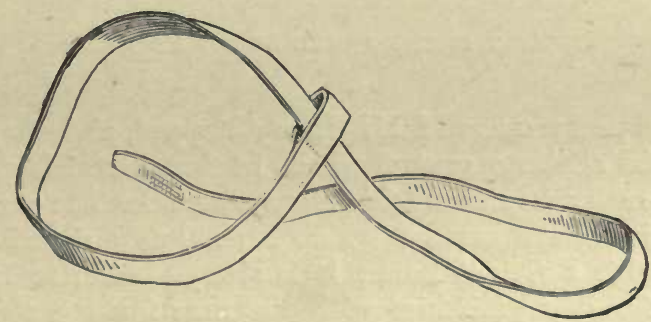

Mr. RAREY'S STRAP. No. 2.

second strap in his pocket, and having already applied the leg-strap No. 1, and the surcingle as shown above, the subject under manipulation is either induced to drop his off foot into the noose, or it is slipped round his ankle, while the off rein is held by the other hand to keep the teeth off the operator. As soon as this loop is firmly drawn round the leg, the other 
end is slipped through the surcingle under the belly, and entire control of the horse is only a work of time. The arrangement of these straps is well shown in the engraving, where Cruiser is sketched ready for the final struggle. Up to this time, almost every horse will be tolerably quiet and unresisting, some squealing when any approach is made to their elbows to tighten the surcingle, and others when the strap No. 2 is slipped through it. Few, however, plunge much; and if they are made to hop on three legs, they are able to go on for so long a time, without producing the necessary amount of fatigue, that the operator would be tired before his pupil. It is at this stage-that is to say, with the use of the leg-strap

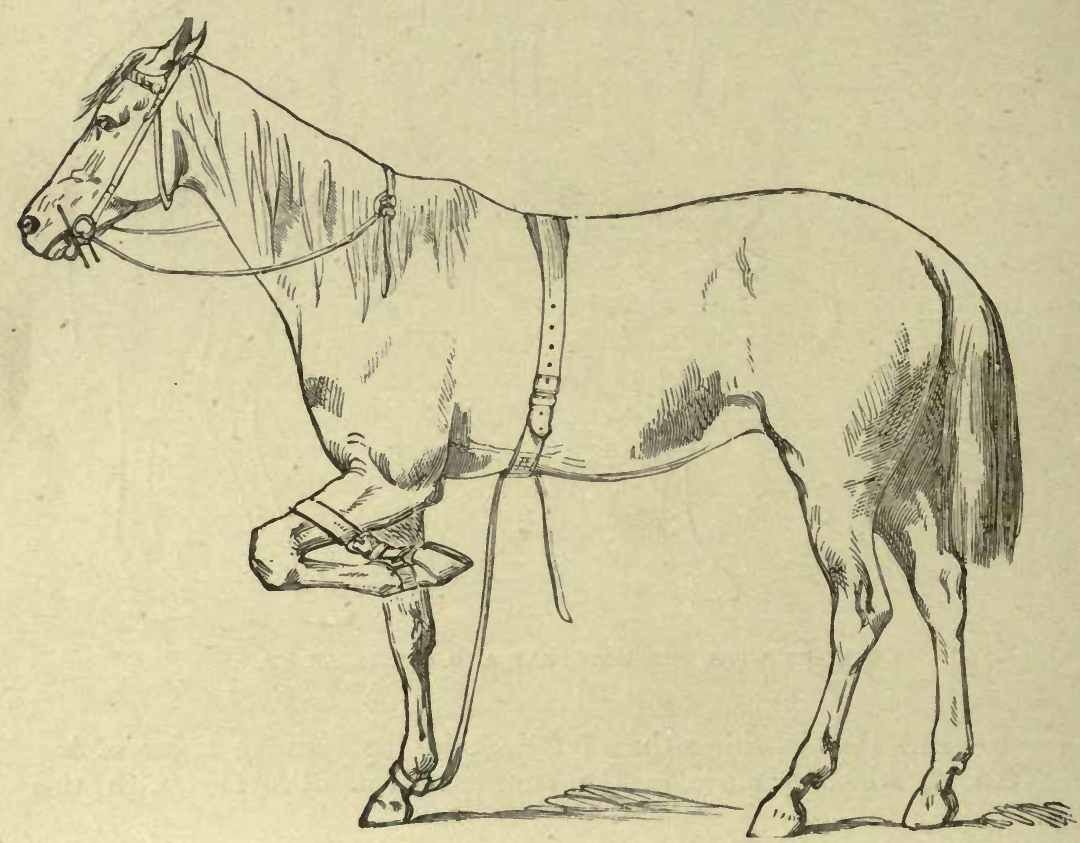

CRUISER IN THE POWER OF HIS MASTER.

No. 1-that the predecessors of Mr. Rarey stopped, and they consequently failed to gain the absolute control which he has invariably obtained with the slight, but really important, additions which he has made, and which he uses in the ingenious manner which I shall now describe. It may be observed that, with a violent horse, it is always better to let him feel his want of power for doing mischief with the near fore-leg strapped up, and the slight degree of fatigue which a few minutes' hopping will produce, before the second strap is called into play, especially if the operator has not acquired great skill in the use of the apparatus. When this is done, and the second strap is applied, and slipped through the surcingle, as shown above, taking care to put a stout glove on the right hand, the left rein is taken in the left hand, and gently jerked-using, if necessary, the usual slight stimulus with the tongue, to make the horse 
move, which he can only do by raising the off fore-leg off the ground in the action known as hopping. The moment this begins, the right hand firmly draws the off leg up to the surcingle, and keeps it there, when the horse must either bound into the air on his hind-legs, or he must go down on the ground, supported from falling on his side in the attitude of kneeling. To avoid mischief, therefore, the loose-box or yard where the operation is carried on should be thickly bedded with straw; for no knee-caps are stout enough to protect the joints from injury on hard ground; nor, if they escape being bruised, will the shock to the body on falling be at all safe. Even straw can hardly be relied on, if the floor beneath is of brick, stone, pebbles, or hard natural soil ; for it is apt to give way during the struggles

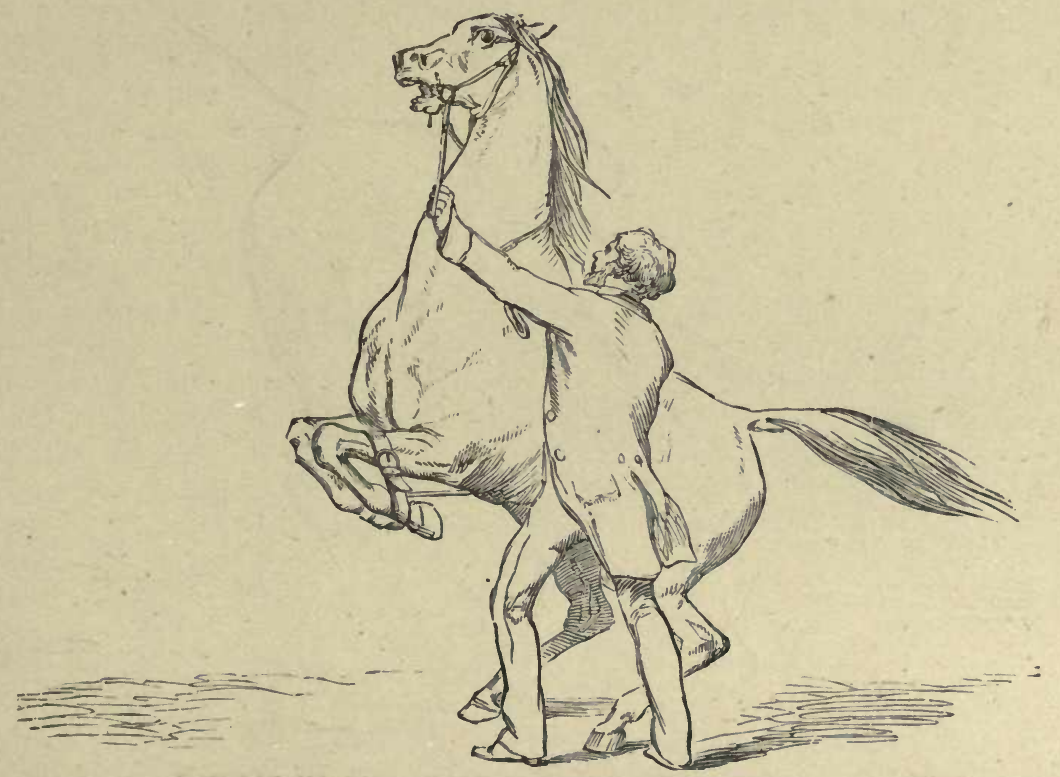

TAS HORSE BOUNDING ON HIS HIND-LEGS.

of the horse, and allow the knees to reach it without the intended protection. When, therefore, there is no tanned riding-schcol, or other similar surface, at command, a good solid bed of manure (which is always to be had wherever horses are) should be spread a foot thick at least, and over this clean straw may be laid. To return to the subject of the operation, whom we left with the alternative of bounding in the air on his hind-legs, or falling on his knees in the annexed attitude (page 198), the chief art in managing this part of the process is to keep firm hold of the strap attached to the off leg close to the surcingle; the hand being protected by the glove, can easily prevent it from slipping through during the struggles of the horse, and at the same time serves as a point d'appui for the operator, so that he can follow the movements of the bounding animal in whatever direction he may progress. The operator must on no account attempt to stand away from his patient, nor must he advance before the girth-place: but keeping 
close to this, he is in no danger, provided he has the sense and the ability to give way if the horse should throw himself down towards his side. The rein, being still held in the left hand, prevents the horse falling away from the operator, and is also used by him as a means of guiding the animal, if he happens to progress in a direction which is not desired. Nothing else is to be attempted till the horse has quite exhausted all his energies, which those possessed of high courage will soon do; but low-bred animals are very apt to turn sulky, and, refusing to plunge, remain on their knees, in spite of every kind of stimulus which can be given them short of severe punishment with the whip, which is to be avoided, as opposed to the principles on

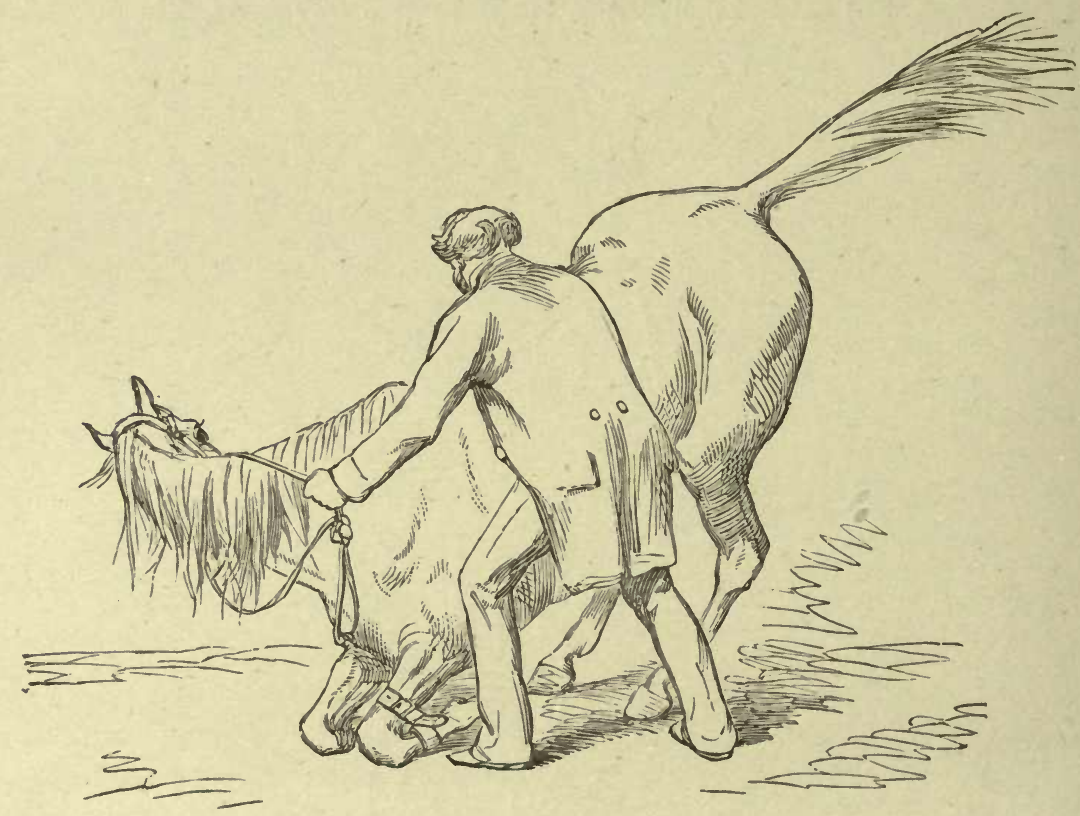

THE IORSE ON HIS RNEES, ABOUT TO FALL ON HIS SIDE.

which the whole process is founded. By taking time with these brutes, they may always be made to tire themselves, for the kneeling position is very irksome to them, and the most stubborn will give a plunge now and then to relieve themselves, though they will not follow up one with another as speedily as a thoroughbred. Sooner or later (the time varying from ten minutes to two or three hours), the tail begins to tremble, the flanks heave, and a profuse perspiration breaks out, which are signs that the horse of himself desires the recumbent position, and will lie down of his own accord, if not pulled over by the right hand of the operator. Mr. Rarey, in his public exhibitions, has never, as far as I am aware, waited for this to take place, but, perhaps to prevent wearying his audience, has always pulled his patient over on his side as soon as he could accomplish the feat. In many cases, this impatience has led to a partial failure; the horse, not being tired out, has refused to submit, and it has only been after repeating the process 
once or twice that complete control has been obtained. Those gentlemen, therefore, who wish to try the experiment for themselves will do well to avoid any risk of a repetition, which they may not be able to manage with the dexterity of the great American tamer. Let them wait till the horse is thoroughly tired, and then only interfere to such an extent as to keep him leaning towards their side, by laying hold of the right rein instead of the left, as shown in the engraving at page 198 ; and drawing the head away from themselves. Mr. Rarey generally used the right hand for this purpose, when he wished to throw his patient before he was exhausted, because he could in that way employ more force; and, at the same time, his dexterity was such, that, if a bound was made, he was always ready to hold the strap attached to the off foot before the horse could get fairly on his hind-legs. In whichever way the task is accomplished, the effect is apparently the same-the horse lies extended on his side, panting and sweating, in the most exhausted condition: but, of course, showing more of these symptoms of distress the longer he has been kept resisting the restraints put upon him. Now comes the test of the practical ability of the operator; for whereas before he had only plain directions to carry out, he has at this stage to judge how far his efforts are successful. If he takes off the straps too soon, the patient is patient no longer, but rises rapidly, and perhaps rewards him by planting a severe blow on his ribs. It is here that Mr. Rarey displayed his great skill to perfection. Apparently by intuition, he knew when his pupil was mastered; but, as he was always ready to explain, it was really by two symptoms that he judged whether he had gained the mastery or not. One of these was the expression of the eye, which it would be difficult to describe, and which experience alone could adequately convey to those who wish to understand it; but the other, being readily tested, is within the reach of every one. This consists in the entire flaccidity of the muscles of the neck and limbs; and until this is ascertained to have been obtained, the straps should not be entirely removed. Mr. Rarey's plan of proceeding at this stage was the following. A second or two after the horse went down, he let him raise his head, and then dragged it down again to the ground by the mane. On repeating this once, twice, or thrice, the animal would give in as far as that part was concerned; and being rewarded with a pat of the hand, the head remained still on the ground, and that part was "gentled." Next removing the leg-straps, the fore-legs were separately gently rubbed downwards; and on being lifted, and let fall, as if dead, they also were passed as in a similar satisfactory state. The operator then going round by the back, proceeded to gentle the hind limbs; and though, in vicious horses, he sometimes had narrow escapes of being kicked, yet, by his great activity and clever mode of seizing his opportunity, he always succeeded in keeping out of harm's way. Finally, the operator passed in front of the legs, and performed all the usual "claptraps" of putting his head between them, knocking the hind and fore shoes together, standing on the body, etc. While in this state, the horse lies in the attitude and with the expression which is very well represented in the accompanying sketch, and there he will gladly lie as long as he is permitted to do so. But he is not to be allowed to recruit his powers; and as soon as he had gone through the tricks which I have described, Mr. Rarey made him rise, and then showed that the power which he had gained was not lost 
as soon as the animal stood on his legs again. Calling for a saddle, it was in every case shown to the horse, and put first on his head, then on his neck, and finally in its proper place. The animal then always submitted to be mounted, and even allowed the dangerous plan recommended and adopted by Mr. Rarey, of standing close to the hind-quarter while putting the foot in the stirrup, to be carried out without kicking, which before the "Rareyfication" most of the vicious brutes operated on in public would probably have done.

BY THIS PLAN, it is indisputable that any active man, of good temper, but possessed of firmness and courage, and accustomed to deal with horses, may gain such a control over even the most vicious, that he can do what

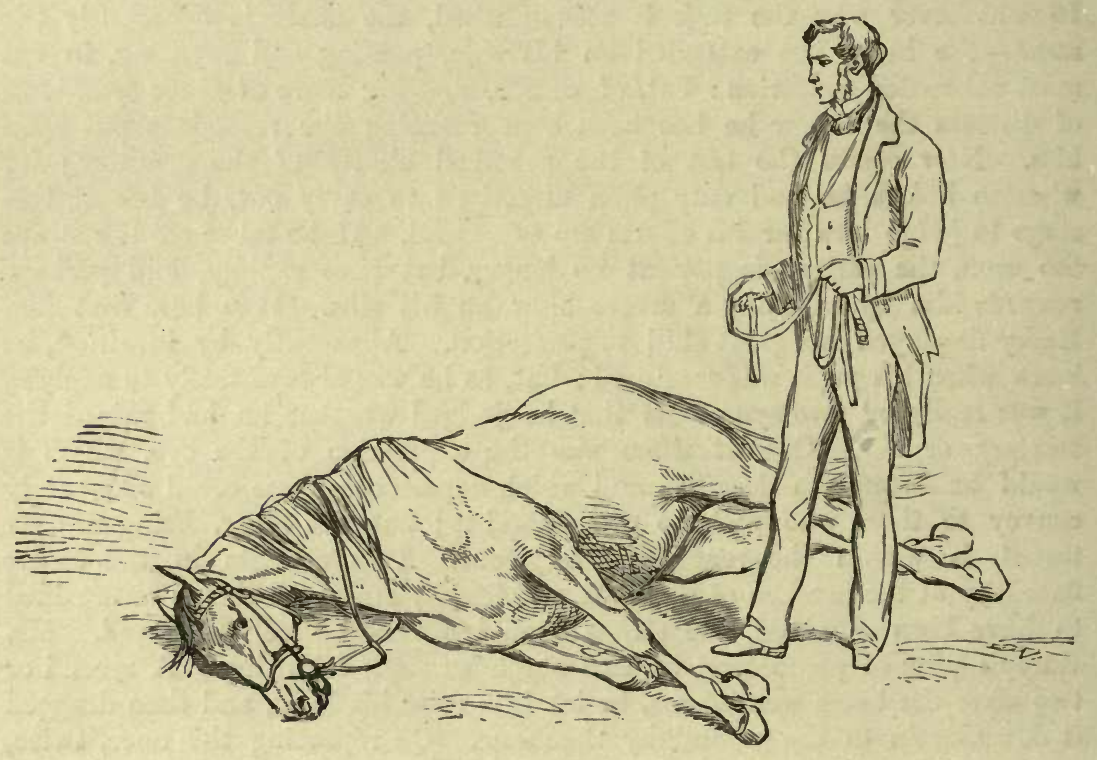

THE HORSE TAMED.

he likes with them indoors. No one who has examined into the matter can doubt Mr. Rarey's power, nor can he refuse him the merit of improving upon the old system of controlling the horse, by the addition of the second leg-strap, which adds so much to the power of the human arm, that the most violent and muscular horse has no chance whatever. The secret lies in two essential features; first, that the horse must never be coerced or resisted unless the man is certain of success in controlling him; and, secondly, that when the former is thoroughly convinced of his powerless condition, and his muscles are tired out, the latter interferes and relieves him of his trammels, "gentles" him, gives him kind words, and at length encourages him to rise. The effect is marvellous-the most vicious brute, who would previously tear any man to pieces, after he is thus first coerced, and then "gentled " and relieved, appears to grow fond of his master, and follows him about like a dog. Clearly, therefore, Mr. 
Rarey may be considered as having been eminently succensful in propounding a system of horse-taming; but it by no means follows that his process is equally, or even at all, useful in horse-breaking. There are other questions, also, which remain to be considered in relation to the method which I have described. First, Is it permanent quoad the individual who has carried it out? Secondly, Does the vicious horse who has been subdued and "gentled" by one man, show the same absence of vice towards others? And thirdly, Is he injured in any way by the operation? On the first of these points there appears to be strong evidence that, if the operator gives occasionally a very slight reminder of his powers, the effect of one, two, or three lessons, repeated at short intervals, will continue for at least a year or two. There are numerous instances which have come to my knowledge of horses resuming their vicious habits within two or three months of receiving such a lesson from Mr. Rarey that they would allow him to do what he liked with them; but in the case of the savage Cruiser, there is reason to believe that he never once rebelled against his master from the time that he first gave in. In his case, however, the operation was repeated hundreds of times; and therefore it does not go so far as I have stated to be the rule, but others might be adduced which keep strictly within it; and there are also private individuals who have practised on horses which have never been exhibited in public who have kept up their control unimpaired. The evidence in favour of the lasting nature of the controlling power, when exercised by the operator himself, is too strong to be gainsaid: and the first question may, I think, be safely answered in the affirmative. But in reference to the second, the evidence is all the other way; and on putting Cruiser into the witness-box, he would tell us that he has several times turned against his groom, and put his life in danger. Still, it must be remembered that, prior to his treatment by "Rareyfication," no man dared enter his box; and on comparing his two states, before and afterwards, it may be truly said, that though not absolutely cured of his vicious propensities, he is comparatively so. Probably the same conclusion may be arrived at in those cases which are related of relapses from virtue to vice; but, at all events, such instances are numerous enough, and attested in a manner so respectable, that every possessor of a coerced horse should be always on his guard. The last question is somewhat difficult to answer, because the injury, if real, is not apparent. The chicf means of testing the effect is on the powers of race-horses, several of which have felt Mr. Rarey's straps, and been controlled by his master hand. Now, I believe, there is no instance of a horse which had gone through the operation, doing any good subsequently on the turf. All have shown either a want of speed or heart; and whatever has been the cause of this, they have run behind those animals whose form was considered by good judges to have been previously inferior to them. Thus, Mr. Merry's Miss Finch, when she first appeared, beat several fields of first-class two-ycar-olds; and it was generally believed, when she afterwards was beaten, that it was only because her temper was so bad. Yet when this defect was so far remedied by the process I am considering, that Mr. M. Dawson could ride her constantly as a hack without much inconvenience, she never recovered her racing powers, and neither in private (as I have been informed), 
nor in public certainly, did she ever exhibit any upproach to her former speed.

ON THE WHOLE, THEREFore, it may fairly be concluded that Mr. Rarey's plans are well adapted for the control of vicious horses, supposing they are not subsequently wanted for the turf, in which case the utility of the process is very questionable. As, however, all our horses are not vicious, and as by the casting and gentling nothing more is effected than a general control, it remains to be considered how far this is useful in breaking colts for general purposes. My own belief is that it acts by producing in the horse a compound feeling of fear and gratitude, the former being the result of his fruitless efforts to get rid of the controlling hand of man, and the latter being established from finding that hand relieve him of his straps, and then caress and "gentle" him. If, therefore, any horse, even without vice, is required to exhibit to his master or mistress any relations more intimate than those which are usually practised in this country, great advantage will result from the establishment of this fear and gratitude. With the exception, however, of cavalry and circus horses, we generally content ourselves with that amount of intercourse which is acquired in the saddle, and we do not want our hacks to exhibit tricks, nor do we require them to follow us about at liberty like our dogs. It has been attempted to show that this particular plan gets rid of a great deal of cruelty to the horse, but this is altogether unfounded, for long before the great American trainer made his appearance, writers on the horse had denounced its use, and though many cruelly severe breakers and grooms existed, as they still exist, yet they were exceptions to the general rule. Cavalry horses, especially when on service, are required to submit to the control of the men in many ways which are never in demand for hacking or hunting, and the mere power of compelling the horse to lie down and remain on the ground is worth a great deal of trouble to acquire. As far as they are concerned, I think the use of Mr. Rarey's straps most valuable; and it must be remembered that this was all that the Canadian military authorities certified in their recommendations which Mr. Rarey brought with him across the Atlantic. The clever management of his partner, Mr. Goodenough, and the profound secrecy maintained for so long, carried the public away far beyond this, and, as in the fable of the fox who had lost his tail, all those who had spent their ten guineas were anxious to place their friends in the same predicament. This is the only way in which I can account for the extraordinary conclusions to which so many practised horsemen arrived in 1858. Since that time, it is true, the fashion has subsided, and a more temperate view has been taken, the general opinion of good judges being, I believe, pretty much in accordance with those which I have always held publicly and privately, and which I have here endeavoured to convey to my readers.

BEFORE PROCEEDING TO INQUIRE into the merits of "Mr. Rarey's plan as compared with our own mode of breaking, it will be well to describe what the latter is, and then ascertain which is the best mode of carrying out our object. No horseman in this country would dream of using the animal he intends to ride or drive without the control of a bit, and although he may aid this powerful instrument with his voice, his leg, his whip, or his spur, yet it always has been, and still is, the chief 
agent in the management of the horse. Again, no colt is to be considered as broken until his rider or driver has altered his paces, and given him such an action in the walk, trot, canter, and gallop, or in some two or three of these paces, that he has become pleasant and safe. Now the plans which I have just described do not affect either of these objects, indeed their tendency is rather to interfere with the making of a good mouth, for the bit will sometimes cut the angles of the lips, and in this way tend to make it afterwards dull. I do not mean to assert that this is necessarily carried far enough by Mr. Rarey to make his plan objectionable on that account, but merely that if anything is done towards breaking a colt, it is injurious rather than beneficial, with the single exception of the establishment of a mental control, which, as I shall presently show, is not wanted in more than one or two per thousand of our horses.

Although, at the time of Mr. Rarey's successful exhibitions in this country, there were persons claiming to have practised the same methods previously, he is to all intents and purposes the founder of a system which has had many successful imitators. Very considerable improvements have been made in the way of hobbles and horse-gear generally, and this chapter cannot be brought to a close without a tribute to the skill and inventive genius displayed by Captain Hayes, whose work on horse-breaking may be taken as the latest and most complete exposition of what he insists should be considered a science as well as an art. "Professor" Crocker and "Professor" Sample and others have been able to exhibit great mastery over horses and interest spectators, but as authors professing to instruct the average reader we cannot give them unqualified praise.

\section{THE ORDINARY ENGLISH METHOD OF BREAK- ING FOR THE SADDLE}

IN THIS COUNTRY the breaker of the hack is not only supposed to produce in his pupil what is called a good "mouth," but also to teach him the use of his legs, so as to give a pleasant feel to his rider in the walk, trot, and gallop, and in the canter, where specially required. The race-horse is only "mouthed" and "backed," his subsequent education being confided to the trainer; and the hunter, in addition to these developments, is taught to get over the various fences which he is likely to meet with, in a clever manner. Lach class must, therefore, go through the same preliminary process, which consists in producing a good mouth, and in making the colt bear his rider patiently in the saddle. To effect these objects, when the colt is running at large he must be caught and haltered, and I shall now proceed to show how the matter is effected $a b$ initio. In doing this it will be necessary to examine into the best apparatus for carrying it out.

The Halter, which in this country is generally first used, is the ordinary one, made of hemp-webbing, for the head, with a running eye in the back of the nose-piece, in which runs a stout rope attached to the head. Thoroughbred colts are always made to carry a light leather head-stall from the end of their first year, and so, indeed, are all well-bred yearlings 
of any value. The large mass of colts run unhaltered till they are to be broken, which is generally commenced when they are three-year-olds. ${ }^{1}$ Ponies and small hacks are then often taken into use, the latter being quietly ridden by the breeder for his own purposes till they are four or five years old, when they are sold. Mr. Rarey recommends for all purposes a leathern halter, made like an ordinary head-stall, but rather lighter. This is at once put on the colt, and by buckling a leading-strap to the nose-band, either before or behind, anything may be done which is required, short of mounting. Two small billets and buckles attach any bit which may be selected to the rings which connect the cheek-pieces to the nose-band, and thus the halter is converted into a very useful breaking bridle. It wants, however, the stiff padded nose-band of the cavesson, but this is only required with very violent and determined colts. The annexed engraving represents Mr. Rarey's halter-bridle, with his ordinary breaking-bit.

The BIT which is usually employed in England for colts is a heavy smooth snaffle, with a tongue-piece and keys depending from its central link. For racing colts a very excellent bit is used extensively, consisting in a mere smooth ring of iron, with a loop on the upper part for attachment to the head-stall, in the same way as in Mr. Rarey's bridle. In front of this loop the ring is introduced into the mouth, and the back of the circle takes the leading-rein, which is thus allowed to slip on either side, and keep a secure hold of the jaw however much the colt may pull at it. I have a dislike to the snaffle for colts, because I have found it constantly pressing on one corner of the mouth more than the other, the animal putting his head on one side, and leaning upon that half of the mouthpiece, so as to relieve each side of the jaw alternately, instead of allowing the two divisions of the snaffle to bear equally on the angles of the mouth. I much prefer a bit made with an unjointed mouthpiece, curved in a segment of a circle, with the usual tongue-piece and keys attached to the middle by a roller. This curved mouthpiece should have smooth rings turned upon it, which will prevent the horse from rubbing his lips from side to side, and tend to form a very pleasant and delicate mouth. I have known it used with great success in breaking hundreds of colts, and I have myself found its advantages in a great number of horses, young as well as old. These, together with a martingale, buckling on to the bit, are all that are required for making the mouth.

In ADDITION to the apparatus for this part of the colt's education, arrangements must also be made for accustoming him to bear the weight of the rider, and for attaching the bit to some part of the body. In commencing the breaking it is customary to put on merely a roller with a leathern surcingle over it, kept in its place by a crupper, which, for facility of putting on, should have a buckle on one side. In front of the surcingle, on each

1 In many breeling districts colts are broken at two years old and given another year's run in which to develop. It is found that a two-ycar-old is more easily broken, as being more impressionable and more rearlily fatigued.

The halter is put on sucking colts during the first month by many good farmers, as their strength is not great and they soon succumb to superior force and never forget the lesson. For various rensons, such as illness or sale, it becomes necessary to secure a colt at almost any age, and a preliminary tussle with the halter is not a good preparation for the trcatinent of a young animal that is sick or in acute pain, or to be led or driven a journey. 
sile, two buckles are stitched, serving to attach the reins either high up, or even crossed over the withers, or low down, or sometimes both high and low. What is called a dumb-jockey may be attached to the roller, lout this is frequently dispensed with, though with the elastic reins introduced by Mr. Blackwell I think it may be made very useful. Lastly, to the crupper long hanging straps are attached, so as to accustom the young animal to the pressure of the coat or habit. Provided with this apparatus,

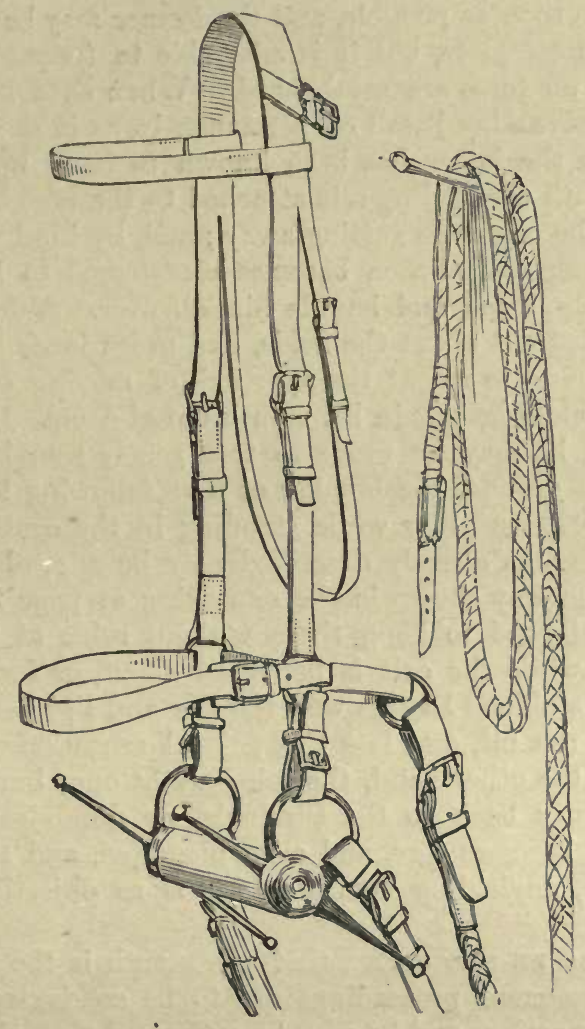

MR. RAREY'S HALTER OR BRIDLE FOR COLTS.

and with a lorg leading-rein of webbing, the breaker is prepared to subdue the wildest colt.

THE FIRST THING TO BE DONE is to get a halter or head-stall on, which is only to be effected either in a stable or similar enclosed place, or among a herd of other horses, when the colt is so closely packed in that he cannot move. Every one must have seen the Welsh and Irish drovers rush into the middle of a herd, and seizing an unbroken colt round the neck, hold him till a halter is slipped over his head. The same plan greatly facilitates the haltering of any colt; but a couple of steady horses are quite enough to keep a colt steady in any building or small yard. The breaker arranges so as to have one on each side, and then going up between them, he has the 
colt held for him while he very slowly and quietly insinuates his hand, with the head of the halter in it, over the neck, just behind the ears. With a little dexterity, this is soon done, and then the nose-band being slipped into its place, a good hold can be secured. Every horseman must, however, agree with Mr. Rarey, that the rope halter with a running noose is most improper, and that a leathern head-stall should always be chosen. It is quite true, that a single turn of the cord of the halter into a half-hitch prevents all mischief, and this is done by good breakers; but the head-stall or cavesson should be put on as soon as possible, and the former may be worn constantly till the breaking is complete, but it is advisable to frequently examine the skin and see that no sores are established. When shod behind it is not a very safe plan to leave a head-stall on permanently, as in scratching the head with the hind-foot the latter has been known to hang up and result in a fatal accident. With the leading-rein attached to the nose-band, the breaker can now restrain the colt from getting away; and, by kind words and gentle treatment, the young animal soon becomes accustomed to his presence, and will allow him to approach and handle him all over. When this is borne easily, he may be led out about the fields, and green lanes if there are any ; but while he continues to resent the approach of moving objects by violent bounds, nothing should be put in his mouth out-of-doors. If he is very wild and ungovernable, he may be made to trot gently round and round in a circle on some soft ground, the breaker at first following him up, but soon being enabled to "longe" him while standing in the centre. After a day or two, the breaking-bit already described may be slipped into his mouth, and attached in the way shown in the engraving at page 205. It should, however, only be allowed to hang there without reins at first, and it may either be kept on while the colt is being led about, or for an hour or two daily while in the stable. In this way the jaw and lips become accustomed to the pressure of the bit, and lose the painful sensation which it at first occasions. If, on the other hand, the reins are at once buckled on, and are then strained tightly back to the surcingle, or dumb-jockey, the delicate mucous membrane becomes sore, and even ulcerated, and the foundation is laid for that dull, unyielding mouth which is so objectionable on every account.

IT SHOULD NEVER BE FORGOTTEN, that the mouth is the foundation upon which all the subsequent proceedings are to be conducted. A horse may naturally have fine action, and he may be so framed that, if he were properly bitted, he would be a delightful hack or hunter; but if his mouth is spoiled in breaking, his fine action is thrown away, because it cannot be regulated and controlled by such a trifling exercise of strength in the hand and arm as is consistent with riding for pleasure. Many a pulling brute has won a steeplechase, or shown to advantage in the hunting-field, with a professional "up," which would not be ridden for ten minutes by an amateur who could afford to make his own selection. Hence, the first thing which the breaker has to set about is the formation of a good mouth; and this is exactly what Mr. Rarey's plans fail to provide, and, indeed, it is what they interfere with in a great degree, as I have observed at page 203. Well, then, let us examine into the received mode of obtaining a good mouth in England. M. Baucher has carried the European principles of producing it to a very high degree, and it will be necessary to allude to his plans also; but, on the 
whole, I cannot but think them superfluous for ordinary purposes, and should be perfectly content with a horse broken in the best English methods, which now combine the "supplings" of the great French breaker with the old dead pressure adopted in the methods of our ancestors. The difference between the two is mainly this, that wo in England content ourselves with confining the head by the reins in a position which, while it does not compel the horse to lean upon his bit, yet makes him try to avoid its pressure by bending his neck, and thus rendering its muscles supple. M. Baucher, on the contrary, prefers that the whole of this suppling shall be performed by the pressure of the breaker's hand; and, doubtless, his is the best plan, if the man employed is competent to the task, and the time thus devoted can be afforded. It takes a fortnight or three weeks to "make" a horse's mouth, so far as to fit him to bear the hands of his rider, in either way; but as less than two hours a day during that time will not suffice, and as in the one case the horse supples himself, while in the other a man must effect the change, M. Baucher's method costs twenty-eight hours of skilled labour, in addition to subsequent breaking, and it is therefore very expensive. The course of proceedings which good English breakers now adopt is as follows. The bit having been allowed for some days to remain in the mouth without reins, as already described, the breaker next proceeds to attach a rein to it in the ordinary way, and to buckle this loosely to the surcingle or dumbjockey, whichever he may employ. Mr. Blackwell's india-rubber reins are thought very highly of by some for this purpose; but, as far as I have tried them, I prefer plain leather, because I object to constant pressure, however slight, upon the mouth. A drop of water falling constantly and regularly upon a stone will wear it away sooner than the same quantity dashed at once upon it; and, in the same manner, permanent gentle pressure upon the mouth is more irksome than a more severe occasional pull. The great art consists in shortening the reins so gradually, that the pressure can always be avoided by bending the neck, and this the horse soon learns to do; and thus, at one and the same time, he gains control over his muscles, and inures his jaws and lips to the bit. It is generally necessary, while the "bitting" is going on, whether in the stable or at exercise, to fix the head down by a martingale, buckled to each side of the bit; for without this the horse, in his struggles to get rid of his restraints, will often toss his head so high as to do himself a serious injury. If the mouthing is conducted in the stable, the horse is either put into a loose-box (which is the best plan), or he is turned round in his stall, and kept in that position by buckling the ordinary pillar-reins to each side of the bit. At first, the reins should hardly confine the head at all beyond the position in which it is naturally carried when the horse is excited; but each day a hole or two may be taken up, until such pressure is made, that the horse has a tendency to relieve his neck and shoulders by advancing his fore-legs and rounding his neck. The best plan is to put on the breaking tackle for an hour in the stable, then loose the reins for a quarter of an hour; after which the colt may be led out for his regular daily exercise, and may be "longed" with the reins buckled more or less tightly, according to the experience of the breaker and the condition of the mouth. In most cases, the process is hurried far too much; the breaker contracts to do all that is required for a given sum, varying from one guinea to three, and it is his object to spend as little time over each of his pupils 
as will serve to make them barely rideable. This is objectionable in principle, though it is very difficult to know how to improve upon it without running the risk of extortion; but when a colt is to be broken for the use of the owner, or any of his family, he will do well to see that plenty of time is devoted to the formation of the mouth, and this I have already said should extend to a fortnight. If the breeder has a lot of colts which are to be placed in the breaker's hands, the latter can, with the assistance of a few lads, go on with a dozen at the same time, and in that way too great an outlay of money is avoided; but if there is only one in his hands, he can hardly do justice to his employer at the ordinary rate. Hitherto I have only alluded to longeing, without describing it or alluding to the object with which it is adopted. I must now, however, say something more about it, because in this stage it becomes an important element of success. It may be remembered, that $I$ have laid down a fortnight as the least interval which should elapse from the commencement of breaking before the colt is fit to be backed with safety to the breaker or his assistant. Not that he may not be ridden in much less time than this, but that if he is, it will be at the expense of his mouth. Longeing is a means of at once giving exercise in a short space of time, and also of accustoming the colt to use his limbs while some degree of pressure is made on the mouth by the bit, without giving himself pain from moving the head. Now, the act of keeping this part still necessitates an even and smooth style of going, and so all things work together to produce the pleasant feel which is given to the rider by a perfect hack. A good mouth may be acquired in the stable, but it is soon spoiled out-of-doors, either by longeing in a hurried manner, or by the bad hands of the rider, whether breaker or subsequent user. To keep it great eare is required at every stage of breaking; and none but a man possessed of head, temper, seat, and hands can finish a colt as he should be turned out. Longeing, therefore, I hold to be a most important part in the art of breaking; and its absence from Mr. Rarey's principles and practice shows that he has taken the dull pulling mouth of the American horse as his model, and not the beautifully yielding, yet steady one of the English hack.

At length, when the breaker is satisfied that the colt has gained the power over his limbs at all paces, which he will have gradually given him in his daily longes, by increasing the tightness of the reins and accelerating the pace (taking care to change the direction of the circles), he thinks it time to give his pupil the finishing lessons, which can only be done in the saddle. Before mounting, however, he is enabled to teach the colt the meaning of each pressure of the rein, which is at first utterly unintelligible. By taking both in each hand, and pressing backwards, he eauses him to back; and by drawing them forward, to proceed in that direction. The right hand moved to the right, makes the colt move his head, and afterwards his body, towards that side, and vice versa with the left hand. In this way, all is prepared for the mounting, which should be first attempted when the colt is somewhat tired after a long and steady longe. The breaker should, during the last week's daily exercise, put on a saddle instead of a roller and surcingle, keeping it in its place by loose girths and a crupper. Every day he should bear occasionally upon the stirrups, smacking them against the saddle, and thus accustoming the colt to noises, and also to pressure on his back. When all is ready, he has only to put his foot in the stirrup, standing with his back to the shoulder, and then, 
after partially rising two or three times, and coming down again, he finally plants himself firmly in the saddle. Most careful breakers have a roll of cloth buckled firmly in front of their saddles; and with this precaution, even if the colt buck's or kicks, it is almost impossible for him to dislodge them. When thus mounted, the breaker should be in no hurry, but let the colt get accustomed to the intruder. Let him wait till the pupil has somewhat recovered from the shock, and then only let him urge him forward at as slow a pace as he likes. If all has been conducted well throughout the preliminary stages, and the colt is good-tempered, he will walk away quietly enough, and generally no trouble will be given for a day or two; when, probably, there will be some slight fight, which may be either in causing the pupil to go where he does not want to go, or in making him face some object which frightens him. At first, neither whip nor spur should be used, for the object of neither is understood; and if the colt will not readily move forward, he should be led or driven by an assistant, and not whipped or spurred by his rider. In process of time, however, he is made gradually to understand these signs by the tact of the breaker; and then if he offends, he must be punished accordingly, but it must always be remembered that the fault must be met immediately, or not at all.

Thie AMUSING AND EXPERIENCED author of The Horse and his Rider has drawn attention to the misconception of the differences in character between a wild horse and a tame one, which is entertained in this country. He says: "It is generally conceived that in the difficulty of sticking on to the back of a horse there exist three degrees of comparison, namely:-

" 1 . That it is rather difficult to ride a horse that has been broken in.

" 2 . That it is exceedingly difficult to ride a tame one that has not been broken in.

" 3 . That it must be almost impossible to mount and ride a wild horse just caught, that has never been broken in.

"We will, however, humbly venture to assert that in certain instances, the three steps of this little ladder might be reversed.

" 1 . In a state of nature the horse is such a zealous advocate of our popular principle of 'self-government,' he is so desirous to maintain his 'independence,' that although he will allow almost any quadruped, even wolves and lions, to approach within a certain distance, yet the moment he sees a man, though on horseback, he instinctively turns his tail towards him, and, when followed, gallops away.

"If, consequently, by the triumph of reason over instinct, he be caught, saddled, and if all of a sudden, to his vast astonishment, he finds sitting astride his back, with a cigar in his mouth, the very human being he has always been avoiding, his first and almost only feeling is that of fear, and accordingly, if he be retained by the bridle, instantaneously, by a series of jumps on all four legs, he makes impromptu his first hurried, untaught, unpractised effort to dislocate a rider. But if, instead of being as it were invited to perform these unsophisticated antics, he be allowed, or rather, by whip and severe spurs, be propelled to do what he most ardently desires, namely, run away, his power of resistance is over, and his subjection inevitable. For at the top of his speed, just as when swimming, a horse can neither rear, kick, nor plunge, and accordingly at his best pace he proceeds on his sure road to ruin, until not only all his wind is pumped out of him, 
but, after that, until twisted hide-thong and sharp iron have converted his terror of man into an ardent desire to be obedient to his will. In fact, like a small nation that has unsuccessfully been contending against a great one, he wishes to put an end to the horrors of war, and to sue for the blessings of peace.

" 2 . If a domestic horse that has never been broken in be suddenly saddled and mounted, the rider has greater difficulties to encounter than those just described ; for the animal is not only gifted by nature with all the propensities of the wild horse to reject man, but, from being better fed, he has greater strength to indulge in them; besides which he enjoys the immense advantage of being in a civilized, or, in plainer terms, an enclosed country. Accordingly, instead of being forced to run away, his rider is particularly afraid lest he should do so, simply because he knows that the remedy which would cure the wild horse, would probably kill him. In fact, the difference to the rider between an open and an enclosed field of battle is exactly that which a naval officer feels in scudding in a gale of wind out of sight of land, and in being caught among sandbanks and rocks in a narrow channel.

" 3 . Of all descriptions of horses, wild and tame, by far the most difficult to ride is that young British thoroughbred colt of two or three years old that has been regularly 'broken in' by himself, without giving the slightest warning, to jump away sideways, spin round, and at the same moment kick off his rider. This feat is a beautiful and well-arranged combination of nature and of art. Like the pugilistic champion of England-Tom Sayers -he is a professional performer, gifted with so much strength and activity, and skilful in so many quick, artful tricks and dodges, that any country practitioner that comes to deal with him is no sooner up than down, to rise from his mother earth with a vague, bewildered, incoherent idea as to what had befallen him, or how he got there.

"If a horse of this description and a wild one in his own country were to be mounted there simultaneously, each by an equally good rider, both the quadrupeds probably at the same moment would be seen to run away; the Briton for ever, to gain his liberty; the other quadruped, just as surely, to lose it!"

Nothing can better convey to the reader the difficulties which the English horse-breaker has to contend with, than this extract from the pages of Sir F. B. Head, who has had ample opportunities of judging both the varieties of the species which he describes. It shows the necessity for the cautious proceedings which I have endeavoured to describe as the proper mode of breaking our young horses, and which I am satisfied will enable the breaker to perform his task in a way which will be satisfactory to his employer. It may, however, be worth while to examine into the methods adopted in the French school, as first introduced by M. Baucher.

His "MEthod of Horsemansmip" has been generally received on the Continent, where the principles of the manège have always been more highly prized than in this country. The author tells us, as his first principle, "that all the resistances of young horses spring from a physical cause, and that this cause only becomes a moral one by the awkwardness, ignorance, and brutality of the rider. In fact, besides the natural stiff: ness peculiar to all horses, each of them has a peculiar conformation, 
the greater or less perfection of which constitutes the degree of harmony that exists between the forces and the weight. The want of this harmony occasions the ungracefulness of their paces, the difficulty of their movements - in a word, all the obstacles to a good education." To remove these defects, M. Baucher adopts certain methods of suppling the neck, in which he considers the chief obstacle to perfect action resides. Without going into the long details of the various supplings, it will be sufficient to describe the general division of the work which the author considers necessary. This, he thinks, must extend to two months, divided into one hundred and twenty lessons of half-an-hour each, two being given each day. During the first series of eight lessons, the breaker will devote twenty minutes to the stationary exercise for the flexions of the jaw and neck, which can hardly be efficiently described without the illustrations given in the book itself. During the remaining ten minutes, he will make the horse go forward at a walk, without trying to animate him; applying himself all the time to keeping the horse's head in a perpendicular position. In the second series, comprising ten days, the first fifteen minutes will be occupied in stationary supplings and backings, followed by an equal time devoted to moving straight ahead in the walk and trot. The rider, while taking care to keep the head in good place, will commence a slight opposition of hand and legs, in order to give regularity to the paces. The third series, making up twelve days, will combine the previous supplings with pirouettes; while the fourth and fifth series, making up the whole time, will go on to develop the various elementary paces of the manège. Now, in all this, it appears to me that we have only our best English modes of breaking carried out to excess; and I am yet to learn that any great novelty has been introduced by this standard authority of the French school.

Under the meading of "Rapid Methods of Breaking," Capt. Hayes says: "We are indebted to American horse-trainers, from Rarey down to Sample, for having furnished us with labour-saving methods of breaking . . I I must say that, with extremely fow exceptions, any unhandled or spoiled horse, no matter how wild, vicious, or old he may be, can be made by quick methods, quiet to ride and ready to obey the ordinary indications of the reins, in from two to four hours. Such a horse, to become a reliable 'conveyance,' would probably require about twelve more lessons-two a day-of an hour's duration each." This gifted author goes on to say, "To those who might advance the argument that because the ordinary course of breaking takes more than ten times as long as the methods I advocate, it must therefore be more permanent in its influence, I would beg to submit that such a contention would hold good only on the untenable supposition that the effects of the respective processes were equal in force. I see no possible benefit, except the questionable one of giving the animal an exaggerated opinion of his own powers of resistance, in taking a month to accomplish what may be done quite as efficiently in an hour . . . The intensity of an effect, and not the time occupied in its production, is the measure of its permanency." 


\section{SUPERIORITY OF THE ORDINARY METHOD}

IT WILL READILY BE GATIERED from what I have already written that for breaking the average colt I greatly prefer the methods which have been in use for many years in this country. Mr. Rarey is entitled to every credit for introducing a novel mode of controlling a vicious horse, which is also of service in training cavalry and circus horses. Beyond these departments, however, his plans effect no good as far as my judgment goes, and instead of improving the mouth they have a tendency to injure it. I have shown that time and patience are grand elements of success in horsebreaking, and that it is a disadvantage to hasten the process, which is all that Mr. Rarey pretends to effect. We do not want to manage our horses without reins, but on the contrary to guide them and stop them with the slightest possible touch consistent with the equilibrium to be maintained in the saddle. Hence the first object is the formation of a good mouth, and as this requires a considerable time to develop, there are ample opportunities for gradually accustoming the colt to the presence and control of his master while it is being produced. If several breakers were to be pitted against each other as to which should first ride a high-spirited, unbroken colt, undoubtedly Mr. Rarey would come off victorious; but, on the other hand, I would back against any horse broken by his method, another which had been submitted to a good breaker on the old English plan, if the palm was to be given to that one which should prove to have the most perfect mouth and action.

ThE USE OF LONG REINS run through the stirrup irons is advocated by Capt. Hayes and other correspondents in the Field of recent date, and it undoubtedly possesses some advantages-young horses can be thus made to jump without unnecessary weight upon their backs.

\section{BREAKING TO HARNESS}

THE FARLY PROceEDINGS in breaking a colt to harness are exactly the same as for the saddle, and indeed it is well in all cases to make him handy to ride before he is put into the break. We may therefore assume that this has been done, or at all events that a good mouth has been made, and the colt handled and accustomed to bear the hip-straps hanging loosely over his sides prior to putting him in harness.

THERE IS SOME DIFFERENCE OF OPINION among breakers as to the best plan of conducting this operation. Some contend that for every kind of harness the horse ought to be put in with another, who will compel him to move or stop at the will of the driver. Others assert that, on the contrary, every young horse should be put in first by himself, and then if he refuses to move he can be allowed to wait till he is tired of inactivity, which practically he soon is. My own opinion is founded upon more than twenty years' experience with all sorts of horses, and I am persuaded that by far the safest and best method is to put every horse into double harness first. Many farmers break their colts in by putting them to 
plough between two other horses, but the pull at this work is too dead for well-bred colts, and many jibbers are produced in this way. Every high-couraged horse has a tendency to jump forward on the first impulse to do so, and feeling the restraint of the collar he is irritated to increase his pull, whereby his shoulders are galled, causing him to dislike his work from the pain which he suffers. It is quite possible to break in a colt of average good temper for single harness without putting him first into double, but the plan is always attended with danger to both horse and driver, and I should strongly caution my readers against it. Even after two or three lessons in the double break, which have been quietly submitted to, the colt often turns restive when put in by himself, but still by that time he knows what he has to do, and is not made sulky by being punished without cause.

The APparatus necessary for breaking to harness consists of, 1st, a set of strong double-and single harness, made in the ordinary way, except that the crupper for the colt should buckle on one side; 2ndly, a double break of the ordinary construction; but it is a safe plan to have the whole space between the fore-carriage and the splinter-bar made up with iron rods so close together that if a horse kicks he cannot get his legs hung over the bar; 3dly, a single break, to be hereafter described.

Before the COLT is put to draw he should be accustomed to the pressure of the harness, and as a matter of course in any case he must have this put on him. Every groom ought to know how to do this, but at the same time, in a colt he should be cautioned to proceed slowly and quietly so as not to frighten him. Mr. Rarey's plan of showing the horse everything which is to be put on him is a very good one, and taking advantage of it, before the collar is slipped over the head a little time may be allowed for the future wearer of it to smell it and examine it with his eyes also. Many breakers, to avoid the danger of alarming their pupils by putting the collar over their heads, have this part made to open at the withers, where a buckle secures it after it has been slipped up under the neck; but collars made in this way are not so firm as when constructed in the ordinary mode, and are more liable to punish the shoulders, so that what is gained in one way is lost in the other. A quiet and handy man can always slip a collar over a horse's head if he will take time, and especially if he has previously handled the animal and made him accustomed to his presence. As soon as this part of the harness is in its place the pad and crupper must be gently put on the back, and then quietly raising the tail with every hair gathered and firmly grasped in the left hand, the right slips the crupper under it; as soon as this is done the left drops the tail and assists the right to buckle the two parts together. In the previous breaking the colt has been accustomed to the crupper, so that there is no occasion for extra care in this part now. The pad is then drawn forward to its place, the bellyband buckled, and the rest of the harness being put on in the ordinary way, the colt is allowed to feel it for a few minutes, and should then be led out in a yard or other convenient place for an hour. The general practice is after this to put him to at once, but it is far better, if the colt is at all shy, to take off the harness and postpone the commencement of actual breaking till the next day.

The aCtual pUtting to is managed differently in double and single 
harness, but as I have endeavoured to show that the former should always precede the latter, I shall commence by describing it. In breaking to double harness a steady old horse should be provided, usually called a breakhorse. All that is wanted is an animal of good courage and free from vice, who will draw steadily off on the slightest notice and will stop firmly when required. Some old horses which have had a great deal of practice in the break will assist their masters in a wonderful manner. If a colt kicks over the pole they will press against the intruding leg and cause him so much pain that he remains quiet till he is relieved. Indeed it matters not what the attempt is, they defeat it by some counter-manœurre; but these horses are rare and fortunately are by no means essential to success. Before attaching the colt the break-horse should be put to, and it is usual to place him on the near side. Then, having the break conveniently situated for starting, the colt is brought out with a halter on and the cord knotted to his trace-bearer so as to give a good hold in case he plunges or kicks. The pole-piece is then loosely buckled up, after which the inside trace is slipped over the roller bolt, and then the breaksman pushing the quarters forcibly inwards, the outside trace is carefully adjusted and the pole-piece buckled up to its proper length. Quickly but quietly and without fuss the reins are crossed and buckled, and the ends being taken by the breaker he mounts to the box, gives the word to the break-horse to move, and the break is quietly started without any notice to the colt, or effort on his part. In the great majority of instances no resistance is made, and all goes on smoothly for some time. The break should be driven slowly for three or four miles, and then the breaksman who assists the breaker going to the side of the colt, pulls him round by the halter as the breaker drives the break-horse in a wide circle for turning. In returning the horses should be stopped and started again several times, and if the colt is pretty handy the turning may be repeated once or twice, but more than an hour's drive should not be attempted for fear of galling the shoulders, to prevent which the inside of the collar should be well oiled on all occasions just before starting. When taking the young horse out the process of putting to should be exactly reversed. A repetition of this lesson, and constant turning into narrow lanes and crowded streets, together with uphill and downhill work, will soon make the young horse handy in double harness, though for town work a considerable time must elapse before he can be depended on in a crush, especially without a steady companion. No horse should be depended upon until he has been roused either by accidental circumstances, or, if these do not present themselves, by an application of the whip, for it often happens that a colt will go quietly enough while his temper is unruffled, but when it is once upset he shows fight until he is conquered or himself gains the victory. Now it is far better that this should occur while in the hands of the breaker than after he is sent home as thoroughly perfect in harness.

When the Colt has had five or six lessons in double harness, and has been made to show the nature of his temper in the way $I$ have just described, he may safely be put in the shafts, but not till then. The single break is a stoutly-built two-wheeled vehicle, with strong and straight ash shafts. It should be so high as to preclude the possibility of the horse kícking over the drawing-bar; and though occasionally it will happen 
that a clever animal will kick very high indeed, yet there are few that will get over a bar three feet from the ground. A kicking-strap and safety-rein should always be used, for fear of accidents ; and a breaker of experience generally uses the driving-rein in the cheek and the safety-rein in the lower bar; both being held in the same way as for four horses. No bearingrein should be employed; and the tugs should be made open above, so as to drop the shafts into them. With these precautions, there is no difficulty in putting a colt into single harness; but, if at all stubborn, he may not be easily made to start, having no break-horse to take him off. Usually, however, when five or six lessons in double harness have been given, the colt walks off quietly enough; but, after one or two lessons, he discovers that what is to be done must be done by him unassisted, and he is then very apt to give himself airs, if his temper is at all inclined to be bad. Kicking may be kept under by the kicking-strap; running away may be restrained by the bit; but jibbing in single harness is very difficult to get over. If necessary, an outrigger may be applied to the break, and a second horse put on; but it is better to exercise the patience by quietly sitting still, when, after a short time, the jibber generally moves on of his own accord. Beyond these expedients, nothing more is required than time and practice. 


\title{
CHAPTER XIII
}

\author{
STABLES
}

SITUATION AND ASPECT-FOUNDATIONS-SUPERFICIAL AREA AND IIEIGITT REQUIRIDSTALLS versus LOOSE BOXES- HAY CHAMBER AND GRANAIY-BEST MATEIIALS FOR WALLS, FLOOR, DOORS, AND WINDOWS-DIAINAGE AND WATER SUPPLY-VENTILATION AND LICHTING-STABLE FITTINGS-HARNESS-ROOM-COACII-HOUSE-SERVANTS' ROOMSPLANS OF STABLES-NECESSITY FOR AIRING NEW STABLES.

In Discussing the various questions connected with the size, form, and arrangements of the stable, it must not be forgotten that we may have to deal with an animal whose varieties extend from the Shetland pony to the race-horse. A stable which suits the one will be quite out of character for the other; and hence, before we begin to consider the formation of a stable, we should settle what variety of the horse it is intended for.

IN ADDITION TO THE KIND OF HORSE to be accommodated, regard must be had to the work which is to be performed. If the horse is to be kept for pleasure only, and is not regularly exercised on those days when he is not wanted, he will, in course of time, get out of health, whatever may be the management indoors. Moreover, a horse so used requires a much greater area of stable, and more complete ventilation, even for preserving him in moderate health, than another of the same breed and constitution who does a proper amount of work from day to day. I have often known gentlemen possessed of a couple of horses, well housed, express their surprise that they could not keep them so free from disease as a lot of cab or coach horses which were kept near them, in some dark, close stable, perhaps underground. The reason is obvious enough: the over-fed and under-worked horse is stimulated by his food to such an extent, that some organ is sure to become inflamed; and if the lungs, stomach, or bowels do not show disease, the heels crack, or the joints enlarge, and, after a single day's work, lameness shows itself in a most severe form. On the other hand, the hard-worked horse is in the fresh air for a great part of his time; and thus the mischief which is done to his blood indoors, is remedied when he is out. His food is all properly expended in nourishing and repairing his muscular system, and there is no surplus to go to form the foundation of disease. Darkness also is grateful, because the moment the feeding is over, sleep is to be desired. Hence it follows that, of necessity, private stables must be very carefully proportioned to the number of horses which are to be placed in them, and their lighting and 
ventilation should be of the most unobjectionable character. In the following pages, when no specific directions are laid down, it may be considered that my remarks apply to the hacks and carriage-horses of private gentlemen. Race-horses and hunters demand a different treatment in many respects; and as to ponies, they are so hardy, that they may be lodged without difficulty.

\section{SITUATION AND ASPECT}

The two Most impontant points to be regarded in the choice of a situation, are, first, the power of excluding damp; and, secondly, the best means of keeping up a tolerably even temperature in winter and summer. It is seldom that the stables are fixed without regard to the convenience of the inmates of the house itself, the corner most out of sight being the one usually selected as good enough for them. It should not, however, be forgotten, that the horse is a native of a dry country, and cannot be kept in health in a damp situation either indoors or out. Nothing, except starvation, tells injuriously so soon upon the horse as damp when exposed to it-he loses all life and spirit; work soon tires him; his coat stares; he will scarcely look at his food, and he becomes rapidly emaciated, severe disease, often in the shape of some prevailing epidemic, showing itself after a short time, and generally soon ending in death. Grease and cracked heels, swelled legs, hide-bound, inflamed eyes, and coughs and colds, are the evils which attend damp, when exhibited only in a slight degree; but these are sufficient to interfere with the use of the horse, and, irrespective of other reasons, as domestic comfort is greatly dependent on the carriage being always at command, the stables should not be sacrificed, as they too often are, to a fancy for keeping them out of sight.

IN choosing the situation, therefore, a spot should be looked out which will be high enough to allow of perfect drainage at all seasons of the year. No periodically overflowing brook should ever be allowed to discharge its contents into the foundations, for even if the floor of the stable itself is kept above the water, yet the soil underneath will be saturated, and, acting like a sponge, will allow the damp to creep up the walls incessantly. Sometimes, in order to keep the stables well out of sight, a hollow is chosen, and the floor is then excavated below the level of the surrounding surface. The consequence is, that even in a summer storm, the rain-fall of the surrounding land finds its way-either into the stable, or around it; and the effect is equally injurious in either. Concrete under the floor, and courses of slate at the bottom of the walls, will do something to meet the evil; but it is better to avoid it altogether by choosing a site at least two or three feet out of the way of all flood water, and with a good fall into a sewer.

As TO THE ASIECT, there is some difference of opinion whether it should be northerly or southerly, all being adverse to a direction either due east or west; the former being too cold, and the latter too hot. As far as I know, all writers on the subject have preferred a southerly aspect, until the appearance of Mr. Miles' General Remarks on Stables, in which valuable work an opinion is expressed that "the 
prevailing desire to have the front of the stable due south is a mistake." The reasons for coming to this conclusion are grounded upon the fact, which is undeniable, that a more even temperature can be maintained if the situation is sufficiently sheltered from the stroke of the wind. No doubt, a southerly aspect allows the sun to enter with great power in the summer; but my experience does not lead me to believe that flies are less likely to get in through a door or window open to the north, than through similar openings looking south. Mr. Miles even objects to the heat of a winter's sun, which, he says, in the middle of the day, makes the stable almost as hot as in the summer; the heat being often suddenly succeeded by a degree of cold approaching the freezing point. Here, again, I certainly cannot follow him, and I should hail with pleasure any beams of the sun ${ }^{1}$ which show themselves between November and March, either in the stable or kennel. Animal life is always benefited by the direct rays of the sun, although, when the heat produced by them is intense, the mischief done is so great as to counteract the advantage. Still, in the winters of this country, such a thing is not, in my opinion, to be dreamt of, as a properly ventilated stable becoming too hot, and I look upon Mr. Miles' conclusions as being considerably strained when he is arguing in favour of a northerly aspect. I do not mean to assert that, on the whole, he is wrong, but that his arguments are based upon certain assumed facts which I hesitate to accept.

\section{FOUNDATIONS}

IN MOST CASES stables are not built of more than the basement storey, with a loft over, which is generally, almost entirely, constructed in the roof; the walls, therefore, are not high, and do not require deep foundations, even if they are built on clay, which is more liable to cause cracks, etc. than any other species of soil of a uniform character. It is a very common plan, on this account, to lay the foundations of any kind of coarse and stony material; but if this is done, a course of broken slates should be laid in cement a little above the level of the ground; or, instead of this, a course or two of hard bricks should be laid in the same material, so as to prevent the damp from striking up the walls by capillary attraction. A neglect of this precaution has, in several instances within my own knowledge, kept stables damp in spite of attention to drainage and a resort to all sorts of expedients which could be carried out subsequent to the building of the walls.

These remarks are intended to apply to the generality of stables, but it will be self-evident that such equine palaces as we find in the newer parts of Kensington and the West End of London need very deep and strong foundations. Iron enters very largely into their construction, the best architects and builders are willing to engage in such work, and everything is done for the comfort of man and beast.

1 Abundance of scientific procf has since been adduced. Perhaps none better than the test applied to the waters of the Danube, samples of which were taken every few minutes for twenty-four hours, when it was found that the largest number of microbes were present in the darkest hours and the fewest in presence of the mid-day sim. - Ed. 


\section{SUPERFICIAL AREA AND HEIGHT REQUIRED}

The Honse, like all the higher animals, requires a constant supply of pure air to renovate his blood, and yet it must not be admitted in a strong current flowing directly upon him, or it will chill the surface and give him cold. Artificial means of warming stables are objected to on account of their costliness, and of the constant and careful supervision which they demand, so that the horse is dependent upon his own heat-producing powers for keeping up the temperature of the air in which he breathes. Hence, it is a matter for experimental research to ascertain what number of cubic feet of air can supply him with what he wants for the purifying of his blood, without reducing the temperature of the stable generally, and without the necessity for admitting blasts of cold air. By common consent it is allowed that no stable divided into stalls should give to each horso less than 800 or 1000 cubic feet, and a loose box should not contain less than 1300 to 1500 cubic feet. An inexperienced person may perhaps fail to discover the reason why a loose box should provide more air for its inhabitant than a stall; but those who are accustomed to use horses, will see at once that the air is more or less changed in a large stable every time the door is opened, which act is repeated a great many times in the day, while the door of the loose box is often kept closed, with the exception of the hours of feeding and dressing. Much will depend upon the thickness of the walls, the nature of their materials, and the exposure of their outer surfaces to the weather; for a fourteen-inch brick wall will retain the heat within its enclosure much more completely than one of nine inches built of the same materials, and this remark applies still more strictly in the case of a wall built of absorbent stone, or inferior bricks. If a substantially-built stable is kept properly clean, and its ventilation is well arranged, my own opinion is that a comparatively limited area is better for its inmates than an extravagantly large one. A "very airy" stable generally means one which is so high that it cannot be kept warm, and in such I have generally seen staring coats and heard coughs perpetually going on. I have myself tried different stables, allowing an area of 750,850 , and 950 cubical feet per horse, extending to three or four stalls; but I confess that my leaning has been rather to the lowest than the highest of these numbers. The most healthy one I ever used scarcely allowed so much as 750 feet per horse, and in it for ten years I scarcely ever had a case of illness, irrespective of legs and feet, consequent upon - hard work. This space may be divided in the way most convenient, as we shall hereafter see.

Witu REGARD to THE NUMBER of stalls or loose boxes which should be grouped together in one apartment, there is little difference of opinion now-a-days among practical men, that more than from four to six horses should not be allowed to stand together. The former number is the better; but sometimes there may be circumstances which will excuse the latter being adopted; as, for instance, when this number are kept, and the space occupied by a partition wall is an object. Even then, however, a boarded partition may be introduced, and as it will not occupy any 
additional room, there is no objection on that account. When a larger number of horses are stabled together, there is great difficulty in keeping up an even temperature, unless, as in the case of omnibus and cab horses, the same number are nearly always absent at work. In private stables, however, all or nearly all the horses are often out at once, and then in a large space the temperature is reduced so much, that when they return, two or three at a time, followed by others, and compel the doors to be constantly opened and shut, there is, first of all, danger of chilling each as he comes in, and if he escapes this, of producing that injurious effect when the next horse comes home. Practically it is found that the long row of stalls does not conduce to the health of the horses, and although it may please the eye of the master to look down a long line of valuable animals, this arrangement is by no means to be recommended. Either two stalls with a loose box at one or both sides, or perhaps, as I said before, even four stalls, with a similar arrangement of loose boxes, should be the aim of the builder of a stable for general private work, and in this, as well as in all other cases, appearances should be sacrificed to utility.

\section{STALLS versus LOOSE BOXES}

For HUNTERS AND RACE-HORSES, when they are doing severe work, there can be no doubt that the quiet and liberty allowed in a box are far preferable to the restraint of a stall, where the horse is constantly liable to be disturbed by the ingress and egress of men and horses. In the stall, also, there must be a slope (though not necessarily a great one), from before backwards, so as to provide for surface drainage; and this compels the horse who is tied to the manger to stand with his hind feet lower than his fore, which is a tiresome position if continued for any length of time, and which, therefore, induces so many to stand back to the full length of their reins. But the horse is a social animal, and does not like solitary confinement any more than the dog; indeed, some which will do well when placed in a stall, will even refuse their food, and actually lose condition, if removed to a loose box, out of sight of companions. If, therefore, the quiet and comparative liberty of a loose box can be combined with the society of the stall, the only objections to each are got rid of, and the best kind of accommodation for the horse is provided, though even in a loose box it is not always desirable to leave the inmate loose.

IN LARGE STABLES intended for business purposes, such as for omnibus, cab, and wagon horses, loose boxes are out of the question, on account of the area which they require, extra width being necessary for the horse to turn round in, inasmuch as he cannot in them put his head over the travis, as he always does while turning in a stall. A full-sized animal must have his box at least 10 feet wide by 12 feet long, which gives an area of 120 superficial feet, instead of 80 or 85 , the area required for a six-foot stall, including the gangway. Jndeed, the above dimensions are scarcely large enough for a box, a roomy one being from 15 to 18 feet long by at deast 10 feet wide. Again, the consumption of straw in a box 
is much greater than in a stall, the droppings of a horse not being deposited in any one place, as in the latter, but scattered all over the surface, and spoiling the litter whereon they may happen to lie. For these reasons loose boxes are not introduced into any stables but those for race-horses, hunters, and in a certain proportion for hacks and carriage-horses. In every large establishment a small number must be set aside for the sick and lame, but I am now solely discussing their merits as applied to horses doing work.

\section{HAY CHAMBER AND GRANARY}

IN EVERY STABLE conducted economically, whether in town or country, a space should be allotted for storing hay, straw, and corn. In London and the large provincial cities and towns, the corn-chandler frequently supplies the stable by contract, at a fixed sum per horse, and in that case of course room for a week's consumption only is required ; but, as I shall hereafter show, the plan is an expensive one. At present I shall take this for granted, referring my readers to the next chapter for proof of what I lay down as an admitted fact among horsekeepers of experience. Hay and straw are either sold by the ton or by the load, which is 2 cwt. less, and on that account the loft should always hold at least a ton of hay, and the same quantity of straw, because if a smaller bulk is purchased, it cannot be obtained at the regular market price. Now a ton of hay cut into trusses will nearly occupy the space over an ordinary loose box, supposing that the walls of the loft are not carried up far above the floor, and every additional yard in height of wall allows stowage for another ton. Straw occupies more space by nearly one-half, and it may be calculated that a loft formed entirely in a tiled roof of the usual pitch, must have an area equal to two roomy loose boxes, or two stalls and a box, to stow away a ton of hay and a ton of straw, and even then there will be a little space for any other purpose. To find room for a cornbruiser and chaff-cutter, as well as for a stock of oats and beans, a granary with an area at least as large as a loose box should be arranged, and with these conveniences a stable may be said to be complete-that is to say, with dry and airy stowage-room, somewhere, amounting altogether to about 2000 cubical feet. If the number of horses kept is larger than three or four, the hay-chamber need not generally be increased to any great extent, because the hay and corn are purchased by the ton or load; but it is often a great convenience to have accommodation for two or three months provender, and therefore it is always well to be provided with space enough for that purpose, if it can be so arranged.

With THESE CALCUlations to GUIDE HIM, the builder has next to consider where he shall fix the stowage-room which I have said will be necessary. Formerly a loft was almost always provided over the stable, in which the provender was kept; but in those days, when high racks were in vogue, a trap-door was left over them to keep them supplied, and the consequence was, that, in the first place, the horses were continually annoyed, and sometimes the eyes injured, with the dust falling through, and, in the second, the hay was injured by the vapour from the stable 
reaching it through the same openings. On these accounts a great out. cry was raised against placing the loft in this situation; and stablearchitects insisted upon a hay chamber, as it was called, being built on the ground-floor, or at all events in some other situation than that usually allotted to it. There was great sense in this precaution, and for a time credit was due to the promoters of the improvement; but on the subsequent introduction of low racks (which the grooms did not object to when they had to bring their hay in through the stable door), and the simultaneous dismissal of the openings over them to the loft, the objections to the old situation of the latter were done away with; and the objections of the grooms having been removed, no opposition could be offered by them, and thus it has come to pass that in all our best stables racks are established without openings over them, and the hay and straw stowed in a loft overhead, perfectly protected from injury from the stable emanations, by means of a sound floor and a good cciling beneath it. The fodder so placed does good instead of harm, inasmuch as being a bad conductor of heat it tends to keep the stable cool in summer and warm in winter. Arrangements are easily made for throwing it down through a shaft in some convenient spot clear of the horses; and as it can more readily be filled from the cart or wagon through the window than a chamber on the ground, labour is economized also.

The fodder is sometimes thrown down from the loft into the yard, and then carried into the stable, but whenever possible it is much better to have a close-boarded shaft, with a close-fitting door at the bottom, down which it may be thrown without making dust or startling the horses. This shaft should be large enough to allow a truss of hay or straw to fall down without jamming; the size of the former varies in different parts of the country, but commonly 2 ft. 9 in. wide by $2 \mathrm{ft}$. $3 \mathrm{in}$. from back to front will do. Chaff may be conveyed in a similar shaft, but made preferably of iron about $10 \mathrm{in.} \mathrm{square,} \mathrm{and} \mathrm{corn} \mathrm{is} \mathrm{best} \mathrm{taken} \mathrm{down} \mathrm{in} \mathrm{a} \mathrm{similar} \mathrm{but}$ smaller iron shoot, about 4 in. by 5 in. At the bottom of the corn-shoot there should be two slides or doors, the space separating them being such as to hold one feed. It is a further convenience to have the two slides connected with a lever handle, so that when one slide is out the other is in, and waste is thus prevented. Some crotchety or suspicious people add a lock to the lever.

THE GRANARY, however, will require several fittings; and, in the first place, it should be so constructed as to be mice-proof. If the walls are soundly built, no mice can gnaw through them, but even if they are of soft materials, a lining of Portland cement will exclude mice altogether. This article also keeps the corn dry, and forms an excellent floor, as well as a lining for the walls. If the granary is on the ground, instead of using boards, which harbour vermin of all kinds, lay a course of bricks edgeways upon concrete, and then upon the former have an inch of Portland cement carefully laid, and take care to allow time for it to harden. When this is done, corn may be stored without fear of loss by mice, and all that is necessary is to turn it over every fortnight if at all new, or once a month if dry. Few grooms are to be trusted with an unlimited supply of oats, as they will almost all waste them in some way or other. It is better therefore to sluut off a part of the granary with open lattice or wire-work, 
admitting a free current of air, but not allowing anything large enough to contain corn to pass. At stated intervals the allowance of corn may be taken out and kept in the other part of the granary till wanted. Here also should be fixed a corn-bruiser and chaff-cutter, and also a bin for beans and chaff.

IN THE NEXT CHAPTER on siable management, I shall enter upon the advantages of chaff-cutters and oat-bruisers; but at present I must beg my readers to take it for granted that they are essential to every wellconducted stable, and shall here only go into the room they occupy, and their prime cost. It is needless, also, to describe their appearance or mode of acting, as they are so generally used, that they may be seen in every stable, and the real thing is much more easily understood than either an engraving or a written description. Every agricultural implement maker sells both, and most of the chief of these establishments have patterns of their own, but in principle there is not much difference. I have obtained the price list of the St. Pancras Iron Works, where, I believe, these and other stable fittings may be obtained of the best quality, and at as reasonable rates as are consistent with this. The oat-bruisers may either be screwed to wooden pillars, or may stand upon iron frames.

\section{IMPROVED OAT-BHUISERS.}

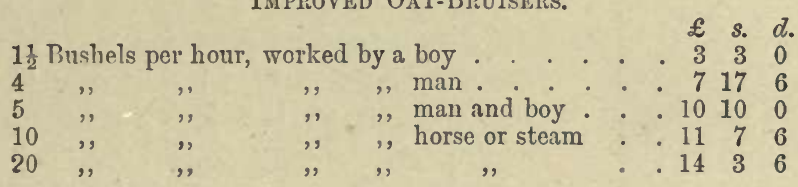

\section{Improved CirafF-Cutters}

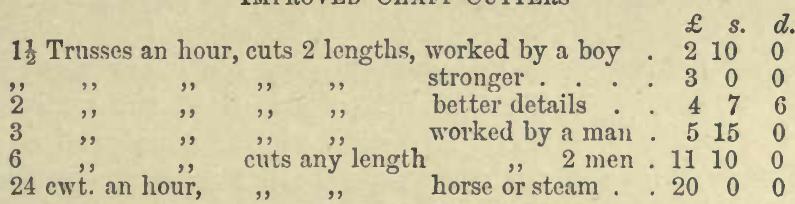

\section{BEST MATERIALS FOR WALLS, FLOORS, DOORS, AND WINDOWS}

The walls of stables, if economy is studied, must be built of the material used in the district, whatever that may be. In some parts of England, bricks are plentiful and cheap; but in others, where there is no clay to be obtained near at hand, the carriage alone from the brick-kilns amounts to a prohibitory sum. But in all cases, when they can be had, well burnt and free from salt, they should be selected as at once the most convenient, the driest, and the least absorbent of all building materials. In some districts, the clay and sand are so bad that they burn into a porous sponge, than which nothing can be worse, if exposed to the rain without and the exhalations from the horse within. Even these, however, will make good walls, if they are cemented inside and out; but no precaution short of this will suffice. Rough stone seldom makes a dry stable, on account of the quantity of mortar which it takes to fill up the interstices; 
for as lime is always an expensive article, the filling in is not sufficiently attended to, and the wet is allowed to enter, more or less. Of course, attention to the proper performance of his work by the stonemason will obviate these objections; and some supervision of this kind is required, whether brick or stone is selected as the material for the walls. In any case, a good thickness should be allowed, in order to keep an even temperature; and for walls much exposed to the east or north, less than 14 in. should never be adopted as the dimensiens.

THE Doors of stables are generally made of yellow, or, as it is called in the midland districts, red deal. Sometimes elm is used, but it is very liable to cast or warp. Oak or teak are used sometimes, when expense is not studied. Unless the proprietor is very particular abont appearances, what is called a "ledge door" is considered sufficient, the rails being of

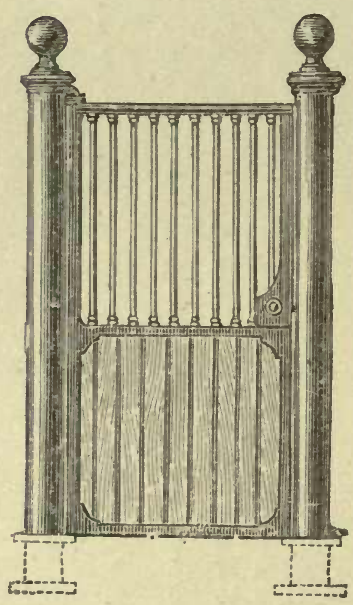

DOOR FOR IOOSE BOX. $1 \frac{1}{2}$ in. stuff, and the boards which are only nailed on, from $\frac{3}{4}$ in. to 1 in. thick; but a framed door is stronger and lasts longer. The ordinary thumblatch is very apt to catch in the skin of the horse as he passes through, causing often a severe wound, and on that account a sunk catch is preferred which drops into a recess made for it in the door-frame, but this is not adapted for a "ledge-door," a frame at least 2 in. in thickness being necessary to allow of the lock being let in. For loose boxes the door should be made with the upper half of open iron-work; the framing may be of wood, but as this is liable to be gnawed by the horse on the edges, it is better to make it in wrought iron, the lower part only being filled in with wood, as in the annexed engraving. In a door of this construction the hinges are so arranged that with a rounded edge to the frame there is no sharp projection, and even when wide open the hip of the horse passing through cannot possibly be injured. Common ledge doors of deal may be hung with ordinary iron hinges and thumb-latches for about $30 s$. to $35 s$. each, while framed doors will run up to $5 \%$. and 67 . apiece. No door should be less than 3 . ft. 6. in. wide and $7 \mathrm{ft}$. high, and the outer door is better if made $3 \mathrm{ft} .9 \mathrm{in}$. or even $4 \mathrm{ft}$. in the clear.

\section{DRAINAGE AND. WATER SUPPLY}

Next in Importance to the choice of the situation and aspect, is the method to be adopted in draining the stable. The former cannot well be altered, but the latter may, and therefore I have placed it second. To ensure the perfect performance of the office of cleansing the stable, the first thing to be done is to provide a means of receiving the liquid which constantly must fall upon the flooring, consisting partly of the urine of the horses, and partly of the water used in keeping it clean. Several plans are 
adopted for this purpose, some of which are founded upon true principles of economy, while others are wasteful in the extreme. In towns and cities provided with sewers and water pipes, jiquid manure is seldom worth the cost of removing it, and hence in them there is no choice and the whole of the liquids flowing through the drains must pass off into the common sewers. Even here, however, a catch-pit should be provided somewhere outside the stable, without which the traps will either become clogged if made gas-tight, or they will admit the foul emanations from the common sewer if they are so arranged as to allow of the free flow of drainage from the stable into them. Such a pit as that represented below will serve all the purposes required, and if it is regularly cleaned out once a week by the groom there will never be an overflow, while in no case can any gas pass through it from the sewers. It is merely a square pit lined with brick or stone and cemented. The size must depend on the number of horses, but if made on the calculation of one cubical foot per horse up to four horses, and half an additional foot for each horse beyond this number, it will fulfil all the

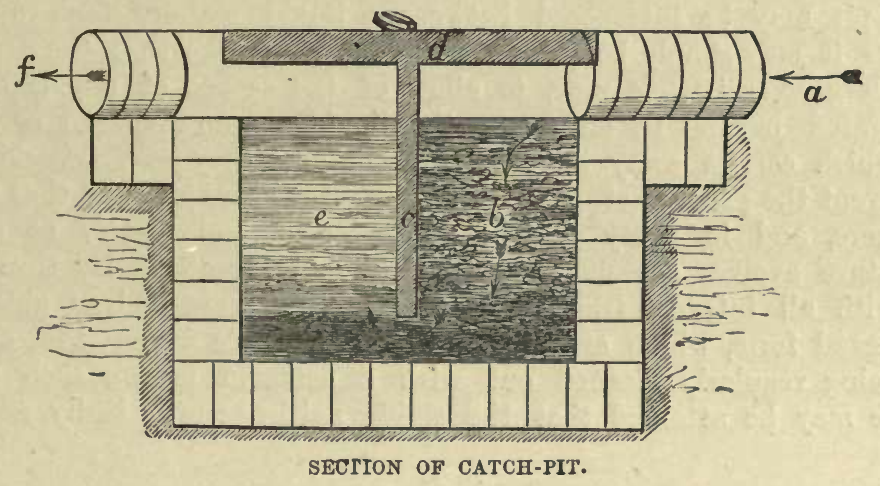

conditions required. The manner in which it acts is as follows:-The liquid drainage enters from the stable at $a$, and falls into the inner half of the pit, marked $b$, which is separated from the other half by an iron partition $(c)$. This is fixed above in a stone or iron lid $(d)$, which, being fitted in a frame at the top of the pit, effectually closes it except when taken up by the groom for the purpose of removing the solid contents at $b$. The sides of the iron partition $(c)$ should run in grooves cut in the cement lining the pit, which it should pretty accurately fit, but only so as to keep all solid matter from passing through. A space of from 2 to 4 in. according to the size of the pit is left beneath the iron partition and the bottom or floor, and through this the liquid passes, filling the outer half $(e)$ and overflowing through the pipe $(f)$ as fast as it has run in at $a$, the same level being always maintained in the two halves of the pit. With this simple apparatus properly constructed all internal stench-traps may be done away with, and the iron surface-drains which I shall presently describe alone introduced. An examination of the engraving of an ordinary stenchtrap which I here append will show how easily they are choked and how badly they fulfil their office. 
The first thing in all stables is to provide for the rapid removal of any fluid which falls upon the litter, whether it be urine or water used in washing legs or floor. Without this damp arises, and the health of the inmates suffers in proportion. Foul gas such as is given off from decomposing matters in sewers is no doubt prejudicial, but damp is still more so; and while I would be careful to guard

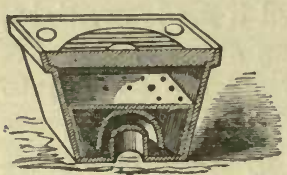

SECTION OF COMMON BELL-TRAP. against the former, I would still more cautiously attend to the exclusion of the latter. Hence it is that I would exclude all internal traps. Frven the old-fashioned simple plan of making the stalls to fall rapidly to an open gutter, and carrying this straight behind the horses through an opening in the wall to the manure hole, will answer batter than neglected stench-traps; and as it is always wise to count upon the occasional carelessness of the men, it is expedient to arrange on this basis if it is practicable, which I know by experience it is, by the adoption of the catch-pit I have described. In the country such a pit may be interposed between a liquid manure tank and the stable, or it may simply be placed outside, taking care that the drain $(f)$ has a large ventilating pipe, to allow of the escape of any gas which is generated beyond it, either in the liquid manure cistern or in the drain which carries away its contents, whatever they may be. No trap will prevent the passage of gas if the pressure is greater than that of the atmosphere, and in many cases decomposing animal matter at a high temperature evolves gas under one considerably greater. By thus doing away with all internal traps, and simply using wrought-iron gutters of the annexed form, which are provided with movable covers, that allow of their being regularly cleaned out with a common besom, such perfect drainage may be attained that the stable neither smells badly nor feels

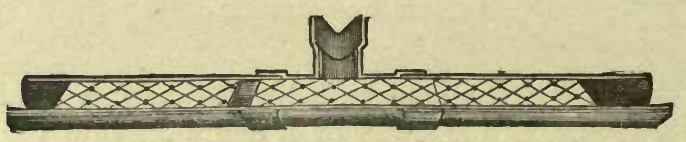

WROUGHT-IRON COVERED SURFACE GUTTER.

at all damp. Angular joints are forged so as to connect the stall drains with those at the backs of the horses, and in this way there is no difficulty whatever in keeping the litter perfectly dry, excepting just at the spot where the urine or water first falls. If the drain at the backs of the horses is a very long one it must be sunk beneath the surface and carried on by means of glazed earthenware or iron pipes, with grated openings behind each horse (not trapped), but the iron gutters above described are quite sufficient to provide for three or four horses. A good, but rather expensive, plan is to have the iron gutters made with a fall in themselves. This will be more fully alluded to when the exact formation of the stalls and loose boxes is entered upon.

An open gutter, without any cover, if made of wrought-iron, sufficiently large and of good shape, such as the one shown on page 227 , is preferred by many, as no accumulation of dirt can be concealed. 
The price of the various articles, as manufactured and sold by the proprietor of the St. Pancras Iron Works, is as follows:-

Patent wrought-iron stable guttering, according to the pattern s. $d$.

engraved, open, per foot .......... . 26

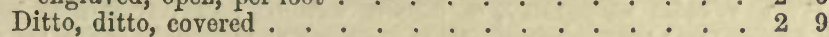

Recently great improvements have been made in the form of stenchtraps, and some makers have succeeded in doing away with the objections

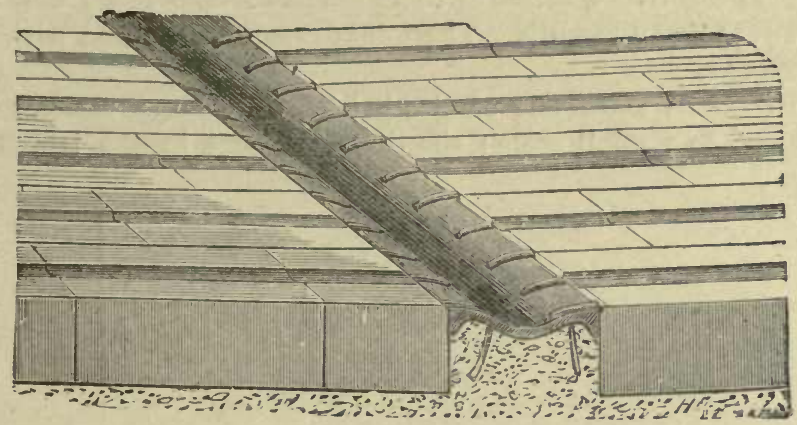

WROUGHT-IRON OPEN GUTTER.

to which the bell-trap was liable. The engraving shows such an one, where a movable pan or basket of iron is made to collect solids, and prevent them entering the drain, and where a luted cover gives ready access to the drain, in case it should become obstructed; the trap in this case is large and fixed.

Common bell-traps cost from 5s. to $10 s$. according to size, and the patent syphon-traps from $15 s$. to $25 s$.

There is no detail of stable building which has made more advance of recent years than the construction of the floor, and many plans recommended by authorities a few years ago are now never used in good stables. The essentials are impermeability, permanence, and a good foothold. The first can never bo got if sand or common lime-mortar

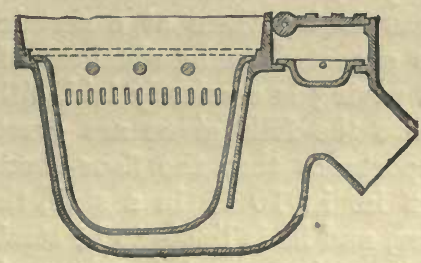

PATENT BASKET TRAP.

is used to bed and grout with. A foundation of good concrete 6 in. thick should be first laid. If Portland cement is used for this, and I recommend it, one part to six of clean gravel or broken brick or stone should be the proportion. On this 1 in. of cement should be laid as a bed for the bricks. The bricks must be very hard, but not 
slippery, and must be scored so as to give foothold. The ordinary blue Staffordshire chequered brick is hard, but the cross grooves prevent the urine running off freely, or dirt being swept out readily. The best material I know is a brindled brick, very hard but gritty, patented by the St. Pancras Iron Works Company, a house which has carried out the late Professor Varnel's ideas about drainage, and has taken a leading part in the modern improvements in paving and draining of stables. These bricks have only one groove down the middle, and when laid in a stall or box they form together a series of little gutters which allow wet or dirt to run or be swept away readily. The joints must be grouted with thin neat Portland cement.

The illustrations show one of the bricks to a large scale, and a stall laid with them to a small scale; the diagonal lines in the latter represent

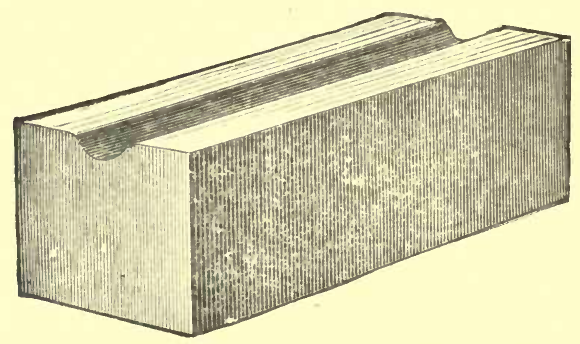

PATENT PAVING BRICK.

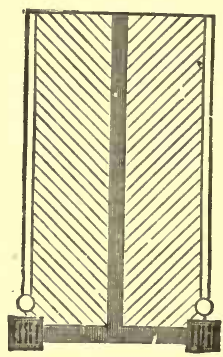

PLAN OF STALL PĀTING

the continuous channels in the bricks, leading into the surface gutter. This plan gives excellent foothold to the horse. About sixty go to a square yard.

For the passages of the stable nothing is better than the yellow adamantine clinker, which has superseded the Dutch clinker, very similar in size and quality, but inferior in appearance and cheapness. One hundred and twenty clinkers are required to a square yard. None of these bricks should be laid by an ordinary bricklayer, as they require special management, gained only by experience. The best plan is to contract with a respectable house to lay them at a certain sum per yard, when full advantage may be expected to be obtained of accurate, regular, and moderate falls. If the paving is carelessly laid, either the water does not drain off properly, or else the falls given are greater than necessary, and it is of the utmost importance that the floor should be nearly level. If the fall is more than $2 \mathrm{in}$. in $10 \mathrm{ft}$. in a stall, the weight of the horse is thrown on his quarters, and he is liable to be strained.

Another material is sometimes used in place of brick, on account of cost, namely Portland cement concrete, finished off with fine cement; but although this when thoroughly well done is impervious and lasts well, it is apt to become greasy, and I have known accidents happen from horses slipping upon it, or straining themselves in rising.

Mr. Haycock, in his Gentleman's Stable Manual, advocated the revival of a plan extensively used at the beginning of this century, of a perforated wooden floor, so as to allow the urine to pass away, and thus keep the litter 
dry, but its want of durability, foothold, and cleanliness, and its retention of ammonia have prevented its adoption.

WATER-PIPES, where there is no pump, must be laid in the ground so as to be out of the reach of frost, and should be furnished with a goodsized cistern in or near the saddle-room, where it can be kept from freezing. The system of laying on water-pipes to the mangers, by which they may be readily filled, is a good one, but it costs money and is by no means necessary. If the iron surface drains which I have described are used no flushing is required, a besom easily cleaning them out, but pipe drains are certainly the better for a good flushing now and then. Hard pump water is not so good for drinking as soft or river water, but in many situations nothing else can be obtained. When soft water is within reach it may easily be conducted into a cistern in the saddle-room, where its temperature will be always nearly that of the stable. A change from hard to soft water should be made gradually, as otherwise the digestive organs may be deranged.

\section{VENTILATION AND LIGHTING}

All stable windows should be of iron, and if they are cast with iron bars six inches apart from centre to centre, no horse will break the glass. Every other bar may be made to project so as to form the framework for the glass, and in this way serve a double purpose. If

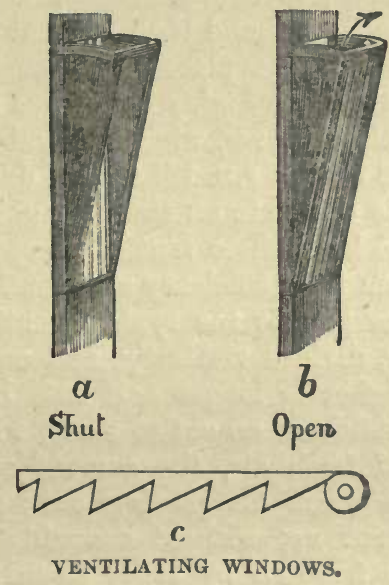

they are made to open in a valvular form, as represented above, on the same principle as has long been adopted in church windows, and as I have for years recommended for lighting and ventilating kennels, there is no down-draught, and every advantage is obtained from the fresh air without the disadvantage which ensues when it blows down upon the back or loins. In the engraving, a represents the window perfectly closed, in the state admitting light but no air; $b$ shows the same window opened as far as the framework will allow, intermediate degrees being regulated by the ratchet rod $c$, which is fixed to the upper edge of the 
frame, and catches on the top rail of the sash. Iron frames of this shape may be obtained by order of any iron-founder, or they may be made of wood. The glass must be guarded with bars either fixed to the sashes themselves or to the framework. It will be seen in the figure (b) that I have indicated with an arrow the direction which the air inevitably takes as it enters the stable. Sometimes, however, there are. already in the building windows of the ordinary construction; and in that case it will be necessary to introduce ventilators of some shape or other, to admit the external air. The common round tube, with a bend at a right angle downwards on the outside of the wall, is the cheapest form in which this can be done; but it is very apt to be rendered totally inefficient by being stuffed with hay in cold weather, and left in this state ever afterwards. Several patents have been lately taken out for getting a down-draught by the side of the up-draught tube ; of which Mr. Moir's four-sectioned plan is one of the best. In this a large tube of iron is made to descend from the apex of the roof to the stable ceiling; and being divided into four tubes by iron plates, which rise above the top, the wind always descends through one or two of these tubes whenever there is the slightest air moving. Unfortunately, however, it happens that when it is most wanted, it is totally inactive-namely, in the hot, calm days of summer. Ventilation is always easy enough when there is a wind blowing; and, indeed, the difficulty then is to moderate it; but it is when there is no air moving that stables become so hot and close. I have known these down-current tubes tried in all sorts of places, including stables, kennels, workrooms, cigar divans, etc. ; but I have always found that, without the power of moderating the down-draught by closing valves placed at bottom of the tubes, they are not only useless in calm weather, but highly dangerous in a wind. Now, horses have not the sense to close valves, when a wind rises in the night, and grooms are absent from 8 o'clock P.M. till 6 A.M., during which time a whole stableful of horses may be chilled to an alarming extent. Hence, if adopted, I should never venture to leave these ventilators open during the night, and this would take away from their efficiency sufficiently to forbid their use.

Another rather similar plan is the syphon ventilator, a zinc tube from 15 in. to 24 in. diameter, divided vertically, and one half carried up higher than the other. The higher or longer half acts by the ascending power of the warm air of the stable as an outlet shaft, while the other or shorter half acts as an inlet of fresh air, the amount of the latter being just sufficient to replace the warm air passing out; thus a constant, gentle interchange of air is kept up, without draught. The best plan of all, however, is to admit the fresh air by tubes placed against the wall of the passage, communicating with the outer air by a hole in the wall, covered on the outside by a grating. These tubes should have a cross-section of about 20 sq. in. to each horse, and their tops should be about $5 \mathrm{ft} .6$ in. from the floor, with a regulating valve. The fresh air coming in by these tubes rises straight upwards to the ceiling, and gradually diffuses itself, without causing any draught whatever.

Having thus provided for the admission of fresh atmospheric air, the next thing to do is to carry it off, when it has been used for the purposes of respiration. As I before remarked, it is not safe to depend upon the wind for this purpase. 
In any successfully ventilated building advantage is taken of the fact that warm air ascends. A small shaft may be fixed over the head of each horse; but in practice it is found that one large shaft, about a foot square, will purify a stable containing four or five horses. It is better to fix this about the middle of the stable, as regards its length, but near the heads of the horses, or else as shown below in the section of a stalled stable. The tube should be made of zinc. Wood is not good, as in the course of time, by shrinkage or accident, the joints are apt to open, and then the action is spoilt, but when the zinc tube passes through a fodder loft or room, it should be cased in wood for protection.

The upper end of this shaft should be guarded from down-draughts, either by a cowl which will turn with the wind, or by a covered ventilator of galvanized iron fixed on the ridge of the roof, the price of which will depend on the size. At the bottom a sheet of zinc, or a board, considerably larger

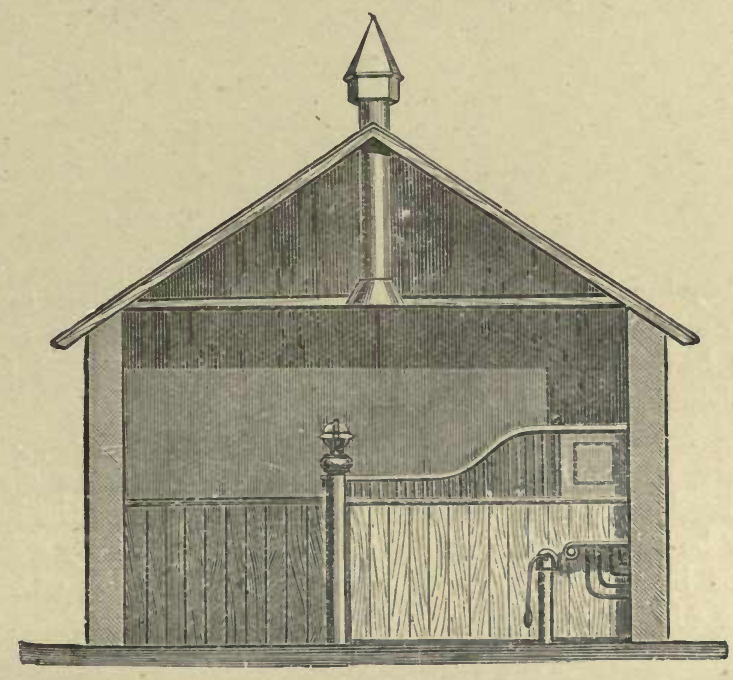

than the shaft, should be fixed about 4 in. below the mouth, so as to prevent any down-draught striking the horses, and also to catch any drip from the condensation of the steam of the stable, as it comes in contact with the interior of the shaft. The bottom of the tube should be fitted with a flap for regulation. Loose boxes must be ventilated separately, if they are not open to the stable; but if they are, the same shaft will take off their foul air as is used for the stalls, provided there are not more than four or five horses in the same space. A shaft about 6 in. in diameter is amply large enough for one box; and this, with the ventilating window or the separate ventilator I have described, will keep any box in a healthy condition, if its drainage is properly attended to. There is a very common notion that no ascending shaft will remove the carbonic-acid gas, which is one of the results of respiration, because its specific gravity is so great that it lies close to the floor. This, however, is a fallacy in practice, though perfectly correct in theory, because all gases have a tendency to mix rapidly 
together; and hence, although the weight of pure carbonic-acid gas is so great that it may be poured from one glass into another, yet, as it is given gradually off by the lungs, it does not remain separate, but mixes with the bulk of air in the stable, and is carried off with it. For this reason, there is not the slightest necessity to admit the fresh air near the bottom of the stable, as is sometimes contended for. If it is attempted, nothing can prevent a draught falling upon the bodies of the horses when they are lying

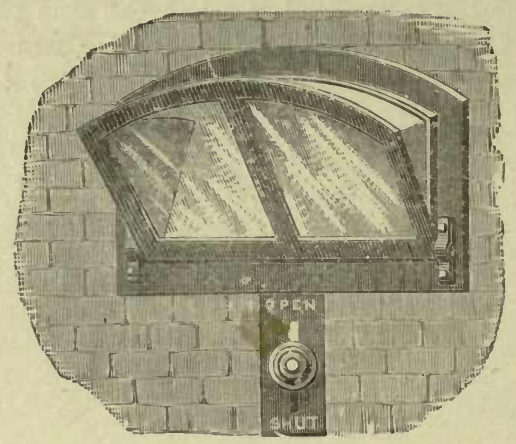

GLAZED VENTILATOR.

down, and they inevitably catch cold. If the upper regions are kept pure, the whole air soon mixes; and thus, when the openings are fixed near the ceiling, as I have described, all the good which is wanted from them is obtained without any risk of draught.

But failing inlet and outlet tubes from any cause, a hopper ventilator, like the above, which may be glazed to act as a window also, should be fixed in the head wall, or in either of the side walls, near the head.

These may be opened and shut by means of a cord, or by a self-regulating slide invented by the St. Pancras Iron Works Company, which cannot be moved by the wind.

\section{STABLE FITTINGS}

UNDER THIS HEAD may be included all the internal additions which are made to the walls in the shape of partitions between the stalls, mangers, racks, etc. It will therefore be necessary to consider each of these subjects separately.

There ARE Two Modes of separating stalls from each other; that most commonly adopted in private stables being the travis, whilst in cavalry and cab stables the hanging bail is used for the sake of economy of money and space. The latter being considerably cheaper than the former, I shall describe it first. All that is necessary is a strong pole of ash, oak, or elm, which is fixed about $3 \mathrm{ft}$. from the ground between the horses, one end being attached to the manger by a strong iron hook and eye, and the other being either suspended from the ceiling by a chain, or attached to a post, reaching from the ground to the ceiling in such a way that, if the horse gets 
fixed under or over it, he can readily be relieved by striking upwards the ring $(a)$ which liberates the hook $(b)$, and allows the bail $(c)$ to fall to the ground. A better plan is to use a plank of elm instead of a pole for the bail, and the difference of cost is not very great. I have myself adopted this plan with advantage in a two-stalled stable which is too narrow for a travis, the whole width for two horses being barely $10 \mathrm{ft}$. Here, of course, two stalls would be unsafe, for no horse can be accommodated properly with less than $5 \mathrm{ft} .6 \mathrm{in}$. from inside to inside of stall-posts, and this would require $11 \mathrm{ft} .6$ in., being 18 in. more than I had to do with. I find that a plank of elm, $1 \frac{1}{2}$ in. in thickness and 18 in. deep, will protect a horse very effectually from the kicks of his neighbour ; and as I happen to have had an inveterate kicker in one of the stalls for six months, without injury to her fellow, the trial has been a pretty severe one. The hangings at each end are just the same as for bails, a chain, in my stable, descending from the ceiling, and no tail-post being used on account of the propensities of the mare n question. She would have demolished any fixed post behind her in a single night; but the hanging plank of elm not being a fixture, gave

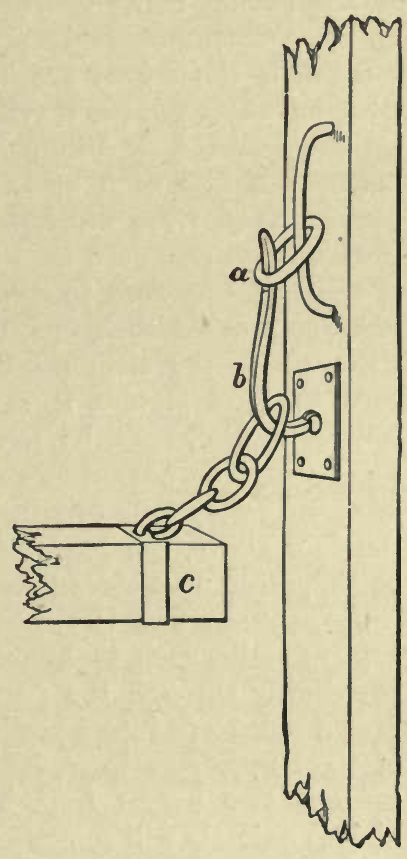
way to her blows, and she soon left it alone.

If the horse is tied up with one rein only, he can bite his neighbour with great facility over the bail, but two reins are just as efficient with hanging bails as with a travis, and these should never be neglected.

THE TRAVIS may be either of wood or iron, or partly of each material. If cheapness is an object, all that is necessary is to fix a head and tail-post, and connect these by three strong rails; inch elm boards are then nailed perpendicularly, and cut at the top to the proper sweep, or "ramp," as it is called, after which a thin fillet of elm is bent to the shape and nailed on to the top. Most travises, however, have an ornamental tail-post, and a framed top rail, rebated on the lower edge to receive the boards. In the present day iron, however, is substituted for wood; but as, when cast, it is very liable to break, it should be wrought for the ramps and cills. An improved form of ramp is that made as a grating with a straight rail about $4 \mathrm{ft}$. from the floor, connected with the ramp by wrought-iron upright bars. Foreigners like cast-iron ornamental scrolls and panels, but these are dirtcatchers, weak and dangerous. This grating ramp assists ventilation and the horse's social instinct. The following are the prices of these articles, varying with the degree of ornamentation :-

Wrought-iron stable posts, with ornamental cast tops, each from

\& s. d. $£$ s. $d$.

Wrought-iron ramp, each from......... 0120 to 0150

Ventilating ramp with patent bars. . . . . . . 276 to 500

Wrought-iron cill, each from ..... 076 to 0126 
Thus a plain iron frame-work, consisting of wrought-iron post, ramp, and cill, may be obtained for about $2 l$., to which must be added the expense of boarding both sides, which will come to about 20 s. in deal or elm, exclusive of the labour, being nearly double the cost of wooden posts and rails, put up in a correspondingly plain way. The length of the travis should be $9 \mathrm{ft}$., or if the horses are 16 hands or more, the travis may be $10 \mathrm{ft}$. long with advantage. No travis should be less than $6 \mathrm{ft}$. 8 in. in height at the head, and $4 \mathrm{ft} .6$ in. or $5 \mathrm{ft}$. at the tail-post. If lower than this, the horses can bite each other over the head, or kick over the tail, and so become hung, from which latter accident serious mischief may ensue.

If wooden posts are used they are apt to rot at the floor level, from damp; it is usual therefore to dowel them into a stone raised above the floor in order to prevent their speedy destruction, and it is then necessary to carry them up to the ceiling. But now that iron posts are almost universally used in good stables, it is no longer necessary to carry them up to the ceiling, as they can be made quite secure by means of long bases set in concrete. The advantages of short posts in respect of appearance, cleanliness, and safety fully counterbalance the disadvantage of having to strengthen the floor above, the joists of which have either to be deeper, or they may be supported on a strong cross beam of wood or rolled iron.

A BARRIER BAR is sometimes used in stables, when valuable horses are kept in stalls, such as hunters and race-horses. It is merely a strong iron bar sliding through the post in a sheath prepared in the travis, and when drawn out drops into a socket fixed in the wall opposite; so that, if either of the horses gets loose, he cannot reach his neighbours. It also serves to prevent two horses from hanging back and kicking at each other, which vicious animals will sometimes do.

The MANGERS AND RACKS are now almost invariably made of the annexed form, whether of wood or iron; the addition of a separate cavity for water, wian mashes, or gruel, being a modern invention. It used to be objected by advocates of the old system that a low manger and hayrack allowed the horse to breathe over his food, and was further a danger if a restless horse reared up and put his foot in it. The first objection is overcome by not putting in too much provender at a time, but the second, though a real danger, is not a frequent cause of trouble. The bars of the hayrack should not be wide enough to permit the foot of a pony to pass between them.

The high rack is sometimes responsible for small particles of hay falling into the eyes, and injuring them, beside the minor evil of filling the mane with dust. The old-fashioned high rack may now be considered quite obsolete, but a medium kind of rack is in use which seems to combine the advantages of the low rack with others of its own. Both sorts are also sometimes sheeted in front with wrought-iron, as shown in the illustration, which has the upright rack. There is a sloping grid at the bottom which throws the hay to the front as it is consumed, and the seeds are caught in a tray below. This is a good plan, as if the seeds drop on to the floor many horses, being fond of them, rub their manes against the manger front in the effort to pick them up.

With REGARD TO THE MATERIAL of which the racks and mangers should be made, I am not quite so settled in my convictions. Wood is undoubtedly the cheapest, and it has the advantage in its favour that the horse, in laying 
hold of the cap with his teeth, when he is being dressed, which most highcouraged horses do, wears them out much less rapidly than with the iron

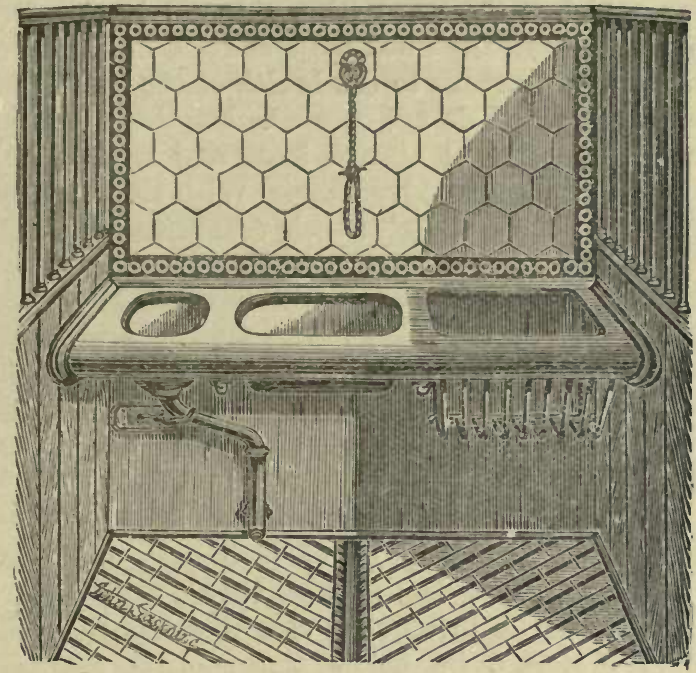

IRON MANGER AND LOW RACK.

manger. This objection is met by making the cap so wide that the horse's jaw will not embrace it, and with this modification I have nothing to allege

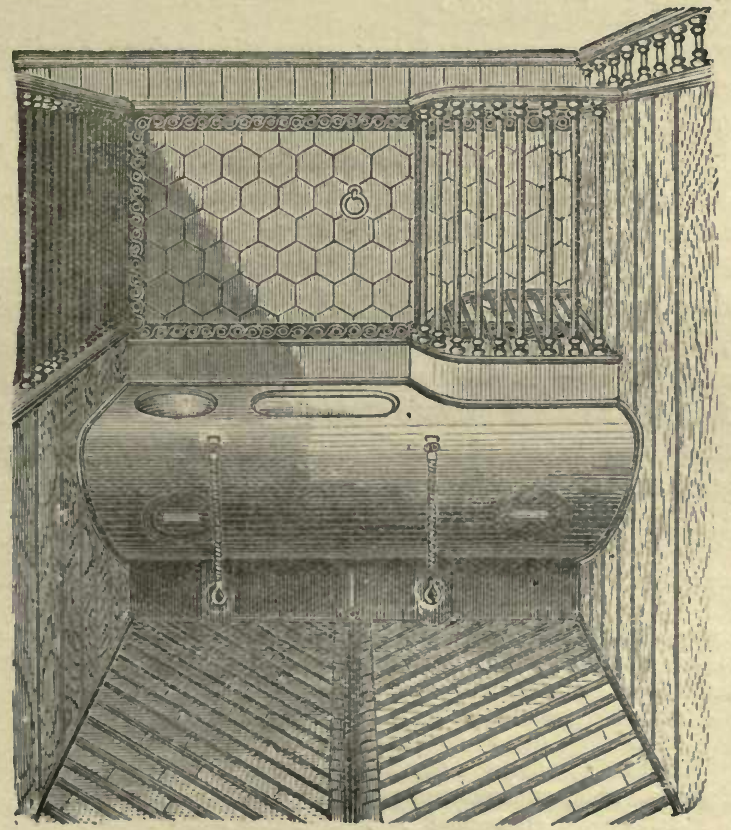

IRON MANGER WTTH UPRIGHT RACK 
against the metal but its price-while it has the advantage that mice cannot gnaw through it, and that it does not become decomposed by remaining constantly damp, which is the case with wood, and is therefore much more durable. The iron is generally lined with enamel, but as I believe that its oxide is absolutely advantageous to the health of the horse when taken into the stomach with his food, I do not care whether this additional expense is incurred or not. The enamel always looks and is clean, which is in its favour, but this is its only real advantage. With these preliminary observations, I shall describe each, and give their cost price in addition, so that in fitting up a stable the proprietor may take his choice.

(1) Wooden mangers may be economically made in part of elm or deal, and in part of oak, which latter wood should always be used for the capping, on account of the wear occasioned by the teeth, and for the bottoms, to prevent decay. The top of the cap should be from $3 \mathrm{ft}$. 3 in. to $3 \mathrm{ft} .6 \mathrm{in}$. from the ground, and the manger itself should be $13 \mathrm{in}$. wide at the top and 9 in. at the bottom; depth 11 in. The cap should be 4 in. deep and $3 \mathrm{in}$. wide, and these should be firmly wedged into the wall or travis at each end. The bottoms may be of inch oak, and the backs, ends, and fronts of inch elm, or, if deal is used, they should be a little stouter. Supposing low racks to be introduced also of wood, they should be $2 \mathrm{ft}$. wide, and should project 5 in. below the manger, making them 16 in. deep inside. An oak post must be dropped into the floor at the junction of the two, so as to give strength at this part, and the two caps may be strongly nailed or bolted to the top of this. The rack is generally made from $2 \mathrm{ft}$. to $2 \mathrm{ft} .3 \mathrm{in}$. deep outside, which leaves a space below sufficient to ensure the free passage of seeds and dust.

(2) Iron MANGers are made of the same dimensions as the above, but the capping of the rack is continuous with that of the manger, as shown in the engraving at page 235. Both ought to be $5 \mathrm{in}$. wide, to prevent the horse laying hold of the iron and thus wearing down his teeth. A water-tank occupies one end of the space at the head of the stall, the manger the middle, and the rack the other end,- the two former being generally enamelled inside. The addition of the tank is in favour of iron as a material; for water remaining in wood soon rots it, and hence, even if wooden mangers are preferred, the tank, if adopted, must be of iron. There is a great variety of patterns sold, suitable to stables of all kinds and sizes, but I know none more adapted to the average private stable than the one I have first figured.

IN COMPARING the prices of wood and iron, it may be assumed that a wooden manger and low rack will cost about 11. including labour and materials. The following are the prices of iron:-

Corner manger, with water trough, but no rack, $3 \mathrm{ft}$. long, plain . . $\begin{array}{rrr}0 & 10 \\ 0 & 0 & 0\end{array}$

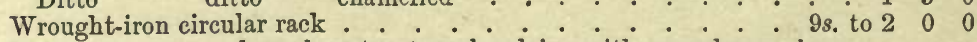

Patent manger, rack and water trough, plain, with guard cap, brass

plug and washer, each . . . . . . . . 376

Ditto ditto enamelled . . . . . . . . 4100

Ditto ditto ditto sheeted in front: $: .: \therefore 7^{\circ} 0$

Ditto ditto ditto ditto upright rack: $: .0^{\circ} 800$

Patent manger and rack, without trough, plain . . . . . . 300

Ditto ditto enamelled . . . . . . . . . 3176

Corner manger racks and troughs for loose boxes, from : . . . $\quad 1150$

Disto ditto ditto to : . : 900

Patent halter guide and rein, extra. ........... 100 
The halter tyeings should be made of leather, so as to work without noise through the ring on the manger, with a short piece of chain at the end to prevent gnawing. The strap has a weight at the other end covered with india-rubber, and working in an iron casing fixed against the wall. When well made such a tyeing works smoothly and noiselessly, and is much safer than the old ball and rope, as the horse cannot get his leg caught in it.

The only ReMaining FitTing yet to be described is the covering of the walls over the mangers. Wood is not good here, for the moisture from the horse's breath and the food foul the joints, and it is usual to use Portland cement or glazed tiles; the latter are superior in cleanliness and appearance. They should never be white, as the glare is very injurious to the eyesight of

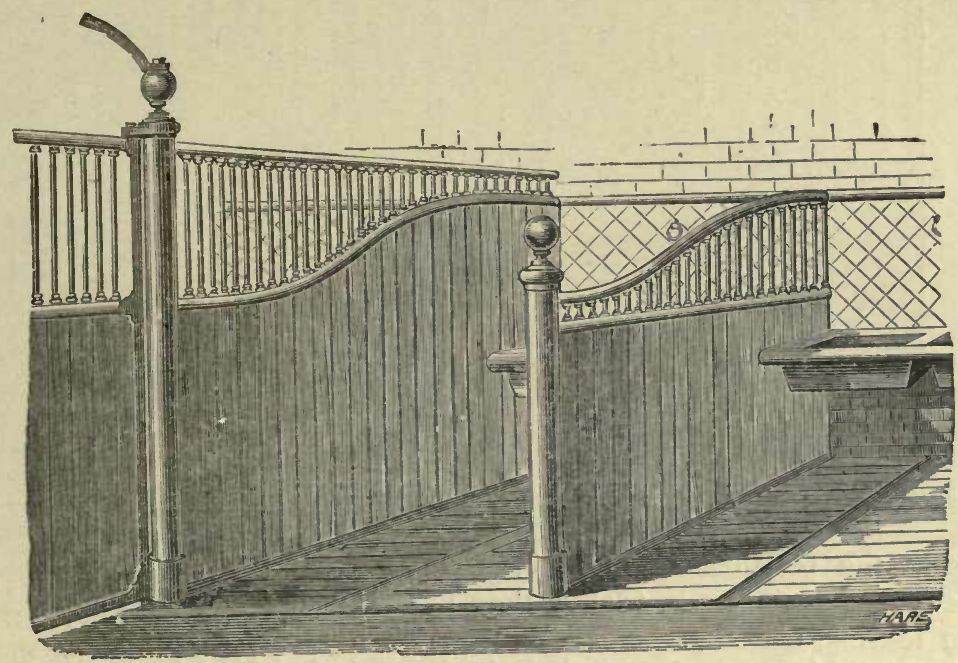

IRON FITTINGS FOR STALLS AND LOOSE BOX.

the horse ; buff, pale green, blue, or smoke colour are the best. I do not, however, like the high glaze which such tiles have, on account of the shine being often startling to the horse. The St. Pancras Iron Works Company has recently brought out a very beautiful tile of all colours, which, while being as impervious as the old ones, is devoid of the objectionable glaze: the cost of a set for a stall is $£ 22 s$. $0 d$.

I have shown these tiles in the annexed engraving of a couple of stalls and a loose box. Here all the iron fittings which I have already described are introduced, and my reader may judge for himself of their appearance, which is certainly, in my opinion, extremely neat and well adapted to the requirements of the horse. The stalls show the iron manger, rack, and trough, and the wrought-iron posts to the travis, with iron ramp, as described at page 233. The floor is laid with blue paviors, cut to fit the wrought-iron gutters alluded to at page 228. The partition from the stalls is of open iron-work. The only objection that I know to these very complete fittings is on the score of expense.

Projections of all kinds are sometimes to be carefully avoided, either 
with crib-biters or very mischievous horses. In such cases, a concealed manger and rack on the following plan is adopted, which is admirably calculated for the purpose. On the left-hand side the manger is seen in the position which it occupies when turned out for feeding, while the right gives a view of it when closed. The whole forms a solid frame, hinged at the bottom near the floor, and prevented from coming further out by a check. The groom, therefore, has nothing to do but to pull the whole out, as shown at $a$, feed his horse, and leave it out till he has eaten his corn, as well as hay, when this is given him; after which the frame is pushed
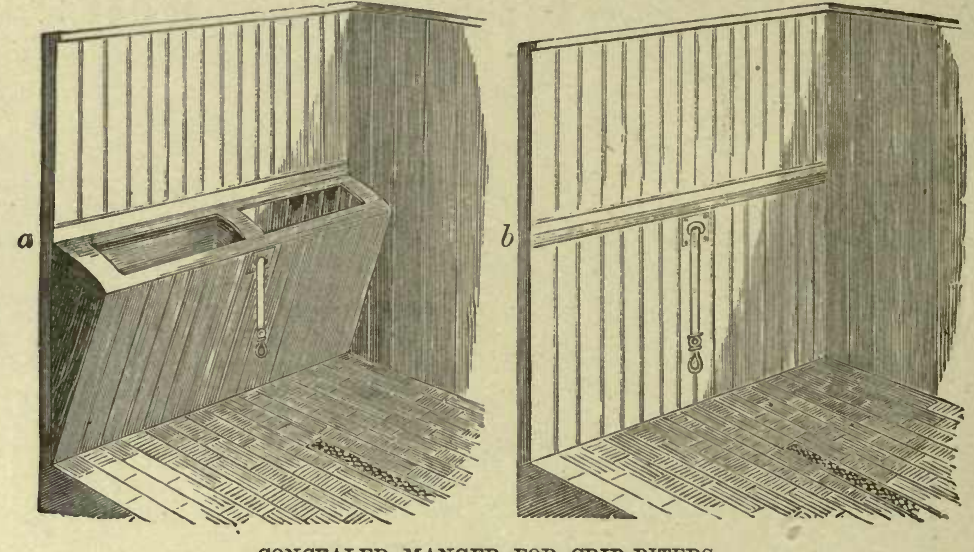

CONCEALED MANGER FOR CRIB-BITERS.

back to the position shown at $b$, when it is flush with the wall. The objection to the plan is, that it does not prevent a horse from crib-biting when feeding, and that he must wear a muzzle in addition; for it is while he is eating his hay and corn that the habit is indulged in to the greatest extent. Besides which, it compels the groom, after he "beds up," at night, to return to the stable, after he has allowed time enough for the horse to feed, without which precaution the concealed manger is useless. On the whole, therefore, I cannot recommend the plan, and crib-biting must be met by some other expedient, such as making the manger front too wide to be grasped.

THe walls of a stable should be lined, wherever they come in contact with the horse, with inch wood. Without this, in cold weather, the brick or stone, whether plastered or not, is too cold, and if a delicate horse lies down with his loins against it, he may be attacked with rheumatism, or perhaps with inflammation of the kidneys.

\section{HARNESS-ROOM}

Every Harness-Room should be provided either with a stove or open fireplace, in order to dry the saddles, harness, and clothing, when they come in wet. If, also, it can be so arranged that a supply of hot water can be obtained, by fitting a boiler to the back of the fire, the groom will be always 
provided with what he must occasionally obtain from some source or other. No establishment can be considered complete which does not provide plenty of hot water when wanted; and if it is heated in the saddle-room, so much the better.

Trie Next thing TO BE Done is to give the groom the means of drying his saddles and harness by the heat of his fire. The former are easily deprived of the moisture arising from the sweat, by putting them in front

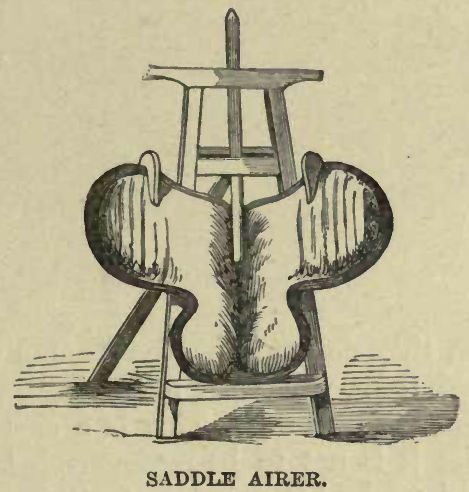

of the fire, spread on an airer of the above form, which is an excellent contrivance for the purpose, and may be obtained of any large saddler, in wood, for a few shillings. In addition to this, what is called a "saddle horse" is required, which may be of either wood or iron. If the former, it should

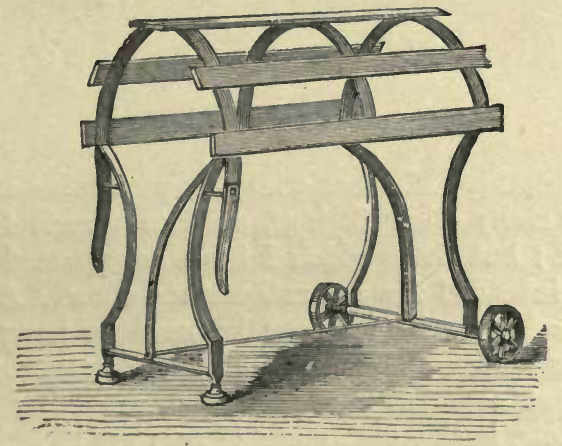

IRON SADDLE HORSE.

have a drawer or two, to hold small articles in common use. The above is the form of those made of iron, resembling in general plan the wooden horse, but being lighter in appearance, though really quite as heavy, if not more so. The same horse is useful for cleaning harness upon, the pad or saddle being put over the top, and the bridle hanging at either end, while it is being cleaned. 
When THE SADDLES AND HARNESS are cleaned, they must be put away till wanted; and here they must be protected from injury, either in the shape of scratches, damp, or dust. Harness and saddle brackets are made either of wood or iron; the former being the cheaper, but the surface they present

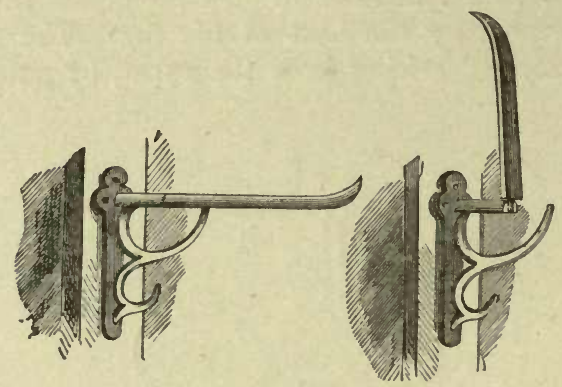

SADDLE BRACKETS.

being necessarily larger, they do not allow the stuffing to dry so well as iron brackets of the annexed form, which are made to turn up and form a hook below, on which bridles may be hung. This is a capital plan where space is scanty, but otherwise it is not to be recommended. Where a long cupboard can be separated off by hanging doors, either of glass or panel, the harness and saddlery can be kept in very nice order; and even a curtain of cloth or canvas will serve a similar purpose, when drawn across in front of them. In addition to the brackets, bridle hooks, either single or double, like the annexed forms, must be attached to the walls, to hang the bridles,
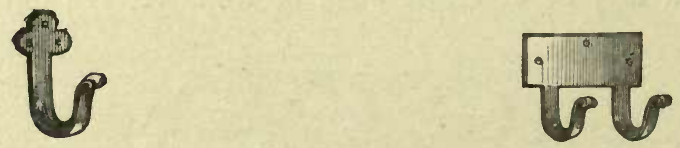

BRIDLE HOOKS.

stirrup leathers, etc., to. Masters who are particular about their stable arrangements have many other fittings, such as wheels for whip-lashes to hang over, etc., etc.; but those which I have enumerated are the essentials for a harness-room intended for use rather than show. A double hook suspended from the ceiling, where it can be used to hang dirty harness on while washing it, is extremely useful; but any groom who understands his business will suggest something of the kind, according to circumstances. The prices of brackets, hooks, etc., made of iron are as follows :-

PATENT SADDLE BRACKETS, ETC.

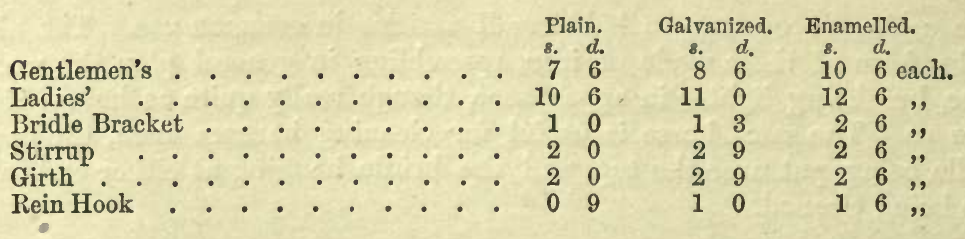


PATENT HARNESS Fittings.

A single set consisting of-

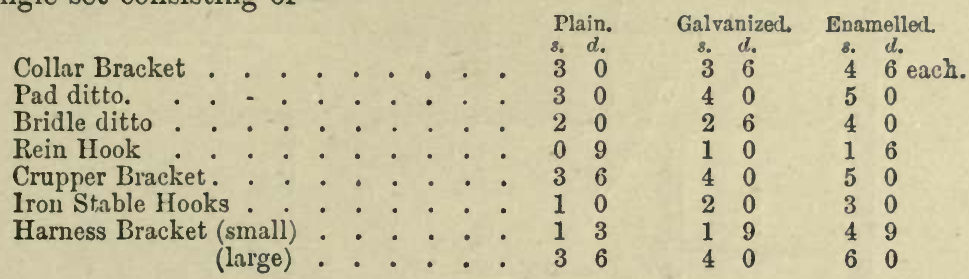

\section{COACH HOUSE}

IN THE COACH HOUSE mere standing room is all that is necessary to provide if the harness-room stove is made to answer the double purpose of airing both, which can generally be managed. Open carriages may be kept in tolerably good order without any stove, but the lining of close carriages soon becomes mouldy unless heat in some form or other be applied. This the groom is more likely to remember than a current of air, which is equally necessary to carry off the moisture.

\section{GROUND PLANS OF STABLES}

IN DECIDING ON THE BEST ground plan for stabling a great deal must always depend upon the kind and number of horses to be placed in it. In the following plans I shall consider the two extremes afforded by those for race-horses or hunters on the one hand, and on the other by the hack or harness stable for two or three horses where space is a great object. As a general rule race-horses and hunters require a loose box each, because they are often greatly distressed, and must then have entire rest and quiet to enable them to recover themselves. They are also a great many hours together in the stable, and being called upon for great exertions when out, they ought to have plenty of air when indoors. The best proportions for their boxes are sixteen to eighteen feet long by twelve feet wide and nine or ten high, but these are perhaps a little above the average. Nevertheless $I$ have given these in the plan on page 242.

It is divided into four separate stables thirty-six feet long and eighteen wide, in which three or even four loose boxes may be separated by partitions seven feet high with open iron tops, as shown at page 237, or one or more may be divided by travises into six stalls each six feet wide. I have already alluded to the fittings for each, and therefore I need say nothing more here beyond alluding to the plan itself.

The ARChitect employed by the St. Pancras Iron Works has designed a plan by which a loose box and two stalls may be arranged in a space only sixteen feet by sixteen, as shown on the following page. Undoubtedly it may sometimes happen that such an area may be at hand, and at the same time, being incapable of alteration, it may be desirable to lodge 

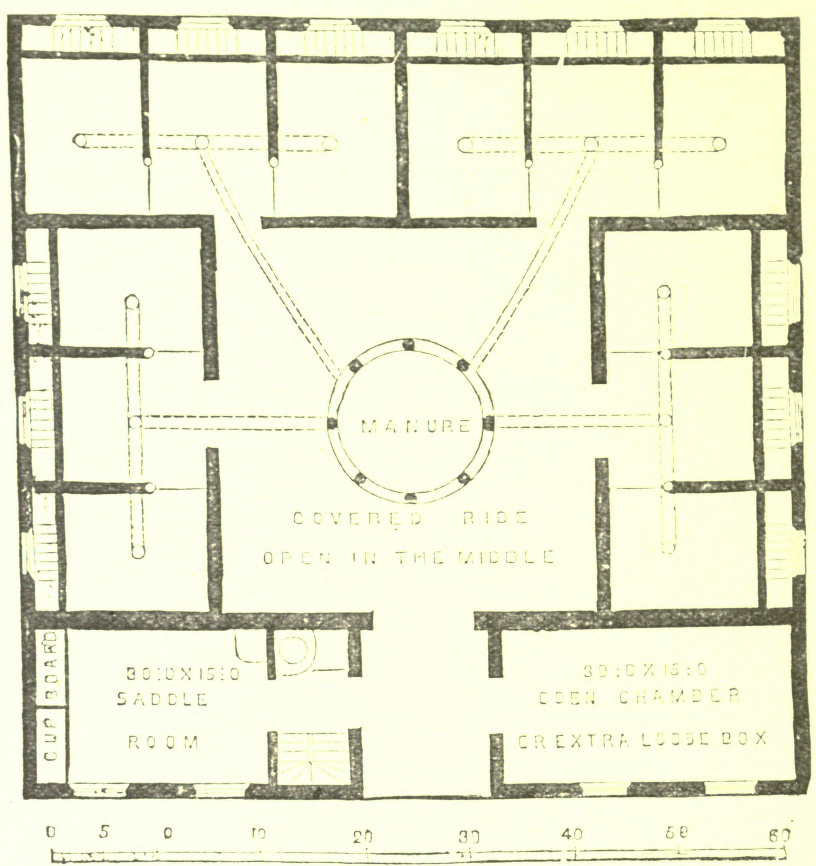

R.ICING OR HUNTING STALLE.

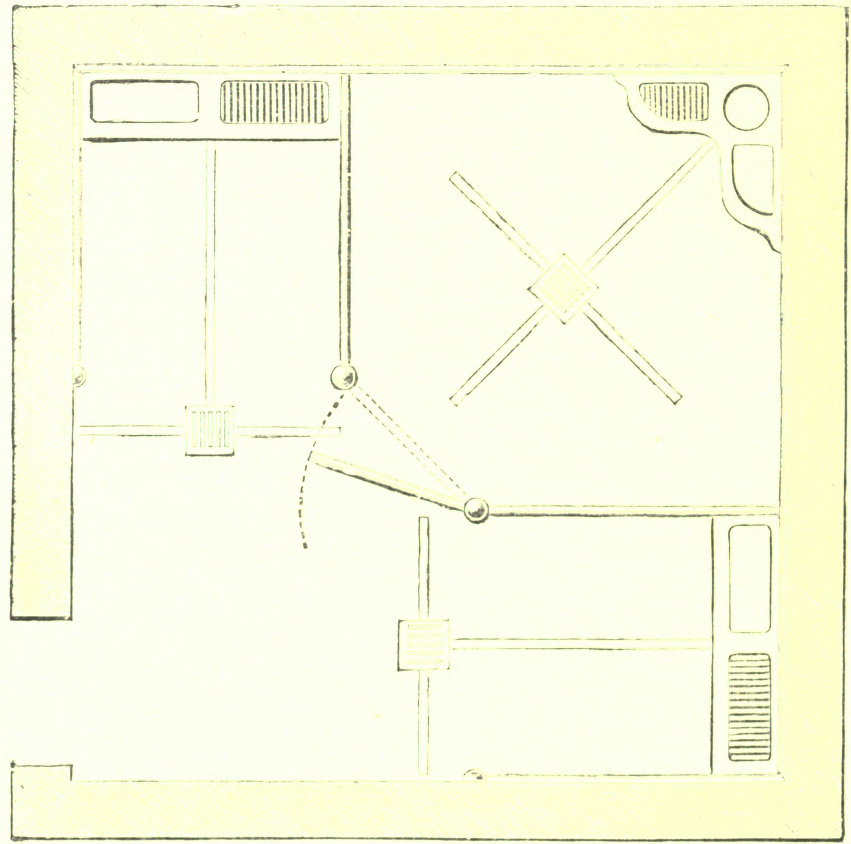

ILAN OF TAILE FUR THILE HORSES. 
three horses within it, which can scarcely be done in any other way. But while I give him credit for his ingenuity, ${ }^{1} \mathrm{I}$ would strongly object to the general adoption of the plan when it can be avoided, on account of the danger of injury from kicking caused by the proximity of the heels of two of the horses to one another. The loose box, moreover, is very small, but still we cannot expect to place three horses without crowding them in such a limited space as this. Two feet more in length (that is eighteen feet) and one foot less in breadth (or fifteen feet) will give three good stalls; or two feet more each way (that is eighteen feet by eighteen) will make the above plan practical.

\section{SERVANTS' ROOMS}

LITTLE NEED BE HERE SAID of the servants' rooms, but I certainly agree with Mr. Miles in his objection to placing them over the horses. Quiet is essential to the sleep of these animals, and if grooms are to be walking overhead at all hours their sleep must necessarily be disturbed. It is always well to have a groom's room within hearing of his horses, so that if any of them get cast, or are taken ill, he may be able at once to go to their assistance, but this can readily be done without placing any lodgingrooms over the stalls or boxes. If grooms sleep over the stables, the floor should be "dead-sounded" for the sake of the horses, and made air-tight for the sake of the man and possibly his family. Cases of glanders are said to have been communicated in this way, and despite the statement that "of the horse and groom, the horse is the nobler animal," modern sanitary science is against the plan of overhead living-rooms, where the ammonia of the stable must necessarily rise if the communication between it and the sleepers above is of such a nature as to permit the latter to hear a griped or cast horse struggling in the night.

\section{NECESSITY FOR AIRING NEW STABLES}

To PUT HORSES INTO NEW STABLES without airing them is to give them cold or rheumatism. Indeed those which have been merely uninhabited for some months are not fit for horses that are accustomed to be kept warm and dry, without taking the following precautions. If the walls are very new some open stoves should be kept burning for at least a week, not with the windows and doors shut, as is often done, but with a good current of air blowing through the whole building. In the absence of regular stoves loose bricks may be built up so as to allow a good draught of air through the coke or wood burnt in them, and thus to give out as much heat as is wanted. For stables that have merely been closed up for a month or two, a fire kindled on the floor and kept burning for a few hours will suffice, but when the horses are first brought in, their beds

1 A very great number of such stables have since been fitted up, especially in the West End of Loudon, where space is costly, and proximity to the owner's residence a sine qua non. 
should previously be made up ready for them, and then the doors, windows, and other ventilators should all be shut till the stable becomes thoroughly warmed by the natural heat of their bodies, which it soon is. When this is accomplished, if the weather is warm, the ventilators should be opened as usual, and the windows also if necessary; but it is better to err on the safe side, and not to do this till the groom is perfectly satisfied that his charges are all comfortably warm. 


\title{
CHAPTER XIV
}

\author{
STABLE MANAGEMENT
}

THE COACHMAN, GROOM, AND HELPER-CLOTHING, STABLE IMPLEMENTS, ETC.-FOOD AND WATER-ROOTS-GREEN FOOD SUITABLE FOR SOILING HORSES-ARTIFICIAL CONDIMENTAL FOODS - WATERING HORSES - THE THEORY AND PRACTICE OF FEEDINGBEDDING-DRESSING OR GROOMING-CLIPPING, SINGEING, AND TRIMMING-USE AND APPLICATION OF BANDAGES-MANAGEMENT OF THF FEET-DAILY EXERCISE.

IN THE FOLLOWING PAGES my attention will be specially directed to the management of private stables; and therefore the race-horse, the omnibus and cab-horse, and the poster, will not pass under review. Those who are engaged in their superintendence make it their business to ascertain what is best to be done; and, whether they do or not, each of them fancies that he knows better than any one else how to effect his object.

\section{THE COACHMAN, GROOM, AND HELPER}

The coachiman is generally understood to be a servant in charge of a horse or horses, drawing either a close carriage or an open one of some importance, and attending to their management, indoors and out. To perform these duties thoroughly, he must possess all his faculties; and should have had considerable practice in driving, if he is wanted for "town" work. If he has more than two horses under his care, he must have a helper; for each of them requires at least two hours' work daily indoors; and to clean a carriage and harness, about three hours more will be occupied. Thus seven hours are accounted for in the stable; and a carriage is often engaged for several more, which is quite enough work for any man to do well. I have certainly known more than one coachman turn out three horses and a carriage extremely well; but on the average it will not be efficiently done; and it must be remembered that top-boots are not kept in nice order without some little trouble. Good and careful driving is the first consideration; for without this, the inmates of the carriage are in constant danger. But unless the coachman knows how to dress and feed his horses, and also to manage their slight ailments, they will be constantly lame or sick; and hence a few additional pounds in wages are well bestowed upon a first-rate servant. The wages of coachmen vary from 20 s. to 40 s. per week out of doors, or from $£ 18$ to $£ 60$ yearly indoors. or even more occasionally. 
UNDER THE WORD GROOM are comprehended all servants having the entire charge of horses, with the exception of those who habitually drive a carriage of full size. There are many grooms who occasionally drive their masters' phaetons, and some who are regularly in charge of small carriages, but who, on that account, do not obtain the name of coachman. As a general rule, however, the office of the groom is to take charge of hunters, hacks, and phaeton horses, both indoors and out: and if the latter he should be able to drive well enough to handle the reins with safety in the absence of his master. The stud-groom does little work himself, but superintends large establishments and occasionally drives as well. On the other hand, the hunting-groom may or may not require assistance; but if he has more than three horses to look after, he cannot do them well himself. Two horses, and a gig or dog-cart, are quite sufficient for a groom, and they will give him eight or nine hours' hard work daily in the stableyard and harness-room, besides what he has to do out of doors, in attendance on his master. The wages of a good groom vary from $18 s$. to $25 s$. weekly out of doors, or from 15l. to $30 l$. yearly indoors.

THE HELPER is merely a strapper, and is only required to use his hands, and not his head. His wages vary from $10 s$. to $18 s$. per week, according to the locality.

\section{CLOTHING, STABLE IMPLEMENTS, ETC.}

THE various ACCESSORIES required in the stable are of two kinds: first, those intended to confine and clothe the horse; and secondly, the implements with which he is dressed, and otherwise attended to.

Whether in A STALL or LOOSE Box, every horse must have a head-collar, which should always be made with a front-piece, as without this the mano is soon worn away for 4 or $5 \mathrm{in}$. behind the ears, instead of two. Nothing so effectually spoils the appearance of the horse as a shabby mane; and the trifling outlay necessary to procure a front-piece is never regretted by those who care about looks. One or two rope halters are also required, by which the horse is tied up, or led out of doors when he is being dressed after his work, or while he is being cooled when he comes home in a sweat. The price of the leather head-collar is from 3s. $6 d$. to $10 \mathrm{~s}$.; that of a rope halter varying from $6 d$. to $2 s .6 d$. according to quality. I have described the headstall rein or halter tyeing on page 237 .

Horse-clothing varies in make, quality, and price, from the small rug, costing about $6 s$., to the complete suit of body-clothes, which will be charged for by first-rate saddlers at the rate of about six guineas or seven guineas. Rugs are made of the same materials as our household blankets, dyed according to taste; and between the quality of those used by small dealers or liverymen, on the one hand, and in well-appointed private stables on the other, there is as much difference as between a workhouse blanket and a "best Witney." The former are small, thin, and light, easily torn, and soon wearing out; while the latter are large, warm, and tolerably stout and enduring, though not being twilled, like the serge used for body-clothes, they tear much more readily. An undyed coarse serge is now used in many livery stables, which is cheap, strong, and enduring; but it shows every 
stain, and is not calculated to please the eye. If rugs are used, they will be found to last much longer when bound with strong galloon; and it is an excellent plan to havo them made, as they now frequently are, with a projecting piece on the off side in front, which wraps round the breast of the horse, and buckles over the near side, so as to protect this part of the horse, both indoors and out. $\Lambda$ roller, well padded, to keep the pressure off the backbone, completes this kind of clothing; but in well-managed stables it is customary to keep two rugs, one for the day and the other to be put on at night. The object of this is not only for the sake of appearances, but to enable the groom to keep the inside as well as the out dry and clean. A rug which is constantly on the horse soon becomes matted with hair, scurf, and sweat, which must occasionally be brushed, or even washed off; for without this the insensible perspiration constantly thrown off by the horse's skin has not a sufficient means of escape. The cuit of body-clothing is made of thick, strong, and warm serge, and consists of a quarter-piece, a breastpiece, and a hood. The quarter-piece is cut so as to cover the body of the horse, and the two sides do not meet in front; so that an open space is left to be covered by the breast-piece, which somewhat resembles a short man's apron in its form, and is buckled to the quarter-piece on each side of the withers, where the latter has a strong piece of leather stitched on, to enable it to stand the drag. The hood is cut to the shape of the head and neck, having holes for the eyes and coverings for the ears, resembling those organs in shape. The muzzle is uncovered for about 6 in., and a strap and buckle confine the hood to this part; while a number of strings tie it under the angle of the jaw and below the neck, in such a way as to let it loosely overlap the quarter-piece and breast-piece. All these three divisions are neatly bound, and the whole looks well upon the horse, when nicely put on with the roller buckled smoothly over the quarter-piece. A cord is sometimes used to confine the quarter-piece behind, when there is much wind. It is simply attached on each side, so as to lie beneath the tail across the quarters of the horse. Body-clothing is made of different degrees of stoutness, according to the time of year when it is to be worn. Race-horses, which are not intended to be trained during the winter, do not require such stout elothing as hunters, and their sheets in the summer are made of very light serge. Brown-holland is not fit for any season, for even in our summer the nights are often unexpectedly cold. The following are the prices at which good rugs and clothing may be obtained fit for private use :-

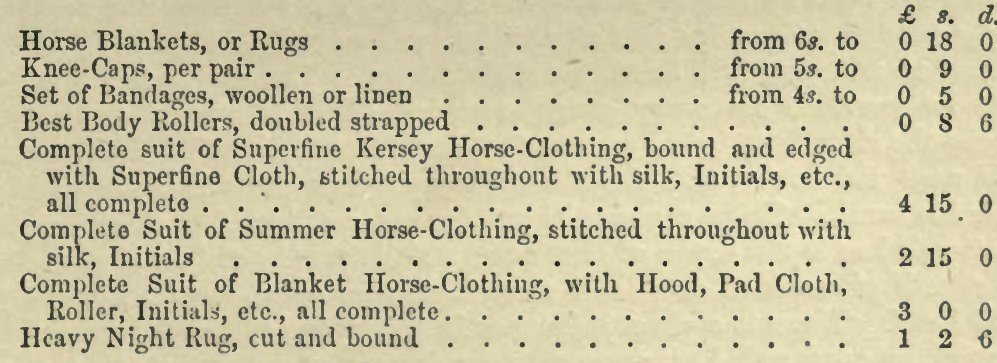

Sweaters are merely warm rugs or blankets which are kept for that especial purpose, and are shaped according to the part they are intended to 
cover, being kept in their places by the body-clothing. Thus if the neck is too heavy, as it often is, especially in entire horses, and it is desired to reduce this part more than any other, one, two, or three old hoods, according to circumstances, with the ears cut away, are put on under the regular hood, and the horse is then sweated, with or without additional body sweaters, as may be decided on. If old hoods are not at hand, a rug is folded and placed over the neck, confining it in its place by a temporary string across the forehead, and by the aid also of a hood over all. So again a rug may be arranged to sweat the bosom by folding it cornerwise like a woman's shawl and drawing the ends up over the withers, crossing them beneath the saddle. Sweaters for the body are simply rugs used for that purpose, which may be one, two, or three beneath the quarter-piece, according to the amount of wasting which is intended. The saddle keeps all in place instead of the roller, which is not taken out of doors excepting for those horses which are only led in hand. Sweaters must be carefully freed from the dried sweat by washing.

THE STABLE ACCESSORIES for cleaning and otherwise attending to the horse are the following, to which I have appended the average price, which will vary to some extent according to quality, and also to the fashionable nature of the establishment at which they are sold:-

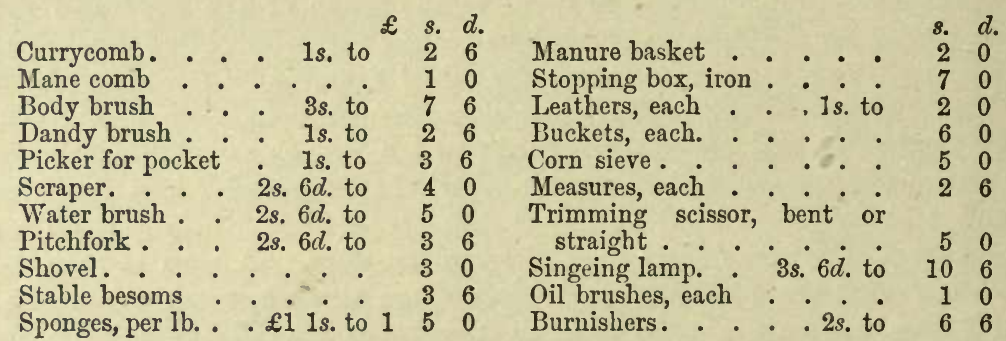

The CuRrycomb is intended to remove the scurf or scales of the scarf skin which are constantly produced from the true skin, and if allowed to remain at the roots of the hair have a tendency to confine the sweat, and thus interfere with the relief to the circulation which is afforded by that natural process. When a horse's skin is once put into good order it inay be kept clean without the use of the currycomb, but a dirty coat cannot well be got right by any other means. The body brush does not penetrate deeply enough unless the coat of the horse is very thin and short, and no amount of whisping will be of the slightest use. The currycomb therefore must be provided for every groom, and indeed it is wanted not only to cleanse the skin, but also to remove the dust from the brush. But the less it is used the better, and the thoroughly good groom will chiefly employ it for his brush. There are several patterns in use, but the chief point to be attended to is the depth of the teeth, which should not be cut more than the eighth of an inch deep, and should only be on alternate rows of the comb itself. There is a great difference in the modes of handling this comb adopted by good and bad grooms. The former sweep it lightly over the skin, just effecting their object without absolutely scratching the surface, whilo the latter bear heavily upon it, and punish the horse to such an 
extent as often to cause even a naturally good-tempered animal to use his teeth or heels most savagely. So also a light thin-coated horse even when very dirty and full of scurf, as it will inevitably be after lying by in a loose box or at grass, does not require the comb to be pressed hard upon the skin, yet the stupid and ignorant groom makes no difference in his favour, but works away just as he would if dressing the woolly winter coat of a carthorse. During the time when a horse is shedding his coat the currycomb should be banished from the stable, for neither it nor the brush should be employed at that time.

The MANE COMB is merely a strong horn, iron, or vulcanized indiarubber comb, with teeth of a suitable degree of coarseness.

BODY BRUsirs are made of hog's bristles, of an oval shape, about nine inches long by four and a half wide, with a strap of webbing across the back to hold them firmly to the hand. They are wanted at all times but during moulting, when their use makes the next coat come on coarser than it otherwise would. This arises from the fact that the brush brings off the old coat too soon, thereby chilling the skin and stimulating the glands which secrete the hair, to develop it more stoutly and of greater length than they would otherwise do. To produce a beautiful new coat the old one should be kept on as long as possible, just as we find in the sheep which is not shorn, but allowed to shed its wool, the next growth will be much shorter and lighter.

THE PICKER is merely a blunt hook for clearing away the gravel which gets between the shoe and the foot of the horse while at work. It is better made to fold up like the pocket button-hook for our own use.

WATER BRUSHES are either made of split whalebone or of a kind of reed, which is cheaper but does not last so long. They are intended to wash off the dirt from the legs and feet, and out of the soles of the latter.

THE USE OF THE PITCHFORK AND SHOvel is too well known to need description here.

Stable BRooms are either made of birch or of a fibre called bass, the choice being dependent upon price, which varies according to the locality. Either will answer the purpose well, and where birch can be readily obtained, its price is so low as to beat the bass out of the market, good besoms of this make being in many parts of England to be bought at $3 d$. or $4 d$. apiece without the handle, which will last out an indefinite number. In London, however, the bass brooms compete with them in economy, birch brooms being sold there at $1 s$. apiece, while bass brooms, which will last out three or four of them, may be obtained for $3 s .6 d$.

SPONGE is an expensive article in the stable, for as it is constantly in use it soon decays. To employ it to the best advantage a double supply should always be on hand, one of each of the sizes wanted being in use for a week, and then put by to dry for a similar period. In this way a soft, flabby, and nearly worn-out sponge recovers its texture in a marvellous manner, and sponge carefully treated on the plan I have described will last fully three times as long as if it is constantly kept wet from first to last. Few grooms, however, will carry out economical principles to this extent without the constant interference of the master, and if the experiment is tried it should be really ascertained that the alternate periods of use and renovation are rigidly adhered to. In ordinary stables one large piece of sponge about 
eight or nine inches square when wetted, another five or six inches square, and a still smaller piece, will be sufficient.

The manure BasKet is either of the ordinary brown willow work, or of galvanized iron wire. No good stableman should be unprovided with this accessory, which enables him to save litter, and also to keep his horse clean and comfortable.

The STOPPING BOX is an oblong box of oak or elm about fifteen to eighteen inches long, nine wide, and six deep. This is filled with fresh cow-dung, mixed with an equal quantity of clay, to which some stablemen add oncfourth or less of pitch ointment, but the dung is the essential ingredient, its use consisting in its great tendency to keep moist and also to moisten the surface to which it is applied. This is so great that a thin sole or a fungous frog may be readily made to waste away by decomposition if the stopping is applied constantly to them. As much harm is often done by overdoing the stopping as by omitting to use it altogether. The stopping box is sometimes also made of galvanized iron.

Leatners are used of the full size sold in the shops, to finally dress over the coat of the horse, and also to wipe the saddlery. Like the sponge they form an expensive item in the accounts of the groom.

RUBBERS or DUSTERs, as they are sometimes called, are made of coarse linen, which should be twilled if economy is studied. Calico does not answer the purpose. From six to twelve rubbers, each about two feet square, will be wanted, the number depending upon the extent of the stable.

Two BUCKETs at the least must be provided for each groom, one being kept for clean water, and the other for washing legs and feet, dirty saddlery, etc. None but well-made oak buckets should be admitted into any stable, although galvanized iron pails are much cheaper.

The CORN SIEve is employed to get rid of the dust, which all corn contains, more or less, and also to expose a large surface of it, so that any stones in it may be readily discovered.

A quartern and a haLf-quartern measure will be indispensable, both being wanted for oats, and the latter for beans.

Trimming scissons are necessary, with straight as well as curved blades, to keep down those hairs which cannot be got rid of by pulling; as, for example, a few of the strongest in each fetlock. They should never be used where the hand, aided by powdered resin, is able to draw the hair out.

A singeivg LAMP, to be used either with naphtha or gas, should form a part of every list of stable implements; for even if the groom is not competent to singe the body of the horse, he should, at all events, use it occasionally to keep down the long and loose hairs which keep growing about the jaws, neck, quarters, and legs. If a horse is singed ever so well in October, and even if the operation is repeated in November, he will bo rough to the eye in the following month, and in January he will be quite unfit for a gentleman's use. Any groom, however, who has the slightest skill in the use of his hands, can avoid this by skimming over these parts with the lamp; and, indeed, most head-grooms in the present day are able to do without the aid of the professed singer and clipper, by repeated applications of the lamp.

OrL Bnusues are required, and also a small can of either neat's-foot or fish 
oil, to apply to the outside of the feet ${ }^{1}$ before going out of the stable, and the former also to dress the saddlery and harness when required.

BANDAGEs are of two kinds: firstly, of flannel, for the purpose of keeping the legs warm, when they have been washed, or during illness; and, secondly, of linen, cotton webbing, or unbleached calico, to give support to the vessels, and keep the legs and feet cool. Both should be about seven inches wide and five or six yards long, and should finish off by turning the corners down to a point where two strings are sewn, which tie round the leg, and prevent the last turn becoming loose. The strings are rolled inwards, so as to come out last; and the whole should be firmly and smoothly rolled up some hours before they are to be applied, so as to get rid of the creases left during the last application.

\section{FOOD AND WATER}

In Great Britain and Ireland horses are chiefly fed upon grass (green or dried into the form of hay), corn, chaff (which is hay cut up with straw into short lengths), and roots of various kinds; but in addition may be mentioned the following kinds of green food-namely, clover, tares or vetches, lucerne, rye-grass, saintfoin, green oats, gorse or furze. The various stimulating mixtures, such as Thorley's, Simpson's, and others, are spicy condiments used to help food down with shy feeders, but care should be exercised in giving them, for having once become accustomed to them, horses are apt to refuse to return to plain fare.

Grass is undoubtedly the natural food of the horse, though in his native plains the same species of plants are not met with as form the green surface of our own fields. English horses, however, may now be said to be thoroughly accustomed to our grasses, which seem to agree with these animals so well as to be one main cause of their superiority. The water grasses, which constitute a large proportion of the herbage found in our lowland meadows, are not suited to the constitution of the animal; and he will not take them, unless forced to do so by the absence of other and preferable food. On our uplands, clover (either white or red) is generally more or less mixed; and in proportion to its presence will the pasture suit the horses turned out to graze upon them. A sound and moderately young animal gets fat during the summer and autumn months, when turned out on a good upland meadow; but he is not able to undergo long-continued exertion, especially at a fast pace, partly because the amount of fat accumulated in his internal organs interferes with his wind, but chiefly from the fact that the grass does not supply sufficient muscle-making materials for the wear and tear of his frame. If the horse is allowed as much oats as usual, and has regular exercise, he will be able to do a good day's work while at grass; but he will sweat profusely, and on that account, if he is required to repeat his task often, he will lose flesh and become jaded in his spirits. For these reasons, grass is not commonly used as food for the horse, excepting for the purpose either of keeping him cheaply and conveniently, while he is undergoing treatment for some accident or disease, or to afford

1 Modern veterinarians disapprove of oily applications to the hoof, but they add greatly to the finished appearance of a horse when brought out of the stable for use. 
a renovating change after a long-continued course of hay and corn. For the former of these purposes, the horse is generally turned into the fields; but for the latter, he is very often supplied with cut grass, or some other kind of green food, in his stall or box. The effect of grass, when given by itself, is apparent in its action on the bowels, which is at first very marked, and also on the kidneys and skin. These increased secretions subside in the course of a few days to a considerable extent, but continue, more or less, as long as the grass continues to be the sole article of food. This will, of course, account for the cooling effect always remarked on horses at grass, in which inflamed joints and swelled legs rapidly subside, and inflammatory diseases of most kinds have a tendency to abate. The amount of nourishment contained in grass is small as compared with its bulk, and hence the belly of every horse enlarges considerably while at grass, because of the necessity for a larger quantity being contained within it, so as to afford a sufficient means of nutrition. Winter grass, which contains no clover, from this plant not being of a nature sufficiently hardy to stand the frost, is so void of nourishment, that the horse confined to it alone speedily becomes very poor, and will almost starve if he has not some hay or corn.

HAY is not merely grass cut when most full of nourishment-that is, just when it is in bloom-but it is also subjected to a degree of fermentation, which converts some of the starch into sugar. Until this change has been fully gone through, the hay is not wholesome; and hence new hay has obtained a character for producing worms, which is not without some foundation; the reason being that the stomach and bowels are put out of order; and this being a condition favourable to the development of the ova of most parasitic animals, it is a natural consequence that worms should be more frequently met with in horses fed upon new hay, than in those whose digestive organs are strengthened by the healthy stimulus of sound old hay. Of course, fodder of all kinds may be too old, as well as too new ; but well-made hay does not begin to lose its good qualities till after the second winter, and remains perfectly fit for ordinary purposes during at least another twelvemonth. There are several varieties of hay grown and sold throughout the country, which may be divided into three principal growths; viz. upland hay, in which no water grasses are met with, and which generally contains a large proportion of clover; meadow or lowland hay, made up of the various kinds of water grasses and plants fond of wet soils; and clover hay, which is made from the common red clover, without any admixture of grasses. Of these, upland hay is alone fit for horses used at high speed; and no other should ever be admitted into the stables of the private gentleman, except clover intended to be cut into chaff.

Good old Upland Hay is known by its peculiarly sweet and grateful smell, and by being made up of fine grasses with no seeds developed, mixed with a small proportion of white clover. The colour should be neither a bright green nor a dark brown, an intermediate shade of brownish-green being the best, and showing by its green cast that the hay has not been lying out in the rain, and by the absence of any deep blackish-brown tint that it has not been put together too soon and thereby become heated. If it has been got up in perfect condition, and without having had any rain on it, a delicate bloom may be observcdon the leaves, like that on a plum or grape. A rick of good hay may be entirely spoilt by a want of proper 
caution in getting it in, and many a one has taken fire from this omission, or if not absolutely burnt it has been so heated that it cuts quite black and is unfit for food. If the hay is dusty it is either from having being flooded, which marks its lowland character, and in this case the dust is of a mineral nature; or the vegetable material becomes powdery from being over-heated, - and thereby rendered brittle, and easily broken down by the slightest friction. Experience alone can enable the purchaser to select exactly the proper kind and condition of hay, but if once a good sample is carefully examined by the eye and nose it can scarcely be forgotten. When hay has been burnt it is not always at first refused even by the most dainty horse, but in a day or two he finds it disagrees with his stomach, and he will then leave the contents of his rack untouched. Of course there are many degrees of "mowburn," but unless the hay is only slightly affected it is better to avoid using it, as it may produce irreparable injury to the stomach or lungs. Half rations of good food are far better than an unlimited quantity of bad hay and corn, and this the horse-master soon learns by experience, but often not until he has paid for it by the production of some serious disease. The staying powers of the horse are dependent upon the quantity and quality of the corn he has eaten, but his health is chiefly affected by his hay. This is an important consideration to every stableman, and of its truth I am convinced from thirty years' experience with my own horses as well as numberless others. Such are the qualities and evidences of good hay; let us now examine into those belonging to this kind of food when it is of an opposite nature.

Burnt hay, as has been said above, has many degrees. When it is almost charred, quite dry, and friable, it should not be used for horses in any case, but it may be given to sheep with safety. If the heating has not gone far enough to destroy a certain oily feeling to the touch, and if it is still fragrant to the smell, it may be used.

Musty hay is known by its peculiar musty smell, its washed-out colour, and its mouldy appearance. The mould is caused by a minute fungus, which is bred by damp coming from rain or dew, left in the grass when carried; the natural sap does not cause fungus. Sometimes this mould is not found throughout the hay, but only in patches; that happens when the crop has been only partially dried. No hay is so unwholesome as that which is musty, and it is instinctively refused by all horses until they are driven to eat it by starvation. Salt is often used to induce horses to eat it, but, though it will have that effect to a certain extent, it scarcely makes it at all less unwholesome, and the groom must not fancy that his charge will escapo the ill effects which result from musty hay in every shape. It is also often cut into chaff with straw; but this plan also has no advantage ; and in every way musty hay may be considered as a poison to the horse, and not a very slow one.

Weather-beaten hay is that which has lain out in the rain for many days before it could be got in dry. It is generally but not necessarily musty, but if not so, it is devoid of nourishment, the soluble matters fit for food having been mostly washed out of it. It may be known by its faint, sickly smell, by its sapless and withered appearance, and by the presence of dust. The colour varies greatly, depending upon the management; for if the hay has not been put together in cocks during the making, 
it does not blacken, but remains of a pale, dirty, olive green. No one who cares for the health and condition of the inmates of his stable should use such hay in it; for he will find it not nearly so nourishing as good bright straw, while it will assuredly disagree with the stomachs of his horses, and then not only do no good to them, but prove positively injurious.

The quantity of hay which is required, if given alone, will average about $1 \frac{1}{2}$ cwt. per week for a horse of middle size and good constitution. This, however, is but an approximation to the truth; for in half-a-dozen horses there will be scarcely two which will require the same quantity of food to keep them in health. Hay alone is insufficient for horses called upon for fast work. Some low-bred animals are like donkeys in their constitutions, and will thrive upon hay alone; but these are exceptions to the rule, and they are only to be met with among horses which have been brought up on this poor diet. I have known one stable in which the carriage-horses were kept on salted hay, without ever tasting corn at home; but though they looked fat enough, and were certainly full of life, they were unable to do fast work, and indeed they were only used for short distances at any time. If a proper allowance of corn is made, from ten to fourteen pounds of hay per day will be ample, the quantity varying with the constitution of each horse and with his allowance of corn. Sometimes clover hay is cut into chaff in addition to the meadow hay, which is put in the racks, and then an allowance should be made, as there is more nourishment in the clover than in the ordinary grasses. In well-managed stables, each horse of average size will consume from two tons to two tons and a half of hay in the course of the year, and this will cost on the average from $£ 8$ to $£ 13$.

Horse CORN consists of oats and beans, to which may be added peas and maize, the last kind of food having been introduced from America. Barley and wheat have occasionally been tried, especially the former when malted; but they have not been found to possess any advantage, and, on the contrary, they have generally disagreed with the stomach to a very appreciable extent. Wheat bran is in very general use, and also linseed.

Oats contain a large amount of nutriment as compared with hay, but as it is the mealy kernel that is the valuable part, while the husk is less digestible, it is most important to secure oats which have thin skins. As a general rule, the lighter they are the greater is the proportion of husk to kernel, and therefore the weight is the first thing to be considered. English oats are thin skinned, but seldom weigh more than $42 \mathrm{lbs}$. to the bushel. Russian oats are thinner skinned than any except Scotch and English winter oats, but there is a new sort of Russian, weighing up to $44 \mathrm{lbs}$., which is not so good, as it has a thick skin. From 40 to 42 lbs. therefore may be taken as the best weight. Of late years the quantity of light oats has much decreased, as the demand for heavy sorts has become more general, and therefore the difference in price between light and heavy (which some years ago was so great as to make it economical to give light oats to horses which had not very hard work to do) has become less, and it is now most economical to give the best heavy thin-skinned oats to hacks and carriage horses, as well as to hunters, racers, omnibus and cab horses, which latter are worked to the utmost extent of which their powers are capable. It is found by experience that horses will consume only a certain bulk of oats; and as the quantity of 
this kind of food which is eaten is generally considered to be the measure of condition, hunting grooms and trainers come to the conclusion that if they can get their horses to take three bushels of heavy oats during the week, instead of the same bulk of lighter ones, they will have benefited to the extent of the difference in weight between one sample and the other. As far as those horses are concerned which are allowed as much corn as they will eat, this is perfectly correct; but for hacks and carriage horses an unlimited quantity of oats would do harm, for they are not so much worn down by muscular exertion, and if overfed they soon become diseased, and in the meantime become unmanageable. For them three quarterns of good oats a day will be enough. Oats should never be given while they are new. As a rule it is best to wait till the March winds have dried last years' crop before using them, but in very dry seasons they may be used earlier with safety. This is a more important point for horses that consume large quantities of them than for hacks and harness horses that eat less.

Good oats should be free from dust and stones, and may be known by their plump look, and full, hard feel to the touch, by their sweet smell and taste, and if white, by their bright straw colour. These qualities are the apparent ones, but they accompany and depend upon the really essential ones of thinness of skin, hardness of kernel, and soundness, placed in the order of importance. It is of no consequence whether oats are black or white if they fulfil these conditions, but at the present time there are more good black oats grown than white.

New oats are indigestible, and act prejudically on the bowels and kidneys. As a natural consequence, the horse eating them becomes flabby in his flesh, sweats profusely, and often throws out the eruption known as "surfeit." If it is necessary to use them at once, they should be kiln-dried; and this plan is always resorted to for oats which are imported into this country, to prevent the heating which would occur in the hold of the vessel from the bulk which is lodged there, and which would soon make damp new oats musty. New oats may be recognized by their softness to the touch, and by the white substance within each grain being pulpy and quite unlike flour, as it ought to be in old oats. When oats are kiln-dried they are said by some fanciful stablemen to produce diabetes, ${ }^{1}$ but it does not appear that any prejudicial effect follows merely from the artificial drying. Many of the oats so treated are previously damaged, and then of course they are likely to produce an injurious effect upon the stomach, but not from the mere drying itself.

It is a common practice in Sweden and Ireland to sulphur oats, in order to improve the colour. There is no harm in the sulphur itself, but such oats should be avoided, as the process is adopted often for the purpose of concealing some defect. Sulphured oats may be detected by their sour smell. Scotch oats are the best of all, on account of their remarkably thin skins. Russian oats are also very good, as they are next to the Scotch in this respect, but they vary in quality more, and the very heavy Russian oat, referred to above, is not to be desired, on account of its thick husk. Hardly any oats now come into the London market from Wales, and

1 Veterinary surgeous are generally agreed that kiln-dried oats are a fruitful source of polyuria, or profuse staling, which was fornerly confounded with true diabetes; a disease in which sugar is found in the urine.-EDITOR. 
few from Ireland; the latter are not good, as they are soft, and often sour.

Oats are either given whole, or converted into meal, when they are used in the shape of gruel, or they are bruised (sometimes called "kibbled"). The entire oat is not always crushed by the grinders of the horse, and it then often passes through the digestive canal without losing the nutritive materials contained in the kernel. Hence there is a great loss, for unless the oats swallowed are digested, they are quite useless in imparting nourishment, and to avoid this defect it is now very usual to bruise all the oats before they are put in the manger. I have already alluded to the oatbruising machine as a necessary appendage in every stable, and I may only here remark, that the saving is supposed to be nearly one-fourth of the consumption. This estimate is in my opinion too high for young and vigorous horses, but for old ones it is accurate enough. There is a vast difference in horses, in respect to their power of digesting oats, and if the droppings of a number of these animals are carefully examined, this will be very apparent. Sometimes a whole oat can scarcely be found in a large mass, while in other cases nearly fifty per cent. will be evidently undissolved. Many people, and especially trainers of race-horses, have an idea that bruising oats interferes with the wind of the horses to which they are given, but this is purely imaginary, and cannot for a moment be supported either on theoretical or experimental grounds. The bruising is always advantageous, but not to the same extent; still it cannot be denied that the labour of working the oat-bruisers is well bestowed. The grains should not be more than cracked, so as to readily admit the gastric juice to the floury kernel, all beyond this being more or less injurious. The quantity of this kind of food which is required depends upon the nature and amount of the work to be done, and upon the constitution and breed of each horse. Race-horses are now often induced to eat eight and even nine quarterns of oats daily, and hunters almost as much, but hacks and harness-horses seldom get more than from three to four quarterns daily, a bushel and a half per week being about the average, costing about 4s. 6d. For ponies and horses doing very little work a proportionate reduction is made. After bruising, oats must not be kept long.

Gruel is made from oatmeal, either with hot or cold water, in the latter case hardly deserving the name, but being the form in which it is too often given by ignorant and careless stablemen. To make it properly, one pound of good oatmeal should be carefully stirred up with sufficient cold water to form a thin mixture of the consistence of cream, which will take nearly a quart. This is then stirred into three quarts of boiling water, and the whole kept stirred over the fire till it thickens, when it is to be set on one side to cool, being given when about lukewarm, or, if the horse is very much exhausted, a little warmer It is an excellent restorative for a tired and exhausted hunter, and careful grooms provide it ready-made against their master's return from hunting. Raw gruel should only be given when time is an object, as, for instance, on a journey, when half-an-hour cannot be devoted to a regular feed. A pint of oatmeal may then be stirred up in some cold water, and given from a pail, affording as much nourishment as a feed of corn. 
Malt is a very good food, but too expensive for general use; it may be given with advantage to horses that are convalescent after illness.

Beans and Pease may be taken together, inasmuch as the nutritive matter contained in them is very nearly the same. Both are extremely stimulating to the horse, rendering him prone to inflammation when given in inordinate quantities, and always producing more or less flatulence. They each contain more than twice as much gluten as oats, the proportions, according to Professor Johnstone, in 100 parts, being 11 in oats, 26 in beans, and 24 in pease. From this cause beans and pease supply the waste in the muscles produced by hard work, more completely than oats, and the former are therefore extensively used by cab and omnibus proprietors, as well as by farmers, who find them cheaper than oats. I shall hereafter be able to make a comparative estimate of the value of the various articles of horse-food in muscle-making ingredients, from which it will be seen that they are right in their conclusions. For private horses, beans are generally too stimulating, and as they also have a tendency to produce constipation, they should be used with caution. Old horses, and those exposed to the wet, require them, and the effect of a few in restoring condition, when it has been lost during wet and cold weather, is sometimes quite marvellous. Almost all horses are passionately fond of beans, and those which have been long used to them will hardly touch oats alone. In private stables, when beans are given, they are generally mixed with three or four times their weight of oats, half a quartern of beans daily being sufficient, when split, for most horses, when mixed with their usual allowance of oats. Of course this addition must be met by a diminution of the oats; and thus a horse which has been allowed a peck of oats daily, if he has a quartern of beans may be reduced to three quarterns of oats in addition. Wherever the feet or legs are inclined to inflame, or there is any tendency to thick wind or broken wind, beans are very injurious, and should be carefully avoided. Indeed, for private work, I should never recommend them, excepting for old horses, or for those which are much exposed to the weather, and especially in standing about at night. In such cases beans are extremely valuable, always supposing that there is none of the diseases which $I$ have instanced as aggravated by them. Many washy, light-carcassed horses, which could not be made to do any work without beans, may by their aid be rendered serviceable; and although they are liable to great abuse, they are a very valuable adjunct to the stableman. Beans should never be used till they are nearly a year old, and after they are thrashed they require turning every ten days to keep them from becoming musty. They are very prone to the ravages of the bean-bug; but so long as they are sweet and old the damage done by this larva is only from the loss of substance, which they cause by scooping out the middle of the bean. Pease produce nearly the same effects as beans on the horse, but they are not so heating, and scarcely so digestible. Beans and pease weigh from 60 to $65 \mathrm{lbs}$. per bushel; the price varying from $32 s$. to $35 s$. for eight bushels.

Maize, formerly known as Indian corn, is now imported at such a low price as to tempt many horse-owners to use it. The great omnibus and tramway companies, railway contractors and others, were not slow to avail themselves of so strong a food, but a long experience has proved that horses consuming any considerable quantity of it are more liable to inflammatory 
diseases, notably fever in the feet. The same objections, but to a lesser degree, apply to barley.

The following is the ration now given (1896) by the General Omnibus Company (London) -

$\begin{array}{cc}\text { Scale } & \text { Beass } \\ \text { lbs. } & \text { 1bs. } \\ 1 & 0 \\ 2 & 1 \\ 3 & 2\end{array}$

OATS
Abs.
3
3
3

MaIzE
lbs.
15
15
15

Chaff
Jbs.
10
10
10

The Great Western Railway. For horses working in town-

$$
\begin{array}{lrrr}
\text { Oats } & \ldots & \ldots & 13 \text { lbs. } \\
\text { Beans } & \ldots & \ldots & 3 \text { lbs. } \\
\text { Bran } & \ldots & \ldots & 2 \text { lbs. } \\
\text { Chaff (cut hay) } & \ldots & 14 \text { lbs. }
\end{array}
$$

Country horses receive-

$$
\begin{array}{lllr}
\text { Oats } & \ldots & \ldots & 7 \text { lbs. } \\
\text { Maize } & \ldots & \ldots & 6 \text { lbs. } \\
\text { Beans } & \ldots & \ldots & 3 \text { lbs. } \\
\text { Bran } & \ldots & \ldots & 2 \text { lbs. } \\
\text { Chaff } & \ldots & \ldots & 14 \text { lbs. }
\end{array}
$$

Durisg the winter months $2 \mathrm{lbs}$. of beans are adled to this scale. Tlie oats, beans, and maize are all given crushed.

The Midland. This company's allowance is sixteen stones per horse per week, composed as follows-

$$
\begin{array}{llll}
\text { Beans or peas (split) } & \ldots & \ldots & 2 \text { stones } \\
\text { Maize } & \ldots & \ldots & 2 \text { stones } \\
\text { Bran } & \ldots & \ldots & 2 \text { stones } \\
\text { Oats (crushed) } & \ldots & \ldots & 4 \text { stones } \\
\text { Chaff (hay or clover) } & \ldots & \ldots & \text { 6 stones }
\end{array}
$$

I here append also, extracted from Earl Cathcart's Report to the Royal Agricultural Society in 1889, the rations given in the French Government Haras, or National Stud, at Lamballe, Brittany.

$$
\begin{aligned}
& \text { Hay } 4 \text { kilos = llbs. } \\
& \text { Straw } 6, "=, 131 \\
& \text { Oats } 5 \not=, "=11
\end{aligned}
$$

The horses here are stallions, and this allowance is more than that of the French cavalry, which is-

$$
\begin{aligned}
& \text { Hay } 3 \text { kilos = about }{ }^{1 b s} \text {. } \\
& \text { Straw } 5, "=, 11 \\
& \text { Corn } 4 \cdot 2, "=", \quad 9 \frac{1}{4}
\end{aligned}
$$

For ordinary hacks and carriage-horses, the cost for food and litter may be taken at $1 s$. per hand per horse per week.

Malted barley and wheaten bread are greedily eaten by horses, but they are generally too costly for use. The husk of wheat separated from the meal in the shape of bran is a very important article in all stables, having a cooling effect from its laxative properties when made into a mash with water. Dry bran is often given with sliced carrots, with which it makes an excellent food for slow working horses; but there is not any great amount of nourishment in it by itself. Bran mash is made either hot or cold. In either case a bucket is half filled with bran, and then as much water as it will absorb is poured upon it, and if hot it is put by till nearly cold, being 
closely covered up in the meantime. All horses which are not inclined to scour should, when they are kept on hay and corn, have a mash once a week, selecting the night before the most idlo day in it. The effect is a gentle action on the bowels without purgation, by which all tendency to mechanical stoppage is prevented without weakening the horse. On the evening when the mash is given the usual feed of corn is omitted, the hay being given in slightly reduced quantity, unless the bowels are very confined, when a bucketful of mash may be given by itself ; but few horses will eat more than half a bucket of bran.

Linseen, like bran, is chiefly used medicinally, that is to say, to produce certain effects upon the body which are not required to be permanent. These are, first, to increase the fatty matter deposited in the flesh; and secondly, to soothe the mucous membranes. For the former purpose half-a. pint or a pint of linseed is scalded and set to simmer by the fire till it has become a glutinous mass, when it is mixed up with a quart of bran, and is given every night till the desired change is produced. To produce an effect upon the mucous membrane, the linseed should be boiled slowly in two quarts of water, and this should be mixed with a quart of bran, and given as warm as the horse will eat it.

Hempseed is occasionally given to entire horses, but it cannot be considered as a regular article of food.

ChAFF is composed of hay and straw, or clover hay alone, or sometimes oat straw by itself, cut into short lengths. It is given mixed with the corn, the object being to induce the horse to masticate this thoroughly. In many large cab and omnibus stables, as well as those where horses stand at livery, no hay is given excepting what is cut up with straw in the shape of chaff. Here the object is to induce the horse to grind his corn well and quickly, so that his whole body, but especially his legs, will be refreshed in the recumbent position. The plan seems to answer well under the peculiar conditions in which such horses are placed, but there can be no doubt that it is unsuited to produce the highest condition of which the horse is capable. Moreover, it is a great object to amuse the animal when he is not worked very hard, and this is far better done by giving him some portion of the hay in his rack for him to play with, than by cutting all of it up into chaff. For these reasons the practice in private stables is to cut up about two bushels of chaff for each horse weekly, thus allowing about a peck a day to mix with an equal quantity of corn. This is quite enough to induce him to grind his oats and beans, if he has any, without depriving him of his amusement in picking his hay out of his rack. I am quite aware that in large establishments economy is practised by cutting all the hay into chaff, but the saving per head is small, and is not worth attention for private horsekeepers, if it can be shown that it affects the health or comfort of the horse in the slightest degree. In Iondon clover hay is extensively used by itself as chaff, but elsewhere throughout England the practice is to cut up equal quantities of oat or wheat straw, with some of the hay that is provided for the racks. These are placed in alternate layers in the chaff-cutting machine, and they are thus sufficiently amalgamated to prevent the horse from picking out the one and leaving the other. If the master has not obtained a machine, there are in all towns men who go about with one to cut the chaff once a week at a small sum per bushel. 


\section{ROOTS}

Carrots and Parsnips are the only roots which are readily eaten by the horse, and no others seem to agree with him well. The effect of each is nearly the same, proving slightly aperient and diuretic at first, and then serving to cool the system. After a short time they fatten him, and may be continued for months together without inconvenience. It is supposed that two pounds of carrots are about equal in nourishment to one pound of oats, but they do not possess the same amount of muscle-making material, and are therefore only suited to slow work. Parsnips are not often given in this country, but in France they are a very common kind of horse-food. By a little starvation the horse may be made to eat mangold-wurzel or turnips, but they are not good for him. Whenever, therefore, a change is desired during the winter, carrots alone supply the want, and they can only be given with advantage to those horses which are not doing hard work. They are made up chiefly of starch and sugar, and afford little gluten and albumen as compared with oats.

Horses in stables are kept in an artificial condition, and though they will generally thrive on the ordinary food of oats and hay for a long time, yet occasional variety and change of food is very desirable. There is also a very great difference in the constitution of these animals: one will go on steadily working with little or no variety of food, while another will get out of condition, and need a change to something more resembling the circumstances which surrounded his ancestors before they were subjected to the service of man. A sensible horse-keeper will remember this, and study his horses' idiosyncrasies, and if he requires them to do constant and heavy work, he will observe the beginning of failure to do as much as they have been accustomed to, and will give them a rest. In ordinary cases the rest of one day in seven is sufficient for horses as for men, but when that is encroached upon, it is sooner or later necessary to give them a long rest and complete change of food by turning them out to grass.

\section{GREEN FOOD SUITABLE FOR SOILING HORSES}

THE овJECT in giving green food to horses in the stable is generally to afford them a temporary change from their unvarying rations of hay and corn without losing their condition entirely, as they do when turned out. All the articles which are used for this purpose, and which $I$ have enumerated below, slightly purge the horse when first given, and act beneficially in that way for some two or three weeks. After this, however, they fatten him rapidly, and then, instead of doing the legs good, as is generally the intention, they make them more stale by increasing the weight of the carcass, as soon as the horse is put to work.

Clover is greedily devoured by all horses, and fattens them quickly, but it is not suited to those cases where a cooling diet is wanted to relieve inflamed joints.

TARES or Vetches when young are very relaxing, and they also act 
powerfully on the kidneys. As soon as the seed is nearly ripe in them, they are nearly as stimulating as corn, and at that time only are they fit for horses at work. This ought to be known to all horse-masters, or they will be apt to make the mistake of giving young vetches to horses at work, and old ones to those which are put by to be freshened up.

LUCERNE is a good kind of green food, being neither so relaxing as young vetches, nor so stimulating as old ones.

RYE-GRASS is chiefly to be recommended as coming very early in the year, when no other kind of green food can be obtained.

SAINTFoIN is very similar to clover in its effects upon the horse, but is not quite so fattening.

Green OATs are only given where the land is so poor that it will not produce clover or vetches. The crop is a very light one, and in an economical point of view it is not to be recommended, excepting for the reasons given above.

Gorse, Furze, or WiIn makes a good food for horses that are not doing fast work, and in those situations where it can be procured it is most economical. As a change it acts quite as beneficially as any other green food, and sometimes it is the only kind which can be procured. The following is the method of using it:- It is cultivated by sowing it with a crop of barley or oats, and it is fit to cut the second autumn after planting. It is then mown every year during the winter, as required, with a common scythe, close to the ground. A tolerably good soil, dry enough for this plant, will cut from seven to ten tons per acre; and the same land has been cut for fourteen years without loss of quantity or quality, but after that time it required to be given up and a fresh plantation made on other land, as the roots became decayed. The plant best adapted for the purpose is very common in England, but is called the French Furze, and it grows well upon an old woodland, stocked up, such as is often useless for other purposes; but it must be dry. Half-an-acre of this land is, on the average, enough to keep a horse twenty weeks; on rich, loamy, dry land a quarter of an acre will serve for the same period, so that an acre of land may be made to keep two small cart-horses for more than a year, though it is better to give them grass in the summer. On the large scale, the mowing, carting, cutting, and bruising cost not quite a penny a bushel; but for small stables the expense would of course be greater. As, however, this item is generally a part of the groom's daily work, it is seldom taken into the calculation. The quantity of seed required is $20 \mathrm{lbs}$. per acre, sown broadcast; but it should be drilled as near in the rows as will admit of hand hoeing for the first year or two, if the land is inclined to run to grass. It is not necessary to manure it, though in its consumption it creates a great deal. When once sown and well rooted, it yields a great quantity of food for cattle, at no other expense than the cutting, bruising, etc. In those districts where winter food is short, it answers well to mow it as soon as the grass is gone, and then it lasts till grass comes again. If there is a threatening of snow, it is necessary to mow some quantity beforehand, as it will keep for some days unbruised.

Ensilage, which has come into general use of late years for ruminant animals, is unfit for horses. 


\section{ARTIFICIAL CONDIMENTAL FOODS}

VARIOUS ARTIFICIALLY PREPARED Foods have been introduced to the notice of the public, under proprietary names. Chemical analysis shows that these foods do not contain more nourishment than the ordinary ones. The following observations in The Field of February 18, 1860, put the matter in its true light, and show that, as a mere article of food, these preparations are far from economical :-

"It is not surprising, when artificial foods should thus come to be adopted as so much fattening power, that various mixtures should be employed largely impregnated with stimulating substances. They are thus made extremely palatable to the animal, who naturally enough thrives upon the good things provided for him. We will not now stop to inquire how far this stimulus may be permanently beneficial, even admitting the temporary advantage; our object is simply a cash account. If the price of cake, ranging at about $£ 10$ a ton, forms the limit from which any ordinary return can be expected, how can an article sold at a price realizing from 300 to 400 per cent. on the cost price of the materials of which it is composed, ever bring any return at all? Such savoury condiments, dished up at from $£ 40$ to $£ 50$ a ton, have no more fattening powers than the ordinary cakes and meals, of which indeed their bulk is principally composed. Locust-beans, the different oil-cakes, and Indian corn form the basis of these cattle foods so often paraded before the public, with which sundry stimulants, making a kind of curry-powder concoction, are mixed up. This, though it may be highly agreeable, yet at the price above stated forms a most costly addition to the ordinary feeding cost, and an animal once pampered on such material can hardly fall back on ordinary food; hence the price of fattening is greatly enhanced, but without any increase of the saleable carcass, for there is a natural limit in this direction. A compound at $£ 40$ a ton will make no more flesh than oil-cake at $£ 10$; but if the farmer approves of and will have the compound, let him simply mix the materials himself. There is no secret in the composition, for the test is at hand in a simple analysis. The following is an ordinary formula:-

TO MAKE ONE TON OF MEAL.

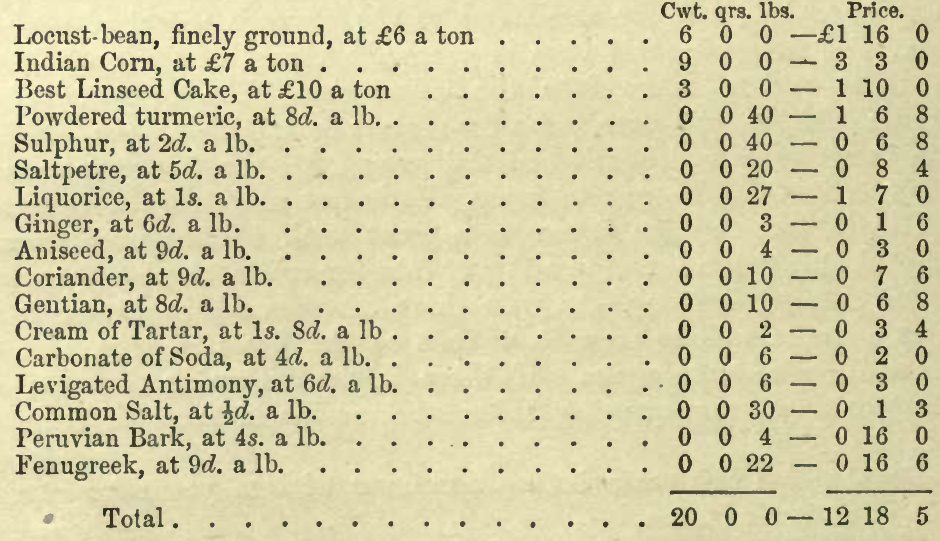


"Looking at this composition, it will be evident at a glance that the chief ingredients are the ordinary commercial locust-bean, Indian corn, and oil-cakes. These form its bulk, and constitute nine-tenths of tho whole; the remainder being made up of condiments and stimulants, the sulphur and antimony being intended to act upon the skin in the production of a fine coat, and the fenugreek forming a kind of mucilage to prevent any ill effects that might arise from the stimulating character of the food. These ingredients have no doubt been selected with skill, and an animal may be expected, and not unreasonably, to thrive upon such savoury substances. For this precious article (which it unquestionably is) the modest sum of about $42 \mathrm{~s}$. a cwt. is demanded, or at the rate of $£ 42$ a ton, or upwards of 200 per cent. on the cost price, even taken at the valuation given above, which for the one-tenth or stimulating portion might be considerably reduced, if the several materials were bought at wholesale prices. We prefer, however, to take the ordinary trade valuation, in order to give the widest margin possible for the cost-this, after all, being the simple point at issue. If a farmer wishes for the article, the use of which, containing as it does so much stimulating matter, is very questionable, and chooses to pay from three to four times the intrinsic value, it is of course at his option to do so; but as the whole question of farming is one of paying, we will put it plainly-Can it pay to feed animals on substances costing from $£ 40$ to $£ 50$ a ton? A knowledge of the constituent elements of these foods may induce a pause before the outlay is made. Some supposed great secret has no doubt with a few acted as a charm, on the principle of omne ignotum pro mirifico; but the analysis at once dispels this illusion, and nothing remains but the cost and its result, mere matters of ordinary calculation."

But though this view of artificial condimental foods is quite correct, it is also true that as an occasional stimulus to a feeble stomach, they are highly useful. I have known horses terribly out of condition brought round by the use of them in an incredibly short space of time; and used in this way, I believe them to be highly beneficial. But no stomach will go on for ever answering to the same stimulus. I can confidently recommend them for the former purpose, but for the latter they are dear even at the reduced rate of about half that named above.

SALT is the only kind of seasoning which has stood the test of experience in this country, and even it is by no means generally employed. Some grooms give an ounce of common salt in the water daily, others give it by sprinkling it on the hay, while a third set leave a lump of rock-salt constantly in the manger for the horse to lick. The last is the only really safe and useful mode of using this article, and I am persuaded that all horses will thrive better if they are allowed a lump of rock-salt constantly within their reach. The quantity which is thus taken is by no means large, for rock-salt does not easily dissolve by the mere contact of the moist tongue. It is only to be procured in certain localities, where it is found in the earth in large quantities, the salt mines of Cheshire affording the chief supply for England and Scotland. A lump weighing two or three pounds is placed in the manger, and it will generally be found that a pound will last nearly a month, but there is a great variation in the quantity consumed by different horses. 
WATERING HoRses. It used to be supposed that watering horses when hot and fatigued was a fruitful source of colic, and those horsemen who did not withhold water until the horse was cool, would permit only one "godown," just to enable the animal to take food. Increased knowledge of the subject has caused a change of practice among those best qualified to form a judgment, and we cannot do better than quote Captain Hayes' opinion and the reasons he gives for allowing a plentiful supply of water, subject only to the condition that the water must not be cold, such as spring or well water. Good stablemen often put a bucket or two of water in the sunshine to get the chill off while their horses are out, or add a little hot water before allowing the animal to take his fill.

"Experience proves that it is perfectly safe to water horses immediately after work, no matter how hot they may be, provided always that the water is not too cold; but that they are apt to get colic or be otherwise injuriously affected, if they are allowed to drink largely after they have cooled down. It is important to recollect that the only harm cold water of itself can do the horse, when digestion is going on, is the shock which its low temperature causes to the nervous system of the animal. A moderate degree of cold acts no doubt as a healthy stimulus, though its excess may injure by nervous shock. A quantity of cold water remaining unabsorbed in the intestines may cause contraction of the muscular coat of the bowels, and consequent colic or diarrhœa. The very time above all others that a horse requires a liberal drink of water, is when he is heated and exhausted by fast work; for his blood will then be in an abnormally thick state on account of the large amount of water in the form of perspiration, etc., it has lost, and will, consequently, be unable to circulate with due facility. When a horse is heated, the small blood-vessels which are situated on the surface of the interior of the stomach and intestines, and whose office it is to absorb fluid, will, owing to the rapid state of the circulation, take up the water drunk with extreme rapidity. But if the horse be allowed to cool down without getting water, his blood will gradually recover its fluidity at the expense of the tissues. It is reasonable, then, to suppose that useless waste of tissue-of which water forms a component part-and consequent exhaustion is entailed by stinting the horse of water when he is heated from exercise. Experience proves both in our own persons and in that of our horses, that drinking a moderate amount of water when the man or animal is hot and tired from hard work, diminishes to a very great extent or altogether obviates any subsequent exhaustion and depression. An owner should exercise his judgment in guarding against the possibility of his horse getting water which is too cold."

Few horses are allowed as much corn as they will eat, and the rattling of the sieve or bin will make every occupant of a stall place himself in an attitude of expectation. But if the lifting of a bucket produces the same eager look, and especially at any hour but the usual time of watering, it may at once be concluded that the horse is not regularly and sufficiently supplied with fluid, and it will generally be found that his condition suffers accordingly. It is astonishing how little water will suffice if it is given at regular intervals, and it is the neglect of this periodical supply which produces the craving that leads to dangerous repletion. If it is decided to adopt the tank, provision should also be made for emptying it readily, 
without calling upon the groom to bale it out with a teacup, which I have actually seen done in one particular stable, the owner of which prided himself on the perfection of his arrangements. If the water only came into contact with the iron, no great harm would ensue, because the oxide formed by the union of the oxygen in the water with the metal itself, in the shape of common rust, is by no means prejudicial to health. But no iron manger containing water will long remain free from decomposing vegetable matter, unless it is regularly scrubbed out daily, because the horse, as he holds his head over it during his feeding, drops particles of hay, corn, etc., into the water, and this, being raised in temperature to that of the stable, soon dissolves the starch and other ingredients which are prone to decomposition. The consequence is, that the sides of the tank become foul, being covered with a thick slime, which not only renders the water nauseous to the horse, but also makes it prejudicial to his health. For this reason a waste-pipe and stop-cock are absolutely essential, for by their aid alone can the groom be expected to do his duty; if enamelled, the tank is also more easily cleaned.

The QUANTITY of WATER which will be imbibed by horses varies even more than that of their solid food, yet ignorant grooms are too apt to give all alike. The most strenuous advocate for the continuous supply would doubtless make an exception at those times when horses are just about to be severely galloped, as in hunting or racing; and on the other hand, almost all grooms who know their business allow their charges to fill themselves at night, and also give them a liberal allowance when they have done their work and are dressed and cooled down after it. I have found in my own stable, in measuring the actual quantity of water drunk by the horses, that even among those which are doing the same amount of work and eating similar food both in quantity and quality, the water will vary from two buckets a day to nearly five. If salt is given, it will produce considerable: thirst at first, but after a time this effect ceases, and I have not found it in the long run make much difference. Green food will also make less alteration in the desire for water than might be expected, which may be accounted for by the fact that it increases the secretions of urine and perspiration, and also acts gently on the bowels; so that, though more fluid is taken into the system with the green food, yet a proportionably large quantity passes off. It is, however, necessary to be cautious in the allowance of water to horses which have just begun to eat grass or vetches, for if given in the usual quantity on a stomach full of green food, it will very probably bring on an attack of colic. As a rule, no horse should go to any moderately fast work with more than half a bucket of water in him, and that should have been swallowed at least an hour. This subject, however, will be better considered under the next head.

THE QUALITY of WATER best suited to the horse is one moderately soft, but it should not bo rain water collected in tanks, which soon becomes full of decomposing vegetable matter. I have known the health of a whole stable full of horses seriously injured by using rain water, as was proved by the fact that its filtration through charcoal, gravel, and sand soon restored the animals to a fair state of health, without any alteration in their solid food or work. On the other hand, very hard water disagrees almost to an equal extent, often producing the state of the skin known 
as "hide-bound," and sometimes affecting the bowels in the form of serous diarrhœea. But in course of time most sound horses become accustomed to hard water, and then a change to that which is soft must be carefully avoided whenever work is to be demanded of them. Thus in sending hunters or harness-horses used in fast work from home, when they have been accustomed to either kind of water, it often happens that their health is upset, and this is quite as likely to occur when the change is from hard to soft, as from soft to hard water. Trainers of valuable racehorses are so aware of this fact, that irrespective of the risk of poisoning, which they thereby avoid, they take water with them, knowing the injurious effects likely to be produced by a sudden change. Hard water, if it contains large quantities of carbonate of lime, may be made to deposit it to some extent by boiling, but the sulphate of lime (or gypsum), which is a far more common ingredient, is as soluble in hot water as in cold. Evaporation by boiling causes the deposit of a large quantity of it on the sides of the vessel used to contain the water, but the fluid remaining still holds as much gypsum per gallon, and is not therefore benefited in the slightest degree.

\section{THE THEORY AND PRACTICE OF FEEDING}

IN ADAPTING the quantity and quality of horse-keep to the wants of each horse, regard must be paid first of all to the small size of this animal's stomach, which affects all alike; secondly, to the work for which he is designed; and thirdly, to the peculiar constitution of each individual. From the first of these causes the horse must never be allowed to fast for any long period if it can possibly be avoided, it being found from experience that at the end of four hours his stomach is empty, and the whole frame becomes exhausted, while the appetite is frequently so impaired if he is kept fasting for a longer period, that when food is presented to him it will not be taken. Previously to the introduction of railroads harnesshorses were often required to do long distances in the day, and it was found that if the whole journey must be performed without stopping to bait, it exhausted the horse less to increase the pace up to nine or ten miles an hour than to dawdle over the ground on an empty stomach. If two horses are driven or ridden fifty or sixty miles under similar conditions as to the weight they have to draw or carry, and the one is taken at the rate of six miles an hour, which will keep him fasting from eight and a half to ten hours according to the distance, while the other is travelled fast enough to do it in six or seven hours, the latter will be less exhausted than the former, though even he would be all the better for a feed in the middle of the journey, the time devoted to this act being easily picked up by the increased energy which would be given by the corn. No horseman of experience is ignorant of these facts, and after a long day the hunting man who knows what he is about will always be seen on the look-out for a feed of corn or a pint of oatmeal for his hunter, before he attends to his own wants. The human stomach will bear hunger far better than that of the horse, and if the rider feels his appetite pretty keen, he may be satisfied that the animal which carries him is still more in want of food. The 
kind of work which the horse is intended for affects not only the quantity of food required, but also its quality. Thus very fast work, as in racing and hunting, strains the muscular system as well as the heart and lungs to the utmost, and therefore the food which is best fitted for the development of the former to the highest degree consists of those kinds which present the elements contained in the muscular tissue in the largest proportions consistent with the due performance of the digestive powers. These are found in oats and beans, but Nature herself teaches every animal instinctively to keep within such limits as are safe, and hence it is found that though every horse will greedily devour a peck or a peck and a half of corn daily, yet he will not go beyond this quantity even though it is not sufficient for his wants, and in spite of his being deprived of every other kind of food. The demands of his muscular system are supplied by the corn, but there are certain saline matters in hay which are not found in the former, and being necessary for the performance of several important functions, the stomach receives its warning through the appetite and no more corn is received into it. On the other hand, the hard-worked horse fed on hay alone craves for corn, and will greedily devour almost any quantity put in his manger until he upsets his digestive powers, when the appetite for it ceases. It is found by experience that a certain proportion of hay and corn is best adapted to each horse according to the work he has to do, and his own particular constitution, so. that in laying down rules for feeding it is necessary first of all to ascertain what demands will be likely to be made upon the system. Few owners of carriage-horses would like to see them driven to the door with their muscles showing the lines between them, as they ought to do in a race-horse when fit to run. Such a state of high training as will put the latter in condition would be impracticable for the former without wearing his legs out, and not only destroying his rounded and level appearance, but taking away the air of high spirit and life which tends so much to gratify the eye. Hence the feeding suited to give the one nothing but muscle is not fitted for the other, who must have more hay and less oats, as well as less work. So also in deciding upon the proportion, if any, of oats and beans, regard must be had to the amount of work which is demanded, for there can be no doubt that while admitting the good effects of beans in large quantities upon the severely tried cab or omnibus horse, they are injurious to the carriage-horse, whose blood soon becomes heated under their constant use. Lastly, the peculiar constitution of each horse must be studied before it can be known whether the average quantity and quality of food which will suit the majority of horses doing the same kind of work, will be enough or too much for him. Some washy animals pass their food through them so quickly that they do not absorb from it one-half of the nutritive elements contained in it. These must be fed largely if they are kept at work, and those articles of food must be selected for them which have a tendency rather to confine the bowels than to relax them. Independently of this extreme case it never can with certainty be pronounced beforehand what amount of food will keep an untried horse in condition, but in a large stable an average can easily be struck, and it is this quantity alone which can be estimated here. In the following pages, therefore, $I$ shall give a description of the several alimentary wants of the horse, and then show in what propor- 
tions they are found in the varieties of keep which have already been described, so as to enable the horse-master to make his selection according to circumstances. All these substances are found in the blood, but the composition of this fluid does not enlighten us as to the wants of the system, because it is continually receiving and giving off its various elements. The blood of a horse fed on highly nitrogenized food does not differ on analysis from that of another which has been kept on the opposite kind of diet. Physiological research, however, tells us that muscle is composed of fibres, and that every time a bundle of them contracts a certain expenditure of nitrogen is made, calling for a corresponding supply from the blood, which cannot be afforded unless the food contains it. Hence the badly-fed horse, if worked, soon loses his flesh, and not only becomes free from fat, but also presents a contracted condition of all his muscles. And thus science is confirmed by every-day experience, and the fact is generally admitted that to increase the muscular powers of a horse he must have a sufficient supply of nitrogenized food. As I have remarked above, the nutrition of muscle requires nitrogenbut in addition the brain and nerves must be supplied with fatty matter, phosphorus, and albumen. The bones demand gelatine and earthy salts, and the maintenance of heat cannot be effected without carbon in some shape or other. But it is chiefly with nitrogenized food that we have to deal in considering the present question, there being plenty of the other substances I have mentioned in all the varieties of food which are not largely composed of fibrine. It may therefore be taken for granted that the hardly-worked horse requires oats or beans, or both mixed together in varying proportions, together with such an amount of hay as will supply him with the starch, gum, sugar, fat, and saline matters which his system requires; while on the other hand the idle animal does not use his muscular system to any extent, and therefore does not require much or any oats or beans. The following table exhibits the proportions of these various elements in the several kinds of horse food most frequently used in this country:-

\begin{tabular}{|c|c|c|c|c|c|c|c|c|c|c|c|c|}
\hline & & & & & & & $\begin{array}{l}\text { Wocdy } \\
\text { Fibre }\end{array}$ & \begin{tabular}{|} 
Starch and \\
Sugar.
\end{tabular} & $\begin{array}{l}\text { Fibrine \& } \\
\text { Albumen. }\end{array}$ & $\begin{array}{c}\text { Fatty } \\
\text { Matter. }\end{array}$ & $\begin{array}{l}\text { Saline } \\
\text { Matters. }\end{array}$ & Water. \\
\hline Oats & & & & & . & . & 20 & 53 & $11 \cdot 4$ & $\cdot 6$ & $2 \cdot 5$ & $12 \cdot 5$ \\
\hline Beans. & . & . & . & . & . & . & $14 \cdot 5$ & 40 & 26 & $2 \cdot 5$ & 3 & 14 \\
\hline l'eas & & . & . & & . & . & 9 & 48 & 24 & 2 & 3 & 14 \\
\hline Barley. & . & . & . & - & . & . & 14 & 52 & $13 \cdot 5$ & $2 \cdot 5$ & 3 & 15 \\
\hline Indian & Jorn & . & . & . & . & . & 6 & 62 & 12 & 5 & 1 & 14 \\
\hline Old Hay & . & . & . & . & . & . & 30 & 40 & 7 & 2 & 7 & 14 \\
\hline Clover 1 & Iay & . & . & . & . & . & 25 & 40 & 9 & 3 & 9 & 14 \\
\hline Barley S & traw & & . & . & . & . & 46 & 34 & $1 \cdot 5$ & 0 & $6 \cdot 5$ & 12 \\
\hline Oat Stra & & . & . & . & . & . & 50 & 31 & $1^{\circ}$ & a trace & $5 \cdot 5$ & $12 \cdot 5$ \\
\hline Wheat S & traw & . & . & . & . & . & 55 & 27 & $\cdot 5$ & 0 & $5 \cdot 5$ & 12 \\
\hline Bran . & . & . & . & . & . & . & 54 & 2 & 20 & 4 & 7 & 13 \\
\hline Linseed & . & . & . & . & . & . & 9 & 35 & 20 & 20 & 6 & 10 \\
\hline Carrots. & . & . & . & . & . & . & 3 & 10 & $1 \cdot 5$ & 0 & $1 \cdot 5$ & 84 \\
\hline
\end{tabular}

RACE-HORses are fed upon the best upland hay, of which about six to eight pounds are given to each on the average daily, and from fifteen to twenty pounds of the best oats, in some cases beans being substituted for an 
equal weight of the latter. The quantity of hay varies according to the constitution, gross feeders being allowed less, and delicate, light-carcassed horses more than the above. The limit to the oats is the appetite, the trainer taking care not quite to satisfy the horse, which would produce satiety and disgust, but giving him as much of this food as he can without this effect. One-third of the hay is given in the morning after exercise, and the remainder at night. The oats are divided into four feeds, one being given the first thing in the morning, the next on coming in from exercise, the third at four o'clock in the afternoon, and the last at seven or eight in the evening, when the stable is closed for the night. Very little water is allowed in the morning, two or three "go-downs" being all that is usually given, about half-a-bucket on coming in from exercise after the horse is dressed and fed, the same quantity in the afternoon, and a full allowance at night. Once a week, if raquired by the state of the bowels, a bran mash is given, but this is omitted when the time of trial is approaching.

The Hunter is fed nearly in the same way as the race-horse, the chief difference being that a little more hay is allowed, and consequently less corn. Few hunters get more than five or six quarterns of oats, and indeed there are not many which will eat more; for in order that the appetite for this kind of food shall $b$ as highly developed as in the race-horse, the animal must have been reared on oats from the earliest period, which few hunters but those bred for the $\mathbf{r}$ icecourse have been. The allowance, therefore, is generally about ten pound; of hay, and five or six quarterns of oats, or five quarterns of oats and half- $x$-quartern of beans. The hay and corn are given at the same times as in the rasing stable, and the water also in the same proportions. Gruel is given when the hunter comes home after a hard day, as it restores the tore of the stomach after long fasting better than oats, which, moreover, the exh uusted horse generally refuses till he has had something to give his stomach a fillip. A bran mash should be given once a week, or every ten days, unless there is a tendency to purge, when of course it is not wanted. No change of food is required during the hunting season, but after this is over it is necessary to decide whether the hunter shall be turned out for the summer, or soiled indoors. The advocates for the two proceedings are warm in support of their several opinions, which will be treated of hereafter under the head of Summering.

$\mathrm{H}_{\mathrm{ACK}}$ require from three quarterns to a peck of oats, and ten to twelve pounds of hay daily. The latter is given in two portions, one at night, and the other in the morning, the former being divided into four feeds, which are put into the manger at 6 or 7 A.M., 10 A.M., 4 P.M., and 7 or 8 P.M. In most stables some of the hay is cut up with an equal quantity of straw, into chaff, and of this about a peck a day is given with the corn, the object being to induce the horse to masticate it thoroughly. The plan is so generally adopted now that I need not insist upon its advantages, which may be accepted as indisputable. If these horses are much exposed to the weather during the winter and early spring, a few beans in place of some of the oats may be used with decided benefit, especially if they have been accustomed to them in previous seasons. It must always be remembered, however, that they have a tendency to produce inflammation, especially in the feet and eyes; and, therefore, in those animals which have a weakness in either of the organs named, beans should carefully be avoided. Generally 
speaking, hacks are of small size, and they do not, therefore, require more than an average allowance of food, on which footing I have calculated their hay and corn; but if it so happens that any of my readers have a hack of full size, he must make allowance accordingly. These horses are now very commonly allowed a water tank, constantly supplied with water, and in that case there is no necessity for doing more than to see that it is daily cleansed, and that the ball-cock acts properly. When they are watered from the bucket, the groom generally gives it them in moderate quantity early in the morning and in the afternoon feed, finishing with a full allowance at night.

Harness Horses are fed in much the same way as hacks, but if they are used for a close carriage and are of full size they must have more hay than I have named, by fully a quarter of a hundredweight weekly.

Ponies may be kept with very little corn, one or two quarterns a day, according to size, being all that is generally allowed. They will eat from $60 \mathrm{lbs}$. to $75 \mathrm{lbs}$. of hay weekly, and they are as much benefited by chaff as large horses.

FARM HoRSES are treated very differently in different localities, independently of the various fancies indulged in by individuals: their work also being subject to great changes, according to the seasons, it is necessary to apportion their food in the same ratio. Again, it happens sometimes that oats or beans are scarce and dear, and the farmer, if he grows them, will be inclined to sell them and use some cheaper kind of food for his horses, or, if he has to buy, he will still more carefully look out for a substitute at a lower price. The following are the most usual modes of feeding these horses, as far as I have been able to ascertain.

Plan I.-Adopted throughout the Midland counties. Weekly allowance per horse in November, December, and January- $\quad \&$ s. $d$. $1 \frac{1}{2}$ bushels of oats, 1 peck of beans, and $1 \mathrm{cwt}$. of hay, costing for three months . 600

Ditto through February, March, and April-

2 bushels of oats, $1 \frac{1}{2}$ pecks of beans, and 1 cwt. of hay, costing . . . . 700

Ditto May, June, and July-

3 pecks of oats, 1 peck of beans, and vetches or lucerne, costing . . . . 500

Ditto in August, September, and October-

1 bushel of oats, $\frac{1}{2}$ bushel of beans, clover, pea straw, etc., costing . . . . 600

Total yearly cost . . . . . . . . . $\overline{2400}$

In districts where oats are scarce, bran or pollard is mixed with beans, and given as follows :-

Weekly allowance in the autumn quarter-

$1 \frac{1}{2}$ bushels of oats, 2 pecks of spilt beans, and 1 cwt. of hay, costing for threo months.................... 7100

Ditto in the winter quarter-

$2 \frac{1}{2}$ bushels of pollard, 2 pecks of split beans, $56 \mathrm{lbs}$. of swedes, and barley or pea straw, costing for the threo months............ . 5100

Ditto in the spring quarter-

$2 \frac{1}{2}$ bushels of pollard, 2 pecks of split beans, and $1 \frac{1}{2}$ cwt. of hay, costing . . 7100

Ditto in the summer quarter-

2 bushels of bran, 1 peck of split beans, clover, retches, or tares, costing . . . 500

Total yearly cost . . . . . . . . $\overline{25100}$ 
Sometimes eut straw, steamed potatoes, and the meal of oats and beans are given, as being the most economical kind of food. The horses are fed three times a day, each time receiving 15 lbs. of food, thus-

In the morning at 6 o'clock, $4 \mathrm{lbs}$. of oat and bean meal, $11 \mathrm{lbs}$. of chaff.

At noon, 3 lbs. of oat and bean meal, 12 lbs. of chaff.

At night, 2 lbs. of oat and bean meal, 2 lbs. of chaff, and 11 lbs. of steamed potatoes.

In some few favoured districts, the pasture is so good that horses can do all but exceptionally hard work on nothing but grass in the summer and hay in the winter.

In Scotland these horses are kept out-of-doors, or soiled in-doors till October, when they are put upon hard food, receiving $1 \mathrm{cwt}$. of hay and a bushel and a half of corn weekly till December, when the hay is replaced by straw, and the oats are reduced one-half. In February $1 \frac{1}{2} \mathrm{ewt}$. of hay, and a bushel and a half of oats are again given, and this is continued till June, when they are fed on grass with a small allowance of corn.

\section{BEDDING}

TIIE BED is generally composed of wheat straw, of which that thrashed by hand is by far the most durable, lasting nearly twice as long if properly kept clean as the same quality thrashed by machine. Oat straw is eaten by most horses almost as readily as hay, and, therefore, it is kept as fodder for farm horses and cattle. It is excellent for cutting into chaff, especially when there is much clover grown with it. Besides wheat straw, moss litter, sawdust, sand, tan, bracken, forest leaves, and bean straw are used either where economy is studied, or for some particular reason. I shall, therefore, have something to say about each of these materials.

Wheat Straw is by far the most general material for the horse's bed, and in private stables it may be considered as the only one used. The cost is continually upward, since more and more land is laid down to grass, and the area of wheat grown is less and less in this country, while its bulkiness is a serious drawback to importation.

It is, however, shipped to this country, being pressed into bales, but every individual straw being broken it is very little cheaper than the home-grown article if used with a reasonable regard for economy. It should be selected for its length, and the size and stoutness of its stalks, taking care that it is quite dry, but not so much so as to be brittle. It is tied up in trusses, or "boltings," as they are called in the Midland districts, which weigh about $36 \mathrm{lbs}$. each. One and a half to two of these ought to serve for a week, after the bed is once made, which will require from two to three trusses, according to the size of the stall or loose box. Unless the straw is properly shaken up and smoothly laid, the horse is not made comfortable, but lies with uneven lumps under him, which he cannot scratch into shape, like a dog. Hence, the good groom takes great trouble with his horses' beds, and having first laid the old litter smoothly all over the stall, as far the back drain, he spreads on the surface with his fork either the cleanest part of the former night's bed, or a fresh truss, according to circumstances.

The straw should be raised against the travis or wall on each side, so that the horse in lying down has his back protected by it, the sharp spinous pro- 
cesses of the vertebra being uncovered by anything but skin, and causing considerable pain when pressed against the hard wood or iron. The straw is also turned under at the lower end, so as to present a neat appearance to the eye, as well as to afford comfort to the horse. In the morning the wet and dirty parts are forked out, and the remainder turned back and pressed tightly under the manger, or it is put into some other convenient place, where it can be dried, which latter plan is an excellent one in point of economy and comfort. When the litter is thus disposed of, the whole surface of the floor is carefully swept, the dirt being shovelled back into the gangway, and finally removed from the stable. A little clean straw is then thinly spread over the stall, and left with a level edge behind the heels of the horse, where natty grooms put a border of plaited straw. During the day the droppings are collected in a basket, and removed as soon as they are perceived by the groom, by which the litter is kept clean, and the hind-feet of the horse are prevented from contracting foul thrushes, which many are apt to do, if they are allowed to be constantly crammed full of moist droppings, as they often are by careless grooms. On the average of seasons country straw may be bought for about $£ 3$ per ton, in which there are about sixty trusses, each therefore costing 1s., and, on the calculation of two trusses per week, the horse's bed will cost $2 s$. for that period, without estimating the value of the manure, which varies greatly. In the neighbourhood of very large towns, where the supply of manure is greater than the demand, it is almost a drug, and will scarcely pay for the labour of removal, but in agricultural districts it is worth $5 s$. per ton, and then an arrangement is often made by the farmer to supply straw on condition of receiving back the manure made with it. It may generally be calculated that an allowance of one-third or onefourth of the cost of the straw may be made for manure, and the litter may then be estimated as costing $1 s$. per week.

Peat-Moss LitTer has come into considerable use during the last few years in cab and omnibus and tradesmen's stables, but requires to be broken up small, and to be used with care. The English moss is cleaner and better than the foreign. It has the advantage of dispensing with drains, but its manurial value is not equal to that made from straw. It is softer than straw, and therefore horses are found to lie down on it more readily than on straw -and this is an advantage; it is also free from smell. For private stables, however, it is seldom used, on account of its inferior appearance, and because it holds more dust than straw. When it was first introduced, it was met with much opposition, as usual with anything new in England; and it was said by grooms to produce rheumatism, but this charge appears to have no foundation in fact.

A good deal of correspondence has taken place in The Field and other journals as to its effect upon the feet, some writers declaring that it produces bad horn and a variety of diseases, and others declaring that groggy or navicular cases do much better on it than on any other bedding.

It is generally agreed thit in close stables where proper ventilation is impossible its power of fixing ammonia is a very valuable quality. It occupies less bulk in the stores saves drainage, and until a good deal soiled saves labour, no unimportant item in a business establishment. There is an objection to it which I have not seen in print, namely, its capacity to retain ringworm, and infect another horse that may lie upon it. 
Bracken or Fern makes a tolerably good bed for a rough carthorse, or hardy pony or donkey, but no one would think of using it in a private stable.

SAwDUST is seldom employed as litter, its cost being quite as great as, and often more than, straw. It is only in or near saw-mills, where there is an unusually large supply of sawdust on the premises, that it can be used advantageously. During the summer months it answers well enough, but it is too cold for use in our winters. It has the disadvantage that it soon heats when wetted with urine, and ammonia is then given off profusely, so that great care. must be exercised to change it as soon as it becomes soiled. All drains must be stopped up, and every day the soiled parts must be removed, and replaced with fresh.

SAND is used in some parts where it is very plentiful, instead of litter, and it must be treated in much the same manner as I have described for sawdust. It is however cold and hard, and anything but satisfactory. When it is used all drains must be carefully stopped up.

Refuse TAN is very commonly introduced as a bedding for horses while being summered, in the belief that it is much cooler to the feet than straw. It has all the disadvantages of sawdust. I have often seen a box in which tan had been left for weeks without change, the groom expecting that it would retain the urine of the horse without decomposition, although his nose ought to have convinced him to the contrary. It is a capital material if it is kept dry, but every one who has seen the heat which is given out by it in a hothouse, will understand that it is not to be allowed to come in contact with fluid, and especially urine, or decomposition will quickly supervene. The cost is seldom more than that incurred in carting it, which will depend upon the distance from the nearest tan-yard.

Forest Leaves are not readily procurable except in some very few localities, and I may therefore dismiss them with the remark that there is no objection to their use with which $I$ am acquainted. Ponies at all events may be comfortably bedded with them.

BEAN Straw is far too hard and unyielding to make a comfortable bed, and if it must be used I should prefer cutting it into chaff rather than employing it in this way.

\section{DRESSING, OR GROOMING}

By the term Dressing is generally understood the purification of the skin which the horse requires. He is never in the highest health unless the pores are kept free from the scurf which forms on them whenever he sweats, and the object of the strapping which he receives at the hands of his groom is to get rid of this mechanical obstruction, as well as to brace the nerves of the surface by the friction of the brush or wisp. This dressing must be renewed daily, even if the horse has not been sweated, and each time that he comes in from work it is necessary to repeat it. The former operation is or should be conducted in the same manner every day, but the latter will vary according to the state of the animal when he comes in, that is to say, depending upon whether he has been sweated and is cool again, or if he is still wet, or has been in the rain with or without exercise enough to warm 
him, or lastly, if he has been ridden or driven through dirty roads or over a deep country. Each of these conditions will therefore require a separate consideration.

The USUal MoRning's DRESSing is commenced either as soon as the horse has done his early feed, or on coming in from exercise, if such is allowed or enjoined. The utility of grooming after work cannot be denied, for it would be absurd to contend that a horse coming in wet and dirty should be left in that state till the next day; but it is perhaps necessary to explain to the idle groom that it is not a mere polishing of the surface of the coat which is wanted, but a deep steady pressure of the brush into the roots of the hair, so as to remove all the scurf which collects around them and clogs the pores, through which the sweat ought to be allowed to exude freely. Practically it is found that an hour's good strapping daily, not only gives a polish to the coat, but it causes the secretion of a fine oil, which has a tendency to throw off water, and thus may save the horse exposed to the rain from catching cold. Moreover, it certainly stimulates the nerves so as to enable them to bear exposure to the weather, which would otherwise tell injuriously on an animal which is covered up with thick clothing indoors, and stripped of everything, even of the long coat which Nature gives him, when he is submitted to the "pelting of the pitiless storm." When the horse is turned out to grass, he is washed by every shower of rain, and though his coat continues to look dirty on the surface, yet the skin itself is braced by the winds and cleansed by the waters of heaven. Not so, however, in-doors. Here his clothing keeps his coat short, and keeps up a continual state of insensible perspiration, the watery particles of which pass off through the woollen rug or serge, leaving the salts and animal matters behind, as is apparent on examining the internal surface of any clothing which has been worn for any length of time without washing, when it will be found to be lined with scurf, and matted with oily animal matters. There are many drugs which will give a gloss to the skin, but they will diminish instead of increasing its capability to bear exposure, and hence their use is altogether forbidden by those who know their injurious effects. The horse which is little used requires dressing to take the place of exercise, and if he has plenty of good strapping, his coat will look like satin; but the hunter and the hack or harness-horse, exposed to all weathers, must be carefully groomed and receive plenty of elbow-grease, or his coat will look hollow and stand out like "the quills of the fretful porcupine" whenever he is allowed to stand for a few minutes in a cool wind.

THE FIRST THING WHICH THE GROOM does in commencing his morning's task is to turn the horse round in his stall, and fold the quarter piece back upon itself, so as to expose the whole of the fore-quarters. Then taking his brush in the hand nearest the head, whichever side he begins with, he works away at the head and face till he has thoroughly cleansed those parts, carefully clearing out the dust and dirt from the roots of the ears, where it is very apt to lodge, and continually cleaning his brush with the curry-comb held in the other hand. Next proceeding to the neck, he works at that part in the same way, turning the mane over to the other side, and then going to the shoulders, bosom, and legs, and finishing off with a wisp of hay slightly damped instead of the brush. Having thoroughly worked at this half of the body, the horse is turned round in his stall, and the hind-quar- 
ters and flank treated in the same way, the clothing being removed entirely while this is going on. In the spring and autumn, when the coat is being shed, the brush should never be used, and the wisp alone should be depended on. Nothing spoils the look of the new coat so surely as the brush, except perhaps the curry-comb; but this latter should not under any circumstances touch the skin of a horse when it is in proper order, and it is searcely necessary to forbid its use when the coat is being shed, at which time it would be positively cruel, as well as injurious to the appearance. The brush and wisp having effectually cleansed the skin, and given the hair itself a certain amount of polish, the finishing stroke is put to the dressing by means of the linen rubber, with the addition, in well-managed stables, of the leather. Either or both of these in succession are steadily passed over the surface in the direction of the hair of each part, and then the quarter piece or rug, as the case may be, is replaced, taking care to throw it lightly in front of its proper place, and then to draw it steadily backwards, so as not to disturb the proper position of a hair. The roller is smoothly put on, being first laid on the back double, and then the off side is turned over into its place, when the straps being laid hold of under the belly, it is properly tightened and the quarter piece smoothed beneath it. This completes the dressing of the body, but there are several minor points still to be attended to. A clean sponge is squeezed out, and with it the nostrils, eyes, and anus are sponged clean, and if necessary, the mane is damped, so as to enable the groom to comb and brush it smoothly down on its right side. The tail also is carefully combed out, beginning at the lower end if it is a full one, and not touching the top until the bottom is smoothly arranged. Lastly, the legs and feet are attended to, the stopping, or whatever may be in the latter, being picked out, the legs washed if stained, and then carefully rubbed dry. Many grooms, when they have white legs to keep clean, begin the dressing by washing them, and then putting on flannel bandages; they leave them on till they have done the body, when they are taken off and the legs rubbed with the leather and linen rubber till they are quite dry, finishing with plenty of hand rubbing if they are at all inclined to fill. All this being done, the litter is put straight, and the horse is ready to have his second feed. A good deal of muscular exertion, and laid out in the right way, is necessary for the due performance of the groom's daily task. There is no royal road to make a horse's coat, when in work, really look well, and not less than an hour's hard strapping will suffice for this daily. White and light grey horses will take up even more time than this, as with all the eare that can be exercised the thighs and legs will occasionally become stained by lying in the dung dropped during the night. Soap and water laid on warm, and well rubbed, will get rid of a great deal of the brown colour left, and if it is not suffered to increase by successive layers, it may be removed with comparative ease. The slight tinge which remains may be got rid of by the aid of washerwoman's blue, a bag of which is to be dipped into clean water and the skin washed with this after the soap has been got rid of. A little experience is required to ascertain the exact amount of blue, but one or two experiments will soon teach an intelligent groom.

WHENEVER a HORSE Is WANTED to go out, he must again be wisped over before his saddle or his harness is put on. The groom strips the whole of the clothes off, turns him round in the stall, and carefully clears all the 
dust away from the ears and head with the rubber; then, proceeding regularly backwards, the whole body is smoothed over, and the saddle and bridle or harness put on. Lastly, the feet are picked, and an oil-brush is rubbed over the outside of the hoofs, to give them a neat appearance, when the pillar reins are buckled to the bit on each side, and the horse is left till he is wanted.

DrESSING AFTER work depends upon the state in which the horse is returned to the stable, when he may be cool and clean, or in a profuse sweat still going on, or with his sweat dried in, or completely smothered with dirt, or wet from rain, but chilled rather than too hot; or lastly, when exhausted from a severe. run or other hard work.

WHEN THE HORSE RETURNS COOL AND CLEAN, the groom throws his rug lightly over his quarters, and, taking a bucket and a brush, he proceeds to pick and wash out the feet, standing on the near side, with his back to the horse's head, so that he can use his left hand to hold the feet, and his right for the brush. If the legs are quite clean, there is no necessity for washing them at all ; but most grooms do so as a matter of course, and if they are properly dried afterwards, there is no objection to the plan. Hunters, and valuable horses of all kinds, are immediately protected by flannel bandages ; but in ordinary stables the legs are merely partially dried with a rubber, and are left in that state till the horse is dressed over. If the work has been continued for more than four or five hours without feeding, it will be well to put on flannel bandages, and let the horse have a feed of corn; but, otherwise, it is better to finish the dressing first. The cloth being removed, a wisp of hay is taken in the hand, and first the head and neck, and then the body, is dressed over; finishing off with the rubber, as previously described. The clothing is then put on, the legs thoroughly dried, the litter put straight, and the task is finished.

WheN BROUGHT IN STILl SWEATING PROFusely, if the weather is warm, the horse must be led about in the shade, with the saddle on, till he is nearly or quite dry; for if he is put into the stable before he is cool, he will break out again as badly as ever, and if the saddle is removed the back will become sore. A hemp halter is cooler and more handy than a head-collar, and it is usually employed out of doors for all purposes connected with cleaning. In the winter, this exposure to the air out of doors is not necessary; and, indeed, it would often be dangerous, the stable being generally cool enough to stop all tendency to sweat, even with a light rug on. At this season, therefore, after the legs are washed and the bandages put on, which they should be whenever the horse is in a sweat, the dressing may be conducted in the usual way, in the expectation, which will seldom be disappointed, that at the end of half-an-hour's strapping, the skin will have become quite cool, and will look all the better for the profuse cleansing which it has received by means of the watery fluid given off by it. A scraper will be necessary, which may be either of wood or metal ; and with this all the superfluous moisture is at once scraped from the surface, which greatly facilitates the process of drying. Two men ought then to set to work, each taking a side, and working first at the head, and then gradually backwards. In this way, no part is allowed to chill, and the moisture is removed as rapidly as possible. In the use of the wisp, the rubbing need not always be hard; and it should be chiefly against the direction of the hair till it is 
nearly dry, when the proper direction is again taken. There is a good deal of art in drying a sweating horse, and nothing but experience and practical teaching will give it. As a general rule, it takes two men nearly three-quarters of an hour to thoroughly dress a horse coming in profusely sweating, supposing the weather to be only moderately warm. In very hot weather such an attempt would be quite fruitless, and the only resource is to wait patiently till the effects of exercise are abated sufficiently to allow of the ordinary clothing being worn. Experience soon tells the groom how soon he can venture to begin, and no rule can possibly be laid down which will supply the place of this valuable power. Even when the horse is taken in, he must not at first be clothed, but he must be dressed without anything on him; and in summer he must often be left for some time afterwards in a naked state. When there is a good open yard shaded from the sun, the dressing should be done out of doors; and when this can be managed, it may be commenced much sooner than in the stable, unless this is a very cool one. Slight muscular action, either by walking or in some other shape, is necessary to prevent congestion of blood in the internal organs; but it matters not whether it is effected by simply leading the horse about, or by stirring him up, as is always the case in dressing even the dullest animal. In other respects there is no difference from the plan last described.

WheN THE SWEAT is COMPLETELY DRIED IN, the hair is full of powdery matter, which must be thoroughly brushed out, before the skin will look well or the horse be properly dressed. To do this, nothing more is required than the use of the brush previously to the wisping over; but a good deal of time must be spent in getting rid of all the foreign matters left behind on the evaporation of the watery particles of the sweat. There is an amount of grease in it, which makes the powder stick to the hair, and nothing but hard labour will get it away. For this reason, many grooms adopt the plan of washing their horses all over with soap and water, when they come home in this state; and although I prefer dry rubbing, I would rather have water used than let the skin remain full of dry sweat. A common water brush is generally used, or, if the coat is thin, a sponge will be far better. No time must be lost in the operation; and unless two men can be spared, the rug must be thrown on as soon as the water is scraped off with the scraper, and the skin is just partially dried. In this state he may be left for a few minutes ; attention, in the meantime, being paid to the thorough drying of the head and neck, which cannot well be clothed advantageously. These parts soon dry ; for in washing them, there is no occasion to wet the mane, which may be turned over to the other side while each is being cleaned, and the ordinary coat of the head and neck holds very little water. After they are made comfortable, the cloth is turned partly back over the loins, and the shoulders, ribs, and bosom are dried with tho wisp and rubber; after which the whole is stripped off, and the hind-quarters thoroughly dried.

A Horse SMOTHERED IN DIRT is by careless grooms too often left to dry with it all on ; and then it is brushed out, or, if idleness reigns triumphant, a besom is taken in hand for the purpose. Where the particles of mud are fow and far between, and are already dry, or nearly so, there is no objection to their being removed by friction alone; but if they are wet and (as they generally are) in large masses, a scraper must be used to get rid of them. Water should never be used for cleaning a horse except for the legs and tail, and 
unless the former are thoroughly dried afterwards, cracked heels and grease will ensue. To leave the mud to dry on and be brushed off in the morning is a lazy but safe plan. After scraping, the legs are rubbed and then bandaged, the clothing is thrown on, and the dressing may be commenced as usual.

IN CASE THE SKIN IS WET FROM RAIN, whether the work has been fast or not, it is seldom necessary to provide against a continuance of the moisture, for the chill of the rain will generally prevent any tendency to break out in a sweat. The horse is, therefore, at once taken into the stable, and, if very wet, he is scraped; after which he is rubbed over, and his clothing put on while his legs are being attended to, by washing, bandaging, etc. The dressing is then conducted as in the case of the horse coming in sweating in cool weather.

AN EXHAUSTED HORSE demands all the resources of the groom's art, without which he will suffer in more ways than one. An extreme case seldom occurs, except in hunters, who require the greatest care to bring them round after a severe run. On coming into the stable, if their powers have been taxed to the utmost, and their ears are cold and drooping, the first thing to be done is to get these warm by friction; an assistant, in the meantime, preparing some gruel, while another puts some warm flannel bandages on the legs. It is wonderful what a restorative is found in the friction of the ears, after a few minutes of which, a moderately tired horse will look quite a different animal, evidently enjoying the process, and dropping his head to the hands of the groom with the most perfect air of enjoyment. Where, however, there is only one groom for the whole task, the bandages should be put on first-that is to say, as soon as the clothing is thrown on; then the gruel should be given, and as soon as this is swallowed, the ears should be warmed by friction. No attempt at dressing should be made till the gruel is taken and the ears are warm; and if they cannot be restored to their proper temperature, a warm cordial of ale and spices should at once be given. Usually, however, there is no occasion for this; and, after getting the stomach attended to, the skin of the body begins to recover its natural temperature, and the extremities become warm again. In the course of an hour, the dressing may generally be effected; but no time should be lost in it, and the skin must not on any account be chilled. After it is done, a feed of oats and a few split beans may be given, if the appetite seems inclined to return; but sometimes when the exhaustion is excessive, no solid food can be taken with safety till the next day; and gruel, with cordials, must be resorted to as the only kind of support which the stomach will bear.

\section{CLIPPING, SINGEING, AND TRIMMING}

THE COAT OF THE HORSE is changed twice a year, the long hair of winter coming off in April and May, or sometimes earlier when the stables are warm and there is no exposure to severe cold. A slight sweat hastens this shedding, as every horseman knows by experience, and even in harness the hairs are cast in the face of the driver to his great annoyance on a windy day. Clipped horses are longer than others in shedding their coats, and present a most disagreeable mottled appearance, which makes the state still more noticeable. The long hair on the legs is about a month later in coming off, and indeed it will not fall till Midsummer, unless some more violent means 
than are used in ordinary dressing are adopted. With some breeds and individuals the winter coat is not very much longer and coarser than that of the summer; but all, save blind horses, show more or less difference in favour of the summer coat. Curiously enough, horses which are totally deprived of sight, have almost invariably a good winter's coat, often better than that which they show at other seasons; but why this is so no one has ever been able to explain, though I have never known the fact disputed. ${ }^{1}$ About the middle of October, or early in November, the summer coat is thrown off ; but some of the hair appears to remain as a sort of under-coat, among which the long, coarse hairs of winter make their appearance. These continue growing for six weeks or two months if they are clipped or singed, and even after Christmas, if the weather is cold and the skin is much exposed, there will be an evident increase in length of some of the hair. In accordance with the growth of this on the body is that of the hair on the legs, which become feathered all the way down below the knees in the forelegs, and half-way down the backs of the cannon-bones in the hind-legs. Low-bred horses have more hair on these parts than thoroughbreds; but even these latter, if they are not stabled tolerably warmly, exhibit a great deal of hair on their legs. Those who can see no possibility of improving on Nature come to the conclusion that this long hair is a defence against the cold, which ought not to be removed, and they argue that clipping and singeing are on that account to be rejected altogether. But these gentlemen forget that the horse in his native plains has always a short coat, and that the winds and rains, which cause him here to throw out an extra protection, are not natural to him. Moreover, if the animal is left to follow his own impulses, even when turned out in this country, he will be all the better for his long coat, for while it has the great advantage of protecting him from the cold, it is not wetted by sweat, because he does not voluntarily gallop long and fast enough to produce that secretion. The natural protection is therefore undoubtedly good for the horse when left in a state of nature; but when man steps in and requires the use of the horse for such work as will sweat him severely, he discovers that a long coat produces such great exhaustion, both during work and after it, that it entirely forbids the employment of the horse for hunting, or any fast work. I have myself many times found it impossible to extend a horse for any distance on account of his long coat, which distressed him so much as to make him blow directly, whereas on removing it with the clipping scissors he could gallop as lightly as a racehorse, and be able to go as fast and as far again as before. When this happens in the course of the week following the previous failure, the only change made being in the coat, there can be no mistake made, and a constant repetition of the same result leaves no room for dispute as to the beneficial effects of removing the hair. But, say the opponents of the plan, "All this may be true, yet it is unsafe to expose the clipped horse after he has been warmed, or indeed at any time." Experience tells a very different tale, and informs us that so far from making the horse more liable to cold, clipping and singeing render him far less so. Suppose one of ourselves to be exposed to a cold wind, should we rather have on a thin dry coat or a thick wet one? Assuredly the former, and undoubtedly the wearer of it

1 It has since been "disputed" in the columns of The Ficld (1898). The editor is, however, able to confirm Stonehenge's statement from his own observations. 
would be less liable to cold than he who has the wet one on. So with the horse. As long as his winter coat can be kept dry he is protected by it, and the slow worker, who is not made to pull such heavy weight as to sweat him, will be all the better for its protection, but the moment the pace is sufficiently accelerated to warm the skin the sweat pours forth, and is kept up in-doors by the matted mass of moist hair with which the horse is covered. In former days I have had horses wet for weeks together, from the impossibility of getting them dry in the intervals of their work. They would break out afresh when apparently cool, and by no possible means could they be thoroughly dried. This of course wasted their flesh to a frightful extent, but on clipping them it was soon put on again, showing the great advantage of the plan. A chronic cough almost always accompanies this state of constant sweat, and it will be lucky for the owner of a horse so treated if it does not become acute and put an end to the miserable existence of the poor ill-treated brute. The case is not always fairly put, as for instance by Stewart in his Stable Economy, at page 120, where he says, "A long coat takes up a deal of moisture, and is difficult to dry; but whether wet or dry it affords some defence to the skin, which is laid bare to every breath of air when deprived of its natural covering. Every one must know from himself whether clothing and a wet skin, or no clothing and a wet skin, is the most disagreeable and dangerous. It is true that clipping saves the groom a great deal of labour. He can dry the horse in half the time, and with less than half of the exertion which a long coat requires; but it makes his attention and activity more necessary, for the horse is almost sure to catch cold, if not dried immediately. When well clothed with hair he is in less danger, and not so much dependent on the care of his groom." Now, I maintain that this passage is full of fallacies and misstatements. The comparison is not between wet clothing and a wet skin, and no clothing and a wet skin; but, as I have before observed, between a wet long coat and a dry short one. The clipping removes the tendency to sweat, or if this secretion is poured out it ceases directly the exercise which produced it is stopped. But taking Mr. Stewart on his own terms, who has not experienced the relief which is afforded by taking off wet gloves and exposing the naked hands to the same amount of wind and cold? This is exactly the case as he puts it, and tells directly against his argument; but it is scarcely worth while to discuss the subject at any length, for I know no horseman of experience in the present day who does not advocate the use of the clipping machine or the lamp, whenever the winter coat is much longer than that of summer. That horses are occasionally to be met with which show little or no change in the autumn I know full well ; but these are the exceptions to the rule, being few and far between. The vast majority would have their hair from one to two inches long if left in its natural state, and they would then be wholly unfit for the uses to which they are put. We may therefore consider that it is admitted to be the best plan to shorten the coat in the autumn, and all I have to do is to discuss the best modes of effecting the purpose, with a view to decide whether clipping or singeing is to be preferred.

Clipping in the old days of scissors and comb was a most laborious art and well paid, the "artists" being in great request and often commanding large fees. When the gas singeing lamp was introduced the professional 
clipper had to speedily reduce his demands, while he was finally extinguished by the invention of Clarke's patent machine. The patent having long since run out, and the competition of trade made these instruments so cheap as to be within the reach of every one, no stableman worthy of the name will confess his inability to clip a horse. Mr. Clarke's invention has been a boon to every one connected with horses, unless exception be made to the men of scissors and comb, few of whom remain in active service.

When the machines cost a guinea and but few men could use them well, many gentlemen were content to pay a guinea for a well-clipped horse, but at the present time if a man has to be hired for the purpose he will usually be satisfied with five shillings for the task and use his own machine.

Some of the cheap ones now in the market soon get out of order and fail to accomplish their purpose, none so far as we are aware being so good as those still supplied by the original maker.

The general custom observed as to clipping is to delay the operation if possible till the first week in October, and clip twice more before Christmas, after which date it is not advisable to do more than singe off the long hairs that sprout out late in the winter. If a horse must be clipped for any special reason after the date named he should have additional clothing and care till late in the spring, as he will almost certainly shed his coat badly and rarely have a good sleek summer one, however well managed.

Power machines driven by a wheel are employed in large studs, but as yet are not generally adopted or indeed necessary for the private gentleman owning but a few horses, and these well looked after with men having time to clip with the ordinary instrument.

While the process is going on, the horse ought to be clothed as far es possible, careful men removing only as much of the quarter piece as is sur. ficient to expose the part they are working at and no more. As soon as the whole body is gone over as well as the legs, the singeing lamp is lightly passed over the surface, which will leave the hair burned to such an extent as to require either washing or a sweat, which latter is generally adopted, in the belief that it has a tendency to prevent cold. My own opinion is that this is a fallacy, and that soap and water used quickly and rapidly, followed up by a good strapping and the use of plenty of warm clothing, is far less likely to chill the horse than the exhaustion consequent upon a sweat. I have tried the plan repeatedly, and known it tried by others still more frequently, but I have never heard of any ill effects resulting. Very often a sweat is exceedingly inconvenient, either from the difficulty in getting ground, as happens in towns, or from the infirm state of the legs. But soap and water can always be obtained, and if carefully used there is not the slightest danger attending them. Of course after the removal of a long coat the skin requires an extra protection in-doors in the shape of a double allowance of clothing, and it will be necessary to avoid standing still out-ofdoors, though, as I before remarked, on the whole the risk of taking cold by horses worked hard enough to sweat them is less if they are clipped than if they have their long coats on.

SingeING requires less practice than clipping, but it cannot be done without some little experience of its difficulties, and a novice generally burns the skin as well as the hair. To keep a horse's coat in good order it must be singed several times in the course of the autumn, beginning as soon 
as the new growth has attained a length of half-an-inch beyond what is usual. The singeing lamp is then passed lightly over the whole body, and soap and water being used, as I have described under the head of clipping, or a sweat given if that plan is preferred, the coat is left for a fortnight or three weeks till it has grown another half-inch, when the process is repeated, and again a third, and even a fourth time if necessary.

The lamp now in common use is attached to a wide copper comb made like a rake in principle, and so arranged that the teeth raise the hair and draw the ends into the flame. Where gas is procurable the comb is attached to the gas-pipe by a flexible tube, and the lamp consists merely in a number of holes perforated along the edge of the comb, so that a series of jets of gas are lighted, and burn so strongly, that the coat is completely removed as near the skin as the teeth of the comb raise it. If gas cannot be obtained, a wide wick of cotton is inserted in a flat holder, and the ends protruding to the level of the teeth, while a reservoir filled with naphtha supplies them with that inflammable fluid, a constant flame is maintained, but not nearly equal in strength to that from gas. As the coat is not allowed to grow so long before it is singed, so the clothing need not be much increased after its removal, and, indeed, in well-regulated stables there is little or no change required. Singeing is performed in less than one quarter the time of clipping, and a shilling's worth of naphtha is enough for one horse, unless his coat is unusually long.

Trimming. The jaws, nostrils, ears, legs, mane, and tail are all more or less subjected to the care of the groom, who removes superfluous hairs from each or all by various means, as follows :-

The jaws, nostrils, and ears are singed, the last-named not being touched inside, as the internal hairs are clearly a protection of the delicate lining membrane of the ear from the cold and wet. There are bristles about the eyes which are generally removed, but it is very doubtful whether many an eye would not be saved from a blow in the dark if they were left untouched. Fashion, however, dictates their removal, and her orders must generally be complied with. The hair which grows an inch or more in length beneath the jaw, being of the same nature as the rest of the coat, can only be singed off with advantage, and it should be done as fast as it grows, especially if the singeing is not universal, or there will be a different colour presented in these parts. Nothing gives a horse such a low-bred appearance as a goat-like beard, and the trimming of this part alone will completely alter the character of the animal where the hair has been at all long. The legs are trimmed partly by singeing, and partly either by clipping or pulling out the hairs. Great dexterity is required to manage this performance in a workmanlike manner, so as to avoid the stale and poster-like appearance which is presented by a leg clipped all over (without a corresponding clipping of the body), and at the same time to remove all, or nearly all, the superfluous hair. In the summer, a clipped leg is totally inadmissible, and even from the legs of a badly bred horse the hair may be pulled by gradually working at it for a little time every day with the fingers, armed with powdered resin. This prevents the hair slipping through them, and by its aid such a firm hold may be obtained that, as I said before, perseverance will enable the groom to clear the legs entirely, with the exception generally of a strong lock of hair behind the pastern. 
When this is very olustinate, it is allowable to use the scissors to clear away the hair below the horny growth which is found there, but there should always be left a slight fringe round this, so as to avoid the sharp and stiff outline presented by the clipped leg. In the winter, the arms and backs of the knees, as well as the bosom and the insides of the quarters, will generally want singeing, whether the body is submitted to the lamp or not; but in the summer, even if any long hairs are left there, they are easily removed by the hand armed with resin. Unless general clipping or singeing is practised, the front surfaces of the legs do not require trimming at any season of the year.

The mane is not now usually cut, with the exception of polo ponies and cobs, but formerly it was a very common practice to "hog" it, that is, to cut it to a sharp-pointed ridge, sticking straight upwards from the crest, and giving that part the appearance of extraordinary height. Sometimes, however, the mane is very thick, and then for the sake of appearances it is necessary to thin it, which is done by twisting a small lock at a time round the comb, and pulling it out; this gives some little pain, but apparently not much, and evidently not more than the trimming of the legs, and not so much as in pulling out the feelers or bristles growing from the nostrils. A small lock of the mane is generally cut just behind the ears where the head of the bridle rests, as it would otherwise lie beneath that part in an untidy manner.

In trimming the tail various methods are adopted, when it is cut square; for if the hairs are allowed to grow to the full length, no interference is necessary beyond an occasional clipping of their points to prevent them from breaking or splitting. A square tail, however, whether long or short, demands the careful use of the scissors or knife, without which the horse to which it belongs is sadly disfigured. Two modes are practised,-in the first the tail is carefully combed out, and then allowing it to fall in its natural position, it is gathered up in the hand just above the part to be cut off, and here a sharp knife is drawn across it backwards and forwards without notching it, till it passes clean through. The tail is then released and any loose hairs projecting are removed with the scissors. The second mode is not so easy, but when well carried out is more satisfactory to the eye, inasmuch as it is capable of giving a sharper and more defined edge to the square tail. As in the first method, the tail is carefully combed out; it is then held by an assistant's hand, placed beneath the root of the dock, as nearly as may be in the position which it assumes in the animal out-ofdoors. While thus poised the operator takes a pair of sharp scissors, and holding the blades horizontally open, he insinuates one of them through the middle of the tail at the place to be cut, passing it straight backwards, and cutting the hair quite level from the central line to the outside on his own left. Then reversing the blades, and keeping to the same level, he cuts towards the right, and if he has a good eye and can use his hands in accordance with its dictates, he will have presented a very prettily squared tail. On the other hand, if these organs are defective, or if he wants experience, he will have notched the end of the tail in a most unsightly manner. If the groom wishes to try his hand in this operation, he should get hold of a long tail, and begin far below the point where the squared end is intended finallv to be. This will afford him five or six experimental cuts, 
and if he cannot satisfy himself, as he nears the proper length, that he will be likely to succeed, he can still call in the aid of a more skilful operator before it is too late. The hair of the tail grows so slowly, that two or three months are required to remove the disfigurement which is sometimes caused in this way, and consequently it behoves the groom to be doubly careful, for his own sake as well as his master's.

There is a fashion in tails as well as manes, and for a long time a "bang" tail was the vogue, and some men are capable of improving on any sort of tail, with no other implement than a shoemaker's knife with a rough edge, produced by rubbing it on a coarse stone, such as mowers use upon a scythe. With a smooth edged tool it is difficult indeed to cut through a quantity of strong tail hair, but the sheer steel and rough edge of the cobbler's knife make short work of it if the operator has the required skill to direct it. An instrument made for the purpose is sold by Messrs. Arnold of Smithfield.

To make the mane lie smoothly on its proper side, which it sometimes obstinately refuses to do, it must be plaited in small locks, and the ends loaded with lead, if it cannot be made to lie down without. An experienced groom, however, will generally succeed in so managing the plaits that they lie close to the neck, which is all that can be effected by the aid of lead, but sometimes the hair is so obstinate that nothing else will effect the object in view. Special appliances for the purpose can now be purchased.

\section{USE AND APPLICATION OF BANDAGES}

BANDAGES are applied to the legs of the horse for three different purposes. First, to give support to the blood-vessels and synovial capsules; secondly, as a vehicle for applying cold lotions; and thirdly, for drying and warming them.

For the mere purpose of support either linen or flannel bandages may be put on, according to the weather, and the tendency to inflammation. The legs of seasoned old horses are seldom so prone to become hot as those of young ones, and excepting in very warm weather, flannel bandages seem to suit them better than linen. On the contrary, if flannel is applied to the legs of a colt, even if they are not inclined to inflame, they will become hot and uncomfortable, and he will learn to tear them off, in which some horses become perfect adepts. Whichever kind of bandage is put on, it should be previously tightly rolled with the tapes inwards, then taking it in the right hand, and unwrapping about six inches, they are laid against the cannon-bone on the side nearest to the groom, so that the folds shall have a tendency to unroll from him and not to him. While the left hand keeps the end from slipping, the right passes the roll of bandage closely round the leg till it meets the left, when the latter, still pressing the end against the leg, lays hold of the roll, and allows the right to be brought back to meet it on the other side. After which the coils are repeated till the whole bandage is run out and the leg encased, one row being slightly above or below the level of the next, as may be required. The great art consists in avoiding unequal pressure, and yet giving 
sufficient to accomplish the purpose for which bandaging is designed. From the projection backwards of the pastern joints it is impossible to make the folds lie perfectly smooth, and there must be loose parts, which however are covered over by the next turn. No written description, however, will suffice to teach this little operation, and the young groom should watch a good bandager, and imitate him as exactly as he can. The tapes at the end serve to tie the bandage on, and these also must neither be so tight as to cut the leg, nor so loose as to allow the bandage to fall down.

When cold lotions are to be applied by means of bandages, linen is the proper material, as flannel is too bad a conductor of heat, by evaporation, for the purpose. The whole bandage, after being rolled up moderately tightly, should be dipped in cold water, or in the lotion which may be recommended, an 1 then while quite wet it is to be applied in the way which I have just described. The following lotion is useful for the purpose :-

\section{Take of Tincture of Arnica a wine-glass full. \\ ,, Nitre $\frac{1}{2}$ oz. \\ , Sal ammoniac $1 \mathrm{oz}$. \\ ", Water half a bucket-full.}

Mix and use by dipping the bandages in before applying them, and by wetting them with this solution afterwards by means of a sponge.

If the groom is careful, he may remove inflammation of the legs better by means of dipping them in cold water, or the above lotion may be applied with a sponge every half-hour, holding each leg over the bucket, than with the aid of bandages. A cold douche by means of a forcing garden engine is also extremely beneficial to the legs, but it must be used out-of-doors, as it will wet the litter and the walls of the stall if the water is splashed over them within-doors.

For Drying and Warming the Legs when the horse is being dressed, flannel is the only proper material for bandages. Its mode of application is not of much consequence, provided the bandages are put on moderately loosely, for tight pressure has a tendency to prevent the return of natural heat, which is so much desired. After wetting the legs the bandages should be applied somewhat more tightly, so as to absorb the moisture as much as possible.

\section{MANAGEMENT OF THE FEET}

IN THE STABLED HORSE THE FEET require constant care, for they are not only artificially shod, but they are allowed to stand on a material which is a much worse conductor of heat than the surface of the earth, by nature designed to bear them. Hence, if neglected, they either become hard and brittle, or they are allowed to be constantly wet, and then the soft covering of the frog is decomposed, and emits a disagreeably smelling discharge, which soon wastes it away, leaving no other protection to the sensible organ beneath, and constituting what is called an ordinary thrush. Again, it is found by experience, that not only must the shoes be renewed as they wear out, but even if no work is done, and consequently they are 
not reduced in size, they no longer fit at the expiration of about three weeks, and they must then be removed. The groom must therefore attend to the following points:- First, to prevent the feet from becoming too dry; secondly, to take measures against their becoming thrushy from wet; thirdly, to see that the shoes are removed at the end of every three weeks, or more frequently if necessary; and fourthly, to examine carefully every day that they are securely nailed on without any of the clenches having started up from the surface, so as to endanger the other leg.

DRYNESS OF THE FEET is prevented by the use of what is called stopping, which is composed either of cow-dung alone, or cow-dung and clay mixed, or of cow-dung and pitch. The first is by far the most powerful application, but it moistens the sole too much if employed every night, and then produces the opposite evil in the shape of thrush. A mixture of equal parts of cow-dung and clay may be used every night with advantage, and this I believe to be the best of all stoppings. It should be kept in a strong box of wood, about a foot long and eight inches wide, with a handle across the top, and it should be applied the last thing at night to the soles of the fore-feet only, by means of a thin piece of wood, a foot long and a couple of inches wide, with which the space between the shoe is completely stuffed. If the feet are obstinately dry, in spite of repeated stoppings with cow-dung alone, which will rarely be the case, a tablespoonful of salt may be added to the cow-dung, and this will never fail. For most horses stopping with cow-dung alone once a week is sufficient, but the groom can judge for himself, by their appearance, of the number of stoppings required. If three parts of cow-dung and one of clay are used, the feet may be stopped twice a week, or perhaps every other night, and if equal parts of each are adopted as the composition, almost any feet will bear being stopped every other night, with the exception of flat or pumiced soles, which should never be stopped at all. Several patents have been taken out for felt pads, to be soaked in water, and then inserted in the hollow of the shoe, but they do not answer nearly so well as cow-dung stopping, which has far more emollient qualities than mere water. I believe nothing has yet been discovered which has qualities at all equal to this old-fashioned natural remedy.

Thrushes are prevented by keeping the frogs free from ragged layers of the elastic substance of which they are partly composed, and at the same time by maintaining a dry state of the litter on which the horse stands. I am not now considering the management of the horse at grass, where thrushes are generally produced when the weather is very wet, or when the pasture is of too marshy a character, but the frogs of the stabled horse, which ought never to be allowed to be so moist as to become decomposed. Some ulcerated conditions of the frog which are still considered to come under the general denomination "thrush," are due to severe internal disease of the bones of the foot, and are not caused by moisture at all. Still these are rare exceptions, and the ordinary thrush of the stable may be considered as caused in the latter way. Cases are also occasionally to be dealt with, in which from general grossness of the system, the sensible frog throws off part of its horny covering, and secretes a foul matter instead. The management of these diseased con- 
ditions comes within the province of the veterinarian, but the prevention of the mere decomposition of the external surface by moisture is a part of the duties of the groom, and so is the application of the proper remedies for it, as soon as the nature of the case is clearly made out. Here antiseptic astringents, which are quite out of place in inflammatory thrush are the only useful applications, and by their means alone can the decomposition be stopped. Of these Sir W. Burnett's solution of chloride of zinc is the best, but in mild cases, the permanganate of soda will answer well, and is not so poisonous in its nature if carelessly left about. Friar's Balsam, with as much of the sulphate of zinc dissolved in it as it will take up, is the old-fashioned groom's remedy for thrush, and a very good one it is if carefully insinuated into the cleft of the frog on a piece of tow wetted with it.

A mixture of tar and salt in the proportion of four or five parts of the former to one of the latter, is an excellent remedy, but there are some cases which may be considered as constitutional or hereditary, and requiring not only local dressing but internal medicines. The grand principle, however, is to prevent thrush rather than to cure it, but when horses are bought, or come home from grass with it, the curative method must be carried out.

The REMOVAL of THE SHoEs at regular intervals, whether they are worn out or not, is a most important part of the duties of the groom. On examining the shape of the foot it will be seen that the diameter of the circle in contact with the shoe is greater than that of the coronet, and hence as the shoe is forced away from its original position by the growth of the horn, it confines the walls to the extent of the difference between the diameter of the foot at its old position and that of the part which it now occupies. For if two lines from the surface of the coronet on each side were continued through the outside surface of the crust to the new seat of the shoe, they would be far from parallel, and yet the shoe-nails must have been carried on in perfect parallel lines on account of the unyielding nature of iron. For this reason a shoe, when it has not been removed at the end of a month, will be found to lie within the heel of one side or the other, by which to some extent contraction is prevented, but at the expense of the heel, into which the corresponding part of the shoe has entered. This is a frequent cause of corns, and horses which have once been subject to that disease should have their shoes removed once a fortnight.

ONE OF THE MOST ANNOYING ACCIDENTS to the horseman is the loss of a shoe, whether it happens in the hunting-field or on the road. Some horses can scarcely be prevented by any care of their grooms from pulling off a shoe in hunting when they get into deep ground, but on the road there is no such excuse, and the frequent loss of a shoe by the hack or harness-horse is sufficient to condemn the groom of carelessness in this particular. Every morning when the feet are picked out it is easy to look the shoes over and feel if they are tight. The clenches also ought to be examined, and if they are not raised at all it may safely be predicated that the day's journey will be completed without the shoe being lost. A raised clench may severely cut a horse on the inside of the other leg, and in those who are predisposed to "speedy cut" it may cause severe injury, and perhaps occasion a fall of the most dangerous character. 


\section{DAILY EXERCISE}

Without REGULAR EXERCISE no horse can long be kept in health, and I believe that as far as this point is concerned, even those which are hardworked would be the better for half-an-hour's airing every morning as soon as they have been fed and before they are dressed. But those masters who are particular about the mouths of the animals they ride or drive, find that the hands of their grooms are generally so heavy that they spoil the delicate "feel" on which the comfort and pleasure of riding and driving so much depends. Hence in such cases the poor horse is condemned to confinement in his stable, not only on the day when he is to be ridden or driven, but on those also when he is to be idle. The health of the body is sacrificed to the maintenance of that delicate condition of the mouth which is so highly prized by good horsemen and accomplished whips, and I confess that I plead guilty to having for a long series of years acted on this principle. A fair share of health may be maintained without exercise if the work is never interrupted for more than a single day, and at the same time there being only one pair of hands to interfere with the mouth, its delicacy is not impaired, that is to say if they are not as bad as those of the groom. Sometimes a large and smooth snaffle is allowed as an exercise bridle, in the hope that it cannot injure the mouth, but even this will do mischief if the weight of the rider is thrown upon it, as is too often the case. Leaving out of the question this objection to the adoption of exercise, there can be no doubt that a daily walk out-of-doors for half-an-hour or an hour, especially if it can be managed on turf will be of the greatest service to the horse's health. 


\title{
CHAPTER XV
}

\author{
STABLE MANAGEMENT CUNTINUEJ
}

RECAPITULATION OF DAILY DUTIES-PROPER TEMPERATURE OF THE STABI.E-REMEDIES FOP STABLE VICES AND BAD HABITS-PREPARATION FOR WORK-DORDINARY SWEATING-THE TURKISH BATH-PHYSIC-FINAL PREPARATION-TREATMENT AFTER WORK-SUMMERING -A WINTER'S RUN-THE STRAW-YARD - OARE OF SADDLERY AND HARNESS.

IN THE LAST CHAPTER I have entered at length upon the consideration of the several duties of the groom; I shall now recapitulate them, so as to enable the master to see at a glance whether his servant is at any particular time doing what he ought to do.

\section{RECAPITULATION OF DAILY DUTIES}

A. .. 5 to 6. Feed, and give a few "go-downs" of water; while the corn is being eaten put the stable straight, by separating the soiled part of the litter and forking it back into the gangway, while the rest is tucked up under the manger. Then sweep out the stall quite clean, and carry the dirt as well as the foul litter at once out of the stable.

6 to 7. Put exercise saddle and bridle on, take the horse out for half-an-hour or an hour, or more, according to the work he has to do. Bring him home, take off saddle and bridle, shake down a little litter, and go to breakfast.

8 to 8.30. Dress each horse for an hour; put all straight; feed, and water lightly; rack up if going out to work, if not allow horse to lie down, arranging a light bed for the purpose; put on bandages when worn.

r. M. 3 to 4 . Feed again and give half a bucket of water; remove droppings.

7 to 8 . Remove droppings; bed up; water and fued; stop feet on those nights when required; take off bandages.

These hours will vary according to circumstances, but in private stables they are the most convenient that can be arranged for hacks and harnesshorses. Hunters are sometimes fed once more, - that is, at six, nine, twelve, five, and eight; but I believe four times a day often enough to give any horse food. When one man has to do three horses, he cannot of course finish them all by the hour named, and even if he begins at five o'clock, he cannot complete all he has to do before eleven or twelve o'clock.

\section{PROPER TEMPERATURE OF THE STABLE}

THere is SCARCELY ANY POINT upon which there is so much difference of opinion, as in relation to the temperature of stables. Some contend for an awount of heat which would raise Fahrenheit's thermometer to $65^{\circ}$ or $70^{\circ}$, 
while others would never have their stables, if they could help it, above $45^{\circ}$. So much depends upon the kind of horse in them, and the work he has to do, that is to say, whether he is much exposed to the cold or not, that no rule can be laid down which is applicable to all stables, but I believe it may be asserted that none should be above $60^{\circ}$, or below $50^{\circ}$, if it can be avoided. There are days in the summer season, when the air out of doors in the shade stands at $90^{\circ}$ or $95^{\circ}$, and, of course, in such weather, it is impossible, even with the doors and windows wide open, to keep the stable at a lower degree, or even within several points of those above stated. So also, with a thermometer scarcely above zero, it will be difficult to keep the air wholesome, and yet to prevent its temperature falling lower than $45^{\circ}$, which, at such seasons, feels very warm to those who come in from the external air. But, with these exceptions, I think the rule which I have laid down is a good one. The warmer the stable, the better the coat looks, till it is exposed to the weather, and even if it is so, it will take no injury if the horse is kept moving, but if not, it soon becomes chilled, and not only does the general health suffer, but the appearance also. There is, however, another, and very serious objection to hot stables, consisting in their ill effect upon the legs and feet, which inflame much more readily in a warm atmosphere than in a cool one. I have often known horses stand severe rattling for months together, while standing in a stable which was so cold as to make their coats as rough as badgers, but when removed to warmer quarters, they have at once gone "all to pieces," their legs or feet becoming inflamed from missing the refrigerating effect of cool air after their daily work. The body may easily be, kept warm enough by extra clothing, and, if necessary, a hood and breastplate may be worn all day and all night, but not even wet bandages will cool the legs if they are surrounded by hot air. On the whole, therefore, for the private gentleman's stable, including those for hunters, hacks, and carriage-horses, I should advise a regular temperature to be preserved as near $55^{\circ}$ of Fahrenheit as possible. In coming in from the external air this will appear very warm to the sensations, but it is far below the high state of heat at which many of our stables were kept, until within the last few years. I have often known $70^{\circ}$ to $75^{\circ}$ of Fahrenheit insisted on as the lowest which would suffice to get a hunter into condition, but practice proves the reverse, and that with plenty of clothing he will do in a cool stable of the temperature I have recommended, far better than in one possessing a higher range. The celebrated "Nimrod" (Mr. Apperley) was a great advocate for a hot stable, which he thought ought never to be reduced much below $70^{\circ}$ or $75^{\circ}$; but his opinions, valuable as they undoubtedly are in the main, cannot be looked upon as in all points to be relied on.

\section{REMEDIES FOR STABLE VICES AND BAD HABITS}

OrIB-BITING is a diseased condition of the stomach, for which there has never yet been a cure discovered, except on the principle of restraint. It may, therefore, be considered under the present head. In crib-biting the teetl are applied to some fixed object-generally the manger, so as to afford 
a fulcrum for the muscles of the neck to act from, and by preventing this, or by contriving so that the contraction of the muscles of the neck shall give pain, the vicious habit is got rid of for the time. The most common method is to buckle a leather strap so tightly round the neck, just behind the jaw, that when the horse attempts to crib, he tightens the muscles of that part, and these being pressed against the strap, occasion such pain that the act is not completely carried out, and even if it is on the first occasion, the attempt is not repeated. The strap is buckled sufficiently tight to do this, without much impeding the act of swallowing, or the flow of blood from the head, through the jugular veins to the body; but in confirmed cribbers no ordinary pressure will suffice, and then the head often becomes affected from the impediment which is caused to the return of the blood from the brain to the heart. To remedy this defect Mr. Cook, saddler, of Long Acre, invented a neck strap, containing a number of prongs, which pass through holes in a spring guard, and unless this is strongly pressed, they do not touch the skin. It is applied by throat straps to an ordinary head collar, and in slight cases it is found to answer most perfectly, but when the vice has become confirmed, and the desire to indulge in it is very strong, the pain occasioned by the prongs is endured, and no effect at all is produced. It is not therefore of much use, as the common strap does no injury in those cases where Mr. Cook's is effectual, and the latter will not a vail when the plain strap is forbidden, on account of the extreme pressure required. I. cannot, therefore, recommend any plan but.such as will totally prevent the prehension of the manger, and this is accomplished by one of two ways. In the first of these, the manger itself is either concealed, on the principle shown at page 238 , or the corn and hay are placed on the ground, in a space slightly separated from the rest of the stall by a row of bricks, or other similar bodies, which cannot be laid hold of. To the concealed manger and rack there is the objection, that while the horse is feeding, he can go on cribbing without interruption, and as this is the time chiefly chosen for the act, success is only partly achieved. Placing the food on the ground is entirely successful in stopping the habit, but it leads to some waste of provender, as the horse is apt to tread upon it, after which he will refuse to eat it. By far the best preventive, in my opinion, is the bar muzzle, consisting in an iron frame-work covering the lips and nose, and suspended from the head by a leather head collar, so that the lips can reach the corn or hay, but the teeth are too wide to pass through the bars and seize the manger. This mechanical contrivance is entirely harmless, and perfectly effectual, the sole objection to it being the fact that it proclaims the wearer to every one who looks into the stable as a cribber. 'This may be a valid reason for rejecting its use for dealers' horses, but in a gentleman's stable, utility and humanity ought to have precedence of such a feeble argument. The price of the bar muzzle is $15 s$., which to a poor man is a consideration, as compared with the plain leather strap to be obtained for 1s. $6 d$. When the bar muzzle is adopted, it should always be kept on, excepting, of course, when the bridle replaces it for work or exercise, or while the head is being dressed.

KICKINǴ THE WALL OR STALL-POST is sometimes a very annoying trick, and though not always done in a vicious manner, it is objectionable, because the kicker is liable to lame himself, or one of his neighbours. In 
mares it is often of a sexual nature, and in them it is much more common than in geldings, - the extent to which it is carried by them being generally greatest at the beginning and end of their being "in use." At such times some mares go almost mad, if they have an irritating neighbour, who keeps smelling them, and I once had one who kicked herself to pieces in a paroxysm of this kind, which nothing but tying up the fore-leg could restrain. There are several remedies in common use, but none can be relied on in all cases. Foremost among these is the use of gorse, nailed to the stall-post, which will almost invariably quiet a low-bred animal, especially if a gelding, but high-bred mares will sometimes kick at it all the more, for the punishment they receive. A padded leather strap, buckled round the cannon-bone, with a common sinker attached to it, or instead of this, a few links of heavy chain, will generally keep the horse from kicking,

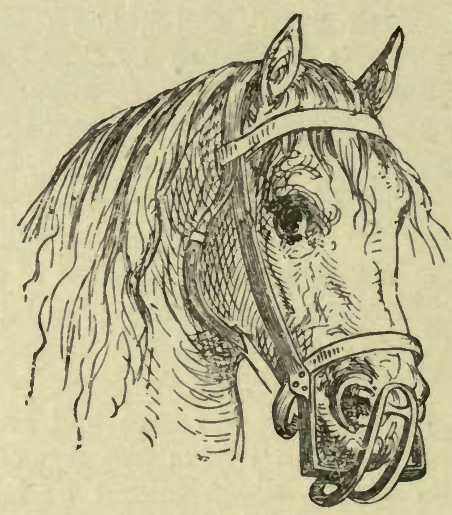

BAR MUZZLE FOR CRIB-BITERS.

because in making the attempt he gives his coronet and pastern a heary blow. If, however, this plan is unsuccessful, it is liable to cause lameness, from the inflammation produced by the blows, and, therefore, the effect must be carefully watched. Few horses kick out with both legs, and a pair of hobbles buckled round the hind fetlocks will, in a vast majority of cases, put an end to the trick as long as they are worn, without any risk, or producing any serious annoyance, save only what is inseparably connected with the prohibition of the indulgence in the desire to kick. A narrow strap buckled round the part just above the hock, so as to confine the ham-string, will have the desired effect, by giving intense pain when any attempt to strike out is made, but it is a most annoying infliction to the horse, and generally prevents his lying down, from the necessity which there is for bending the hock, in reaching the ground. I should, therefore, give the preference to the bunch of gorse, or if that is not readily procurable, to the sinker of wood or iron suspended to a strap round the leg.

IN SCRATCHING THE EAR with the hind-foot, the horse is very apt to get his leg over the collar-rein, if the sinker is not heavy enough to keep the rein tightly strained between the head collar and the ring in the manger. Impatient animals, also, which are continually pawing at their litter, will 
sometimes get one of their fore-feet over it, but this is not so serious an accident. To prevent the mischief occasioned in either case by the struggles to get free, especially when the hind-leg is thus caught, the rings for the collar-reins are sometimes made to draw down with a spring-catch, which releases them when pulled in. that direction, but in no other. When, however, the sinker is properly weighted, it is almost impossible for such an accident to occur; and this simple invention has now become obsolete.

TEARING THE CLOTHES ofF is by no means an unusual stable habit, and it is one very difficult to cure. There are two effectual preventives, however : one of which consists in the regular employment of a rough horsehair cloth,

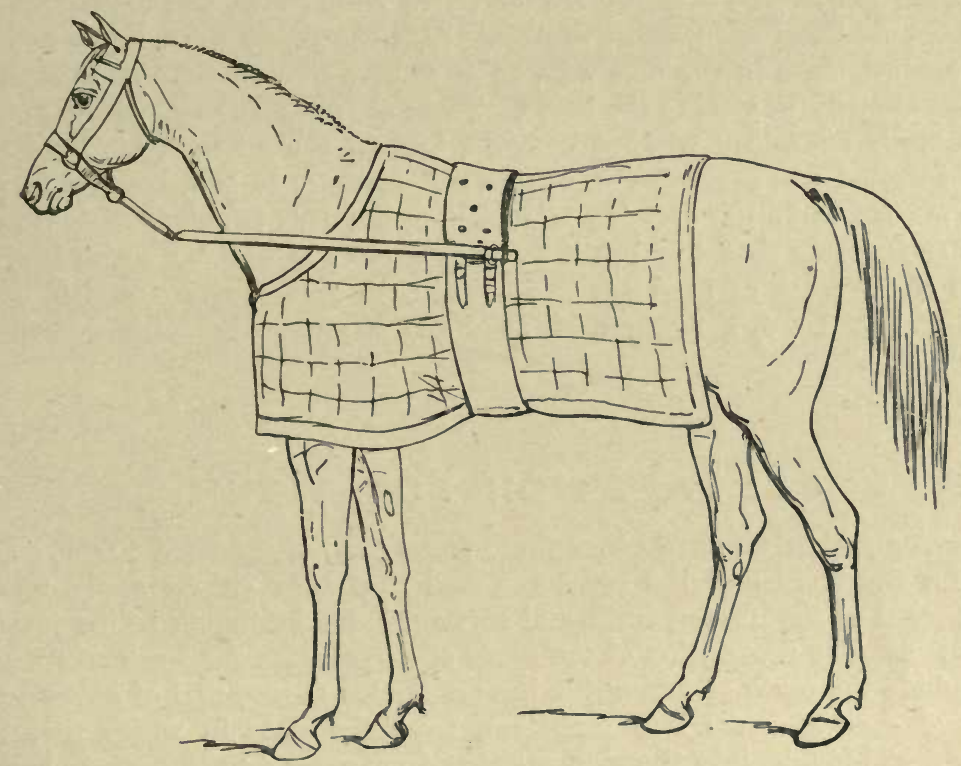

REMEDY FOR TEARING THE CLOTIIES.

made like that for hops, outside the rug, and which is so disagreeable to the teeth, that no horse will attempt to tear it; the other is carried out by means of a pole of ash, about three-quarters of an inch in diameter, with an iron eye attached to each end. One of these is fastened, by means of a short leathern strap and buckle, to the side of the roller pad, while the other has a strap or chain about a foot long, which attaches it to the head collar. The pole should reach about fifteen inches beyond the point of the shoulder, and it should be fixed on the side which is generally uppermost when the horse lies down, so as not to be under him in that position. It is a very simple and cheap apparatus, and any village blacksmith can make and apply it. The above engraving will illustrate my meaning better than the most detailed description without it.

WeAving is a mark of an irritable nervous system, beyond which it is harmless, but quite incurable. It consists in a perpetual moving of the head from one side of the manger to the other, with an action like that of a 
wild beast in his den. The constant friction soon wears out the collar-reins when there are two, and on that account a single rein may be adopted in this particular instance with advantage.

EATING THE LitTER is a peculiar appetite, which chiefly occurs either in those horses which are kept short of hay on account of their tendency to fatten, or when the animal possessing it has been stabled for a very long time together and requires a change. In the former case nothing but the muzzle will be of the slightest service, but in the latter a run at grass, or soiling indoors for a month or two, will remedy the disorder of the stomach. Rock-salt in the manger will sometimes have the desired effect, producing a degree of thirst which will make dry litter distasteful.

KICKING AND BITING savagely are marks of actual vice, and scarcely come within the limits of the present section. Still the groom must know how to guard against them in the best way, so as to save himself from danger without unnecessarily punishing the horse. There are some animals which cannot be effectually restrained without severity, but on the average, kindness and firmness united will overcome any horse. Sometimes it is necessary to put on the muzzle while the dressing is going on, but this is chiefly because the skin is so irritable that the brush or wisp excites sensations which lead to the use of the teeth or hind-legs to prevent their recurrence. In such cases as these Mr. Rarey's method of subduing a savage horse is extremely valuable.

\section{PREPARATION FOR WORK}

I HAVE ALREADY OBSERVED that these pages are not intended to serve as a guide for the trainer of the racehorse, and that they chiefly apply to the management of the hunter, hack, and carriage-horse belonging to the private gentleman. The description of the mode of preparation for work will therefore include the mode of fitting the hunter for his duties, and of getting the hack and carriage-horse into condition, from the state in which they are usually first brought into the stable, either from grass or the dealer's hands.

IN THE PRESENT DAY, THE HUNTER is prepared almost as carefully as the racehorse or steeplechaser, when he is intended for any of the grass countries. Nothing short of a regular preparation will enable a horse to go through a fast thing in Northamptonshire or Leicestershire, and no man in his senses would ride a horse there in the front rank, unless he was thoroughly fit. The stud-groom, therefore, requires for his purpose a training-ground where he can give his horses their sweats, without which it would be impossible to get them into condition. A very large space is not necessary, but a very small one will not suffice, the constant turning incidental to a limited gallop producing a great strain upon the joints. If possible a gallop measuring at least a mile and a half or two miles in circumference should be obtained, and with this length, including a moderate rise in its extent so as to open the horse's pipes well at the finish of a sweat, it is the groom's fault if his charge is not brought out thoroughly fit when the hunting season commences. Of course, when making this assertion, I am calculating that he has been allowed sufficient time, which will depend greatly upon the state ir which he finds his horses in August. If they have been at grass, it is almost impossible 
to get them ready by the middle of November, but a well-summered horse soiled in a loose-box with a proper allowance of corn, may be thoroughly prepared by that time if he is set to work by the middle of August. This will allow of two clear preparations, with an intervening week for cooling physic. ${ }^{1}$ Should the horse be up from grass, another month or six weeks at least will be required, which must be employed in giving him nothing but walking exercise, with a dose of physic at the beginning, and repeated at the end of three weeks or a month. Horses at grass in the summer are seldom allowed any corn, and the change from grass to the more stimulating food of the stable must be made gradually, or some of the important organs will assuredly fail. Hence the necessity for extra time, and the addition which I have made to the calculated period for conditioning a hunter summered in-doors, is barely sufficient for this purpose, when he is full of grass or of the fattening food which is given to make him up for the dealers. In either case great care and some experience are necessary in altering the entire management of the animal, so as to give him corn and exercise enough to prepare his frame gradually for the strains which it will have to bear in the hunting-field, without producing inflammation. With all the objections which I hold to physic, I must confess that here $I$ think it to be indispensable; and invariably, as soon as a raw horse is settled in the stable, I should get him thoroughly cleaned out before I began to give him hay and corn. I have always found it advantageous just to allow a couple of days to elapse before giving the physic, which will serve to fill the large bowels with the new kind of food. A mash should then be administered at night, and repeated if necessary till it has had the desired effect in softening the dung, when the physic may be given. Two or three days will elapse before it has set sufficiently to allow of walking exercise; but as soon as this can be ordered with safety, the horse should be walked out twice a day for an hour and a half each time, or two hours in the morning and one in the evening, whichever may be preferred. The division of the exercise into two periods is far better than keeping the green horse out for so long a time as three hours, which will make him weary; whereas, the shorter period will not tire any horse, and a mid-day rest will restore his whole frame, and enable him to go out again in the evening as cheerfully as ever. I need scarcely observe that the shoes should be attended to, and the feet put in proper order, for three hours' walking exercise in ill-fitting shoes will do great harm, especially to feet that are not accustomed to their pressure. By persevering with steady slow work, and feeding on a moderate allowance of hay and corn, the latter not exceeding two feeds at first and three at the end of the month, the horse will be ready by the middle of August to have a second dose of physic, after which he may commence in earnest his first real preparation. This also is chiefly confined to slow work, but if the horse is gross he may have in the course of the four or five weeks to which it extends one or two sweats of moderate length and speed. Great caution must always be exercised by the groom at this time; on no account should any fast work be given, unless he is satisfied that his horse

1 This custom has to a great extent fallen into desuetude, but the editor after thirty years' practice among hunters is decidedly in favour of at least one dose of physic, which in stable nomenclature always means a dose of aloes in the form of a ball. 
is in perfect health and in good spirits. Every increase in the food and work should be carefully watched, and its effects noted, so as to guide him in deciding whether he can venture to take another step. It must be remembered that hitherto the feeds of corn have been only three quarterns of oats daily, and the exercise has not extended beyond a walk; but during the next few weeks the former must be doubled, or nearly so, and the latter must go on into a daily slow trot of two or three miles on turf, with an occasional steady gallop in place of this, and, as I have before remarked, one or two sweats if the system is overloaded with fat. But unless the hunter is very fleshy, nothing more than slow trots and canters will be required until after the next dose of physic. The increase in the quantity of corn will seldom tend to put on fat, and as the amount of hay should be small, not exceeding $10 \mathrm{lbs}$. a day, unless the horse is gross in his nature, he will have put on muscle, and lost some of the internal fat which is so prejudicial to condition.

The OBJECT OF THE SWEATING PROCESS is to remove superfluous fatty matters, which act prejudicially in a twofold manner. In the first placo the fat itself is so much dead weight to carry, and on the calculation that seven pounds are equal to a distance in an average length of race, it may readily be understood that the huge quantity of adipose tissue, which is carried by a fat horse, will, by its weight alone, retard any attempt at high speed. But not only is fat to be objected to on this score; for it is also known by experience, that its pressure on the important internal organs, when it is deposited around them, interferes with the proper performance of their several functions. The muscles of the limbs, when they are marbled with fat, as we see them in the slaughtered ox and sheep, are unable to contract vigorously, but when a similar condition occurs in the muscular tissue of which the heart is composed, violent exertions are interdicted, or, if they are attempted, they are attended with dangerous and often fatal results. Again, it is ascertained that sweating has a local, as well as a general effect, and that, by producing a copious discharge of fluid from the skin covering any particular part, there will be a removal of any superfluous fat which may be lodged beneath it, before the rest of the body is perceptibly acted on. Hence, when the groom thinks that his horse is loaded with fat about the heart, he puts on extra "sweaters" over that part, or, on the contrary, if his object is to unload the ridge of dense adipose membrane which constitutes a high crest, he puts on two or three extra hoods, and sweats chiefly in that region of the body. The local effect of these partial sweats is, perhaps, a good deal overrated, but undoubtedly there is some foundation for the general belief. The use of clothing for sweating is not nearly so frequent as it used to be, even in racing stables, and horses are not now drawn so fine, by a great deal, as they were formerly. At one time runners in the Derby, or in any other great race, when they were saddled, looked like living skeletons, and to an eye unaccustomed to the hard lines presented by their limbs, the beauty of their forms was entirely gone. Now a different system prevails; the object is not to reduce the horse as much as he will bear, but to bring him out as big as he can be, consistently with good wind. The celebrated trainer, John Scott, has shown what can be done in this way, and his example is now generally followed. So also with hunters, although they 
are often required to do more, perhaps, than any other variety of the horse, and in the grass countries are made as fit as if they were going to run in a steeplechase, yet they are brought to covert looking big and full of muscle, without any pretensions to be considered as drawn fine. Still the sweat, either in clothes or without them, must be occasionally carried out, or the internal organs will continue loaded with fat, as is natural to them when they have been for some time in a state of rest, coupled with high feeding. The use and amount of sweaters must be proportioned to the constitutional peculiarities of the individual; in one horse a slow gallop will produce a perfect lather on the skin, while in another treated in all respects in the same way, there shall be hardly a hair turned. So also the effect of apparently the same degree of sweating on different horses is very variable, producing a great relief in one case, and scarcely any in another. The groom must not attempt to carry out any fixed rule, but must watch the effect of each day's work, and increase or diminish the amount next day according to circumstances. As I before remarked, a sweat may be with clethes or without, the object in each case being not so much to do a certain amount of work, but to get rid of a fixed quantity of superfluous fat and humours. On the other hand, a gallop has quite the opposite end in view, being intended to brace the muscles, heart, blood-vessels, and lungs, by stimulating them to act in an extraordinary degree, but without any view to reduce the weight of the body or any part of it. In a sweat, therefore, the pace is slow and long continued; no exertion is made to render it smart, or to develop action in any shape, the whole attention of the groom being devoted to the single object which is connected with the removal of fat. It is usual, therefore, to send the horse along at a slow, steady, hand gallop for four miles, or in very gross animals for five or six, the last half-mile only being done at anything like a fast pace, and even then the horse should not be extended to the utmost, on account of the great extra weight he has to carry, if he has two or three sweating blankets on. It is quite necessary to bear in mind this special object of the sweat, as the Turkish bath is in some establishments still used, and for a time was in great favour. The opponents of the Turkish bath contend that it can never supersede the old plan, because, though it will get rid of superfluities, it will not develop muscle; but they forget that it is not used for the latter purpose, but is solely confined to the one object, which by the employment of sweating blankets out-of-doors is accompanied with considerable risk. The Turkish bath is, in fact, a means to one end only, and must not be employed for any other. No horse could have his muscles and heart, his wind and limbs, made more wiry and enduring than before by any number of baths; but he may be put into a condition which shall fit him for being so, without the risk to the legs and feet which a number of sweats in heavy clothing will always cause. No wonder, therefore, that trainers eagerly resort to the use of the bath, especially as every year their horses seem to be getting more and more liable to break down. It is quite true that the old-fashioned sweat combines muscular exercise with the process of unloading the system, but in so doing, the time of the groom is the only thing saved, and no one would take that into the calculation, as being worthy of consideration. By the use of the bath when he is too gross, the horse is sweated on one day, and on the next he may be galloned if necessary, the bath producing so 
little fatigue, that he may have any amount of exercise directly after it, to which he is accustomed. In resorting to the bath at first the attempt was made to save doubtful legs only, but the good effect was soon found to extend beyond this, and in almost all cases where there would be any necessity for sweats and clothing, the Turkish bath is adopted instead, by those who have the means at their disposal. I shall, therefore, describe each of these plans in detail.

\section{ORDINARY SWEATING}

WheN THE OLD-FASHIONED SWEAT is intended to be given, and it is not proposed to reduce any part in particular, it is usual to put on an old rug next the skin, or, in large stables, a sheet kept expressly for the purpose, and hence called a "sweater"; then an old hood and breast-cloth, next a second quarter piece is put on, and even a third in some cases, and lastly, a complete set of clothing over all, the saddle, as usual, completing the arrangement. If any special part is to be reduced, as, for instance, the brisket or bosom, an extra cloth is folded like a shawl, and the ends being crossed over the withers, it is kept in its place under the breast-cloth, by the pressure of the saddle; or a rug may be folded and placed round the chest, without extending to the loins, in case the heart is supposed to be oppressed with fat. All these points of detail will call upon the groom for an exercise of ingenuity and tact, and if he possesses these qualities, he will have no difficulty in placing his sweaters where they will be required. When they are all securely fixed the horse is ridden out, and after walking for a short time to empty himself, he is started off to go his sweat, which is generally four miles, doing three-quarters of the distance at a slow pace, and then being set going a little faster, and at last brought out to his top-speed, if in full training, or nearly so if in his second preparation. By his top-speed, however, is not to be understood the very outside pace which can be got out of the horse, but only such a speed as is short of that by so much as will preserve his stride in full vigour, and prevent that over-pacing which leads to the rupture of muscular or tendinous structure. In his first preparation he should seldom be extended, and it is better to increase the distance rather than to accelerate the speed beyond the steady gallop; but few horses refuse to sweat at a slow pace in this stage of training. As soon as he has finished the distance, the trainer examines his state, and either directs him to be walked or trotted on to the rubbing place, which should be a box set apart for the purpose, either on the training-ground or at the usual stables; or if the ground is at a distance from any available stable, the shelter of a haystack or high hedge should be sought for. The full benefit of the sweat is not obtained unless the fluid is scraped off before it has had time to be re-absorbed, which is the result, if it is allowed to remain on the skin after this has ceased to give out any fluid. Its vessels in that case, instead of perspiring, adopt the opposite extreme, and appropriate the sweat by their own power of absorption; thus doing away with the chief benefit which was expected and desired from the sweat itself. When the hand of the groom, applied to the shoulder of the horse under his breast-cloth, tells him that the sweat is coming kindly, the horse may 
have a couple of rugs heaped upon him, and be suffered to give out fluid for a very few minutes only; but if it does not break out at once three or four must be put on him, and he must wait a quarter of an hour or twenty minutes before he is fit to scrape. If he sweats freely, the groom in charge of his head may rub his ears and wipe his eyes, so as to refresh him slightly; but if there is any difficulty in bringing on the sweat this will only retard the process, and he may be allowed to stand quite quietly, and without any attempt to refresh him by the above little attentions, or by rubbing his legs, or wiping his thighs or bosom. As soon as the groom is satisfied, the hood is taken off, and the head and neck rapidly scraped, together with the bosom, from which the breast-cloth is removed, and the rugs and quarter piece turned back so as to expose the whole neck and the points of the shoulders. One or two strappers may be employed in scraping and afterwards drying this part, besides the one holding the bridle; but if the horse is quiet enough, this may be removed, and the head dressed all the more effectually. A very few minutes suffice for drying this half of the horse, when the bridle should be readjusted, and the quarter piece and sweaters wholly turned off over the croup; upon this the strappers again set to work with their scrapers and rubbers, they soon get rid of every particle of sweat, and have the coat perfectly dry and smooth. Much depends upon the stage of training; in the early part, the sweat is profuse, thick, and soapy, and takes more time to dry; while in the latter stages, when the horse is getting fit, it is watery and scanty, the horse will scarcely scrape, and dries without the slightest trouble. This is a good sign of condition, and the necessity for a repetition of the sweat may generally be gathered by the appearance of the fluid, which, when thick and lathery, shows that there is much gross fat in the system requiring removal; but, nevertheless, it also shows that great care must be taken in the process, lest mischief should be done, by calling upon Nature too rapidly while the animal is in this fat state, and liable to inflammations of all kinds. After rubbing all the coat dry, and smoothing it down with the leather rubber, the usual clothing should be put on, and the horse allowed his exercise, which he may have as usual, care being taken that he does not catch cold if the weather is severe. The reason why the horse is taken out again is, that if he were left in the warm stable he would break out into a second sweat, and if he were placed in a cool one he would surely take cold. Walking exercise, therefore, with a short canter, is adopted as a means of avoiding both of these injurious conditions; but he should not continue it longer than to put him into a cool state, and restore his nerves and bloodvessels to their usual condition. The length of ground and pace for sweating vary with the age, condition, and purpose for which the horse is trained, the maximum length being six miles, and the minimum two to three, with a speed varying with every individual case, and depending upon the age, breed, and action of the horse, as well as his constitution and legs, and the state of preparation in which he is. Sweats are given at periods varying from once a week to once a fortnight after the first preparation, but seldom so often during that time. When sweats are given without clothing, they are in other respects just the same as described above, and the strappers are required in a similar way to dry the horse at once; but the quantity of sweat is not nearly so great, and two good hands will 
generally suffice for the purpose. In almost all cases, even where clothing is not used, it is heaped on when the horse is taken into the stable, in order to encourage the flow of perspiration. (For "Sweaters," see page 247.)

\section{THE TURKISH BATH}

The Turkisir bath when employed for horses, requires two boxes to be prepared, contiguous to each other, and, if economy is an object, to the saddle-room also, in order that one fire shall serve for all. The annexed plan has been carried out on this principle, the fire-place A being placed in the saddle-room, and heating it, as well as a boiler for hot water. It is sunk eighteen inches beneath the floor of the saddle-room, so as to allow of the commencement of the flue at B entering the bath-room, with its bottom two feet from the floor of that apartment, and to pass beneath the final exit of the flue, as it leaves to enter the chimney at F. The flue is supported on arches, clear of the wall, from $\mathrm{B}$ to $\mathrm{C}$ rising two inches in the foot, so that when it reaches the corner C, its bottom is four feet from the ground. It is built exactly like the usual flue of a hot-house, with dampers, and all the arrangements peculiar to that apparatus. From $\mathrm{C}$ to D it may be either on arches, or supported on slate built into the wall, as the heat is from this point not sufficient to crack that material. At $D$ the bottom is about six feet high, and when it reaches the entrance $B$, it will give plenty of head room for a horse to pass beneath. On this side it is built in the wall, but still on arches so as to expose as large a radiating surface as possible, and serves to heat the other box $\mathrm{H}$ to the temperature required to prepare the horse for his sweat. Finally, it passes along the upper part of the fourth wall, in which also it is built in the same manner, and makes its exit over the part where it entered, at F. Here the flues are so arranged by dampers, that the current of warm air may either be directed along the flue B C D.E F, or it may be turned off into the chimney F, entirely or partially. Ventilators must be introduced freely in the walls, so as to give plenty of fresh air when it is required, or to shut it off completely, to raise the temperature to the proper degree before the horse is admitted. One or two valves, in addition to the door I, all capable of being opened and closed at will, must also be fixed in the wall, between the boxes $G$ and $H$, and by their means, added to the heat given off by the flue in it, this preparatory box may be heated to $80^{\circ}$ or $90^{\circ}$ of Fahrenheit, so as to bring on a gentle action of the skin, before the horse is introduced to the actual sweating box-G. The preparatory box, H, may be fitted up like a common loose box, and may be used as such, whenever the bath is not required, but the latter should have no manger or any other projecting body of metal, for when the heat is raised to $160^{\circ}$, the contact with the teeth and tongue is by no means pleasant. Tan forms the best material for the floor, or, if this cannot readily be obtained, sawdust will answer nearly as well, if the wetted parts are changed after each bath. A brick floor feels too warm to the feet, and when the bath is given very hot, it may injure them, if uncovered by some non-conductor of heat, so that it is better to avoid all risk, by using tan or sawdust. With this apparatus in working order, and the fire lighted in the stove $\mathrm{A}$, the box $\mathrm{H}$ is heated 
to $80^{\circ}$ or $90^{\circ}$ of Fahrenheit, by robbing $G$ of its warm air through the open door I, and the valves in the wall between the two to which $I$ have already alluded. As soon as this is prepared, the horse is brought into it with his clothing on, and allowed to remain for a short time, which may be

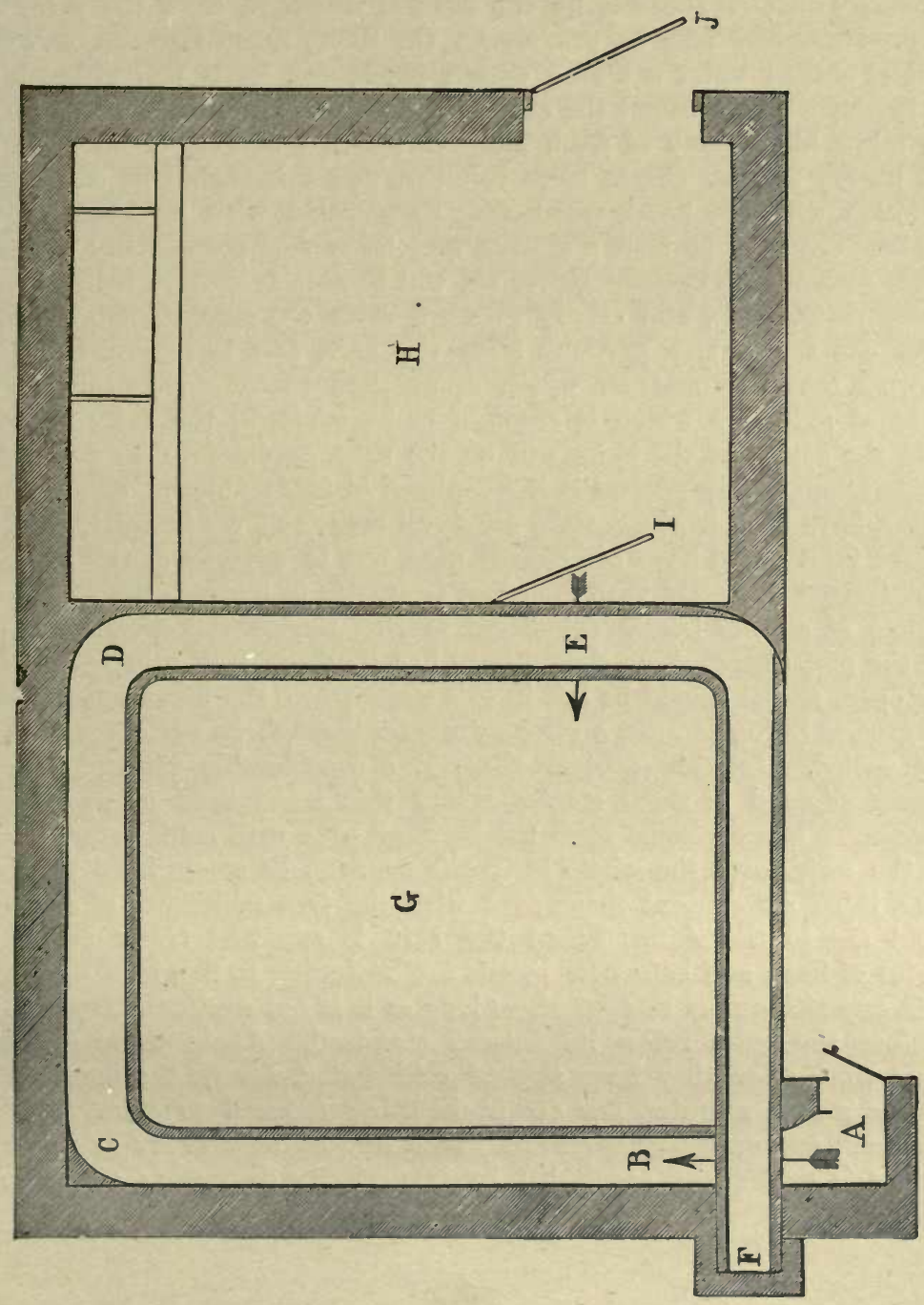

twenty minutes, half-an-hour, or an hour, according to the state of his skin, and the warmth of the box. As soon as he is settled in it, the clothes may all be removed, and here he may remain, with a wisp of hay in the rack, to amuse him, and chilled water in the tank, till his skin shows evident symptoms of breaking out, and the bath is prepared, that is, until the latter is raised to a temperature of $140^{\circ}$ at the least. To effect this the door I and the adjacent valves may have been closed, if necessary; for a small 
box once raised to $80^{\circ}$ or $90^{\circ}$ will keep its temperature with the horse in it for the time which is required. The groom must be careful not on any account to take his charge into the bath till his skin is beginning to sweat, for if he does, the blood may be driven too forcibly to the brain, without the relief which is afforded by the natural discharge from the skin, and dangerous mischief may be produced. On being taken into the bath $\mathrm{G}$, a bucket of chilled water is placed within reach, and he is tied up with his head in the corner nearest the entrance door, which must be left open, so as to allow him plenty of fresh air. In about a quarter of an hour the sweat begins to pour out in large volumes, and this should be encouraged by friction with the hand, which may be guarded with horsehair gloves. As it becomes very profuse, a scraper may be applied occasionally, but two grooms, each with horsehair gloves on, will be able to remove it by keeping up continuous, deep, and steady pressure upon the skin, so as at once to squeeze out the watery particles from the hair, and to remove any scurf and other tenacious matters which accumulate there. According to the amount of reduction which is required to be made in the fatty deposits, and to the action of the skin, will be the time required to be devoted to this operation, but in general it is completed in half-an-hour. Some horses, however, have been kept sweating for a full hour, as I am informed, without apparent injury, and have afterwards gone out to exercise as full of life as ever. Indeed, it is said that the effect is usually to increase the spirits and liveliness of all the horses submitted to it. During the operation of the bath, the preparatory room should have had its doors and windows thrown freely open, and it should be left in this state when the horse returns to it, some grooms liking to have a strong draught through it while the horse is being cooled. In this process there is a considerable variation in the practices adopted in those stables where this novel kind of sweating is introduced. Some grooms wash the horse all over with cold water; others dash the water over the whole body the moment he comes from the bath, while a third set content themselves with the free admission of a current of cold air to the skin. When the skin is sweating freely under the stimulus of heat, and before its vessels are beginning to flag in their action, cold in any shape may be applied, so long as it is not continued long enough to reduce the pulse below its natural standard. Again there are some grooms who, after they have applied cold water, return the horse to the bath for a few minutes, the air in it being reduced to about $100^{\circ}$ of Fahrenheit, and on bringing him out, take him at once to his box or stall, when he is dressed as usual, till he is perfectly dry, after which he is clothed and fed.

\section{PHYSIC}

IN MY PREvious REMarks I have alluded to physic as necessary for the purpose of getting rid of the food which the horse may have been taking, before he comes into the stable, without injury, but the effects of which are somewhat in opposition to the condition required for hard work. In addition to this object, however, physic is given with several other purposes in view; but these may be said to bring it within the province of the 
veterinarian rather than of the groom. Thus, in the horse recently brought up from grass, it will often be necessary to expel worms; and though the experienced groom may be able to do this without risk, yet it is scarcely safe to recommend the young hand to attempt the task. At all events, if he does, he must be guided by the directions given in another part of this book; and I shall merely direct my attention to the effects of physicfirstly, in getting rid of injurious food; secondly, in cooling the stomach and general system, and thus enabling the latter to bear the increased stimulus afforded by extra food; and thirdly, to get rid of internal fat and humours in conjunction with sweating.

To TIIE EFFECTS OF PHYSIC IN GETTING RID OF INJURIOUS FOOD, I have already alluded; but I may here mention two or three circumstances which will serve to modify the dose, or to forbid it altogether. Curiously enough, when a horse comes in from grass, his bowels being in the usual loose state which accompanies that kind of feeding, he will generally require more aloes than when fed upon dry food. The reason of this seeming paradox is simple enough: his bowels have become accustomed to the stimulus presented by grass to their lining membrane, and are not easily roused to action by aloes, which is only a vegetable, still more stimulating, it is true, but simply in degree. A man accustomed to drink, will not be so much affected by swallowing a pint of brandy, even if he is already half drunk, as a perfectly sober man would be, if he had not previously been inured by long usage to its effects. The groom must not, therefore, fancy that a physic-ball of three drachms, or even sometimes four drachms, will be sure to act on a horse of average size and constitution, just up from grass ; for he will find from four and a half to five and a half drachms more likely to serve his purpose. Unless he knows the constitution of the animal, he had better content himself with the former; but generally this quantity will not have much appreciable effect beyond a very gentle clearing out of the bowels. No mash is necessary, because the grass has already prepared the bowels quite sufficiently. Of course, if the horse is already too low in flesh, no physic should be given at this time.

THE COOLING POWERS OF PHYSIC are those which render it particularly valuable in aiding the preparation of the horse for fast work. If at any time the legs become hot, a dose will carry off the plethoric condition which shows itself in this way, and the rest which must be given after it will assist in relieving them. At this time, a mash should always precede the physic; and a second on the following night will often be necessary before the dose can safely be given. The same effect would be produced by permanently taking away some of the corn; but this would put an end to the preparation altogether, and it is to avoid this alternative that the physic is given. The old plan was in all cases to give a course of three doses, at intervals of nine days, to every horse when first taken into work; but if plenty of walking exercise is used, and the corn is gradually increased, with an ounce of nitre in the mash every Saturday night, this routine is quite unnecessary, and a couple of doses at the intervals I have fixed will suffice. Very gross, lusty horses will, perhaps, requie one, or even two additional doses; and, on the contrary, light herring-gutted animals will do without any. The art of the groom consists in fixing upon the proper quantum, beyond or below which he ought not to go. 
THE THIRD OBJECT OF PHYsIC is that which is superseded by the use of the Turkish bath, with much less injury to the system. Both act by removing superfluous fluids from the body, through the agency of the bloodvessels, absorbents, and secreting organs; all of which must co-operate in either case. The fluids lie stored up in the meshes of the cellular membrane, either in the shape of oily or watery matters. To remove them, the blood in circulation must first be called upon to part with some of its corresponding materials, which it does either through the mucous membrane of the bowels, when physic is given, or by means of the skin, when sweating is adopted. This sudden drain from the blood is then made up from the store which has been previously taken from it, and laid by in case of such an emergency; and thus, though the external means employed are very different, the real effect is the same. Both drain the blood of large quantities of water, containing certain soluble matters; and this sudden call upon the vital fluid compels its vessels to fall back upon the stored-up materials which are lodged around the heart and other internal organs, and which it is the grand object of the training-groom to remove.

But THE EFFECTS OF PHYSIC are not always so simple and innocent as those to which I have alluded. A strong horse is sometimes over-purged by a very mild dose, and a weak one will occasionally die from this cause. Hence, this agent should not be idly used; and not only is it actually dangerous to life in some few cases, but it weakens the tone of the stomach in many more. Still, in the majority of horses, a well-mixed physic-ball, carefully given, and followed by proper management, will freshen the digestive organs rather than weaken them, and may be regarded as a most valuable addition to the resources of the groom.

\section{FINAL PREPARATION}

TO FET A HUNTER THOROUGHLY FIT, he must not only have gone through the preparatory work which I have described, but he must undergo a further winding up, according to the old-established rule on the subject. Having had a gentle dose of physic at the end of his first preparation, he is proceeded with as follows :- Every day he is walked out for three or four hours, either at one or two periods of the day. If he is thorough-bred, he will bear some brisk gallops and one or two sweats, with or without clothing, every week; but half-breds do not stand much fast work, and are better confined to walking and trotting exercise, with an occasional spirt of half-a-mile. These low-bred animals cannot bear any liberties to be taken with their systems; and I am told that with them the Turkish bath is far more effectual than with the horse of pure Eastern blood. I can easily imagine this, as I know how badly the former class bear reduction, and yet how important it is to clear their wind. The feeding should be confined to oats and hay, with a bran-mash on Saturday night. About five quarterns of oats will, on the average, suffice; but no rule can be laid down, nor can it be positively asserted that no beans should be given. In some cases the appetite is so bad, that without them enough corn will not be taken; and this is especially true with reference to those old horses which have been accustomed to beans for many years. When the feet and legs, as well as the 
wind, are all sound, beans may be allowed without fear; but when there is a screw loose in any of these departments, they produce inflammation there, and should be carefully avoided. Ten pounds of hay may also be laid down as the average quantity of this article suited to the hunter; but here, also, no absolute rule can be carried out. Some horses would "drop in two," as the grooms say, if only allowed ten pounds of hay daily; while others would look quite lusty with that quantity. A handful of chaff with each feed of corn is all that should be given of this article, as more than this is apt to fill the horse out in the middle of the day. Towards the end of this period, which may extend to five or six weeks, the horse gradually gets into high condition, and at any time, on a day's notice, he may be ready for the hunting-field. All that is required is to give him no hay on that morning, but to feed him twice on his usual allowance of corn, with a few go-downs of water only each time. The hunter does not require to be "set" overnight, like the racehorse, and he may advantageously be given his usual weight of hay at the bedding him up the night before; but if he has any tendency to eat his litter, it is prudent at all times, but more especially then, to put a muzzle on him late at night, when he has eaten his hay.

Hacks and Harness-Horses demand nearly as much time and care to prepare them for their work, especially in relation to the amount of corn which is allowed them. They seldom want so much as five quarterns daily; but whatever quantity they may require, it should not be given them until they are gradually accustomed to its use. So also with regard to the hammering of their feet and legs on the road, it will be found that these demand seasoning as much as their wind and muscles. If this is not attended to, the best-formed legs and feet will become inflamed, and a valuable horse may be lamed when, with proper care, he might be made to do his work with ease. Our own bodies, when untrained to bear the blows of the fist, show the marks of the glove clearly enough; but in the course of time, when the skin has gradually become inured to the stimulus, even the terrible right hand of a prize-fighter would fail to leave its mark upon the ribs of a well-trained opponent. This difference in the result of the application of physical force arises partly from the tendency to inflammation being subdued by temperate living and abundant exercise, and partly from the nerves and vessels of the skin becoming habituated to the blows which they receive. So also with the hack and harness-horse; when first they are brought into the stable, their vessels are full of gross humours, and their feet and legs have long been accustomed only to the soft and elastic turf upon which they have been reared. They are, therefore, prone to inflammation in every way; and until their systems have been hardened by plenty of exercise, and their legs and feet have been gradually inured to our hard roads, they should be kept from every kind of fast work.

\section{TREATMENT AFTER WORK}

AFTER WORK the horse requires to be treated according to its nature, and the extent to which it has been carried. Thus the hunter or the polo pony may demand remedies for exhaustion, blows on the legs, thorns in the legs, overreaches, cuts, etc. ; but the hack and carriage-horse will only need the 
ordinary grooming, which has been described at page 273 ; that is to say, provided the feet are not in pain from ill-fitting shoes.

Exhaustion is sometimes so great that before any food can be taken a cordial must be given, in the shape either of a warm ball, or a quart of warm spiced ale. Generally, however, some gruel, made according to the directions given at page 256, will suffice, when aided by a warm box and the other comforts which are afforded by the groom, including dressing, clothing, bandaging, etc.

BLows on the legs are reduced by hot fomentations, continued for half-an. hour at a time, and repeated at intervals of one, two, or three hours, in proportion to the severity of the mischief. Cold applications are too apt to relieve the skin and cellular membrane beneath it at the expense of the joints, and I have never seen them of much service. Nothing, I believe, is so valuable in all blows received in the hunting-field as hot fomentation, but it should be thoroughly carried out, and not done by halves, as it too often is by careless grooms. It no doubt has a tendency to increase the swelling for a time, but in doing this the blood is drawn to the surface, and internal mischief is often prevented. I have had young horses come home with their knees and shins terribly bruised over timber and stone walls, but though the fomentation with hot water has enlarged the knees to a frightful size, there has been no lameness on the next day; and the swelling has gradually disappeared, leaving the joints as free as ever at the expiration of forty-eight hours. On the other hand, I have tried cold wet bandages for similar injuries, but I have invariably found that they gave present relief to a slight extent, but left the limbs stiff and rheumatic often for the next two or three weeks. The addition of a little tincture of arnica to the water for fomentation is a great improvement when it is at hand, and I should always advise the hunting groom to keep a stock of it by him during the season. A wineglassful is enough for half a bucket of hot water.

Thonss are most troublesome to the groom, and it is often a question of great doubt whether to persevere in the endeavour to remove them, or to leave them alone until they clearly manifest themselves by the inflammation they produce. When the hunter comes home, his legs should be carefully examined while they are wet (that is to say, if his exhausted condition does not forbid the loss of time); and if the hand clearly detects any projection, search should at once be made with a view to the removal of the foreign body. Usually, however, the thorn has buried itself, and it is only when it has produced some considerable degree of inflammation that attention is drawn to the spot. When lameness is shown in any of the limbs on coming home from hunting, the groom always is inclined to suspect a thorn as the cause of mischief, and I have known the penknife used in half-a-dozen different places to cut down upon what was supposed to be a buried thorn, which was never discovered, for the plain reason that no such matter was present in the leg.

Overreaches must be dried up as quickly as possible, and should not be treated like common wounds, for the reason that the horny substance of the foot, when it becomes softened and decomposed by the matter flowing from a wound near it, acts like a poison upon the ulcerated surface. It is better, therefore, to apply a little friar's balsam, or some other astringent, such as 
sugar of lead, rather than to use wet bandages or bran poultices, which I have sometimes known to be applied.

Simple AS WELl AS CONTUSED cuts are far better treated in the horse with hot fomentations than by any attempt to heal them at once. Unless they are very extensive or deep, the only point in which they are to be regarded is with reference to the blemish which they may leave. Sometimes the edges gape so wide, that a stitch or two must be inserted, but in such a case it is better to entrust the operation to a competent veterinary surgeon.

\section{SUMMERING}

IT was formerly tha custom to strip hunters of their clothing in April, and turn them out to grass on or about the first of May, and without gradual preparation, such as is now recognized as desirable if we would avoid risk of inflammation of the lungs, bowels, etc., caused by sudden and violent changes, nor is it any answer to say that horses more frequently get a cold in coming in to a hot stable than on being turned out, even in winter, a fact which is referr 3 d to in another place (see Catarrh, page 538). Much will depend on the werther as to the propriety of turning out, since the month of April may be more genial in some years than May in others. The system of turning out early and upon good pasture has the disadvantage of making some horses too fat and heavy for their legs, and the superabundance of fat has to be removed before they can be got into condition again.

Considering the slow pace at which hunting was carried on in the eighteenth century, a horse recently up from grass, if he had been allowed corn while out of doors, as was generally done, was able to go through a run, though it might be at the expense of the coat tails worn by his rider, which were liberally lathered with soapy sweat. But in the present day, when the hunter requires to be as fit as a racehorse, he must have the same amount of preparation; and we all know what sort of chance a horse would have of winning a race in November if he is eating nothing but grass in August. Indeed a fast run in Leicestershire is even more trying to condition than an ordinary race, because, though the pace is not quite so good, it is more true, and lasts four or five times as long. Hence the old plan has been given up or greatly modified by the best horsemen, some preferring to soil him on vetches, lucerne, rye-grass and clover, keeping him in a loose box entirely or with a yard only in which to exercise himself.

The advocates of soiling insist that far more good is done to the legs by keeping the animal in doors, and the weight of experience is on their side, but we have to remember that the feet do not benefit so much as upon a cool, moist pasture, and it is even more necessary to cool them and remove the effects of concussion than the legs, since the latter can be acted upon in or out of the stable, by medicaments applied directly over the strained structures and greater results obtained by a month's treatment than by three months' rest, in or out doors, but the feet need the cooling grass and the moisture of the soil, the benefit of a summer's run being largely dependent on the rainfall. In dry seasons where the ground was previously 
parched and left rough the turned-out horse may suffer almost as seriously in the feet as if he had been driven on the road. Flies also torment the horse at grass, and cause him to gallop about, and in some instances neutralize all the benefit by day of the rest and moist dews at night, and where more than one horse is turned out they may be seen under a tree on a sultry day, languidly swishing their tails, or the short dock which in most hunters does duty for a tail, nibbling at one another's withers out of sheer ennui, and often doing considerable damage to the mane and adjacent skin.

All or most of these evils are avoided by soiling in a loose box, but those who choose this method should make periodical inspections of the feet and see that the bedding has not become heated by fermentation, as is too often the case, since the horse thrown out of condition and resting will receive but very little attention except from the most assidnous of studgrooms.

As there are equally good men in favour of turning out to grass under proper conditions and of not turning out but "soiling," directions for both are here given.

Sollivg is conducted as follows:-At the conclusion of the hunting season tho horse is gradually cooled down, either by removing his clothing in the stable, and letting him first stand there naked for two or three weeks, or by putting him with it on into a moderately warm loose box, and after he has been there a day or two taking it away by degrees. At the same time he is deprived of his corn, and fed upon hay only; but this change also must not be too sudden, demanding a month for its complete carrying out, which will bring the time on to the beginning or middle of the month of May. A large airy loose box should then be provided, the floor being covered with six inches of tan, sand, moss, litter, or other suitable bedding; preference being given to such material as is least liable to fermentation, and the consequent development of heat so detrimental to the feet (see Bedding), and the door being so arranged that in warm weather it may be left open, a chain being drawn across from post to post. Here the horse is left for a few days till he is thoroughly accustomed to his new berth, and his coat is full of dust and scurf, when he may have a dose of physic, and while under its effects, his legs may be blistered, or dressed with iodine ointment, or some of the many applications which are used for the purpose of producing absorption of the morbid deposits which have been thrown out during the winter. After the physic is set, green food of some kind may be commenced, consisting of Italian rye-grass, young vetches, or lucerne, or, if these cannot be obtained, of ordinary meadow grass. At first an equal quantity of hay must be allowed for old hunters, or the change from dry food to green will produce too great an effect on the bowels. Young and hearty horses will, however, be none the worse for this ; and, indeed, when they are turned out, all have to bear the change in its fullest extent.

Objection is sometimes made to vetches on account of their laxative action on the bowels when young. Much of this is due to their being carted home wet and becoming heated in a very short time; the experienced dorseman preferring to shake them out in the sun and giving them to his charges in a condition slightly withered, and not looking so appetizing, 
but much safer where a considerable quantity is allowed. The aperient action, the gases developed in the intestines, or some medicinal quality as yet unascertained, has the advantage of expelling worms of the lumbricoid order, more especially the common ascaris megalocephala, which may have previously resisted the effects of time-honoured vermifuges. When vetches are old and the seed-pods are well developed they are too heating for horse food and liable to produce colic. As there is no galloping over hard ground the shoes may be removed altogether, and even tips may be dispensed with. Now is the time to attend to any early symptoms of sandcrack, seedy toe, etc., prompt measures at this season often leading to a prevention of these annoying evils. If the horse is not more than ten or twelve years old, his corn may be stopped altogether while he is eating green food in June and July, but a favourite old hunter should be indulged with a couple of quarterns daily, or he will probably lose flesh to a great extent. The young horse is always prone to inflammation, which a cooling treatment will remove, but the old one is more seasoned, and he will get more harm from being lowered in his general system than the benefit to his legs will repay. By the month of August all these plans will have cooperated to produce the desired effect; the legs are cool and fine, and the lumps and bumps incidental to the hunting-field have disappeared or been reduced to a harmless condition. The practice of giving an aloetic ball, or dose of physic, as that particular aperient is still called in stable nomenclature, has perhaps fallen too much into desuetude. It may be granted that in the days of bleeding and drugging there was an abuse of aloes, but we may easily fall into the opposite error, and by not giving it at all the animal is not so well prepared for a change of diet, especially the change from soft to hard and dry food, and we are of opinion that more cases of gripes and impaction are encountered in those establishments where a prejudice against the aloetic ball has resulted in its discontinuance. Individuals differ very greatly, and while some "washy" animals may never need an aperient a second dose may be desirable in the case of others. For the average hunter an aloetic ball may be recommended at the beginning and end of his period of soiling, which will be about the middle of August if sufficient time is to be allowed for that gradual and progressive training described elsewhere as conditioning.

\section{TURNING OUT TO GRASS OR PASTURING}

Tuis should not be done too early in the season, and a few precautions may be mentioned. Though many eminent authorities of the older school of horsemen have dilated on the dangers of turning horses out to grass, except in the height of summer, we must dissent from them, insomuch as their fears were chiefly based upon the supposed liability of taking cold and inflammation resulting. Greater, we think, are the dangers of bad fencing and playing the fool with each other. Veterinary surgeons in country practice tell us of a dozen accidents occurring to horses at grass for one illness, and although we have known hundreds of horses come direct from hard work in towns without any preparation for the change, and without bad results, we should strongly recommend a gradual preparation, since the 
temperature may vary in the spring from freezing-point at daybreak to $70^{\circ}$ Fahrenheit at midday.

The corn should be first withheld, and only hay and a few bran mashes given, then a dose of physic, after which one rug may be removed, then the second after an interval of a few days; the temperature of the stable should also be lowered by degrees, leaving a window open first and then a door, while all attempts at grooming should be abandoned to allow of the natural weather-proofing to accumulate on the skin. Two or three weeks should be occupied in this tempering process if the animal has been well clothed and kept in a warm stable, while less time will suffice for others with more natural coat or less artificially cared for. It should be a sine qua non of any turn out or pasture, that a hovel should exist which does not open to the east, and while not so low as to risk striking the poll in going in and out, the back part of it should be higher than the front, as affording a darker portion more free from flies. The shade of trees may be grateful in other respects, but they afford no protection from flies, certain kinds making them their chosen home, as with those velvet-footed fiends which descend upon their victims in shaded lanes and draw blood almost before the horseman discovers the cause of the animal's discomfort. In fly-infected districts one can understand horse-owners being determined, after one or two trials, never to turn out again, since flies will feed upon decomposed material one moment and infest the eyes of horses at another; but all pastures are not affected, and in the choice of a run regard should be paid to the object for which it is intended. Sometimes this is for the purpose of removing inflammation from the legs and feet, at others it is intended to renovate the general health; while, again, the most frequent reason for pasturing is to save the greater expense incurred in the stable. Different kinds of pasture and seasons of the year are best fitted for each of these intentions, as we shall presently see after examining into the nature of the former.

UPLAND PASTURE may consist of fine dry enclosures out of floods' ways, where clover and other plants, exactly suited to the constitution of the horse, grow in profusion, mixed with the best grasses. In the early summer season these are generally put up for mowing, and it is not until the aftermath makes its appearance that they are available for grazing in many districts, but it is not good management of land to mow it year after year, and in all grass districts there is early keep to be had, though it be shared with stock other than horses.

With the changed conditions of agriculture-alas that it should be for the worse! - farmers in the vicinity of towns and with some of the commorcial aptitude of their inhabitants, lay themselves out to receive hunters and other horses to keep, and find it possible to pay a second rent in the shape of advertisements. These should not be accepted without examination, as many fly-bitten wrecks are brought home in the autumn too poor to be got up again and a disgrace to the establishment. The character both of the place and the man should be taken into consideration before sending one's horses away. Good water, as well as shelter from inclement weather, are essential conditions. Grass keep from May to July is worth double as much as aftermath, and the farmer will reasonably expect a better scale of payment.

If autumn grass were as good, the turn-out would still be of less value, 
both on account of the greater number of flies and the hard condition of the ground, which may break the unshod foot instead of providing it with that moisture so conducive to healthy growth. The length of grass is not always proof of feeding qualities, as in wet summers it is often so washy as to purge the animals upon it, while, given plenty of good drinking water, they may get fat upon a short bite that has the advantage of plenty of sunshine.

Meadow LAND IN FLoods' way, when the soil is of a gravelly nature, or if it is well drained, will produce many excellent grasses, and contain a good deal of clover; in which case it is almost as well suited to the horse in dry seasons as the finest upland. But too often it is either constantly flooded or so badly drained that it is full of water-grasses, which the stomach of the horse does not relish, so that in the latter case it is not at all adapted to pasture him. The worst of it is, that there is seldom any happy medium in this kind of land, being either baked hard in dry 'seasons, or flooded in wet. The same remarks as to the times at which it is available for grazing apply to this kind of land as to the last.

Marshes, whether salt or fresh water, should only be selected as grazing land for those horses whose legs or feet are so damaged by work that they either will not bear harder ground or are so bad as to require the restorative action of constant moisture and cold applied to them. There is no great difference in this power between the salt and fresh water marsh; but the former seems to suit the constitution the better of the two, and on that account is to be preferred. Where a summer's run is desired for horses with unsound legs or feet, a salt marsh is the best situation for carrying out the intention.

WHEN UNSOUNDNESS OF THE FEET OR LEGS is the inducement to turn out, and the time at which it is desirable to do this is the summer season, the choice should fall upon a marsh. Hard ground will increase the mischief, and, between July and September, although it may be soft just at one particular time, it cannot be expected to remain so long. In any case some precaution should be taken against the horse galloping about on his first being let loose, which, from the joy he experiences at getting his liberty, he almost invariably does. In the case of horses blistered a few days before, when they are swollen, stiff, and sore, a gallop would be so extremely painful as to be altogether out of the question. A cradle must be kept on to prevent blemishes, but this is no more objectionable out of doors than in, except for their getting lost. Fetters or hobbles may be put on the fore-legs with the same object, if the feet only are the seat of mischief; but to inflamed joints or back sinews they are not so well suited, from the pressure they produce on the former, and the strains which they cause to the latter. After a few days' Jiberty, the tendency to gallop will be lost, and as the legs gradually recover their elasticity, the horse is not so prone to overdo himself in his exercise, and will generally remain content with a moderate pace; or, if the legs are very unsound, the blister may be repeated.

The Renovation of the health, when this has been broken down by disease or hard work, is best effected on good sound uplands. The herbage on salt marshes will sometimes agree with the horse even better than ordinary meadow grass, but this forms the exception to the rule, and is not to be relied on in general. In selecting a run in such a case care should be 
taken that the herbage is of the desired nature, the best proof of which is that it has agreed with horses in previous seasons. Experienced judges can generally pronounce upon the probability of the desired result after inspecting the situation, but on the whole their opinion, however well founded, is not so much to be relied on as the fact that horses have actually become fresh while turned out there.

WheN THE SAVING OF EXPENSE is the principal object, a good aftermath may generally be chosen, on which horses will be "tacked" at $4 s$. or $5 s$. per week from August to December. In large parks they are often taken in at even lower rates, but there are many objections to these, such as the increased danger of contracting infectious diseases, and the greater risk of accident among a large number of horses and cattle; and to these must be added very often the poorness of the herbage. There is also generally a difficulty in superintending the feet, etc., owing to the difficulty of catching the horses in a large park, so that the plan is not to be recommended whenever a run in a comparatively small enclosure can be obtained.

THE FORE-FEET should always be protected by "tips," which are merely short shoes reaching only two-thirds of the way to the heels, which are then left uncovered. These should be sunk to the level of the planter surface, by cutting down the crust or wall and leaving the sole, bars, and frog untouched. In this way a level bearing is obtained, and that natural frogpressure brought to bear upon soft ground or natural pasture which is so desirable in horses long shod and stabled, and whose frogs are generally more or less wasted and heels shrunken by reason of the shod-crust taking all the weight. When the horse is rested the opportunity is afforded of growing a new, strong, and serviceable frog, and this end will be sooner attained by sinking the tip. The ordinary tip or short shoe is too often a thick and clumsy affair putting a strain on the back tendons.

The object is to avoid the risk of breaking away the toes, which is incurred whenever the foot is battered on hard ground, as it often is when it is stamped continually, as horses are very apt to do, on the bare surface which is kept dry beneath a sheltering tree. Here the flies are very apt to collect around the horses, and to get rid of their annoyance the legs are constantly in motion. If the full shoe is left on, the hind toe is very apt to catch its heel in deep ground, and tear it wholly or partially off; and moreover, it is too often neglected, and either the heels press into the sole, producing corns, or they confine the frog, and lead to disease of that important organ. Tips may safely be left on without removal for two or three months, whereas shoes require attending to every three or four weeks. The hind shoes are always taken off, partly because the hind-feet are not so liable to be broken at the toes, but chiefly because they would be dangerous to other animals if they were left on, from the severe damage which is done by a kick with an armed heel.

HORSES WHOSE JUGULAR vEINS have become obliterated from adhesive inflammation following bleeding, are unfit to be turned out in consequence of the difficulty which is presented to the return of the blood from the head by its low position in grazing. So also those which have recently suffered from staggers should not be sent out to grass, for fear of the position causing a return of the disease. This precaution is 
often disregarded and without bad results when collateral circulation is well established.

Since the earlier editions of this work were published there has been a great diminution in the number of obliterated veins, as bleeding is seldom resorted to now and not performed in the rough-and-ready way of our grandsires.

\section{A WINTER'S RUN}

There ARE ONLY Two CaUses that can ever influence an owner in turning his horse out to grass during the winter, one being a desire to restore his legs or feet to a state of health, and the other the diminution of expense. The former is a perfectly valid reason, for experience teaches us that the comparative starvation and cold incidental to a winter's run are highly beneficial in reducing the effects of inflammation. A horse will frequently remain all the summer out-of-doors without the siightest benefit to his legs, but after a month's cold they will show a marked improvement, and by the spring be wonderfully restored.

Turning out in the case of old horses with indifferent teeth and constitutions enfeebled by long years of indulgence in too much corn is an undoubted hardship, but for others the so-called cruelty of a winter's run has been somewhat exaggerated. Of course, if a clipped horse, clothed and hitherto maintained in a warm stable, is turned out without preparation, he will pass a very miserable week or two until scurf and dirt and sprouting coat havo formed some defence for him against cold and wet. His ability to withstand the exposure will depend largely upon the amount of food supplied him, a great part of it being used in producing heat. For the foregoing reason a winter's run is not the economic success expected, since in addition to greater risk of death from disease, all animals need more food in proportion to the exposure to which they are subjected. The opponents of wintering horses at grass, or out-doors we should prefer to say, since they should never in this fickle climate be compelled to depend on winter grass, - the opponents, we say, rather presuppose a clipped horse or one whose services are to be suddenly discontinued rather than the deliberately planned winter's run arranged with judgment and care. In speaking of summering at grass we have pointed out the desirability of inquiring into the antecedents both of the pasture and the agister; how much more necessary should such assurance of the horse's care be when it is intended to winter him out! The hovel in which he sought shelter from flies and the glare of the sun will in the winter protect him from the east wind if it is constructed as it should be; in it he can be fed with hay or roots when snow lies thickly around. It should be part of the contract that hay or corn shall be given in case of snow, as the agister is not then relieved of all responsibility for returning a horse as poor as a rook, by telling the owner there was plenty of grass and he was not liable for the snow covering it. Many thousands of horses, both agricultural and nags, upon the rich pastures of counties like Somerset and Devon, never come into a stable except to be harnessed for work; they maintain too much fat, as a rule, certainly not suffering from the want of it, and only when the snow happens to hide their food or too many animals to 
the acre have been kept, do they need any hay or chaff that they do not themselves cut; but such horses are not clipped or singed, and any grooming they receive is of the most perfunctory kind, therefore the skin is full of Nature's water-proofing, and although preferring shelter against a strong cold wind, they are indifferent about visiting a hovel, if one exist, unless in anticipation of food. Knowing then so many horses in robust health and capable of moderate work while wintered out-doors, we cannot think there is any great hardship in average seasons and with due preparation. A horse clipped early in October will grow coat enough in a cool stable without clothing to be turned out in three or four weeks, and, if clipped as late as the middle of November, he can grow enough coat to go out before Christmas. The custom, now generally established, of not clipping after Christmas, is founded on the fact that no real growth of warm covering takes place after that time, although coarse hairs sprout until the spring months.

\section{THE STRAW YARD}

The advantages and disadvantages of the straw yard, as a place for wintering the horse, will to a certain extent depend upon its management. Generally the proper term for it would be a manure tank, for though there is almost always a thin coating of straw on the surface, yet the horse's feet sink through this and reach the wet mass of manure which is gradually allowed to decompose beneath it. In point of economy there is much to lose by the straw yard, for, as in the case of the winter's run, more food is demanded by the system than in a loose box. The only excuse for it is to be found in the beneficial effects of cold and wet upon the legs, which are restored by the straw yard to the same extent as in the fields; but on the other hand the feet suffer terribly, the frogs becoming thrushy almost invariably, and their horny coverings frequently having quite disappeared when the horse is brought into the stable. When the straw is liberally used, and the manure is raised into a heap in the middle of the yard as fast as it is made, which is the proper arrangement, the frogs may remain tolerably sound, and the objection on this account is to a certain extent removed. When barley straw without hay is the only provender allowed, it is not to be wondered at if he comes out in the spring a complete skeleton. This straw should be "barred" as so productive of lice, and consequent skin irritation and loss of hair and condition.

Oat straw is not at all a bad food for rest horses, as there is a certain amount of oiliness in it which raises it above all other straws in feeding value. The water supply is too apt to be forgotten both in meadow and straw yard when the horse-owner is prospecting for a resting-place. The stupidity of farm servants cost the editor a valuable horse in a time of frost by not observing that the otherwise abundant supply was all frozen over. 


\section{CARE OF SADDLERY AND HARNESS}

The management of SaddLery must have a treble object. First, the groom should take care that he does nothing which shall injure the horse. Secondly, he must have a due regard to his master's comfort in using it. And, thirdly, he must please the eye. I must therefore show how each of these purposes can best be effected.

To AVOID INJURivg the Horse the groom should begin when he first comes in from work, and bejore he removes the saddle or collar. It is ascertained by experience that if these are taken off when the skin beneath them is hot and sweating, inflammation may follow, while by leaving them loosely in their places for a short time no injurious effect is perceived.

Many horsemen in various parts of the world where the climate is hot and dry habitually disregard this precaution, and we presume that experience has taught them that no harm comes of it. On the other hand the number of horses to be had in case of one having a "back," the trifling value set upon them, and the general custom of turning them adrift when incapacitated (we are now speaking of the Australian bush), make it diffcult to ascertain whether, what we in England should consider a want of care is or is not a source of injury to the horse in other parts of the world.

If a groom who is master of his business is watched when his horses come in, he will be seen to loosen their girths and lift the saddles from their backs for a second, replacing them loosely, and leaving them there while he takes off the bridles and makes his arrangements for dressing. In harness-horses everything but the collars may be taken off, and after turning them to remove the harness and traces, they may be replaced and left as near to the shoulder as the position of the horse with his head in the manger will allow. This rule should be invariably followed whenever horses come into the stable after having done any amount of work. If they have merely gone out for a short airing, and the skin beneath the saddle or collar is not even damp, there is no occasion for the precaution, and the saddle or collar may at once be removed. The next thing to be done to the saddlery in reference to the horse's comfort is to dry the lining carefully before it is again used. Even the lining of harness-pads should be attended to, and in the winter this cannot be done without placing each before the fire. In another place is inserted an engraving of the best form of saddle airer, in which the saddle is securely fixed in such a position that the fire only reaches the interior of the lining. Without some such machine there are two risks incurred, for by placing the saddle on the ground the edges of the leather covering the tree are worn away, and the flaps are liable to be curled inwards, presenting their outer surface to the fire, which dries them till they become hard, and are then liable to crack. The expense of one of these airers is soon saved in diminishing the wear and tear of saddles, and no well-managed harness-room should be without one. After the serge lining is dry, it is an excellent plan to beat the stuffing with a stick, so as to remove the powdery particles left by the sweat, which soon clog up the interstices and form a matted cake with the woollen materials usece if they are allowed to remain 
IN ATTENDING TO THE COMFORT OF THE MASTER the groom must take care to keep all the leather which comes in contact with the hands or legs perfectly supple, yet so clean that no stain is left behind. Nothing is more annoying than to get off the saddle for the purpose of paying a morning call, and find the insides of a light pair of trousers stained all the way down. This is perfectly inexcusable, and its occurrence marks the ignorance and carelessness of a servant in the most unmistakable manner. The same remark applies to the reins, which never ought to soil a pair of white gloves. Whenever blacking is applied to harness it is impossible altogether to prevent the tendency to leave a stain, but if it is carefully put on, and well brushed, as long as it is kept dry it may be lightly handled with impunity. If buckles are to be altered, the gloves must suffer, and for this reason, when gentlemen drive their own horses, they generally prefer brown driving reins, which may be treated in the same way as riding reins, and kept clean accordingly. The following directions for cleaning saddles and riding bridles, and also for brown driving reins, or any other parts of the harness made of undyed leather, will serve the purpose extremely well. As long as the leather remains dry and clean it needs no attention, but when it is wetted, either by rain, or by the water necessary for cleaning it from road dust, it becomes hard and stiff, and must be softened with some kind of oily matter. Neat's-foot oil is that usually employed, but for saddles it is rather of too greasy a nature, being apt to leave a mark on the trousers if it has been liberally applied. The best application is deer's suet, which should be gently warmed and rubbed in before the leather is quite dry again, after being wetted; that is to say, while it remains limp, for if it is held to the fire long enough, all wet leather becomes hard and stiff. A very little oil or suet will suffice, if it is used as soon as the leather is nearly dry, after each wetting, but when leather has been left for days in a dry place after being thoroughly wet, it becomes so stiff that nothing but a good soaking with oil will restore its pliability, and even with this it remains stiff to a certain extent, unless it is very slightly damped, in conjunction with the use of the oil. Vegetable oils, with the single exception of castor oil, are too much inclined to become hard to suit leather, and none but the latter should ever be employed. Its nauseous smell is an objection to it, but otherwise it wil! answer the purpose almost as well as neat's-foot. Horse fat, if used carefully, and in very small quantities, is a capital application, but one liberal dressing with it spoils the look of leather, giving it a sodden appearance, which it never recovers.

To MAKE SADDLERY AND HARNESS LOOK WELL to the eye, several receipts, and directions for using them, are necessary; including the following, for avoiding injury from chemical decomposition:-

(1) Do not allow brass or plated furniture to be within reach of the air of the stable; for the ammonia given off from the urine will tarnish them. Gas, also, is prejudicial ; and if it is burned in the harness-room, it should be contained within a glass chamber, which has a ventilating shaft, so as to carry off the products of combustion into the external air. Gas stoves are particularly prejudicial; and, indeed, so are all stoves which allow the fumes given off by the coais to pass into the room.

(2).As soon as possible after the harness is taken off, if the weather is 
fine, take a leather, kept specially for the purpose, and wipe off the dust; sponging with a damp sponge those parts which are soiled with sweat. If the traces, belly-band, etc. are splashed with mud, wash them at once; on no account soaking them in water, or using more of it than is necessary. Dry them, as far as possible, with the leathers, and put to the fire on the horse represented at page 239 . If the black dye with which the leather is stained has come off to any serious extent, a little of a solution of green copperas may be used, but this is not often necessary. Unbuckle the bits from the bridle, put them in clean water for a short time, then take them out, and remove every particle of dirt from them. Dry with the leather, and rub a very little neat's-foot oil on them. Before they are used again, they must be polished with the dry leather, aided by a little silver sand, if they have become at all rusty. The curb-chain will always want rubbing loosely in the hand with a little silver sand, finishing with the leather.

No metal is likely to wholly supersede steel both for strength and appearance in the gentleman's stable where an adequate amount of labour can be expended on burnishing, but for general utility, and especially among the class of men who keep a horse in the country with only but indifferent service, the employment of white metal non-corrosive bits are now general. They need only to be washed clean and polished with a chamois leather or soft fine powder such as is used in knife machines (Oakey's Wellington knife polish), or the common powder known as rottenstone will serve. These were first invented by a country saddler in Sussex, who deserves the thanks of all poor as well as lazy horse-keepers, and especially doctors and vets. who come in wet at night and can just hang up the bridle without the fear of red rust staring the servant in the face and demoralizing him with the feeling that cleaning bits is about as much real use as polishing the anchor at sea.

The makers have so far improved upon the original alloy that there is now no fear of bending if one will give the price for good bits. A similar material white throughout is used for hame and saddle terrets and buckles in lieu of the old plate, which so soon came off with wear and indifferent treatment. We have not, however, seen hames that were made throughout of this material.

Black Harness must be kept constantly polished by hand-brushing it with some composition specially prepared for the purpose. This must be of a greasy or waxy nature, to prevent the rain from dissolving it, and washing it off upon the coat of the horse. One or other of the fcllowing compositions will answer the purpose.

\section{RECIPES FOR HARNESS BLACKING.}

No. 1.

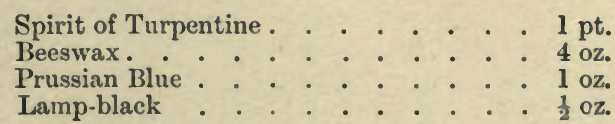

Slice the wax very thin, put it in a jar and pour on the turpentine. Let it stand twentyfour hours, then grind the other ingredients together on a stone or marble slab, and mix carefully up. It must be kept in a covered tin box. 
No. 2 .

Take No. 1 "compo" and add the following, which improves the polish :-

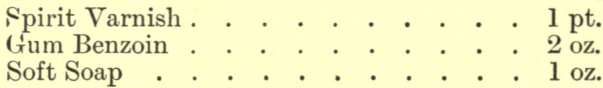

Melt together in a water bath, and when thoroughly incorporated mix all together on a stone and cover up directly.

The above may be taken as the basis of all the "compos," but the competition in trade and the world-wide distribution of these things make it hardly worth while making them, and we can imagine no outpost of civilization where the ingredients could be procured but not the ready-made article in convenient tins.

Gelatinous preparations intended for softening leather that has been ill-used and neglected are now sold in convenient bottles and tins; they are made of gelatine, lamp-black, Prussian blue and soap in varying quantities, and are much favoured by cab-masters and others who have but little time to spare, and wish to make the best show for the smallest outlay of labour and material. These preparations are put on with a sponge, and need but little polishing with a very soft brush or rubber. 


\title{
CHAPTER XVI
}

\author{
RIDING AND DRIVING
}

SADDLES-BRIDLES- MOUNTING AND DISMOUNTING-THE SEAT-MANAGEMENT OF TUE REINS-USE OF SPURS-MODES OF STARTING THE HORSE INTO HIS VAIIOUS PACESRIDING TO HOUNDS-OUT-DOOR VICES AND BAD HABITS-HARNESS-DRIVING A SINGLE HORSE-A PAIR-FOUR-IN-HAND.

\section{SADDLES}

THERE IS A FASHION in saddles, as in everything else which admits of alteration. For the last fifty years it may be said that no real improvement has been made in our English saddles, and we have simply gone from plain flaps to padded ones, and back again. Up to the beginning of the present century the trees were made too heavy and clumsy, and a hunting saddle of less weight than fourteen pounds was never thought of, while the majority would turn the scale at sixteen pounds. But when the pace of the hunter was increased the attention of the saddler was directed to the diminution of the weight of the tree without loss of strength, and certainly with an excellent result, as is shown in a first-class nine-pound saddle, roomy enough to carry a man of sixteen stone with moderate comfort. Whether his horse can do his work proportionately better for this saving of five pounds admits of some question; but there can be no doubt that wherever a very light saddle is used in the hunting-field the greatest care is necessary that it fits to a nicety, and it can seldom be adapted to more than one horse in a stud without altering the stuffing of the pannel. The attempt should never be made to reduce the size of the tree, for although the rider may be willing to put up with the want of roominess, yet the horse will suffer in his back from the weight not being sufficiently distributed.

A tree was at one time in vogue which had the merit of not pressing on the withers, as the pommel was cut back two or three inches, but the extra strength and weight incurred soon drove it out of use, besides which it was found that it did not fit both a narrow and a thick shoulder equally well. For these reasons it is now admitted that in the tree itself there is little variety for choice, and that the saddles of the best London makers only differ in their peculiar cut from one another, while in this point alone (excluding of course workmanship and material) are they superior to the worst specimens made in our country towns. The change from plain flaps to padded ones has been alluded to, and it will be necessary here to discuss the merits of each. In "the Shires" the fashion now is to adopt the revived plain flap, and the reason which is given is that the padding arrests 
the knee when the horse comes down after his leap, thereby throwing the strain upon the muscles of the inside of the thigh instead of on the seat of honour. That such strains have been of late years very general is a wellknown fact, but their increase of frequency cannot be said to be coincident. with the introduction of the padded flap, which is at least fifty years old. Padded flaps were in general use for forty years before this objectionable quality was discovered, and even now they are preferred by a large majority of hard riders in provincial countries. A thin man with a large knee depends for his seat chiefly on the grip which this gives him of the saddle, and there are many riders so made that they can scarcely touch the saddle. with the muscles of the thigh, or of the calf of the leg. In them a padded surface is indispensable for the bone of the knee to act upon, as the smooth plain flap is too hard and slippery for it to lay hold of. Hence, although the muscular rider may well have his choice, and indeed will often do better with a plain flap, this will not suit others differently formed, and the fashion should not therefore be indiscriminately followed. The plain flap costs about fifteen shillings or a pound less than its rival; but to hunting men this difference in price is not often the reason for its selection, although the wear and tear of saddles is by no means an unimportant article in their expenditure. In choosing a saddle where the maker has not a well-known reputation, the peculiar marks on the surface by which pigskin is distinguished from horse or cow-hide should be carefully examined, as an imitation. is now fraudulently carried out by means of copper-plates taken by the electro-type process from real pigskin. A horse or cow-hide is stretched upon a slab and wetted, when the heated plate is pressed by steam power upon it, and every mark existing in the real skin is transferred to the imitation hide. The fraud may, however, be detected by the want of depth in the holes, which all show a bottom, whereas the real skin is perforated to a depth beyond the reach of the eye. Consequently, instead of a cul de sac, there is a fine valvular opening visible.

THE GIRTHS of ordinary saddles are still made in pairs, and buckled up to two straps fixed on each side to the tree; but for hunting, the Fitzwilliam girth, double the width of the ordinary one, and somewhat stouter in its web, is considered an improvement in grass countries. It has two buckles at each end, which are fastened to the usual straps; but in addition a narrow girth is provided, lying outside in loops stitched to the broad girth, and keeping it in its place if by any chance both the buckles should break. The Fitzwilliam girth is alone depended on for fixing the saddle, and the narrow one is merely intended to keep it from dangling, and the saddle from actually falling off if the former should burst, either in its webbing or at the buckles or straps.

The breastplate is provided for hunting saddles in order to avoid tight girthing, which interferes sadly with a horse's wind by confining the ribs, and thus preventing a full dilatation of the chest. Besides this, many horses have a way of blowing themselves out while the groom is girthing them up, and if they start with their saddles firmly on, they soon have them so loose as to be dangerous in going up-hill. Very many well-bred horses when fit to go are so light in their back ribs that their saddles easily slip back if not kept in their places by their breastplates, and hence the general adoption of the latter in the hunting-field. 


\section{BRIDLES}

There is at almost tNFinite variety in the make of bits, but nearly all nay be reduced to three leading principles-namely, the snaffle, the curb, and the combination of the two in one bit, as in the Pelham, whether of the ordinary or Hanoverian kinds. The double-reined bridle may either be fitted with a snaffle and curb, or with a Pelham.

Among THE Various Kinds of SNaffles, with the exception of the gag, which I shall presently describe, all are intended to bear chiefly on the jaw, slightly relieved by the angles of the mouth. When, however, the jaws are so narrow that they cannot be bent on the neck, or when the rider's hands are carried so high that the line of the reins is across the angles, these latter parts take all the bearing, and the horse yaws about with his mouth wide open. Without good hands the tendency of the snaffle is always to get the head up with the nose out, and with them this bit never offers any obstacle to the straight carriage of the neck which is wanted to admit of free respiration at high speed. Hence the snaffle is universally employed in racing and hunting, for even when a Pelham is used, the one rein acts upon the bit exactly as in the common snaffle. The difference between this and the curb consists in the fact that the former can rarely be made to interfere with a horse's action either in the gallop or the leap, whilo the latter should never be employed at a fast pace except to keep the animal from over-tasking himself, since it always has a tendency to bend the neck too much for the development of high speed or jumping power. Hence the snaffle may with many sober horses be used alone, but as a rule the curb should never be so employed. In the hunting-field no one who is not possessed of great strength of arm should trust any but a horse whose sobriety of temper is well known, without a double-reined bridle. It is true that there are many which will go well in a snaffle on smooth turf or light arable land where there are no ridges, but when they come to deep ground or high ridges, or when it is necessary to jump into an orchard or plantation, a means of holding the horse well together is required in the former case, while in the latter, if it is not possessed, a dangerous or fatal blow may easily be received before the horse can be stopped after coming down from his leap. In defining the snaffle, it may be described as consisting of a ring on each side the mouth to which the rein is attached, connected together by one or two mouthpieces, which may be variously jointed in the middle, or may be without any break, which last is not always called a snaffle, but bears the name of a straight bit. Thus it is subdivided into the following:-
1. The plain snaffle.
2. The twisted snaffle.
3. The snaffle with double mouthpiece.
4. The chain snaffle.
5. The double-jointed snaffle.
6. The double ring snaffle.
7. The gag snaffle.
8. The unjointed snaffle.

1. The plain snaffle is the most simplo form of all, with the exception of 
the straight bit, consisting merely of the two rings with the mouthpiece of smooth steel, jointed in the middle. The rings, when the bit is to be used alone, are generally guarded from slipping through the mouth by light bars projecting up and down. This bit is made of all sizes in point of substance, from the very light racing snaffle no larger than a goose quill to the heavy breaker's bit in which the mouthpiece is as large as a man's thumb. The size of this part should be proportioned to the delicacy of the horse's mouth, which can only be judged of by an actual trial; but the proper substance of metal may generally, though not always, be ascertained by putting one in the mouth and pressing upon the jaw, when; if it produces such an effect as to cause the horse to back readily, it will in most cases be sufficiently severe. There are, however, some tempers which do not show themselves until they are excited, and in those animals possessing such as these a bit which will act in a stable-yard is perfectly useless in company.

2. The twisted snaffle differs only from the preceding in the mouthpiece, each of the two halves being made square instead of round, and twisted more or less on themselves, so as to present sharp edges to the mouth, and thus produce more pain on pressure. This effect is not fully developed by a steady pull; but when the snaffle is sawed from side to side, as is sometimes necessary before a pulling horse can be stopped, the sharp twisted edges act severely upon the delicate membrane covering the jaw and lips, and as the horse gets his head into the air to take the pressure off the most sensitive part, he is almost compelled to pull up by being thrown out of his stride. For this reason some high-couraged animals will go better in a smooth snaffle than in a twisted one, the latter maddening them by the pain which it occasions; but with the ordinary run of horses a moderate twist properly used is not objectionable, and the smooth mouthpiece is scarcely sufficient.

3. The snaffle with double mouthpiece is made with two mouthpieces attached in the usual way, but one above the other, to the ring. The joints in the middle are, however, not opposite each other, and thus when the reins are pulled the jaw is embraced in a narrower vice than in the single snaffle. It is, however, very apt to cause the mouth to be opened widely, as there is a greater breadth of the bit at the angles. Nevertheless, I have known it very effectual in a puller which would not bear a curb.

4. The chain snaffle has a mouthpiece made of a steel chain, the links of which may be made large or small, open or close, according to the nature of the mouth. It is a very light kind of bit, and many irritable horses which fight at more severe kinds will go kindly in it. Sometimes the chain is covered by leather to give the mouth still more ease.

5. A double-jointed mouthpiece is merely a modification of the chain, which it resembles in its effect. The celebrated Dick Christian's bridle had a snaffle of this description.

6. The double ring snaffle is not so much used for riding as for harnesswork, in which it is now very generally employed for horses which are not likely to be too fresh, as for instance those in omnibuses and cabs. It is very difficult to ascertain in what particular the merits of this bit consist, but that it has many advantages over the ordinary snaffle I can speak from long experience, which is supported by its general adoption 
among practical men. That it is far more severe is manifest, and when suddenly pulled sideways through the mouth in leading a horse, the pain occasioned is so great as often to make him run back. I believe that this is sometimes occasioned by the pinching of the lip between the mouthpieces and the ring, but this cannot always happen, nor can it take place during the ordinary use of the bit in riding or driving.

7. The gag snaffle resembles the ordinary twisted form in all but one respect, which consists in the different mode of attaching the ring to the bridle. Where it is used without a curb, it is customary to have two reins on each side, one of which is stitched on to the ring in the ordinary way, and when this is pulled, the effect is similar to that of the common snaffle; the other is made round for about twelve inches, and, passing through two pulley-like holes in the ring, is attached to the check-piece of the head of the bridle. When this is drawn upon, the power is greatly increased by the pulley; and as the direction is changed by the drag being partly from the check-piece, the effect is the same as if the hands were raised very considerably. For this reason, it is well suited to those horses who get their heads down, and bore upon their bits; while, on the contrary, it is prejudicial to pullers who have a tendency to carry their heads in the air, in the attitude which is familiarly known as "star gazing." The gag snaffle is particularly well adapted to the double-reined bridle intended for pulling horses carrying their heads too low, which the curb has a tendency rather to increase than diminish. The combined use of the two, however, corrects this fault, and a pleasant as well as safe carriage of the head may be effected.

8. The unjointed snaffle is merely a mouthpiece without any joint, and it may be either slightly curved forwards, or straight. Sometimes, also, it is smooth, and at others with rings turned on it. Very light-mouthed horses go well in this bit on the road; but it is not suited for hunting or racing.

THE CURB-BIT is always a lever, in which the inside of the mouth is the fulcrum, while the increase of power afforded hy this mechanical arrangement is brought to bear upon the outside of the jaw through the medium of the curb-chain. The leverage may be long or short, but the principle is the same in all cases, varying in the mode of its application. In some curb-bits the mouthpiece is curved in the middle, rising more or less into an arch, which is called "the port," and which presses upon the roof of the mouth when the lever is pulled. If the horse is allowed to open his mouth wide, this pressure cannot be made, and the port is useless; but the addition of a noseband of leather, buckled tightly round the jaw, closes the mouth, and keeps the roof in apposition with the port. Thus in estimating the power of all curb-bits, we must take into consideration-1st, the length of the lever; 2nd, the tightness of the curb-chain, which may be adjusted at pleasure; $3 \mathrm{rd}$, the height of the port; and 4 th, whether used with a noseband or not.

The varieties of curb-bits in common use are as follows:-

1. The ordinary curb-bit.

2. The Pelham.

3. The Hanoverian Pelham.

4. The Chifney. 
1. The ordinary curb-bit does not differ from the general type already described; it need not, therefore, be alluded to further than to caution the inexperienced horseman against leaning heavily upon it. The pain occasioned in this way is at first excessive; but in course of time the parts pressed upon become callous, and the mouth is irretrievably spoiled. Thus a rider with a heavy hand may begin with a mouth which is too light, and in a month or two he may find it so dull as to be quite unpleasant, in spite of a tight curb-chain and noseband, a high port, and a long lever. All these should be as easy as will suffice to control the horse for which they are adapted, and no more use should be made of them than is absolutely necessary.

2. The plain Pelham combines the snaffle and curb, and requires no addition of the former to make it a double-reined bridle. The mouthpiece is jointed in the middle, just like a snaffle; and, like this, it may be smooth or twisted. There is a ring opposite this for the one rein, and the other is attached to the end of the lever, as in the ordinary curb-bit. This is an extremely useful bit for general purposes.

3. The Hanoverian Pelham is similar in principle to the plain one; but it has two joints in the mouthpiece, united by a high port, and the sides of the mouthpiece are covered with rollers, which prevent the horse from grasping them with his teeth, and thus interfering with the action of the port and curb chain. For hard-pulling horses this bit is very useful, but it is a very severe one.

4. The Chifney bit is provided with a joint at the junction of the lever and mouthpiece, so that the action of the former is not confined by the head of the bridle. But though in theory this is all very pretty, in practice it is found to be of no service whatever.

There are many other kinds of curb-bits, but those which I have described comprehend all in general use.

The Bucephalus noseband is a great addition to the curb-bridle intended for a pulling horse. It is merely a stitched leather strap, long enough to encircle the jaw and cross behind it to be attached to the hook of the curb-chain. This noseband is not really more powerful than the ordinary one when tightly buckled, the whole of its efficiency depending upon its keeping the mouth closed, and thus allowing the port to have its full power on the roof of the mouth. The advantage is, that when the rein is not pulled, the noseband slackens, and the mouth may then be relieved, which it cannot be with an ordinary tight noseband. (Since the invention of the above, it has been found that nothing so well restrains a puller as a nose-net, a simple appliance invented by a coachman who should have derived some substantial benefit from his discovery.)

\section{MOUNTING AND DISMOUNTING}

UNTIL THE ADVENT of the celebrated Rarey, whose horse-taming feats produced such a sensation in this country, the directions of Captain Richardson, as given in his valuable work on Horsemanship, were generally accepted, and despite a host of teachers who have since been eminent for their horsemanship, his methods have not been materially improved 
upon. They are based, as any cavalryman will recognize, upon the military commands, "stand to your horses," "prepare to mount," and "mount," but the objection has been urged that civilians do not always come up to the recognized standard of height to be able to carry out those directions in their entirety, and a certain amount of latitude must therefore be allowed for the short, thick, successful merchant who begins to ride for the benefit of his liver at fifty. As such a man will choose a very quiet cob for his constitutional ride, he may be permitted to mount with his back to the horse's quarter since that position is the more easy, but it is a method to be condemned in the young and athletic who may ride restive animals. One cannot be kicked in mounting from the front, but the position above described is attended with considerable danger, and a kick may easily fracture the thigh. Professors of horsemanship, in writing on this subject, assume that their readers are already horsemen, and in giving Captain Richardson's advice we suppose that the reader is not, but that he wishes to adopt the best method.- "Stand opposite the near fore-foot of the horse, place the left hand on the neck near to the withers, having the back of the hand to the horse's head, and the reins lying in front of the hand. Take up the reins with the right hand, put the little finger of the left hand between them, and draw them through until you feel the mouth of the horse; turn the remainder of the reins along the inside of the left hand, let it fall over the fore-finger on the off-side, and place the thumb upon the reins. Twist a lock of the mane round the thumb or fore-finger, and close the hand firmly upon the reins. Take the stirrup in the right hand, and place the left toe in it as far as the ball; let the knee press against the flap of the saddle, to prevent the point of the toe from irritating the side of the horse ; seize the cantle of the saddle with the right hand, and springing up from the right toe, throw the right leg clear over the horse, coming gently into the saddle by staying the weight of the body with the right hand resting on the right side of the pommel of the saddle; put the right toe in the stirrup." Now this is in the main applicable to a man of five feet ten inches or six feet, but to a shorter individual attempting to mount a horse of fifteen hands three inches, it is an impossibility, simply because he cannot reach the cantle from the same position which enables him to hold the stirrup in the left hand. The Captain is also wrong, in my opinion, in directing that the body should be raised into the saddle directly from the ground, with one movement. This will always bring the rider down into the saddle with a very awkward jerk; and the proper direction is to raise the body straight up till both feet are on a level with the stirrupiron, and then with the left leg held against the flap of the saddle by the left hand on the pommel, the right leg is easily thrown over the cantle, and the body may be kept in the first position until the horse is quiet, if he is plunging or rearing. A short man can generally place his foot in the stirrup while held in his hand, but it should be known that all cannot do this, because-I have seen young riders much vexed at finding that they could not possibly do what is directed. Most of our writers on horsemanship are of the military school, and endeavour to cut every one's cloth by their own coats. They are able to do certain things easily, and so are their men, because they are mostly of the height already specified, but as sportsmen and civil equestrians are of all heights, I shall endeavour to 
accommodate my remarks to all heights and classes. In all cases the rider should stand at the shoulder, though with a short man it is much easier to mount a tall horse from the hind-quarter, but the danger of kicking is very great; and even in mounting with "a leg," in the jockey style, I have known the thigh very nearly broken by a kick. If the hand can steady the stirrup it should do so, but if the person is too short, the foot can be placed in the stirrup without its aid; then taking the reins between the fingers, much as directed in the passage already quoted, and grasping a lock of the mane with the finger and thumb, the body is raised till the right foot is brought to a level with the left, when the right hand seizes the cantle, and with the left grasping the pommel, the body is steadied for a short time, which in the ordinary mount is almost imperceptible, but in a fidgety horse is sometimes of considerable length. The leg is now thrown gently over the saddle, and as it reaches the cantle the hand is withdrawn, after which the body sinks into the saddle in an easy and graceful manner. The right foot is then placed in the stirrup, with or without the aid of the right hand holding it.

Such is the Evglish Method. Mr. Rarey and others in opposition to this plan, advise that the right hand and arm shall be thrown over the saddle, the horseman standing with his back to the quarters, and thus incurring the chance of being severely kicked.

\section{THE SEAT}

Tire position of THE rider in the saddle, called "the seat," admits of several variations according to the purpose to which he is devoted, but it is mainly influenced by the length of the stirrups. In the military stylo these are so long that the weight of the body is conveyed to the saddle by the inside of the thighs, or "fork" alone, while in that adopted in the East this part scarcely touches the saddle, and the breech and feet distribute the weight between them. Colonel Greenwood, who is the only military writer on horsemanship that can be taken as a guide for the road, tells us-"There is one direction which I think applies to all seats. Turn the thigh from the hip, so as to bring the hollow to the saddle; this places the foot straight to the front, with the heel out and the toe in. Trotting without stirrups on the thigh only, with the heel down and the too up, shoulders back, a snaffle-rein in each hand like a rough rider, is the best possible position for sitting." Now the latter part of this is quite true, but the former is not quite consistent with my own experience, for if the short stirrups of the Eastern horsemen are adopted, the hollow of the thigh cannot be brought to the saddle, yet this style he admits is "admirable in its way." Dismissing then the military seat for which Colonel Greenwood's directions may suffice, I may assert that, in the ordinary English style, there are four points necessary to be considered; namely, (1) the position of the weight, which will be mainly influenced by (2) the position of the knees well forward on the flap, (3) the proper length of the stirrup-leathers, and (4) the carriage of the body. If the wcight is not laid upon the middle of the saddle, which is the axis of the "seesaw "motion made in the gallop, it has to be raised at every stricle, whl 
thus additional labour is thrown on the horse. With long stirrups in the military style this is of necessity done; but with short stirrups the knees are often placed on the flaps behind the leathers, and then the breech remains close to the cantle and sometimes almost overlapping it. To get the length of leather adapted to most men, though there are occasionally exceptions, the rider should sit well on his fork, and then the stirrups should be taken up or let down till they just touch the ankle-bone. For road riding this enables the hollow of the thigh to touch the saddle, because the ball of the foot being on the stirrup, the heel is down an inch and a half below it; whilst in the hunting-field, as the stirrup is worn "home," the knee is carried higher and more forward on the saddle, and the weight is distributed between it, the breech, and the foot. With regard to the carriage of the body, all the directions in the world will not make it easy, and without the supervision of a master, or a friend, to point out defects, no one can be sure that he is sitting in a good, much less an elegant style. It is not possible even to know that the shoulders are square, or that the body is not carried on one side, defects which I have known persisted in for years without the slightest consciousness of them on the part of the rider, who would gladly have rectified them if he had known of their existence. One rule may, however, be given, namely, that no effort should be made to move in any direction, and that, on the contrary, every endeavour should be directed to keep the body and legs as still as the action of the horse will allow, bearing in mind that the opposite extreme of stiffness is almost equally bad.

\section{MANAGEMENT OF THE REINS}

THERE ARE THREe DISTINCT Modes of holding and managing the reins. In the first, adopted by the military school, the left hand does all, without any assistance from the right, which is occupied with the sword, lance, or carbine. In the second, the left hand holds the reins, aided occasionally by the right; and in the third, or "two-handed method," the reins are permanently held one in each hand. The first of these is only needed in the manège, and $I$ therefore shall not allude to it; while the last requires no description, further than to mention that it is the mode adopted by the co.t-breaker, and that it gives far more control over the mouth than either of the others. As single and double reins are differently placed in the hand, a description of each will be necessary.

THe SINGLE REIN is held by placing all the fingers but the first between the two leathers, and then, making both turn over that one, they are firmly held by pressing the thumb against it. This gives a firm grasp, and at the same time allows of either being pulled tighter than the other by turning the wrist. To shorten the grasp, the right hand has only to lay hold of the loose part of the rein, and then the left, sliding forwards towards the neck, can close wherever it may be desired. In order to be sure that the elbow is held against the side, the thumb should always point towards the horse's ears; and the nearer the little finger can be carried to the pommel of the saddle the better. In using the single rein, the management of the mouth, if a good one, is easy enough; nevertheless, there are various 
directions for the purpose adopted in different schools, which are dependent upon altogether conflicting principles. Every tyro knows that the horse turns to the left by pulling the left rein, and to the right by pulling the opposite one; and the problem to be solved is to do this by one hand only. Now, this with the single rein is easily effected by raising the thumb towards the right shoulder, when the right rein is to be pulled, or by drawing the little finger towards the fork for the left; in both cases by a turn of the wrist, without lifting the whole hand. But over and above this action on the mouth, and in many cases independent of it, is a movement which, in trained horses, is capable of much greater delicacy, and which depends upon the sensibility of the skin of the neck for its due performance.

It is effected by turning the whole hand to the right or left, without any wrist action, so as to press the right rein against the neck, in order to cause a turn to the left, and the left rein against the neck for the opposite purpose; at the same time rather slackening the reins so as not to bear upon the mouth by so doing. In this way a horse may be turned with a much greater degree of nicety and smoothness than by acting on the corner of his mouth. But highly-broken horses, such as the military troop-horses, are often too much used to their bits to answer to this slight and delicate manipulation; and therefore it is eschewed by Captain Richardson, as well as by Colonel .Greenwood, but, strangely enough, for opposite reasons, and each attempting to substitute a very different process for it. I am well aware that some horses can never be taught it, but must always have a bearing made on the mouth before they will turn; yet, when it can be inculcated, it makes the animal so tractable and agreeable to ride, that it is a highly desirable accomplishment; and I cannot, therefore, join in condemning its use, but should rejoice if it could in all cases be fully developed.

The DOUbLe ReIN is usually held by those who ride for pleasure in this country as follows:-Begin by taking up the snaffle-rein, and place the fore and middle fingers between its two portions; then lay hold of the curb-rein, and either hook it loosely on to the little finger, if not immediately wanted, or draw it up to the requisite degree of tightness and turn it over the fore-finger, when it will lie upon the snaffle-rein, and, together with it, will be gripped by the thumb. By adopting this plan, the curbrein is always at the command of the right hand; and it may be shortened or let out in a moment, which is of constant occurrence in every day's ride. The hand is held as with the single rein, with the thumb pointing to the horse's ears; in turning, however, there is much less power of bearing on either side of the bit by raising the thumb or lowering the little finger, because the distance between the snaffle-reins is only half what it was, and therefore the mode of turning by pressure upon the neck is doubly desiratele; and hence its general adoption in those cases where double-reined bridles are used, as in the field and on the road. Sometimes, to obviate this objection, the snaffle-reins are placed as in the single-reined bridle, outside the little finger, and then the curb is hooked over the ring-finger, between the snaffle-reins, so as to allow of the full manipulation of the mouth by the hand, without bearing upon the neck. But the objection to this is, that the curb cannot be shortened without 
releasing the snaffle; and therefore the horse must either be ridden on the curb alone while this process is being effected, or his head must be loosed altogether; whereas, in the other mode, his mouth is still under the control of the snaffle all the time that the curb is being let out or taken in.

The atTainment of "GOOD IIANDS," by which is to be understood a light and delicate handling of the reins, is, or ought to be, the aim of every rider. The most delicate mouth in the world is soon spoilt by bearing heavily on it, as is too often done by grooms, and, indeed, by the average run of our horsemen. So also in hunting, if the horse is not allowed his head in making his effort, he will be almost sure to fail in exactly doing what he meant, and will hit timber, if he is put at that class of fence, or will drop his hind-legs into the ditch, if there is one. Bad riders use the reins as a means of balancing themselves in the saddle, and this is especially done in the hunting field, where they would be utterly unable to maintain their seats without the aid thus afforded to the proper grip and balance. Every one in learning to ride ought to be taught to go through all the paces, and to jump the bar without any reins in his hand; and when he finds he is able to do without them, he will learn to use them only in the way for which they are intended.

\section{THE USE OF SPURS}

SPURS are employed for three distinct purposes, which are-first, to stimulate the energies of the flagging or idle horse; secondly, to punish the vicious or refractory animal; and thirdly, to induce him to improve his pace without accelerating it,--from which last office they are specially termed "persuaders." Sir Francis Head lays it down as a rule, that all horses in this country are so generous, as to be excited by every carriage or rider that passes them; but though this is certainly the rule, there are numerous exceptions to it, and to ride a "slug" without spurs on the road would be a nuisance, and in the hunting-field a service of extreme danger. That they may be abused is true enough; and that they often are so, is equally correct; but that is no reason why they should not be worn by those who can be trusted with them. On the road, they are only required for sluggish or vicious horses; but in the hunting-field, it is never safe to be unprovided with them, as a prick at the right moment has saved many a fall.

\section{MODES OF STARTING THE HORSE INTO HIS VARIOUS PACES}

To Make a HoRse start off in a quick walk, when he is not inclined to do so, either from being too fresh or too raw, is by no means an easy task. I have often ridden one for several days in succession, before I could make him settle down to a fair walk, and even then the slightest excitement would upset all my apparent previous progress. This is especially true of those horses possessed of such elastic joints, that they could "jog" 
at a rate much slower than they could walk. Here restraint by the bridle is out of the question, and any excitement by the voice or heel increases the jog into a full trot, without passing through any intermediate stage. The difficulty consists in the fact that for a perfect walk the head must be at liberty, and when this is allowed to a generous horse, he is inclined to go off at a rate faster than suffices for the pace in question. The only plan, therefore, is to ride such horses quietly, till they are leg weary, whatever the number of hours may be required, and then it is possible to loose their heads without their taking advantage of the liberty to go off "at score." Indeed, in the walk, the head should never be much confined, and yet the rider should not entirely leave it uncontrolled; the finest possible touch is enough, so that on any trip the hand is at once informed of it by the drop of the head, when, by a sudden jerk of the bridle, not too forcible, it rouses the horse, and prevents his falling. It is not that he is kept up by pulling the rein, but that he is roused by it and made to exert himself, for many horses seem regardless of falls, and would be down twenty times a day if they were not stimulated by the heel and bit. Confinement of the head in the walk is absolutely injurious, and more frequently causes a fall than saves one. A good walker will go on nodding his head to each step, more or less as it is a long or a short one; and if this nodding is prevented by the heavy hand of the rider, the fore-foot is not properly stretched forward, the step is crippled, and very often the toe strikes the ground; when, if the head were at liberty, it would clear it well. In horses which are apt to stumble in the walk, I have generally found that a loose rein, with the curb held ready for a check, is the safest plan; and then the horse soon finds that he is punished the moment he stumbles, and in a very short time he learns to recover himself almost before he is reninded. I do not like the spur or the whip so well, because the use of either makes the horse spring forward, and often blunder again in his hurry to avoid this kind of punishment. The check of the curb, on the other hand, makes him recover himself without extra progress, or rather by partially stopping him, and thus he is better able to avoid his fall. The body is allowed to yield slightly to the motions of the horse, but not to waddle from side to side, as is sometimes seen. Some horses do not stir the rider at all, while others throw him about and fatigue him greatly; and this may generally be foretold when the tail sways much from side to side in the walk, which is caused by the over-long stride of the horse, a very desirable accomplishment in the race-horse or hunter, but not in the hack.

Tripping or stumbling is often a matter of conformation, and for hacking a horse should never be chosen if he has a disposition to turn out his toes. Many thoroughbred horses have this defect to a glaring degree, but as it does not affect them in the gallop, and their capacity to win races is too often the sole merit desired, it is to be feared that this malformation will continue to be disregarded.

THE JOG-TROT is a pace that there is seldom any difficulty in effecting, and on the contrary, as I have just observed, the rider is often engaged for hours or days in breaking the young horse of it.

THE REGULAR TROT is generally easy to produce, but sometimes when the canter has been much adopted, it is not so readily effected. The best plan 
is as follows:-Take hold of both the reins of the snaffle, and bear firmly, but steadily, upon the mouth, lean slightly forwards in the saddle, press the legs against the horse's sides, and use the peculiar click of the tongue, which serves as an encouragement to the horse on all occasions. If properly trained, he will now fall at once into the trot, but if he breaks into a canter or gallop, he must be checked, and restrained into a walk, or a " jog-trot." Where the horse has been much used to canter, and can go at that pace as slowly as he walks, there is often great difficulty in making him trot, for no restraint, short of a total halt, will prevent the canter. In such cases, laying hold of an ear will often succeed, by making the animal drop his head, which movement interferes with the canter, and generally leads to a trot. The rising in the stirrups is generally practised in civil life, as being far less fatiguing to both horse and rider; but in the military schools the opposite style is inculcated, because among a troop of horse it has a very bad effect if a number of men are bobbing up and down, out of all time. If it were possible for all to rise together, perhaps the offence against military precision might be pardoned; but as horses will not all step together, so men cannot all rise at the same moment, and the consequence is that they are doomed to bump upon the sheep-skins in a very tiresome manner, fatiguing alike to man and horse. This rising in the saddle of itself encourages horses which have been accustomed to it to trot in preference to any other pace, and they understand the faintest indication of it as a sign that this particular pace is to be commenced, and trot accordingly. The civilian's mode of riding the trot is as follows :-At the precise moment when the hind and fore-legs are making their effort to throw the horse forward in progression, the body of the rider is thrown forcibly into the air, in some horses to so great an extent as to make a young rider feel as if he never should come down again. After reaching the utmost height, however, the body falls, and rexches the saddle just in time to catch the next effort, and so on as long as the trot lasts. In this way the horse absolutely earries no weight at all during half his time, and the action and reaction are of such a nature that the trot is accelerated rather than retarded by the weight. No horse can fairly trot above twelve miles or thirteen miles an hour without this rising, though he may run or pace in the American style, so that it is not only to save the rider's bones but also to ease the horse that this practice has been introduced, and holds its ground in spite of the want of military sanction. It is here as with the seat; utility is sacrificed to appearances; and whenever the long and weak seat of the barrack-yard is supplanted by the firm seat of the civilian, I shall expect to see the rising in the trot abandoned, but certainly not till then. The military length is not now what it was formerly; and perhaps some time or other soldiers may adopt the rise, but I am afraid not until they have produced many thousands more sore backs than they need have done if they had never practised it. ${ }^{1}$ In the trot, the foot should bear strongly on the stirrup, with the heel well down, and the ball of the foot pressing on the foot-piece of the stirrup, so that the elasticity of the ankle takes off the jar, and prevents the double rise, which in some rough horses is very apt to be produced. The knees should al ways be maintained exactly in the same place, without that shifting motion which is so common with

1 Sore backs are roct neariy so frequent in the army now, as the saddling is quite changed-more adapted to the toilitary seat or style of riding.-EDITOR. 
bad riders, and the legs should be held perpendicularly from the knew downwards. The chest should be well forward, and the waist in, and the rise nearly upright, but slightly forward, and as easily as can be effected without effort on the part of the rider, and rather restraining than adding to the throw of the horse.

GOOD HANDS and a quiet seat only, with the aid of a curb-bit properly adapted to the mouth, are required to develop the canter, by restraining the gallop; but to make a horse start off at once, with a lead of either leg as desired, is altogether another matter. To do this, the canter with either leg leading must first be completely taught, so that there is no difficulty in making the horse display that particular pace at any time. Then just at the moment before starting, pull the rein, and press the heel on the side opposite to the leg which it is desired the horse should lead. The reason of this is obvious enough; every horse in starting to canter (and many even in the canter itself) turns himself slightly across his line of progress, in order to enable him to lead with that leg which he thereby advances. Thus, supposing a horse is going to lead off with the off fore-leg, he turns his head to the left and his croup to the right, and then easily gets his off-leg before and his near-leg behind into the line which is being taken. Now, to compel him to repeat this action, it is only necessary to turn him in the same way, by pulling his head to the left, and by touching him with the left heel, after which he is made to canter by exciting him with the voice or whip, whilst at the same moment he is restrained by the curb. When once this lead is commenced, the hold on the curb and pressure on the legs may be quite equal; but if, while the canter is maintained, it is desired to change the leading leg, the horse must be collected and roused by the bit and voice, and then reversing the pull of the reins and the leg-pressure from that previously practised, so as to turn the horse in the opposite way to that in which he was started, he will generally be compelled to change his lead, which is called "changing his leg." The seat in this pace is a very easy one, the knees taking a very gentle hold of the saddle, the feet not bearing strongly upon the stirrups, and the body tolerably upright in the saddle. The hands must not be too low, but should keep a very gentle but constant pressure upon the bit, and should, if there is the slightest tendency to drop the canter, rouse the mouth by a very slight reminder, and also stimulate the spirits by the voice or whip.

ThE GaLlop being generally, though not always, his fastest pace, the horse may be forced into it readily enough by the stimulus of the voice, whip, or spurs. Sometimes very fast trotters cannot gallop so fast as they can trot, but these are rare exceptions, and need not be considered in any other light. It is therefore useless to describe the mode of starting this pace; but some allusion may advantageously be made to the best method of riding it. There are two seats adopted, the ordinary one being to sit down into the saddle and keep as close to it as possible, but another being also practised called standing in the stirrups. The former is the usual seat, and it is only in racing or in the very fast gallop at other times that the latter is adopted. In sitting down the feet may be either resting on the ball of the toe, as in the other paces, or with the stirrup "home" to the boot, as is common in all field-riding. The body is thrown easily and slightly back, the knees take firm hold, the rider being careful not to grip 
the horse so tight as to distress him, which fault I have known very muscular men often commit. The hands should be low, with sufficient pull at the mouth to restrain, but not to annoy and make him "fight"; and if he is inclined to get his head down too much, or the reverse, they must be raised or lowered accordingly. When the standing in the stirrups is to be practised, the weight is thrown upon them, steadying it with the knees and thighs, which should keep firm hold of the saddle. The seat of the body is carried well back, while at the same time the loin is slightly arched; but by this combined action the weight is not hanging over the shoulder of the horse, as it would be, and often is, when the breech is raised from the saddle and brought almost over the pommel, with the eyes of the rider looking down his horse's forehead, or very nearly so. If a jockey of more than seven or eight stone, with a good seat, is watched, it will be seen that his leg does not descend straight from the knee, but that it is slightly thrown back from that line, and consequently that his centre of gravity is behind it, so that he can, by stiffening the joint, carry his body as far behind it as his stirrup is, without ceasing to stand in it. Very light jockeys adopt a somewhat different seat, riding with longer stirrups and throwing their weight greatly on the muscles of the thigh, while they raise the breech entirely from the saddle, but only for a comparatively small distance. This gives them a strong hold of their horses, without which, being so small, they could not ride them. Standing in the stirrups cannot long be maintained without fatigue to the rider, and it is only adopted in racing or in short gallops over bad ground, as in hunting, when there is a deep piece of fallow, or a steep hill, or any other kind of ground calculated to tire the horse.

\section{RIDING TO HOUNDS}

THE KIND OF SEAT generally adopted in riding to hounds has been already described, and I need not therefore allude to it again. I may, however, remind the tyro that the less he depends upon balance, and the stronger hold he can get of the saddle with his knees and calves, the more likely he will be to avoid a fall without his horse coming down also. If this accident happens, a loose seat sometimes befriends the rider by causing him to be thrown out of the way of the horse, but in the long run the man who has a strong grip of his saddle will fare the best. Good hands and judgment are equally necessary, and the combination of these three qualities makes up the finished performer across country, always supposing the presence of nerve in addition.

There are CERTAIN RULes adopted in all hunting countries, which must be stringently carried out in order to ensure the safety of the hounds and horsemen, and avoid those disputes which would otherwise constantly occur between riders jealous of each other's prowess. These may be summed up in the following plain directions :-

WHEN NEAR THE HOUNDS keep to the right or left of them, and not directly behind, where you are always in danger of riding over some of the tail hounds. So also when the pack are crossing a thick fence, when 
there is often only one gap weak enough to allow of their getting over avoid its proximity, and take a place at least a dozen yards off.

INDEPENDENTLY of hounds, every rider should take a line of his own, or if he is unable to do this and must follow a leader, let him keep such a distance behind that if a fall takes place he can avoid jumping upon him. In a large field of horsemen, every one cannot possibly take a different line, nor is it easy to keep always at a safe distance; but at big places there is generally some hesitation, and a proper interval can be maintained. No one should attempt to pass his neighbour either on the right or left of the line he has chosen, when near a fence; but of course this is not to deprive him of his chance of taking the lead in the middle of a large enclosure, when a little racing can do no harm. By the adoption of this rule, jostling and crowding at a weak place are avoided, which without it would be sure to lead to serious accidents.

USE YoUR JUDGMENT in saving your horse in deep ground, making up for the apparent loss by putting him along whenever a sound headland or good turf can be obtained. It is not going straight over sound land that distresses a horse, but the making use of him over deep ground, and at the wrong time. Many men seem to know no difference between sound turf and rotten or wet arable, and will kick their horses along over high ridge-and-furrow in a wet clay district, at a pace which no horse can bear for more than a mile or two in such a country. A workman would look out for headlands or footpaths, etc. ; and would, by a slight détour, gain upon those who disdained to leave the line even for a few yards. Wet and sticky ridge-and-furrow tires a horse dreadfully, and the consequence is, that if he is pushed over it he speedily loses his powers and wind, and falls in a very ugly way at the first fence he comes to of a size above the average. Hence, every man who aspires to go well to hounds must learn to be "a judge of pace," and should endeavour to make out the signs of distress, and the best way of avoiding it. So much depends upon condition and breeding, that it is very difficult for a man with a strange horse to know what liberties he may take with him. Some well-bred ones will be blown, yet if nursed they will come again and again, while the dunghill animal will give up when once he has lost his wind, and is gone for that day at least. In ascending steep banks, a careful and active horseman will dismount and lead his horse up, and by so doing often gains a mile or two upon his less humane and cautious antagonist. In ascending hills it is often expedient to make a zigzay ; but in descending you can never go too straight, as the opposite course often leads to a dangerous slip on the side, with a crushed knee or ankle as a consequence. Few horses fall forwards, and they always manage to save themselves by slipping down on their haunches. This is a point of great importance, and should always be strictly attended to.

There ARE Two General Directions, which will serve for almost all descriptions of fence. These are, that if a height is to be overcome, the horse should be taken slowly up to it, in a collected manner, with his liaunches well under him. On the other hand, width requires impetus, and the pace should be forced during the last few strides up to a very high rate. Under the former head may be classed timber (in all the varieties of gates, single posts-and-rails, stiles, and palings), walls, strong pleached 
fences, and banks. To the latter belong water in all shapes, double postsand-rails, bullfinches, and those fences with a ditch on both sides, as well as those which have a wide one on the landing side. In addition to these there are the actual standing leap, seldom practised in the present day, the creeping style, the "on and off " leap, and the "drop," which is a variety of the standing leap.

In COLleCting the Horse, and properly putting him at his fence, there is a great art, and nothing but practice will give it in perfection. Double posts-and-rails require a great deal of collecting and rousing, and the horse must go pretty fast at them, as also must he at all wide jumps, including water in all its forms. One essential is, that the horse shall have confidence in his rider; for if he thinks he may turn to the right or left he will most probably do so, unless he is very fond of jumping. Nervous men communicate their feelings to their horses, and though it may be difficult to explain how it is done, there is no doubt of the fact. It is remarkable how soon horses find out what kind of man they carry, and how they alter under different hands. This is partly owing to a mismanagement of the mouth, but in great measure also to the trepidation of the rider. Unless, therefore, he has full confidence in his own courage, he need never expect his horse to go steadily and straight at his fences. The collecting is much easier than the management of the bit at the leap itself, for there are two opposite things to be done, and the delicate point is to hit the moment of change from one to the other to a nicety. The first is to "catch hold of the horse's head," as it is called-that is, to bear more or less upon the mouth, pull the horse on his haunches, and rouse him, either by voice, heel, or whip. This lasts till the moment of the effort made to rise over the obstacle, when the head should be released, so that the horse may have all his bodily powers at his command. If the head is confined the haunches do not act fully, because in making the spring the head is protruded, and pain is given by the bit if it is still held fast; and hence, to avoid the pain, the extension does not take place, the leap is not made with sufficient spring or power, and the horse alights too near the ditch, if there is one, or possibly in it. But in releasing the head judgment is required, for if the rein is too loose the horse is apt to alight in such a position that he is "all abroad," and without great help he will often fall; hence, most good performers, though they do not absolutely confine the head, yet they keep a very gentle and delicate hold of the mouth, and not only thus prevent the horse over-extending himself, but. are also prepared to assist him if he is inclined to fall. This is the finished style of riding, and is only in the power of a man with a good seat as well as good hands. Both are wanted, because without the former it is impossible to avoid "riding the bridle" - that is, holding on by it as well as by the saddle; and without good hands that delicate management of the bridle which I have attempted to describe is impracticable. What is called "lifting" the horse is sometimes attempted with the bit, but I do not recognize its utility. When a horse is likely to touch the top bar of a gate, or in any way to use too small an effort, a stroke of the whip down the shoulder is the best lift. Rousing and collecting are quite distinct irom lifting, which $\mathrm{I}$ believe to be a myth altogether. In creeping, good inands and quietness in the saddle are the chief elements of success, and without them both, no one is likely to do much in this particular style; 
hence it is that so few men can "creep" well, even though they have horses accustomed to it under other liands. When the horse has been thoroughly taught to creep his head may almost be left without control, merely guiding him quietly to the gap, and then letting him take his own way; but where the horse has to be made to creep, a rein should be taken in each hand, and the head guided as if with a silken thread, to the right or left, or wherever the animal is required to go. These remarks will perhaps be useful to all who have no experienced friend ready to afford a practical demonstration of the same fundamental points. One actual lesson in the field is worth all the reading in the world ; but, in default of this, the preceding observations will serve to assist the young aspirant for honours in riding to hounds.

\section{OUT.DOOR VICES AND BAD HABITS}

OUT-DOor vices depend upon the temper of the individual, and include shying, rearing, kicking, lying down, plunging or bucking, shouldering, and running away. Bad habits arise from a defective formation of the body, and are confined to stumbling and cutting.

SHYing generally arises from timidity, but sometimes it is united with cunning, which induces the animal to assume a fear of some object for the sole purpose of finding an excuse for turning round. The usual cause of shying is doubtless the presence of some object to which the colt has not been accustomed, and if he has buck eyes, which render him short-sighted, it will be difficult to convince him of the innocent nature of the novel object. There are endless peculiarities in shying horses, some being dreadfully alarmed by one kind of object, which to others is not at all formidable. When a horse finds that he gains his object by turning round, he will often repeat the turning without cause, pretending to be alarmed, and looking out for excuses for it. This is not at all uncommon, and with timid riders leads to a discontinuance of the ride, by which the horse gains his end for the time, and repeats the trick on the first occasion. In genuine shying from fear the eyes are generally more or less defective; but sometimes this is not the cause, which is founded upon a general irritability of the nervous system. Thus, there are many horses which never shy at meeting tilted wagons, or other similarly alarming objects, but which almost drop with fear on a small bird flying out of a hedge, or any other startling sound. These last are also worse, because they give no notice to the rider, whereas the ordinary shyer almost always shows by his ears that he is prepared to turn round.

THE BEST PLAN OF TREATMENT which can be adopted, is to take as little notice as possible of the shying, and to be especially careful not to show any fear of its recurrence when a wagon appears in the distance. When the horse begins to show alarm, but not till then, the rider should speak encouragingly to him, and, if necessary, with a severe tone, which may even be supported by the use of the whip or spurs, if his onward progress cannot be otherwise maintained. The principle which should be carried out is to adopt such measures as will get the horse to pass the object at which he shies somehow or other, and this should be effected with as little violence as possible, always commending in an encouraging tone as soon as the 
purpose is gained. Nothing has so great a tendency to keep up the habit as the plan so common among ignorant grooms, of chastising the shyer after he has passed the object of his alarm. If he can be persuaded to go quietly up to it and examine it with his muzzle as well as with his eyes, great good will be effected; but this can seldom be done with moving wagons, and heaps of stones are generally only alarming from defect of vision, so that each time they assume a new phase to the active imagination of the timid animal.

REARING is seldom met with excepting among raw colts, or if it is continued to a later period it is generally incurable. When existing in an aggravated form it is a most dangerous vice, as a fall backwards over the rider has often led to fatal consequences.

The UsUar REMEdy for it in the colt is the ordinary running martingale, which will keep down the rearer who is merely indulging in his playful fancies. When, however, the vice has become confirmed, nothing short of severe punishment will be of any service, and the horsebreaker generally resorts to the plan of knocking the horse down as he rises by a blow between the ears with a loaded crop. This stuns the horse for a time, and alarms him so much that he is often cured by one act of the kind; but it is attended with some danger of injuring the horse, and the rider does not always escape. Another plan adopted by active breakers is to wait till the horse is just on the balance, and then slipping off to the left, it is easy to pull him over backwards; but this also is often followed by severe injury to the horse when the ground is hard. I have almost invariably found that bad rearers have very supple necks, which increases the difficulty of keeping them down by any kind of martingale, and probably this will account for the babit having becoming inveterate. A stiff-necked horse can scarcely rise high if his head is confined even by the running martingale; but when the side-straps are tightly buckled to the bit, he is effectually restrained, whereas with a loose neck the head can be so bent in to the brisket that no obstacle is offered. In such cases I have known a cavesson with the noseband lined with sharp prickers, and the martingale buckled to it; a most effectual prevention, as the slightest pull opens it, presses the prickers into the nose, and gives acute pain. Whenever the rider finds a horse inclined to rise, he should at once lean forward, and after ineffectually trying the martingale to keep the horse down, he must loose his head, or he will be almost sure to bring him backwards and cause a severe fall.

For KICKERS, except when the habit is merely a mode of letting off supertluous spirits, severity is the only remedy, and a strong application of the whip down the shoulder the best means of using it. At the same time the snaffle-reins ought to be firmly held, and by their means the head kept up, for there is always a tendency to lower this part in the act of kicking; the gag snaffle is very effectual for this purpose.

LYING DOWN is rare in the present day, being chiefly confined to underbred horses and Welsh ponies, which are gradually going out of use. The spur is the only means likely to keep a stubborn brute up; but in some cases its application is followed by the animal throwing himself down suddenly instead of graaually.

Plunging may be described as a series of bounds into the air, which when 
they are made up and down in the same place, or nearly so, are called "bucking," from their resemblance to the playful antics of the deer. A bucking horse is very difficult to sit, but by sawing the mouth with a twisted snaffle it may generally be stopped at once.

By shouldering is understood the attempt to crush the leg of the rider against a wall, which some ill-tempered horses are fond of doing. It is easily avoided by pulling the horse's head round to the wall instead of from it.

Running AWAY is too well known to need description. In some horses it is a species of temporary madness, and scarcely any bit, however severe, will stop them. When there is room and scope enough, the remedy is simple, but, unfortunately, runaway horses generally choose a crowded thoroughfare to indulge their fancies in. A gallop to a standstill, with the free use of the spur or whip at the latter part of it, will sometimes prevent a recurrence of this vicious act; but where the tendency is very strong it will have little effect. Punishing bits only make some highcouraged horses worse, but the majority of runaways would be dangerous with a plain snaffle only, and yet there are some which will go quietly enough in it, while the adoption of a curb will rouse their tempers at once. Of course they can only be ridden with great care and judgment and must never be roused unnecessarily. Fortunately the mouths of horses are now made so much more carefully than in former times, and their management is so much better understood, that we seldom hear of or see an accident from this cause, either in the saddle or in harness. The most essential part of the treatment of a runaway is the proper selection of a bit, which should be sufficient to control him without exciting opposition from the pain it gives. For the majority of such horses I know nothing better than the Bucephalus noseband, which I have already described at page 324 .

Stumbling arises from a variety of causes, and the nature of any particular case should be thoroughly investigated before any remedy for it is attempted. Sometimes it is merely dependent upon low or "daisycutting" action, and then it is possible that it may not be attended with danger. I have known many horses which would stumble at least every halfmile, but yet they would travel for years with sound knees, the other leg being always ready to catch the weight. In other cases a stumble would only occur at rare intervals, but if the trip was made it was rarely recovered, and a fall was almost sure to follow. Again, it happens with some horses that when they are fresh out of the stable, their action is high and safe, but after a few miles the extensors of the leg tire and they are constantly making a mistake. Inexperienced judges are very apt to examine the action of the fore-legs alone, while that of the hind-quarter is of quite as much importance to safety, and is more so as regards the ease of the rider. Lameness is a frequent source of a fall, from the tendency to put the foot too soon to the ground in order to take the weight off the other. And lastly, upright pasterns will produce stumbling, when the shoulders are so formed that the foot is put down too near the centre of gravity.

The Best plans for REMEdying these several conditions are as follows. If the cause is weakness of the extensors no care can be of much service; 
all that can be done is to be on the look-out for a trip, and then to take the weight off the fore-quarter as much as possible by sitting well back, at the same time using such an amount of sudden pressure on the bit as to cause the horse to exert himself, without any attempt to keep up the head by mechanical force, which is an impossibility. When laziness is the cause, the stimulus of the spur or whip will suffice, and it often happens that a horse is safe enough at his top pace while a slower one is full of danger. In lameness of course the remedy is to wait till the foot or feet are sound again.

Cutring depends either upon the legs being set on too near together, or on their joints not acting in a proper hinge-like manner. Many horses cut when in low condition, but are quite free from the defect when in flesh, and in such cases it is only necessary to let them wear a boot until they have had time enough to become fresh. Wherever horses "go close" care should be taken that the shoes do not project beyond the hoof, and the clenches of the nails should be carefully watched, the groom seeing that they are filed down by the smith if they stand up at all above the level of the horn. Cutting may take place either on the prominent part of the fetlock-joint, or midway between it and the knee, or just below the latter, which is called "speedy cutting," and is very apt to cause a fall. A boot should be fitted to the leg in either case, and worn till the part is thoroughly healed and all swelling has disappeared, when if any likely method of treatment has been adopted the horse may be tried without it, but no journey should be undertaken without one in the pocket in case it may be needed. A method of shoeing, called a feather-edged shoe, will often prevent this bad habit as long as it is adopted.

\section{HARNESS}

HARNESS should always be chosen of the best leather which can be procurea, and double stitched throughout. Inferior materials and workmanship are dear at any price. There is no improvement in principle upon the oldfashioned collar, and the buckle which has been in use ever since carriages came into fashion is still the best.

\section{DRIVING A SINGLE HORSE}

THE HARNESS used in driving a single horse for general purposes is shown in the annexed engraving, and this form will serve either for two or four wheels. A complete set consists of three parts-1st, the drawing part; 2nd, that for holding up the shafts and backing the carriage; and 3rd, that for guiding the horse.

THE DRAWING PART consists of the collar $(a)$, which is an oval ring padded so as to fit the horse's shoulders, to which two iron bars, called hames $(c)$, are buckled on each side of it by a strap at top and bottom. called the hamestraps $(d d)$. These pass through a flat eye at each end of the hames, and draw the two tightly together. Towards the top of each hame is a ring called the hame terret $(e)$, intended to confine the rein in its place as it 
passes to the head; while a little below the middle is a metal arm, with an eye $(f)$ in it, to which is attached the tug of the trace, a clip of iron stitched into a double piece of leather, which is fixed to the buckle for the trace $(g)$. This last is simply a long double-leather strap, attached at one end to the above buckle, and at the other by an eye to the drawing bar of the gig or carriage; or sometimes the buckle is at the other end, and then the tug is stitched at once into the trace.

The supporting AND BACKING PART consists of the pad or saddle $(h)$, somewhat similar in principle to the riding saddle, but much narrower and lighter. This has two rings for the reins, called the terrets $(i)$, and a hook $(j)$ for the bearing rein, all at the top. It is fastened to the horse by a

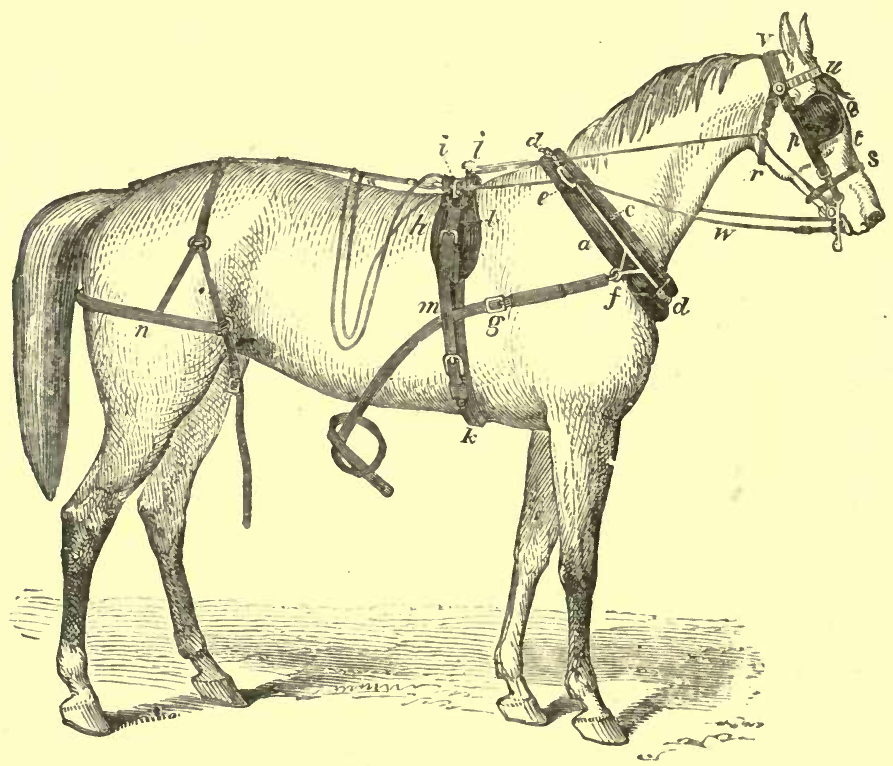

DETAILS OF SINGLE HARNFSS.

belly-band $(k)$, and at the back of it there is an eye for the crupper, which is a leather strap from it to the tail, round the root of which it passes, and thus holds the pad from pressing forwards. Through the middle of the pad passes a strong leather strap, called the back-band $(l)$, which is attached to a buckle and strong loop on each side, called the shaft tug $(m)$, by which the shaft is supported, and also kept back from pressing upon the horse's quarters, in which latter office it is sometimes assisted by a leather strap passing round these parts, and buckled on each side, either to the shaft or to its tug, and called the breechen $(n)$.

THE PART FOR GUIDING the HORSE consists of the bridle and the reins, the former being made up of two cheek-pieces and winkers $(p$ and $q)$, a throat-lash $(r)$, a noseband $(s)$, a face-strap $(t)$, a front-piece $(u)$, and a headpiece $(v)$. The cheek-pieces are buckled to the bit, which is generally a strong curb, but sometimes only a double-ringed snaffle, now very commonly 
used in driving. The reins $(w)$ are merely long and narrow strips of leather passing from the bit through the hame and pad-terrets to the driver's hands. Bearing-reins are additional reins attached to bridoon bits, and passing through ear-rings on or near the throat-lash to the hook on the pad. They are, however, now seldom used in single harness; but are shown in the plan at page 340. Where the bearing-rein is not used, a long ear-ring is now sometimes suspended from the head of the bridle, through which the driving-rein passes, and by which the horse is prevented from getting the rein under the point of the shaft, an accident which is very annoying to those who leave their horses standing about with their servants, as unless the rein is at once slackened, the horse is made to back and upset the carriage.

THE CIIEF variations in the details of single harness are in the drawing part and in the breechen, independently of the bearing-rein to which I have already alluded.

Kicking-straps as usually applied are quite useless for the purpose because

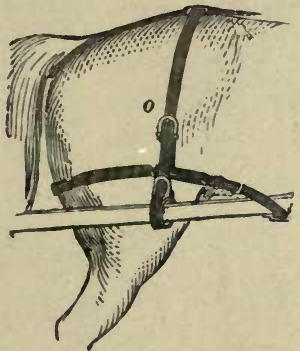

BREECHEN AND KICKING-STRAP UNITED.

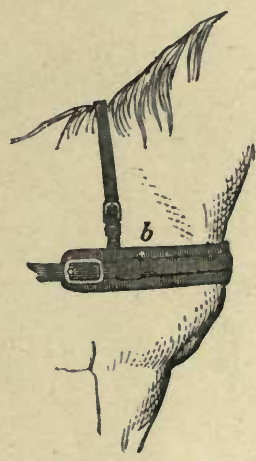

BREAST-STRAP.

too far forward. If the amateur will look at a breaksman's arrangement he will find a loop of leather attached to the crupper and tugs much further back on the shafts than those intended for breechen-straps.

THE BREECHEN is sometimes made in the form shown in the illustration, combining it with the kicking-strap, which is intended to keep down the croup, when the horse attempts to indulge in that dangerous vice. The kicking-strap is made to pass over the hips, and buckles to a loop or tug which encircles each shaft. To this is suspended by another buckle at $(o)$, which can be taken up or let down at will, a breechen on the ordinary plan, but it must be made of stout leather, or it will not be stiff enough to support itself.

IN THE DRAWING PART a breast-strap is sometimes substituted for the collar, its shape being shown in the above engraving at (b). It is merely a broad padded strap to which the traces are buckled, and it is supported by a withers strap, which is likewise buckled to it. It has the advantage of being lighter than the collar, although with heavy weights to draw it confines the shoulders, but for those persons who now avail themselves of the light and cheaply constructed American gigs they are very suitable. They have 
the additional advantage that a horse galled at the withers may continue at work, and are often substituted for the ordinary collar, thereby saving much loss of time in waiting for a bad place to get sound again, and avoiding any risk of incurring " collar pride" or jibbing. Undertakers still generaily use the breast collar for their black Flemish stallions.

\section{A PAIR}

PaIr-horse harness only differs in detail from that already described, both being made on the same principle. Double harness consists, like single harness, of three essential parts ; but as there is no shaft to be supported, the pad is much lighter and more simple. The drawing part is

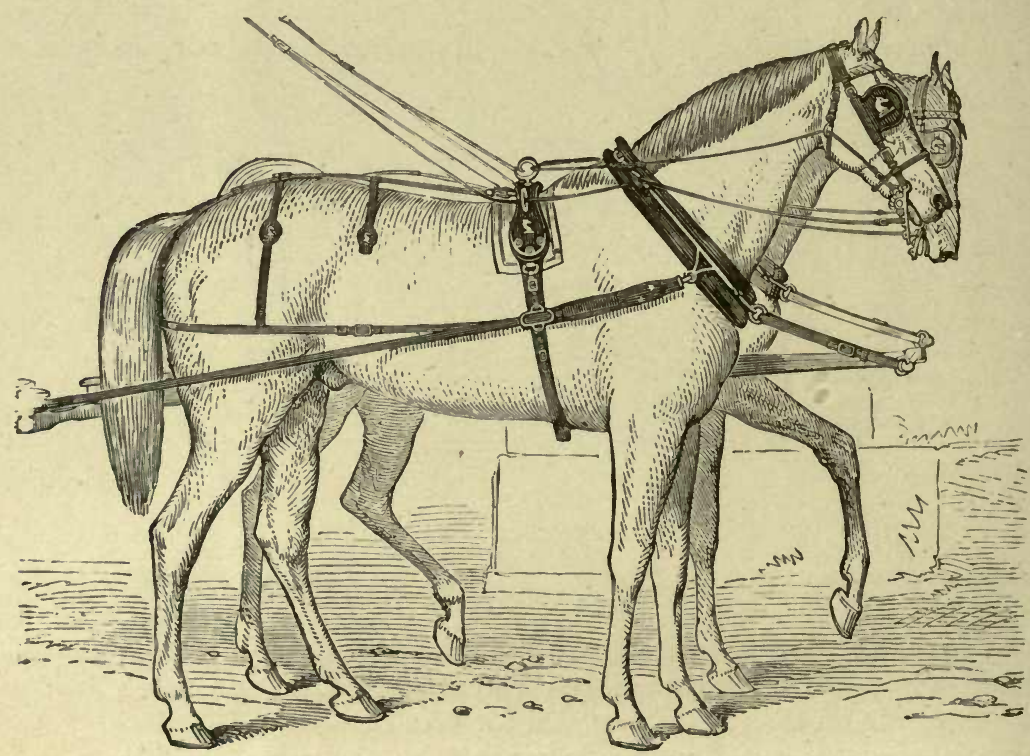

DOUBLE HARNESS.

similar to that already described, except that the lower eyes of the hames are permanently connected by an oval piece of metal, upon the lower part of which a ring freely travels, to which the pole-piece of the carriage is buckled, and by which it is backed. The trace-buckles, also, are opposite the pad, and supported from it by a light strap, called the trace-bearer. The traces themselves either end with an eye, or, with a full fold upon themselves, with an iron eye, called a roller, and intended to be used upon the roller-bolt of the splinter bar. The pad is very light, and has no backband; sometimes a long breechen runs to the trace-buckle; but for light harness a mere supporting strap for the traces, called a hip-strap, is all that is used. The bridle is nearly the same as for single harness, except that there are no ornaments on that side which is towards the pole. The reins have, in addition to the single rein which is attached to the outside of each 
horse's bit, another called a coupling-rein, which has a buckle towards the driver running upon the driving-rein, so that it may be taken up or let out at pleasure, according to the mouth of the horse and his tendency to do more or less work than his share. These several points of difference are shown in the engraving (page 342 ), in which a set of double harness, suited to a light phaeton or brougham, is shown. The traces are made to slip on roller-bolts, instead of having eyes as for single harness.

\section{FOUR-IN-HAND}

THE HARNESS for four-in-hand wheelers resembles that shown on page 342, excepting that it is more massive, and the terrets are double for the passage of the leaders' reins. A ring is also fixed to the top of the head-piece of the bridle so as to carry the reins forward to the leaders well above their croup. The leaders' traces have eyes which slip on to the bars attached to the pole. 


THE BOOK IS DUE ON THE IAST DATE STAMPED BELOW

AN INITIAL FINE OF 25 CENTS WILL BE ASSESSED FOR FAILURE TO RETURN THIS BOOK ON THE DATE DUE. THE PENALTY WILL INCREASE TO 50 CENTS ON THE FOURTH DAY AND TO \$1.00 ON THE SEVENTH DAY OVERDUE.

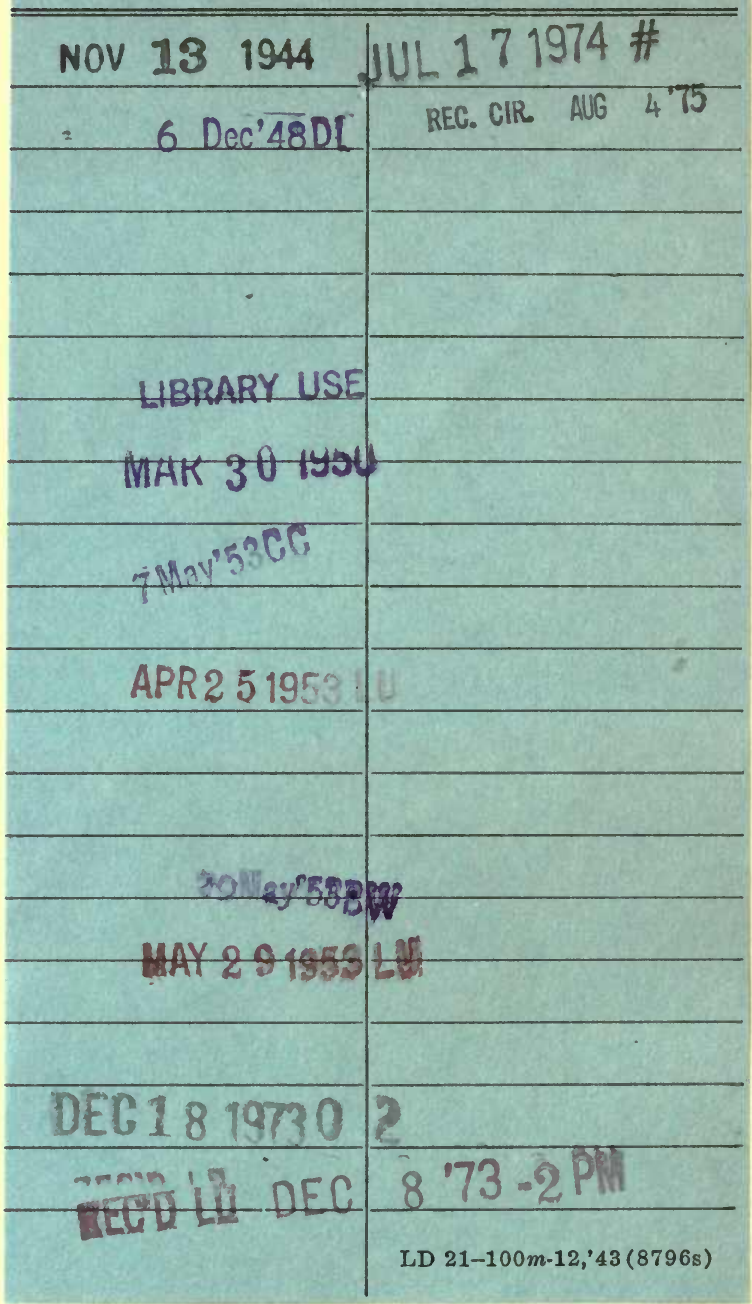




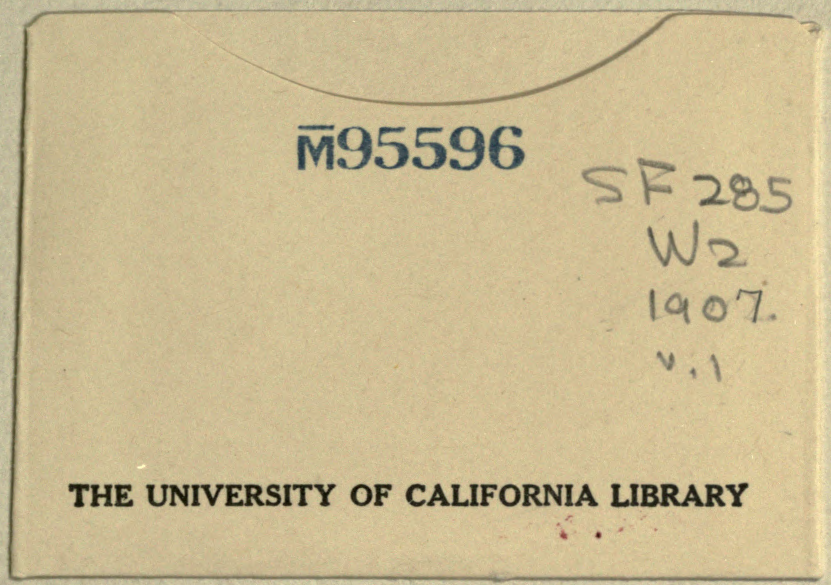


